
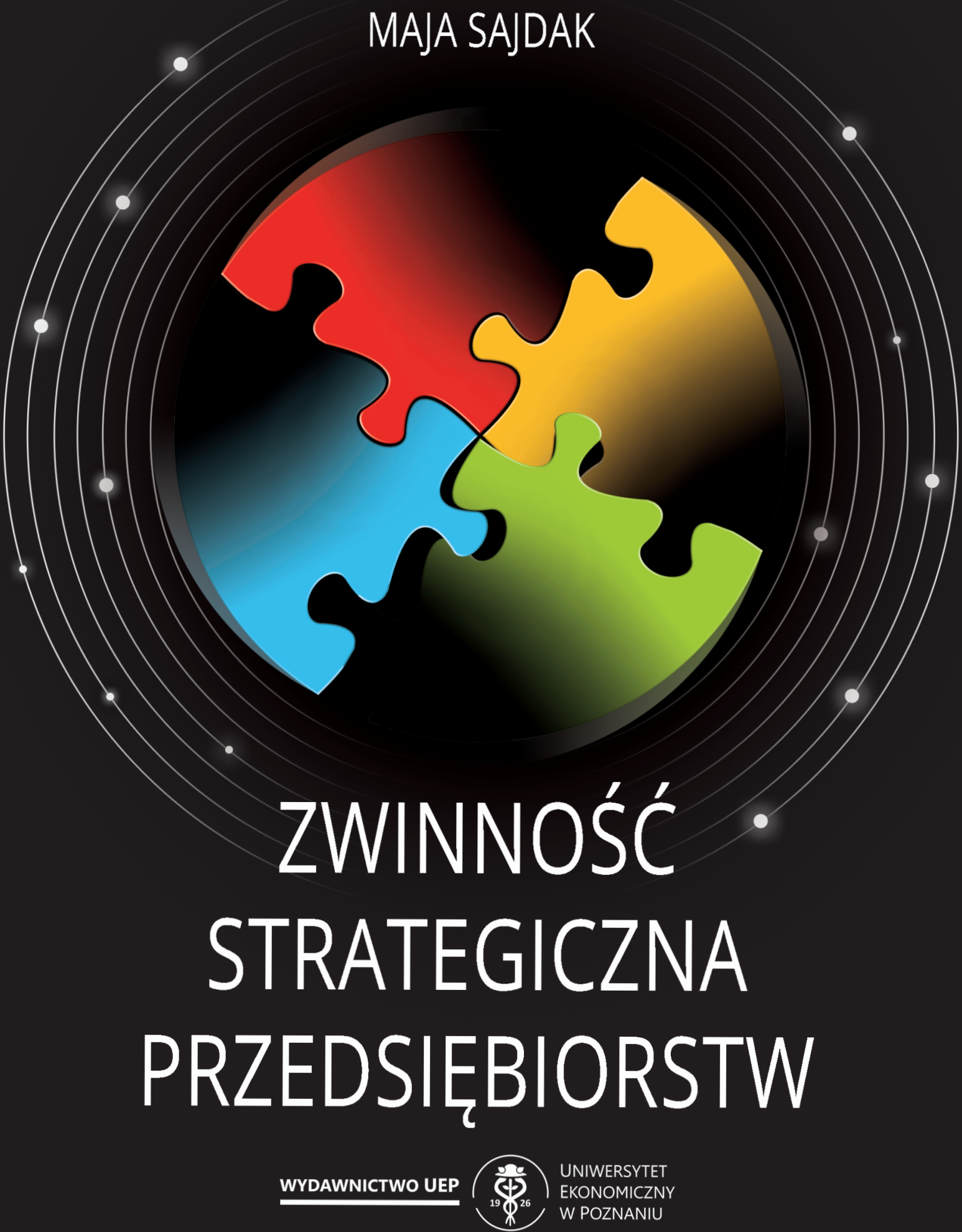


\author{
MAJA SAJDAK
}

\title{
ZWINNOŚĆ \\ STRATEGICZNA \\ PRZEDSIĘBIORSTW
}

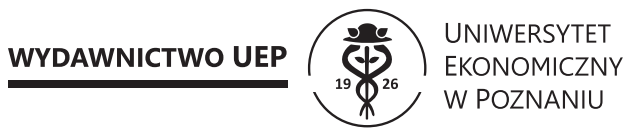

Poznań 2019 


\section{Komitet Redakcyjny}

Szymon Cyfert, Elżbieta Gołata (przewodnicząca), Jacek Lisowski, Ewa Małuszyńska, Eliza Szybowicz (sekretarz), Krzysztof Walczak, Ryszard Zieliński

\section{Recenzenci}

Wojciech Dyduch, Stefan Trzcielinski

\section{Projekt okładki}

Booby Group

Marta Brzóstowicz

\section{Redakcja i korekta}

Deal

ISBN 978-83-7417-998-0, eISBN 978-83-66199-32-3

https://doi.org/10.18559/978-83-66199-32-3

(c) Copyright by Uniwersytet Ekonomiczny w Poznaniu

Poznań 2019

\section{(9) $(1) \Theta$}

Ta książka jest udostępniana na licencji Creative Commons Uznanie autorstwa-Użycie niekomercyjne-Bez utworów zależnych 4.0 Międzynarodowe (CC BY-NC-ND 4.0)

WYDAWNICTWO UNIWERSYTETU EKONOMICZNEGO W POZNANIU

ul. Powstańców Wielkopolskich 16, 61-895 Poznań

tel. 618543154,618543155

www.wydawnictwo.ue.poznan.pl, e-mail: wydawnictwo@ue.poznan.pl

adres do korespondencji: al. Niepodległości 10, 61-875 Poznań

Skład: eMPI ${ }^{2}$

Druk: Zakład Graficzny Uniwersytetu Ekonomicznego w Poznaniu

ul. Towarowa 53, 61-896 Poznań

tel. 6185438 06, 618543803 


\section{SPIS TREŚCI}

Wstęp

Rozdział 1. Zwinność przedsiębiorstw w naukach o zarządzaniu ............................... 11

1.1. Imperatyw samoorganizowania się przedsiębiorstw ........................................... 12

1.2. Zdolność przedsiębiorstw do przystosowania się do otoczenia .......................... 17

1.3. Rozwój idei zwinności przedsiębiorstw................................................................ 23

1.4. Przegląd badań nad zwinnością przedsiębiorstw w naukach o zarządzaniu...... $\quad 38$

Rozdział 2. Podstawy teoretyczne zwinności strategicznej przedsiębiorstw ............. 51

2.1. Przegląd wybranych koncepcji teoretycznych ...................................................... 51

2.2. Założenia w podejściach będących źródłem zwinności na poziomie indywidualnym

2.3. Założenia w podejściach będących źródłem zwinności na poziomie przedsiębiorstwa.

2.4. Przesłanki z rozważań teoretycznych.............................................................. 80

Rozdział 3. Koncepcja zwinności strategicznej ...................................................... 84

3.1. Istota i pojęcie zwinności strategicznej przedsiębiorstwa .................................. 85

3.2. Wrażliwość strategiczna jako atrybut zwinności zorientowany na identyfikowanie szans

3.3. Przedsiębiorczość strategiczna jako atrybut zwinności zorientowany na wykorzystywanie szans

3.4. Elastyczność jako atrybut zwinności zapewniający odpowiedź na wyzwania otoczenia

3.5. Koncepcja przywództwa strategicznego w budowaniu zwinności

3.6. Rezultaty przedsiębiorstw jako zmienna zależna w modelu zwinności strategicznej.....

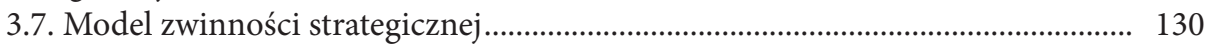

Rozdział 4. Zwinność strategiczna w ujęciu empirycznym .................................... 134

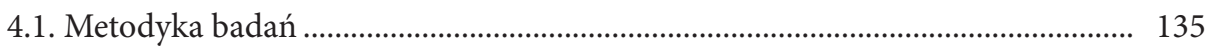

4.2. Opis doboru próby badawczej ............................................................................... 137 
4.3. Charakterystyka próby badawczej ...................................................................... 141

4.4. Pomiar zwinności strategicznej ........................................................................... 142

Rozdział 5. Modelowanie strukturalne zwinności strategicznej .............................. 170

5.1. Istota i procedura modelowania strukturalnego ................................................... 171

5.2. Operacjonalizacja zmiennych nieobserwowalnych ........................................ 176

5.3. Budowa modeli pomiarowych zwinności strategicznej .................................... 184

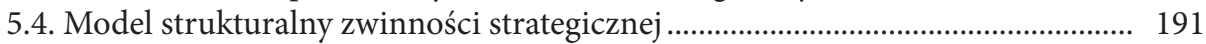

5.5. Ocena testowanych hipotez i wnioski badawcze ............................................... 194

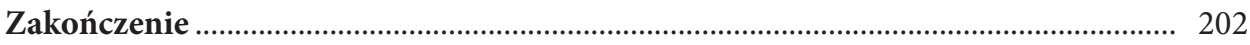

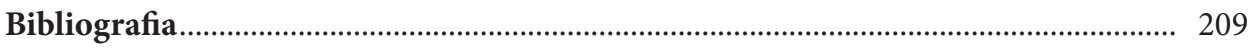

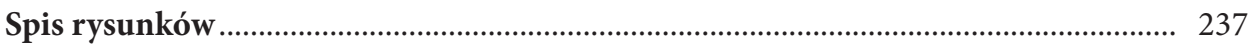

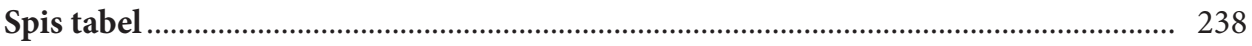

Strategic Agility of Enterprises (summary) ............................................................... 240 


\section{WSTĘP}

Relacje organizacji z otoczeniem od zawsze stanowily obszar zainteresowań naukowców, zarówno teoretyków, jak i praktyków zarządzania. W literaturze przedmiotu można się spotkać z dwoma dominującymi poglądami na temat kształtowania relacji między organizacją a otoczeniem. Pierwsza perspektywa odnosi się do przekonania, że to otoczenie uzależnia organizację i z tego względu organizacja jest podporządkowana wpływom zewnętrznym. W ramach drugiej perspektywy uznaje się, że to organizacja ma możliwość wywierania wpływu, a dzięki temu również kształtowania otoczenia. Prezentowane podejścia wskazują na pasywną i aktywną optykę pojmowania relacji pomiędzy organizacją a otoczeniem (Stańczyk-Hugiet, 2013, s. 16). Uznany pogląd przedstawiony w literaturze jest oparty na stwierdzeniu, że zachowania strategiczne przedsiębiorstw postępują w ślad za charakterystykami otoczenia. Podejmowanie decyzji strategicznych jest jednak utrudnione i determinowane przez niejednoznaczność otoczenia, która przejawia się w określonych własnościach, wśród których E. Stańczyk-Hugiet (2013, s. 24-27) wymienia: turbulencję, złożoność, dynamikę, emergencję oraz dużą prędkość. Wskazane cechy są źródłem zmian, wobec których przedsiębiorstwa, aby przetrwać, muszą podjąć działania dostosowawcze. Często podejmowane przez przedsiębiorstwa działania nie wynikają ze szczególnie w tym celu rozwiniętych zdolności, lecz są jedynie intuicyjnymi, przypadkowymi aktywnościami podjętymi pod presją czasu. Ze względu na różnorodność zmian nie sposób się na nie przygotować, tym bardziej szczegółowo planować działania strategiczne. Brak możliwości kontrolowania sytuacji w tak trudnych warunkach oraz narastająca presja wynikająca ze zmieniających się źródeł przewagi konkurencyjnej powodują wyłonienie się zdolności przedsiębiorstw do podejmowania zmian strategicznych i radzenia sobie z dynamiką (zmiennością) otoczenia. W rozprawie zdolność ta została określona mianem zwinności strategicznej, ponadto wskazano na cztery atrybuty ją konstytuujące: wrażliwość strategiczną, przedsiębiorczość strategiczną, elastyczność oraz przywództwo strategiczne.

Istotą zwinności strategicznej jest jej ukierunkowanie na okazje, które pojawiają się właśnie dlatego, że otoczenie jest zmienne i nieprzewidywalne. Identyfikowanie przewagi konkurencyjnej może się odbywać poprzez wyróżniające cechy przedsiębiorstw, zapewniające im szybsze, sprawniejsze i efektywniejsze reagowanie na zmiany w otoczeniu i pojawiające się w nim okazje. Dzięki szybkiej reakcji i odpowiednim kompetencjom przedsiębiorstwo może wykorzystywać nadarzające się sposobności, tym samym sprawniej realizując statutowe cele i zamierzenia. 
W zmiennym i niestabilnym otoczeniu przedsiębiorstwa poszukują nowych sposobów na sprostanie wzrastającym wymaganiom klientów dzięki przygotowaniu jeszcze doskonalszej oferty i ciągłemu poprawianiu wyników produkcyjnych. Muszą nie tylko radzić sobie ze zmieniającymi się warunkami rynkowymi, które są trudne do przewidzenia, prowadzić nieustanną walkę z globalną konkurencją, ale również wymaga się od nich adaptowania struktur i procesów w przedsiębiorstwie do sprostania wszystkim tym wyzwaniom. Umiejętność konkurowania polegająca na działaniu i przetrwaniu w konkurencyjnym otoczeniu stanowi najbardziej pożądaną cechę współczesnych przedsiębiorstw.

Analiza literatury przedmiotu wskazuje na zainteresowanie badaczy wpływem odmiennych rodzajów zwinności na wyniki przedsiębiorstw. Potwierdzono istotną rolę zwinności wytwarzania w kształtowaniu konkurencyjności przedsiębiorstw (Goriwondo, Mhlanga i Mutsambwa, 2013). Badacze podjęli się także weryfikacji zwinności produkcyjnej jako głównego czynnika sukcesu w różnych sektorach (Vazques-Bustelo, Avella i Fernandez, 2007). W obszarze zwinności organizacyjnej i jej wpływu na wyniki przedsiębiorstw poddano analizie zwinność współpracy z klientem (Roberts i Grover, 2012) oraz zweryfikowano poprawienie wyników przedsiębiorstwa poprzez jego zwinność i strukturę sieciową (Yang i Liu, 2012). Obszar badawczy analizujący wpływ zwinności strategicznej na wyniki nie został do tej pory rozpoznany. Efekt prac naukowców w tym zakresie stanowią nieliczne publikacje mające charakter raczej wstępnych, opisowych badań aniżeli gruntownej analizy weryfikacji zwinności strategicznej w kontekście wyników przedsiębiorstw. Badania koncepcyjne na ten temat podjęli K. Fartash i S. Davoudi (2012), natomiast nigeryjscy naukowcy (Ofoegbu i Akanbi, 2012) wykazali wpływ zwinności strategicznej na postrzegane wyniki jedynie w przedsiębiorstwach produkcyjnych. Dostępne opracowania nie wskazują na jednoznaczne stanowisko autorów dotyczące operacjonalizacji teoretycznego konstruktu, jakim jest zwinność strategiczna, ani także na jednoznaczny wniosek badawczy wskazujący na pozytywny wpływ zwinności strategicznej na wyniki przedsiębiorstw. Zasadne jest zatem rozpoznanie luki badawczej odnoszącej się do zwinności strategicznej jako obszaru wciąż nowego i mało rozpoznanego.

Analiza dotychczasowego stanu wiedzy i badań w zakresie zwinności przedsiębiorstw umożliwia wskazanie istotnych luk w czterech płaszczyznach. Są to:

- Luka poznawcza - wynikająca z braku w literaturze jednoznacznego zdefiniowania pojęcia „zwinność strategiczna” oraz określenia atrybutów, które współtworzyłyby ten konstrukt teoretyczny. Brakuje systematyzacji pojęć związanych ze zwinnością oraz określania jej roli w przystosowywaniu się przedsiębiorstw do otoczenia. Nie ma również w dotychczasowym dorobku jasno sprecyzowanego problemu rozwoju zwinności w czasie, bo choć zwinność strategiczna to pojęcie stosunkowo nowe, to problematyka zwinności przedsiębiorstw sięga lat 90. i od tego czasu uległa głębokim przemianom (konieczność usystematyzowania rozproszonej wiedzy w tym obszarze). Ponadto dostrzeżono niewielki dorobek lite- 
raturowy, który wyjaśniałby powiązania zagadnienia zwinności przedsiębiorstw z głównymi nurtami teoretycznymi w zarządzaniu strategicznym, co stanowiło powód omówienia w pracy szerokiego wachlarza podejść teoretycznych stanowiących podłoże dla zwinności. Warto wspomnieć, że prowadzone w literaturze badania empiryczne dotyczące zwinności strategicznej mają przede wszystkim charakter opisowy, często pozbawiony podstaw teoretycznych. Ponadto odczuwalny jest także deficyt opracowań dotyczących określenia mechanizmu wpływu zwinności strategicznej na wyniki przedsiębiorstw w kontekście budowania przewagi konkurencyjnej.

- Luka metodyczna - wynikająca z niedostatku metod i narzędzi w zakresie konceptualizacji oraz operacjonalizacji zwinności strategicznej. Naukowcy zajmujący się tą dziedziną nadal nie osiągnęli konsensusu w sprawie najlepszej metody pomiaru zwinności. W dotychczasowych badaniach operacjonalizacja zwinności miała niekiedy charakter przypadkowy bądź fragmentaryczny - nie wnikała z merytorycznej analizy uwarunkowań zwinności strategicznej przedsiębiorstw. Powstałe do tej pory miary traktuje się jako przyczynkowe do wypracowania precyzyjnego narzędzia.

- Luka empiryczna - wynikająca z nielicznych publikowanych badań w zakresie zwinności strategicznej i jej wpływu na wyniki przedsiębiorstw. Wśród motywów zwinności wskazuje się: zaspokojenie potrzeb klientów, chęć uzyskania przewagi konkurencyjnej, przetrwanie w trudnych warunkach oraz chęć osiągnięcia wyższej efektywności. W literaturze zakłada się, że zwinność strategiczna może mieć pozytywny wpływ na wyniki przedsiębiorstw (Ofoegbu i Akanbi, 2012; Fartash i Davoudi, 2012; Shin, Lee, Kim i Rhim, 2015). Brakuje jednak dogłębnych badań potwierdzających istnienie tego związku.

- Luka aplikacyjna - odnosząca się do uświadomienia kadrze najwyższego szczebla znaczenia zwinności strategicznej i możliwości jej rozwoju poprzez kształtowanie i doskonalenie atrybutów ją współtworzących. W większości przedsiębiorstw brakuje systemowego podejścia do zwinności strategicznej, co wynika z braku rozwiniętej teorii i właściwych narzędzi pomiarowych. Czynnik ten stanowi barierę w rozwoju i możliwości wykorzystania potencjału tkwiącego w zwinności strategicznej przedsiębiorstw. Odczuwalny jest również deficyt opracowań dotyczących rekomendacji dla praktyki gospodarczej, wskazujących na korzyści wykorzystania zwinności jako zdolności do podejmowania zmian, umożliwiającej szybszą i efektywniejszą adaptację do zmieniających się warunków otoczenia współczesnych przedsiębiorstw.

W pracy przyjęto założenia ontologiczne, epistemologiczne i metodologiczne zgodne z kanonem krytycznego realizmu (critical realism), w którym rzeczywistość jest realna, ale nie jest poznawana perfekcyjnie, mamy raczej do czynienia z prawdą probabalistyczną aniżeli absolutną (Bisman, 2010). Krytyczny realizm, jako jedno z podejść postpozytywistycznych w filozofii nauki, znajduje coraz większe uznanie w metodologii nauk o zarządzaniu (Easton, 1998; Tsoukas, 1989; Miller i Tsang, 2010; 
Sousa, 2010). W pracy wykorzystano modelowanie, które posłużyło do wyodrębnienia istotnych składowych zwinności strategicznej i przedstawienia zależności między nimi. W perspektywie krytycznego realizmu rolę modelowania upatruje się przede wszystkim w wyjaśnieniu i zrozumieniu, predykcja natomiast ma rolę drugorzędną. Zgodnie z tym podejściem należy „zidentyfikować mechanizmy przyczynowe, które leżą u podstaw procesów, które obserwujemy" (Easton, 1998, s. 85). W modelowaniu sugeruje się wykorzystanie rozumowania abdukcyjnego, czyli procesu testowania teorii, w którym dąży się do (najlepszego) wyjaśnienia podejmowanych zjawisk (Urbański, 2009, s. 43). Postępowanie abdukcyjne umożliwia badaczowi testowanie teorii za pomocą tworzonych przypuszczalnych związków. Abdukcja nie gwarantuje niezawodności twierdzeń czy teorii, ale umożliwia opracowanie hipotetycznego modelu i wskazanie najbardziej prawdopodobnych hipotez.

Głównym celem pracy jest opracowanie modelu zwinności strategicznej ukierunkowanego na poprawę wyników przedsiębiorstw. Realizacja głównego celu pracy wymagała określenia celów szczegółowych na trzech płaszczyznach:

- teoretycznej, w tym:

- przeprowadzenie systematyzujących studiów w zakresie zwinności,

- identyfikacja zwinności strategicznej,

- konceptualizacja pojęcia zwinności strategicznej i jej atrybutów,

- ustalenie potencjalnego mechanizmu wpływu zwinności strategicznej na wyniki przedsiębiorstw;

- metodycznej, w tym:

- zaprojektowanie modelu zwinności strategicznej przedsiębiorstw,

- opracowanie metody pomiaru zwinności strategicznej,

- rozwinięcie procedury testowania modelu,

- budowa modeli pomiarowych i modelu strukturalnego zwinności strategicznej;

- empirycznej, w tym:

- określenie poziomu i znaczenia poszczególnych wskaźników składających się na konstrukty teoretyczne zwinności strategicznej,

- identyfikacja czynników zwinności strategicznej z zastosowaniem modelowania strukturalnego,

- ustalenie zależności występujących między elementami modelu strukturalnego zwinności strategicznej.

Podejmując próbę realizacji tak zdefiniowanego zbioru celów, sformułowano główną hipotezę badawczą, zgodnie z którą zwinność strategiczna, tworzona przez wrażliwość strategiczną, przedsiębiorczość strategiczną, elastyczność oraz przywództwo strategiczne, ma pozytywny wpływ na wyniki przedsiębiorstw. Hipoteza główna została rozpisana na pięć hipotez cząstkowych, a ich treść i rozwinięcie znajdują się w dalszej części rozprawy.

Ze względu na charakter przedmiotu badań zdecydowano się na badania empiryczne z wykorzystaniem metod ilościowych, które w głównej mierze są nastawione 
na eksplorację i wyjaśnienie zjawisk słabo rozpoznanych oraz relacji między nimi. Zdecydowano się na metodę sondażu diagnostycznego z wykorzystaniem popularnego narzędzia, jakim jest kwestionariusz ankiety. Przeprowadzono pilotaż narzędzia badawczego na celowo dobranej grupie przedsiębiorstw, a następnie wykonano badania zasadnicze. Badanie zostało przeprowadzone w okresie maj - czerwiec 2017 $\mathrm{roku}^{1}$. Ostatecznie otrzymano 424 poprawnie wypełnione kwestionariusze ankiety, co przy akceptowalnym błędzie pomiaru daje możliwość wnioskowania na temat zbiorowości średnich i dużych polskich przedsiębiorstw. Wyniki badań stanowiły podstawę do analizy danych i wnioskowania w ramach badań opisowych oraz przyczynowych w postaci modelowania strukturalnego.

Wyznaczone cele pracy oraz sformułowana hipoteza badawcza mają odzwierciedlenie w strukturze monografii. Praca składa się z dwóch zasadniczych części, pierwszej teoretycznej (rozdziały 1-3) i drugiej empirycznej (rozdziały 4-5).

W rozdziale pierwszym przedstawiono rozważania teoretyczne dotyczące zwinności przedsiębiorstw w naukach o zarządzaniu. Wskazano na złożoność otoczenia oraz potrzebę przedsiębiorstw do samoorganizowania w celu adaptacji do zmieniających się warunków. Omówiono istotę i uwarunkowania zwinności, przedstawiając definicje prezentowane w literaturze. Ponadto przedstawiono rozwój idei zwinności przedsiębiorstw, wskazując na wyodrębnienie jej trzech rodzajów: zwinności wytwarzania, organizacyjnej oraz strategicznej. Dokonano także systematyzacji obszarów i kierunków badawczych nad zwinnością przedsiębiorstw w ujęciu przedmiotowym.

Drugi rozdział w całości obejmuje analizę i krytyczną ocenę podstaw teoretycznych, na których gruncie rozwija się współczesna wiedza naukowa na temat zwinności przedsiębiorstw. Zebrano najważniejsze koncepcje i podejścia teoretyczne, które uzasadniają i wyjaśniają pojęcie zwinności. W kolejnych podrozdziałach przedstawiono krytyczną analizę poszczególnych podejść i koncepcji uwzględniającą ich wpływ na zwinność strategiczną na różnych poziomach analizy przedsiębiorstwa. Wskazno na podejścia uwzględniające zwinność strategiczną na poziomie jednostki oraz podejścia rozpatrujące zwinność strategiczną na poziomie przedsiębiorstwa. Przedstawione w tym rozdziale wnioski odgrywają rolę fundamentu teoretycznego stanowiącego podstawę dalszych rozważań w pracy dotyczących konceptualizacji definicji zwinności strategicznej i jej atrybutów.

W rozdziale trzecim, ze względu na występujące w literaturze niejasności semantyczne, dokonano delimitacji pojęcia „zwinność strategiczna”, wyznaczając w ten sposób zakres przedmiotowy pracy. Sformułowano definicję zwinności strategicznej przygotowaną na potrzeby monografii oraz dokonano identyfikacji i konceptualizacji elementów współtworzących zwinność strategiczną. W ramach czterech atrybutów zwinności strategicznej (wrażliwości strategicznej, przedsiębiorczości

${ }^{1}$ Badania zasadnicze przeprowadzono w ramach realizacji projektu badawczego pt. „Zwinność przedsiębiorstw w procesie przystosowania się do otoczenia i jego zmian", sfinansowanego ze środków Narodowego Centrum Nauki (nr DEC - 2013/11/D/HS4/03858). 
strategicznej, elastyczności oraz przywództwa strategicznego) wyróżniono dziewięć konstruktów teoretycznych współtworzących poszczególne atrybuty i wskazano na ich pozytywny wpływ na wyniki rynkowe przedsiębiorstw, a te z kolei na wyniki finansowe. Wskazane konstrukty składają się na model zwinności strategicznej. Przedmiotem zainteresowania są związki pomiędzy elementami modelu sformułowane w postaci hipotez cząstkowych.

W rozdziale czwartym przedstawiono wyniki badań empirycznych ukierunkowanych na rozpoznanie zwinności strategicznej, a w szczególności pomiar atrybutów ją konstytuujących. Zaprezentowano metodykę badań, ze szczególnym uwzględnieniem procesu gromadzenia danych, informacji o populacji oraz próbie badawczej. W dalszej części przedstawiono badania opisowe mające na celu pomiar zwinności strategicznej oraz ustalenie poziomu i znaczenia poszczególnych wskaźników wyjaśniających atrybuty zwinności strategicznej. Zaprezentowano opinie respondentów dotyczące występowania poszczególnych cech w badanych przedsiębiorstwach w zakresie ich zdolności do adaptacji do zmieniających się warunków otoczenia.

W rozdziale piątym przedstawiono badania przyczynowe w postaci modelowania strukturalnego zwinności strategicznej. Wyjaśniono istotę i procedurę modelowania strukturalnego, dokonano operacjonalizacji zmiennych nieobserwowalnych, prezentując narzędzia pomiarowe wykorzystane następnie w modelowaniu. Opisano kolejne etapy konstrukcji modelu pomiarowego, w szczególności jego testowanie i ocenę. Następnie zaprezentowano model strukturalny, w którego ramach, na podstawie rezultatów empirycznych procesu modelowania, sformułowano wnioski dotyczące postawionych hipotez. Zaprezentowano ostateczną ocenę hipotez oraz dyskusję nad wnioskami badawczymi.

W ramach zakończenia przedstawiono wnioski badawcze dotyczące wkładu w rozwój teorii nauk o zarządzaniu, sformułowano zalecenia dla praktyki gospodarczej oraz wskazano ograniczenia wynikające z postępowania badawczego i kierunki przyszłych poszukiwań badawczych. 


\section{Rozdział 1}

\section{ZWINNOŚĆ PRZEDSIĘBIORSTW W NAUKACH O ZARZĄDZANIU}

W naukach o zarządzaniu rozwinęło się wiele subdyscyplin i obszarów badawczych, wśród których wciąż dynamicznie się rozwija i chętnie poddawane jest eksploracji naukowej zarządzanie strategiczne. $W$ ramach nauk o zarządzaniu podejmuje się problemy związane z powstawaniem, funkcjonowaniem, przekształcaniem, rozwojem i współdziałaniem organizacji (Sudoł, 2007, s. 28). Podejmowane aktywności naukowo-badawczej, w ramach wymienionych problemów wynikają z działania sił na zewnątrz organizacji. Brak możności kontrolowania otoczenia wymusił procesy dostosowywania się przedsiębiorstw do zmian w otoczeniu. Ustawicznie zmieniające się zewnętrzne uwarunkowania sprawiają, że procesy adaptacji powinny być ciągłe (Stańczyk-Hugiet, 2013, s. 11), a zwinność jako koncepcja silnie osadzona w ramach teoretycznych zarządzania strategicznego stanowi zdolność umożliwiającą szybkie i efektywne sprostanie temu wyzwaniu.

Zwinność, jako pojęcie stosunkowo nowe i nadal niejednoznacznie określone, wymaga pogłębionych studiów literaturowych i przeglądu dotychczasowych badań, które umożliwiłyby lepsze rozpoznanie jego istoty. W literaturze pojęcie zwinności często jest odnoszone do różnych dziedzin nauki, co tym bardziej potęguje chaos definicyjny i trudności w interpretacji. Wynika to z odmiennych doświadczeń naukowców, podejść metodologicznych, jak również potrzeb w zakresie wyjaśnienia nurtujących ich zagadnień. W związku z powyższym celem tego rozdziału jest przeprowadzenie systematyzujących studiów literaturowych w zakresie zwinności w naukach o zarządzaniu.

Rozważania dotyczące istoty zwinności należy rozpocząć od warunków otoczenia, stanowiących imperatyw dla wyłonienia się owej zdolności. Główna potrzeba zwinności wynika ze złożoności otoczenia i dążenia przedsiębiorstw do samoorganizowania się, jako procesu adaptacyjnego prowadzącego do „nowego porządku”. Bodźcem do tego działania może być zarówno wyłaniająca się w otoczeniu szansa ${ }^{2}$, jak i obrona przedsiębiorstwa przez wpadnięciem w chaos. W kolejnych

2 W pracy, ze względów leksykalnych, pojęcie „szansa” będzie stosowane zamiennie z pojęciem „okazja”, choć autorka zdaje sobie sprawę z różnic semantycznych obu pojęć, na które wskazuje też R. Krupski (2013). 
podpunktach rozdziału wyjaśniona została potrzeba zdolności przedsiębiorstw do przystosowania się do otoczenia i jego zmian, wskazano na najbardziej znane definicje zwinności, a następnie omówiono rozwój koncepcji zwinności w naukach o zarządzaniu. $\mathrm{W}$ ostatnim podpunkcie tego rozdziału przedstawiono dostępne w literaturze badania nad zwinnością przedsiębiorstw, omawiając je według kryterium przedmiotowego.

\subsection{Imperatyw samoorganizowania się przedsiębiorstw}

Zainteresowanie wpływem otoczenia na przedsiębiorstwo ewoluuje, czego efektem jest wielość publikacji o tej tematyce w ostatnich dziesięcioleciach. We wcześniejszych pracach (Lawrence i Lorsch, 1967; Duncan, 1972; Miles i Snow, 1978) wykorzystywano modele nawiązujące do niepewności otoczenia. Podejście autorów spotkało się z krytyką, gdyż nie uwzględnili w swoich modelach nagłych zmian kreujących niepewność, analizując jedynie postrzeganą przez menedżerów nieprzewidywalność zmian, podczas gdy inni badacze uważali, że bardziej istotny jest pomiar obiektywnego stanu otoczenia (Milliken, 1978). Obecnie autorzy często podejmują temat oszacowywania burzliwości otoczenia, dokonując dekompozycji tego zagadnienia i rozkładając konstrukt badawczy na mniejsze elementy, stanowiące źródła owej turbulencji. Na przykład O. Kuivalainen, S. Sundqvist, K. Puumalainen i K.W. Cadogan (2004) oszacowują turbulencję otoczenia, uwzględniając obszar prawny, technologiczny, konkurencyjny oraz otoczenie klienta, wykorzystując do pomiaru skale użyte wcześniej przez B.J. Jaworskiego i A.K. Kohli (1993) oraz F.R. Dwyera i M.A. Welsha (1985), U. Lichtenthalera (2009). Z. Zhang i H. Sharifi (2007) dokonują pomiaru w nieco inny sposób, identyfikując pięć grup czynników wpływu na przedsiębiorstwo (rynek, konkurencja, klient, technologia, czynniki społeczne). Na podstawie odpowiedzi respondentów ustalają ranking, które z nich mają najsilniejszy, a które mniejszy wpływ na przedsiębiorstwo. W większości prezentowanych badań proponuje się szacowanie turbulencji otoczenia na podstawie subiektywnych miar odnoszących się do percepcji menedżerów zamiast obiektywnej oceny źródeł turbulencji otoczenia (Yauch, 2011).

Pojęcie burzliwości otoczenia zyskało popularność w zarządzaniu strategicznym za sprawą badań prowadzonych przez H. I. Ansoffa, który uznaje, że otoczenie organizacji w XX wieku charakteryzuje się wzrastającą turbulencją, przejawiającą się w zwiększeniu: nowości zmian, intensywności otoczenia, szybkości zmiany i złożoności otoczenia. Wielość zmiennych i różnorodny kierunek ich ewolucji sprawia, że zmiany, które zachodzą w otoczeniu, są coraz bardziej nowatorskie, kosztowne, szyb- 
kie i trudne do przewidzenia (Ansoff, 1985, s. 58-61). Poglądy P. Kotlera i J.A. Caslione (2009) odnoszące się do atrybutów otoczenia są bardzo bliskie wnioskom prezentowanym przez H.I. Ansoffa. Autorzy stoją na stanowisku, że turbulencja otoczenia stanowi obecnie normę działalności przedsiębiorstwa, a nie wyjątek, jej konsekwencją jest natomiast chaos, ryzyko i niepewność. Skutki turbulencji mogą się przejawiać dwojako, z jednej strony przedsiębiorstwo musi się zmierzyć z nieprzewidywalnymi zagrożeniami, $\mathrm{z}$ drugiej strony turbulencja otoczenia może stanowić wyjątkową szansę. Wśród głównych czynników źródeł turbulencji wskazują na: postęp techniczny i rewolucję informatyczną, przełomowe technologie i innowacje, wschodzące gospodarki, hiperkonkurencję, środowisko oraz wzrost siły klienta (Kotler i Caslione, 2009, s. 12, 33).

Zależności pomiędzy burzliwością a niepewnością otoczenia przedstawia A. Zakrzewska-Bielawska (2018, s. 61-62). Autorka wskazuje na własności turbulencji, takie jak dynamizm zmian oraz ich złożoność. Dynamizm zmian określa poprzez ich intensywność, częstość oraz szybkość, natomiast złożoność determinowana jest przez liczbę elementów, ich różnorodność oraz ich wzajemne powiązanie w kontekście ciągłości i liniowości. Turbulentne otoczenie nie jest tożsame z otoczeniem niepewnym, gdyż pomimo złożoności i dynamiczności może być przewidywalne. Autorka, rozwijając tę myśl, wskazuje na cechę, która moderuje związek pomiędzy turbulencją otoczenia a jego niepewnością, jest nią przewidywalność związana z dostępnością informacji oraz umiejętnością ich analizy i przetwarzania.

Potoczne określenie „chaotyczne otoczenie” obrazuje diametralnie zmieniający się kontekst funkcjonowania przedsiębiorstw oraz poziom strategiczny ulegający ciągłym przeobrażeniom w wyniku niejasności i złożoności. Teoria chaosu wywodząca się z teorii złożoności wyjaśnia, że to atraktory kształtują system, pomiędzy nimi występuje sfera turbulencji, czyli tzw. krawędź chaosu. Stan ten charakteryzuje się dużym poziomem niepewności, w którym bardzo trudno prognozować przyszłość, a długookresowe planowanie jest wręcz niemożliwe (Stańczyk-Hugiet, 2013, s. 26). W tym kontekście strategia jest wyrazem procesów uczenia się, które tworzą warunki do radzenia sobie z niejasną i niepewną sytuacją. H.I. Ansoff (1985, s. 61) twierdzi, że uwzględniając takie przesłanki, zasadne jest zwrócenie uwagi na adaptacyjny i elastyczny charakter strategii opartej na formułowaniu portfela możliwych opcji strategicznych. Im bardziej niepewna sytuacja, tym więcej możliwości powinno się rozważać w procesie refleksji strategicznej. P. Kotler i J.A. Caslione (2009, s. 62-63) zwracają uwagę na kontinuum zarządzania w chaosie, które uwypukla ciągły, nieskończony charakter procesu zarządzania koncentrującego się na dopasowaniu strategii w reakcji na turbulencje i chaos.

Przedsiębiorstwa działające na krawędzi chaosu powinny przyjąć założenie, że wzrastająca turbulencja otoczenia determinuje zarządzanie zmianą jako centralne i najważniejsze wyzwanie zarządzania strategicznego. Strategia przedsiębiorstwa powinna zatem umożliwiać budowę organizacji (struktura, procesy, systemy) mogącej się zmieniać w sposób ciągły i efektywny. Autorki znanej publikacji Competing 
on the edge (Brown i Eisenhardt, 1998, s. 7-9), zwracają uwagę na sześć elementów, które w radykalny sposób zmieniły kierunek myślenia strategicznego:

- trudność w przewidzeniu/przewidywaniu przyszłości (unpredictable) - konkurowanie na krawędzi chaosu wiąże się bezpośrednio z brakiem informacji, niewiadomą, dlatego wykorzystuje się metodę małych kroków, obserwując, które z działań przynoszą korzyści i które należy kontynuować;

- trudność w kontrolowaniu (uncontrolled) - duża liczba bodźców i zmian w sektorach wymaga od przedsiębiorstw ciągłych zmian i działań dostosowawczych, co utrudnia proces kontroli, konkurowanie na krawędzi wymaga podejmowania decyzji scentralizowanych $\mathrm{w}$ ramach poszczególnych jednostek, a nie centrali przedsiębiorstwa;

- problem braku efektywności (inefficient) - konkurowanie na krawędzi może się okazać nieefektywne w krótkim okresie, wynika to z podejmowania prób i z błędów, uczenia się i bycia innowacyjnym; jednak nie efektywność czy rentowność są najistotniejsze, ale raczej wykorzystanie zmiany do nieustannego odkrywania możliwości biznesowych poprzez dostrzeganie nowych szans na wzrost i rozwój przedsiębiorstwa;

- potrzeba proaktywności (proactive) - w konkurowaniu na krawędzi nie można pozostawać pasywnym, czekając na aktywność innych przedsiębiorstw, liczy się wczesna antycypacja zmian lub własne ich wprowadzanie przez przedsiębiorstwo;

- potrzeba kontynuacji (continuous) - ciągłość czynności zapewnia przedsiębiorstwu rytm, nie chodzi o kilka niespójnych działań, dużych transformacji, dużych fuzji, ale o powtarzalne, bezwzględne wprowadzanie zmian, które staną się naturą przedsiębiorstwa;

- konieczność różnorodności (diverse) - konkurowanie na krawędzi chaosu wymaga różnorodności działań obarczonych różną skalą i odmiennym ryzykiem; zatem potrzebne jest kreowanie silnej i zróżnicowanej strategii zapewniającej wielość działań, z których kilka będzie genialnych, większość dobrych, a kilka błędnych. Jak deklarują J. Rokita i A. Dziubińska (2016, s. 44), rozpatrywanie chaosu ze względu na determinizm uwzględnia wrażliwość i czujność na inicjalne warunki oraz atraktory. Interakcje powstające $w$ takich strukturach mogą powodować powstawanie wysoce złożonych sieci zachowań. Transformacja systemu ze stanu stabilności do stanu chaosu następuje w wyniku interakcji między stabilizującymi system ujemnymi sprzężeniami zwrotnymi z powodującymi utratę stabilności dodatnimi sprzężeniami zwrotnymi. W takich warunkach mogą się wyłaniać systemy samoorganizujące się, typowe dla struktur dyssypatywnych, które albo utrzymują się w stanie stabilnym, choć dalekim od równowagi, albo tworzą nowy wzorzec. Wśród cech samoorganizujących się systemów autorzy wymieniają (Rokita i Dziubińska, 2016, s. 36):

- stabilność daleką od równowagi,

- amplifikację procesów przez dodatnie sprzężenia zwrotne,

- „załamanie” się stabilności prowadzące do nowej formy zorganizowania, 
- nieustanny przepływ energii przez system,

- możliwość opisu systemu za pomocą równań nieliniowych.

Zjawisko samoorganizowania się prowadzące do złożonych struktur zostało poddane modelowaniu w celu poznania życia i organizacji systemów biologicznych (geny, zorganizowanie komórek, organizmy, systemy ekologiczne, systemy społeczne). Dynamika systemów biologicznych, mających cechy społeczne, stanowiła sedno pracy C.V. Reynoldsa (1987, s. 25-34). Modele, w których uwzględnia się wyłanianie się wzorców w wyniku podobnego zachowywania agentów (jednostek) oraz ich bezpośrednich sąsiadów, zainspirowały badaczy z zakresu nauki o zarządzaniu do stosowania prostych zasad tych warunków, które umożliwiają samoorganizowanie $i$ adaptowanie.

F. Capra (2002, s. 23-25) przekonuje, że działanie sprzężeń zwrotnych może doprowadzić do nowego porządku i złożoności. Ten wniosek stanowi istotny wkład w teorię struktur dyssypatywnych opisującą, jak poprzez samoorganizowanie i wyłanianie się struktur powstaje spontaniczne, nowe uporządkowanie tworzące znacznie ,większą" całość. Samoorganizowanie jest naturalnym procesem organizującym systemy dyssypatywne, które są przedmiotem oddziaływania czynników energetyzujących je. Porządek wyłania się w wyniku interakcji powodujących napięcia powstające pod wpływem różnic energii znajdujących się w autonomicznych jednostkach tworzących pewną całość (Rokita i Dziubińska, 2016, s. 44). Analogię do nauk o zarządzaniu można odnaleźć $\mathrm{w}$ interpretacji różnic energii jako poziomu zmian w otoczeniu w stosunku do przedsiębiorstwa powodujących napięcia i kształtujących nowe formy adaptacji. Porządek może być rezultatem uczenia się agentów, a interakcje między nimi tworzą synergię. Gdy system znajduje się w obszarze niestabilności, dalekiej od równowagi, następujące w nim zmiany umożliwiają wyłanianie się jakiegoś nowego porządku. Nowy porządek w systemie powstaje wówczas, gdy czynniki oddziałujące na system wywierają w nim napięcia. Jeśli w następstwie małych zmian procesy powodujące transformację systemu są zasilane nowymi, ważnymi ze względu na transformację zasobami, następują zmiany prowadzące do nowego porządku. Samoorganizacja może następować poprzez (Rokita i Dziubińska, 2016, s. 51):

- spontaniczną fluktuację czynników, które inicjują nowy porządek,

- autokatalityczne sprzężenia zwrotne, które zachęcają i wzmacniają tę fluktuację,

- odpowiednią koordynację, która wzmacnia wyłanianie się porządku,

- rekonfigurację zasobów, która wzmacnia nowy porządek i podtrzymuje działanie dodatnich sprzężeń zwrotnych.

Procesy samoorganizowania się systemu są spowodowane powstawaniem szansy na dokonanie zmiany, a następnie ochronę „nowego", które wyłania się jako obrona przed wpadnięciem w chaos. W konsekwencji nowemu porządkowi także towarzyszą napięcia, które generują wyłanianie się kolejnych działań w przyszłości. Systemy cechujące się wielowymiarowością mogą być systemami samoorganizującymi się. W konsekwencji ich dynamika powoduje, że mogą się cechować adaptacyjnością. 
Organizacje możemy określić mianem samoorganizujących się, gdy „[...] wpływające na nie czynniki oddziaływają jednokierunkowo, a rosnąca liczba czynników dodatnich - wzmacniających, i ujemnych - równoważących, zwiększa prawdopodobieństwo osiągnięcia uporządkowania. Przedsiębiorstwa takie charakteryzują się procesami nieciągłych przekształceń i ich stanów: stabilnej równowagi, z której wyłania się nowy porządek lub chaos. Impulsem dla przekształceń są inicjujące je napięcia, wzmocnione i kontrolowane. Prognozowanie możliwe jest jedynie w krótkich przedziałach czasowych, $\mathrm{z}$ udziałem zmian inkrementalnych. Wyłanianie się "nowego porządku” ma charakter adaptacyjny - poprzez konkretną rekonfigurację" (Rokita i Dziubińska, 2016, s. 52).

Spontaniczne wyłanianie się nowych wzorców jest charakterystyczne dla przedsiębiorstw funkcjonujących na krawędzi chaosu. S.A. Kauffman (1991) wskazuje, że sieci będące na krawędzi chaosu i porządku mogą się cechować zdolnością do szybkiej adaptacji poprzez akumulowanie korzystnych dla siebie wariantów. Z reguły systemy te adaptują się do zmieniającego się otoczenia w sposób kaskadowy, choć w niektórych sytuacjach mogą przechodzić mutację w sposób nagły i intensywny. J. Rokita i A. Dziubińska (2016, s. 38) zwracają uwagę, że nauki o zarządzaniu powinny konceptualizować problem samoorganizowania się systemów oraz ich ewolucji jako istotny z poznawczego punktu widzenia. Odwołując się do teorii złożoności, autorzy podkreślają, że systemy adaptacyjne wykształcają się ze zagregowanych, współzależnych względem siebie zachowań agentów (Rokita i Dziubińska 2016, s. 46). Proces ten jest wspierany przez zasady określające zachowania systemu, w którym działają agenci, jednak agenci mogą z jednej strony dostosowywać się do tych zasad, z drugiej jednak zmieniać je, tworząc nowy porządek. Wątpliwości, które dostrzegają autorzy, dotyczą roli przyczynowości i charakteru wyłaniającego się porządku, w którym szanse grają kluczową rolę. Charakter interakcji z natury jest jednak deterministyczny, a zasady są stałe w wyniku wyboru lub natury. Dlatego, jak słusznie konstytuują J. Rokita i A. Dziubińska (2016, s. 46), „szanse otwierają sposobności dla żywotnych wariantów kombinacji, poprzez które system rozwija się w kierunku wyłaniającego się porządku”.

W badaniach europejskich nad samoorganizowaniem się systemów zauważono, że w dłuższych przedziałach czasowych stabilność jest stanem przejściowym, z którego wyłania się samoorganizacyjna zdolność systemu. W świecie organizacji, jak piszą J. Rokita oraz A. Dziubińska (2016, s. 50-51), może być to popyt i podaż, a luka pomiędzy nimi kreuje adaptacyjną cenę napięcia, która albo powoduje powstawanie inicjatyw przedsiębiorczych, albo jest czynnikiem sprawczym restrukturyzacji. Interakcje oraz napięcia $\mathrm{z}$ nimi związane powodują wyłanianie się nowego porządku. Po przekroczeniu pewnej wielkości krytycznej system przekształca się $\mathrm{z}$ jednego stanu $\mathrm{w}$ drugi. W dłuższych okresach stabilność jest więc stanem przejściowym, z którego wyłania się samoorganizacyjna zdolność systemu.

Nurtujące dla badaczy jest pytanie o przyczyny samoorganizowania się systemów. Według autorów badań - I. Prigogine oraz I. Stengers (1984) - system zawsze 
ma zdolność do samoorganizowania się, trzeba jednak odkryć w nim ten potencjał. Przyczyną nowego porządku jest jego wcześniejszy brak, który prowadzi do napięć będących z kolei czynnikiem sprawczym nowego porządku. Nowy kontekst, w którym funkcjonują przedsiębiorstwa, wymaga odejścia od tradycyjnych rozwiązań opartych na hierarchii, strukturach, koordynacji. Nowy porządek cechuje się wyłanialnością dzięki temu, że (Plowman, Baker, Beck, Kolkarni, Solansky i Travis, 2007):

- małe zmiany i ich wzmocnienia mogą powodować powstawanie zmian radykalnych,

- akceleracja zmian jest spowodowana dostępnością zasobów, stosownym językiem i symbolami,

- interakcje pomiędzy elementami systemu są czynnikiem zachęcającym do akceleracji zmian,

- duży wpływ na akcelerację wywołują czynniki kontekstualne.

Jeśli w następstwie małych zmian procesy powodujące transformację systemu są zasilane nowymi, ważnymi z punktu widzenia transformacji zasobami, następują radykalne zmiany prowadzące do nowego porządku.

\subsection{Zdolność przedsiębiorstw do przystosowania się do otoczenia}

Przedsiębiorstwa, aby trwale osiągać zadowalające wyniki i odnieść sukces, muszą umiejętnie się dostosowywać do konkurencyjnego otoczenia, wyszukiwać atrakcyjne przestrzenie rynkowe i tam budować przewagę konkurencyjną ${ }^{3}$. W tak trudnej do funkcjonowania rzeczywistości umiejętność szybkiej reakcji na zmiany otoczenia stanowi jedną z najbardziej pożądanych i najistotniejszych umiejętności dla przedsiębiorstw chcących osiągnąć i utrzymać przewagę konkurencyjną (Matson i McFarlane, 1999; Meehan i Dawson, 2002; Holweg, 2005; Storey, Emberson i Reade, 2005; Reichhart i Holweg, 2007; Bernardes i Hanna, 2009). Zwiększona złożoność otoczenia sprawia, że zarządzający przy formułowaniu strategii dysponują ogromną liczbą zmiennych odnoszących się do otoczenia konkurencyjnego, a ich zadaniem jest umiejętne i efektywne ich przefiltrowanie. Ponadto wymagana jest wysoka adaptacja do otoczenia w konfrontacji z jego dynamiką i ograniczonymi możliwościami prognozowania (Bogner i Barr, 2000, s. 212-226).

Wielu naukowców definiuje zwinność jako zdolność przedsiębiorstwa do adaptacji w wyniku szybko następujących zmian w otoczeniu (Breu, Hmingway, Strathern i Bridger, 2001; Gunasekaran, 1999a; Kassim i Zain, 2004; Yusuf, Sarhadi

\footnotetext{
3 Temat adaptacji przedsiębiorstw do wyzwań otoczenia został podjęty przez autorkę w pracy (Sajdak, 2014c).
} 
i Gunasekaran, 1999). Zwinność przedsiębiorstw zawsze jest analizowana w perspektywie otoczenia (Charbonnier-Voirin, 2011), jednak rdzeń koncepcji odnosi się do wnętrzna przedsiębiorstwa i zdolności efektywnego radzenia sobie ze zmieniającymi się warunkami rynkowymi (Joroff, Porter, Feinberg i Kukla, 2003). Już S.L Goldman, R.N. Nagel, K. Preis (1995) podkreślają rolę zwinności jako zdolności umożliwiającej przedsiębiorstwu prowadzenie działalności w konkurencyjnym otoczeniu, gdzie szanse rynkowe permanentnie ulegają zmianom w trudny do przewidzenia sposób.

Jak zaważają S. Mishra, S.S. Mahapatra i S. Datta (2014), zwinność od początku była związana $\mathrm{z}$ adaptacją poprzez rekonfigurację zasobów przedsiębiorstwa. Wśród najczęściej wyróżnianych elementów zwinności autorzy na pierwszym miejscu wskazują na zdolność do szybkiej i skutecznej reakcji na zmiany otoczenia (rozwoju technologicznego, rosnących wymagań klientów, strategii konkurowania) (Gunasekaran, 1998; Yusuf i in., 1999; Zhang i Sharifi, 2001; Kassim i Zain, 2004; Lin, Chiu i Chu, 2006; Charbonnier-Voirin, 2011). Wielu autorów podkreśla także rolę działań proaktywnych w ramach zwinności, mających na celu wykorzystanie pojawiającej się zmiany jako szansy dla przedsiębiorstwa (Kidd, 1994; Zhang i Sharifi, 1999; Dove, 2001; Jamrog, McCann, Lee, Morrison, Selsky i Vickers, 2006; Doz i Kosonen, 2007).

Tabela 1.1. Kluczowe definicje zwinności prezentowane w najczęściej cytowanych artykułach

\begin{tabular}{|l|c|c|l|}
\hline \multicolumn{1}{|c|}{ Zwinność - definicja } & $\begin{array}{c}\text { Liczba cy- } \\
\text { towań wg } \\
\text { bazy } \\
\text { Google } \\
\text { Scholar* }\end{array}$ & $\begin{array}{c}\text { Liczba cy- } \\
\text { towań wg } \\
\text { bazy } \\
\text { Web of } \\
\text { Science* }\end{array}$ & Autor, rok \\
\hline $\begin{array}{l}\text { Zdolność przedsiębiorstwa do przygotowa- } \\
\text { nia oferty umożliwiającej sprostanie zmie- } \\
\text { niającym się wymaganiom indywidualnych } \\
\text { klientów }\end{array}$ & 459 & - & $\begin{array}{l}\text { Agile Forum AT } \\
\text { Iacocca Institute, } \\
\text { Lehigh University, } \\
\text { USA (1991) }\end{array}$ \\
\hline $\begin{array}{l}\text { Zdolność przedsiębiorstwa do odpowiedzi } \\
\text { na zmiany we właściwy sposób i w jak naj- } \\
\text { szybszym czasie oraz wykorzystanie nadcho- } \\
\text { dzących zmian w otoczeniu gospodarczym } \\
\text { jako szans dla tworzenia przewagi konku- } \\
\text { rencyjnej }\end{array}$ & 879 & - & Kidd (1994) \\
\hline $\begin{array}{l}\text { Zdolność przedsiębiorstwa do kompleksowej, } \\
\text { strategicznej reakcji na fundamentalne i nie- } \\
\text { odwracalne zmiany strukturalne, które pod- } \\
\text { ważają ekonomiczne podstawy konkurencji } \\
\text { masowej produkcji }\end{array}$ & 2456 & - & $\begin{array}{l}\text { Goldman, Nagel i Pre- } \\
\text { is (1995) }\end{array}$ \\
\hline
\end{tabular}


cd. tab. 1.1

\begin{tabular}{|c|c|c|c|}
\hline $\begin{array}{l}\text { Zdolność produkowania i skutecznego ofero- } \\
\text { wania szerokiego zakresu niskokosztowych, } \\
\text { wysokiej jakości produktów w krótkim czasie } \\
\text { oraz w pełnej gamie rozmiarów, dzięki czemu } \\
\text { przedsiębiorstwo tworzy wartość dla klienta } \\
\text { poprzez kastomizację }\end{array}$ & 183 & - & $\begin{array}{l}\text { Vokurka i Fliedner } \\
(1998)\end{array}$ \\
\hline $\begin{array}{l}\text { Zdolność przedsiębiorstwa do szybkiej i efek- } \\
\text { tywnej odpowiedzi na nadchodzącą zmianę }\end{array}$ & 75 & - & McGaughey (1999) \\
\hline $\begin{array}{l}\text { Umiejętność przedsiębiorstwa przetrwania } \\
\text { dzięki szybkiej i efektywnej reakcji na zmia- } \\
\text { ny rynkowe, napędzane przez zaprojektowane } \\
\text { przez klientów produkty i usługi }\end{array}$ & 714 & 200 & Gunasekaran (1999a) \\
\hline $\begin{array}{l}\text { Zdolność przedsiębiorstwa do radzenia so- } \\
\text { bie z nieprzewidywalnymi zmianami w celu } \\
\text { przetrwania zagrożeń występujących w oto- } \\
\text { czeniu biznesowym oraz wykorzystywanie } \\
\text { zmian jako szans dla tworzenia przewagi kon- } \\
\text { kurencyjnej }\end{array}$ & 667 & 147 & Zhang i Sharifi (2000) \\
\hline $\begin{array}{l}\text { Zdolność organizacji do zdobycia przewagi } \\
\text { konkurencyjnej dzięki inteligentnemu, szyb- } \\
\text { kiemu i proaktywnemu wykorzystaniu szans } \\
\text { w otoczeniu i odpowiedniej reakcji na za- } \\
\text { grożenia }\end{array}$ & 130 & - & $\begin{array}{l}\text { Meredith i Francis } \\
(2000)\end{array}$ \\
\hline $\begin{array}{l}\text { Zdolność do przeprowadzenia wydajnej zmia- } \\
\text { ny poziomu operacyjnego jako odpowiedzi } \\
\text { na niepewność i zmieniające się wymagania }\end{array}$ & 462 & 163 & $\begin{array}{l}\text { Narasimhan, Swink } \\
\text { i Kim (2006) }\end{array}$ \\
\hline $\begin{array}{l}\text { Zdolność przedsiębiorstwa do myślenia } \\
\text { i działania w inny, nieznany dotąd sposób, } \\
\text { prowadzący do opracowania nowych, inno- } \\
\text { wacyjnych modeli biznesowych }\end{array}$ & 277 & - & $\begin{array}{l}\text { Doz i Kosonen } \\
(2008 \mathrm{a})\end{array}$ \\
\hline $\begin{array}{l}\text { Koncepcja skierowana na osiągnięcie przewa- } \\
\text { gi konkurencyjnej w turbulentnym otoczeniu. } \\
\text { Zdolność do „zarządzania niepewnością” po- } \\
\text { przez dostępne opcje w ramach obecnej kon- } \\
\text { figuracji oraz ustalonych z góry ograniczeń }\end{array}$ & 210 & 54 & $\begin{array}{l}\text { Bernardes i Hanna } \\
(2009)\end{array}$ \\
\hline $\begin{array}{l}\text { Umiejętność wykorzystania pojawiających } \\
\text { się okazji dzięki takim cechom przedsiębior- } \\
\text { stwa, jak: bystrość, elastyczność, inteligen- } \\
\text { cja i spryt }\end{array}$ & 72 & - & Trzcieliński (2011) \\
\hline $\begin{array}{l}\text { Zdolność przedsiębiorstwa do umiejętności } \\
\text { identyfikacji zmian w otoczeniu i sprawne- } \\
\text { go reagowania na nie dzięki szybkiemu do- } \\
\text { stosowaniu zasobów, procesów, wiedzy oraz } \\
\text { umiejętności }\end{array}$ & 38 & 13 & $\begin{array}{l}\text { Yang i Liu } \\
(2012)\end{array}$ \\
\hline
\end{tabular}

* Cytowania wg bazy cytowań Google Scholar oraz bazy Web of Science - z dnia 30.06.2017 r. 
Zestawienie definicji w tabeli 1.1 wskazuje na niejednoznaczność zagadnienia zwinności, autorzy zauważają zarówno na jej charakter proaktywny, jak i reaktywny. Naukowcy rozpatrują odmienne aspekty zwinności oraz analizują różne jej perspektywy (Yusuf, Sarhadi i Gunasekaran, 1999), co świadczy o wielowymiarowości i braku precyzji w definiowaniu teoretycznego konstruktu, jakim jest zwinność (Tsourveloudis i Valavanis, 2002). Można uznać, że nie istnieje jedna wspólna definicja przyjęta i obowiązująca przez społeczność naukową. Jednak widoczna jest zgodność autorów w terminologii dotyczącej istoty zwinności, określenia jej jako zdolności (czy umiejętności ${ }^{4}$ ) przedsiębiorstwa do dostosowywania swoich strategii, procesów, zasobów do sprostania zmianom (Almahamid Awwad i McAdams, 2010), ze szczególnym uwzględnieniem zdolności do szybkiej reakcji na nieprzewidziane zdarzenia (Mahmoud Hamad i Yozgat, 2017). W większości formułowanych definicji autorzy utożsamiają zwinność ze zdolnością przedsiębiorstwa do wykorzystania szansy, szybkiej i efektywnej odpowiedzi na zmiany, umiejętności podejmowania zmian na poziomie operacyjnym i strategicznym. Uogólniając, zwinność jest to zdolność przedsiębiorstwa ukierunkowana na adaptację (procesy dostosowawcze), która może mieć charakter reaktywny bądź proaktywny. Zapewnienie adaptacji wymaga szeroko rozumianej elastyczności. Umiejętności dostosowawcze przedsiębiorstw są wspierane poprzez organizacyjną zdolność do przewidywania zmian oraz szybkie adaptowanie się do nowego otoczenia (poprzez działania reaktywne), a nawet wywoływanie zmian warunków rynkowych w celu czerpania z nich korzyści (działania proaktywne). Ze względu na szeroki zakres przedmiotowy prezentowany w kontekście definiowana zwinności podjęto próbę zrekonstruowania dotychczasowych definicji w formie schematu (rysunek 1.1). Na

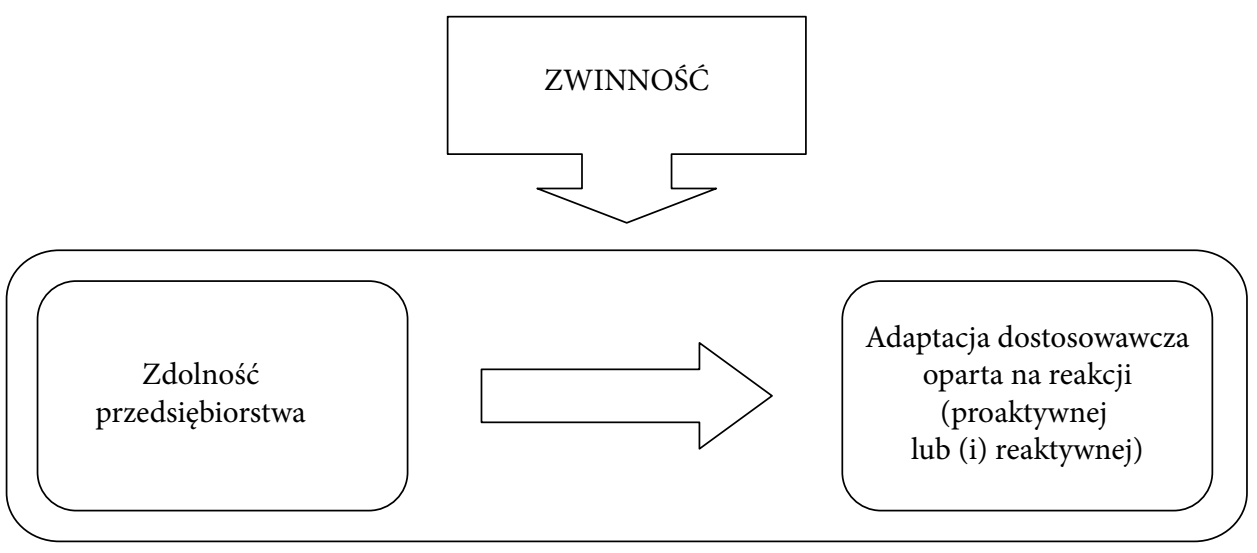

Rysunek 1.1. Zwinność w ujęciu definicyjnym

4 Pojęcia capability lub ability w języku angielskim są używane zamiennie, tłumaczy się je jako zdolność lub umiejętność. W dalszej części pracy autorka, znając różnice semantyczne obu terminów, będzie wykorzystywać je jako synonimy, definiując zdolność jako „mający predyspozycje do łatwego opanowania pewnych umiejętności” (sjp.pwn.pl, data odczytu 30.05.2017 r.). 
tym etapie rozprawy przedstawiono jedynie ogólną definicję zwinności podsumowując dotychczasowy dorobek literaturowy. W podrozdziale 1.3 zostanie zaprezentowany rozwój idei zwinności przedsiębiorstw ze wskazaniem na jej rodzaje, a dopiero w rozdziale 3.1 zostanie zaprezentowana autorska definicja zwinności strategicznej opracowana na podstawie podejść i koncepcji teoretycznych omówionych $\mathrm{w}$ rozdziale 2 .

W literaturze wykorzystuje się różne własności mające wskazywać na charakter zmiany w procesach konkurowania i otoczenia przedsiębiorstw. Jedną z nich jest otoczenie dużej prędkości - charakteryzujące się złożonymi i nieprzewidywalnymi zmianami przejawiającymi się we wstrząsach rynkowych. W otoczeniu dużej prędkości ${ }^{5}$ (high velocity) wymagana jest wysoka zdolność dostosowawcza organizacji w konfrontacji z dynamiką otoczenia i ograniczonymi możliwościami prognozowania. Podkreśla się znaczenie elastyczności, wrażliwości oraz prostych zasad (Eisenhardt i Sull, 2001). Kluczem wyjaśniającym charakter otoczenia dużej prędkości jest szybka, nieciągła i jednoczesna zmiana popytu, konkurentów, technologii i relacji, której konsekwencją jest przyjęcie założenia dotyczącego właściwości informacji, a więc faktu, że informacja jest tymczasowa, nieprecyzyjna, a nawet niedostępna (Bourgeois i Eiesenhardt, 1998, s. 816-835). W otoczeniu dużej prędkości nie chodzi jedynie o to, że zmian nie można przewidzieć, ale głównie o to, że jeśli się już pojawią, to ocena ich znaczenia jest znacznie utrudniona. W takim otoczeniu występuje ciągła dynamika procesów lub zmienność, których charakterystyką jest gwałtowna zmiana nieciągła. M. Fisher (1997, s. 105-116) uznaje, że kluczowa dla sukcesu organizacji działającej w otoczeniu dużej prędkości jest cecha wrażliwości i uważności na otoczenie. Proaktywność odgrywa istotną rolę i jest uznawana za centralny obszar strategii, warunkujący wykorzystanie szans (Nelson i Winter, 1982; Wirtz, Mathieu i Schilke, 2007). W otoczeniu, w którym istnieją dynamiczne i złożone rynki, przewaga konkurencyjna ma jedynie znaczenie tymczasowe. Niezwykle potrzebna staje się propozycja ciągłego przekształcania przedsiębiorstwa (continuous morphing) zaproponowana przez V. Rindova oraz S. Kotha (2001), polegająca na częstym odnawianiu przewagi konkurencyjnej. Cykle życia produktów i cykle innowacji są krótkie, a wymagania i potrzeby klientów - zmienne. $Z$ tego względu proaktywność ma kluczowe znaczenie w utrzymaniu przywództwa rynkowego a także w utrzymaniu premii pierwszeństwa w otoczeniu dużej prędkości (Stańczyk-Hugiet, 2017).

Istnieje wiele sposobów wyjaśniania istoty relacji między organizacją a otoczeniem, jednym z nich jest perspektywa adaptacyjna postrzegana przez pryzmat teorii racjonalnej adaptacji. Nieodłączną cechą adaptacji jest proces spójnego rekonfigurowania zasobów ze strategią przedsiębiorstwa w celu osiągnięcia stanu dopasowy-

5 Termin „otoczenie dużej prędkości” wywodzi z się z badań prowadzonych przez K.M. Eisenhardt, J.A. Martin (2000). Badania te pozwalają na uznanie, że właściwym atrybutem otoczenia jest duża prędkość. 
wania do permanentnych zmian w otoczeniu (Chakravarthy, 1982). Teoria adaptacji eksponuje znaczenie posiadania przez przedsiębiorstwo zdolności do systematycznego dostosowywania się do zmian w otoczeniu. Co więcej, uznaje się, że organizacje mają zdolność do rozpoznawania otoczenia, interpretowania pojawiających się problemów i zmiany wewnętrznej organizacji, co warunkuje ich przetrwanie (Stańczyk-Hugiet, 2017). G.T. Lumpkin oraz G.G. Dess (1996) definiują adaptacyjność jako chęć do podejmowania zmian podczas nieustannie zmieniającego się otoczenia biznesowego. Perspektywa adaptacji oznacza, że wszelkie zmiany w organizacji są indukowane przez otoczenie. Organizacje różnicują swoje działania w poszukiwaniu sposobu na zniwelowanie niedopasowania do otoczenia, podejmując zmiany zgodnie z przyjętymi ścieżkami rozwoju (Smith i Cao, 2007, s. 331).

Istotny wkład w dorobek teorii adaptacji mają zaproponowane przez L. Hrebiniaka i W. Joycea (1985) wzorce strategicznej adaptacji organizacyjnej opierające się na założeniu, że organizacja nie jest wyłącznie pasywnym odbiorcą sygnałów płynących z otoczenia, ale ma także możliwości i cechy, dzięki którym może kształtować otoczenie. Korzystając ze swobody decyzyjnej, organizacje mogą podejmować zachowania adaptacyjne (strategie). $\mathrm{W}$ rezultacie adaptacja jest procesem dynamicznym łączącym w sobie element aktywności ze strony menedżerów i oddziaływania otoczenia, zatem ma charakter wzajemnego dostosowania (Stańczyk-Hugiet, 2017). Adaptacyjność podkreśla konieczność działań reaktywnych, responsywność jest uznawana za kluczowy proces w organizacji adaptacyjnej. Proces reagowania (responsywność) opiera się na zdolności efektywnego wyczuwania (sensing) zmian w otoczeniu, określanego także wrażliwością na otoczenie. Warunkiem adaptacji jest posiadanie unikatowych umiejętności adaptacyjnego uczenia się (adjustment learning) (Morgan, 2008; Senge, 1990). Procesy uczenia się utrzymują organizację na poziomie adaptacji dostosowawczej, mogą mieć jednak głębszy wymiar i wówczas stawiają organizację na wyższym poziomie adaptacji rozwojowej lub kreatywnej (Kasprzak, 2000).

Zwinność stanowi relatywnie nowy termin w badaniach z zakresu zarządzania. Różnorodność podejmowanych w literaturze wątków badawczych utrudnia systematyzację istniejącego dorobku z zakresu zwinności. H. Shin i współautorzy (2015) wskazują, że badania dotyczące zwinności najczęściej dotyczą dwóch aspektów. W pierwszym zwinność jest rdzenną zdolnością przedsiębiorstwa skoncentrowaną na zewnątrz, która umożliwia mu szybkie dostosowanie działań operacyjnych do radzenia sobie z burzliwymi warunkami rynkowymi oraz nagłymi zmianami w wymaganiach klientów (Braunscheidel i Suresh, 2009). W drugim aspekcie zakłada się, że zwinność nie ogranicza się do umiejętności na poziomie operacyjnym, ale stanowi zdolność zorientowaną strategicznie, opartą na zróżnicowanych umiejętnościach (Dyer i Shafer, 1998; Zhang i Sharifi, 1999; Yusuf i in., 1999; Cao i Dowlatshahi, 2005; Li, Chung, Goldsby i Clyde, 2008; Brannen i Doz, 2012). Odwołując się do tego aspektu, zwinność przedsiębiorstwa nie powinna się przejawiać jedynie w elastyczności działania na poziomie operacyjnym, ale także powinna się koncen- 
trować na dostosowywaniu swoich działań strategicznych do zmian w otoczeniu. Wspomniani autorzy (Shin i in., 2015), opowiadając się za drugim z prezentowanych podejść, przekonują, że jest ono znacznie odpowiedniejsze dla współczesnych przedsiębiorstw prowadzących działalność $\mathrm{w}$ dynamicznie zmieniającym się otoczeniu pod warunkiem, że traktuje się je w sposób holistyczny i wprowadza na wszystkich poziomach i obszarach działalności przedsiębiorstwa.

Pojęcie zwinności ma także swoje konotację z metodykami zwinnymi w zarządzaniu projektami wykorzystywanymi w ramach adaptacyjnego zarządzania projektami (Agile Project Management - APM) (Highsmith, 2005, s. 13-19). W kontekście zarządzania projektami przymiotnik zwinny (agile) oznacza taki styl zarządzania projektem, aby mógł on posłużyć do niezawodnego wytworzenia innowacyjnego produktu w trudnych warunkach niepewności, wynikających $\mathrm{z}$ jednej strony $\mathrm{z}$ niejasnych końcowych własności wytwarzanego produktu, a z drugiej - z braku ustalonych i przetestowanych sposobów jego wytworzenia (spowodowanych wykorzystaniem najnowszych technologii, sposobów produkcji czy też udziału interdyscyplinarnego zespołu).

\subsection{Rozwój idei zwinności przedsiębiorstw}

Zwinność przedsiębiorstw obejmuje wiele zagadnień, których listę trudno uznać za zamkniętą. Wynika to $\mathrm{z}$ faktu, że pojęcie zwinności jest przedmiotem zainteresowania $\mathrm{w}$ wielu dyscyplinach naukowych. Problem badawczy zwinności przedsiębiorstw po raz pierwszy został sformułowany przez czterech autorów (Goldman, Preiss, Nagel i Dove, 1991) tworzących formację Agile Forum AT Iacocca Institue, Lehigh University, USA, w 1991 roku (Iacocca Institute, 1991) jako termin zwinności wytwarzania (agile manufacturing - AM). Badacze byli poproszeni przez Kongres Amerykański do opracowania raportu okolicznościowego dotyczącego strategii wytwarzania przedsiębiorstw w XXI wieku. W raporcie ustalono, że obecny system produkcji masowej nie był wystarczający w zakresie zapewniania poprawy parametrów konkurencyjności przedsiębiorstw przy tak dużym natężeniu konkurowania przedsiębiorstw azjatyckich, których przewagą była elastyczność działania. Wnioskiem $\mathrm{z}$ raportu była potrzeba opracowania nowego systemu wytwarzania, który byłby oparty właśnie na zwinności przedsiębiorstwa umożliwiającej zaspokojenie potrzeb generowanych przez nowe czynniki konkurencyjności. Krótko po pojawieniu się raportu założono Agile Manufacturing Enterprise Forum (AMEF), którego celem było rozprzestrzenienie informacji oraz zachęcenie amerykańskich przedsiębiorstw do korzystania z opracowanej koncepcji. W praktyce w połowie lat 90. koncepcja „zwinnego przedsiębiorstwa” została chętnie zaadaptowana przez naj- 
większe amerykańskie koncerny, zwłaszcza w branży IT i sektora telekomunikacyjnego. Na początku XX wieku Microsoft reklamował się poprzez slogan „zwinny biznes" (agile business), ukierunkowując całą strategię na zaadaptowanie zwinnego modelu, mając na uwadze zarówno potrzeby swoje, jak i klientów. Takie przedsiębiorstwa jak IBM czy Google także opierały swoje działania na zwinnym zarządzaniu, chcąc podwyższyć konkurencyjność (Dyer i Shafer, 1998).

Koncepcja zwinności produkcyjnej polega na zachęcaniu przedsiębiorstw produkcyjnych do przygotowania oferty umożliwiającej sprostanie zmieniającym się wymaganiom indywidualnych klientów. Zatem u podstaw obu podejść MC (mass customisation) oraz AM leży chęć sprostania oczekiwaniom i aspiracjom indywidualnych klientów (Vindoch, Sundararaj, Devadasan, Kuttalingam i Rajanayagam, 2010). Od tego czasu zagadnienie zwinności przedsiębiorstw znacznie ewoluowało, rozwijając się w obszarze organizacyjnym oraz łańcuchów dostaw, aż dostrzeżono jego walory strategiczne.

Pogłębiona analiza literatury dostarcza ciekawych wniosków dotyczących rozwoju idei zwinności przedsiębiorstw w czasie, wskazując na trzy wyłaniające się jej rodzaje, które rozwijały się na przestrzeni ćwierćwiecza: zwinność wytwarzania, zwinność organizacyjna ${ }^{6}$ oraz zwinność strategiczna. Każdy z kolejnych rodzajów zwinności dotyczy innego kluczowego aspektu dostosowania przedsiębiorstwa do otoczenia. Zaprezentowane etapy rozwoju zwinności (rysunek 1.2) wynikają z naturalnego rozwoju nauk o zarządzaniu, dla których bodźcem zawsze był rozwój cywilizacji oraz odkrycia naukowe rozpoczynające nową jakościową fazę, nazywaną zwykle rewolucją. Rewolucja przemysłowa na przełomie XIX i XX wieku, związana z szybką ewolucją nauki i wynalazkami technicznymi, przyczyniła się między innymi do rozwoju przemysłu samochodowego (H. Ford w 1913 roku rozpoczął w USA taśmową produkcję samochodów na masową skalę). W historii niezwykle istotną rolę odegrały także wizjonerskie projekty, które doprowadziły do opracowania i powszechnego wykorzystania internetu. Przełom ten zapoczątkował nową erę, zwaną epoką społeczeństwa informacyjnego czy gospodarką opartą na wiedzy. Rosnący poziom wiedzy kadry zrządzającej oraz wzrastająca turbulencja otoczenia kształtowały kolejne etapy w rozwoju idei zwinności, dostosowując jej rodzaje do aktualnie podejmowanych wyzwań otoczenia.

Aby zrozumieć istotę zwinności wytwarzania, należy sięgnąć do jej korzeni, czyli do rozwoju produkcji przemysłowej. Rozwojowi technologicznemu towarzyszył, czasami go wyprzedzając, a częściej następując po nim, rozwój organi-

${ }^{6}$ Zwinność organizacyjna (organizational agility) - jest bezpośrednim tłumaczeniem z języka angielskiego, na potrzeby pracy przytaczane są oryginalne użyte przez autorów terminy, jednak przegląd badań wskazuje, że odnoszą się one do działalności gospodarczej, a podmiotami badań są przedsiębiorstwa. Zwinność organizacyjna dotyczy aspektów organizacji procesów (nie tylko produkcyjnych) i zasobów przedsiębiorstwa w taki sposób, aby mogło ono uzyskać i utrzymać przewagę konkurencyjną w niestabilnym otoczeniu (więcej o zwinności organizacyjnej znajduje się na stronach 33-34). 


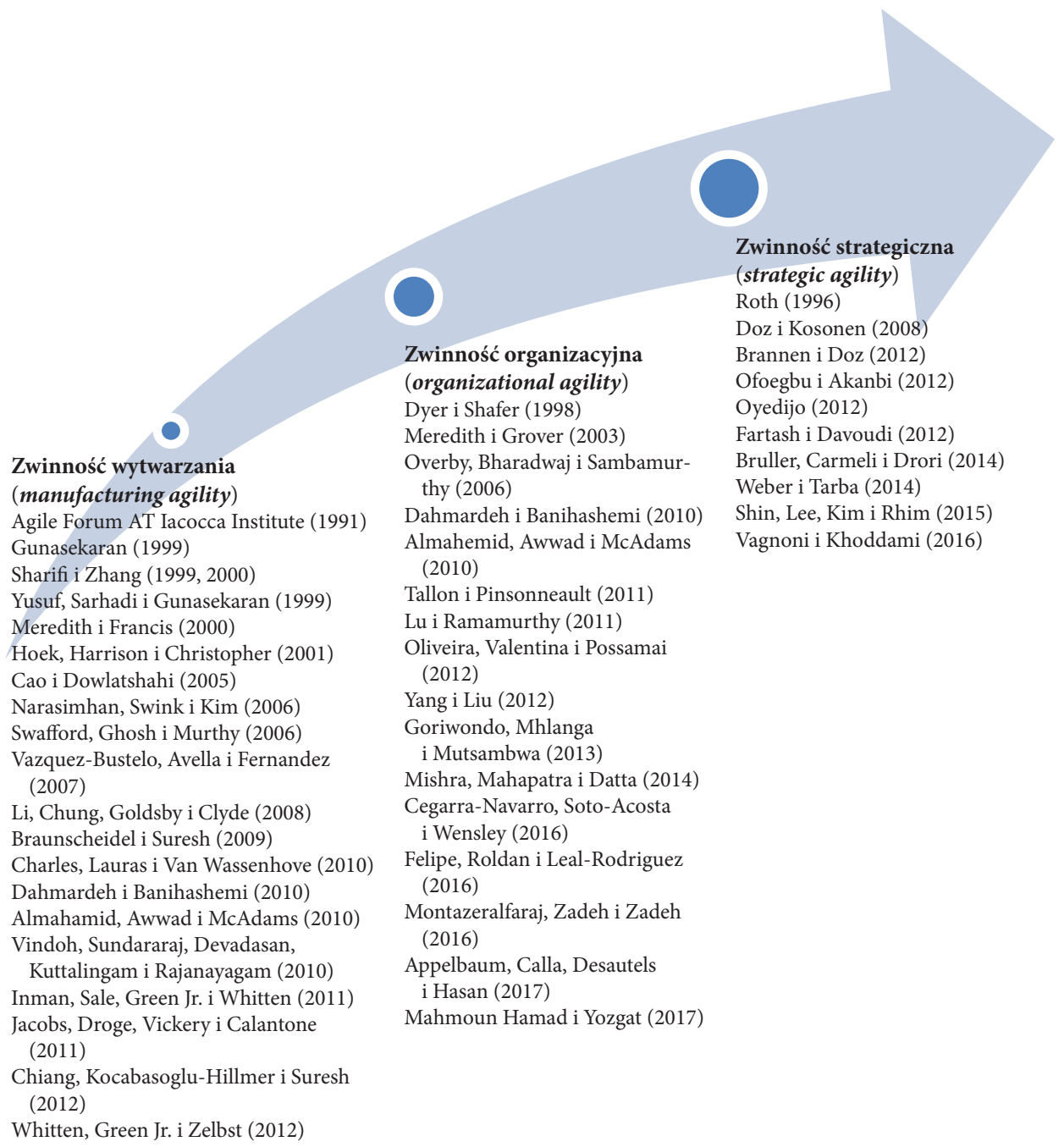

\section{Rysunek 1.2. Rozwój idei zwinności przedsiębiorstwa}

zacyjny, który od samego początku ery produkcji przemysłowej był zauważalny w dwóch obszarach: organizacji produkcji (organizacji procesów wytwórczych) i organizacji zarządzania (struktury organizacyjne oraz procesy informacyjno-decyzyjne, w tym koncepcje i metody zarządzania). Można w nim wyróżnić cztery fazy oparte na odmiennych koncepcjach produkcji przemysłowej: produkcję w manufakturach, produkcję masową, szczupłe wytwarzanie oraz produkcję zwinną (Trzcieliński, 2011, s. 10-14, Smith, D.C., 1992; Womack, Jones i Roos, 1990; Hormozi, 2001) - rysunek 1.3. 


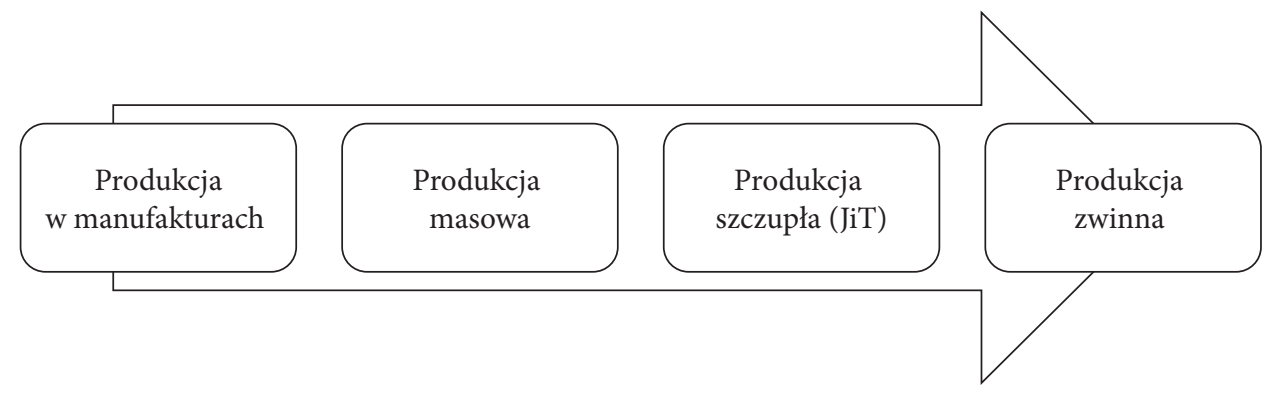

\section{Rysunek 1.3. Etapy produkcji przemysłowej}

Źródło: (Hormozi, 2001).

Produkcja w manufakturach (rzemieślnicza) - zapoczątkowana w drugiej połowie XVIII wieku pierwszą rewolucją przemysłową, powstała w efekcie zastosowania maszyn i zmniejszenia udziału pracy ręcznej, typowej dla rzemiosła. Produkcja w manufakturach była oparta na dużych umiejętnościach i wprawie pracowników, którzy posługując się uniwersalnym wyposażeniem (Dove, 2001, s. 5), wytwarzali wyroby zaspokajające indywidualne oczekiwania klientów. Uniwersalność dotyczyła zarówno umiejętności pracowników, jak i rozwiązań technicznych niezbędnych do produkcji (Womack i in., 1990). Wyroby odznaczały się wysoką jakością, ale jednocześnie wysokimi kosztami produkcji oraz cenami.

Produkcja masowa - oparta na paradygmacie ekonomii skali uzyskiwanej dzięki specjalizacji (Dove, 2001, s. 5-6) zarówno w sferze procesów produkcyjnych, jak i zarządzania. W układzie dychotomicznym można rozróżnić jej dwie skrajne formy - technologiczną i przedmiotową. O ile w procesie produkcyjnym w manufakturach dominowała specjalizacja przedmiotowa (wąska grupa pracowników wykonywała gotowy produkt), o tyle w produkcji masowej pojawiły się obie formy - specjalizacja technologiczna występowała głównie w procesach obróbki, natomiast specjalizacja przedmiotowa zdominowała procesy montażowe - zorganizowane albo w linie produkcyjne o obciążeniu stałym, albo w linie przezbrajane. Produkcja masowa spowodowała znaczne obniżenie kosztów i cen wyrobów na skutek ekonomii skali, jednak skutkowało to małą zdolnością producentów do zaspokojenia zindywidualizowanych potrzeb odbiorców. Rezultatem produkcji masowej było polepszenie standardów życia społecznego poprzez podwyższenie płacy pracowników. Nastąpiło jednak znaczne ograniczenie kreatywności dotyczącej efektów ich pracy, co stanowiło największą wadę produkcji masowej.

Szczupłe wytwarzanie (lean manufacturing) - przyjęcie przez Toyotę założenia, że można zmniejszyć koszty produkcji samochodów bez ekonomii skali, zapoczątkowało pod koniec lat 40. XX wieku trzeci etap produkcji przemysłowej opartej na koncepcji likwidacji marnotrawstwa. Koszty zostały zmniejszone przez zastosowanie metod i narzędzi, które odwołują się do wiedzy, inteligencji, innowacyjności pracowników i są wyrazem istotnego przewartościowania roli człowieka w systemach pro- 
dukcyjnych (Trzcieliński, 2011, s. 13). Porównując do produkcji masowej, w której człowiek (operator) był traktowany w sposób przedmiotowy - jako jedna z części wymiennych, w japońskich modelach „szczupłej produkcji” pracownik był traktowany w sposób podmiotowy - jako sprawca zmian. W przemyśle japońskim szczupłe zarządzanie stało się praktyką w latach 60 . XX wieku. W przemyśle samochodowym wprowadzono wiele usprawnień, co zaowocowało większą zdolnością producentów do zaspokajania zindywidualizowanych potrzeb klientów (częstsze wprowadzanie na rynek nowych modeli samochodów, krótsze serie produkcyjne), zmniejszeniem kosztów bezpośrednich (zmniejszenie zapasów, robót w toku, zmniejszenie liczby produktów wadliwych w cyklu produkcyjnym) i pośrednich (zmniejszenie kosztów magazynowania w magazynach zaopatrzenia i wyrobów gotowych, liczby nastawiaczy i czasów przezbrojeń, amortyzacji przez ograniczenie nadmiernej automatyzacji), a także poprawą jakości wyrobów gotowych (zmniejszenie wadliwości wyrobów, bezawaryjna eksploatacja wyrobów, która pozwoliła kształtować ceny na poziomie rekompensującym zmniejszony efekt ekonomii skali). Wzbudziło to ogromne zainteresowanie metodami lean - zwłaszcza po opublikowaniu książki J.P. Womacka i współautorów (1991), która dostarczyła naukowego wyjaśnienia tej koncepcji, co zapoczątkowało wdrażanie lean management w skali światowej. Struktury organizacyjne uległy spłaszczeniu, a dominującą formą organizacyjną stała się praca zespołowa.

Produkcja zwinna (agile manufacturing) - zmienność i nieprzewidywalność otoczenia sprawiła, że przedsiębiorstwa musiały zmienić sposób postrzegania otoczenia jako niesprzyjającego, a nauczyć się burzliwość i turbulencję traktować jako szansę i możliwość rozwoju. Konceptualizację modeli ujmujących taką percepcję otoczenia rozpoczęli S.L. Goldman i współautorzy (1991), publikując 21st Century manufacturing enterprises strategy: an industry-led view. Wprowadzili w niej pojęcie zwinności (agility), które odnieśli do wytwarzania, produkcji i przedsiębiorstwa. Autorzy zdefiniowali zwinność przedsiębiorstwa jako jego zdolność do odnoszenia sukcesów w konkurencyjnym otoczeniu, w którym permanentnie zachodzą nieprzewidywalne zmiany, stwarzające okazje rynkowe (Goldman i in., 1995, 8, 42-43). A. Gunasekaran określa zwinność jako umiejętność przetrwania i radzenia sobie w konkurencyjnym otoczeniu, pełnym nieprzewidywalnych zmian, wymagających szybkiej i skutecznej reakcji. Chcąc sprostać wymaganiom klientów na zmieniającym się rynku, przedsiębiorstwo musi podjąć szybkie działania umożliwiające utrzymanie przewagi konkurencyjnej. Wprowadza innowacje w procesie produkcyjnym, technologie informacyjne i komunikacyjne wymagające reorganizacji przedsiębiorstwa i nowych strategii marketingowych (Gunasekaran, 1998). Zwinny proces wytwarzania charakteryzuje sześć atrybutów (Meredith i Francis, 2000):

- wytwarzanie na zamówienie - w przeciwieństwie do tradycyjnego procesu produkcyjnego, gdzie produkowano na zapas i przechowywano na składzie,

- sprostanie specyficznym wymaganiom klientów - w przeciwieństwie do masowego procesu produkcyjnego, w którym produkowano dla „przeciętnego” klienta, - osiągnięcie szybkości, elastyczności i funkcjonalności procesu produkcyjnego, 
- inteligentne mobilizowanie i zarządzanie wszelkimi formami wiedzy w celu wsparcia zwinności,

- kreowanie „wirtualnego" projektu i organizacji ad hoc w celu wykorzystania potrzebnych umiejętności wtedy kiedy są potrzebne.

Analizując ewolucje koncepcji przedsiębiorstwa przemysłowego od produkcji w manufakturach po produkcję zwinną, można zauważyć, że przyczyną rozwoju tych koncepcji było dążenie do konkurencyjności przedsiębiorstw w warunkach przełomowych zmian w ich otoczeniu, czyli takich, które przerwały ciągłość wcześniejszych trendów. Porównanie poszczególnych etapów produkcji przemysłowej (tabela 1.2) wskazuje na cechy poszczególnych rodzajów produkcji, w ramach których produkcja zwinna w najwyższym stopniu zwraca uwagę na eliminację marnotrawstwa, elastyczność produkcji oraz wrażliwość na potrzeby klienta, zapewniające przy tym wysoki poziom komunikacji organizacyjnej oraz współpracy.

Tabela 1.2. Porównanie wybranych cech dla odmiennych etapów produkcji przemysłowej

\begin{tabular}{|l|c|c|c|c|}
\hline \multicolumn{1}{|c|}{$\begin{array}{c}\text { Cechy przedsiębiorstw } \\
\text { produkcyjnych }\end{array}$} & $\begin{array}{c}\text { Produkcja } \\
\text { rzemieślnicza }\end{array}$ & $\begin{array}{c}\text { Produkcja } \\
\text { masowa }\end{array}$ & $\begin{array}{c}\text { Produkcja } \\
\text { szczupła }\end{array}$ & $\begin{array}{c}\text { Produkcja } \\
\text { zwinna }\end{array}$ \\
\hline $\begin{array}{l}\text { Nacisk na eliminację marno- } \\
\text { trawstwa }\end{array}$ & średni & niski & wysoki & wysoki \\
\hline $\begin{array}{l}\text { Stopień wyrównywania pozio- } \\
\text { mu produkcji }\end{array}$ & niski & średni /wysoki & wysoki & elstyczny \\
\hline $\begin{array}{l}\text { Poziom komunikacji orgniza- } \\
\text { cyjnej }\end{array}$ & wysoki & niski & wysoki & wysoki \\
\hline Wrażliwość na potrzeby klienta & wysoka & niska & średnia & wysoka \\
\hline $\begin{array}{l}\text { Poziom wykwalifikowanych } \\
\text { pracowników }\end{array}$ & wysoki & niski & średni & wysok \\
\hline $\begin{array}{l}\text { Stopień współpracy pomiędzy } \\
\text { przedsiębiorstwami }\end{array}$ & średni & niski & niski & wysoki \\
\hline $\begin{array}{l}\text { Różnica kosztów w zależności } \\
\text { od wielkości serii }\end{array}$ & taka sama & duża & średnia & taka sama \\
\hline Czas realizacji zamówień & zmienny & krótki & krótki & krótki \\
\hline
\end{tabular}

Źródło: (Hormozi 2001, s. 137).

Interesujące w ramach charakterystyki poszczególnych faz produkcji przemysłowej są także implikacje biznesowe sformułowane przez A.M. Hormoziego (2001) (tabela 1.3). Autor uważa, że zwinna produkcja stanowi kolejny logiczny etap ewolucji technologii produkcyjnej nie tylko z punktu widzenia wydajności produkcji i satysfakcji klienta, ale także z punktu widzenia pracowników i korzyści społecznych.

Zdolność przedsiębiorstwa do strategicznej odpowiedzi na nowe kryteria otoczenia biznesowego w praktyce oznacza wykorzystanie metod, procesów produk- 
Tabela 1.3. Implikacje biznesowe dla poszczególnych faz produkcji przemysłowej

\begin{tabular}{|c|c|c|c|c|}
\hline Obszary & $\begin{array}{c}\text { Produkcja } \\
\text { rzemieślnicza }\end{array}$ & $\begin{array}{c}\text { Produkcja } \\
\text { masowa }\end{array}$ & $\begin{array}{l}\text { Produkcja } \\
\text { szczupła }\end{array}$ & $\begin{array}{c}\text { Produkcja } \\
\text { zwinna }\end{array}$ \\
\hline \multicolumn{5}{|c|}{ Wzronictwo } \\
\hline Udogodnienia we wzornictwie & wysokie & niskie & średnie & wysokie \\
\hline $\begin{array}{l}\text { Liczba opcji dostępna dla } \\
\text { klienta }\end{array}$ & wysoka & średnia & średnia & wysoka \\
\hline \multicolumn{5}{|c|}{ Produkcja } \\
\hline Stopień elastyczności & wysoki & niski & średni & wysoki \\
\hline Szybkość produkcji & niska & wysoka & wysoka & wysoka \\
\hline \multicolumn{5}{|c|}{ Dystrybucja } \\
\hline $\begin{array}{l}\text { Liczba wyrobów gotowych } \\
\text { w magazynach }\end{array}$ & brak & wysoka & średnia & niska \\
\hline $\begin{array}{l}\text { Możliwość doskonalenia pro- } \\
\text { duktu na rynku wtórnym }\end{array}$ & mała & średnia & średnia & wysoka \\
\hline \multicolumn{5}{|c|}{ Klient } \\
\hline Satysfakcja z produktu & wysoka & średnia & średnia & wysoka \\
\hline Satysfakcja z usługi & wysoka & niska & średnia & wysoka \\
\hline
\end{tabular}

Źródło: (Hormozi, 2001, s. 138).

cyjnych i organizacyjnych, praktyk i narzędzi, z których większość została do tej pory rozwinięta. Opracowane narzędzia i metody są najczęściej wykorzystywane w przedsiębiorstwach produkcyjnych do zwiększenia efektywności procesów, inne natomiast są wykorzystywane na poziomie zarządzania i organizacji. W osiągnięciu pożądanego poziomu zwinności organizacje najczęściej wykorzystują przekaźniki zwinności (agility providers ${ }^{7}$ ) umożliwiające im uzyskanie i utrzymanie niezbędnych umiejętności zwinnych (Dahmardeh i Banihashemi, 2010). Do najbardziej popularnych przekaźników zwinności należą m.in.: kompleksowe zarządzanie jakością (TQM - total quality management), systematyczne doskonalenie (CI - continuous improvement), outsourcing (OS), partnerstwo w łańcuchu dostaw (SCP - supply chain partnering), zespołowe formy pracy (TBW - team based working), just in time (JiT), upodmiotowienie szczebla wykonawczego (EMP - empowerment) oraz komputerowo zintegrowane systemy zarządzania (ICT - integrated computer based technologies). Implementacja powyższych praktyk wspiera zwinność przedsiębiorstw i zapewnia im szybsze i efektywniejsze sprostanie wymaganiom współczesnych klientów. Jedną z najistotniejszych różnic pomiędzy przedsiębiorstwem charakteryzującym się zwinnością a tradycyjnym jest intensywne wykorzystanie przez te pierwsze zintegrowanych systemów informacyjnych (Mondragon, Lyons

7 Przekaźniki zwinności (agility providers) to pojęcie wprowadzone przez Zhang i Sharifi (1999) i rozwinięte w kolejnej ich publikacji w 2000 roku, oznacza praktyki umożliwiające uzyskanie i utrzymanie niezbędnych umiejętności zwinnych. 
i Kehoe, 2004) w ramach przekaźników zwinności zapewniających najwyższą aktualność i bogactwo danych, jak również efektywną komunikację̧.

N. Dahmardeh i S. Banihashemi (2010) wskazują, że celem zwinności przedsiębiorstwa jest satysfakcja jego klientów i pracowników. W celu osiągnięcia zwinności przedsiębiorstwo musi rozwinąć wyróżniające kompetencje, takie jak: praktyki zarządzania zasobami ludzkimi, technologie informacyjne, praktyki zarządzania zmianą oraz formy współpracy z partnerami biznesowymi nazywane przez autorów właśnie przekaźnikami zwinności. Dzięki nabytym istotnym umiejętnościom przedsiębiorstwo może w odpowiedni sposób zareagować na zmiany następujące $\mathrm{w}$ otoczeniu gospodarczym.

Celem rozwijania zwinności wytwarzania jest szybsza reakcja na zmieniające się wzorce popytu, efektywniejsze zorientowanie na klienta, lepsze zrozumienie jego potrzeb oraz bliższe relacje z klientem. W literaturze wiele uwagi poświęcono identyfikacji atrybutów zwinności wytwarzania (tabela 1.4), zwracając uwagę na charakterystyczne cechy odróżniające przedsiębiorstwa wykorzystujące praktyki wspierające zwinność od przedsiębiorstw niewykorzystujących umiejętności charakterystycznych dla zwinności.

Tabela 1.4. Porównanie przedsiębiorstw produkcyjnych zorientowanych i niezorientowanych na praktyki zwinne

\begin{tabular}{|l|l|l|}
\hline \multicolumn{1}{|c|}{ Cechy } & $\begin{array}{c}\text { Przedsiębiorstwo pro- } \\
\text { dukcyjne niewykorzystu- } \\
\text { jące zwinnych praktyk }\end{array}$ & \multicolumn{1}{c|}{$\begin{array}{c}\text { Przedsiębiorstwo produkcyjne wykorzystujące } \\
\text { praktyki zwinne }\end{array}$} \\
\hline $\begin{array}{l}\text { Struktura orga- } \\
\text { nizacyjna }\end{array}$ & $\begin{array}{l}\text { Struktura pozioma, linio- } \\
\text { wa (Maskel, 2001; Vokur- } \\
\text { ka i Fliedner, 1998; Assen, } \\
\text { 2000) }\end{array}$ & $\begin{array}{l}\text { Spłaszczona struktura organizacyjna, zarządzanie ze- } \\
\text { społem (Vokurka i Fliedner, 1998; Bustamante, 1999; } \\
\text { Sohal, 1999; Assen, 2000; Meredith i Francis, 2000; } \\
\text { Hooper, Steeple i Winters 2001; Hormozi, 2001; Ma- } \\
\text { skell, 2001; Mondragon i in., 2004 ) }\end{array}$ \\
\hline $\begin{array}{l}\text { Planowanie } \\
\text { strategiczne }\end{array}$ & $\begin{array}{l}\text { Oparte na umiejętności } \\
\text { kształtowania długookre- } \\
\text { sowego bezpieczeństwa } \\
\text { przedsiębiorstwa }\end{array}$ & $\begin{array}{l}\text { Antycypacja przyszłości poprzez wnikliwy monito- } \\
\text { ring otoczenia oraz identyfikację szans i realistyczną } \\
\text { ocenę możliwości ich wykorzystania (Vazques-Buste- } \\
\text { lo, Avella i Fernandez, 2007) }\end{array}$ \\
\hline $\begin{array}{l}\text { Decentralizacja } \\
\text { władzy }\end{array}$ & $\begin{array}{l}\text { Brak umocowania szczebla } \\
\text { wykonawczego, scentra- } \\
\text { lizowanie władzy, niefor- } \\
\text { malna władza }\end{array}$ & $\begin{array}{l}\text { Samoistna autonomia i umocowanie szczebla wy- } \\
\text { konawczego (empowerment), zespoły pracownicze } \\
\text { tworzą strukturę sieciową interakcji pomiędzy au- } \\
\text { tonomicznymi jednostkami (Vernadat, 1999; Zhang } \\
\text { i Sharifi, 2000; Maskell, 200; Crociott i Youssef, 2003; } \\
\text { Vazques-Bustelo i in., 2007) }\end{array}$ \\
\hline
\end{tabular}

8 Na istotny wpływ przekaźników zwinności (agility providers) na redefinicję celów i zmian strategicznych wskazują D. Vazques-Bustelo i współautorzy (2007). Według F.B. Vernadat (1999) przekaźniki zwinności powinny promować pełną integrację podstawowych elementów przedsiębiorstwa, takich jak zasoby ludzkie, struktura, technologie. 
cd. tab. 1.4

\begin{tabular}{|c|c|c|}
\hline Cechy & $\begin{array}{l}\text { Przedsiębiorstwo pro- } \\
\text { dukcyjne niewykorzystu- } \\
\text { jące zwinnych praktyk }\end{array}$ & $\begin{array}{l}\text { Przedsiębiorstwo produkcyjne wykorzystujące } \\
\text { praktyki zwinne }\end{array}$ \\
\hline $\begin{array}{l}\text { Organizacja } \\
\text { produkcji }\end{array}$ & $\begin{array}{l}\text { Długotrwający, sztywny } \\
\text { proces produkcyjny, nie- } \\
\text { tolerujący zmian }\end{array}$ & $\begin{array}{l}\text { Elastyczny proces, łatwo podlegający rekonfiguracji, } \\
\text { szybko reagujący na zmiany (Kirk i Tebaldi, 1997; } \\
\text { Quintana, 1998; Vernadat, 1999; Sohal, 1999; Malek } \\
\text { i Das 2000; Meredith i Francis, 2000; Maskell, 2001; } \\
\text { Hormozi, 2001; Ramasesh, Kulkarni i Jayakumar, } \\
\text { 2001; Hoek, Harrison i Christopher, 2001; Yusuf, } \\
\text { Adeleye i Sivayoganathan, 2003; Swafford, Ghosh } \\
\text { i Murthy, 2006; Vazques-Bustelo i in., 2007; Dah- } \\
\text { mardeh i Banihashemi, 2010; Chiang, Kocabasoglu- } \\
\text {-Hillmer i Suresh, 2012) }\end{array}$ \\
\hline Poziom jakości & Satysfakcja klienta & $\begin{array}{l}\text { Zachwyt klienta (McGaughey, 1999; Maskell, 2001; } \\
\text { Hormozi, 2001; Hoek i in., 2001) }\end{array}$ \\
\hline $\begin{array}{l}\text { Poziom pro- } \\
\text { duktywności }\end{array}$ & $\begin{array}{l}\text { Stały poziom produk- } \\
\text { tywności bez ewaluacji } \\
\text { i potrzeby udoskonalania }\end{array}$ & $\begin{array}{l}\text { Nagły wzrost produktywności i realna jego ocena, } \\
\text { produktywność i jakość są zintegrowane (Hoek i in., } \\
\text { 2001; Devadasan, Goshteeswaran i Gokulachandran, } \\
\text { 2005; Swafford i in., 2006) }\end{array}$ \\
\hline $\begin{array}{l}\text { Status pracow- } \\
\text { ników }\end{array}$ & $\begin{array}{l}\text { Nieujawnianie wśród pra- } \\
\text { cowników nowych funk- } \\
\text { cji i umiejętności, brak } \\
\text { elastyczności w podejmo- } \\
\text { wanych funkcjach i działa- } \\
\text { niach, ignorowanie zmian }\end{array}$ & $\begin{array}{l}\text { Uczący się pracownicy, wielofunkcyjność, samozaan- } \\
\text { gażowanie pracowników, szeroki zakres umiejętności, } \\
\text { (Vokurka i Fliedner, 1998; Bustamante, 1999; Sohal, } \\
\text { 1999; Maskell, 2001; Hoek i in., 2001; Meredith i Fran- } \\
\text { cis, 2000; Assen, 2000; Zhang i Sharifi, 2000; Hormozi, } \\
\text { 2001; Yusuf Adeleye i Sivayoganathan, 2003; Vazques- } \\
\text {-Bustelo i in., 2007; Ribeiro i Fernandes, 2010) }\end{array}$ \\
\hline $\begin{array}{l}\text { Zaangażowanie } \\
\text { pracowników }\end{array}$ & $\begin{array}{l}\text { Małe zaangażowanie pra- } \\
\text { cowników w podejmowa- } \\
\text { niu decyzji, pracownicy } \\
\text { rzadko dzielą się i wyko- } \\
\text { rzystują swoją wiedzę i po- } \\
\text { mysły }\end{array}$ & $\begin{array}{l}\text { Pełne umocowanie pracowników - pomysły i wiedza } \\
\text { pracowników są często wykorzystywane (Gunaseka- } \\
\text { ran, 1999; Vernadat, 1999; Bustamante, 1999; Mere- } \\
\text { dith i Francis, 2000; Hormozi, 2001; Hoek i in., 2001; } \\
\text { Crociott i Youssef, 2003; Jin-Hi, Anderson i Harrison, } \\
\text { 2003; Vazques-Bustelo i in., 2007) }\end{array}$ \\
\hline Styl kierowania & Autokratyczny & $\begin{array}{l}\text { Zarządzanie oparte na współpracy, kierownictwo } \\
\text { jest wrażliwe na zmiany i skłonne do doskonalenia } \\
\text { (Bustamante, 1999; Hooper, Steeple i Winters, 2001; } \\
\text { Hoek i in., 2001; Crociott i Youssef, 2003; Ribeiro } \\
\text { i Fernandes, 2010) }\end{array}$ \\
\hline $\begin{array}{l}\text { Odpowiedź } \\
\text { na wymagania } \\
\text { klientów }\end{array}$ & $\begin{array}{l}\text { Bardzo wolna ze względu } \\
\text { m.in. na biurokrację }\end{array}$ & $\begin{array}{l}\text { Bardzo szybka, w dużej mierze popyt jest przewi- } \\
\text { dywany (Perry, Sohal i Rumpf, 1999; Maskell, 2001; } \\
\text { Meredith i Francis. 2000; Bustamante, 1999; Assen, } \\
\text { 2000; Hoek i in., 2001; McGaughey, 1999; Almaha- } \\
\text { mid, Awwad i McAdams, 2010; Vindoh, Sundararaj, } \\
\text { Devadasan, Kuttalingam i Rajanayagam, 2010) }\end{array}$ \\
\hline $\begin{array}{l}\text { Cykl życia pro- } \\
\text { duktu }\end{array}$ & Długi i nieefektywny & $\begin{array}{l}\text { Krótki i efektywny ( Meredith i Francis, 2000; Chris- } \\
\text { topher i Towill, 2000; Hoek i in., 2001; Maskell, 2001; } \\
\text { Crociott i Youssef, 2003) }\end{array}$ \\
\hline
\end{tabular}


cd. tab. 1.4

\begin{tabular}{|c|c|c|}
\hline Cechy & $\begin{array}{l}\text { Przedsiębiorstwo pro- } \\
\text { dukcyjne niewykorzystu- } \\
\text { jące zwinnych praktyk }\end{array}$ & $\begin{array}{l}\text { Przedsiębiorstwo produkcyjne wykorzystujące } \\
\text { praktyki zwinne }\end{array}$ \\
\hline $\begin{array}{l}\text { Udoskonalanie } \\
\text { wzornictwa }\end{array}$ & $\begin{array}{l}\text { Bardzo rzadko praktyko- } \\
\text { wane, zazwyczaj stosowa- } \\
\text { ne są jedynie modyfikacje }\end{array}$ & $\begin{array}{l}\text { Bardzo często i systematycznie praktykowane po- } \\
\text { przez prowadzenie eksperymentów (Vernadat, 1999; } \\
\text { Bustamante, 1999; Meredith i Francis 2000; Maskell, } \\
\text { 2001; Crociott i Youssef, 2003, Zhang i Sharifi 2000; } \\
\text { Yusuf i in., 2003) }\end{array}$ \\
\hline $\begin{array}{l}\text { Organizacja } \\
\text { produkcji }\end{array}$ & $\begin{array}{l}\text { Zdominowana poprzez } \\
\text { produkcję wewnętrzną }\end{array}$ & $\begin{array}{l}\text { Zdominowana głównie poprzez montaż komponen- } \\
\text { tów, zlecanie produkcji na zewnątrz, outsourcing }\end{array}$ \\
\hline $\begin{array}{l}\text { Planowanie } \\
\text { produkcji }\end{array}$ & $\begin{array}{l}\text { Długookresowe i nieefek- } \\
\text { tywne (Tersine, Wacker } \\
\text { 2000) }\end{array}$ & $\begin{array}{l}\text { Krótkie, zastosowanie strategii just in time (Takaha- } \\
\text { shi i Nakamura, 2000; Tersine i Wacker, 2000; Mistry, } \\
\text { 2005; Swafford i in., 2006) }\end{array}$ \\
\hline $\begin{array}{l}\text { Zarządzanie } \\
\text { kosztami }\end{array}$ & $\begin{array}{l}\text { Podejście tradycyjne (kla- } \\
\text { syfikacja na koszty ogólne } \\
\text { i koszty zmienne) }\end{array}$ & $\begin{array}{l}\text { Poprzez działania strategiczne, system jakości i pro- } \\
\text { duktywności oparty na kosztach (Hooper i in., 2001) }\end{array}$ \\
\hline Automatyzacja & $\begin{array}{l}\text { Bezpośrednia i sztywna } \\
\text { (Dove 1999) }\end{array}$ & $\begin{array}{l}\text { Elastyczna, podlegająca adaptacji do zmieniających } \\
\text { się warunków otoczenia }\end{array}$ \\
\hline $\begin{array}{l}\text { Integracja tech- } \\
\text { nologii infor- } \\
\text { macyjnej }\end{array}$ & $\begin{array}{l}\text { Bezpośrednia integracja } \\
\text { systemów IT z istniejący- } \\
\text { mi systemami }\end{array}$ & $\begin{array}{l}\text { Integracja systemów IT w ramach radykalnych zmian } \\
\text { w procesach biznesowych (Gunasekaran, 1999; } \\
\text { McGaughey, 1999; Zhang i Sharifi, 2000; Maskell, } \\
\text { 2001; Hormozi, 2001; Crociott i Youssef, 2003; Pa- } \\
\text { ixao i Marlow, 2003; Mondragon, Lyons i Kehoe, } \\
\text { 2004; Swafford i in., 2006) }\end{array}$ \\
\hline $\begin{array}{l}\text { Zmiany } \\
\text { w biznesie } \\
\text { i procesach } \\
\text { technicznych }\end{array}$ & $\begin{array}{l}\text { Bardzo trudne do imple- } \\
\text { mentacji, prawie niemoż- } \\
\text { liwe }\end{array}$ & $\begin{array}{l}\text { Wykorzystanie zestawu elastycznych metod i narzę- } \\
\text { dzi mających wpływ na efektywność procesów ( Gu- } \\
\text { nasekaran, 1999; Hormozi, 2001; Hoek i in., 2001; } \\
\text { Paixao i Marlow, 2003) }\end{array}$ \\
\hline $\begin{array}{l}\text { Orientacja na } \\
\text { innowacje }\end{array}$ & Znikoma & $\begin{array}{l}\text { Zaangażowanie w badania i rozwój oraz implemen- } \\
\text { tacja innowacji - mierzone inwestycjami w nowe } \\
\text { technologie i programy innowacyjne (Vazques-Bu- } \\
\text { stelo i in., 2007) }\end{array}$ \\
\hline $\begin{array}{l}\text { Zarządzanie } \\
\text { czasem }\end{array}$ & Bardzo nieefektywne & Bardzo efektywne (Assen, 2000) \\
\hline Outsourcing & $\begin{array}{l}\text { Wykorzystywana jest je- } \\
\text { dynie współpraca oparta } \\
\text { na umowie }\end{array}$ & $\begin{array}{l}\text { Zarządzanie łańcuchem dostaw (Vokurka i Fliedner, } \\
\text { 1998; Malek i Das, 2000; Christopher i Towill, 2000; } \\
\text { Maskell, 2001) }\end{array}$ \\
\hline
\end{tabular}

Źródło: (Sajdak, 2013c).

Drugim poziomem zwinności, który odcisnął istotne piętno w obszarze nauki i rozwoju tej dziedziny, jest zwinność organizacyjna (organizational agility). Wyznaczone trzy poziomy zwinności (rysunek 1.2) nie oznaczają całkowicie odrębnych jej obszarów czy rodzajów. Jednak rozwój badań (zarówno koncepcyjnych, jak 
i empirycznych) daje wszelkie podstawy do formułowania takiego właśnie kierunku rozwoju zwinności w czasie. Wielu autorów, analizując zagadnienia dotyczące zwinności, zwłaszcza organizacyjnej i strategicznej, traktuje je jako synonimy (organizational agility - enterprise agility - strategic agility), często nie zastanawiając się nad ich pierwotnym znaczeniem i wynikającymi z niego konsekwencjami. Pogłębiona analizy literatury pozwala jednak na zidentyfikowanie kluczowych problemów w obszarze zwinności, z których niemalże naturalnie wynikał rozwój tej koncepcji. Istota samej koncepcji, identyfikowana jako zdolność do szybkiej adaptacji do zmieniających się warunków otoczenia, pozostała bez zmian, ale punkt ciężkości kierunku analiz w obszarze zwinności ewoluował wraz z rozwojem kolejnych dyscyplin naukowych. Tak jak w przypadku zwinności wytwarzania punktem kluczowym analizy była doskonałość operacyjna przejawiająca się w zdolności przedsiębiorstwa do szybkiej i efektywnej odpowiedzi na zmieniające się potrzeby klientów, tak zwinność organizacyjna koncentruje się na aspekcie zwinności związanym ze współpracą zarówno z klientami, jak i innymi interesariuszami przedsiębiorstwa (Sambamurthy, Bharadwaj i Grover, 2003; Tallon i Pinsonneault, 2011). W rozwoju zwinności organizacyjnej dużego znaczenia zaczęły nabierać wiedza (Dahmardeh i Banihashemi, 2010) oraz innowacje i technologie informacyjne (Sambamurthy i in., 2003). Badania dotyczące roli umiejętności zwinnych i praktyk dzielenia się wiedzą w celu utrzymania przewagi konkurencyjnej przedstawili S. Almahamid i współautorzy (2010), w których wykazali że:

- umiejętności zwinne mają znaczący wpływ na przewagę konkurencyjną,

- praktyka dzielenia się wiedzą ma znaczący pozytywny wpływ na organizacyjną przewagę konkurencyjną,

- istnieje potrzeba ustanowienia i implementacji umiejętności zwinnych i praktyk dzielenia się wiedzą w celu uzyskania przewagi konkurencyjnej.

N. Roberts oraz V. Grover (2012) zajmujący się zwinnością współpracy z klientem (customer agility) proponują wyrażenie tego rodzaju zwinności poprzez dwie umiejętności przedsiębiorstwa zdolność do wyczuwania potrzeb klienta oraz zdolność do szybkiego reagowania. Propozycja wyboru właśnie tych umiejętności była poparta wcześniejszymi badaniami, które potwierdziły, że wysoki poziom zdolności do wyczuwania potrzeb klienta oraz umiejętność szybkiego reagowania na nie stanowią krytyczne czynniki determinujące sukces w burzliwym otoczeniu (Haeckel, 1999; Zaheer i Zaheer, 1997). Autorzy analizują znaczenie dostosowania zdolności wyczuwania potrzeb klienta i szybkości reagowania na nie oraz ich wpływu na wyniki działalności przedsiębiorstwa.

Tak istotna dla przedsiębiorstw współpraca przejawiała się także w usieciowieniu (Yang i Liu, 2012). W przeprowadzonych badaniach dotyczących poprawienia wyników przedsiębiorstwa poprzez jego zwinność oraz strukturę sieciową ujawniono, że zarówno zwinność przedsiębiorstwa, jak i struktura sieciowa mają wpływ na wyniki przedsiębiorstwa. 
Kontynuując wątek zwinności organizacyjnej, silnie zaznaczonym aspektem w tym obszarze jest forma przywództwa (Oliveira, Valentina i Possamai, 2012). Temat ten był podejmowany przez badaczy jeszcze w ramach badań nad zwinnością organizacyjną, jednak szczególnie silnie wyłonił się na trzecim poziomie - zwinności strategicznej (strategic agility). Przywództwo strategiczne stanowi kluczowy atrybut zapewniający szybkie, efektywne i skuteczne adaptowanie do nieprzewidzianych zmian oraz reorganizację zasobów przedsiębiorstwa w celu wykorzystania pojawiających się okazji.

Analizując pojęcie przywództwa strategicznego, G. Rowe i M. Nejad (2009, s. 2-6), definiują je jako wyjątkowe połączenie przywództwa wizjonerskiego i menedżerskiego ze zwróceniem szczególnej uwagi na zachowania etyczne i decyzje oparte na wartościach. Przywództwo strategiczne wymaga nadzoru operacyjnego codziennych czynności, a jednocześnie strategicznej - długoterminowej odpowiedzialności. M. Crocitto i M. Youssef (2003, s. 388-397) zwracają uwagę na rolę przywództwa w zwinności, ukierunkowując działania przywódcze na wspieranie pracowników w formułowaniu bezpośrednich relacji z dostawcami i klientami. Autorzy wprowadzają termin „zwinne zarządzanie”, które odnosi się do przywództwa charakteryzującego się zdolnością do kreowania zmian strategicznych. Umiejętności dostosowawcze przedsiębiorstw są wspierane poprzez organizacyjną zdolność do przewidywania zmian oraz szybkie adaptowanie się do nowego otoczenia, a nawet wywoływanie zmian warunków rynkowych w celu czerpania z nich korzyści.

Zarządzanie strategiczne, tradycyjnie związane $\mathrm{z}$ umiejętnością kształtowania długookresowego bezpieczeństwa przedsiębiorstwa, w obecnych czasach nieco zmieniło swoją perspektywę. Jak zauważa P. Banaszyk (2013), długookresowość i bezpieczeństwo są stopniowo degradowane i przestają być potrzebne. Podstawowym instrumentem przestaje być budowa planów, lecz rozpoznawanie prawdopodobieństwa zajścia rozmaitych zdarzeń. Istotne jest odnalezienie lub wykreowanie okazji rynkowej, dlatego szczególnie cenni są pracownicy, którzy charakteryzują się bardzo wysokim stopniem kreatywności i innowacyjności. W tak niepewnych warunkach otoczenia Y. Doz i M. Kosonen (2008a, s. 6) dostrzegli walory zwinności strategicznej jako umiejętności myślenia i działania w inny, nieznany dotąd sposób, inicjowania i doświadczania nowych modeli biznesowych opartych na innowacyjnych rozwiązaniach. Przełomowym momentem, który zapoczątkował zainteresowanie naukowców tym obszarem, było opublikowanie książki Y. Doza oraz M. Kosonena Fast strategy (2008a), w której autorzy wprowadzają pojęcie zwinności strategicznej, wskazując na przyczyny wyłonienia się nowego rodzaju zwinności oraz wymieniając jej charakterystyczne cechy. Naukowcy zauważają, że przedsiębiorstwa same stają się ofiarami swoich sukcesów. W procesie wzrostu i rozwoju tracą umiejętności dostosowawcze. Skupione na realizacji celów, osiąganiu efektywności zapominają o tak istotnej potrzebie elastyczności i zwinności. Sukces wypiera wrażliwość strategiczną. Y. Weber i S.Y Tarba (2014) twierdzą, że celem zwinności strategicznej nie jest umiejętność poradzenia sobie z jedną radykalną zmianą wywołaną 
przez kryzys czy inne nagłe zagrożenie, ale raczej posiadanie stałej umiejętności do zmiany swojego kursu strategicznego w celu zapewnienia i utrzymania przewagi konkurencyjnej. Zwinność strategiczna umożliwia przedsiębiorstwu inicjowanie ciągłych zmian, które obejmują dostosowanie obecnych zasobów i kompetencji do permanentnie zmieniającego się otoczenia przy jednoczesnym ich rekonfigurowaniu dla zapewnienia przeżycia i sukcesu w długim okresie. Wspomniana praca Y. Doza i M. Kosonena (2008a) stanowiła inspirację dla dalszych badań zarówno koncepcyjnych, jak i empirycznych dotyczących zwinności strategicznej (Brannen i Doz, 2012; Ofoegbu i Akanbi, 2012; Oyedijo, 2012; Fartash i Davoudi, 2012; Mavengere, 2013; Fourne, Jansen i Mom, 2014; Weber i Tarba, 2014; Bruller, Carmeli i Drori, 2014; Shin i in., 2015; Vagnoni i Khoddami, 2016). W istocie jednak zagadnienie to nadal nie zostało przez autorów dokładnie rozpoznane, a dotychczasowy stan wiedzy i badań umożliwia wskazanie istotnych luk poznawczych.

Y. Doz i M. Kosonen (2008a, s. 17-35) identyfikują zwinność strategiczną jako decyzje i działania najwyższego kierownictwa dotyczące „przemyślanego i celowego współgrania” pomiędzy trzema metazdolnościami. Pierwszą z nich jest wrażliwość strategiczna (strategic sensitivity) - definiowana jako kombinacja ostrości percepcji oraz wysokiej świadomości i uwagi na warunki zewnętrzne. Strategiczna wrażliwość stanowi kombinację silnego połączenia zewnętrznie zorientowanego procesu strategicznego powiązanego $\mathrm{z}$ wewnętrzną partycypacją (tworzoną poprzez wysoki poziom zaangażowania oraz intensywny i otwarty wewnętrzny dialog). Wrażliwość strategiczna polega na prognozowaniu strategicznym (strategic foresight) i antycypowaniu konsekwencji kluczowych trendów w celu wczesnego zidentyfikowania zagrożeń i niepokojących zjawisk. Dzięki temu podejściu przedsiębiorstwa mogą wykorzystać swoją przewagę i silne strony w celu ochrony przed zagrożeniem lub zaplanować efektywne działania dostosowawcze do nowych standardów. Jednak krytyczną rolę według autorów pełni spojrzenie strategiczne (strategic insight), czyli wnikliwość od wnętrza przedsiębiorstwa. Nacisk kładzie na jakość i intensywność czujności zewnętrznej opartej na posiadaniu dobrej jakości informacji oraz sieci kontaktów z partnerami biznesowymi i interesariuszami przedsiębiorstwa. Nie bez znaczenia jest także poziom świadomości zarządzających dotyczącej potencjału przedsiębiorstwa oraz uwaga skierowana na rozwój strategiczny.

Drugą umiejętność autorzy nazywają jednością przywództwa (leadership unity) - czyli zdolnością zarządzających do podejmowania odważnych i szybkich decyzji na najwyższym szczeblu. Zmiany modeli biznesowych często wymuszają podejmowanie decyzji w warunkach wysokiej nieprzewidywalności z koniecznością uwzględnienia wysokiego ryzyka, przy braku informacji i presji czasu. Taka sytuacja wymaga dokonywania współzależnych wyborów strategicznych. Wymiar kompleksowości stanowi kolejne wyzwanie, w którym zobowiązanie poszczególnych części stanowi sekwencję zintegrowanego łańcucha kreowania wartości. Wzajemne wsparcie strategiczne oraz dzielenie się kluczowymi kompetencjami oraz zasobami intensyfikuje współzależność pomiędzy decyzjami. Decyzje w ramach 
jednego obszaru nie mogą być podejmowane bez wzięcia pod uwagę konsekwencji strategicznych i operacyjnych dla innych obszarów.

Ostatnia wskazana zdolność to mobilność ${ }^{9}$ zasobów (resource fluidity) - zapewniająca szybkie przesunięcie bądź rekonfigurację zasobów i systemów przedsiębiorstwa w celu wykorzystania wyłaniającej się szansy. Jest to możliwe dzięki wykorzystaniu procesów alokacji zasobów, praktykom zarządzania zasobami ludzkimi oraz mechanizmom i bodźcom, dzięki którym modele biznesowe oraz działalność systemu informacyjnego jest szybsza i łatwiejsza. Dzielenie się wiedzą i zasobami niematerialnymi stanowi podstawę tego procesu.

Autorzy podkreślają istotność i kompatybilność wszystkich wymienionych zdolności. Podjęcie dobrych decyzji w ramach tych obszarów nie wystarczy, dopiero możliwość ich wdrożenia zapewni pożądany efekt. Przedsiębiorstwa powinny intensywnie rozwijać wszystkie trzy obszary, gdyż tylko wtedy mogą powiększyć zdolność zwinności strategicznej i zdobyć przewagę konkurencyjną nad swoimi rywalami (Doz i Kosonen, 2008a, s. 33-35). Definicja zwinności strategicznej zaproponowana przez Y. Doza i M. Kosonena stanowiła inspirację i punkt odniesienia dla kolejnych badaczy podejmujących tę tematykę. Większość autorów czerpie bezpośrednio lub pośrednio z pracy Y. Doza i M. Kosonena (2008a). Opracowane przez nich metaumiejętności stały się podstawą dla kolejnych badaczy do eksploracji zagadnienia zwinności strategicznej (tabela 1.5). Choć wielu z nich prezentuje idiosynkratyczne ujęcie zwinności, to jednak retoryka, którą wyrazili Y. Doz i M. Kosonen (2008a) jest uwypuklona w każdej z dostępnych publikacji z zakresu zwinności strategicznej.

Tabela 1.5. Przegląd wybranych definicji zwinności strategicznej

\begin{tabular}{|c|c|c|}
\hline Autorzy & Definicja pojęcia & Przyjęte wymiary zwinności \\
\hline $\begin{array}{l}\text { R.E Morgan } \\
\text { i K. Page (2008) }\end{array}$ & $\begin{array}{l}\text { Zdolność przedsiębiorstwa do podjęcia nagłej } \\
\text { zmiany kierunku strategicznego w celu czer- } \\
\text { pania korzyści ze zmieniających się warun- } \\
\text { ków rynkowych }\end{array}$ & - transformacja biznesu \\
\hline $\begin{array}{l}\text { O.E. Ofoegbu } \\
\text { i P.A. Akanbi } \\
(2012)\end{array}$ & $\begin{array}{l}\text { Zdolność do ciągłego i odpowiedniego ukie- } \\
\text { runkowania strategicznego biznesu przedsię- } \\
\text { biorstwa w zmieniających się okolicznościach } \\
\text { oraz silne eksponowanie wrażliwości przedsię- } \\
\text { biorstwa na otoczenie }\end{array}$ & $\begin{array}{l}\text { - wrażliwość strategiczna } \\
\text { - jedność przywództwa } \\
\text { - mobilność zasobów }\end{array}$ \\
\hline A. Oyedijo (2012) & $\begin{array}{l}\text { Zwinność strategiczną zbadano, wykorzystu- } \\
\text { jąc cztery wymiary: wymiar organizacyjny, } \\
\text { wymiar ludzki, wymiar technologiczny, wy- } \\
\text { miar planowania }\end{array}$ & $\begin{array}{l}\text { - wymiar organizacyjny } \\
\text { - wymiar ludzki } \\
\text { - wymiar technologiczny } \\
\text { - wymiar planowania }\end{array}$ \\
\hline
\end{tabular}

9 O mobilności potencjału pisze J. Lichtarski (2005). 
cd. tab. 1.5

\begin{tabular}{|c|c|c|}
\hline Autorzy & Definicja pojęcia & Przyjęte wymiary zwinności \\
\hline $\begin{array}{l}\text { K. Fartash } \\
\text { i S. Davoudi (2012) }\end{array}$ & $\begin{array}{l}\text { Zdolność do stałego korygowania i dostoso- } \\
\text { wywania kierunku strategicznego. Stanowi } \\
\text { ona funkcje strategicznych ambicji i zmienia- } \\
\text { jących się okoliczności prowadzenia bizne- } \\
\text { su w dążeniu nie tylko do kreowania nowych } \\
\text { produktów i usług, ale także nowych modeli } \\
\text { biznesowych oraz innowacyjnych sposobów } \\
\text { kreowania wartości }\end{array}$ & $\begin{array}{l}\text { - elastyczny outsourcing } \\
\text { - wrażliwość na rynek }\end{array}$ \\
\hline $\begin{array}{l}\text { M. Brannen } \\
\text { i Y. Doz (2012) }\end{array}$ & $\begin{array}{l}\text { Zdolność do rozwoju strategicznych możliwo- } \\
\text { ści oraz podejmowania przemyślanych i termi- } \\
\text { nowych decyzji }\end{array}$ & $\begin{array}{l}\text { - wrażliwość strategiczna } \\
\text { - wybór alternatyw strate- } \\
\text { gicznych }\end{array}$ \\
\hline $\begin{array}{l}\text { N. Bruller, } \\
\text { A. Carmeli } \\
\text { i I. Drori (2014) }\end{array}$ & $\begin{array}{l}\text { Zdolność zorientowaną na zwinne, szybkie } \\
\text { strategiczne działania przedsiębiorstwa im- } \\
\text { plementowane z dużą precyzją }\end{array}$ & $\begin{array}{l}\text { - zorientowanie na tworzenie } \\
\text { kontekstu (knowledgeable } \\
\text { sensmaking) } \\
\text { - zwinne podejmowanie de- } \\
\text { cyzji (nimbie decision ma- } \\
\text { king) } \\
\text { - szybkie przesunięcie zaso- } \\
\text { bów (rapid resource rede- } \\
\text { ployment) }\end{array}$ \\
\hline $\begin{array}{l}\text { Y. Weber i S. Tarba } \\
(2014)\end{array}$ & $\begin{array}{l}\text { Zwinność strategiczna uwzględnia zarówno } \\
\text { zdolność do identyfikowania i oceny szans } \\
\text { w otoczeniu oraz zagrożeń, jak i odpowiedzi } \\
\text { na nie }\end{array}$ & $\begin{array}{l}\text { - przywództwo oparte na } \\
\text { wrażliwości strategicz- } \\
\text { nej i wyczuwaniu kierun- } \\
\text { ku potrzebnych zmian } \\
\text { oraz organizacja zasobów } \\
\text { potrzebnych do realizacji } \\
\text { zmiany } \\
\text { - organizacja mechanizmów } \\
\text { służących adaptacji }\end{array}$ \\
\hline $\begin{array}{l}\text { S. Fourne, J. Jansen } \\
\text { i T. Mom (2014) }\end{array}$ & $\begin{array}{l}\text { Zdolność identyfikowania lokalnych szans } \\
\text { (sensing local opportunities) poprzez utrzymy- } \\
\text { wanie silnych kontaktów z lokalnymi partne- } \\
\text { rami oraz stosowanie zindywidualizowanych } \\
\text { wskaźników oceny i nagradzania inicjatyw }\end{array}$ & $\begin{array}{l}\text { - wyczuwanie lokalnych } \\
\text { możliwości } \\
\text { - wprowadzenie globalnej } \\
\text { komplementarności } \\
\text { - przechwytywanie wartości } \\
\text { lokalnej }\end{array}$ \\
\hline R. Vecchiato (2015) & $\begin{array}{l}\text { Zdolność do ciągłego dostosowywania kie- } \\
\text { runku strategicznego przedsiębiorstwa } \\
\text { w zakresie podstawowej działalności, inter- } \\
\text { pretowana jako funkcja ambicji strategicz- } \\
\text { nych i zmieniających się okoliczności. Polega } \\
\text { na zmianie i dostosowaniu nie tylko nowych } \\
\text { produktów i usług przedsiębiorstwa, ale także } \\
\text { nowych modeli biznesowych i innowacyjnych } \\
\text { sposobów tworzenia wartości (na podstawie: } \\
\text { Doz i Kosonen, 2008) }\end{array}$ & $\begin{array}{l}\text { - wrażliwość strategiczna } \\
\text { - mobilność zasobów } \\
\text { - jedność przywództwa }\end{array}$ \\
\hline
\end{tabular}


cd. tab. 1.5

\begin{tabular}{|c|c|c|}
\hline Autorzy & Definicja pojęcia & Przyjęte wymiary zwinności \\
\hline $\begin{array}{l}\text { H. Shin, J. Lee, } \\
\text { D. Kim i H. Rhim } \\
(2015)\end{array}$ & $\begin{array}{l}\text { Zdolność na poziomie strategicznym do osią- } \\
\text { gnięcia zwinności operacyjnej poprzez sku- } \\
\text { pienie się zarządzających na udoskonaleniu } \\
\text { podstawy przewagi konkurencyjnej dotyczącej } \\
\text { responsywności i umiejętności dostosowania } \\
\text { się do potrzeb i wymogów klientów }\end{array}$ & $\begin{array}{l}\text { - zdolności technologiczne } \\
\text { - wspólne tworzenie inno- } \\
\text { wacji } \\
\text { - organizacyjne uczenie się } \\
\text { - wewnętrzna zgodność } \\
\text { i spójność struktury, celów } \\
\text { i działań }\end{array}$ \\
\hline $\begin{array}{l}\text { E. Vagnoni } \\
\text { i D. Khoddami } \\
(2016)\end{array}$ & $\begin{array}{l}\text { Zdolność, która umożliwia przedsiębiorstwu } \\
\text { wczesne wykrywanie szans, szybkie podejmo- } \\
\text { wanie decyzji oraz działanie z dużą siłą i pre- } \\
\text { cyzją (na podstawie: Doz i Kosonen, 2008) }\end{array}$ & $\begin{array}{l}\text { - } \text { kompetencje IT } \\
\text { - prognozowanie strate- } \\
\text { giczne } \\
\text { - wnikliwa analiza potencjału }\end{array}$ \\
\hline $\begin{array}{l}\text { I. Alon, } \\
\text { M. Madanoglu } \\
\text { i A. Shoham (2016) }\end{array}$ & $\begin{array}{l}\text { Zdolność przedsiębiorstwa do efektywnego } \\
\text { rozwoju swoich modeli biznesowych, wycho- } \\
\text { dzenie naprzeciw turbulentnemu otoczeniu } \\
\text { (na podstawie: Doz i Kosonen, 2008) }\end{array}$ & $\begin{array}{l}\text { - wrażliwość strategiczna } \\
\text { - mobilność zasobów (fran- } \\
\text { chising) } \\
\text { - jedność przywództwa }\end{array}$ \\
\hline $\begin{array}{l}\text { A. Arbussa, } \\
\text { A. Bikfalvi } \\
\text { i P. Marques (2016) }\end{array}$ & $\begin{array}{l}\text { Zwinność strategiczna stanowi kombinację } \\
\text { trzech dynamicznych umiejętności: wrażli- } \\
\text { wości strategicznej, mobilności zasobów oraz } \\
\text { jedności przywództwa (na podstawie: Doz } \\
\text { i Kosonen 2008) }\end{array}$ & $\begin{array}{l}\text { - wrażliwość strategiczna } \\
\text { - mobilność zasobów } \\
\text { - jedność przywództwa }\end{array}$ \\
\hline
\end{tabular}

Przeprowadzona analiza rozwoju idei zwinności wskazała na historyczne uwarunkowania jej pochodzenia, związane między innymi z rozwojem koncepcji produkcji przemysłowej. Zarówno zmiany w otoczeniu przedsiębiorstw (pogłębiająca się globalizacja, nasilające się więzi współzależności między podmiotami gospodarczymi, rozwój procesów integracji w warunkach niestabilności rynków), jak i sposobów zarządzania nimi stanowiły asumpt do rozwoju zwinności i wyłonienia się trzech jej rodzajów. Każdy z wyłonionych rodzajów zwinności w nieco inny sposób ujmuje odpowiedź przedsiębiorstw na zmieniające się wyzwania otoczenia biznesowego. Przeprowadzona systematyzacja zagadnienia pozwoliła na uporządkowanie kwestii dotyczącej zakresu przedmiotowego poszczególnych rodzajów zwinności ze wskazaniem ich cech charakterystycznych.

\subsection{Przegląd badań nad zwinnością przedsiębiorstw w naukach o zarządzaniu}

Poprzedni podrozdział wskazał na rozwój zwinności w czasie, ukazując rozkwit tej koncepcji na przestrzeni ćwierćwiecza, identyfikując trzy kluczowe jej etapy: wytwarzania, organizacyjny oraz strategiczny. W tej części opracowania uwagę skon- 


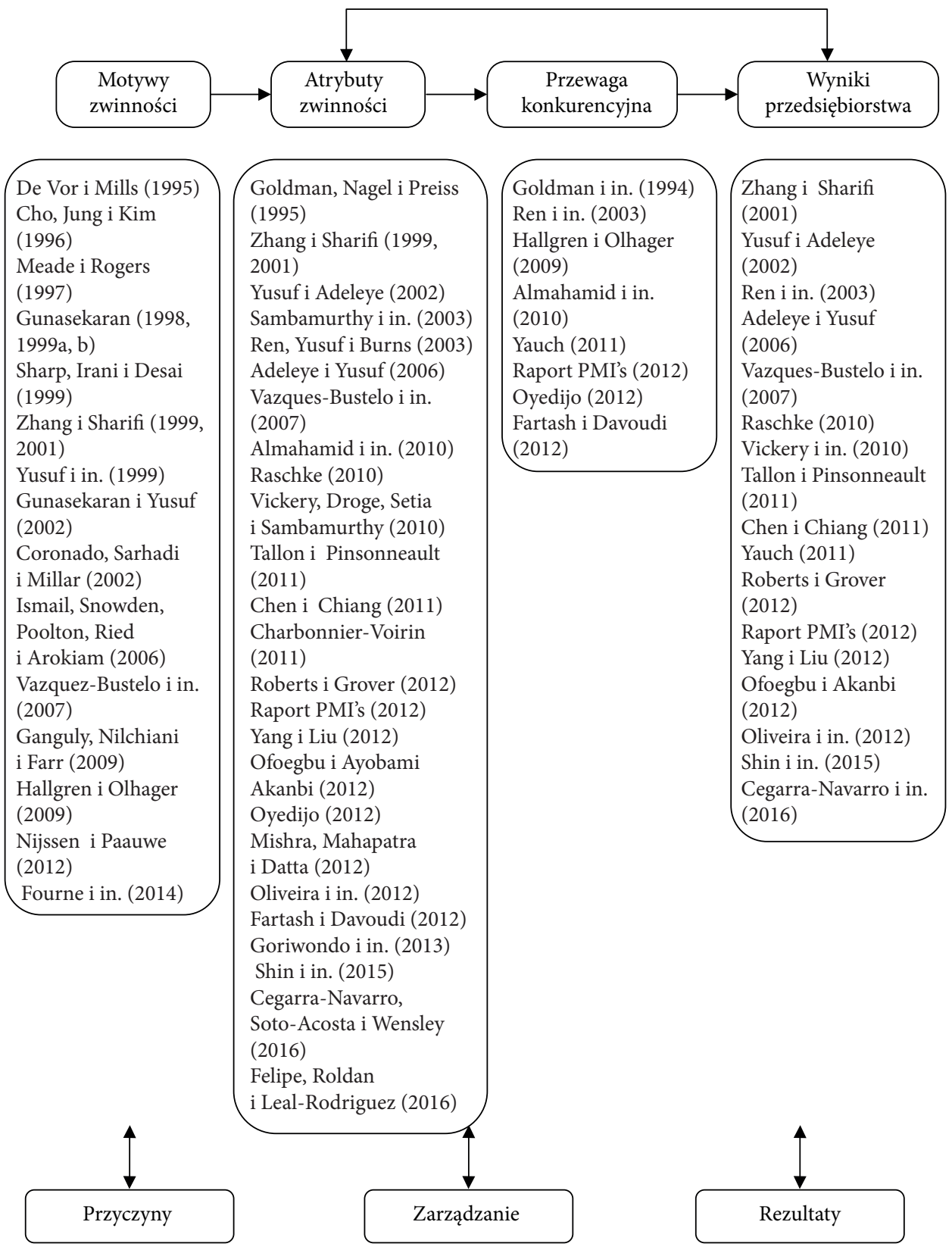

Rysunek 1.4. Przedmiotowy kontekst badawczy w obszarze zwinności przedsiębiorstw 
centrowano na najważniejszych nurtach badawczych prezentowanych w literaturze związanej z dyscypliną nauk o zarządzaniu, a przede wszystkim w obszarze zarządzania strategicznego. Interesujący wydaje się kontekst przedmiotowy, w którego ramach na uwagę zasługują: motywy zwinności, atrybuty zwinności oraz wyniki jego działalności z uwzględnieniem przewagi konkurencyjnej (Sambamurthy i in., 2003; Chen i Chiang, 2011; Yang i Liu, 2012). W obrębie wyłonionych etapów rozwoju zwinności - od zwinności wytwarzania, poprzez zwinność organizacyjną aż po zwinność strategiczną - można wskazać podejmowane, częściowo odrębne, a w większości powiązane problemy badawcze. Zaproponowany podział obszarów badawczych wraz z wykazem głównych prac przedstawiono na rysunku 1.4.

Duże zainteresowanie badaczy przez lata towarzyszyło motywom zwinności. Poszukiwano ich, odwołując się do zmieniających się warunków rynkowych, które stanowiły coraz większe wyzwanie dla przedsiębiorstw. Pomimo że zwinność przedsiębiorstw stanowi stosunkowo nowy obszar badawczy, wymagający pogłębionych badań eksploracyjnych, to temat zdolności i potrzeby przedsiębiorstw adaptacji do zmieniających się warunków otoczenia doczekał się wielu publikacji podejmujących zagadnienie zarówno operacyjne, jak i strategiczne. Badacze zajmują się zagadnieniem adaptacji od lat 60 . A efekty badań doprowadziły ich do wniosku, że wyniki przedsiębiorstw są bezpośrednio uzależnione od ich zdolności dostosowania się do zmian w otoczeniu (Duncan, 1972; Hambrick, 1982; Miller i Friesen, 1983; Dess i Beard, 1984; Miller, 1987; Daft, Sormunen i Parks, 1988; Fahey i Narayanan, 1989; Wholley i Brittain, 1989). Naukowcy zdefiniowali otoczenie jako burzliwe, pełne nierozpoznanych zjawisk, będących poza kontrolą przedsiębiorstwa, stanowiących źródła szans i zagrożeń (Burgeois, 1980; 1985), mających wpływ na wyniki przedsiębiorstw (Duncan, 1972; Swamidass i Newell, 1987; Ward, Duray, Leong i Sum, 1995). Badania empiryczne prowadzone przez trzy dekady stanowią silne umocowanie dla teorii głoszącej, że przedsiębiorstwa odnoszące sukces mają wyższe zdolności adaptacyjne do otoczenia aniżeli te, które uzyskują gorsze rezultaty. Stąd też definiowanie zwinności jako istotnej zdolności przedsiębiorstwa do prowadzenia działalności w turbulentnym otoczeniu biznesowym (Goldman i in., 1995; Zhang i Sharifi, 1999; Maskell, 2001; Yusuf i Adeleye, 2002; Adeleye i Yusuf, 2006).

Czerpiąc z dorobku autorów w zakresie definiowania zwinności, można wskazać na cztery odmienne, niestanowiące jednak odrębnych zbiorów motywy zwinności najczęściej wskazywane przez badaczy. Należą do nich: zaspokojenie potrzeb klientów, przewaga konkurencyjna, przetrwanie w trudnych warunkach oraz chęć osiągnięcia wyższej efektywności.

Zaspokojenie potrzeb i wymagań klientów oraz tworzenie wartości dla odbiorców stanowią istotne motywy, dla których zwinność jest rozwijana w przedsiębiorstwach (Iacocca Institute, 1991; Vokurka i Fliedner, 1998; Dahmaradeh i Banihashem, 2010; Shahrabi, 2012; Weber i Tarba, 2014; Shin i in., 2015). Kolejnym wskazywanym motywem jest chęć utrzymania przewagi konkurencyjnej poprzez wykorzystanie okazji w otoczeniu biznesowym (Kidd, 1994; Zhang i Sharifi, 2000; Meredith i Fran- 
cis, 2000; Shin i in., 2015; Felipe i in., 2016). Przetrwanie w trudnych warunkach poprzez zdolność przedsiębiorstwa do szybkiej i efektywnej odpowiedzi na nadchodzącą zmianę stanowi kolejny bodziec dla przedsiębiorstw do rozwijania zwinności (Kumar i Motwani, 1995; McGaughey, 1999; Gunasekaran, 1999a; Rigby, Day i Forrester, 2000; Zhang i Sharifi, 2000; Ashrafi, Xu, Sathasivam, Kuilboer, Koelher, Heimann i Waage, 2005; Narasimhan i in., 2006; Vazquez-Bustelo i in., 2007; Dahmaradeh i Banihashem, 2010; Tallon i Pinsonneault, 2011; Shahrabi, 2012; Weber i Tarba, 2014; Felipe i in., 2016). Ostatnim, równie istotnym motywem zwinności jest chęć podwyższenia efektywności działań przedsiębiorstwa na poziomie operacyjnym (Goldman i in., 1995; Vokurka i Fliedner, 1998; Highsmith, 2005; Storey i in., 2005; Vazquez-Bustelo i in., 2007; Weber i Tarba, 2014; Shin i in., 2015). Duży dynamizm otoczenia, konkurencyjne rynki, bliskie relacje pomiędzy przedsiębiorstwami i ich dostawcami, dystrybutorami, klientami, konkurentami oraz duża różnorodność produktów, klientów oraz modeli biznesowych sprawiają, że wskazane motywy zwinności odzwierciedlają najpilniejsze potrzeby przedsiębiorstw w zakresie adaptacji (Vazquez-Bustelo i in., 2007).

Często wiąże się motywy zwinności z siłami napędowymi (agility drivers), którymi są zmiany oraz bodźce otoczenia biznesowego wymuszające niejako na przedsiębiorstwie poszukiwanie nowych sposobów prowadzenia działalności w celu utrzymania przewagi konkurencyjnej (Zhang i Sharifi, 2001). Wynikiem jest dezagregacja otoczenia biznesowego na elementarne obszary, takie jak: rynek, otoczenie konkurencyjne, wymagania klienta, technologie, czynniki społeczne, dostawców oraz kompleksowość procesów. Identyfikując poziom odczuwalnej przez przedsiębiorstwa turbulencji w poszczególnych obszarach, bada się potrzebę zwinności celem sprostania wyzwaniom w poszczególnych sferach.

Wychodząc od kwestii motywów zwinności, logiczną sekwencją tematyczną jest problem atrybutów zwinności przedsiębiorstw, czyli cech, które ją konstytuują. Problem braku porozumienia dotyczącego sposobów operacjonalizacji zwinności wynika zarówno $\mathrm{z}$ chaosu definicyjnego, jak i różnic w postrzeganiu samego zagadnienia (Sherehiy, Karwowski i Layer, 2007), jego wielowymiarowości i niejdnoznaczności (Yang i Liu, 2012), co stanowi konsekwencje dla przyjętej metodologii naukowców. Stąd naturalne różnice w odmienności identyfikowania atrybuów w poszczególnych rodzajach zwinności.

W badaniach nad zwinnością wytwarzania wskazuje się na takie aspekty operacyjne, jak: szybkkość działania, responsywność, elastyczność, zdolność do rekonfiguracji zasobów (Zhang i Sharifi, 2001; Sambamurthy i in., 2003; Swafford i in., 2006a; Inman, Sale, Green i Whitten, 2011; Jacobs, Droge, Vickery i Calantone, 2011). Natomiast rozwój technologii IT (Raschke, 2010), współpraca przedsiębiorstw (Tallon i Pinsonneault, 2011; Mishra i in., 2014) oraz coraz silniejsza rola innowacyjności i kreatywności (Cegarra-Navarro i in., 2016) zarówno w tworzeniu nowych rozwiązań organizacyjnych, jak i umiejętności współtworzenia wartości z klientem (Sambamurthy i in., 2003) stanowią istotne wymiary dla pomiaru zwinności orga- 
nizacyjnej. Z kolei wśród atybutów zwinności strategicznej wskazuje się wrażliwość strategiczną, płynność zasobów oraz zaangażowanie zespołowe (Doz i Kossonen, 2008a). Istotny wpływ przywództwa na zwinność przedsiębiorstw został wykazany w kolejnych pracach i uznany za kluczowy w procesie uczenia się w radzeniu sobie z wyzwaniami otoczenia (Oyedijo, 2012; Weber i Tarba, 2014; Bruller i in., 2014). W publikacjach dotyczących zwinności strategicznej w naturalny sposób wyłaniają się miary dotyczące zdolności do szybkiej adaptacji (Bruller i in., 2014), wewnętrznej zgodności i spójności celów, struktury oraz działań (Weber i Tarba, 2014; Shin i in., 2015), a także dotyczące rozwoju strategicznych alternatyw i możliwości zmiany modelu biznesu (Brannen i Doz, 2012).

Motywy zwinności zainspirowały badaczy do weryfikacji empirycznej pozytywnego związku pomiędzy zwinnością przedsiębiorstwa a przewagą konkurencyjną i jego wynikami. Ten obszar badawczy nie doczekał się wielu publikacji, jednak próby podjęte przez naukowców można potraktować jako inspirację do dalszych badań ${ }^{10}$. W ciągu ostatniej dekady pojawiły się pierwsze publikacje dotyczące prowadzenia badań empirycznych analizujących wpływ zwinności na budowanie przewagi konkurencyjnej i wyniki przedsiębiorstw. W prezentowanym dorobku brakuje jednak systematyzacji i całościowego podejścia do koncepcji zwinności, stanowi on zaledwie zestawienie rozmaitych dociekań naukowców, co świadczy o początkowym stadium prowadzonych badań. Analizując zawartość publikacji dotyczących prowadzonych rozważań teoretycznych i empirycznych w ramach zwinności, można stwierdzić, że kluczową kwestię sporną w tym zakresie stanowi sposób pomiaru zwinności. Naukowcy zajmujący się tą dziedziną nadal nie osiągnęli zgodności w zakresie najlepszej metody pomiaru zwinności. W dotychczasowych badaniach operacjonalizacja zwinności niekiedy miała charkter przypadkowy bądź fragmentaryczny - nie wynikała z merytorycznej analizy uwarunkowań zwinności przedsiębiorstw.

Badania dotyczące roli zwinności organizacyjnej i praktyk dzielenia się wiedzą w celu utrzymania przewagi konkurencyjnej w przedsiębiorstwach produkcyjnych (Almahamid i in., 2010) wykazały, że umiejętności zwinne oraz praktyka dzielenia się wiedzą mają znaczący wpływ na organizacyjną przewagę konkurencyjną. Umiejętności zwinne definiowane jako: responsywność, kompetencyjność, elastyczność i szybkość, zostały przez autorów zaadaptowane z badań Z. Zhang i H. Sharifi (2000).

Istotny związek pomiędzy zwinnością strategiczną a sprawnością konkurowania (wynikiem konkurencyjnym) wykazały badania przeprowadzone przez A. Oyedijo (2012) - tabela 1.6. Zwinność strategiczną zbadano, wykorzystując cztery wymiary: wymiar organizacyjny, wymiar ludzki, wymiar technologiczny, wymiar planowania. Natomiast sprawność konkurowania została zdefiniowana przez autora dzięki następującym zmiennym: wzrost zysku, przychody ze sprzedaży, siła finansowa,

${ }^{10}$ Część z prezentowanych badań była wcześniej omówiona w opublikowanych artykułach (Sajdak, 2013c, 2014a). 
efektywność operacyjna, stabilność wyników, wizerunek przedsiębiorstwa, morale pracowników, adaptacja do otoczenia, nowe pomysły oraz wpływ na społeczeństwo. Wyniki badań pozwoliły na sformułowanie wniosku, że istnieje istotny związek pomiędzy zwinnością strategiczną a przewagą konkurencyjną. Ponadto zwinność strategiczna została jednocześnie uznana za skuteczny wskaźnik do przewidywania sprawności konkurowania przedsiębiorstw. W celu podwyższenia sprawności konkurowania zaleca się przedsiębiorstwom rozwijanie zdolności zwinności strategicznej.

Tabela 1.6. Wpływ zwinności strategicznej na sprawność konkurowania w branży telekomunikacyjnej w Nigerii

\begin{tabular}{|c|l|c|}
\hline Lp. & \multicolumn{1}{|c|}{ Treść hipotezy } & Ocena \\
\hline H1 & $\begin{array}{l}\text { Nie ma wyraźnego związku pomiędzy zwinnością strategiczną a sprawnością } \\
\text { konkurowania przedsiębiorstwa }\end{array}$ & odrzucona \\
\hline H2 & $\begin{array}{l}\text { Zwinność strategiczna nie ma istotnego wpływu na sprawność konkurencyjną } \\
\text { przedsiębiorstwa }\end{array}$ & odrzucona \\
\hline H3 & $\begin{array}{l}\text { Nie ma istotnej różnicy pomiędzy sprawnością przedsiębiorstw charakteryzu- } \\
\text { jących się wysoką zwinnością strategiczną a wynikami przedsiębiorstw o niż- } \\
\text { szej zwinności strategicznej }\end{array}$ & odrzucona \\
\hline
\end{tabular}

Źródło: (Oyedijo, 2012).

W literaturze wyróżnia się też strategiczne obszary zwinności organizacyjnej w kształtowaniu konkurencyjności przedsiębiorstw, należą do nich: partnerstwo strategiczne, odpowiedź na potrzeby klienta, procesy i systemy umożliwiające szybką reakcję, podnoszenie kwalifikacji pracowników i rozwój wiedzy, technologia informacyjna i system zarząadzania. Autorzy przekonują, że wdrożenie wymienionych praktyk w przedsiębiorstwie zapewni: dostarczenie wartości klientowi, gotowość na zmiany dotyczące potrzeb klientów, wartościowanie i rozwijanie wiedzy oraz kompetencji pracowników, budowanie relacji w ramach partnerstwa strategicznego (Goriwondo i in., 2013).

Przechodząc od wątku przewagi konkurencyjnej do wyników przedsiębiorstwa, należy zaznaczyć, że niewiele dostępnych badań dotyczy analizy wpływu zwinności na wyniki przedsiębiorstw. Badania w tym zakresie są konsekwencją przyjętych odmiennych założeń metodologicznych. Część prowadzonych badań ma jedynie wymiar koncepcyjny, inne zostały poddane weryfikacji empirycznej. W celu uporządkowania dostępnych w literaturze badań dotyczących wpływu zwinności na wyniki przedsiębiorstw zostaną one przedstawione zgodnie z rozwojem idei zwinności, począwszy od zwinności wytwarzania, poprzez organizacyjną aż po strategiczną.

D. Vazques-Bustelo i współautorzy (2007) przeprowadzili badania, których celem była weryfikacja zwinności wytwarzania jako głównego czynnika sukcesu w różnych sektorach (tabela 1.7). Autorzy zwrócili uwagę na istotny wpływ nabycia przekaźni- 
ków zwinności (agility providers). Implementowane przekaźniki powinny promować pełną integrację podstawowych obszarów przedsiębiorstwa, takich jak zasoby ludzkie, struktura, technologie. Autorzy grupują przekaźniki zwinności w następcy sposób (Vazques-Bustelo i in., 2007):

- praktyki w ramach zasobów ludzkich w celu wykształcenia wysoko wykwalifikowanego i zmotywowanego personelu, umiejącego pracować w zespole,

- systematyczna implementacja i integracja zaawansowanego wzornictwa, produkcji i technologii,

- praktyki związane z wewnętrznymi i zewnętrznymi relacjami przedsiębiorstwa, uwzględniające rozwój mechanizmów integrujących i koordynujących działania łańcucha wartości, praktyki związane ze współpracą i integracją operacyjną pomiędzy departamentami w przedsiębiorstwie oraz pomiędzy przedsiębiorstwem i jej interesariuszami,

- praktyki związane z rozwojem produktu,

- praktyki związane z zarządzaniem wiedzą i uczeniem się.

Tabela 1.7. Wpływ zwinności na wyniki przedsiębiorstwa

\begin{tabular}{|c|l|c|}
\hline Lp. & \multicolumn{1}{|c|}{ Treść hipotezy } & Ocena \\
\hline H1 & $\begin{array}{l}\text { Turbulentne otoczenie (o wysokim poziom dynamizmu i wrogości) ma pozy- } \\
\text { tywny wpływ na nabycie zwinności produkcyjnej }\end{array}$ & $\begin{array}{c}\text { potwier- } \\
\text { dzona }\end{array}$ \\
\hline H2 & $\begin{array}{l}\text { Nabycie zwinności produkcyjnej odzwierciedla się w systematycznej integracji } \\
\text { zwinności zasobów ludzkich, zwinności technologicznej, integracji łańcucha } \\
\text { wartości i zarządzaniu wiedzą }\end{array}$ & $\begin{array}{c}\text { potwier- } \\
\text { dzona }\end{array}$ \\
\hline H3 & $\begin{array}{l}\text { Nabycie zwinności produkcyjnej ma pozytywny wpływ na zdolności produk- } \\
\text { cyjne (rozumianych poprzez kombinację: poziomu kosztów, elastyczności, ja- } \\
\text { kości, dostawy, usług i otoczenia) }\end{array}$ & $\begin{array}{c}\text { potwier- } \\
\text { dzona }\end{array}$ \\
\hline H4 & $\begin{array}{l}\text { Rozwój zdolności produkcyjnych (rozumianych poprzez kombinację poziomu } \\
\text { kosztów, elastyczności, jakości, dostawy, usług i otoczenia) prowadzi do lep- } \\
\text { szych wyników przedsiębiorstwa }\end{array}$ & $\begin{array}{c}\text { potwier- } \\
\text { dzona }\end{array}$ \\
\hline
\end{tabular}

Źródło: (Vazques-Bustelo i in., 2007).

W obszarze zwinności organizacyjnej i jej wpływu na wyniki przedsiębiorstw można przytoczyć dwa badania wcześniej już wspominane, pierwsze przeprowadzone przez N. Robertsa oraz V. Grovera (2012), zajmujących się zwinnością współpracy z klientem, oraz drugie opracowane przez Ch. Yang i H. Liu (2012).

N. Roberts oraz V. Grover (2012) zwinność współpracy z klientem definiują poprzez dwie umiejętności przedsiębiorstwa - zdolność do wyczuwania potrzeb klienta oraz zdolność do szybkiego reagowania. W podjętych badaniach analizują znaczenie dostosowania omawianych zdolności, jak również ich wpływ na wyniki działalności przedsiębiorstwa. Dostosowanie autorzy rozumieją jako stopień, w jakim potrzeby, wymagania oraz cele i (lub) struktury jednego komponentu są zbieżne z potrzeba- 
mi, wymaganiami oraz celami i (lub) strukturami drugiego komponentu (Roberts i Grover, 2012). Ustalono, że wyniki przedsiębiorstw są wyższe, jeśli obie zdolności - wyczuwania potrzeb klienta oraz reagowania na te potrzeby - są do siebie odpowiednio dostosowane (tabela 1.8).

Tabela 1.8. Wpływ zwinności współpracy z klientem na wyniki przedsiębiorstwa

\begin{tabular}{|c|l|c|}
\hline Lp. & \multicolumn{1}{|c|}{ Treść hipotezy } & Ocena \\
\hline H1 & $\begin{array}{l}\text { Istnieje pozytywny związek pomiędzy zwinnością przedsiębiorstwa a wynika- } \\
\text { mi działalności przedsiębiorstwa. Oznacza to, że przedsiębiorstwa o wysokim } \\
\text { (niskim) poziomie odczuwania oraz wysokim (niskim) poziomem zdolności } \\
\text { do szybkiej reakcji osiągają wysokie (niskie) wyniki działalności }\end{array}$ & $\begin{array}{c}\text { potwier- } \\
\text { dzona }\end{array}$ \\
\hline H2 & $\begin{array}{l}\text { Umiejętność szybkiej reakcji na potrzeby klientów pośrednio wpływa na zwią- } \\
\text { zek pomiędzy poziomem odczuwania potrzeb klienta a wynikami działalności } \\
\text { przedsiębiorstwa }\end{array}$ & $\begin{array}{c}\text { potwier- } \\
\text { dzona }\end{array}$ \\
\hline
\end{tabular}

Źródło: (Roberts i Grover, 2012).

Badacze dowiedli, że istnieje pozytywny związek pomiędzy zwinnością przedsiębiorstwa a wynikami jego działalności. Oznacza to, że przedsiębiorstwa o wysokim poziomie odczuwania potrzeb klientów oraz umiejętności szybkiego reagowania osiągają wyższe wyniki działalności, niż przedsiębiorstwa posiadające niski poziom analizowanych cech. Ustalono również, że umiejętność szybkiej reakcji na potrzeby klientów pośrednio wpływa na związek pomiędzy wrażliwością na potrzeby klientów a wynikami działalności przedsiębiorstwa. Do przeprowadzenia tej analizy wykorzystano test analizy współczynników zaproponowany przez M.E. Sobel (1982). Współczynnik regresji dla efektu pośredniego reprezentuje zmianę zmiennej wynikowej (wyników przedsiębiorstwa) dla każdej jednostki przypadkowej w zmiennej niezależnej (zdolność odczuwania potrzeb klientów), która ulega wpływowi zmiennej interwencyjnej (umiejętność reagowania na potrzeby klientów).

W badaniach dotyczących poprawienia wyników przedsiębiorstwa poprzez jego zwinność oraz strukturę sieciową ujawniono, że zwinność przedsiębiorstwa oraz struktura sieciowa mogą stanowić o podstawie konkurowania w obszarze wyników przedsiębiorstwa (Yang i Liu, 2012). Co więcej, struktura sieciowa również wpływa na zwinność przedsiębiorstwa i na jego wyniki. Autorzy udowodnili, że poprzez wzmacnianie zwinności przedsiębiorstwa mogą lepiej reagować na nieprzewidywalne zmiany (tabela 1.9). Wśród implikacji praktycznych zaproponowano większe zaangażowanie przedsiębiorstw $\mathrm{w}$ rozwijanie i utrzymanie swoich struktur sieciowych jako zewnętrznych zbiorników, dzięki którym mogą formułować bardziej różnorodne i godne zaufania struktury dla nabycia cennych zasobów i umiejętności (McEvily i Marcus, 2005; Zaheer i Bell, 2005; Gnyawali i Madhavan, 2001; Van Wijk i in., 2008). Funkcja strategicznej sieci jest porównywana do zewnętrznego rezerwuaru zasobów i umiejętności, w tym różnorodnej wiedzy (Burt, 1992; Van Wijk 
i in., 2008), informacji (Bharadwaj, 2000), wspólnych zasobów (Uzzi, 1997) oraz wsparcia sojuszników (Stuart, Hoang i Hybels, 1999).

Tabela 1.9. Poprawa wyników przedsiębiorstwa poprzez jego zwinność i strukturę sieciową

\begin{tabular}{|c|l|c|}
\hline Lp. & \multicolumn{1}{|c|}{ Treść hipotezy } & Ocena \\
\hline H1 & $\begin{array}{l}\text { Przedsiębiorstwa, które wykazują wysoki poziom zwinności, osiągają wyższe } \\
\text { wyniki działalności }\end{array}$ & $\begin{array}{c}\text { potwier- } \\
\text { dzona }\end{array}$ \\
\hline H2 & $\begin{array}{l}\text { Przedsiębiorstwa, które charakteryzują się wysoko rozwiniętą strukturą siecio- } \\
\text { wą, mają wyższe wyniki działalności }\end{array}$ & $\begin{array}{c}\text { potwier- } \\
\text { dzona }\end{array}$ \\
\hline H3 & $\begin{array}{l}\text { Przedsiębiorstwa, które wykazują wysoki poziom zwinności, zazwyczaj charak- } \\
\text { teryzują się bardziej rozwiniętą strukturą sieciową }\end{array}$ & $\begin{array}{c}\text { potwier- } \\
\text { dzona }\end{array}$ \\
\hline H4 & $\begin{array}{l}\text { Struktura sieciowa pośredniczy we wpływie zwinności przedsiębiorstwa na } \\
\text { jego wyniki działalności }\end{array}$ & $\begin{array}{c}\text { potwier- } \\
\text { dzona }\end{array}$ \\
\hline
\end{tabular}

Źródło: (Yang i Liu, 2012).

Ostatnim obszarem badawczym dotyczącym wpływu zwinności na wyniki są nieliczne badania nad zwinnością strategiczną i jej weryfikacją w kontekście wyników przedsiębiorstwa. Badania koncepcyjne na ten temat podjęli K. Fartash, S. Davoudi (2012), tworząc model oparty na trzech kluczowych elementach: kompetencjach budujących zwinność, zdolności przedsiębiorstwa do rozwinięcia zwinności oraz wyników przedsiębiorstwa (competence - capability - performance, CCP). Wśród kluczowych kompetencji wzmacniających zwinność autorzy wymieniają: chęć podjęcia zmiany, wewnętrzną gotowość adaptacji do zmian w otoczeniu, wykorzystywanie zarówno fizycznych, jak i wirtualnych kanałów wymiany wiedzy oraz umiejętność wyczuwania zmian w otoczeniu. Autorzy, doceniając wpływ poszczególnych kompetencji na kształtowanie zwinności przedsiębiorstw, zwracają szczególną uwagę na wrażliwość strategiczną przedsiębiorstwa ${ }^{11}$ (market acuity) w stosunku do rynku, która według autorów odgrywa najistotniejszą rolę w przekształceniu przedsiębiorstwa tradycyjnego w przedsiębiorstwo charakteryzujące się zwinnością strategiczną. Wyostrzone zdolności percepcji przedsiębiorstwa w stosunku do rynku umożliwiają mu wcześniejszą identyfikację zmian rynkowych niż u konkurencji, przewaga czasowa daje przedsiębiorstwu możliwość przygotowania się na zmianę, a w konsekwencji daje przewagę konkurencyjną.

Z kolei nigeryjscy naukowcy wykazali wpływ zwinności strategicznej na postrzegane wyniki w przedsiębiorstwach produkcyjnych (Ofoegbu i Akanbi, 2012). Zwinność strategiczną zdefiniowali jako zdolność do ciągłego i odpowiedniego ukierunkowania strategicznego biznesu w zmieniających się okolicznościach

\footnotetext{
${ }^{11}$ Pojęcie market acuity - w bezpośrednim tłumaczeniu znaczy ostrość rynku, jednak w polskiej literaturze stosuje się raczej bystrość lub wrażliwość przedsiębiorstwa na sygnały płynące z rynku.
} 
dzięki wrażliwości strategicznej, zespołowemu zaangażowaniu oraz płynności zasobów. Wyniki badań pozwoliły potwierdzić skuteczność działan proaktywnych w celu radzenia sobie ze zmianami w otoczeniu i ich pozytywny wpływ na wyniki przedsiębiorstw (tabela 1.10). Działania proaktywne wymagają zmotywowanych i zaangażowanych pracowników, których praca bezpośrednio wpływa na sprawność przedsiębiorstwa. Poza procesem planowania i podejmownia decyzji kluczowy jest proces implementacji w celu zapewniania zwinności strategicznej i trwałej przewagi konkurencyjnej.

Tabela 1.10. Wpływ zwinności strategicznej na postrzegane wyniki w przedsiębiorstwach produkcyjnych w Nigerii

\begin{tabular}{|c|l|c|}
\hline Lp. & \multicolumn{1}{|c|}{ Treść hipotezy } & Ocena \\
\hline H1A & $\begin{array}{l}\text { Niezależne zmienne (wrażliwość strategiczna, zespołowe zaangażowanie, } \\
\text { płynność zasobów) wspólnie wpływają na postrzegane wyniki przedsiębior- } \\
\text { stwa }\end{array}$ & $\begin{array}{c}\text { potwier- } \\
\text { dzona }\end{array}$ \\
\hline H1B & $\begin{array}{l}\text { Istnieje relatywny wpływ niezależnych zmiennych (wrażliwość strategiczna, } \\
\text { zespołowe zaangażowanie, płynność zasobów) na postrzegane wyniki przed- } \\
\text { siębiorstwa }\end{array}$ & $\begin{array}{c}\text { potwier- } \\
\text { dzona }\end{array}$ \\
\hline H2 & $\begin{array}{l}\text { Istnieje znacząca różnica pomiędzy wrażliwością strategiczną a postrzegany- } \\
\text { mi wynikami przedsiębiorstwa }\end{array}$ & $\begin{array}{c}\text { potwier- } \\
\text { dzona }\end{array}$ \\
\hline H3 & $\begin{array}{l}\text { Istnieje istotny związek pomiędzy zespołowym zaangażowaniem a postrzega- } \\
\text { nymi wynikami przedsiębiorstwa }\end{array}$ & $\begin{array}{c}\text { potwier- } \\
\text { dzona }\end{array}$ \\
\hline H4 & $\begin{array}{l}\text { Istnieje efekt interakcji pomiędzy wrażliwością strategiczną i zespołowym za- } \\
\text { angażowaniem na postrzegane wyniki przedsiębiorstwa }\end{array}$ & $\begin{array}{c}\text { potwier- } \\
\text { dzona }\end{array}$ \\
\hline H5 & $\begin{array}{l}\text { Istnieje istotny związek pomiędzy płynnością zasobów a postrzeganymi wy- } \\
\text { nikami przedsiębiorstwa }\end{array}$ & $\begin{array}{c}\text { potwier- } \\
\text { dzona }\end{array}$ \\
\hline
\end{tabular}

Źródło: (Ofoegbu i Akanbi, 2012).

W dostępnej literaturze można również znaleźć badania wskazujące na brak wpływu zwinności strategicznej na wyniki finansowe. W badaniach koreańskich naukowców zwinność strategiczną zdefiniowano poprzez cztery zmienne: umiejętności technologiczne, wspólne opracowanie innowacji, organizacyjne uczenie się oraz wewnętrzną zgodność oraz spójność celów i działań. Natomiast wyniki przedsiębiorstw były mierzone za pomocą dwóch zmiennych - utrzymania klienta oraz wyników finansowych. Badanie z wykorzystaniem metody modelowania strukturalnego wykazało, że zwinność strategiczna koreańskich przedsiębiorstw ma pozytywny wpływ zarówno na działania operacyjne, jak i na utrzymanie klienta, jednak nie ma wpływu na wyniki finansowe przedsiębiorstw (tabela 1.11) (Shin, i in., 2015).

Podsumowując wyniki badań dotyczące zwinności przedsiębiorstw, można zidentyfikować lukę w tym obszarze (tabela 1.12). Ze względu na tematykę pracy i obszar 
Tabela 1.11. Wpływ zwinności strategicznej na działania operacyjne i wyniki przedsiębiorstwa

\begin{tabular}{|c|l|c|}
\hline Lp. & \multicolumn{1}{|c|}{ Treść hipotezy } & Ocena \\
\hline H1 & $\begin{array}{l}\text { Zwinność strategiczna ma pozytywny wpływ na zdolności technolo- } \\
\text { giczne }\end{array}$ & potwierdzona \\
\hline H2 & $\begin{array}{l}\text { Zwinność strategiczna ma pozytywny wpływ na wspólne opracowa- } \\
\text { nie innowacji }\end{array}$ & potwierdzona \\
\hline H3 & $\begin{array}{l}\text { Zwinność strategiczna ma pozytywny wpływ na organizacyjne ucze- } \\
\text { nie się }\end{array}$ & potwierdzona \\
\hline H4 & $\begin{array}{l}\text { Zwinność strategiczna ma pozytywny wpływ na wewnętrzną zgod- } \\
\text { ność oraz strukturę celów, działań i potrzeb (harmonię) }\end{array}$ & potwierdzona \\
\hline H5 & $\begin{array}{l}\text { Zwinność strategiczna ma pozytywny wpływ na wyniki przedsiębior- } \\
\text { stwa }\end{array}$ & $\begin{array}{c}\text { częściowo po- } \\
\text { twierdzona }\end{array}$ \\
\hline H5A & $\begin{array}{l}\text { Zwinność strategiczna ma pozytywny wpływ na utrzymanie klienta } \\
\text { potwierdzona }\end{array}$ \\
\hline H5B & $\begin{array}{l}\text { Zwinność strategiczna ma pozytywny wpływ na finansowe wyniki } \\
\text { przedsiębiorstwa }\end{array}$ & odrzucona \\
\hline H6 & $\begin{array}{l}\text { Zwinność strategiczna ma pozytywny wpływ na elastyczność opera- } \\
\text { cyjną }\end{array}$ & potwierdzona \\
\hline H7 & $\begin{array}{l}\text { Elastyczność operacyjna ma pozytywny wpływ na wyniki przedsię- } \\
\text { biorstwa }\end{array}$ & $\begin{array}{c}\text { częściowo po- } \\
\text { twierdzona }\end{array}$ \\
\hline H7A & Elastyczność operacyjna ma pozytywny wpływ na utrzymanie klienta & potwierdzona \\
\hline H7B & $\begin{array}{l}\text { Elastyczność operacyjna ma pozytywny wpływ na finansowe wyniki } \\
\text { przedsiębiorstwa }\end{array}$ & odrzucona \\
\hline H8 & $\begin{array}{l}\text { Elastyczność operacyjna oddziałuje na związek pomiędzy zwinnością } \\
\text { strategiczną a wynikami przedsiębiorstwa }\end{array}$ & $\begin{array}{l}\text { częściowo po- } \\
\text { twierdzona }\end{array}$ \\
\hline H8A & $\begin{array}{l}\text { Elastyczność operacyjna oddziałuje na związek pomiędzy zwinnością } \\
\text { strategiczną a utrzymaniem klienta }\end{array}$ & potwierdzona \\
\hline H8B & $\begin{array}{l}\text { Elastyczność operacyjna oddziałuje na związek pomiędzy zwinnością } \\
\text { strategiczną a finansowymi wynikami przedsiębiorstwa }\end{array}$ & odrzucona \\
\hline
\end{tabular}

Źródło: (Shin i in., 2015).

zainteresowań autorki najbardziej interesujące są dotychczasowe badania dotyczące wpływu zwinności strategicznej na wyniki przedsiębiorstw. Ich znikoma liczba i niejednoznaczne wnioski świadczą o potrzebie dalszych badań umożliwiających lepsze rozpoznanie tego problemu.

Dostępne opracowania nie świadczą o zgodności autorów w zakresie operacjonalizacji konstruktu, jakim jest zwinność strategiczna, ani także nie prowadzą do jednoznacznego wniosku badawczego wskazującego na pozytywny wpływ zwinności strategicznej na wyniki przedsiębiorstw. Zasadne jest zatem rozpoznanie luki badawczej odnoszącej się do zwinności strategicznej jako obszaru wciąż nowego i mało rozpoznanego. 
Tabela 1.12. Podsumowanie dorobku w ramach badań dotyczących wpływu zwinności na wyniki przedsiębiorstw

\begin{tabular}{|c|c|c|c|c|}
\hline Autorzy badań & Rok & $\begin{array}{l}\text { Czaso- } \\
\text { pismo }\end{array}$ & Komponenty lub wymiary zwinności & $\begin{array}{l}\text { Rodzaj } \\
\text { badań }\end{array}$ \\
\hline \multicolumn{5}{|c|}{ Badania dotyczące wpływu zwinności wytwarzania na wyniki } \\
\hline $\begin{array}{l}\text { Z. Zhang } \\
\text { i H. Sharifi }\end{array}$ & 2001 & IJOPM & $\begin{array}{l}\text { - responsywność } \\
\text { - kompetencja } \\
\text { - elastyczność } \\
\text { - szybkość }\end{array}$ & $\begin{array}{l}\text { empiryczne } \\
\text { (case study) }\end{array}$ \\
\hline $\begin{array}{l}\text { D. Vazques- } \\
\text {-Bustelo, } \\
\text { L. Avella } \\
\text { i E. Fernandez }\end{array}$ & 2007 & IJOPM & $\begin{array}{l}\text { - zwinność w obszarze HR } \\
\text { - integracja łańcucha dostaw } \\
\text { - synchroniczna inżynieria } \\
\text { - zwinność w obszarze technologii } \\
\text { - zarządzanie wiedzą }\end{array}$ & empiryczne \\
\hline $\begin{array}{l}\text { S. K. Vickery, } \\
\text { C. Droge, } \\
\text { P. Setia i V. Sam- } \\
\text { bamurthy }\end{array}$ & 2010 & IJPR & $\begin{array}{l}\text { - czas wprowadzania nowych produktów } \\
\text { - szybkość dostarczenia produktu } \\
\text { - czas produkcji } \\
\text { - elastyczność modyfikowania } \\
\text { - szybkość reakcji na zmiany wymagań klien- } \\
\text { tów }\end{array}$ & empiryczne \\
\hline \multicolumn{5}{|c|}{ Badania dotyczące wpływu zwinności organizacyjnej na wyniki } \\
\hline $\begin{array}{l}\text { N. Roberts } \\
\text { i V. Grover }\end{array}$ & 2012 & JBR & $\begin{array}{l}\text { - zdolność do wyczuwania potrzeb klienta } \\
\text { - zdolność odpowiedzi na wymagania klienta }\end{array}$ & empiryczne \\
\hline $\begin{array}{l}\text { Ch. Yang } \\
\text { i H. M. Liu }\end{array}$ & 2012 & MD & $\begin{array}{l}\text { - zwinność w obszarze współpracy z klientem } \\
\text { - zwinność w obszarze działań konkurencyj- } \\
\text { nych } \\
\text { - zwinność w obszarze współpracy z dostaw- } \\
\text { cami }\end{array}$ & empiryczne \\
\hline \begin{tabular}{l|} 
P. P. Tallon \\
i A. Pinsonneault
\end{tabular} & 2011 & MISQ & $\begin{array}{l}\text { - zwinność w obszarze współpracy z klientem } \\
\text { - zwinność o obszarze partnerstwa bizneso- } \\
\text { wego } \\
\text { - zwinność operacyjna }\end{array}$ & empiryczne \\
\hline $\begin{array}{l}\text { V. Sambamur- } \\
\text { thy, A. Bhara- } \\
\text { dwaj i V. Grover }\end{array}$ & 2003 & MISQ & $\begin{array}{l}\text { - zwinność współpracy z klientem } \\
\text { - zwinność o obszarze współpracy z dostawca- } \\
\text { mi, dystrybutorami oraz innymi partnerami } \\
\text { - zwinność operacyjna }\end{array}$ & koncepcyjne \\
\hline R. Raschke & 2010 & IJAIS & $\begin{array}{l}\text { - zdolność do rekonfigurowania umiejęntości } \\
\text { - responsywność } \\
\text { - zdolność pracowników do adaptacji } \\
\text { - spojrzenie procesowe }\end{array}$ & empiryczne \\
\hline $\begin{array}{l}\text { W. H. Chen } \\
\text { i A. H. Chiang }\end{array}$ & 2011 & IMM & $\begin{array}{l}\text { - zwinność współpracy z klientem } \\
\text { - zwinność partnerstwa } \\
\text { - zwinność operacyjna }\end{array}$ & $\begin{array}{l}\text { koncepcyj- } \\
\text { na/studium } \\
\text { przypadku }\end{array}$ \\
\hline
\end{tabular}


cd. tab. 1.12

\begin{tabular}{|c|c|c|c|c|}
\hline $\begin{array}{l}\text { J. G. Cegarra- } \\
\text {-Navarro, } \\
\text { P. Soto-Acosta } \\
\text { i A. K. P. We- } \\
\text { nsley }\end{array}$ & 2016 & JBR & $\begin{array}{l}\text { - zdolność do szybkiego reagowania na zmia- } \\
\text { ny wymagań klientów } \\
\text { - zwinność operacyjna } \\
\text { - zdolność współpracy z dostawcami } \\
\text { - zdolność do wykorzystywania zmian rynko- } \\
\text { wych jako szans }\end{array}$ & empiryczna \\
\hline \multicolumn{5}{|c|}{ Badania dotyczące wpływu zwinności strategicznej na wyniki } \\
\hline $\begin{array}{l}\text { O. E. Ofoegbu } \\
\text { i P. A. Akanbi }\end{array}$ & 2012 & IBERJ & $\begin{array}{l}\text { - wrażliwość strategiczna } \\
\text { - zespołowe zaangażowanie } \\
\text { - płynność zasobów }\end{array}$ & empiryczne \\
\hline $\begin{array}{l}\text { K. Fartash } \\
\text { i S. Davoudi }\end{array}$ & 2012 & IJEMR & $\begin{array}{l}\text { - wrażliwość strategiczna } \\
\text { - elastyczny outsourcing } \\
\text { - umiejętność podejmowania zmian } \\
\text { - plany biznesowe }\end{array}$ & koncepcyjne \\
\hline $\begin{array}{l}\text { H. Shin, } \\
\text { J. Lee, D. Kim } \\
\text { i H. Rhim }\end{array}$ & 2015 & IJPE & $\begin{array}{l}\text { - umiejętności technologiczne } \\
\text { - wspólne opracowanie innowacji } \\
\text { - organizacyjne uczenie się } \\
\text { - wewnętrzna zgodność i spójność celów } \\
\text { i działań }\end{array}$ & empiryczne \\
\hline
\end{tabular}




\section{Rozdział 2}

\section{PODSTAWY TEORETYCZNE ZWINNOŚCI STRATEGICZNEJ PRZEDSIĘBIORSTW}

W poprzednim rozdziale omówiono istotę zwinności jako zdolności przedsiębiorstwa do dostosowania się do zmian w otoczeniu. Dorobek w zakresie zwinności umożliwił wskazanie trzech jej rodzajów, wytwarzania, organizacyjnej oraz strategicznej, wyłonionych na podstawie podejmowanych przez lata badań. Zaprezentowany przegląd literatury ujawnił odmienność podejmowanych przez naukowców obszarów, wielość wątków badawczych oraz zróżnicowane podstawy teoretyczne prowadzonych dociekań. Usystematyzowanie tej wiedzy wymaga określenia podstaw teoretycznych zwinności oraz wskazania wpływu poszczególnych podejść na jej zakres przedmiotowy.

Pojęcie zwinności strategicznej jest pojęciem nadal nierozpoznanym, dlatego wymaga odpowiedniego wsparcia teoretycznego, które dostarczy solidnych podstaw wyjaśniających i uzasadniających występowanie zwinności. Celem tego rozdziału jest przedstawienie najważniejszych teorii dotyczących istoty i rozwoju zwinności. W pierwszej kolejności uwzględniono najważniejsze podejścia teoretyczne stanowiące o istocie, podstawach i zasadności zwinności oraz dokonano ich klasyfikacji ze względu na dwa wymiary. W kolejnych podrozdziałach zostały opisane wybrane koncepcje teoretyczne ze wskazaniem ich znaczenia w wyjaśnieniu i uzasadnieniu istoty zwinności.

\subsection{Przegląd wybranych koncepcji teoretycznych}

Zwinność jest przedmiotem licznych rozważań, często odległych w swojej istocie, mimo że łączy je obiekt zainteresowań, jakim jest przedsiębiorstwo. Fakt ten wynika $z$ istnienia różnorodnych perspektyw teoretycznych mniej lub bardziej ugruntowanych w naukach o zarządzaniu. Należy zauważyć, że nie istnieje jedna metateoria dająca podstawy zwinności strategicznej. Ze względu na złożoność tego zagadnienia istotna staje się identyfikacja teorii rozwiniętych w nurcie zarządzania oraz interdy- 
scyplinarnych, takich podejść jak ujęcie ewolucyjne oraz behawioralne teorie w zarządzaniu, których systematyczny przegląd przyczyni się do lepszego zrozumienia przedmiotu badań. W tej części pracy zebrano najważniejsze koncepcje i podejścia teoretyczne, które uzasadniają i wyjaśniają pojęcie zwinności. Wybór teorii ${ }^{12}$ jest podyktowany dotychczasowym wykorzystaniem danej teorii w wyjaśnianiu i badaniu zwinności przedsiębiorstw. Każda z nich ma istotne walory poznawcze, jednak żadna nie wydaje się wystarczająca, aby wyjaśnić zjawisko zwinności przedsiębiorstw w całości. Rdzeń atrybutów zwinności przedsiębiorstw jest osadzony na styku różnych perspektyw i podejść badawczych, stanowiąc tym bardziej interesujący przedmiot badań. Wykaz wybranych podejść teoretycznych przedstawia tabela 2.1.

Tabela 2.1. Podejścia uzasadniające zwinność przedsiębiorstw

\begin{tabular}{|c|c|c|}
\hline Podejścia & $\begin{array}{l}\text { Poziom analizy } \\
\text { jednostka/ } \\
\text { przedsiębiorstwo }\end{array}$ & $\begin{array}{l}\text { Przykłady badań nad zwinnością } \\
\text { wykorzystujących dane podejście }\end{array}$ \\
\hline Podejście przedsiębiorcze & jednostka & $\begin{array}{l}\text { Overby, Bharadwaj i Sambamurthy (2006) } \\
\text { Inman i in. (2011) } \\
\text { Tallon i Pinsonneault (2011) } \\
\text { Chen i Chiang (2011) } \\
\text { Ofoegbu i Akanbi (2012) } \\
\text { Fartash i Davoudi (2012) } \\
\text { Goriwondo i in. (2013) } \\
\text { Fourne i in. (2014) } \\
\text { Weber i Tarba (2014) } \\
\text { Bruller, Carmeli i Drori (2014) }\end{array}$ \\
\hline Podejście innowacyjne & jednostka & $\begin{array}{l}\text { Bessant, Francis, Meredith i Kaplinsky (2001) } \\
\text { Sambamurthy i in. (2003) } \\
\text { Raschke (2010) } \\
\text { Shahin, Nikjoot i Nilipour (2011) }\end{array}$ \\
\hline Podejście behawioralne & $\begin{array}{l}\text { jednostka/zespół/ } \\
\text { przedsiębiorstwo }\end{array}$ & $\begin{array}{l}\text { Zhang i Sharifi (1999) } \\
\text { Gunasekaran (1998, 1999a) } \\
\text { Gunasekaran i Yusuf (2002) } \\
\text { Yusuf i in. (1999) } \\
\text { Meredith i Francis (2000) } \\
\text { Goldman i in. (1995) } \\
\text { Vokurka i Fliedner (1998) } \\
\text { Bustelo, Crocitto i Youssef (2003) } \\
\text { Vazques-Bustello i in. (2007) } \\
\text { Rowe i Nejad (2009) }\end{array}$ \\
\hline
\end{tabular}

${ }^{12} \mathrm{~W}$ pracy przyjęto definicję, zgodnie z którą teoria naukowa stanowi „spójny system rozumowań i twierdzeń wyjaśniający jakieś zjawiska i niekiedy również pozwalający przewidywać jakieś zjawiska lub dostrzegać nowe możliwości” (Noga, 2009, s. 44). 
cd. tab. 2.1

\begin{tabular}{|c|c|c|}
\hline Podejścia & $\begin{array}{c}\text { Poziom analizy } \\
\text { jednostka/ } \\
\text { przedsiębiorstwo }\end{array}$ & $\begin{array}{l}\text { Przykłady badań nad zwinnością } \\
\text { wykorzystujących dane podejście }\end{array}$ \\
\hline $\begin{array}{l}\text { Koncepcja organizacji } \\
\text { uczącej sie }\end{array}$ & $\begin{array}{l}\text { jednostka/ } \\
\text { zespół/organizacja }\end{array}$ & $\begin{array}{l}\text { Dayer i Shafer (1998) } \\
\text { Vazquez-Bustelo i in. (2007) } \\
\text { Li i in. (2008) } \\
\text { Dahmardeh i Banihashemi (2010) } \\
\text { Oliveira, Valentina i Possamai (2012) } \\
\text { Goriwondo i in. (2013) } \\
\text { Shin i in. (2015) } \\
\text { Bahrami i in. (2016) }\end{array}$ \\
\hline $\begin{array}{l}\text { Podejście oparte na wie- } \\
\text { dzy }\end{array}$ & przedsiębiorstwo & $\begin{array}{l}\text { Mondragon i in. (2004) } \\
\text { Overby i in. (2006) } \\
\text { Doz i Kosonen (2008a, b) } \\
\text { Li, Huang i Tsai (2009) } \\
\text { Tallon i Pinsonneault (2011) } \\
\text { Mavengere (2013) }\end{array}$ \\
\hline Podejście relacyjne & przedsiębiorstwo & $\begin{array}{l}\text { Overby i in. (2006) } \\
\text { Chen i Chiang (2011) } \\
\text { Tallon i Pinsonneault (2011) } \\
\text { Yang i Liu (2012) } \\
\text { Goriwondo i in. (2013) }\end{array}$ \\
\hline $\begin{array}{l}\text { Perspektywa dynamicz- } \\
\text { nych umiejętności }\end{array}$ & przedsiębiorstwo & $\begin{array}{l}\text { Roberts i Grover (2012) } \\
\text { Oliveira i in. (2012) } \\
\text { Mavengere (2013) } \\
\text { Fourne i in. (2014) }\end{array}$ \\
\hline Podejście zasobowe & przedsiębiorstwo & $\begin{array}{l}\text { Gunasekaran (1999a) } \\
\text { Zhang i Sharifi (2000) } \\
\text { Meredith i Francis (2000) } \\
\text { Maskell (2001) } \\
\text { Overby i in. (2006) } \\
\text { Swafford, Ghosh i Murthy (2006a, b) } \\
\text { Dahmardeh i Banihashemi (2010) } \\
\text { Almahemid i in. (2010) } \\
\text { Oliveira i in. (2012) } \\
\text { Goriwondo i in. (2013) } \\
\text { Weber i Tarba (2014) } \\
\text { Bruller i in. (2014) } \\
\text { Shin i in. (2015) }\end{array}$ \\
\hline Podejście ewolucyjne & $\begin{array}{l}\text { jednostka, zespół/ } \\
\text { przedsiębiorstwo }\end{array}$ & $\begin{array}{l}\text { Roth (1996) } \\
\text { Gunasekaran (1999a) } \\
\text { Meredith, Francis (2000) } \\
\text { Li i in. (2008) } \\
\text { Dahmardeh i Banihashemi (2010) } \\
\text { Oliveira i in. (2012) } \\
\text { Weber i Tarba (2014) } \\
\text { Mishra i in. (2014) }\end{array}$ \\
\hline
\end{tabular}


Analiza podłoża teoretycznego pozwala na umiejscowienie wspomnianych podejść według dwóch wymiarów: założenie o racjonalności ekonomicznej działań oraz poziom analizy, w rozumieniu głównej jednostki analizowanej w danej teoriii ${ }^{13}$. Według pierwszego kryterium teorie można umiejscowić na symbolicznej osi rozciągającej się od racjonalności ekonomicznej (economic rationale) aż po relatywną racjonalność behawioralno-poznawczą (behavioral rationale). Propozycje konceptualnego kontinuum od polegania na przesłankach racjonalnych ekonomicznie aż po przesłanki behawioralne prezentują w swojej pracy B.R. Barringer ora J.S. Harrison (2000, s. 381-381). Na rysunku 2.1 przedstawiono propozycję umiejscowienia teorii według przyjętych wymiarów: charakter racjonalności i poziomu analizy.

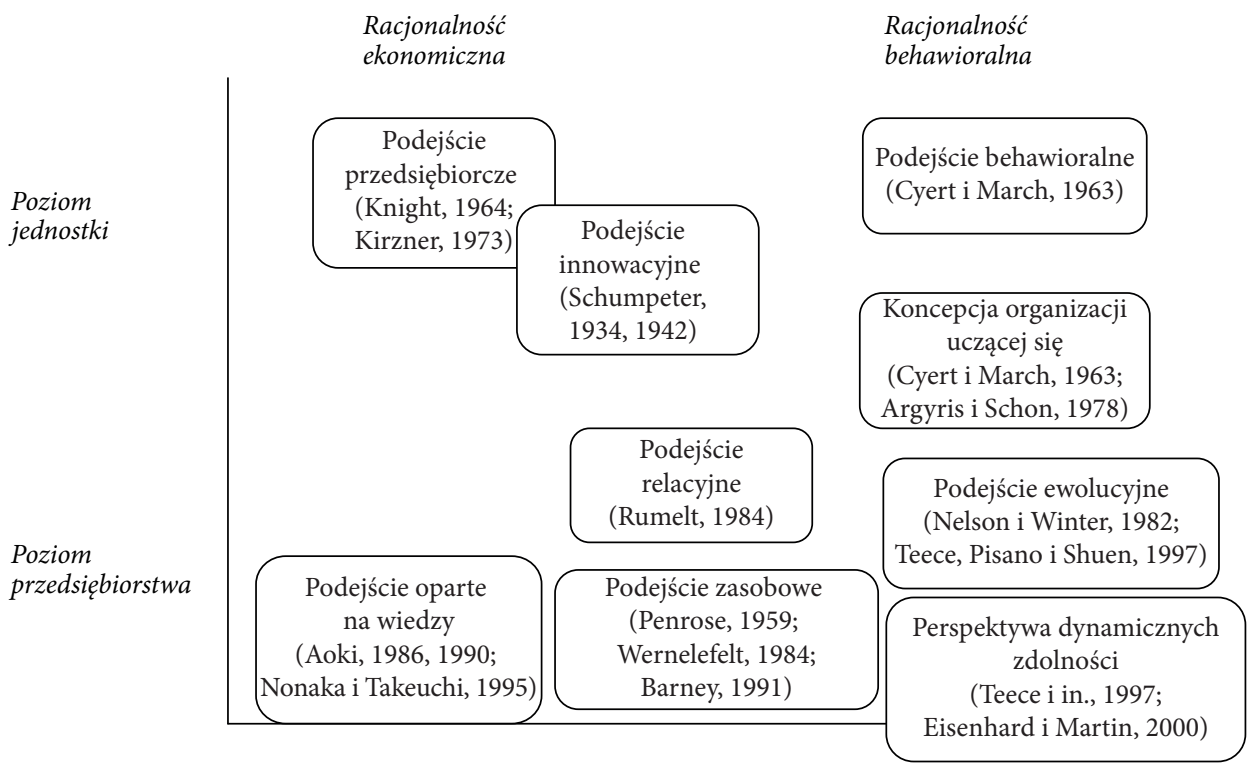

\section{Rysunek 2.1. Podział podejść wykorzystywanych w badaniach nad zwinnością przedsiębiorstw}

W kolejnych podrozdziałach przedstawiono krytyczną analizę poszczególnych podejść uwzględniającą ich wpływ na zwinność strategiczną na różnych poziomach analizy przedsiębiorstwa:

- podejścia uwzględniające zwinność strategiczną na poziomie jednostki,

- podejścia rozpatrujące zwinność strategiczną na poziomie przedsiębiorstwa.

${ }^{13}$ Należy zauważyć, że niektóre teorie wraz z rozwojem badań zostały zaadaptowane do analiz na różnym poziomie rozważań. Na przykład teoria innowacyjna znajduje obecnie szerokie zastosowanie w badaniach przedsiębiorstw podobnie jak teoria przedsiębiorcza. Wskazane w pracy umiejscowienie odnosi się do pierwotnego przeznaczenia teorii. 


\subsection{Założenia w podejściach będących źródłem zwinności na poziomie indywidualnym}

\section{Podejście przedsiębiorcze}

Za prekursora przedsiębiorczości uznaje się F. Knighta (1964), który zdefiniował przedsiębiorczość jako zbiór działań związanych z akceptacją niepewności wyników działalności przedsiębiorstwa. Założenie o niepewności jest tu kluczowe, zaś przedsiębiorca to właściciel przedsiębiorstwa akceptujący niepewność. Jak przekonują R.G. McGrath i I. MacMillan (2000, s. 1), niepewność może być źródłem szans, jeśli przedsiębiorstwo wykorzystuje myślenie przedsiębiorcze (entrepreneurial mindset) - czyli zdolność postrzegania swojego biznesu przez pryzmat korzyści, jakie płyną z niepewności. I.M. Kirzner (1973), kontynuując poszukiwania badawcze F. Knighta, zwraca uwagę, że kluczowa dla przedsiębiorczości jest umiejętność dostrzegania nowych szans, poszukiwania okazji, których inni jeszcze nie dostrzegli, a które mogą stanowić o źródle przewagi konkurencyjnej. Spostrzeżenie I.M. Kirznera wydaje się niezwykle słuszne w obliczu „nieustających zmian w krajobrazie nowej gospodarki" i trudnego wyzwania przystosowania się przedsiębiorstw (Brown i Eisenhardt, 1998). E. Penrose (1959, s. 5) w prezentowanej teorii efektywnego zarządzania zasobami przedsiębiorstwa zwraca uwagę na kluczową rolę menedżerów podejmujących działania proaktywne zmierzające do dostrzegania i wykorzystania szans w otoczeniu. Umiejętności przedsiębiorcze nie są równo dostępne dla menedżerów wszystkich przedsiębiorstw, tym, którzy je posiadają, udaje się zidentyfikować wyjątkowe szanse i utrzymać ponadprzeciętne zwroty (Penrose, 1959, s. 37).

Pomimo że F. Knighta uznaje się za ojca przedsiębiorczego podejścia, to już wiele lat wcześniej tematyka ta stanowiła źródło ożywionych dyskusji naukowców. Pierwotnie dużą rangę nadawano przedsiębiorcy. A. Smith już w XVIII wieku uznał przedsiębiorcę za osobę dostarczającą kapitał z umiejętnością jego oszczędzania i mobilizowania, a J.B. Say oraz J.S. Mill w XIX wieku wprowadzili postać przedsiębiorcy do teorii ekonomii, zwracając uwagę na rolę i funkcje przedsiębiorcy, który tworzy przedsiębiorstwo lub sprawuje nad nim kontrolę, dostrzega sprzyjające interesom szanse i wykorzystuje je, będąc jednocześnie motorem zmian ekonomicznych i postępu. Od tak rozumianego terminu przedsiębiorcy ujęcie J.A. Schumpetera (1934) jest zarazem węższe w sensie znaczeniowym i szersze w sensie podmiotowym. Jego definicja przedsiębiorcy dotyczy wyłącznie funkcji i działań związanych z innowacyjnością. Jednocześnie przedsiębiorcą może być także osoba, która nie jest właścicielem kapitału. W odróżnieniu do modelu przedsiębiorcy opracowanego przez I.M. Kirznera $(1973,1979)$, w którym wrażliwość przedsiębiorcy pozwala mu na odkrywanie nowych okazji, już istniejących, a dotąd niedostrzeżonych, zmniejszenie swojej niewiedzy, uczenie się, w ujęciu J.A Schumpetera przedsiębiorca kre- 
atywnie poszukuje kombinacji czynników wytwórczych tworzących nową wiedzę (Hockuba, 1995, s. 114). Przedsiębiorca nie musi mieć aktywów (Kirzner, 1973), muszą go natomiast charakteryzować: zdolność zarządzania, cechy przywódcze, kreatywność, wyobraźnia, osąd przyszłości, innowacyjność.

Późniejszy chronologicznie przegląd definicji przedsiębiorczości pozwala zauważyć kilka terminów najczęściej wykorzystywanych przy ich formułowaniu, takich jak: innowacyjność, elastyczność, dynamiczność, kreatywność oraz skłonność do podejmowania ryzyka (Dyduch, 2008, s. 24-31). Jednak z punktu widzenia adaptacji do otoczenia szczególnie istotny wydaje się przytaczany przez badaczy aspekt przedsiębiorczości dotyczący identyfikacji i wykorzystania szans w otoczeniu (Shane i Venkataraman, 2000, s. 218-219). Jak zauważa A. Noga (2009, s. 144), przedsiębiorstwo jest to instytucja, która musi mieć pomysł (osąd), jak w warunkach niepewności wykorzystywać (alokować, kreować, dzielić, nadawać wartości, rewitalizować) swoje aktywa.

Warunki, w których działają przedsiębiorstwa, wymagają od nich rozwijania kompetencji przedsiębiorczych, ale także działania w sposób strategiczny. Identyfikowaniu i wykorzystaniu szans oraz kreowaniu niepewności wskutek rozważania dużej liczby nowych idei i wariantów decyzyjnych musi towarzyszyć myślenie strategiczne skierowane na realizację wizji (Ireland, Kuratko i Covin, 2003). Zarówno przedsiębiorczość, jak i zarządzanie strategiczne są związane ze wzrostem i tworzeniem dobrobytu (wealth creation) (Amit i Zott, 2001; Hitt i Ireland, 2000; Hitt, Ireland, Camp i Sexton, 2001, 2002; Morris, 1998), a dokładniej stanowią one główny cel ich realizacji (Certo, Covin, Daily i Dalton, 2001; Ireland i in., 2003). Przedsiębiorczość jest postrzegana jako bodziec tworzenia dobrobytu w rozwijających się gospodarkach dzięki działaniom przedsiębiorczym podejmowanym przez pojedyncze przedsiębiorstwa (Peng, 2001; Zahra, Ireland, Gutierrez i Hitt, 2000).

R.D. Ireland, M.A. Hitt oraz D.G. Simon (2003), analizując przedsiębiorczość strategiczną (strategic entrepreneurship, SE) dostrzegają, że przedsiębiorczość i zarządzanie strategiczne to nie osobne dyscypliny, które można analizować rozłącznie. Stanowią one dyscypliny komplementarne, o bardzo istotnym wpływie na rozwój nauki o organizacji. G.D. Meyer oraz K.A. Heppard (2000) twierdzą nawet, że przedsiębiorczość i zarządzanie strategiczne to dyscypliny nierozerwalnie ze sobą powiązane, a dobre ich zrozumienie wymaga jednoczesnego śledzenia postępów naukowych w rozwoju obu dziedzin.

W literaturze dominuje stwierdzenie, że przedsiębiorczość koncentruje się na nowatorstwie i oryginalności nowych produktów, procesów i kreowaniu nowych rynków dla tworzenia dobrobytu (Daily, McDougall, Covin i Dalton, 2002; Lumpkin i Dess, 1996; Sharma i Chrisman, 1999; Smith i Di Gregorio, 2002). Natomiast S. Shane i S. Venkataraman (2000) zwracają uwagę, że to właśnie odkrywanie i wykorzystywanie zyskownych szans stanowi fundament dla tworzenia dobrobytu poprzez działania przedsiębiorcze. Opinie badaczy odnoszą się do stwierdzenia, że to właśnie rozpoznanie okazji stanowi sedno przedsiębiorczości (Brown i Eisenhardt, 
2000; McCline, Bhat i Baj, 2000). Jak zauważa D.J. Teece (1998), zdolność do kreowania wysokiej wartości sprzyja tym przedsiębiorstwom i tym przedsiębiorcom, którzy są wyposażeni w odpowiednie umiejętności rozpoznania i wykorzystania przedsiębiorczych szans (entereprenurial opportunities).

W opracowaniach dotyczących tematyki przedsiębiorczości badacze poszukują odpowiedzi na następujące pytania (Shane i Venkataraman, 2000, s. 218):

- Dlaczego, kiedy i w jaki sposób pojawiają się w otoczeniu szanse stanowiące źródło kreowania nowych dóbr i usług?

- Dlaczego, kiedy i w jaki sposób jedni przedsiębiorcy są w stanie zauważyć pojawiające się szanse, a inni ich nie dostrzegają?

- Dlaczego, kiedy i w jaki sposób różne formy działania są podejmowane przez przedsiębiorstwa do wykorzystania przedsiębiorczych szans?

W nawiązaniu do przedstawionych poglądów stwierdza się, że przedsiębiorczość wiąże się bezpośrednio z konfiguracją i rekonfiguracją zasobów oraz ich rozwijaniem w celu stworzenia ich nowej architektury (Schoonhoven i Romanelli, 2001). Proces ten stanowi odpowiedź przedsiębiorstwa na niepewność (działania adaptacyjne i proaktywne), których rezultatem są pojawiające się szanse. M.A. Hitt i współautorzy (2001) twierdzą, że przedsiębiorczość strategiczna wiąże się z podejmowaniem przedsiębiorczych działań w perspektywie strategicznej. Przedsiębiorcy mający zdolność identyfikowania szans, jednak nieposiadający umiejętności ich wykorzystania nie zdają sobie sprawy z potencjału tworzenia dobrobytu. Podobnie przedsiębiorcy podtrzymujący swoją przewagę konkurencyjną, jednak niedostrzegający nowych szans w otoczeniu, które mogliby wykorzystać, są narażeni na coraz wyższe ryzyko prowadzonej działalności wynikające z pojawiających się zmian rynkowych, czego efektem może być spowolnienie tworzonej wartości (dobrobytu) lub nawet pomniejszenie wartości wcześniej wygenerowanej. Autorzy uważają, że dobrobyt (wealth) może być wykreowany tylko wtedy, gdy przedsiębiorca potrafi połączyć zachowanie efektywnego poszukiwania szans (effective opportunity-seeking bahavior) - zwane właśnie przedsiębiorczością, z zachowaniem efektywnego poszukiwania przewagi (effective advatage-seeking bahavior) - zwane zarządzaniem strategicznym).

Przedsiębiorczość strategiczna jest niezwykle istotna w kontekście zdolności przedsiębiorstw do adaptacji, tym samym stanowi rdzeń zwinności przedsiębiorstw. Zwinność wymaga jednocześnie umiejętności oceny adekwatności zasobów niezbędnych do wykorzystania okazji, rozwijania zasobów własnych (materialnych i niematerialnych) oraz zdolności pozyskania niezbędnych zasobów z otoczenia, gdyż jak zauważają H.H. Stevenson i J.C. Jarillo (1990), przedsiębiorczość to także poszukiwanie szans, których wykorzystanie stanowi dla przedsiębiorstwa wyzwanie w obszarze zasobów. Autorzy zwracają uwagę na swoistą umiejętność, którą uznają za kluczową dla przedsiębiorczości, jest nią umiejętność wykorzystania zasobów, które znajdują się poza kontrolą przedsiębiorcy (Stevenson, 1983; Jarillo, 1989). Tym samym naukowcy dostrzegają prawidłowość, że organizacje, które sprzyjają powstawaniu nieformalnych wewnętrznych i zewnętrznych układów sieciowych i umoż- 
liwiają stopniową alokację oraz udostępnianie zasobów, będą wykazywały wyższy stopień zachowań przedsiębiorczych (Stevenson i Jarillo, 1990).

\section{Podejście innowacyjne}

J.A. Schumpeter, uznany za prekursora teorii innowacji, jest autorem szerokiej definicji innowacji, która z uwagi na swój pionierski i ogólny charakter jest uważana za klasyczną w literaturze ekonomicznej, stanowiąc punkt wyjścia do określenia pojęć z zakresu działalności innowacyjnej (1960, s. 104). Pomimo wielu opracowań teoretycznych, przykładów z praktyki gospodarczej i publikacji naukowych z tego zakresu trudno uznać, że pojęcie innowacji jest interpretowane jednoznacznie. Innowacyjnością określa się skłonność i zdolność przedsiębiorstwa do rozwijania i przyswajania nowych i udoskonalonych produktów, świadczonych usług bądź stosowanych technologii (Janasz i Kozioł, 2007, s. 57). Jednocześnie umiejętność przedsiębiorstwa tworzenia „nowości” zarówno w zakresie produktów czy usług, jak i procesów biznesowych stanowi nieodłączną cechę przedsiębiorstw skutecznie dostosowujących się do zmieniających się warunków otoczenia.

Należy zwrócić uwagę, że w teorii J.A. Schumpetera można znaleźć swoistą apoteozę przedsiębiorcy. Pomimo że w kolejnych swoich pracach autor odżegnuje się od gloryfikacji przedsiębiorcy, twierdząc, że podkreśla jedynie jego funkcję ekonomiczną, to jednak jest oczywiste, że właśnie przedsiębiorcza jednostka, jej zachowanie, motywacje oraz funkcja społeczna i ekonomiczna były główną życiową fascynacją myślową i teoretyczną J.A. Schumpetera. Potwierdzenie tej fascynacji można znaleźć we wszystkich jego głównych pracach (Schumpeter, 1934, 1960, 1964, 1965). H. Kisch podsumowuje: „Architektura schumpeterowskiego systemu z pewnością posiada przynajmniej jeden niezbędny składnik wielkości - prostotę. W centrum jego systemu stoi przedsiębiorca - innowator, człowiek o niezwykłej intuicji, energii, wytrwałości i zdolnościach organizacyjnych. To właśnie jednostka, jak przedstawia ją J.A Schumpeter, w połowie marzyciel, w połowie twardy realista, inicjuje zmianę ekonomiczną" (1979, s. 191).

Innowacja może być obecnie definiowana w różnych kategoriach pojęciowych, takich jak: innowacje produktowe bądź procesowe lub inkrementalne bądź radykalne (Zaltman, Duncan i Holbek, 1973; Utterback, 1994; Cooper, 1998). Wielość postrzeganych wymiarów innowacji nie ułatwia ich zrozumienia, a raczej wprowadza chaos poznawczy. C.I. Wang oraz P.K. Ahmed (2004) dokonali syntezy opracowań dostępnych w literaturze z zakresu innowacji i wyłonili pięć głównych obszarów determinujących innowacyjność przedsiębiorstwa (tabela 2.2).

Największym zainteresowaniem badaczy cieszą się innowacje produktowe (Massaki i Scott, 1995; Schmidt i Calantotne, 1998), które w istotny sposób stanowią o sukcesie produktu na rynku (Zirger, 1997; Sethi, Smith i Park, 2001), co bez- 


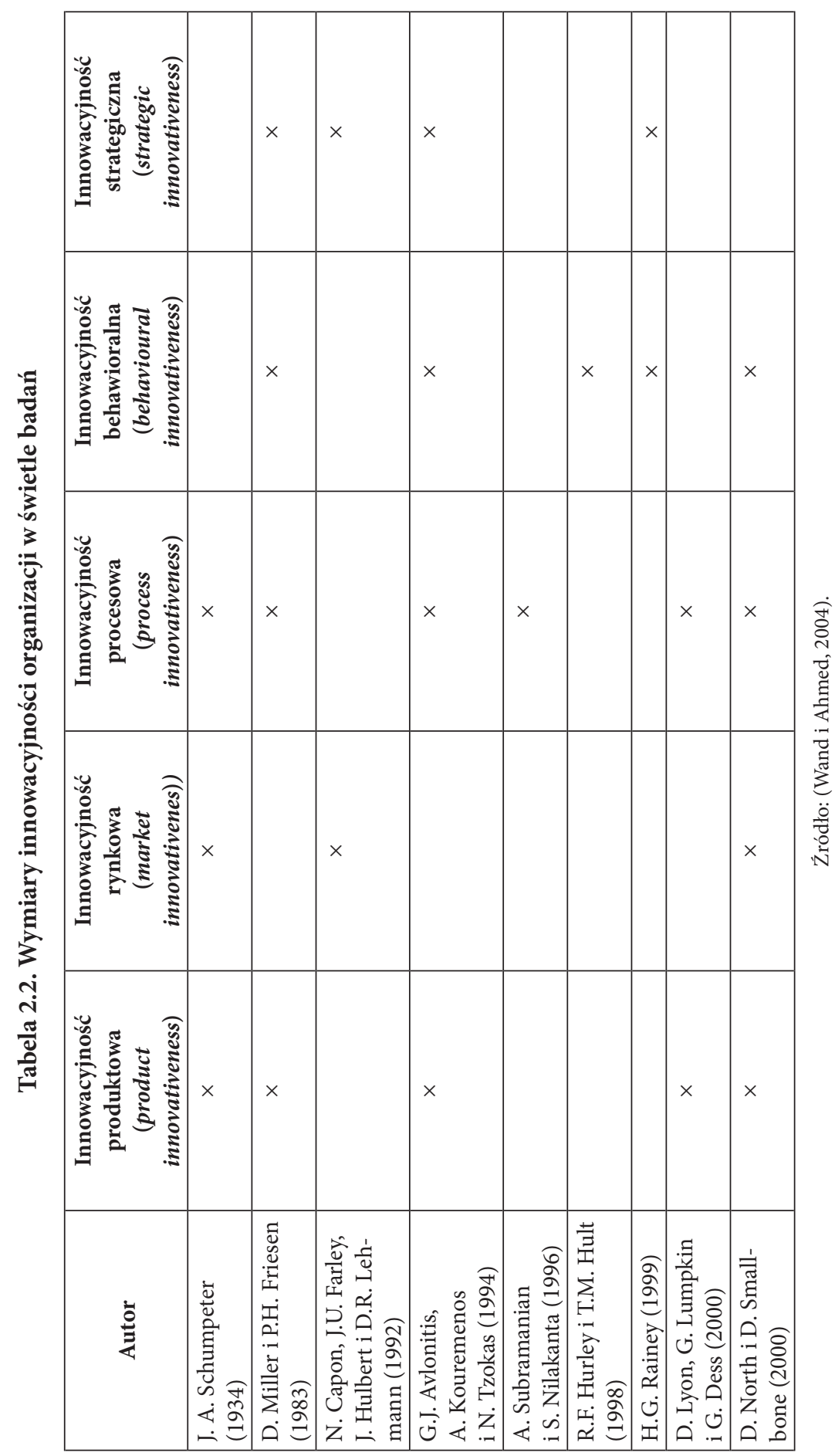


pośrednio wiąże się z uzyskaniem przez niego przewagi konkurencyjnej (Henard i Szymanski, 2001). Znaczące innowacje umożliwiają przedsiębiorstwom zdobycie uprzywilejowanej pozycji rynkowej, dodając odwagi dla wykorzystania pojawiających się szans i wejścia na nowe rynki (Danneels i Kleinschmidt, 2001). Innowacyjność produktowa najczęściej odnosi się do postrzegania produktu z punktu widzenia jego nowości, oryginalności, nowoczesności, wyjątkowości (Henard i Szymanski, 2001). Innowacje produktowe mogą dotyczyć nowych produktów lub dokonywania znaczących zmian w produktach już istniejących, zmiany te odnoszą się do cech produktu lub sposobu jego wytwarzania. W szczególności zalicza się do nich udoskonalenia w specyfikacji technicznej, wykorzystanie nowych surowców, zmiany $\mathrm{w}$ charakterystykach funkcjonalnych, stworzenie nowego sposobu wykorzystania. Innowacja produktowa może być oparta na nowo stworzonej wiedzy czy technologii, może również wykorzystywać wiedzę bądź technologię już istniejącą w nowy sposób (Schumpeter, 1960, s. 121).

Kolejny obszar bezpośrednio powiązany z innowacyjnością produktową stanowi innowacyjność rynkowa, określana też często jako innowacyjność produktowo-rynkowa (Schumpeter, 1934; Cooper, 1973; Miller, 1983). Innowacyjność rynkowa dotyczy prowadzenia badań rynku i prowadzenia działań marketingowych (Ali, Krapfel i Labahn, 1995). Innowacje rynkowe odnoszą się do nowych rozwiązań w zakresie metod marketingowych, takich jak zmiany wyglądu produktu, jego opakowania, strategii promocji, pozycjonowania produktu czy polityki cenowej. Innowacje rynkowe mogą być związane $\mathrm{z}$ różnymi zmianami dokonywanymi w ramach nowej koncepcji marketingowej.

Trzeci obszar to innowacje procesowe, które dotyczą znaczących zmian w procesie tworzenia lub metodach dostarczania dóbr i usług. Innowacje procesowe często są utożsamiane $\mathrm{z}$ innowacyjnością technologiczną i dotyczą zmian $\mathrm{w}$ technice wyposażenia czy wykorzystywanym oprogramowaniu (Kitchell, 1997; Avlonits, Kouremenos i Tzokas, 1994). Celem wprowadzenia innowacji procesowych może być obniżenie kosztów produkcji lub świadczenia usług, podniesienie jakości lub dostarczenie nowego lub ulepszonego produktu. Do innowacji procesowych można zaliczyć wprowadzenie nowych metod produkcyjnych, automatyzację linii produkcyjnej, wykorzystanie komputerów w procesie projektowania nowych produktów, wprowadzenie nowych rozwiązań logistycznych, w tym w szczególności nowych metod i narzędzi zaopatrywania w zasoby, alokacji tych zasobów wewnątrz przedsiębiorstwa oraz dostarczenie produktów do odbiorców końcowych. Innowacyjność procesowa stanowi imperatyw dla zdolności innowacyjnej przedsiębiorstwa do wykorzystania zasobów i umiejętności, a co najważniejsze - zdolności do rekonfiguracji zasobów materialnych i niematerialnych w celu sprostania wymaganiom kreatywnej produkcji (Wang i Ahmed, 2004).

Czwarty obszar wskazany przez C.I. Wanga oraz P.K. Ahmeda (2004) to innowacyjność behawioralna, która może być rozpatrywana na różnych poziomach: indywidualnym, zespołu i najwyższego kierownictwa. Pomiar innowacyjności be- 
hawioralnej przedsiębiorstwa powinien odzwierciedlać trwałe zmiany zachowania członków organizacji odnoszących się do innowacji, takich jak między innymi zaangażowanie i otwartość na nowe pomysły i innowacje (Avlonits i in., 1994). Indywidualna innowacyjność może być interpretowana jako chęć podjęcia zmiany zachowania i postawy przez osoby indywidualne (Hurt, Joseph i Cook, 1977), natomiast innowacyjność zespołu jest określana jako zdolność zespołowa do adaptacji do zmian (Lovelace, Shapiro, Weingart 2001), nie poprzez prostą sumę innowacyjności indywidualnych osób, ale jako synergię opartą na dynamice grupy. Natomiast innowacyjność kierownictwa jest demonstrowana poprzez chęć kierownictwa do podjęcia zmian i zaangażowanie w zachęcaniu pracowników do eksperymentowania z nowymi rozwiązaniami i popieraniu nowych inicjatyw (Rainey, 1999).

Ostatni obszar dotyczy innowacyjności strategicznej odnoszącej się do fundamentalnych zmian sedna prowadzonego biznesu lub sposobów jego realizacji (Markides, 1998). D. Besanko, D. Dranove, M. Shanley (1996) definiują innowacyjność strategiczną jako rozwój nowych strategii konkurowania kreujących wartość dla przedsiębiorstwa. Głównym celem innowacyjności strategicznej jest określenie zdolności przedsiębiorstwa do zarządzania wiązką ambitnych celów przedsiębiorstwa oraz identyfikowania luk zasobowych, a także podejmowania kreatywnych działań na rzecz ich minimalizacji. C. Markides (1998) wskazuje na wiele barier, z którymi przedsiębiorstwa muszą się zmagać, chcąc utrzymać innowacyjność strategiczną. Należy do nich między innymi przekonanie o braku potrzeby zmiany oraz braku umiejętności do przeprowadzenia skutecznej zmiany (Wells, 2014, s. 21-43). Badania empiryczne dotyczące innowacyjności strategicznej są mocno ograniczone, większość autorów nie rozważa tego obszaru jako części składowej innowacyjności organizacyjnej, niemniej w kilku opracowaniach można znaleźć pojedyncze elementy dotyczące innowacyjności strategicznej poddane analizie, takie jak: skłonność do ryzyka w identyfikowaniu i wykorzystywaniu szans (Miller i Friesen, 1983), innowacyjne zamierzenia strategiczne (Avlonits i in., 1994) oraz zdolność do utrzymania przewagi konkurencyjnej dzięki innowacyjności strategicznej (Capon i in., 1992).

Jak zauważa A. Noga (2009, s. 148), najważniejszym podmiotem w przedsiębiorstwie jest przedsiębiorca, on ponosi ryzyko wdrożenia innowacji i decyduje o przyszłości. P. Drucker (1992, s. 29), zdefiniował innowację jako wyjątkowe narzędzie przedsiębiorców, za którego pomocą ze zmiany czynią okazję do podjęcia nowej działalności gospodarczej lub świadczenia nowej usługi. Trudno nie dostrzec, jak ta definicja istotnie wpisuje się w koncepcję zwinności przedsiębiorstwa, której rdzeniem jest zdolność podejmowania zmian (Goldman i in., 1995; Day, 2000; Dove, 2001), a podstawę stanowią innowacje w postaci nowych modeli biznesu, sposobów działania, innowacyjnych produktów i usług (Bessant i in., 2001; Sambamurthy i in., 2003; Oyedijo, 2012). Współtwórcą innowacji jest często klient, to on w znacznym stopniu decyduje, ile z pomysłów uda się wdrożyć. Poprzez działania innowacyjne i kreowanie nowych produktów, rozwiązań organizacyjnych i proce- 
sów przedsiębiorstwa osiągają wyższy poziom zwinności, zapewniając sobie jednocześnie lepszą pozycję konkurencyjną (Sajdak, 2013c). Klienci stanowią zatem źródło pomysłów i rozwiązań innowacyjnych, są też użytkownikami w procesie testowania nowych produktów lub informowania o ich istnieniu (Sambamurthy i in., 2003; Roberts i Grover, 2012).

\section{Podejście behawioralne}

Teoria tradycyjna jest teorią normatywną, podczas gdy teoria behawioralna odrzuca podejście normatywne i opisuje „to, co jest”, co oznacza zmianę paradygmatu. Przedsiębiorstwo jest to organizacja o charakterze wręcz politycznym, stanowiąca koalicję i subkoalicję różnych interesariuszy. Sprzeczność ich interesów powoduje, że nie ma pewności, do jakiej realizacji wiązki celów ostatecznie dojdzie w przedsiębiorstwie. W formie najbardziej rozwiniętej, teoria behawioralna przedsiębiorstwa jest prezentowana w klasycznej pracy R.H. Cyerta i J.G. Marcha (1963). Obaj autorzy wychodzą z założenia separacji własności i kontroli. Zauważają, że menedżerowie nie mają jednego celu, mają różne cele indywidualne w zależności od poziomu i zakresu odpowiedzialności na ich stanowiskach. Ze względu na ścieranie się celów wymagają one mechanizmu uzgodnienia chociażby poprzez przetarg, koalicję, manipulowanie informacją. Cel faktycznie realizowany staje się „,wypadkową" różnych interesów (Noga, 2009, s. 195). Ujęcie behawioralne wyjaśnia funkcjonowanie przedsiębiorstwa poprzez analizę negocjacji prowadzonych przez indywidualne jednostki w ustanawianiu celów organizacyjnych, na które mogą mieć wpływ (Cyert i March, 1963):

- ograniczona racjonalność, która wpływa na gromadzenie i interpretację posiadanych informacji, co z kolei wpływa na formułowanie oczekiwań organizacji,

- podejmowanie decyzji poprzez wykorzystanie procedur operacyjnych i dostosowanie ich do poziomu istniejących aspiracji w precyzowaniu celów,

- rezultat wyboru dokonanego na podstawie dotychczasowych doświadczeń.

Podejście behawioralne umożliwiło wyjaśnienie wewnętrznego napięcia pomiędzy sztywnością organizacyjną a adaptacją. Na procesy decyzyjne z jednej strony oddziałuje dynamiczna natura aspiracji umożliwiających generowanie alternatywnych opcji, z drugiej jednak strony wypracowane i sprawdzone procedury działania zapewniają wewnętrzną jedność i stabilność, hamującą jednak zwinność strategicznych zachowań. Standardy procedur operacyjnych są efektem wypracowanych latami rozwiązań, wzbogaconych o doświadczenia, zakorzenionych w ludzkich nawykach, tak trudnych do zmiany czy modyfikacji. M. Augier i D.J. Teece (2008) przekonują jednak, że adaptacja standardowych procedur operacyjnych jest możliwa, aczkolwiek bardzo trudna, przedsiębiorstwa mogą dysponować odmiennymi zdolnościami dla wprowadzania zmian w ramach zachowań strategicznych. 
Podejście behawioralne eksponuje rolę menedżerów, podstawę podejmowanych przez nich wyborów, które stanowią de facto o wynikach przedsiębiorstwa. Uznając menedżerów i ich zachowanie za jeden z kluczowych elementów budujących zwinność przedsiębiorstw poprzez nadanie priorytetu działaniom adaptacyjnym, wpływ tego podejścia wmożna uznać za oczywisty. D.C. Hambrick i P.A. Mason (1984) udowodnili, że wyniki przedsiębiorstw w większym stopniu są odzwierciedleniem wartości i doświadczeń poznawczych menedżerów zarządzających, niż odbiciem korporacyjnych organów kontrolnych czy wynikiem wpływów otoczenia. Wnioski te zostały sformalizowane jako teoria wyższych eszelonów (upper echelons theor), a jej prekursorami byli między innymi K.R. Andrews (1971) oraz J. Child (1972). Teoria wyższych eszelonów, która poprzedzała teorię strategicznego przywództwa, koncentrowała się na tzw. czynnikach demograficznych, czyli obserwowalnych cechach menedżerów, takich jak: wiek, staż w organizacji, doświadczenia funkcyjne, wykształcenie czy pozycja finansowa. $Z$ czasem jednak przekształciła się w bardziej rozbudowaną perspektywę nazywaną teorią strategicznego przywództwa, zgodnie z którą to zarządzający menedżerowie odgrywają kluczową rolę w formułowaniu strategii organizacji (Finkelstein i Hambrick, 1996). Korzenie tej teorii są mocno osadzone w psychologii, w której się zakłada, że menedżerowie różnią się pod względem psychologicznego profilu, na który składają się między innymi wiedza, preferencje, wyznawane wartości. Zmienność ta wpływa na ich sposoby mentalnego przetwarzania informacji, a to z kolei oddziałuje na ich wybory strategiczne. Badania przywództwa strategicznego potwierdzają, że tzw. dominująca koalicja w przedsiębiorstwie ma wpływ na jego funkcjonowanie i wyniki. Przywództwo strategiczne powinno być definiowane jako zdolność wywierania wpływu na pracowników organizacji, tak aby z zaangażowaniem podejmowali oni działania, które w efekcie prowadzą do długookresowego wzrostu przedsiębiorstwa. Przywództwo polega na integracji cech wizjonerskich oraz zarządzaniu operacyjnym poprzez podejmowanie równoległych, czasem ryzykownych działań przy jednoczesnym zachowaniu odpowiedniego stopnia racjonalności (Rowe i Nejad, 2009). Przywództwo strategiczne powinno swoim zasięgiem obejmować całe przedsiębiorstwo, nie może być domeną jedynie najwyższego szczebla zarządzania. Według I. Ansoffa $(1985$, s. 167) taki rodzaj przywództwa może być sprawowany nie tylko przez naczelne kierownictwo przedsiębiorstwa, ale także przez pracowników niższych szczebli, którzy często posiadają dużo większą wiedzę i doświadczenie w swoich obszarach działalności i mogą się stać ośrodkiem strategicznego przywództwa w przedsiębiorstwie.

Dla zwinności przedsiębiorstw przywództwo strategiczne stanowi kluczowy atrybut zapewniający szybkie, efektywne i skuteczne adaptowanie do nieprzewidzianych zmian oraz reorganizację zasobów przedsiębiorstwa w celu wykorzystania pojawiających się okazji. Ten rodzaj przywództwa oznacza ciągłe dostosowywanie, reorientację i usprawnienia organizacji. Istotą jest wprowadzanie zmian, począwszy od kierunków działania przedsiębiorstwa aż po opracowanie wizji przyszłości oraz ustalenie niezbędnych strategii koniecznych do jej realizacji. 


\section{Koncepcja organizacji uczącej się}

Termin organizacji uczącej się po raz pierwszy został wykorzystany w 1963 roku przez R.M. Cyerta oraz J.G. Marcha w pracy dotyczącej behawioralnych aspektów organizacyjnego podejmowania decyzji $(1963$, s. 2). Autorzy uważają, że organizacyjne uczenie się stanowi efektywną strategię podniesienia wydajności przedsiębiorstw (Krohwinkel-Karlsson, 2007) i pojawia się, kiedy dochodzi do zmian zachowań (Gold, Malhotra i Segars, 2001). Jednak to P. Senge (1990, s. 3-4) jest uważany za jednego z najważniejszych twórców idei organizacji uczącej się. Głosił on, że ludzie w organizacji nieustannie poszerzają swoje zdolności w zakresie osiągania pożądanych efektów, tworzą nowe, innowacyjne wzorce myślenia, sami lub w zespołach uczą się, w jaki sposób uczyć się razem efektywniej i skuteczniej. Organizacyjne uczenie się oznacza proces doskonalenia działań poprzez lepsze ich zrozumienie dzięki nabytej wiedzy (Fiol i Lyles, 1985, s. 803). C. Argyris, D.A. Schön (1978), korzystając z pracy G. Batesona (1972), zaprezentowali model obejmujący trzy poziomy uczenia się. Pierwszy określa pojedynczą pętle (single-loop), pojawia się, kiedy członkowie organizacji wykrywają i korygują błędy, utrzymując jednocześnie wykorzystanie organizacyjnych norm i teorii. Drugi poziom to podwójna pętla uczenia się (double-loop), pojawia się, kiedy następuje potrzeba zmian organizacyjnych norm. Na trzecim poziomie pojawia się refleksja członków organizacji dotycząca wcześniejszych doświadczeń uczenia się, co skutkuje doskonaleniem procesu uczenia się.

Uczenie się może poprawić efektywność zarządzania poprzez nabycie umiejętności wychwytywania szans w otoczeniu (Li, Chen, Liu i Peng, 2014). C. Argyris (1999) definiuje organizacyjne uczenie się jako proces wykrywania i korygowania błędów wynikających z dzielenia się wiedzą, przekonaniami i założeniami pomiędzy jednostkami i całymi zespołami. Dwa aspekty mają mieć kluczowe znaczenie dla tworzenia organizacyjnego uczenia się, są nimi szybkość zmian oraz wzrost presji konkurencyjnej. Uczenie się organizacji sprawia, że wzbogacane są zasoby wiedzy będącej w dyspozycji przedsiębiorstwa. Zwinność to zdolność do podejmowania szybkich zmian ze względu na zmieniające się okoliczności i warunki otoczenia, dlatego potrzebne jest uczenie eksploracyjne zwiększające różnorodność zasobów wiedzy, umożliwiające szybkie nabywanie wiedzy i dzielenie się nią.

Różnorodność wiedzy to właściwa odpowiedź na różnorodność otoczenia. Uczenie zyskuje sens, gdy udaje nam się szybko doprowadzić do komercjalizacji wiedzy, gdyż turbulencja otoczenia może doprowadzić w krótkim czasie do jej dezaktualizacji. Zatem procesy komercjalizacji wiedzy powinny być maksymalnie skrócone, gdyż szybka odpowiedź na turbulencję jest często ważniejsza niż nadmierna dbałość o jakość w sensie procedur, analiz czy poprawności metodycznej (Stańczyk-Hugiet, 2005). Nie bez znaczenia są tzw. zdolności absorpcyjne (absorptive capacity) określające możliwość i szybkość uczenia się, umiejętność rozpoznawania wartości nowej wiedzy, jej asymilacji oraz zastosowania w celach komercyjnych (Cohen i Levinthal, 
1990, s. 127-128). Tym bardziej celowe dla zwinności jest nie tylko wykształcenie, ale także ciągłe doskonalenie tych kompetencji.

Naukowcy dostrzegają znaczenie organizacyjnego uczenia się dla uzyskania przewagi konkurencyjnej i przetrwania przedsiębiorstw. Organizacyjne uczenie się stanowi istotną zdolność strategiczną przedsiębiorstwa do wyjaśnienia przewagi jednych przedsiębiorstw nad drugimi (Babuji i Crossan, 2004; Ussahawanitchakit, 2012). Jak zauważa J. Rokita (2003, s. 67), wraz z rozwojem zarządzania strategicznego coraz szerszym zainteresowaniem naukowców cieszyła się perspektywa zarządzania strategicznego jako procesu kolektywnego uczenia się, w którym następuje rozwój i wykorzystanie kluczowych kompetencji, niezwykle trudnych do skopiowania przez konkurentów. W zwinności kluczowa jest wiedza ukryta, która ze względu na trudność imitacji stanowi cenne źródło przewagi konkurencyjnej. Strategiczny charakter wiedzy ukrytej (tacit knowledge) dostrzegli już I. Noaka i H. Takeuchi (1995), twierdząc, że menedżerowie powinni doceniać ważność wiedzy ukrytej, różniącej się od wiedzy jawnej, która ma charakter formalny. Jest to rozwinięcie wcześniejszej konstatacji M. Polanyi (1966), który jako pierwszy sformułował pojęcie ukrytej wiedzy, twierdząc, że „możemy wiedzieć więcej, niż możemy powiedzieć” a „wiedza milcząca jest osobistym, szczególnym kontekstem i tym samym jest trudna do formalizacji i przekazu”, inaczej niż wiedza jawna, cechująca się możliwością przekazania jej w formalnym języku.

Organizacyjne uczenie się może być definiowane jako kreowanie i wykorzystanie wiedzy dla wyeksponowania przewagi konkurencyjnej poprzez uzyskanie i dzielenie się informacjami o potrzebach klientów, zmianach rynkowych i działaniach konkurentów. Jest procesem zakorzenionym wewnątrz organizacyjnej kultury i wartościach promujących uczenie się (Panayides, 2007). P. Ussahawanitchakit (2012) potwierdza w swoich badaniach, że organizacyjne uczenie się stanowi także kluczowy czynnik determinujący strategiczne przywództwo. Oznacza umiejętność przedsiębiorstw polegającą na odpowiedniej reakcji na zmiany zachodzące w sposób ciągły, w celu utrzymania przewagi konkurencyjnej w długim okresie, kreowania nowych źródeł przewagi oraz uzyskania lepszych wyników.

Pomimo wielu różnych podejść do koncepcji organizacyjnego uczenia się za wyjątkowo cenne można uznać pięć zasad sformułowanych przez B. Burnesa (2009), które stanowią istotny wkład w zrozumienie zwinności przedsiębiorstw. Przetrwanie organizacji zależy od zdolności uczenia się w tempie tym samym, a nawet szybszym aniżeli zmiany następujące $\mathrm{w}$ otoczeniu, zatem uczenie się musi się stać wspólnym, a nie indywidualnym procesem.

Konieczna jest zasadnicza zmiana kierunku systemu myślenia (potrójna pętla) członków organizacji. W tym celu niezbędne jest nabycie umiejętności organizacyjnego uczenia się - organizacja ma zdolność nie tylko szybkiego i odpowiedniego adaptowania się do zmieniających się okoliczności, ale także własnej transformacji, jeśli jest to konieczne. Poprzez umiejętność własnej transformacji w procesie adaptacji organizacja może wpływać lub nawet przekształcać swoje otoczenie. 
Organizacyjne uczenie się obejmuje kreację, adaptację oraz replikację wiedzy (Dyer i Shafer, 1998), prowadząc z biegiem czasu do akumulacji wiedzy (Senge, 1990; March, 1991). Integracja wewnętrznej (zarówno indywidualnej, jak i organizacyjnej) bazy wiedzy i organizacyjnego uczenia się poprawia efektywność organizacyjną poprzez doskonalenie wykonanych zadań bazujące na doświadczeniu (Ranft i Lord, 2002; Braunscheidel i Suresh, 2009). Zwinność wymaga wiedzy powstającej w ramach organizacyjnych procesów uczenia się przez wykwalifikowanych pracowników (Roth, 1996). Przedsiębiorstwa charakteryzujące się zwinnością polegają na umocowanych pracownikach (empowered employees), którzy dzięki posiadanej wiedzy są czujni na pojawiające się szanse oraz wyzwania i potrafią w odpowiednim czasie dokonać elastycznej korekty działań (Li i in., 2008). Rozwój procesów uczenia się w organizacji dzięki sprzyjającej kulturze organizacyjnej, umocowanym pracownikom i elastycznym warunkom pracy jest niezbędny dla zwinności. Kreatywność, wszechstronność i doskonałość w rozwiązywaniu problemów to cechy organizacji, w których wiedza i procesy uczenia się stanowią fundament ich funkcjonowania.

\subsection{Założenia w podejściach będących źródłem zwinności na poziomie przedsiębiorstwa}

\section{Podejście oparte na wiedzy}

Za twórców tego podejścia uważa się M. Aoki (1986; 1990), I. Nonaka oraz H. Takeuchi (1995), japońskich naukowców, którzy w wyniku empirycznych porównań - uporządkowania tzw. faktów stylizowanych - między przedsiębiorstwami japońskimi i innymi, głównie amerykańskimi, zidentyfikowali cechy japońskich przedsiębiorstw, które zainspirowały ich do odmiennego postrzegania teorii przedsiębiorstwa. Zgodnie z tą koncepcją przedsiębiorstwo jest postrzegane jako instytucja, która potrafi zapewnić lepszą i bogatszą strukturę wymiany informacji niż rynek. Organizacja i hierarchia w przedsiębiorstwie wynikają z ważności (adekwatności, szybkości) informacji, a nie z formalnej struktury stworzonej przez menedżerów. W przedsiębiorstwie ważniejsze są „szczeble” wartości informacji niż szczeble ludzi i zadań. Silna przewaga przedsiębiorstwa nad konkurentami wyraża się w bogatszej i efektywniejszej wymianie informacji. Granice przedsiębiorstwa są płynne, zmieniają się elastycznie do potrzeb struktury informacyjnej. Płynne granice przedsiębiorstw powodują, że przedsiębiorstwo o nieefektywnej strukturze informacji traci swoją część rynku, która jest przejmowana przez przedsiębiorstwa o lepszej strukturze informacji (Noga, 2009, s. 166-167). 
Stosując hierarchiczną strukturę, zarządzający dysponują doskonałą wiedzą technologiczną powiązanych jednostek, ale są niezdolni do przeprowadzania monitoringu wyłaniających się zdarzeń mających wpływ na wykorzystywane technologie lub koniecznych, szybkich działań naprawczych implementowanych w jednostkach. Natomiast horyzontalna struktura przedsiębiorstwa pozwala na koordynację decyzji produkcyjnych pomiędzy powiązanymi jednostkami, które w istocie mają niepełną wiedzę technologiczną, ale stopniowo stają się zdolne do szybkiego reagowania na pojawiające się nieprzewidziane zdarzenia poprzez efektywniejsze wykorzystanie posiadanej wiedzy (Aoki, 1986).

Integralną częścią informacyjnej teorii przedsiębiorstwa jest wiedza, której podziału na jawną (explicit knowledge) i ukrytą (tacit knowledge) dokonał w latach 50. M. Polanyi (1958). We wczesnych latach 90. I. Nonaka (1991) wykorzystał tę koncepcję w teorii kreowania wiedzy w przedsiębiorstwie, uwypuklając przede wszystkim rolę ukrytej wiedzy w rozwoju wiedzy gospodarczej. Opracowano model SECI odnoszący się do przetwarzania wiedzy tajnej i jawnej w wyniku czterech procesów (socjalizacji, eksternalizacji, kombinacji, internalizacji) (Nonaka i Takeuchi, 1995). M. Li oraz F. Gao (2003) podkreślają, że transfer wiedzy (knowledge transfer) nie jest tym samym co tworzenie wiedzy (knowledge creation). Transfer wiedzy odnosi się do współzawodnictwa i ciągłego uczenia się od konkurentów na rynku lub licencjonowanych wynalazców. Uczestnicy procesu transferu wiedzy, wykorzystując benchmarking, identyfikują rynkowe trendy i najlepsze praktyki biznesowe dzięki gromadzeniu dobrej jakości informacji oraz inteligentnym systemom informacyjnym $^{14}$. Proces kreowania wiedzy nie stanowi podstawy polepszenia konkurencyjności przedsiębiorstwa, jest nim raczej zdolność do ciągłego uczenia się. Autorzy opracowali model koncepcyjny odnoszący się do wpływu transferu wiedzy na przewagę konkurencyjną (rysunek 2.2). Teoria tworzenia wiedzy przedsiębiorstwa (the-

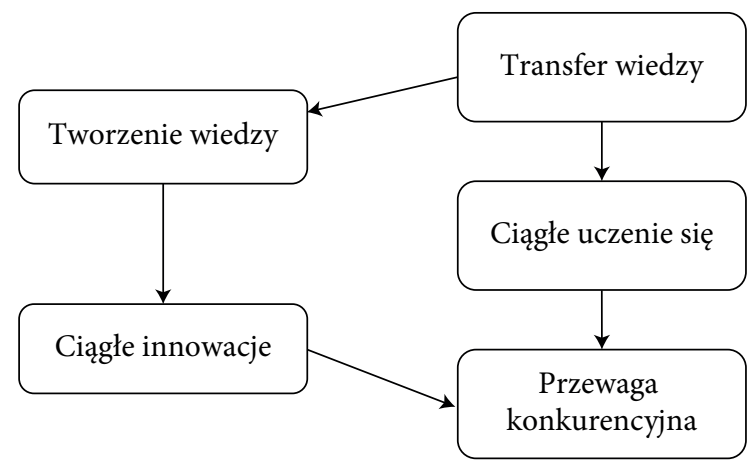

Rysunek 2.2. Wpływ transferu wiedzy na przewagę konkurencyjną Źródło: (Li i Gao, 2003).

${ }^{14}$ Wykorzystywanym przez przedsiębiorstwa japońskie dwie dekady temu, a w wielu nowo industrializowanych krajach wykorzywanym obecnie. 
ory of knowledge-creating company) odniosła sukces w wyjaśnieniu, w jaki sposób japońskie przedsiębiorstwa produkcyjne kreują i utrzymują dynamiczny rozwój innowacji w realizowanych procesach, rozwoju produktu i adaptacji organizacyjnej. W literaturze nie brakuje także badań dotyczących wpływu procesu kreacji wiedzy na wyniki przedsiębiorstwa. Y.H. Li, J.W. Huang oraz M.T. Tsai (2009), wykorzystując model kreacji wiedzy SECI, wykazali, że każdy proces kreacji wiedzy w przedsiębiorstwie jest istotny i ma pozytywny wpływ na jego wyniki.

W zakresie nauk o zarządzaniu rola systemu informacyjnego jest jednoznacznie określona jako rola podsystemu zarządzania pełniącego wiele funkcji użytkowych w celu uzyskania sprawności jednostki w horyzoncie krótko- i długookresowym. Zgodnie z modelem procesu decyzyjnego na każdym etapie procesu podejmowania decyzji konieczne jest dysponowanie informacjami: przedstawiającymi problem, opisującymi i identyfikującymi jego istotę, umożliwiającymi określenie wariantów rozważań owego problemu oraz podjęcie decyzji o sposobie rozwiązania trudności przy wykorzystaniu podstawowych elementów decydowania. Zatem system informacyjny należy potraktować jako integralną cześć systemu zarządzania, stanowiącą jego podsystem. Znaczna część systemów informacyjnych wspomaga procesy gospodarcze w zakresie rejestracji operacji gospodarczych i ich rozliczania, gospodarowania zasobami, w zakresie sprzedaży produktów, komunikacji z innymi podmiotami (dostawcami, klientami, konkurentami) i wymiany informacji w przedmiotowych zakresach wynikających z wykonywanych zadań (Urbanowska-Sojkin, 2011, s. 209-244). Identyfikacja pojawiających się szans w otoczeniu wymaga informacji pochodzącej z monitoringu otoczenia, zdobywania wiedzy o otoczeniu oraz interpretowania zjawisk otoczenia (Rapp i in., 2010; Teece, 2007). Wiele uwagi w literaturze poświęca się korzyściom z powiązania strategicznych technologii informacyjnych (strategic information technology) ze zwinnością i w konsekwencji wpływu na wyniki przedsiębiorstw (Tallon i Pinsonneault, 2011). Praktyki dzielenia się wiedzą i zachowania sprzyjające temu procesowi stanowią istotny czynnik w identyfikowaniu zagrożeń oraz szans w otoczeniu, poprzedzając decyzje przedsiębiorstwa o sposobie, czasie i formie reakcji na zaistniałe zmiany (Gibson i Birkinshaw, 2004; Preston i Karahanna, 2009; Reich i Benbasat, 1996).

O kluczowej roli informacji w zdolności przedsiębiorstw do podejmowania zmian (nowych modeli biznesu) piszą Y. Doz i M. Kosonen (2008a, s. 17-35), którzy charakteryzując zwinność strategiczną, identyfikują ją między innymi z posiadaniem wrażliwości strategicznej (strategic sensitivity). Według autorów wrażliwość strategiczna polega m.in. na prognozowaniu strategicznym (strategic foresight) i antycypowaniu konsekwencji kluczowych trendów w celu wczesnego zidentyfikowania zagrożeń i niepokojących zjawisk. Dzięki temu przedsiębiorstwa mogą wykorzystać swoją przewagę $\mathrm{w}$ celu ochrony przed zagrożeniem lub zaplanować efektywne działania dostosowawcze do nowych standardów. Także M.L. Fischer (1997, s. 105-116) twierdzi, że receptą na sukces organizacji w otoczeniu dużej prędkości (high velocity) jest posiadanie wrażliwości strategicznej. Kluczem wyjaśniającym charakter 
otoczenia dużej prędkości jest szybka, nieciągła i symultaniczna zmiana popytu, konkurentów, technologii i regulacji (Bourgeois i Eisenhardt, 1998, s. 816-835). Występuje ciągły dynamizm lub zmienność, których charakterystyką jest gwałtowana zmiana nieciągła, zatem nie tylko trudno zmiany przewidzieć, ale równie trudne jest określenie ich znaczenia, kiedy się już wydarzą.

Wkład informacyjnej teorii przedsiębiorstwa w kontekst zwinności przedsiębiorstw jest nie do przecenienia. Informacja stanowi fundament wrażliwości strategicznej, która jako jeden z atrybutów zwinności jest definiowana jako zdolność percepcji szans, na którą składają się: identyfikacja okazji, ocena okazji, kryteria wyboru okazji, nastawienie przedsiębiorstwa do korzystania z okazji. Wszystkie te elementy wymagają informacji, na podstawie której przedsiębiorstwa są w stanie podejmować efektywne decyzje. Przewagę uzyskują te przedsiębiorstwa, które zdobędą informację szybciej niż konkurenci, będzie ona lepszej jakości i będzie odpowiednio zinterpretowana. W koncepcji zwinności przedsiębiorstw widoczny jest między innymi wkład M. Aoki (1986) dotyczący przewagi efektywnej struktury wertykalnej nad hierarchiczną w obszarze informacyjnym przedsiębiorstwa. Należy docenić również koncepcję transferu wiedzy i jej roli dla adaptacji przedsiębiorstwa do otoczenia i utrzymania przewagi konkurencyjnej (Li i Gao, 2003).

\section{Podejście relacyjne}

W ramach podejścia relacyjnego pozycja przedsiębiorstwa wynika z uczestnictwa w kooperacjach (sieciach), a celem przedsiębiorstwa staje się maksymalizacja zysku wspólnie z konkurentami (kooperantami), co z kolei najskuteczniej się dokonuje, gdy przedsiębiorstwo przestrzega zasady $4 \mathrm{~W}$ - wspólne wartości, wspólna wiedza, wzajemność i wiarygodność (zaufanie) (Noga, 2009, s. 168). Jednak jak zauważa A. Noga (2009, s. 170), potencjał tej teorii w zarządzaniu przedsiębiorstwem jest wciąż bardzo słabo wykorzystywany (poza przedsiębiorstwami japońskimi). Zazwyczaj struktury organizacyjne przedsiębiorstw charakteryzują się (z punktu widzenia tej teorii) patologiami: tam, gdzie powinna być kooperacja, wspólny interes (win-win), dochodzi do destrukcyjnej konkurencji, tam, gdzie stymulująca jest wewnętrzna konkurencja (gra niekooperatywna), dochodzi do obstrukcyjnej kooperacji.

Współpraca oznacza poszukiwanie korzyści z działania w grupie, dążenie do efektu synergii wynikającego z relacji współdziałania, jest jedną z wytycznych sprawnego działania. Współpraca może wzmacniać możliwości generowania wartości poprzez wykorzystanie szans oraz wykorzystanie wiedzy i zasobów innych przedsiębiorstw. Może się stać istotnym impulsem realizacji określonych przedsięwzięć, odgrywa ona rolę relacyjną, pozwalając na zwinne dostosowywanie się do zmieniających się warunków w drodze kształtowania form i zakresu współpracy międzyorganizacyjnej (Kozłowski i Matejun, 2012, s. 36). Dzięki współpracy przedsiębiorstwa mogą także 
ograniczyć ryzyko (poprzez jego dywersyfikację), zwiększyć szybkość wprowadzania produktów na rynek, zmniejszyć koszty rozwoju produktu, doskonalić procesy oraz dostęp do rynków i technologii (Eisenhardt i Schoonhoven, 1996, s. 136-150; Hagedoorn, 1993, s. 371-385; Kogut, 1988, s. 319-332; Wheelwright i Clark, 1992, s. 2-14). Współdziałanie może występować $\mathrm{w}$ dwóch formach - wertykalnej oraz horyzontalnej. Współdziałanie wertykalne jest rozumiane w kategoriach współdziałania strategicznego, natomiast relacje horyzontalne współpracy odnoszą się do relacji między konkurentami i są zorientowane na wspólne z nimi budowanie potencjału konkurencyjnego (Stańczyk-Hugiet, 2013, s. 74-75).

Podejście relacyjne (relational view), podobnie jak podejście zasobowe (resource based view $R B V$ ), przedstawia rozwiązania i wyjaśnia podstawy teoretyczne odnoszące się do problemu rozwijania sieci relacji. Przedsiębiorstwa kooperujące dążą do osiągnięcia renty relacyjnej, a przez to także i przewagi konkurencyjnej. Cel ten mogą realizować na trzy sposoby, poprzez (Czakon, 2005):

- wzrost efektywności ze względu na racjonalizację kosztów - może się odbywać poprzez ograniczenie kosztów transakcyjnych, ograniczenie kosztów operacyjnych oraz poprawę elastyczności kosztów;

- przyspieszenie i doskonalenie procesów uczenia się - relacje przedsiębiorstwa wspierają zarówno pozyskiwanie istniejącej wiedzy, tworzenie nowej wiedzy, jak i dostęp do informacji;

- ułatwienie realizacji celów strategicznych - tworzenie relacji przedsiębiorstwa $\mathrm{z}$ otoczeniem stanowi narzędzie realizacji jego strategii poprzez dostęp do kluczowych zasobów oraz zmniejszenie ryzyka niepowodzenia.

W. Czakon (2005) zauważa, że poprawa elastyczności kosztów wiąże się z możliwością konfigurowania relacji przedsiębiorstwa ze względu na potrzeby rynku. Autor docenia możliwość wyboru zmiany aktywów przedsiębiorstwa bez ponoszenia kosztów inwestycji oraz kosztów stałych z tytułu posiadania. Umiejętność tę określa jako strategic agility. Dostęp do aktywów, które znajdują się w posiadaniu partnerów przedsiębiorstwa, uzyskuje się poprzez zmianę partnerów. Wymaga to oczywiście wzajemnej lojalności partnerów i transparentności działań.

J.H. Dyer oraz H. Singh (1998) zauważają, że w podejściu relacyjnym kategoria przewagi konkurencyjnej jest ściśle powiązana z siecią relacji, którą tworzą przedsiębiorstwa będące w konsekwencji zdeterminowane idiosynkratycznymi relacjami międzyorganizacyjnymi. Rentę relacyjną definiują jako ponadprzeciętne przychody osiągane wspólnie przez przedsiębiorstwa uczestniczące we wzajemnej wymianie, których nie mogłyby osiągnąć osobno, a które są możliwe do osiągnięcia wyłącznie poprzez unikatowy wkład konkretnych partnerów. Renta relacyjna wynika z relacji wymiany i pojawia się, gdy partnerzy inwestują w zasoby specyficzne dla danej relacji (relastion-specific assets), rozwijają międzyorganizacyjne rutyny dzielenia się wiedzą (knowledge-sharing routines), wykorzystują komplementarne zasoby i umiejętności (complementary resources and capabilities), dbają o niskie koszty transakcyjne (effective governence). 
Kooperacja stanowi istotną cechę zwinności przedsiębiorstw. Podstawy tej teorii są widoczne w atrybucie przedsiębiorczości strategicznej, który bezpośrednio odnosi się do zdolności pozyskania niezbędnych zasobów z otoczenia w celu wykorzystania szans rynkowych. Wykorzystując perspektywę kluczowych kompetencji (core competences approach), przedsiębiorstwa budują alianse zapewniające im dostęp do funkcji i procesów niestanowiących rdzenia ich działalności. W najbardziej ekstremalnej formie może to być przedsiębiorstwo wirtualne, gdzie grupa niezależnych przedsiębiorstw, w której każde dysponuje cennymi kluczowymi kompetencjami, współpracuje w celu wykorzystania pojawiającej się na rynku szansy, a po jej wykorzystaniu następuje ich rozwiązanie. Przedsiębiorstwa mogą podejmować współpracę niezależnie od położenia geograficznego, wykorzystując sieci komputerowe i rozwiązania IT (Baker, 1996).

\section{Perspektywa dynamicznych zdolności ${ }^{15}$}

Dynamiczne zdolności ${ }^{16}$ (dynamic capabilities), zgodnie z najbardziej rozpowszechnioną w literaturze definicją zaproponowaną przez D.J. Teece’a i współautorów (1997), umożliwiają „integrację, budowę i rekonfigurację wewnętrznych i zewnętrznych kompetencji organizacji w celu dostosowania się do dynamicznie zmieniającego się otoczenia. Dynamiczne zdolności odzwierciedlają zdolność organizacji do tworzenia nowych, innowacyjnych sposobów osiągania przewagi konkurencyjnej”. Przymiotnik „dynamiczne” w tym pojęciu pochodzi od predyspozycji organizacji do utrzymania swoich kompetencji w zmieniającym się otoczeniu. Wymaga to innowacyjnego podejścia, wyczucia czasu oraz umiejętności podjęcia natychmiastowych działań. Z kolei słowo „zdolności” jest związane z umiejętnością zarządzania wewnętrznymi i zewnętrznymi zasobami oraz kompetencjami organizacji umożliwiającą jej przetrwanie w turbulentnych warunkach. K. Eisenhardt i J.A. Martin (2000), opierając się na wcześniejszej definicji D.J. Teece’a, G. Pisano i A. Shuena, charakteryzują dynamiczne umiejętności jako organizacyjne i strategiczne rutyny (organizational and strategic routines), dzięki którym przedsiębiorstwo jest w stanie rekonfigurować swoje zasoby, podczas gdy rynki łączą się, dzielą, ewoluują oraz zanikają. Podejście oparte na dynamicznych zdolnościach ma charakter bardziej teoretyczny niż empiryczny, przez co czasami trudno je odnieść do rzeczywistości biznesowej.

${ }^{15}$ Treść tego punktu została zaczerpnięta z pozycji: (Malewska i Sajdak, 2017).

${ }^{16} \mathrm{~W}$ pracy pojęcie dynamic capablities jest tłumaczone zamiennie jako dynamiczne umiejętności (Stańczyk-Hugiet, 2013, s. 108) lub dynamiczne zdolności (Wójcik-Karpacz, 2012; Stańczyk-Hugiet, 2013, s. 108), lub kompetencje dynamiczne (Czakon, 2010) zgodnie z przyjętymi w polskiej literaturze tłumaczeniami. 
W literaturze przedmiotu można zidentyfikować dwa podstawowe podejścia dotyczące problematyki dynamicznych zdolności. Pierwsze z nich jest oparte na teorii ewolucyjnej (Nelson i Winter, 1982), zgodnie z którą organizacje posiadają zdolności umożliwiające przeprowadzanie zmian. Zdolności te jednak dotyczą wyłącznie określonego obszaru, w którym przedsiębiorstwo się specjalizuje (domeny). Wymagają one ciągłych inwestycji oraz procesu uczenia się (Fiol i Lyles, 1985). W ramach tego podejścia dynamiczne zdolności są definiowane jako predyspozycje umożliwiające rozszerzenie, modyfikację oraz kreowanie podstawowych zdolności organizacji (Winter 2003). Do cech dynamicznych zdolności w tym podejściu można zaliczyć (Winter, 2003; Teece i in., 1997):

- Związek ze złożonymi procedurami, które oznaczają stałe wzory czynności umożliwiające zmianę bieżących zdolności organizacji (są to ustrukturyzowane czynności bazujące na umiejętnościach).

- Kreowanie dynamicznych zdolności wymaga stałych i kosztownych inwestycji związanych z realizacją długoterminowych zobowiązań w określonych domenach. Według G. Pisano (1996) proces budowy zdolności jest uzależniony od procesu uczenia się wynikającego z każdego realizowanego projektu. Z kolei M. Zollo i S.G. Winter (2002) postulują, że formułowanie zdolności jest związane $\mathrm{z}$ każdym procesem uczenia się łącznie $\mathrm{z}$ akumulowaniem doświadczenia, które nie wymaga celowych inwestycji w sam proces nauki, przetwarzania i kodyfikacji wiedzy.

- Rozwój nowych zdolności jest uzależniony od sposobu funkcjonowania danej organizacji (zajmowanej przez nią pozycji oraz wybranego wcześniej kierunku działania).

- Dynamiczne zdolności zawsze związane są z określoną domeną.

Warto zauważyć, że w podejściu opartym na teorii ewolucyjnej zakłada się, że otoczenie, w którym funkcjonuje organizacja, ma kluczowe znaczenie dla osiąganych przez nią wyników. Jeżeli otoczenie gwałtownie się zmienia, przedsiębiorstwo może nie być $\mathrm{w}$ stanie dostosować się do tych zmian, mimo rekonfiguracji posiadanych w danym obszarze zdolności. Może się okazać, że adaptacja do otoczenia będzie wymagać wykroczenia poza daną domenę, w której specjalizuje się organizacja.

W drugim wspomnianym podejściu do zagadnienia dynamicznych zdolności zakłada się, że ewolucyjna teoria w tym obszarze znajduje swoje zastosowanie wyłącznie w odniesieniu do organizacji funkcjonujących w umiarkowanym otoczeniu, w ramach którego zmiany pojawiają się relatywnie często, ale można je przewidzieć. W zawiązku $\mathrm{z}$ faktem, że struktura danej branży w tym przypadku pozostaje bez zmian, oznacza to, że organizacja może skutecznie przeprowadzać zmiany, korzystając z posiadanej wiedzy dotyczącej danej domeny. Natomiast w sytuacji, w której przedsiębiorstwa funkcjonują w turbulentnym otoczeniu charakteryzującym się częstymi, nieprzewidywalnymi, zachodzącymi w sposób nieliniowy zmianami, na dynamiczne zdolności składają się proste reguły i strukturalne zasady, które (Eisenhardt i Martin, 2000): 
- zapewniają swoiste ramy ułatwiające skupienie uwagi menedżerów na potrzebie dokonania zmiany,

- umożliwiają koncentrację zarządzających na kluczowych kwestiach, jednocześnie pozostawiając im swobodę wyboru sposobu działania, niekoniecznie związanego $\mathrm{z}$ daną domeną.

Zgodnie z prezentowanym podejściem dynamiczne zdolności oznaczają nieustrukturyzowane, elastyczne sposoby działania umożliwiające dostosowanie się do dynamicznych zmian zachodzących w otoczeniu. Jedną z podstawowych cech dynamicznych zdolności w tym ujęciu jest elastyczność działań umożliwiająca aplikację określonych rozwiązań w ramach różnych obszarów funkcjonowania (domen). Oznacza to, że organizacje mają zdolności transformacyjne umożliwiające im przeprowadzanie zmian o charakterze strategicznym, gwarantujące adaptację do zmieniających się warunków otoczenia. Wykorzystanie dynamicznych zdolności może zatem prowadzić do zmiany strategii organizacji jako całości.

W problematyce dynamicznych zdolności kwestią niejednoznacznie sprecyzowaną jest ich rola w osiąganiu przewagi konkurencyjnej przez organizacje. Nie ma sporów co do faktu, że stanowią one źródło przewagi konkurencyjnej w szybko zmieniającym się otoczeniu, jednak proces, w jaki to następuje, poddany jest dyskusji naukowców. W literaturze przedmiotu przyjmuje się, że dynamiczne zdolności mogą być podobne wśród przedsiębiorstw funkcjonujących na tym samym rynku, różnica sprowadza się do określenia konfiguracji zasobów, która umożliwi uzyskanie przewagi konkurencyjnej. Można zatem wnioskować, że samo posiadanie dynamicznych zdolności nie gwarantuje osiągnięcia przewagi, ale zdolności te są niezbędne w procesie rozwoju istniejących oraz kreowaniu nowych konfiguracji zasobów (Eisenhardt i Martin, 2000). Według D.J. Teece’a i współautorów (1997) dynamiczne zdolności mogą być źródłem przewagi konkurencyjnej, a jej trwałość zależy od tego, jak szybko i skutecznie zdolności te mogą zostać skopiowane przez konkurentów. Z kolei K.M. Eisenhardt i A. Martin definiują dynamiczne zdolności jako proste procesy, które mogą się przyczynić do osiągnięcia przewagi konkurencyjnej, ale jej trwałość jest dyskusyjna, gdyż wymaga ciągłej rekonfiguracji posiadanych przez organizację zasobów. Zdaniem autorów, przewagę konkurencyjną w niewielu przypadkach można tłumaczyć kreowaniem i wykorzystaniem dynamicznych zdolności. Argumentem przemawiającym za tym poglądem jest fakt, że stworzenie unikatowej kombinacji zasobów jest procesem bardzo trudnym do realizacji w praktyce (Eisenhardt i Martin, 2000). Podobnie twierdzą E. Cavusgil, S. H. Seggie i M. Berk Talay (2007), dostrzegając złożoność tego procesu i trudność w przełożeniu dynamicznych zdolności opierających się na wewnętrznych procesach na unikatową konfigurację zasobów. Jeżeli jednak proces ten zakończy się pomyślnie, możliwe jest opracowanie strategii rozwoju kreującej wartość dla organizacji.

Biorąc pod uwagę szybko i dynamicznie zmieniające się rynki, utrzymanie unikatowej kombinacji zasobów i umiejętności jest utrudnione. Coraz bardziej pożą- 
dane stają się takie cechy organizacji jak zdolność do przeprowadzania szybkich zmian czy umiejętność adaptacji (Schreyögg i Kliesch-Eberl, 2007). Przedsiębiorstwa są w stanie osiągać ponadprzeciętne zyski, będąc w posiadaniu określonych zasobów i kompetencji, lecz bez sformułowania dynamicznych zdolności korzyści te mają charakter wyłącznie krótkoterminowy (Teece i Augier, 2009). W literaturze podkreśla się, że dynamiczne zdolności są raczej wbudowane w procesy organizacyjne, niż są procesem samym w sobie. Umożliwiają proces transformacji zasobów i umiejętności organizacji w produkt lub usługę, które dostarczają wartość dodaną ostatecznemu klientowi. Szczególną ich rolę w budowaniu zwinności przedsiębiorstw odgrywają trzy komponenty wskazane przez C.L. Wang i P.K. Ahmed (2007). Autorzy w ramach dynamicznych zdolności wyróżniają zdolność do adaptacji do zmian w otoczeniu poprzez elastyczność zasobów, zdolność chłonności, czyli zdolność do pozyskiwania informacji z otoczenia i jej integracji z informacjami wewnętrznymi, jak również zdolność do innowacyjności umożliwiającą integrację wewnętrznej zdolności innowacyjnej przedsiębiorstwa z okazjami pojawiającymi się na rynku.

Im bardziej dynamiczny rynek, tym silniejsza potrzeba rozwoju dynamicznych zdolności. Większość autorów prac naukowych podejmujących tematykę dynamicznych umiejętności skupia się na zmianie, kreowaniu i rozwijaniu oraz rekonfigurowaniu zasobów w odpowiedzi na zmiany w otoczeniu. Perspektywa dynamicznych zdolności odnosząca się do dynamicznej efektywności idealnie uzupełnia myśl przewodnią podejścia zasobowego odnoszącą się do znaczenia efektywności alokacyjnej (wiązki zasobów i umiejętności) dla uzyskania i utrzymania przewagi konkurencyjnej (Najda-Janoszka, 2016, s. 72).

Należy zauważyć, że komponenty tych zdolności są typowe dla większości przedsiębiorstw. Różnica sprowadza się do wewnętrznych procesów związanych z kreowaniem określonej konfiguracji zasobów i umiejętności (sposobu, w jaki są przeprowadzane, formowane, zmieniane, zastępowane) oraz szybkości ich realizacji. S. Cyfert oraz K. Krzakiewicz (2017, s. 332-333), dokonując krytycznej analizy literatury przedmiotu, w której wskazuje się od czterech do ośmiu etapów w procesie kształtowania dynamicznych zdolności, proponują autorski, pięcioetapowy model, na który składają się:

- uczenie się, związane z pozyskiwaniem wiedzy, jej transferem wewnątrz organizacji, alokacją i przechowywaniem,

- poszukiwanie okazji, związane $\mathrm{z}$ analizowaniem trendów i zjawisk $\mathrm{w}$ otoczeniu, tworzeniem nowych idei oraz identyfikacją potrzeby zmian,

- koordynacja, związana z tworzeniem wizji integrującej interesariuszy, integracją działań w łańcuchu dostaw, zarządzaniem aliansami strategicznymi, budowaniem zaangażowania pracowników, integracją i koordynacją procesów biznesowych,

- konfiguracja i rekonfiguracja, związane z tworzeniem i pozyskiwaniem zasobów i umiejętności, ich integracją, tworzeniem innowacji, pozbywaniem się 
zbędnych i nadmiernych zasobów i umiejętności, wdrażaniem nowych technologii,

- adaptacja organizacji, związana z transformacją modelu biznesowego, zarządzaniem granicami organizacji, zapewnieniem dynamicznego procesu zarządzania strategicznego, doskonaleniem organizacji, zapewnieniem elastyczności struktury, zarządzaniem tożsamością organizacji.

W literaturze postuluje się, że dynamiczne zdolności mogą stanowić swego rodzaju ramy teoretyczne dla analizy koncepcji zwinności przedsiębiorstw (Roberts i Grover, 2012). Pojawiają się również opinie, że zwinność jest postrzegana jako jedna z dynamicznych zdolności organizacji umożliwiająca osiąganie przewagi konkurencyjnej (Goldman i in., 1995; Sambamurthy i in., 2003; Mason, 2010).

\section{Podejście zasobowe}

W nurcie zasobowym (RBV - resource-based view) przedsiębiorstwo jest postrzegane w perspektywie endogenicznego wzrostu. Jest podmiotem rozwijającym się, akumulującym zdobywaną wiedzę, tworzącym wewnętrzne kompetencje i umiejętności, na których jest budowana zdolność i pozycja konkurencyjna. Każde przedsiębiorstwo charakteryzuje się inną ścieżką wzrostu wewnętrznego, co skutkuje zajmowaniem różnych pozycji na rynku i zdolnością przedsiębiorstw do tworzenia i utrzymania trwałej przewagi konkurencyjnej. Początki rozwoju nurtu zasobowego sięgają lat 50. XX wieku i istotnego wkładu E. Penrose (1959), która $\mathrm{w}$ swojej teorii wzrostu przedsiębiorstwa przedstawiła nowatorskie podejście do zasobów, nie nazywając ich czynnikami produkcji, ale zbiorem zasobów produkcyjnych, które mogą być wykorzystane do różnych celów w różnym czasie. Według autorki zasoby nie powinny być traktowane jako „wsad do procesu produkcji, ich istotą jest to, że w zależności od kombinacji ilości i/lub jakości zasobów oraz sposobów ich wykorzystania przedsiębiorstwo może dostarczać otoczeniu (klientom) określony (choć zmienny) zestaw usług (ofertę rynkową). To właśnie możliwość wykorzystania posiadanych zasobów w tak zróżnicowany sposób powoduje wyjątkowość każdego przedsiębiorstwa na rynku, od tej wyjątkowości zależy zaś ich siła" (Penrose 1959, s. 25). E Penrose (1959) przekonuje, że wzrost ekonomiczny wymaga zachowania odpowiedniego balansu pomiędzy wykorzystaniem posiadanych zasobów i rozwojem nowych zasobów, co się wiąże z utrzymaniem dynamicznego napięcia pomiędzy rozwojem wewnętrznej wiedzy i nabyciem wiedzy z otoczenia. Heterogeniczność strategicznych zasobów wpływa na zróżnicowaną efektywność aktywów między konkurującymi przedsiębiorstwami, co prowadzi do uzyskania renty ekonomicznej. Prace E. Penrose stanowiły inspirację między innymi dla B. Wernerfelta (1984, s. 172), który czerpiąc z wcześniejszego dorobku, definiuje zasoby jako materialne i niematerialne aktywa przypisywane $\mathrm{w}$ niemal 
trwały sposób do przedsiębiorstwa. Wczesnymi przykładami takich zasobów były: marka, wiedza technologiczna, umiejętności pracowników, kontrakty handlowe, efektywne procedury itp. Autor wyraźnie odnosi się do prac E. Penrose w dwóch rozważanych aspektach:

- analizując przedsiębiorstwo jako szeroki zestaw zasobów,

- rozwijając myśl optymalnego wzrostu przedsiębiorstwa wymagającego utrzymania balansu pomiędzy stopniem wykorzystania posiadanych zasobów a rozwojem nowych zasobów.

A. M. Rugman i A. Verbeke (2002) zwracają uwagę na istotny wkład podejścia zasobowego w obszar zarządzania strategicznego, wyróżniając cztery jego cechy:

- ostatecznym celem przedsiębiorstwa w podejściu zasobowym jest osiągnięcie ponadprzeciętnego zwrotu w stosunku do konkurentów,

- zasoby (nierównomiernie dostępne dla wszystkich przedsiębiorstw), tworzące kompetencje i umiejętności, które określają możliwość uzyskania ponadprzeciętnych zwrotów,

- kompetencje i umiejętności prowadzą do ponadprzeciętnych zwrotów, jeśli można określić je mianem unikatowych (m.in. niedoskonale mobilnych), rzadkich dla klientów, niezastępowalnych i trudnych w imitacji,

- z perspektywy dynamicznej innowacje pojawiające się w ramach nowej kombinacji zasobów mogą mieć istotny wpływ na uzyskanie ponadprzeciętnych zwrotów.

Dzięki menedżerom (przedsiębiorcom) następuje w przedsiębiorstwie rozwój zasobów materialnych i kompetencji przez ich wzajemne wzbogacanie się, dywersyfikację, osiąganie wyjątkowej różnorodności. Według jednej z definicji zasoby to aktywa posiadane i kontrolowane przez przedsiębiorstwo, natomiast zdolności odwołują się do możliwości wykorzystania i kojarzenia zasobów poprzez organizacyjną pracę w celu osiągnięcia wyznaczonych celów (Amit i Schoemaker, 1993, s. 35). Przewaga konkurencyjna utrzymuje się dzięki unikatowości połączenia aktywów materialnych i niematerialnych przedsiębiorstwa w kluczowe kompetencje (core competences) zbudowane i kumulowane $\mathrm{w}$ ramach granic organizacji (Hitt, Ireland i Hoskisson, 2009, s. 72) i odznaczające się cennością rzadkością, trudnością w imitacji i trudnością w ich zastąpieniu (VRIN - value, rare, imperfactly imitable, non-substitutable) (Barney, 1991). Zasoby, które mają potencjał do utrzymania przewagi konkurencyjnej, powinny się odznaczać czterema atrybutami: powinny być cenne z punktu widzenia wykorzystywania szans $\mathrm{w}$ otoczeniu i neutralizowania zagrożeń, powinny być rzadkie wśród obecnych przedsiębiorstw oraz ewentualnych konkurentów, nie powinny łatwo poddawać się imitacji oraz nie powinny mieć strategicznych substytutów (Barney, 1991). Kluczowe kompetencje stanowią podstawę całych rodzin produktów i wchodzenia na nowe rynki, dlatego w trosce o swoje podstawowe kompetencje przedsiębiorstwo powinno przyjąć strukturę organizacyjną w postaci drzewa, gdzie główne kompetencje to korzenie dostarczające drzewu pożywienie i zapewniające stabilność, pień i konary reprezentują główne 
produkty, mniejsze gałęzie to strategiczne jednostki biznesu, a liście i owoce to produkty końcowe (Hamel i Prahalad, 1990).

W podejściu zasobowym kooperacja jest postrzegana jako podstawowy sposób umożliwiający zdobycie zasobów, zdolności i wiedzy (Hamel, 1991; Irealand, Hitt i Vaidyanath, 2002). Komplementarność zasobów implikuje nawiązywanie współpracy pomiędzy przedsiębiorstwami. Działania zmierzające do nabycia komplementarnych zasobów umożliwiają przedsiębiorstwu nauczenie się nowych, istotnych umiejętności (Overby i in., 2006). Alianse strategiczne mogą być atrakcyjną alternatywą dla nabycia komplementarnych zasobów, gdyż inwestycja w nie lub długoterminowe zobowiązania $\mathrm{z}$ nimi związane są mniejsze niż te wymagane w procesie przejęć przedsiębiorstw (Harrison, Hitt, Hoskisson i Ireland, 1991). M. Fiol (2001) słusznie zauważa, że w obecnym, znacznie bardziej konkurencyjnym środowisku zasoby i umiejętności przedsiębiorstw oraz sposoby ich pozyskiwania i wykorzystywania muszą nieustannie podlegać zmianom w celu generowania permanentnie zmieniających się tymczasowych przewag przedsiębiorstw. K.M. Eisenhardt oraz J.A. Martin (2000) określają specyficzne warunki, w jakich może zaistnieć przewaga konkurencyjna, zwracając uwagę na wykorzystanie przy podejmowaniu decyzji strategicznych dynamicznych umiejętności (dynamic capablities). Przedsiębiorstwa, które w obliczu szybkich zmian rynkowych mają umiejętność ich wykorzystania, są bardziej wyczulone na zmiany w swoim otoczeniu konkurencyjnym, będą w stanie szybciej się dostosować do zmiennego otoczenia niż konkurenci, a tym samym zdobyć przewagę konkurencyjną.

Wpływ teorii zasobów i kompetencji jest niezwykle istotny dla koncepcji zwinności przedsiębiorstw, zwłaszcza w kontekście osiągania przewagi konkurencyjnej i uzyskiwania ponadprzeciętnych wyników przedsiębiorstw dzięki posiadaniu wyjątkowych zasobów i umiejętności oraz przekucia ich na proces tworzenia wartości. Zwinność przedsiębiorstw bezpośrednio czerpie z perspektywy wewnętrznego wzrostu przyjętej przez nurt zasobowy, w którym podstawowym zadaniem strategii przedsiębiorstwa jest zapewnienie spójności wewnętrznej podejmowanych działań oraz rozwijanych wewnątrz umiejętności w taki sposób, aby zapewnić przedsiębiorstwu elastyczność odpowiadającą tempu zmian otoczenia i siłę wewnętrzną do podejmowania nowych wyzwań. Dąży się raczej do chociaż częściowego kształtowania otoczenia aniżeli prostego odpowiadania na jego sygnały (Sulimowska-Formowicz, 2002).

Turbulencja, chaotyczność czy nieciągłość otoczenia wymusza na przedsiębiorstwach zarówno kooperację w celu zdobycia zasobów (materialnych, niematerialnych), jak i zdolność do odnawiania kompetencji własnych w celu wykorzystania szans i tworzenia nowych, innowacyjnych sposobów osiągania przewagi (Teece i in., 1997). E. Stańczyk-Hugiet (2013, s. 32), analizując koncepcję otoczenia dużej prędkości, sugeruje zasadność stosowania strategii normatywnych czerpiących $\mathrm{z}$ dorobku RBV, wśród których jest podkreślane znaczenie zasobów, jednak przede wszystkim są eksponowane dynamika, proaktywność, poszukiwanie nowych rozwiązań, nowych modeli biznesu oraz istotna relacja współpracy. 


\section{Podejście ewolucyjne}

Pierwszy ewolucyjny model przedsiębiorstwa przedstawili na początku lat 80 . R.R. Nelson i S. Winter (1982, s. 9) w publikacji pt. Ewolucyjna teoria zmiany ekonomicznej (An evolutionary theory of economic change). Według autorów termin „ewolucyjna" sygnalizuje, że ekonomię ewolucyjną tworzą wyłącznie koncepcje, które w interpretacji procesów gospodarczych wykorzystują biologiczną teorię ewolucji, w szczególności teorię Darwina. Wielu jednak teoretyków zajmujących się problematyką ewolucji ekonomicznej wyraźnie zaznacza odrębność swoich koncepcji od teorii ewolucji w biologii. Powszechny jest także głos, że na skutek odmienności procesów biologicznych i gospodarczych (społecznych) biologiczne analogie nie mają zastosowania w naukach społecznych (Pottts, 2000, s. 10). Reasumując, wynika $\mathrm{z}$ tego, że ekonomia ewolucyjna jest nurtem niejednorodnym, obejmującym zarówno koncepcje odwołujące się do szerokiego rozumienia ewolucji jako stopniowego i ciągłego procesu przemian i adaptacji, jak i koncepcje wyjaśniania procesów gospodarczych na podstawie darwinowskiej frazeologii (Borkowska, 2004). Naukowcy definiują założenia ewolucyjnej teorii przedsiębiorstwa w sposób wielotorowy. Z jednej strony wskazują na nowe elementy, na których opiera się ta teoria (wykorzystanie pojęcia rutyn, analogii do teorii ewolucyjnej w biologii), z drugiej strony opierają się na krytyce dotychczasowych mankamentów teorii przedsiębiorstwa (Karaś, 2008).

M. Karaś (2008) wskazuje na swoiste cechy podejścia ewolucyjnego do teorii przedsiębiorstwa:

- Modele ewolucyjne są oparte na założeniu niedoskonałego dostosowania do otoczenia, odejście od neoklasycznych założeń racjonalności powoduje, że zachowania przedsiębiorstw są silnie uzależnione od słabych sygnałów otoczenia oraz kluczowe staje się analizowanie procedur (sposobów ich powstawania, przechowywania, modyfikowania), które są stosowane przy podejmowaniu decyzji.

- W modelach ewolucyjnych kładzie się nacisk na znaczenie różnorodności agentów. W modelach ewolucyjnych dynamiki branż wyłania się potrzeba mikropodstaw, które uwzględniają stałą różnorodność między przedsiębiorstwami ze względu na cechy charakterystyczne (wielkość, technologia, kultura organizacyjna), a także wyniki (konkurencyjność, rentowność itp.).

- W modelach ewolucyjnych zakłada się, że kolektywna adaptacja oraz uczenie się wymagają zróżnicowania (mutacji), ale także mechanizmów, które gwarantują spójność ogólną - mechanizmów selekcji. Każda organizacja ekonomiczna może być rozpatrywana w obszarze tego, co tworzy bazę uczenia się organizacji. Napotykają one barierę między koncentrowaniem swoich zasobów na wykorzystanie (zastosowanie) wiedzy a poszukiwaniem nowych możliwości. Do przeżycia organizacji potrzebne jest zarówno wykorzystanie, jak i poszukiwanie, które zapewnia dostosowanie i adaptację do zmieniających się warunków otoczenia. Jednak przedsiębiorstwa poświęcające wszystkie swoje zasoby na poszukiwanie 
nowych możliwości nie wykorzystają nabytej wiedzy ze względu na towarzyszący pojawiającym się okazjom wysoki poziom ryzyka.

- W modelach ewolucyjnych zakłada się, że proces uczenia się jest stymulowany przez poszukiwanie lepszych osiągnięć. Przedsiębiorstwa w swojej logice adaptacji mają zdolność nie tylko do uczenia się i przekazywania wiedzy, ale także do skoncentrowania się na szczególnych celach, aby poddać system pewnemu określonemu mechanizmowi wyboru i ukierunkować mechanizm generowania różnorodności.

Podstawowym elementem ewolucyjnej teorii przedsiębiorstwa jest pojęcie rutyny organizacyjnej wprowadzonej przez R.R. Nelsona i S.G. Wintera (1982), stanowiącej organizacyjną analogię umiejętności pojedynczej osoby. W przedsiębiorstwie rutyny przejawiają się w postaci wzorców zachowań, standardowych procedur operacyjnych lub stanowią zbiorowe dyspozycje do adaptowania nabytych lub wcześniej wykorzystanych zachowań w odpowiedzi na pewne stymulanty lub kontekst (Stańczyk-Hugiet, 2015). Podlegają one zazwyczaj formalizacji, najczęściej w formie zapisów, ale także mogą występować jako niezapisane, powtarzalne wzorce zachowań. Rutyny pojawiają się $\mathrm{w}$ przedsiębiorstwie $\mathrm{w}$ wyniku uczenia się, naśladowania procedur innych przedsiębiorstw oraz wskutek lokalnej adaptacji (Karaś, 2008). Takie ujęcie rutyny organizacyjnej wskazuje na jej powiązanie z koncepcją zwinności, która jest oparta na adaptacji i ciągłym uczeniu się i wykorzystuje wzorce sprawniejszych i szybszych procesów dostosowawczych. W postaci rutyny akumulowane są wiedza, doświadczenie i umiejętności odnoszące się do szeroko rozumianej organizacji i jej działalności, mające w dużym stopniu charakter unikatowy - dostosowany do określonych warunków. Dzięki tak specyficznym cechom, rutyny zapewniają pewną ciągłość i wzmacniają wewnętrzną stabilność organizacji. Powtarzalność stosowania i towarzyszące temu akumulowanie kompetencji pozwala na przypisanie wzorcowym zachowaniom organizacyjnym formy pamięci organizacji, a także traktowanie jej jako odpowiednika genów w teorii ewolucyjnej. Wykształcił się on jako sposób dopasowania do środowiska i do sprzeczności interesów członków organizacji. Będąc podstawą organizacyjnej pamięci, jest jednocześnie jej fundamentem i uzasadnieniem.

Jak zauważają P. Cohendet oraz P. Llerena (1998), na rynku odbywa się proces selekcji przedsiębiorstw poprzez dokonanie wyboru tych, które w najwyższym stopniu spełniają wymagania rynku. Przyczyną owej selekcji jest fakt, że nie wszystkie przedsiębiorstwa są $\mathrm{w}$ stanie w sposób równie skuteczny i efektywny dostosować się do wymogów rynku. Powodem są m.in. właściwości rutyn, które są w dużym stopniu odpowiedzialne za bezwład i nieelastyczność zachowań organizacji. Poza selekcją przedsiębiorstw elementem teorii ewolucyjnej jest też proces stałego różnicowania. Przedsiębiorstwa opierają się na odmiennych wzorcach zachowań organizacyjnych i ich wiązkach, które są dla nich swoiste, których imitacja lub przekształcanie jest kosztowne i utrudnione. Proces różnicowania przedsiębiorstw jest spowodowany ich ciągłym uczeniem się, a w efekcie modyfikowaniem i do- 
stosowywaniem wzorców zachowań organizacyjnych i ich kombinacji (wiązek) do lokalnych warunków funkcjonowania organizacji (Karaś, 2008). Zatem z jednej strony rutynowe zachowania ułatwiają gromadzenie specyficznej wiedzy operacyjnej, stanowiąc pamięć organizacyjną, z drugiej natomiast mogą być barierą dla podejmowania zmian i innowacyjności. Przedsiębiorstwa charakteryzujące się zwinnością stanowią sieć rutyn (Grant, 1991), które podlegają zmianom ze względu na zmiany otoczenia. Wewnątrz przedsiębiorstwa niezbędny jest proces selekcji i modyfikacji procedur przez kierownictwo w celu ich doskonalenia. Zadaniem przedsiębiorstw ukierunkowanych na zwinność jest rozwój i doskonalenie rutyn, zarówno tych centralnych, jak i peryferyjnych, a kluczem do sukcesu jest zapewnienie szybkich rutynowych działań w odpowiednim czasie i miejscu, zapewniających wysoką efektywność działalności.

\subsection{Przesłanki z rozważań teoretycznych}

Zaprezentowany w rozdziale przegląd ma na celu wskazanie wkładu każdego z prezentowanych podejść w rozwój istoty zwinności. Pomimo faktu, że zaprezentowane podejścia teoretyczne rozwijały się jako niezależne koncepcje, dostrzec można komplementarność poszczególnych teorii. W naukach o zarządzaniu można zaobserwować tendencję do łączenia podejść teoretycznych pochodzących $\mathrm{z}$ różnych dziedzin, co jest zgodne z paradygmatem systemowym w nauce (Światowiec-Szczepańska, 2012, s. 82). Łączenie różnych podstaw teoretycznych może zapewnić lepsze poznanie i zrozumienie istoty zwinności i potrzeby jej rozwijania w przedsiębiorstwach. Pomimo że poszczególne podejścia teoretyczne dość dobrze wyjaśniają naturę zwinności, to jednak odczuwalny jest brak teorii uwzględniającej wszystkie aspekty definicyjne zwinności. W tabeli 2.3 przedstawiono wnioski dotyczące analizowanych podejść teoretycznych z uwzględnieniem ich wpływu na istotę i rolę zwinności.

Fundament teoretyczny zaprezentowany w niniejszym rozdziale ma istotny wkład w zrozumienie i wyjaśnienie istoty zwinności, szczególnie w tworzeniu jej atrybutów. Zauważalny jest silny wpływ poszczególnych podejść teoretycznych w budowaniu kluczowych cech współtworzących zwinność strategiczną. Przedstawiając przesłanki wybranych podejść teoretycznych, wskazano na ich rolę dla atrybutów kszałtujących konstrukt teoretyczny, jakim jest zwinność. Analiza prezentowanych podejść stanowi punkt wyjścia do określenia w kolejnym rozdziale pojęcia zwinności strategicznej przedsiębiorstwa, wskazania jego położenia na styku wybranych podejść oraz odniesienia się do istoty prezentowanego pojęcia proponując jego autorską definicję. 


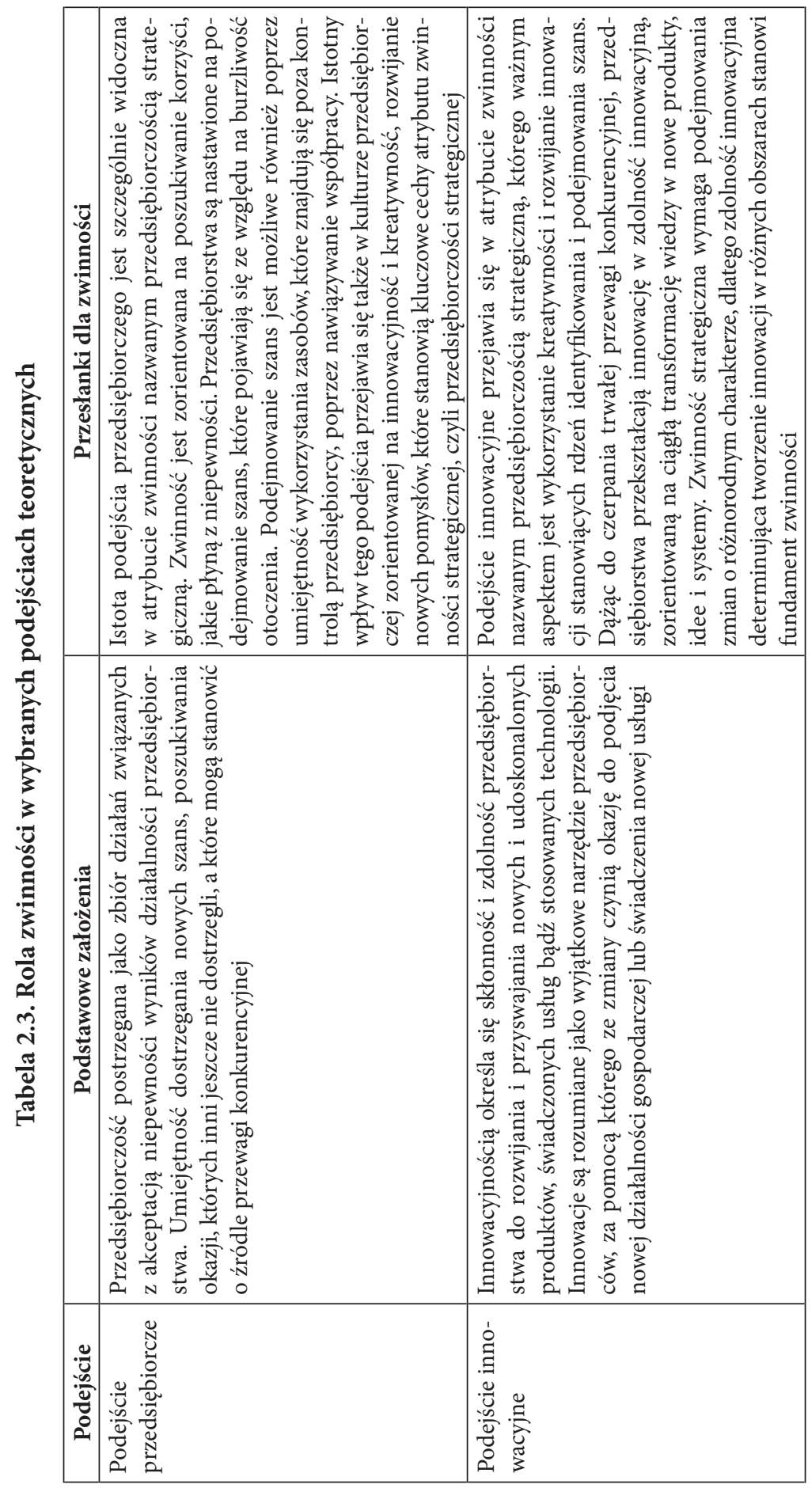

[81] 


\begin{tabular}{|c|c|c|c|}
\hline 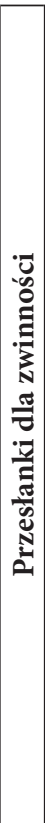 & 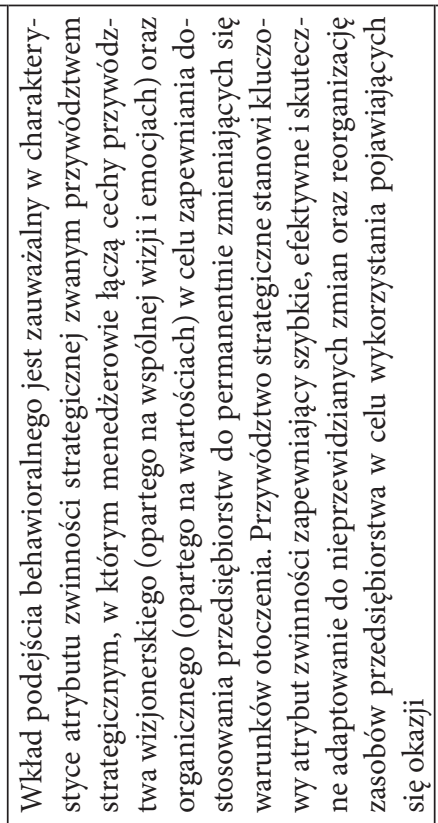 & 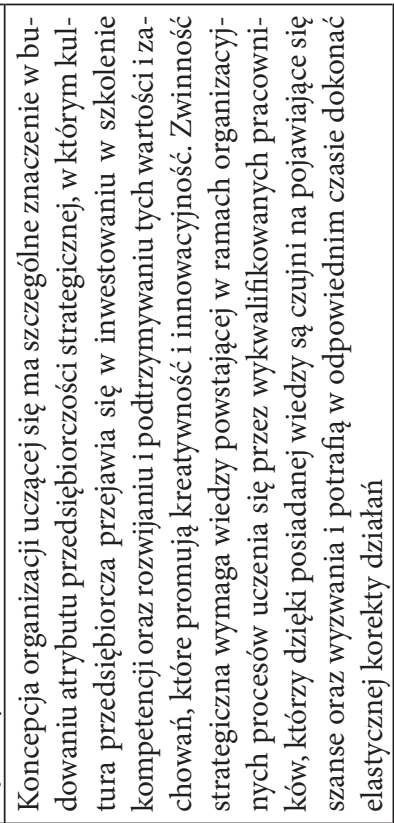 & 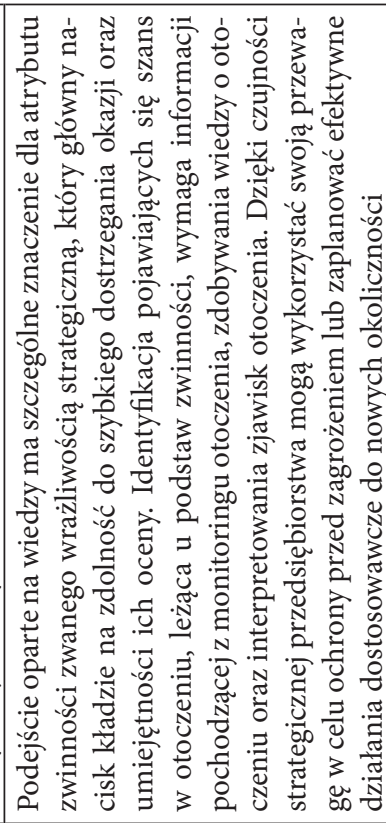 \\
\hline & 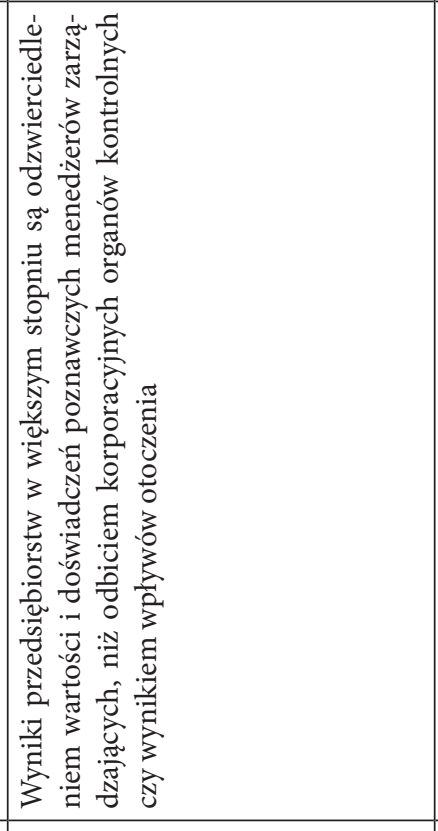 & 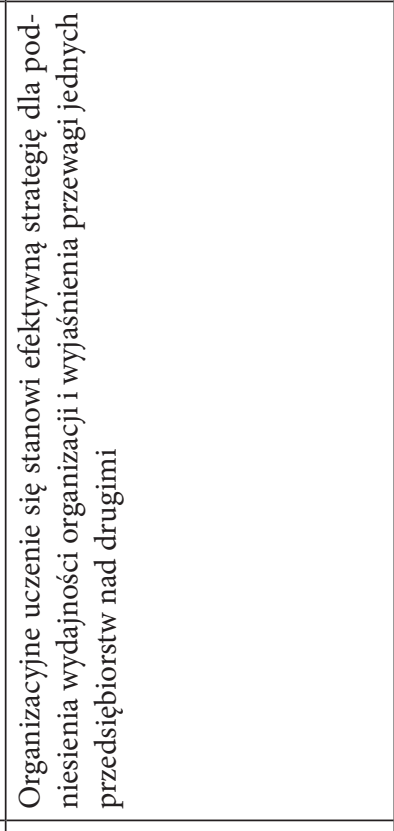 & 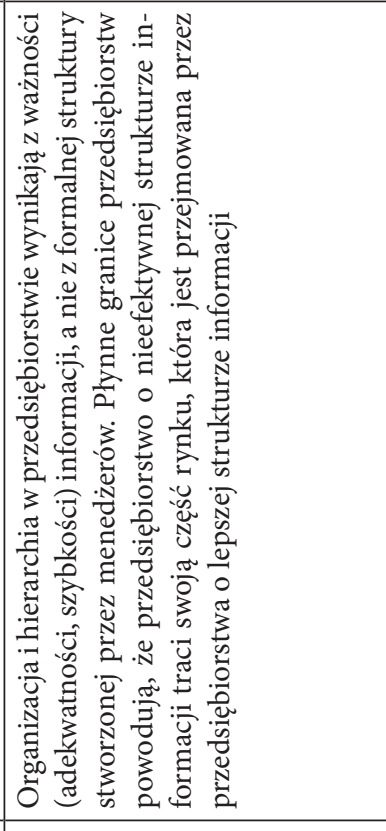 \\
\hline & 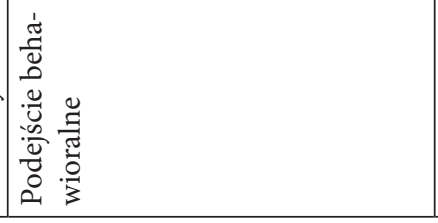 & 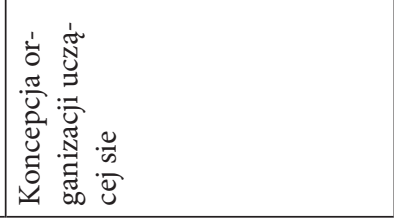 & 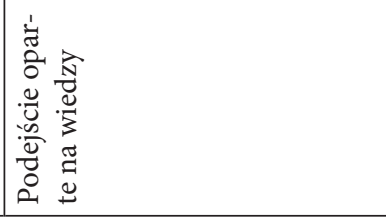 \\
\hline
\end{tabular}




\begin{tabular}{|c|c|c|c|}
\hline 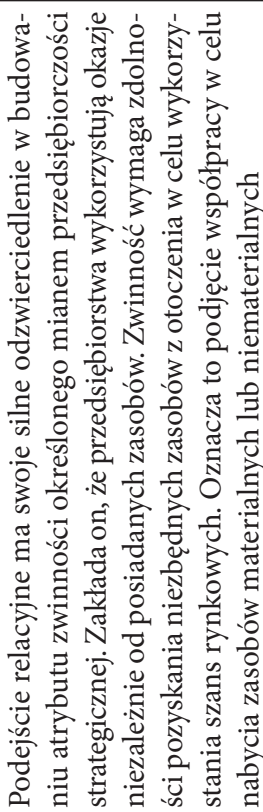 & 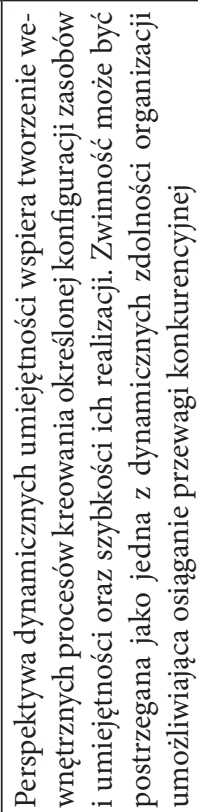 & 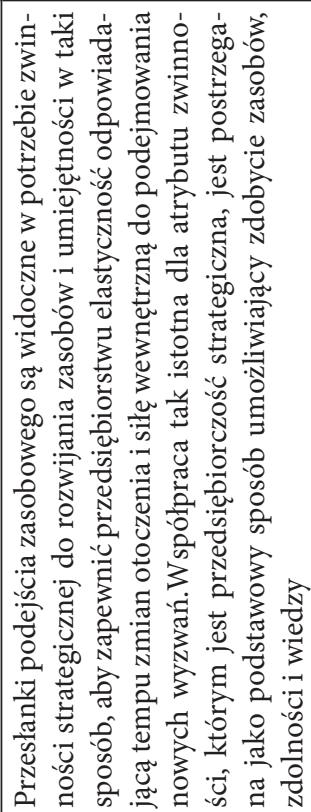 & 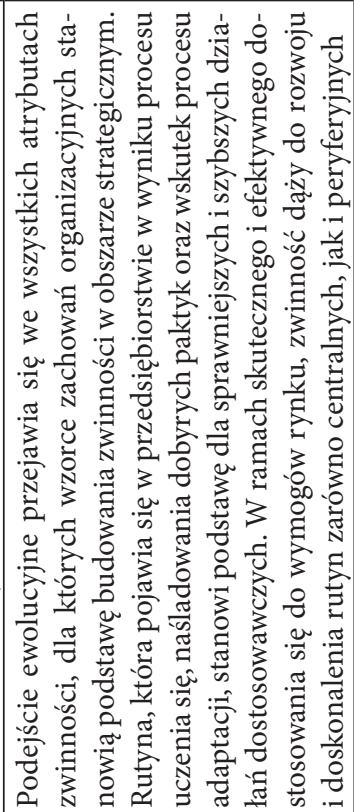 \\
\hline 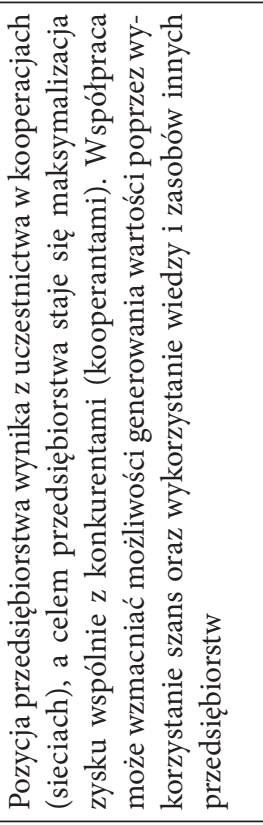 & 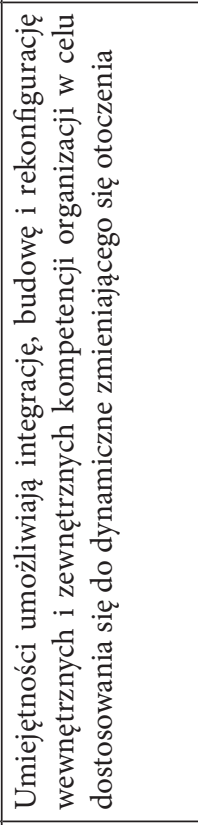 & 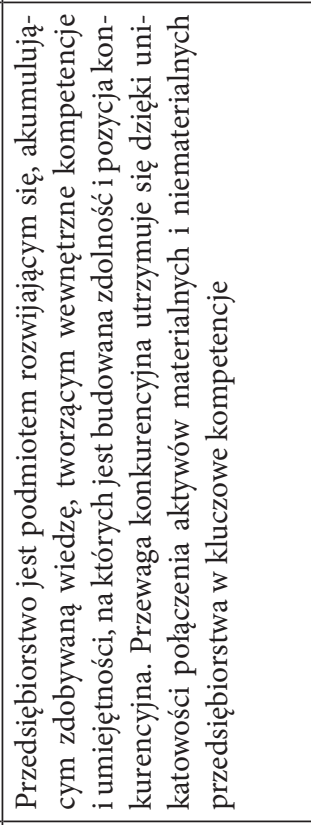 & 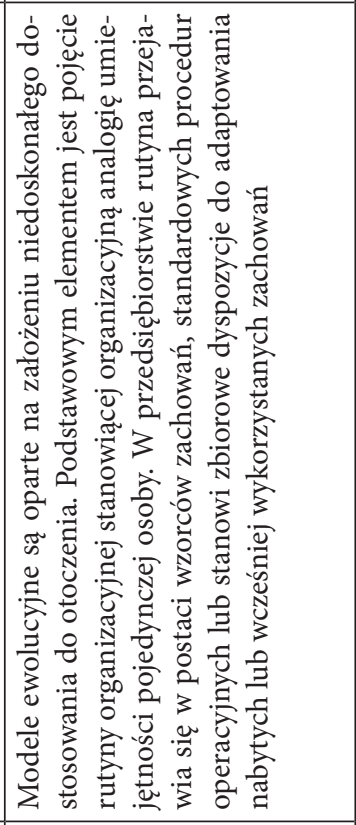 \\
\hline 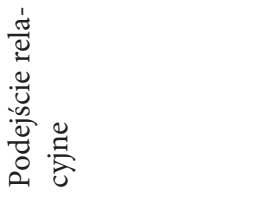 & 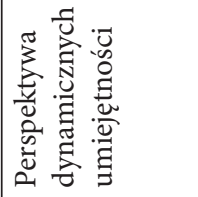 & 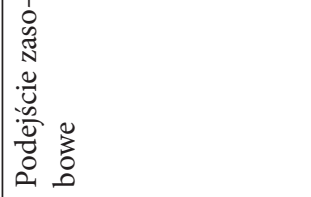 & 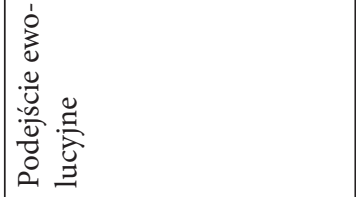 \\
\hline
\end{tabular}

[83] 


\section{Rozdział 3}

\section{KONCEPCJA ZWINNOŚCI STRATEGICZNEJ}

Przedsiębiorstwa dążą do rozwijania zdolności szybkiego i efektywnego podejmowania zmian, ponieważ zdają sobie sprawę, że jest to jedyny sposób utrzymania swojej pozycji dzięki tworzeniu przewagi konkurencyjnej nad tymi przedsiębiorstwami, które takich zdolności nie posiadają. W literaturze przedmiotu można spotkać szeroki opis działań, jakie przedsiębiorstwa powinny podjąć w celu lepszej adaptacji, jednak znacznie trudniej znaleźć jasno określone zdolności stanowiące atrybuty przedsiębiorstw umożliwiające im podejmowanie skutecznych działań dostosowawczych. Istnieje zatem luka, którą należy uzupełnić, aby poznać i zrozumieć mechanizm tworzenia przewagi konkurencyjnej wynikającej z nadzwyczajnej sprawności działania i doskonałej obserwacji rynku. W celu wyjaśnienia zależności pomiędzy zdolnością adaptacyjną przedsiębiorstw a uzyskiwaniem przez nie przewagi konkurencyjnej wykorzystano ideę zwinności strategicznej.

Celem niniejszego rozdziału jest konceptualizacja pojęcia zwinności strategicznej i jej konstruktów, określenie mechanizmu wpływu zwinności strategicznej na wyniki przedsiębiorstwa oraz zaprojektowanie modelu zwinności strategicznej. Ze względu na fakt, że zwinność strategiczna jest zmienną nieobserwowalną, konieczne było dokonanie jej dekompozycji i wyszczególnienie konstruktów teoretycznych ją współtworzących.

W związku z tym, że pojęcie zwinności strategicznej nie zostało do tej pory jasno sprecyzowane w literaturze, na początku tego rozdziału przedstawiono jego istotę. W tym celu dokonano delimitacji pojęcia „zwinność strategiczna” oraz przedstawiono i scharakteryzowano trzy ujęcia zwinności: funkcjonalne, ewolucyjne oraz behawioralne. Następnie dokonano konceptualizacji pojęcia zwinności strategicznej, wskazując jego położenie na pograniczu przedstawionych perspektyw. W kolejnych podrozdziałach opisane zostały poszczególne atrybuty zwinności strategicznej i współtworzące je konstrukty teoretyczne. Na podstawie rozważań literaturowych zaproponowano hipotezy badawcze. Jako podsumowanie niniejszego rozdziału zaprezentowano model zwinności strategicznej przedsiębiorstw. 


\subsection{Istota i pojęcie zwinności strategicznej przedsiębiorstwa}

Pojęcie zwinności strategicznej nie zostało w literaturze jasno określone. Powodem tego jest nie tylko słabe jak do tej pory rozpoznanie samej idei zwinności (zarówno w literaturze międzynarodowej, jak i krajowej), ale także analizowanie zwinności przedsiębiorstw na kilku płaszczyznach poznawczych. Rozważane ujęcia są istotne dla zwinności strategicznej przedsiębiorstw, niemniej ich identyfikacja i osobna analiza są niezbędne w celu dokonania delimitacji pojęcia zwinności strategicznej. Wyróżniono trzy ujęcia zwinności strategicznej:

- funkcjonalne - którego przedmiotem analizy są cele osiągane dzięki zwinności i funkcji jaką pełni względem przedsiębiorstwa,

- ewolucyjne - którego przedmiotem rozważań są zdolności adaptacyjne,

- behawioralne - którego obszarem zainteresowań są stosowane normy społeczne determinujące zachowania ludzi w przedsiębiorstwie i wspierające zwinność. Zwinność strategiczna jest pojęciem określanym na styku wskazanych ujęć. Każda $\mathrm{z}$ zaproponowanych perspektyw wnosi istotny wkład w rozumienie zagadnienia zwinności strategicznej (rysunek 3.1) Istotą jest znalezienie wspólnej części wyznaczającej zakres przedmiotowy zwinności strategicznej.

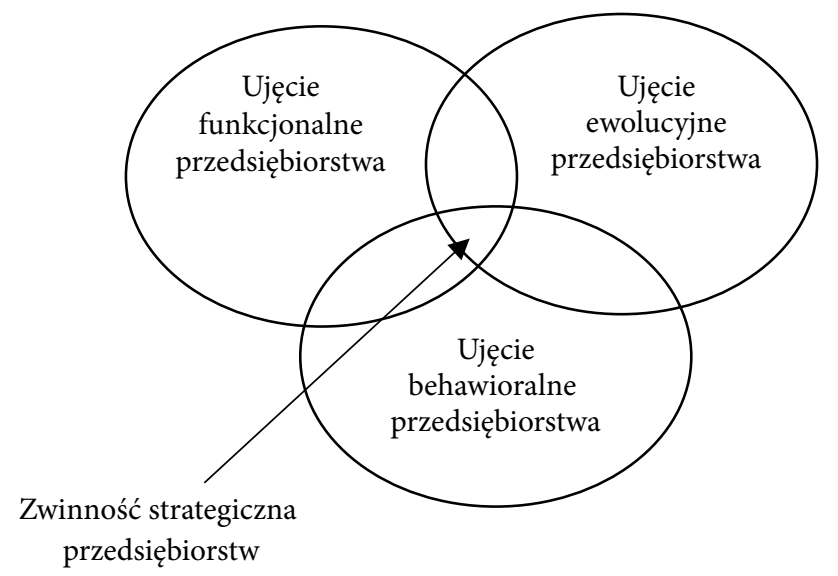

Rysunek 3.1. Delimitacja pojęcia zwinności strategicznej przedsiębiorstw

W ramach ujęcia funkcjonalnego można wyróżnić dwa wymiary: strategiczny i operacyjny. Rozróżnienie zwinności ze względu na pełnioną funkcję i określenie jej znaczenia z punktu widzenia osiągania celów strategicznych jest dokonywane w ramach zarządzania strategicznego w obszarze podejścia zasobowego. Wymiar strategiczny dotyczy osiągania głównych celów przedsiębiorstwa powiązanych ze 
ścieżką rozwojową przedsiębiorstwa, natomiast wymiar operacyjny jest ukierunkowany na osiąganie celów taktyczno-operacyjnych, związanych z krótkookresowym wzrostem efektywności. Jak już wcześniej wskazano w niniejszym opracowaniu, wśród najczęściej występujących strategicznych motywatorów zwinności (drivers) są przewaga konkurencyjna (Kidd, 1994; Meredith i Francis, 2000; Bernardes i Hanna, 2009) i przetrwanie w trudnych warunkach (Kumar i Motwani, 1995; McGaughey, 1999; Gunasekaran, 1999a; Rigby i in., 2000; Zhang i Sharifi, 2000; Narasimhan i in., 2006; Dahmaradeh i Banihashemi, 2010). Motywy zwinności o charakterze operacyjnym ujawniają się m.in. w dążeniu do sprostania potrzebom zmieniających się wymagań klientów (Agile Forum AT Iacocca Institute, Lehigh Universty, 1991; Vokurka i Fliender, 1998; Dahmaradeh i Banihashemi, 2010) oraz zwiększenia efektywności (Goldman i in., 1995; Vokurka i Fliender, 1998; Highsmith, 2005; Storey i in., 2005). Rozróżnienie celów przedsiębiorstw wynika jednocześnie z rozwoju koncepcji zwinności i odmiennego jej postrzegania. W pierwszym stadium rozwoju koncepcji autorzy bezpośrednio nawiązywali do takich praktyk, jak lean management, outsourcing czy partnerstwo w łańcuchu dostaw, czyli działań operacyjnych służących zapewnieniu wyższej efektywności prowadzenia działalności. Taka perspektywa odnosi się do zwinności produkcyjnej. Dopiero praca Y. Doz i M. Kosonen (2008a) nadała zwinności wymiar strategiczny, uwzględniając takie jej cechy, jak wrażliwość strategiczną, jedność przywództwa oraz płynność zasobów.

Druga perspektywa dotyczy ujęcia ewolucyjnego, w którym organizacja funkcjonuje w selekcyjnym otoczeniu, a procesy różnicowania służą adaptacji i przetrwaniu, o czym przekonuje E. Stańczyk-Hugiet (2013, s. 95). Autorka zauważa, że procesy różnicowania wymagają wskazania „różnicowalności organizacji”, co sprowadza się do elastyczności, adaptacyjności, dynamiki i sprężystości. Tym samym ujęcie to może służyć do określenia zdolności adaptacyjnych osiąganych dzięki zwinności strategicznej. Na aspekt wpływu na organizacje zmiennych egzogenicznych i potrzeby adaptacji do otoczenia zwrócił uwagę już J.B. Lamarck, który opracował pierwszą teorię ewolucji, stawiając tezę, że organizmy kształtują się pod wpływem środowiska (Stańczyk-Hugiet, 2013, s. 95-96). W ekonomii ewolucyjnej kładzie się duży nacisk na zjawiska dynamiczne, co podkreślają przedstawiciele ekonomii ewolucyjnej R.R. Nelson i S.G. Winter (1982) w stwierdzeniu dynamic first, a elastyczność przedsiębiorstw staje się główną charakterystyką działania dynamicznego. W ostatnich dwóch dekadach często można się spotkać z opinią ekonomistów ewolucyjnych, twierdzących, że analiza ekonomiczna musi być osadzona w teorii złożonych systemów adaptacyjnych, odpowiednio przystosowanych do wykorzystania w warunkach gospodarczych (Foster i Metcalfe, 2012, s. 430-432). Tylko w ten sposób można wyjaśnić ekonomiczne zachowania podmiotów (Witt, 2008, s. 493-511).

Ujęcie ewolucyjne postrzega przedsiębiorstwo jako zbiór rutyn (swoisty genotyp, czynników dziedzicznych) oraz warunków środowiska (Noga, 2009). Podążając za badaniami R. Nelsona i S. Wintera (1982) w ujęciu ewolucyjnym, rutyny są postrze- 
gane jako obiekt adaptacji. Organizacja jest w tym modelu pochodną współdziałania zbioru wzorców zachowań oraz otoczenia. Rutyny wykształciły się jako sposób dopasowania do środowiska i do sprzeczności interesów członków organizacji. Zgromadzone w pamięci przedsiębiorstwa informacje muszą znajdować potwierdzenie nie tylko w działaniu (rutynowym), ale też tworzyć fundament i uzasadnienie dla zebranych informacji (wiedzy) służących kształtowaniu warunków, które dają szanse na działanie (Stańczyk-Hugiet, 2015). W literaturze nie ma zgody dotyczącej definicji rutyn eksponującej ich treść. Identyfikuje się rutyny jako wzorce zachowań lub jako standardowe procedury operacyjne. Zwinność strategiczna, ze względu na swoją adaptacyjną naturę, podkreśla znaczenie wzorców zachowań organizacyjnych jako zbiorowych dyspozycji do adaptowania zachowań w odpowiedzi na pewne stymulanty lub kontekst (szanse w otoczeniu, ograniczenie ryzyka). Rutyny stanowią integralną część zwinności przedsiębiorstw i choć powszechnie ich charakter może być funkcyjny (wspierający, budujący) lub dysfunkcyjny (mogą być źródłem inercji), to jednak w kontekście zwinności strategicznej są źródłem organizacyjnej adaptacji, responsywności i elastyczności oraz refleksyjności (Becker, 2002; Zhang i Sharifi, 2000; Dahmardeh i Banihashemi, 2010). R. Nelson i S. Winter (1982), podkreślając kluczową rolę rutynowych zachowań przedsiębiorstw, uznają, że decydenci podejmują decyzję w warunkach niepewności. Przyjmuje się założenie, że podmioty gospodarcze podejmują decyzję, redukując niepewność, oraz zmierzają do osiągnięcia celów gospodarczych zgodnie z określonym zestawem zasad. Jednocześnie w podejściu ewolucyjnym zakłada się, że poszukiwanie rutynowych wzorców zachowań organizacyjnych i strategicznych jest procesem przemyślanym, w którym wyszukiwanie efektywniejszych i skuteczniejszych sposobów działania ma na celu poprawę wyników przedsiębiorstw (Nelson, 1995, s. 48-52; Zolloi i Winter, 2002, s. 339-351).

Trzecia perspektywa dotyczy ujęcia behawioralnego, którego punktem odniesienia są stosowane normy społeczne determinujące postawy i zachowania ludzi $\mathrm{w}$ przedsiębiorstwie. $\mathrm{W}$ teorii behawioralnej prezentowanej $\mathrm{w}$ klasycznej pracy R. Cyerta i J. Marcha (1992) przyjmuje się założenie separacji własności i kontroli. Ze względu na odmienne cele menedżerów (wynikające $\mathrm{z}$ różnych celów lokalnych oraz odmiennego poziomu i zakresu odpowiedzialności ich stanowisk) nie jest możliwa maksymalizacja wszystkich celów, dlatego można mówić o realizacji wiązki celów, która zawsze przechodzi przez filtr poziomu aspiracji i jest wynikiem kompromisu (Gruszecki, 2002, s. 228-229). Ujęcie behawioralne, przyjmując kryterium norm społecznych, wyróżnia dwa mechanizmy kontroli w przedsiębiorstwie: formalną (kontrola zachowań i wyników) i nieformalną (Ouchi, 1978). Kontrola nieformalna, tzw. klanowa, jest oparta na wspólnych wartościach, rytuałach i tradycji, jest rekomendowana, gdy trudno obserwować zachowania, rozumieć istotę pracy i mierzyć jej wyniki (Ouchi, 1979). Kontrola klanowa jest często stosowana w projektach informatycznych ze względu na ich specyfikę (Kirsch, Sambamurthy, Ko i Purvis, 2002) - przykład ten stanowi dobrą egzemplifikację natury zwinności 
przedsiębiorstw, które ze względu na deficyt czasu i potrzebę szybkiego dostosowania się (np. do potrzeb klienta) działają pod presją czasu i ciągłych zmian.

Zwinność strategiczna stanowi zmienną, której nie da się bezpośrednio zaobserwować, niemniej można dokonać jej dekompozycji na atrybuty zwinności strategicznej. W związku z brakiem w literaturze jednoznacznego stanowiska dotyczącego wymiarów tworzących tę zmienną w niniejszym opracowaniu uznano, że zwinność strategiczną tworzą cztery konstrukty teoretyczne. W pracy przyjęto definicję określającą zwinność strategiczną przedsiębiorstwa jako zdolność do podejmowania zmian strategicznych i radzenia sobie z dynamiką (zmiennością) otoczenia. Zdolność tę konstytuują cztery atrybuty: wrażliwość strategiczna, przedsiębiorczość strategiczna, elastyczność oraz przywództwo strategiczne.

B. de Wit oraz R. Meyer (2007, s. 164) definiują pojęcie „zdolności” jako połączenie w sobie wielu umiejętności, które z kolei odnoszą się do zadań ograniczonych funkcjonalnie (wąsko zdefiniowanych). Zdolność może też zostać zdefiniowana jako zdatność do czegoś związana z integrowaniem i realizowaniem poszczególnych procesów w celu osiągnięcia efektów synergicznych (Bratnicki, 2000, s. 33). Typologię zdolności przedsiębiorstwa zaprezentowano w tabeli 3.1.

Przyjmując za kryterium stopień rozwoju zdolności w przedsiębiorstwie, można wyróżnić: zdolności zwykłe (operacyjne), zdolności dynamiczne oraz najwyższy ich poziom określany jako metazdolności. Poziomy rozwoju zdolności przedstawiono na rysunku 3.2.

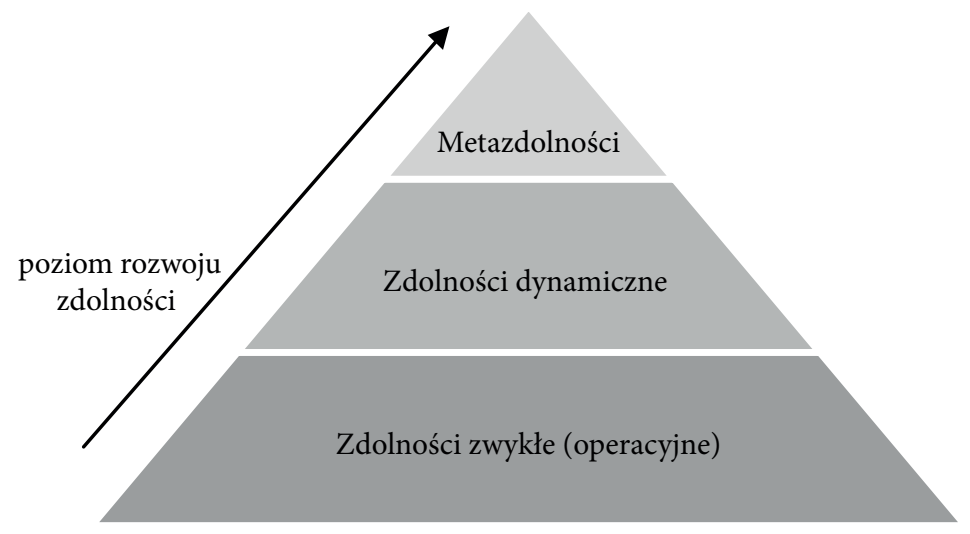

Rysunek 3.2. Poziomy zdolności w przedsiębiorstwie

Jak zauważa R. Makadok (2001), zdolności zwykłe (operacyjne) przyczyniają się do poprawy jakości istniejących procesów i produktów przedsiębiorstwa, co pośrednio lub bezpośrednio wpływa pozytywnie na jego wyniki. Mają one wymiar krótkookresowy (Drnevich i Kriauciunas, 2011), co oznacza, że pozwalają przedsiębiorstwu na prowadzenie bieżącej działalności za pomocą dotychczasowych technik wytwarzania oraz oferowanych dotychczas produktów i usług. 
Tabela 3.1. Typologia zdolności przedsiębiorstwa

\begin{tabular}{|c|c|c|}
\hline $\begin{array}{c}\text { Typ zdolności } \\
\text { przedsiębiorstwa }\end{array}$ & Autor & Definicja \\
\hline \multirow[t]{2}{*}{ Zdolności zwykłe } & $\begin{array}{l}\text { R. Makadok } \\
(2001)\end{array}$ & $\begin{array}{l}\text { Zdolności zwykłe (operacyjne) przyczyniają się do popra- } \\
\text { wy jakości istniejących procesów i produktów przedsiębior- } \\
\text { stwa, co bezpośrednio (lub pośrednio) wpływa pozytywnie } \\
\text { na jego wyniki }\end{array}$ \\
\hline & \begin{tabular}{|l|} 
P.L. Drnevich \\
i A.P. Kriauciunas \\
$(2011)$
\end{tabular} & $\begin{array}{l}\text { Zdolności zwykłe umożliwiają przedsiębiorstwu przetrwa- } \\
\text { nie w krótkim okresie, pozwalając na prowadzenie bieżącej } \\
\text { działalności za pomocą dotychczasowych technik wytwa- } \\
\text { rzania, oferując istniejące już produkty i usługi }\end{array}$ \\
\hline \multirow[t]{7}{*}{$\begin{array}{l}\text { Zdolności dyna- } \\
\text { miczne }\end{array}$} & $\begin{array}{l}\text { R. Agarwal } \\
\text { i C.E. Helfat } \\
(2009)\end{array}$ & $\begin{array}{l}\text { Zdolności dynamiczne to zdolności organizacji do celo- } \\
\text { wego tworzenia, rozszerzania lub zmieniania swojej bazy } \\
\text { zasobowej }\end{array}$ \\
\hline & $\begin{array}{l}\text { M. Blyer i R. Coff } \\
(2003)\end{array}$ & $\begin{array}{l}\text { Zdolności dynamiczne to proces integrowania, rekonfigu- } \\
\text { rowania, pozyskiwania i uwalniania zasobów po to, by re- } \\
\text { agować na zmiany rynku bądź je wywoływać }\end{array}$ \\
\hline & $\begin{array}{l}\text { D. Teece i in. } \\
(1997)\end{array}$ & $\begin{array}{l}\text { Zdolności przedsiębiorstwa do integrowania, budowania } \\
\text { i rekonfigurowania wewnętrznych i zewnętrznych kom- } \\
\text { petencji w obliczu zmieniających się warunków otoczenia } \\
\text { biznesowego }\end{array}$ \\
\hline & \begin{tabular}{|l|} 
P.L. Drnevich \\
i A.P. Kriauciunas \\
$(2011)$
\end{tabular} & $\begin{array}{l}\text { Zdolności dynamiczne to zdolności wykorzystywane do } \\
\text { wzbogacenia zmiany, modyfikacji i (lub) tworzenia zwy- } \\
\text { kłych zdolności }\end{array}$ \\
\hline & \begin{tabular}{|l|} 
S. Zahra \\
i G. Gorge (2002)
\end{tabular} & $\begin{array}{l}\text { Dynamiczne zdolności są osadzone w organizacyjnych pro- } \\
\text { cesach i umożliwiają przedsiębiorstwu rekonfigurację jego } \\
\text { podstawowych procesów i adaptację do zmieniających się } \\
\text { warunków rynkowych w celu uzyskania przewagi konku- } \\
\text { rencyjnej }\end{array}$ \\
\hline & $\begin{array}{l}\text { M. Zollo } \\
\text { i S.G. Winter } \\
(2002)\end{array}$ & $\begin{array}{l}\text { Zdolności dynamiczne to wyuczony i stabilny wzorzec } \\
\text { (wzorce) zbiorowej aktywności, poprzez który organizacja } \\
\text { systematycznie generuje i modyfikuje swoje rutyny } \\
\text { operacyjne w poszukiwaniu poprawy efektywności }\end{array}$ \\
\hline & $\begin{array}{l}\text { K.M. Eisenhardt } \\
\text { i J.A. Martin } \\
(2000)\end{array}$ & $\begin{array}{l}\text { Zdolności dynamiczne to procesy integrowania, rekonfi- } \\
\text { gurowania, zdobywania oraz uwalniania zasobów przed- } \\
\text { siębiorstwa w celu dopasowania lub kreowania zmian } \\
\text { rynkowych. Dynamiczne zdolności stanowią organizacyj- } \\
\text { ne i strategiczne rutyny, dzięki którym przedsiębiorstwo } \\
\text { osiąga nową konfigurację zasobów podczas gdy rynki wy- } \\
\text { łaniają się, ewoluują a inne zanikają }\end{array}$ \\
\hline \multirow[t]{3}{*}{ Metazdolności } & \begin{tabular}{|l|} 
R. Evaristo \\
i S. Zaheer (2014)
\end{tabular} & $\begin{array}{l}\text { Metazdolność to zdolność do zarządzania przepływem za- } \\
\text { sobów i umiejętności poprzez kreowanie cennej ich kombi- } \\
\text { nacji z punku widzenia tworzenia przewagi konkurencyjnej }\end{array}$ \\
\hline & \begin{tabular}{|l|}
$\begin{array}{l}\text { R. Makadok } \\
(2001)\end{array}$ \\
\end{tabular} & $\begin{array}{l}\text { Metazdolność to zdolność do równoczesnego wybierania, } \\
\text { budowania i rekonfigurowania zasobów }\end{array}$ \\
\hline & $\begin{array}{l}\text { M. Blyler i R. Coff } \\
(2003)\end{array}$ & $\begin{array}{l}\text { Przedsiębiorstwo tworzy ciąg tymczasowych przewag po- } \\
\text { przez dodawanie, odejmowanie i konfigurowanie zasobów, } \\
\text { które mogą stanowić trwałą korzyść, gdy będzie rozpatry- } \\
\text { wany pełen ich zakres }\end{array}$ \\
\hline
\end{tabular}


Natomiast konceptualizując zdolności dynamiczne, można je zdefiniować jako narzędzia do zarządzania istniejącymi zasobami i ich przegrupowywania w celu tworzenia nowych konfiguracji (Eisenhardt i Martin, 2000). Zatem zdolności dynamiczne, oprócz rutynowych sposobów postępowania, zmieniają także bazę zasobową organizacji. Osadzone w organizacyjnych procesach wpływają na zbiór posiadanych zasobów, kształtując jego elementy zarówno pod względem ilości, jak i jakości (Zahra i George, 2002). Celem jest pozbycie się mniej potrzebnych zasobów oraz pozyskanie takich, które są niezbędne w procesach tworzenia wartości (Czakon, 2012, s. 156). Dzięki wykorzystaniu zdolności dynamicznych przedsiębiorstwa dążą do rozwiązania problemu braku dopasowania do otoczenia, gdyż służą one do identyfikowania szans i zagrożeń oraz reagowania na nie, co pociąga za sobą modyfikowanie, rekonfigurowanie i (lub) podnoszenie zdolności zwykłych, umożliwiających dokonywanie zmian (Wójcik-Karpacz, 2012). Definicje pozwalają zauważyć, że zdolności dynamiczne determinują szybkość i stopień, w jakim poszczególne zasoby przedsiębiorstwa mogą być ustanawiane i rekonfigurowane w stosunku do warunków i szans w otoczeniu.

M. Blyler i R. Coff (2003), korzystając z definicji K.M. Eisenhardt i J.A. Martin (2000), określają zdolności dynamiczne również jako proces integrowania, rekonfigurowania, pozyskiwania i uwalniania zasobów po to, by reagować na zmiany rynku bądź je wywoływać. Ci sami autorzy identyfikują zagadnienie metazdolności (meta-capability) i definiują przyjęte pojęcie jako zdolność do zarządzania przepływem zasobów i umiejętności w celu wykreowania cennej ich kombinacji z punku widzenia tworzenia przewagi konkurencyjnej. Metazdolności wymagają od przedsiębiorstwa wyjątkowej umiejętności do jednoczesnego prześcigania innych przedsiębiorstw $\mathrm{w}$ wybieraniu i pozyskiwaniu zasobów oraz budowaniu zdolności (Makadok, 2001). Logika metazdolności polega na tym, że przedsiębiorstwo tworzy ciąg tymczasowych przewag poprzez dodawanie, odejmowanie i konfigurowanie zasobów, które mogą stanowić trwałą korzyść, gdy będzie rozpatrywany pełen ich zakres. Podczas gdy imitacja konfiguracji zasobów nie stanowi większego problemu dla przedsiębiorstw występowanie metazdolności w procesie nabywania zasobów i ich rekonfigurowania znacznie utrudnia proces kopiowania przyjętych rozwiązań (Blayler i Coff, 2003). Pojęcie metazdolności zostało wyjaśnione także w pracy R. Evaristo i S. Zaheera (2014) podejmujących tematykę ustrukturalizowania wiedzy o strategicznych zdolnościach w przedsiębiorstwie. Autorzy definiują metazdolność jako zdolność do identyfikowania i tworzenia dźwigni pomiędzy zdolnościami rozdystrybuowanymi w przedsiębiorstwie. Wymaga to nie tylko wiedzy dotyczącej tego, w jakich obszarach znajdują się poszczególne zdolności, ale także wiedzy dotyczącej ich zakresu i intensywności wykorzystania, charakteru wzajemnego powiązania oraz wpływu na kierunek strategiczny przedsiębiorstwa. Według autorów menedżerowie zaangażowani w proces implementacji strategii powinni mieć nie tyko wiedzę dotyczącą istotności czy zbędności poszczególnych zdolno- 
ści, ale również pewność, czy odpowiednie kombinacje zdolności są podejmowane na rzecz działań strategicznych.

Ujęcie metazdolności w perspektywie zwinności wykorzystali Y. Doz i M. Kosonen (2010), którzy identyfikują zwinność strategiczną jako rezultat kombinacji trzech głównych metazdolności, które zapewniają jej fundament. Jak już wcześniej wspomniano, są nimi: wrażliwość strategiczna, jedność przywództwa oraz płynność zasobów. Metazdolności wykorzystali także w swojej pracy S. Fourne i współautorzy (2014), którzy prezentując badania międzynarodowych przedsiębiorstw, starali się połączyć dorobek naukowy z obszaru zwinności strategicznej, dynamicznych umiejętności oraz biznesu globalnego w celu lepszego wyjaśnienia idiosynkratycznej natury zwinności strategicznej w ramach różnych kontekstów analizy. Autorzy definiują zwinność strategiczną jako metazdolność kreującą i utrzymującą równowagę pomiędzy: wrażliwością na lokalne szanse (sensing local opportunities), uchwaleniem globalnej komplementarności (enacting global complementarities) i zawłaszczaniem wartości lokalnej (appropriating local value).

Jak wskazano w rozdziale pierwszym w punkcie 1.4, niewiele dostępnych badań dotyczy analizy wpływu zwinności strategicznej na przewagę konkurencyjną i wyniki przedsiębiorstw, a dostępne badania w tym zakresie są konsekwencją przyjętych odmiennych założeń metodologicznych i metodycznych. Część prowadzonych badań ma jedynie wymiar koncepcyjny i nie została poddana weryfikacji empirycznej (Fartash i Davoudi, 2012). Inne z kolei wskazują jedynie na częściowy wpływ zwinności strategicznej na wyniki przedsiębiorstw (Shin i in., 2015). Niektórzy badacze dowiedli istotnego związku pomiędzy zwinnością strategiczną a przewagą konkurencyjną, uznając, że w celu podwyższenia sprawności konkurowania zaleca się przedsiębiorstwom rozwijanie zdolności zwinności strategicznej (Oyedijo, 2012). Kluczowym obserwowanym problemem jest jednak definiowanie przez autorów zwinności strategicznej w incydentalny sposób. Widoczne jest to w silnie zróżnicowanym przez autorów wyborze atrybutów zwinności strategicznej (tabela 1.5). Wyłonione przez autorów atrybuty nie stanowią efektu pogłębionych studiów teoretycznych, a raczej wyłaniają się na podstawie wstępnych dociekań lub są zaadaptowane od innych autorów. W dotychczasowym dorobku brakuje opracowań skoncentrowanych stricte na zwinności, w których autorzy w sposób pogłębiony podejmowaliby problemy i zagadnienia związane z tym pojęciem. Dotychczasowy dorobek naukowców stanowi jedynie zbiór refleksji, co świadczy o początkowym stadium prowadzonych badań i istniejącej luce poznawczej w zakesie zwinności strategicznej przedsiębiorstw oraz potrzebie jej wypełnienia.

Poczynione wnioski skłaniają do sformułowania hipotezy głównej:

Hg: Zwinność strategiczna wspóltworzona przez wrażliwość strategiczna, przedsiębiorczość strategiczna, elastyczność oraz przywództwo strategiczne ma pozytywny wplyw na wyniki przedsiębiorstw. 


\subsection{Wrażliwość strategiczna jako atrybut zwinności zorientowany na identyfikowanie szans}

Wrażliwość przedsiębiorstwa na otoczenie to warunek konieczny jego egzystencji. Obecne warunki funkcjonowania przedsiębiorstw, takie jak: nagłe nieprzewidywalne zmiany, wysoka dynamika oraz kompleksowość i złożoność zmian, wymusiły na przedsiębiorstwach rozwijanie i doskonalenie narzędzi i procesów usprawniających identyfikację trendów oraz zjawisk w otoczeniu, kreowanie nowych pomysłów oraz formułowanie potrzeb dotyczących zmian. Wrażliwość na otoczenie oznacza zdolność do szybkiego dostrzegania okazji rynkowych oraz zagrożeń wynikających z otoczenia oraz umiejętność kategoryzowania sytuacji jako sprzyjających bądź niesprzyjających przedsiębiorstwu. Cecha wrażliwości dotyczy umiejętności rozpoznawania okazji rynkowych dzięki prowadzeniu analiz strategicznych, wykorzystaniu systemów wczesnego ostrzegania bądź wypracowaniu własnych, skutecznych metod poszukiwania w otoczeniu rynkowym szans dla swojej działalności (Trzcieliński, 2011). Jak przekonuje P. Banaszyk (2013), zarządzanie strategiczne powinno się koncentrować na rozpoznawaniu okazji w splocie przypadkowych zjawisk. Prowadząc dyskusję o treści strategii, R. Krupski (2010) twierdzi, że strategia w języku okazji to długofalowy plan organizacji zawierający m.in.:

- ustalenie, jakiego rodzaju zdarzenia w otoczeniu przedsiębiorstwo będzie identyfikować jako okazje (czyli przyjęcie filtru oraz przestrzeni okazji);

- ustalenie, jakiego rodzaju zdarzenia we wnętrzu przedsiębiorstwa (najczęściej mające charakter innowacyjny) będą identyfikowane jako okazje;

- zamiary w zakresie kształtowania redundancji zasobów własnych i systemu dostępności do zasobów obcych, który umożliwi wykorzystanie okazji;

- rozwiązania w zakresie „organizacji w ruchu” (systemy procedur na różne okazje, symulacji, generowania pomysłów itp.).

Wrażliwość na otoczenie oznacza także umiejętność wykorzystania pojawiających się szans dzięki innowacyjności i kreatywności. Kluczowa jest współpraca z klientem $\mathrm{w}$ celu poszukiwania i odkrywania szans w otoczeniu dla wykorzystania innowacji rynkowych i szybkich działań konkurencyjnych (Sambamurthy i in., 2003, s. 237-263). Nie wszystkie szanse można wykorzystać, zatem bezcenna jest umiejętność nadawania priorytetów szansom rynkowym, mając na uwadze zasoby i umiejętności, które posiada przedsiębiorstwo lub które jest w stanie „wypracować $\mathrm{z}$ otoczeniem".

E. Overby, A. Bharadwaj oraz V. Sambamurthy (2006) przekonują, że kluczowe dla zwinności przedsiębiorstw są dwa komponenty - wyczuwanie (sensing) oraz reagowanie (responding). Wyczuwanie zmian $\mathrm{w}$ otoczeniu jest utożsamiane właśnie z wrażliwością na zmiany, oba określenia stanowią synonimy wynikające $\mathrm{z}$ różnic $\mathrm{w}$ tłumaczeniu terminu $\mathrm{z}$ języka angielskiego. Wspomniani autorzy 
zmiany w otoczeniu postrzegają jako wynik działań konkurentów, zmian preferencji klientów oraz zmian w regulacjach prawnych, politycznych, ekonomicznych oraz zaawansowania procesów technologicznych. Wielość i złożoność zmian następujących w otoczeniu wymaga od przedsiębiorstw zróżnicowanych zdolności i mechanizmów do ich wyczuwania i identyfikowania. Autorzy, dokonując dekompozycji konstruktu teoretycznego, jakim jest wyczuwanie, przyporządkowują mu odpowiednie zdolności umożliwiające identyfikację zmian w wyszczególnionych obszarach otoczenia. Inteligencja rynkowa przedsiębiorstwa (market intelligence) umożliwia śledzenie zmian w zakresie działań podejmowanych przez konkurentów, zmian preferencji wymagań klientów oraz zmian ekonomicznych. Natomiast od departamentów prawnych wymaga się intensywnych działań zmierzających do identyfikowania zmian w sferze legislacyjnej. Zadaniem departamentu ds. badań i rozwoju powinno być wyczuwanie zmian wynikających z postępu technologicznego oraz poszukiwanie rozwiązań IT umożliwiających utrzymanie przewagi konkurencyjnej (Overby i in., 2006).

Do inteligencji przedsiębiorstwa naukowcy często nawiązują, podejmując problematykę zwinności, zwłaszcza w obszarze zdolności do wyczuwania zmian w otoczeniu i identyfikowania okazji. Inteligencja ( $\mathrm{z}$ łac. intelligentia) to zdolność pojmowania, rozum, też identyfikowana jako zdolność do postrzegania, analizy i adaptacji do zmian otoczenia, zdolność rozumienia, uczenia się oraz wykorzystywania posiadanej wiedzy i umiejętności w sytuacjach nowych. To cecha umysłu warunkująca sprawność czynności poznawczych, takich jak myślenie, reagowanie, rozwiązywanie problemów (https://pl.wikipedia.org/, data odczytu 20.05.2016 r.). Organizacja inteligenta powinna być bodźcem dla pracowników do wyrażania gotowości do uczenia się. Dzięki temu ogół pracowników będzie wspierać procesy zmian, których celem jest zwiększenie efektywności funkcjonowania przedsiębiorstwa. Bardzo ogólną i szeroką definicję organizacji inteligentnej zaproponował M.J. Thannhuber (2005, s. 67), twierdząc, że przedsiębiorstwo inteligentne to przedsiębiorstwo elastyczne, adaptujące się oraz innowacyjne, które potrafi radzić sobie z wysoką złożonością, ogromną ilością informacji, wysoką różnorodnością oczekiwanych usług oraz wykonywać działania z wysoką precyzją w celu uzyskania wyróżniającej efektywności. Atrybuty wskazane w tej definicji jednocześnie dobrze odzwierciedlają desygnaty zwinności przedsiębiorstw. Jak uważa M. Bratnicki (2002, s. 191), każde inteligentne przedsiębiorstwo ma wysokie zdolności do rozpoznawania i dopasowania się do środowiska oraz rynku, na którym funkcjonuje, identyfikując nowe pola aktywności mieszczących się w dotychczasowym otoczeniu. Atrybutem silnie wyeksponowanym zarówno w koncepcji zwinności, jak i w inteligentnym przedsiębiorstwie jest informacja, która w dzisiejszych czasach, charakteryzujących się wysokim poziomem niepewności, stanowi częste źródło przewagi konkurencyjnej. Nadmierna ilość informacji powoduje chaos informacyjny i stanowi duże wyzwanie dla przedsiębiorstw; sukces osiągają te spośród nich, które potrafią uporządkować nieograniczony zasób i wyłonić z niego dane, które są istotne z punktu widzenia 
celów strategicznych. Inteligencja przedsiębiorstwa w dużej mierze utożsamia jego sukcesy, na które składają się m.in. (Kaczmarek, 2013):

- sposób wykorzystania okazji, jakie pojawiają się na rynku,

- zdolność dostosowywania się do nowych sytuacji,

- tworzenie i wprowadzanie nowych pomysłów oraz koncepcji prowadzenia działalności, stała analiza słabych i mocnych stron,

- traktowanie szans w otoczeniu jako wyzwań dla ciągłego doskonalenia procesów pracy.

Wskazane przez B. Kaczmarka (2013) pozytywne efekty inteligencji przedsiębiorstwa można jednocześnie przypisać zwinności, gdyż podstawy obu koncepcji tkwią w zarządzaniu wiedzą, organizacyjnym uczeniu się, umiejętności dynamicznego wdrażania najlepszych praktyk i procesów zarządzania wiedzą. Istota tkwi w nadawaniu sensu złożonym sytuacjom i efektywnym działaniu na podstawie wydarzeń i sygnałów otoczenia. W. Dyduch oraz M. Bratnicki (2016) traktują oba pojęcia jako synonimy, podkreślając ich orientację na zarządzanie wiedzą, umiejętność budowania relacji wewnątrz i na zewnątrz przedsiębiorstwa, dynamiczne dostosowywanie nowych form organizacyjnych, niespotykanych wcześniej praktyk i procesów, uczenie się oraz działanie przedsiębiorcze w kontekście poszukiwania, podejmowania i wykorzystywania szans. Na podobieństwo obu zagadnień wskazuje także B. Gabryś (2016), definiując inteligencję właśnie jako zdolność organizacji do dynamicznego dopasowania się do zmieniających się wymagań, opartą na elastyczności, samodzielności zakorzenionej w efektywnej strukturze oraz doskonałej komunikacji.

Pojęcie wrażliwości strategicznej (strategic sensitivity) w kontekście zwinności strategicznej zostało wprowadzone przez Y.L. Doza i M. Kosonena (2008a, s. 17-25), którzy definiują ją jako ostrość percepcji tego, co dzieje się wokół przedsiębiorstwa, oraz osiągnięcie pełnej świadomości i uwagi ukierunkowanej na rozwój strategiczny. Wrażliwość strategiczna oznacza bycie otwartym na różnorodność informacji, któremu powinna towarzyszyć inteligencja i innowacyjność poprzez tworzenie i utrzymywanie relacji z interesariuszami przedsiębiorstwa jako źródłami informacji. W ramach wrażliwości strategicznej autorzy zwracają uwagę na dwa zagadnienia: prognozowanie strategiczne (strategic foresight) oraz wnikliwość strategiczna (strategic insight). Prognozowanie strategiczne pozwala na przewidzenie konsekwencji kluczowych trendów, wcześniejsze zidentyfikowanie zakłóceń i nieciągłości oraz przygotowanie się na zmiany lub wykorzystanie ich do własnej przewagi konkurencyjnej. Ze względu na złożoność i niestabilność natury otoczenia antycypowanie zjawisk i wyłaniających się szans często staje się bardzo trudne lub wręcz niemożliwe do przewidzenia. Dlatego autorzy stawiają na spojrzenie i wnikliwość od wnętrza przedsiębiorstwa. Wnikliwość definiują jako zdolność do dostrzeżenia, analizowania i tworzenia sensu strategicznego na podstawie kompleksowości zmian otoczenia oraz gotowości wykorzystania ich jako szansy dla utrzymania przewagi konkurencyjnej. Kluczowa dla wnikliwości strategicznej 
jest jakość posiadanych informacji o otoczeniu oraz intensywność komunikacji zewnętrznej. Badacze zwracają również uwagę na kluczową rolę inteligencji, która wspiera rozumienie i nadawanie sensu obserwowanym zmianom, współkreując jakość owej wrażliwości strategicznej. Reasumując, wrażliwość strategiczna jest wspierana przez powiązanie silnego zewnętrznego zorientowania na otoczenie oraz wewnętrznego zaangażowania w proces strategiczny przy wysokim poziomie uważności na otoczenie oraz intensywnym wewnętrznym dialogu (Doz i Kosonen, 2008). Systematyczna wnikliwość przedsiębiorstwa (systematic insight) jest definiowana jako zdolność do wykorzystania pojawiających się szans ze względu na posiadane zasoby i umiejętności, z uwzględnieniem możliwości rozwinięcia lub nabycia potrzebnych zasobów (Vagoni i Khoddami, 2016). Proces badania rynku jest zdeterminowany możliwością wykorzystania okazji, usprawnia reagowanie na zmieniające się potrzeby klientów oraz sprzyja rozwijaniu innowacyjnych rozwiązań satysfakcjonujących klienta (Raschke i Smith, 2007).

Wymiar wrażliwości strategicznej jest często wykorzystywany przez badaczy jako jedna z miar teoretycznego konstruktu zwinności strategicznej (Mavengere, 2013). Wśród grona badaczy, dla których wrażliwość strategiczna opracowana przez Y. Doza i M. Kosonena stanowiła inspirację do własnych badań, znaleźli się: E. Vagnoni oraz S. Khoddami (2016), O.E. Ofoegbu oraz P.A. Akanbi (2012), A. Arbussa i współautorzy (2016), N.B. Mavengere (2013).

Pozostając w głównym nurcie badań, R. Vecchiato (2015) definiuje prognozowanie strategiczne jako zestaw technik, praktyk i procesów, które przedsiębiorstwo wykorzystuje do: wykrywania nowych zdarzeń w otoczeniu, badania ich ewolucji i efektów, określenia możliwości reakcji na wykryte zdarzenia. Założenie przyjęte w prognozowaniu dotyczy ograniczeń w celu przewidzenia przyszłości czy też z góry założenia pewnych faktów oraz przekonań, że na przyszłość istotny wpływ mają obecnie podjęte decyzje przez przedsiębiorstwo i jego interesariuszy (Martin, 1995). Autor przekonuje, że przedsiębiorstwa powinny ostrożnie wykorzystywać prognozowanie strategiczne, formułując alternatywne wizje przyszłości, ale nie powinny ich traktować jako wyroczni dotyczących przyszłości, a jedynie jako perspektywę tego, co może się wydarzyć. Takie ujęcie kładzie znacznie większy nacisk na czerpanie informacji i wiedzy $\mathrm{z}$ samego procesu prognozowania aniżeli z jego efektów w postaci na przykład scenariuszów wydarzeń.

W dostępnych publikacjach pozostaje jednak dylemat dotyczący efektywności wykorzystania prognozowania strategicznego i jego wpływu na długoterminowe wyniki przedsiębiorstwa (Bradley MacKay i Costanzo, 2009; Grant, 2003; Wiltbank, Dew, Read i Sarasvathy, 2006). Sceptycyzm naukowców jest widoczny w niewielkiej liczbie publikacji w najnowszych czasopismach naukowych dotyczących efektywności wykorzystania prognozowania w przedsiębiorstwach (Vecchiato, 2015). Taka retoryka sprawia, że kluczowy staje się proces uczenia się, który sprzyja elastyczności i zwinności strategicznej przedsiębiorstwa poprzez zdolność do odpowiedzi na zmiany otoczenia (Grant 2003). W prowadzonych badaniach 
R. Vecchiato (2015) poddał analizie problem, który sformułował w następujący sposób: czy i w jakich okolicznościach prognozowanie strategiczne wzmacnia zwinność strategiczną przedsiębiorstwa? Podstawa teoretyczna podejmowanej przez autora dyskusji została osadzona w trzech nurtach badawczych: pierwszy dotyczy obszaru niepewności otoczenia (environmental uncertainty), drugi nawiązuje do planowania strategicznego (strategic planning) i uzyskania pierwszej przewagi (first mover advantage), natomiast trzeci został osadzony w literaturze dotyczącej organizacyjnego uczenia się i pamięci organizacyjnej. Autor określa dwa obszary, które charakteryzują interakcje pomiędzy niepewnością otoczenia, prognozowaniem strategicznym a długoterminowymi wynikami przedsiębiorstwa. Pierwszy z nich dotyczy wiedzy, jaką przedsiębiorstwo powinno budować i rozwijać dzięki prognozowaniu, drugi skupia się na warunkach, dzięki którym możliwe byłoby efektywniejsze uczenie i rozwijanie umiejętności adaptacyjnych. Dużą wagę autor przypisuje pamięci organizacyjnej, która ma bezpośredni wpływ na strategiczne reakcje przedsiębiorstwa poprzez wykorzystywanie wcześniejszych doświadczeń w teraźniejszych i przyszłych działaniach. Według J.P. Walsha i G.R. Ungsona (1991) pamięć organizacyjna odgrywa trzy zasadnicze role: informacyjną, która wspiera zarządzających w wybieraniu i odczytywaniu sygnałów z otoczenia, koordynacyjną, która redukuje koszty transakcyjne, często związane z implementacją nowych decyzji, oraz polityczną, dzięki której pracownicy lub ich grupy mogą wpływać na działania innych. Literatura dotycząca pamięci organizacyjnej wskazuje, że kluczową rolą prognozowania strategicznego jest wsparcie przedsiębiorstwa w budowaniu swojej własnej „pamięci przyszłości” (memories of future). Komplementarnym źródłem wiedzy jest pamięć dotycząca przeszłości (memories of the past), jednak pojawianie się nowych, nieznanych dotąd wyzwań wymaga innowacyjnego i kreatywnego podejścia do sprostania im.

Przedsiębiorstwo ma do wyboru wiele kanałów, źródeł, mediów, dzięki którym uzyskuje informacje o nowych zdarzeniach, trendach i zmianach w otoczeniu (Aguilar, 1967; Daft i in., 1988; Elenkov, 1997; Boyd i Fulk, 1996). Źródła te mogą mieć zarówno charakter wewnętrzny (pracownicy), jak i zewnętrzny (konkurenci, dostawcy, naukowcy, konsultanci), formalny (wywiadownie gospodarcze, konferencje naukowe, źródła internetowe), jak i nieformalny (spotkania, wydarzenia społeczne). Zdobyta w ten sposób wiedza jest następnie opracowywana przez pracowników z wykorzystaniem wspomnianych technik prognozowania strategicznego. Na proces ten składają się (Vecchiato, 2015, s. 6-7):

- socjalizacja ukrytej wiedzy dotyczącej zmian w otoczeniu przedsiębiorstwa (wymiana wiedzy i spostrzeżeń opartych na symbolach, zachowaniach i doświadczeniach podczas spotkań pracowników różnych szczebli);

- przemiana ukrytej wiedzy dotyczącej zmian w otoczeniu w wiedzę jawną (pracownicy wyższych szczebli, na podstawie zebranych danych, wykorzystując techniki prognozowania, formułują wizję zmian, ich wpływ na przedsiębiorstwo oraz dostępne opcje reagowania przedsiębiorstwa - w postaci scenariuszy wydarzeń 
lub map działania), te formalne opracowania stanowią źródło „pamięci przyszłości" wykorzystywanej w procesie decyzyjnym;

- połączenie jawnej wiedzy dotyczącej zewnętrznych zmian (wyniki prognozowania strategicznego powinny być udostępniane wszystkim pracownikom, również tym, którzy nie brali udziału w procesie prognozowania);

- internalizacja wiedzy jawnej dotyczącej zmian w otoczeniu w wiedzę ukrytą (pracownicy wyższych szczebli, na podstawie „pamięci przyszłości”, wyciągają wnioski dotyczące nowych zdarzeń i zmian, które mogą stanowić szanse dla przedsiębiorstwa, a ich wykorzystanie może umożliwić utrzymanie przewagi konkurencyjnej w dłuższym okresie).

W świetle powyższego prognozowanie strategiczne określa fundamenty dla trwającego procesu, dzięki któremu nowa wiedza (jawna i ukryta) dotycząca zmian w otoczeniu jest systematycznie pozyskiwana, a świadomość potrzeby myślenia o przyszłości przedsiębiorstwa jest uaktualniana i sprawdzana przez jej pracowników poprzez procesy socjalizacji, artykulacji, kombinacji oraz internalizacji. Ważnym wnioskiem dotyczącym kształtowania zwinności strategicznej jest stwierdzenie, że prognozowanie strategiczne ma istotny wpływ na szybką adaptację przedsiębiorstwa do otoczenia i jego wyniki (Rohrbeck, 2012). Turbulentne otoczenie sprawia, że przedsiębiorstwa prognozujące i planujące swoje posunięcia strategiczne mogą uprzedzić działania swoich rywali, wcześniej dostrzegając wyłaniające się szanse (Sull, 2009). Postrzegając prognozowanie strategiczne jako proces uczenia się, należy zauważyć, że kształtuje on i wzmacnia umiejętności adaptacyjne przedsiębiorstwa (Vecchiato, 2015, s. 7). Poprzez budowanie organizacyjnej „pamięci przyszłości” prognozowanie strategiczne wzmacnia wrażliwość strategiczną przedsiębiorstwa poprzez:

- identyfikowanie i czerpanie informacji z różnych źródeł,

- wykorzystywanie pierwszej przewagi konkurencyjnej wynikającej z wcześniejszego wykorzystania informacji aniżeli konkurenci,

- dystrybuowanie informacji podtrzymującej spójność i świadomość celów w całym przedsiębiorstwie.

Podejmowanie decyzji dotyczącej wykorzystywania okazji w przedsiębiorstwie wiąże się bezpośrednio z postawą decydentów wobec podejmowania ryzyka i postrzegania go jako naturalnego elementu gry rynkowej. Odnosi się ona do skłonności menedżerów do podejmowania ryzykownych projektów i odzwierciedla preferencje śmiałych decyzji służących osiągnięciu organizacyjnych celów (Gasse, 1982). J. Wiklund oraz D. Shepherd (2003) podejmowanie ryzyka określają jako angażowanie zasobów w projekty, których wyniki nie są pewne. Skłonność do podejmowania ryzyka oznacza tolerancję błędów, niepowodzeń i niejednoznaczności (Chiva, Alegre i Lapiedra, 2007). Konsekwencją podejmowania ryzyka jest uczenie się dobrych praktyk opartych na sukcesach, ale także formułowanie wniosków z popełnionych błędach, co z kolei może prowadzić do wykreowania nowych okazji (Vargas, 2013). Logika tego podejścia polega na tym, że chęć podjęcia ryzyka przyczynia się bezpo- 
średnio do dążenia przedsiębiorstwa do rozwijania i wdrażania nowych pomysłów w dążeniach strategicznych (Jambulingam, Kathuria i Doucette, 2005). Podejście zarządzających do podejmowania ryzyka ma wpływ na ogólny poziom zwinności przedsiębiorstwa (Mishra i in., 2014). Przedsiębiorstwa charakteryzujące się zwinnością akceptują wysoki poziom ryzyka, „muszą być narażone na wysokie ryzyko, aby zachować zwinność" (Lyytinen i Rose, 2006). Istota zwinności tkwi w radzeniu sobie z nieprzewidzianymi zmianami, stąd konieczność podejmowania ryzyka. Zachęcenie pracowników do współpracy w celu zmniejszenia obaw i uzyskania otwartości może ich zmotywować do podejmowania różnych rodzajów ryzyka w przyszłości (Mat i Cherazak, 2011). Niemniej podejmowanie decyzji w warunkach niepewności i presji czasu stanowi duże wyzwanie dla decydentów. Nawet podjęcie próby identyfikacji i oceny ryzyka w niestabilnych warunkach może być trudne i nie zawsze umożliwi precyzyjne jego określenie. Metody prognozowania strategicznego oraz uzyskanie satysfakcjonującego poziomu wnikliwości strategicznej mogą wesprzeć proces analizy ryzyka, jednak ostateczna decyzja o jego podjęciu zależy od skłonności do ryzyka samego decydenta, jak i przyjętej kultury organizacyjnej. Badania potwierdzają, że zarządzający w przedsiębiorstwach o wysokim poziomie zwinności chętnie podejmują ryzyko (Dai, Meuse i Tang, 2013; Mahmoud Hamad i Yozgat, 2017).

Powyższe rozważania prowadzą do wniosku, że wrażliwość strategiczna, charakteryzująca się umiejętnością oceny szans oraz skłonnością do ryzyka, ma wpływ na lepsze przygotowanie przedsiębiorstwa na wyzwania otoczenia i może wypływać na jego przewagę konkurencyjną i wyniki. W związku $\mathrm{z}$ tym sformułowano następującą hipotezę badawczą modelu zwinności strategicznej:

H1: Wrażliwość strategiczna (współtworzona przez umiejętność oceny szans oraz skłonność do ryzyka) ma pozytywny wpływ na wyniki rynkowe przedsiębiorstw.

H1a: Umiejętność oceny szans ma pozytywny wpływ na wyniki rynkowe przedsiębiorstw.

H1b: Skłonność do ryzyka ma pozytywny wplyw na wyniki rynkowe przedsiębiorstw.

\subsection{Przedsiębiorczość strategiczna jako atrybut zwinności zorientowany na wykorzystywanie szans}

Rozprzestrzeniające się dynamizm i niepewność w burzliwym otoczeniu wymagają od przedsiębiorstw rozwijania kompetencji przedsiębiorczych, ale także działania w sposób strategiczny. Identyfikowaniu i wykorzystaniu okazji oraz kreowaniu niepewności wskutek rozważania dużej liczby nowych idei i wariantów decyzyjnych musi towarzyszyć myślenie strategiczne skierowane na realizację 
wizji (Ireland i in., 2003). Według D.F. Kuratko, M.H. Morrisa oraz J.C. Covina (2011) przedsiębiorczość strategiczna obejmuje strategiczne zdarzenia przedsiębiorcze, które dotyczą realnych działań ukierunkowanych na zróżnicowanie i przekształcenie przedsiębiorstwa w celu dostosowania do zmieniających się warunków rynkowych. W praktyce obejmuje ona zestaw decyzji i działań niezbędnych do identyfikowania szans oraz ich wykorzystywania za pomocą tworzenia i utrzymania przewagi konkurencyjnej w celu tworzenia wartości dla klientów i bogactwa dla interesariuszy (Hitt, Ireland, Sirmon i Trahms, 2011). Dynamiczny model przedsiębiorczości strategicznej zaproponowany przez M.A. Hitta, R.D. Irelanda, G. Sirmona oraz Ch.A Trahmsa, (2011) obejmuje trzy wymiary: układy zasobowe, procesy orkiestracji zasobów oraz efekty. Podstawą dynamiki przedsiębiorczości strategicznej jest współewoluowanie procesu przedsiębiorczego polegającego na wynajdywaniu szans (przedsiębiorcze myślenie ukierunkowane na tworzenie i wykorzystanie szans, przedsiębiorcza kultura organizacyjna sprzyjająca, elastyczności, twórczości, kreatywności, innowacyjności, przedsiębiorcze przywództwo) z elementem strategicznym nastawionym na przewagę konkurencyjną budowaną wokół zarządzania zasobami (tworzenie wiązek zasobów, rekonfigurowanie zasobów, pozyskiwanie zasobów, pozbywanie się zasobów) (Kyrgidou i Hughes, 2010). Podsumowania dokonują W. Dyduch oraz K. Bratnicka (2014), uznając, że „organizacja, która wynajduje szanse, strategicznie zarządza zasobami, uczy się i buduje zdolności dynamiczne, stosuje twórczość dla innowacji i ma wizję rozwojową oraz kontekst sprzyjający dwustronności zachowań oraz dynamicznie integruje te elementy w celu uformowania i wykorzystania przewagi konkurencyjnej - jest organizacją przedsiębiorczą strategicznie”.

Przedsiębiorczość strategiczna ma niezwykle istotny wkład w kontekście zdolności przedsiębiorstw do adaptacji poprzez identyfikację i wykorzystanie okazji w otoczeniu. Jest nośnikiem strategicznej zręczności, elastyczności i innowacyjności (Kraus, Kauranen i Reschke, 2011). Zwinność strategiczna wymaga umiejętności oceny zasobów niezbędnych do wykorzystania okazji. Przedsiębiorstwo może je zdobyć w ramach rozwoju zasobów własnych (materialnych i niematerialnych), poprzez szeroki zakres inwestycji, lub pozyskać poza przedsiębiorstwem. Jak zauważają H.H. Stevenson i J.C. Jarillo (1990), przedsiębiorczość to także poszukiwanie okazji będących poza zasobami obecnie kontrolowanymi. Dlatego tak istotne są kompetencje budowania relacji i współpracy, które według autorów są kluczowe w sytuacji, gdy zasoby potrzebne do wykorzystania okazji znajdują się poza kontrolą przedsiębiorcy. Tym samym dostrzegają oni prawidłowość, że organizacje, które sprzyjają powstawaniu nieformalnych wewnętrznych i zewnętrznych układów sieciowych i umożliwiają stopniową alokację i udostępnianie zasobów, będą wykazywały wyższy stopień zachowań przedsiębiorczych (Stevenson i Jarillo, 1990). Owa współpraca może przybierać wiele postaci. Z punktu widzenia kooperatywnego zachowania ukierunkowanego strategicznie ciekawą typologię relacji prezentuje A.T. Himmelman (1996, s. 19-35). Zachowania strategiczne przedsiębiorstwa w tym zakresie 
koncentrują się m.in. na: wymianie informacji, osiąganiu wzajemnych korzyści, zmianie form działania, osiąganiu wspólnych celów, wspólnym wykorzystaniu zasobów, a także zwiększeniu kompetencji. Dodatkowo analiza form współdziałania dowodzi, że przynosi ono korzyści w przypadku nie tylko budowania formalnych związków współpracy partnerskiej, ale również nieformalnych relacji, na przykład $\mathrm{w}$ formie sieci relacji. Sukces nowych przedsięwzięć, niezależnych od posiadanych zasobów, podkreśla również J.A. Timmons (1999), uznając, że „robienie więcej przy mniejszych zasobach stanowi potężną broń konkurencyjną”.

W. Dyduch (2008, s. 96-97) definiuje orientację przedsiębiorczą (entreprenuerial orientation) jako orientację strategiczną organizacji przedsiębiorczej, czyli takiej, w której przedsiębiorczość kształtuje cele, priorytety i procesy podejmowania decyzji. Orientacja przedsiębiorcza umożliwia podejmowanie działań przedsiębiorczych oraz poszukiwanie i wykorzystywanie okazji. Orientacja przedsiębiorcza odzwierciedla nastawienie organizacji do angażowania się w działania strategiczne mające charakter innowacyjny, proaktywny i obarczony ryzykiem (Covin i Slevin, 1989). Operacjonalizacja orientacji przedsiębiorczej początkowo obejmowała elementy zdefiniowane przez D. Millera i P. Friesena (1982) oraz J.G. Covina i D.P. Slevina (1989). Swoiste wymiary orientacji przedsiębiorczej zaproponowane przez D. Millera (1983) stanowily użyteczny punkt wyjścia do dalszych badań w tym zakresie. Według autora „firma przedsiębiorcza” to taka, która „,angażuje się w tworzenie innowacyjnych produktów rynkowych, akceptując ryzyko związane z przedsięwzięciami oraz podejmuje proaktywne działania w kreowaniu innowacyjnych rozwiązań wcześniej niż konkurenci”. D. Miller (1983) wykorzystał trzy wymiary do określenia i mierzenia przedsiębiorczości, są nimi: innowacyjność, podejmowanie ryzyka oraz proaktywność. Miary zaproponowane przez D. Millera zostały zaadaptowane przez innych naukowców do prowadzonych przez nich badań (Covin i Slevin, 1989; Ginsberg, 1985, Morris i Paul, 1987; Naman i Slevin, 1993; Schafer, 1990).

Następnie miary te zostały rozszerzone przez G.T. Lumpkina i G.G. Dessa (1996), którzy wyszczególnili pięć wymiarów użytecznych dla scharakteryzowania kluczowych procesów przedsiębiorczych - autonomia, innowacyjność, podejmowanie ryzyka, proaktywność oraz konkurencyjna agresywność. Zgodnie z ich koncepcją orientacja przedsiębiorcza to zbiór procesów, struktur, metod, praktyk, stylów i zachowań, jakie menedżerowie wykorzystują, aby działać w sposób przedsiębiorczy, uporządkowany w postaci pięciu wymiarów (Lumpkin i Dess, 1996):

- autonomia - dotyczy działań podejmowanych przez indywidualnych członków organizacji lub grupę, zmierzających do realizacji pomysłów oraz wizji; oznacza samoukierunkowanie w rozpoznawaniu, podejmowaniu i wykorzystywaniu szans; w szerszym kontekście organizacyjnym autonomia odnosi się do działań podejmowanych niezależnie od barier i granic organizacyjnych;

- innowacyjność - odzwierciedla tendencję organizacji do angażowania się w proces twórczy, którego wynikiem mogą być nowe produkty i usługi, procesy technologiczne, a także eksperymentowanie i promowanie oryginalnych pomysłów; 
- podejmowanie ryzyka - określone jako stopień gotowości kadry zarządzającej do dużego i ryzykownego zaangażowania zasobów w celu otrzymania wysokich zwrotów dzięki wykorzystaniu rynkowej szansy;

- proaktywność - odnosi się do procesu polegającego na przewidywaniu i działaniu uwzględniającym przyszłe potrzeby, poszukiwaniu nowych szans, wdrażaniu nowych produktów/usług szybciej niż czynią to konkurenci; obejmuje zarówno podejmowanie przez przedsiębiorstwo inicjatyw dotyczących kształtowania otoczenia dla własnych potrzeb, jak i umiejętność odpowiedzi na wyzwania stawiane przez konkurentów;

- konkurencyjna agresywność - dotyczy skłonności organizacji do stawiania wyzwań konkurentom w celu wejścia na dany rynek lub poprawienia własnej pozycji konkurencyjnej; konkurencyjna agresywność jest określona przez reaktywność, która może przybrać formę konfrontacji lub walki konkurencyjnej.

Wskazane wymiary orientacji przedsiębiorczej mogą być odzwierciedlone w atrybutach zwinności strategicznej. Wyszczególnione wymiary nie odnoszą się jedynie do jednego atrybutu zwinności strategicznej, ale raczej ich wpływ jest widoczny w kilku jego aspektach przedmiotowych (tabela 3.2).

Miary zaproponowane przez G.T. Lumpkina i G. Dessa (1996) adaptowali do swoich potrzeb badawczych inni autorzy (Li i in., 2009), niekiedy dodając własne wymiary. Przykładem mogą być badania T. Jambulingama i współautorów (2005), którzy wykorzystali orientację przedsiębiorczą jako podstawę do klasyfikacji przedsiębiorstw $w$ ramach sektora usług farmaceutycznych. Zaproponowali oni wymiary orientacji przedsiębiorczej, uwzględniając zdolność przedsiębiorstwa do: innowacyjności, proaktywności, autonomii, agresywności konkurencyjnej, podejmowania ryzyka oraz motywacji. B. Antoncic (2003), odnosząc się do indywidualnego poziomu przedsiębiorczości, analizuje uwarunkowania podejmowania ryzyka w dziedzinie intraprzedsiębiorczości. Autor sugeruje, że kultura organizacyjna dominująca w przedsiębiorstwie oraz skłonność do podejmowania ryzyka determinuje postawę wobec ryzyka, która wpływa na intencje behawioralne. Intencje behawioralne z kolei prowadzą do intencji i działań indywidualnych i podejmowania ryzyka na poziomie przedsiębiorstwa (Antoncic, 2003). W podobnym duchu proponuje się rozważanie intencji przedsiębiorczych ułatwiających zaangażowanie przedsiębiorstwa w działania przedsiębiorcze. D. Kantur (2016) udowodnił pozytywny związek pomiędzy orientacją przedsiębiorczą a przedsiębiorczością strategiczną.

Koncepcyjny model przedsiębiorczości strategicznej został zaproponowany przez R.D. Ireland, M.A. Hitt, D.G. Sirmon (2003), dla których inspiracją były wcześniejsze badania prowadzone w ramach przedsiębiorczości strategicznej (Hitt i in., 2001). Stworzony przez autorów model przedsiębiorczości strategicznej obejmuje cztery charakterystyczne obszary przedmiotowe: myślenie przedsiębiorcze (entrepreneurial mindset), przedsiębiorczą kulturę organizacyjną (entrepreneurial culture), przedsiębiorcze przywództwo (entrepreneurial leadership), strategiczne zarządzanie zasoba- 


\section{Tabela 3.2. Definiowanie i wykorzystanie wymiarów orientacji przedsiębiorczej w warunkach zwinności strategicznej}

\begin{tabular}{|c|c|c|}
\hline $\begin{array}{c}\text { Wymiar } \\
\text { koncepcyjny }\end{array}$ & Opis wymiarów & $\begin{array}{c}\text { Definiowanie i wykorzystanie wymiarów } \\
\text { orientacji przedsiębiorczej w warunkach } \\
\text { zwinności strategicznej }\end{array}$ \\
\hline Autonomia & $\begin{array}{l}\text { Niezależne działania przedsię- } \\
\text { biorcy. } \\
\text { Wprowadzenie w życie pomy- } \\
\text { słu, wizji i doprowadzenie ich } \\
\text { do końca. } \\
\text { Zdolność do bycia samoukie- } \\
\text { runkownym w procesie poszu- } \\
\text { kiwania szans. } \\
\text { Działania podejmowane w or- } \\
\text { ganizacji niezależnie od sztyw- } \\
\text { nych ram organizacyjnych. } \\
\text { Kontekstualność - zależy od } \\
\text { wielkości organizacji, stylu za- } \\
\text { rządzania i struktury }\end{array}$ & $\begin{array}{l}\text { Istotna staje się kultura wynikająca z przy- } \\
\text { wództwa strategicznego łączącego cechy przy- } \\
\text { wództwa charyzmatycznego i organicznego, } \\
\text { zaangażowani, kreatywni i umocowani pracow- } \\
\text { nicy autonomicznie podejmują działania, reali- } \\
\text { zują pomysły i wizje przedsiębiorstwa, twórczo } \\
\text { rozwiązują problemy, nie zrażając się trudno- } \\
\text { ściami i barierami, w przypadku ograniczonej } \\
\text { dostępności zasobów przedsiębiorstwo zorien- } \\
\text { towane przedsiębiorczo nie zaniecha autono- } \\
\text { micznych procesów kładących nacisk na nowe } \\
\text { przedsięwzięcia, gdyż uczestnicy charakteryzują } \\
\text { się swobodą działania w podejmowaniu decy- } \\
\text { zji. Niezależność przywódcy może się przeja- } \\
\text { wiać w postaci oryginalnej, scentralizowanej } \\
\text { wizji, a pracowników - poprzez oddolne eks- } \\
\text { perymentowanie }\end{array}$ \\
\hline Innowacyjność & $\begin{array}{l}\text { Twórcza destrukcja. } \\
\text { Tendencja do rozwijania } \\
\text { i wspierania nowych pomysłów. } \\
\text { Wychodzenie z przedsięwzięcia- } \\
\text { mi poza istniejący stan rzeczy. } \\
\text { Od eksperymentowania z no- } \\
\text { wym produktem po odda- } \\
\text { nie z pasją ulepszaniu nowych } \\
\text { technologii }\end{array}$ & $\begin{array}{l}\text { Wykorzystanie innowacyjności w procesach, } \\
\text { produktach, modelach biznesu oraz sposobach } \\
\text { pozycjonowania przedsiębiorstwa. Występuje } \\
\text { kultura wspierająca innowacyjność, w której } \\
\text { pracownicy mogą liczyć na pomoc w rozwi- } \\
\text { janiu nowych pomysłów. Bardziej istotna niż } \\
\text { sama innowacyjność jest zdolność innowacyjna }\end{array}$ \\
\hline $\begin{array}{l}\text { Podejmowanie } \\
\text { ryzyka }\end{array}$ & $\begin{array}{l}\text { Przedsięwzięcia w nieznanych } \\
\text { polach działalności. } \\
\text { Angażowanie zasobów. } \\
\text { Pożyczanie dużych ilości środ- } \\
\text { ków }\end{array}$ & $\begin{array}{l}\text { Ryzyko stanowi naturalny element gry rynko- } \\
\text { wej, zamiast się go obawiać, należy nauczyć się } \\
\text { je ograniczać. Traktowane jest raczej jako szansa } \\
\text { na pojawienie się ciekawych okazji. Zarządzają- } \\
\text { cy chętnie podejmują ryzyko. } \\
\text { Podobnie definiowane jak dla orientacji przed- } \\
\text { siębiorczej }\end{array}$ \\
\hline Proaktywność & $\begin{array}{l}\text { Aktywne poszukiwanie szans. } \\
\text { Przewodzenie konkurentom. } \\
\text { Promowanie innowacji zamiast } \\
\text { koncentrowania się na ustabili- } \\
\text { zowanych systemach. } \\
\text { Wprowadzanie nowych pro- } \\
\text { duktów i pokonywanie konku- } \\
\text { rentów zamiast współpracy. } \\
\text { Strategiczne eliminowanie }\end{array}$ & $\begin{array}{l}\text { Proaktywność w warunkach zwinności odno- } \\
\text { si się do atrybutu „wrażliwości strategicznej”, } \\
\text { skupionego na aktywnym poszukiwaniu szans } \\
\text { poprzez wykorzystanie prognozowania strate- } \\
\text { gicznego (strategic foresight) oraz wnikliwości } \\
\text { przedsiębiorstwa (strategic insight). } \\
\text { Antycypowanie konsekwencji kluczowych tren- } \\
\text { dów w celu wczesnego zidentyfikowania zagro- } \\
\text { żeń i niepokojących zjawisk }\end{array}$ \\
\hline
\end{tabular}


cd. tab. 3.2

\begin{tabular}{|c|c|c|}
\hline $\begin{array}{c}\text { Wymiar } \\
\text { koncepcyjny }\end{array}$ & Opis wymiarów & $\begin{array}{l}\text { Definiowanie i wykorzystanie wymiarów } \\
\text { orientacji przedsiębiorczej w warunkach } \\
\text { zwinności strategicznej }\end{array}$ \\
\hline & $\begin{array}{l}\text { działań, które znajdują się w fa- } \\
\text { zie dojrzewania lub schyłku } \\
\text { w cyklu życia }\end{array}$ & \\
\hline $\begin{array}{l}\text { Konkurencyjna } \\
\text { agresywność }\end{array}$ & $\begin{array}{l}\text { Ukierunkowane działanie or- } \\
\text { ganizacji na stawianie wyzwań } \\
\text { konkurentom. } \\
\text { Dążenie do pozyskania lepszej } \\
\text { pozycji na rynku. } \\
\text { Chęć bycia niekonwencjonal- } \\
\text { nym. } \\
\text { Odpowiadanie na sygnały pły- } \\
\text { nące z rynku. } \\
\text { Tworzenie trendów, a nie podą- } \\
\text { żanie za nimi }\end{array}$ & $\begin{array}{l}\text { Konkurencyjna agresywność sprowadza się do } \\
\text { eksperymentowania z nowymi modelami bizne- } \\
\text { su, źródłami przewagi konkurencyjnej i narzę- } \\
\text { dziami konkurowania. Przewaga konkurencyjna } \\
\text { jest tymczasowa, dlatego zdolność do szybkiej, } \\
\text { efektywnej zmiany w ramach budowania źródeł } \\
\text { przewagi konkurencyjnej stanowi fundament } \\
\text { zwinności strategicznej }\end{array}$ \\
\hline
\end{tabular}

Źródło: (Sajdak, 2017).

mi oraz zastosowanie kreatywności w rozwoju innowacji (the strategic management of resources and applying creativity to develop innovations).

R.D. Ireland i współautorzy (2003) zdefiniowali myślenie przedsiębiorcze jako perspektywę zorientowaną na rozwój, poprzez którą indywidualne jednostki promują elastyczność, kreatywność, ciągłe innowacje i odnowę. Nawet pod płaszczem niepewności strategiczni przedsiębiorcy mogą identyfikować i wykorzystywać nowe możliwości poprzez zdolności poznawcze, które pozwalają im nadawać sens niejednoznacznym i fragmentarycznym sytuacjom. Za elementy myślenia przedsiębiorczego uznano: rozpoznanie możliwości przedsiębiorczych, czujność przedsiębiorcy, logikę opcji rzeczywistych, ramy przedsiębiorczości i rejestr możliwości. Wszystkie wskazane komponenty stanowią istotne działania wspierające myślenie przedsiębiorcze tak potrzebne dla zapewnia adaptacji przedsiębiorstw do zmieniających się warunków otoczenia. Nawiązują one do atrybutu zwinności strategicznej zwanej wrażliwością, która łącząc prognozowanie strategiczne i wnikliwość przedsiębiorstwa, z jednej strony zapewnia ostrość percepcji szans poprzez antycypowanie konsekwencji kluczowych trendów, z drugiej natomiast zapewnia wewnętrzną czujność opartą na dobrej jakości informacjach i kontaktach zewnętrznych.

Kultura przedsiębiorcza i przedsiębiorcze przywództwo są istotnymi aspektami przedsiębiorczości strategicznej. Skuteczna kultura przedsiębiorcza charakteryzuje się wieloma oczekiwaniami i ułatwia podejmowanie wyzwań oraz strategiczne zarządzanie zasobami. Kultura przedsiębiorcza ma na celu jednoczesne poszukiwanie szans i określanie ich korzyści dla przedsiębiorstwa. Skuteczna kultura przedsiębiorcza to taka, w ramach której oczekuje się nowych pomysłów i kreatywności, zachę- 
cania do podejmowania ryzyka, tolerowania niepowodzenia, promowania uczenia się, innowacji produktowych, procesowych i administracyjnych. Podejmowanie ciągłych zmian jest postrzegane jako przenośnik pojawiających się możliwości. Przedsiębiorcza kultura rozwija się w przedsiębiorstwach, w których liderzy wykorzystują myślenie strategiczne (Ireland i in., 2003). Kultura przedsiębiorcza koresponduje z uwarunkowaniami zwinności strategicznej. Pracownicy wykorzystujący myślenie przedsiębiorcze koncentrują się na poszukiwaniu przedsiębiorczych możliwości istniejących w niepewnym środowisku biznesowym, a następnie określeniu zdolności potrzebnych do ich skutecznego wykorzystania. Zatem kultura przedsiębiorcza i myślenie przedsiębiorcze są ściśle ze sobą powiązane. Liderzy czują się odpowiedzialni za rozwijanie i pielęgnowanie kultury przedsiębiorczej, czyli kultury w której przedsiębiorczość strategiczna może być skutecznie wykorzystana (Covin i Slevin, 2002; McGrath i MacMillan, 2000). Zastosowanie elementów przedsiębiorczego zarządzania jest jednocześnie widoczne w warunkach zwinności strategicznej, należą do nich: zdolności przedsiębiorcy, ochrona innowacji zagrażających obecnemu modelowi biznesowemu, umiejętność nadawania szansom sensu biznesowego, kwestionowanie dominującej logiki działań i procesów oraz podejmowanie prób robienia rzeczy lepiej, taniej lub szybciej, a także połączenie przedsiębiorczości i zarządzania strategicznego.

Strategiczne zarządzanie zasobami to kolejny istotny wymiar przedsiębiorczości strategicznej, odwołujący się do założeń szkoły zasobowej ujmującej teoretyczne podstawy zrozumienia sposobów strategicznego zarządzania zasobami. Jak sugeruje podejście zasobowe, przewaga konkurencyjna jest funkcją zasobów, które przedsiębiorstwo rozwija lub nabywa w celu realizacji swojej strategii rynkowej (Wernerfelt, 1984). W celu zrozumienia różnic w wynikach przedsiębiorstw badacze podejmujący wątek przedsiębiorczości koncentrują się na różnych rodzajach zasobów, szczególnie w aspekcie umiejętności identyfikacji szans biznesowych (Michael, Storey i Thomas, 2002). R.D. Ireland i współautorzy (2003) wyróżniają trzy podstawowe rodzaje zasobów współtworzące przedsiębiorczość strategiczną, należą do nich: jednostkowy składnik aktywów - kapitał finansowy, i dwa niematerialne aktywa kapitał ludzki i kapitał społeczny.

Wykorzystanie kreatywności i rozwijanie innowacji odgrywa ważną rolę w identyfikowaniu i podejmowaniu okazji biznesowych, stanowiąc istotny aspekt przedsiębiorczości strategicznej. Skuteczne innowacje tworzą nową wartość dla klientów, stąd potrzeba kreatywności niezbędnej w rozwijania innowacji. Kreatywność wpływa zarówno na jakość i liczbę innowacji przełomowych - zwanych twórczą destrukcją (disruptive innovation), jak i innowacji podtrzymujących. Twórcza destrukcja implikuje rewolucyjną zmianę na rynkach, podczas gdy podtrzymujące innowacje prowadzą do stopniowej zmiany. Innowacje inkrementalne lub podtrzymujące to efekt uczenia się, jak lepiej wykorzystać istniejące możliwości, które przyczyniają się do osiągnięcia przewagi konkurencyjnej. Natomiast radykalne lub destrukcyjne innowacje pochodzą z identyfikowania i wykorzystywania możliwości przedsiębior- 
czych poprzez nowe kombinacje zasobów w celu stworzenia nowych możliwości, które prowadzą do przewagi konkurencyjnej (Ireland i in., 2003).

Najskuteczniejszym sposobem przekształcenia innowacji w trwałą przewagę konkurencyjną jest budowa zdolności innowacyjnej, ogólnie określanej jako zdolność do ciągłej transformacji wiedzy i idei w nowe produkty, procesy i systemy dla korzyści przedsiębiorstw (Lawson i Samson, 2001). Innowacyjność to pojęcie oznaczające otwartość na nowe pomysły, stanowi integralną cześć kultury organizacyjnej. Innowacyjność kultury organizacyjnej stanowi miarę orientacji organizacyjnej zorientowanej na innowacje. Do antecedencji innowacyjności można zaliczyć: kulturę organizacyjną zorientowaną na uczenie się, partycypacyjny proces podejmowania decyzji, wsparcie i współpracę, dzielnie się władzą (Hurley i Hult, 1998). Natomiast zdolność innowacyjna (capacity to innovate) to pojęcie użyte pierwszy raz przez T. Burnsa oraz G.M. Stalkera (1961), oznacza ono zdolność organizacji do efektywnej adaptacji oraz implementacji nowych pomysłów, procesów oraz produktów. Obecnie przedsiębiorstwa bardziej konkurują zdolnościami do rozwoju nowych produktów niż nowymi produktami (Lawson i Samson, 2001; Zhang, Garrett-Jones i Szeto, 2013). W tym kontekście zdolność innowacyjna może być rozpatrywana jako wskaźnik sukcesu innowacji. W ostatnich latach podjęto liczne badania koncentrujące się głównie na rozpoznaniu specyfiki zasobów i zdolności niezbędnych do podejmowania różnego rodzaju innowacji realizowanych w dynamicznym otoczeniu. Za kluczowe uznaje się nabycie zdolności organizacyjnych do szybkiej odpowiedzi na zmiany w otoczeniu, rozwój rynków, technologii i rozwój biznesu. Efektywność innowacji jest związana z odmienną zdolnością przedsiębiorstwa do stałego mobilizowania swoich zasobów i zdolności dopasowania do zmieniających się okazji (Lichtenthaler i Muethel, 2012). Kształtowanie zdolności innowacyjnej przedsiębiorstwa ma istotne znaczenie w warunkach zwinności strategicznej, szczególnie ze względu na jej wpływ na tworzenie przewagi konkurencyjnej.

Zwinność strategiczna przedsiębiorstwa wymaga przedsiębiorczości ukierunkowanej na działania strategiczne. W wyłanianiu składowych przedsiębiorczości strategicznej niezwykle istotne znaczenie ma koncepcja zarówno orientacji przedsiębiorczej, jak i przedsiębiorczości strategicznej. Z obu koncepcji zaadaptowano miary, które najtrafniej określają przedsiębiorczość strategiczną w warunkach zwinności. Poza innowacyjnością, przedsiębiorczym myśleniem i kulturą przedsiębiorczą niezwykle istotna dla zwinności strategicznej jest współpraca przedsiębiorstw w celu wykorzystania pojawiających się szans. Potrzebę owej współpracy podkreślają H.H. Stevenson and J.C. Jarillo (1990), twierdząc, że zarządzanie przedsiębiorcze jest bezpośrednio powiązane z wykorzystaniem okazji, niezależnie od zasobów kontrolowanych przez przedsiębiorstwo. Czerpiąc z powyższej definicji, ustalono, że przedsiębiorczość strategiczna jako atrybut zwinności strategicznej wymaga zdolności do oceny adekwatności zasobów niezbędnych do wykorzystania okazji i decyzji, w jaki sposób zapewnić dostęp do potrzebnych zasobów oraz czy podjąć inwestycje służace rozwojowi zasobów własnych, czy rozwijać współpracę partnerską. Jak 
zauważa B. Maskell (2001), żadne przedsiębiorstwo nie posiada wszystkich umiejętności i zasobów, które mogą mu być potrzebne w celu sprostania zmieniającym się warunkom otoczenia, stąd też naturalna jest współpraca w ramach dostarczenia dodatkowych usług, wiedzy czy wymagań logistycznych. Częstą praktyką jest podejmowanie współpracy wirtualnej poprzez tworzenie nieformalnych struktur, powstałych w konkretnym celu biznesowym. Postanowienia dotyczące współpracy i wzajemne wymagania są określone najczęściej bez zbędnej biurokracji, tak aby jak najszybciej przejść do działania. Jednak wybór takiego rozwiązania wymaga zaufania, szacunku oraz otwartości. Zaawansowanie nowych technologii umożliwia sprawną komunikację w wirtualnej współpracy, zapewniając sprostanie podejmowanym wyzwaniom (Maskell, 2001). Tworzone alianse mogą wzmacniać i promować atmosferę uczenia się poprzez wymianę unikatowych umiejętności i kompetencji (Shukla, 2013).

A. Charbonnier-Voirin (2011), podejmując problematykę praktyk kooperacyjnych (cooperative practices) wykorzystywanych przez przedsiębiorstwa charakteryzujące się zwinnością, określa je jako metody wspierające wewnętrzną kooperację oraz rozwijające współpracę w celu skrócenia czasu odpowiedzi na zmianę, podniesienia jakości oferty oraz służące wzrostowi potencjału innowacyjnego. Działania kooperacyjne oznaczają również wzmacnianie wewnętrznej i zewnętrznej współpracy poprzez nawiązywanie partnerstwa z dostawcami, dystrybutorami, konkurentami oraz klientami (Maskell, 2001; Vargas, 2013; Mahmoud Hamad i Yozgat, 2017). Zatem realizowanie wspólnego celu może się odbywać poprzez współdziałanie o charakterze wertykalnym lub horyzontalnym. Przykładem może być współpraca dostawców i odbiorców pozwalająca na uzyskanie dodatkowych wzajemnych korzyści w procesie osiągania różnych indywidualnych celów podporządkowanych wspólnemu dążeniu do zapewnienia sprawności i efektywności (Witkowski, 2011, s. 21-22). Relacje horyzontalne współpracy odnoszą się natomiast do relacji między konkurentami, a ich intensywność w praktyce jest tak duża, że - jak twierdzi E. Stańczyk Hugiet (2013, s. 75) - można postawić tezę, że są one „innowacyjnym działaniem adaptacyjnym”. Wiele badań potwierdza tę tezę, wskazując, że relacje horyzontalne są zorientowane na budowanie potencjału konkurencyjności wspólnie z innymi konkurentami. Z tego względu strategiczna orientacja na współpracę dominuje w wielu sektorach, a nawet mówi się o strategii kooperacji określanej jako podstawa adaptacji - adaptacja kooperatywna (Stańczyk Hugiet, 2013, s. 74-75). R. Kozłowski i M. Matejun (2012) wskazują na wiele zalet wynikających z relacji współpracy, wymieniając wśród nich: dywersyfikację ryzyka, poprawę koordynacji działań a także ograniczenie kosztów. Współpraca jest związana $\mathrm{z}$ kreacją wiedzy i efektów synergii wynikających z tej współpracy, może się stać istotnym impulsem realizacji określonych przedsięwzięć, pełni funkcję reakcyjną, pozwalając na elastyczne dostosowywanie się do zmieniających się warunków w drodze kształtowania form i zakresu współpracy międzyorganizacyjnej, umożliwiając dostęp do zasobów. 
Zarówno wewnętrzna, jak i zewnętrzna kooperacja prowadzi do efektu synergii i odgrywa istotną rolę w rozwoju zwinności przedsiębiorstw (Sanchez i Nagi, 2001). W ramach omawianej przedsiębiorczości strategicznej uwaga jest zwrócona głównie na zewnętrzną kooperację, wspierającą skuteczność wykorzystania okazji. Nie umniejsza się jednak wartości pracy zespołowej oraz wielozadaniowości pracowników, tematyka kooperacji wewnętrznej zostanie podjęta w ramach atrybutu zwinności zwanego „przywództwem strategicznym” w podrozdziale 3.5.

Organizacyjna zdolność do adaptacji wymaga, aby struktura umożliwiająca adaptację zmieniała się w tempie charakterystycznym dla zmian zewnętrznych. Oznacza to, że im bardziej burzliwe otoczenie, tym częściej powinna mieć miejsce rekonfiguracja wewnętrznych i zewnętrznych relacji. Wysoka dynamika powiązana ze złożonością otoczenia stawia wyzywanie przed przedsiębiorstwami w kontekście eksperymentowania poprzez rekonfigurowanie swoich struktur (Galbraith, 2010, s. 115-120). Poprzez zdolność do budowania relacji współpracy przedsiębiorstwa realizują projekty biznesowe $\mathrm{w}$ ramach podejmowanych procesów samoorganizacji. Samoorganizacja pozostaje jednak w relacji z mechanizmami, dzięki którym możliwe jest zrozumienie zagrożeń i okazji, a w konsekwencji identyfikowanie i kształtowanie relacji z właściwymi partnerami. Jak zauważa M. Romanowska (2007, s. 2), zmieniają się oczekiwania wobec współpracy, głównie pod względem motywu, którym jest strategiczne umocnienie konkurencyjności i pozycji na rynku.

Powyższe rozważania umożliwiły opracowanie proponowanych składowych przedsiębiorczości strategicznej osadzonej w warunkach zwinności strategicznej (rysunek 3.3), z uwzględnieniem miar z wcześniej opracowanych koncepcji (Lumpkin i Dess, 1996; Ireland i in., 2003) przedstawionych i omówionych w tym podrozdziale.

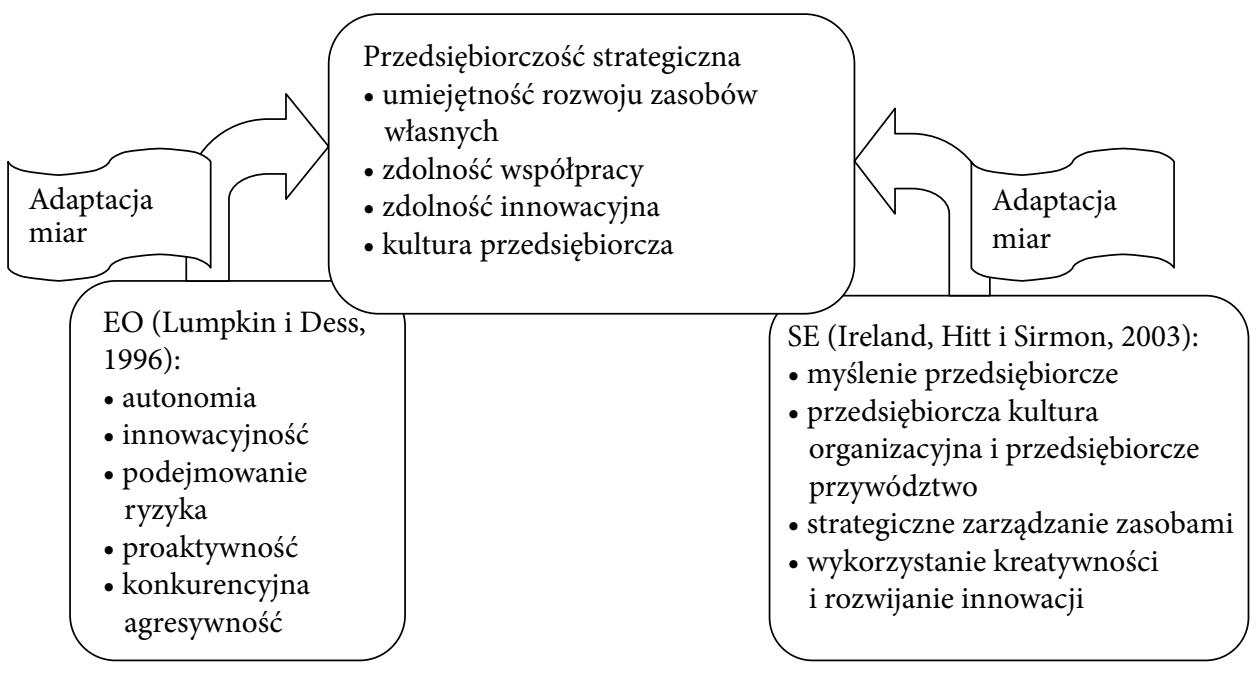

Rysunek 3.3. Opracowanie składowych przedsiębiorczości strategicznej

Źródło: (Sajdak, 2017). 
Istotny wpływ przedsiębiorczości na wzrost i poziom rentowności przedsiębiorstwa został w literaturze udowodniony (Antoncic, 2006; Zahra i Covin, 1995; Zahra i Garvis, 2000). Podczas gdy wielu badaczy analizowało jedynie bezpośredni wpływ działań przedsiębiorczych na wzrost i zyskowność przedsiębiorstwa (Zahra, 1991, 1993; Zahra i Covin, 1995), B. Antoncic i R.D. Hisrich (2004) przeanalizowali pośrednie skutki, udowodniając również pozytywną relację pomiędzy tymi zmiennymi.

Na podstawie powyższych spostrzeżeń przyjęto kolejną hipotezę badawczą modelu zwinności strategicznej:

H2: Przedsiębiorczość strategiczna (współtworzona przez: umiejętność rozwoju zasobów własnych, zdolność wspótpracy, zdolność innowacyjna, kulturę przedsiębiorcza) ma pozytywny wplyw na wyniki rynkowe przedsiębiorstw.

H2a: Umiejętność rozwoju zasobów własnych ma pozytywny wplyw na wyniki rynkowe przedsiębiorstw.

H2b: Zdolność wspólpracy ma pozytywny wplyw na wyniki rynkowe przedsiębiorstw. H2c: Zdolność innowacyjna ma pozytywny wptyw na wyniki rynkowe przedsiębiorstw. H2d: Kultura przedsiębiorcza ma pozytywny wpływ na wyniki rynkowe przedsiębiorstw.

\subsection{Elastyczność jako atrybut zwinności zapewniający odpowiedź na wyzwania otoczenia}

W myśl podejścia behawioralnego nie ma jednego uniwersalnego sposobu zarządzania przedsiębiorstwem, a styl zarządzania zależy od istniejących ograniczeń otoczenia, w którym przedsiębiorstwo funkcjonuje. Pogląd ten opiera się na podejściu traktującym przedsiębiorstwo jako otwarty system, który musi współdziałać z otoczeniem, aby odnieść sukces. W celu utrzymania skuteczności działania przedsiębiorstwa muszą się nieustannie dostosowywać do zmieniających się warunków. Badając związek między cechami otoczenia a atrybutami przedsiębiorstwa, T. Burns i G.M. Stalker (1961) zaproponowali dwa typy przedsiębiorstw, uwzględniając ich strukturę i formę - mechanistyczne i organiczne. Wyniki tych badań świadczą o tym, że w stosunkowo stabilnych i przewidywalnych środowiskach przedsiębiorstwa mają raczej formę mechanistyczną. Natomiast przedsiębiorstwa działające w niestabilnym, zmiennym i nieprzewidywalnym otoczeniu zwykle przyjmują formę organiczną - mniej formalną, mniej hierarchiczną i mniej mechanistyczną. Organiczna forma organizacji charakteryzuje się mniej dokładnym podziałem pracy, szerszym zakresem kontroli, bardziej zdecentralizowanym autorytetem, mniejszą liczbą reguł i procedur oraz bardziej bezpośrednim kontaktem z pracownikami (Sherehiy i in., 2007). Naukowcy określili główne cechy mechanistycznych i organicznych or- 
ganizacji (Burns i Stalker, 1961; Hatch, 1997; Donaldson, 2001; Vecchio, 2006), ich zestawienie zaprezentowano w tabeli 3.3.

Tabela 3.3. Charakterystyka mechanistycznych i organicznych organizacji

\begin{tabular}{|l|l|}
\hline \multicolumn{1}{|c|}{ Forma mechanistyczna } & \multicolumn{1}{c|}{ Forma organiczna } \\
\hline Hierarchia władzy & Mniejsze uznanie autorytetu i kontroli \\
\hline Hierarchiczny układ komunikacyjny & Komunikacja sieciowa \\
\hline Scentralizowanie wiedzy i kontroli & Zdecentralizowanie wiedzy i kontroli \\
\hline $\begin{array}{l}\text { Nacisk na lojalność i posłuszeństwo wobec or- } \\
\text { ganizacji }\end{array}$ & $\begin{array}{l}\text { Lojalność i zaangażowanie w realizowane pro- } \\
\text { jekty }\end{array}$ \\
\hline Wysoki stopień formalizacji & Wysoki stopień elastyczności i dowolności \\
\hline Formalne formy współpracy & Nieformalne formy współpracy \\
\hline Wysoka specjalizacja zadań & $\begin{array}{l}\text { Podział zadań, zaangażowanie pracowników we } \\
\text { wspólne projekty }\end{array}$ \\
\hline
\end{tabular}

Źródło: (Burns i Stalker, 1961; Hatch, 1997; Donaldson, 2001; Vecchio, 2006).

J. Hage i R. Dewar (1973) już w latach 70. wykazali, że zdecentralizowana organizacja o niskim sformalizowaniu i wysokiej złożoności (wyuczone zadania o wysokiej specjalizacji) prowadzi do wyższych wskaźników innowacyjności. Stwierdzono, że przedsiębiorstwa organiczne są bardziej innowacyjne, elastyczne i bardziej zdolne do adaptacji, co przemawia za implementacją tej formy organizacyjnej wobec niestabilnych i permanentnie zmieniających się warunków otoczenia. Narastająca turbulencja otoczenia i konieczność adaptacyjnych zachowań przedsiębiorstw wymaga realizowania określonych strategii działania dla zapewnienia ich utrzymania i rozwoju. B. Nogalski oraz P. Niewiadomski (2017) wskazują na koncepcję elastycznej organizacji jako jednej z form strategii działania.

Nawiązując do pojawiających się ze strony zarówno teoretyków, jak i praktyków zaleceń dla współczesnych organizacji warunkujących możliwość przetrwania i rozwoju, G. Osbert-Pociecha (2011, s. 151) postrzega elastyczność jako zdolność organizacji do reagowania, radzenia sobie z imperatywem dokonywanych zmian w warunkach nasilającej się turbulencji otoczenia oraz rosnącej dynamiki zmian wewnątrzorganizacyjnych. Najczęściej elastyczność jest rozumiana jako właściwość podmiotu lub przedmiotu, która sprowadza się do jego podatności na zmiany (pod wpływem określonych czynników), czyli szczególnej łatwości i szybkości reagowania na nie oraz w następstwie dokonywania odpowiednich przekształceń (Osbert-Pociecha, Moroz i Lichtowski, 2008, s.181).

W większości definicji zwinności uznaje się cechę szybkości i elastyczności jako istotne charakterystyki zwinności przedsiębiorstw (Gunasekaran, 1999a; Zhang i Sharifi, 1999; Yusuf i in., 1999). Pojęcie zwinności mieści w sobie zarówno cechy kluczowe dla adaptacyjności, jak i dla elastyczności. Jak zauważa R. Krupski (2005, 
s. 21), adaptacja i elastyczność wydają się wyrazami bliskoznacznymi w kontekście organizacji. Autor przyjmuje założenie, że wszystkie mechanizmy i rodzaje adaptacji są również rodzajami i mechanizmami elastyczności organizacji. Biorąc pod uwagę cele adaptacji, można wyróżnić dwa rodzaje przystosowania (Krupski, 2008, s. 28):

- przystosowanie pierwotne, dzięki któremu organizacja (system) zapewnia sobie przetrwanie, samo istnienie czy utrzymanie się przy życiu;

- przystosowanie wtórne, dzięki któremu organizacja dąży do osiągnięcia czegoś więcej niż przetrwanie, pragnie realizować swoje aspiracje, oczekiwania innych oraz normy.

Analogicznie można wyróżnić elastyczność pierwotną, w ramach której organizacja zapewnia sobie przetrwanie, oraz elastyczność wtórną, która jest egzemplifikowana głównie przez wykorzystanie okazji umożliwiających rozwój organizacji. W ramach analizowanej zwinności strategicznej szczególne znaczenie ma elastyczność wtórna. Według R. Krupskiego (2005, s. 21) „adaptacja to przystosowanie, a elastyczność to zwinność, ruchliwość, rozciągliwość, ale również szybkie odreagowanie (a więc również adaptacja)". Takie ujęcie definicji wskazuje na uznanie elastyczności i zwinności jako synonimów, co nie jest zbieżne z założeniami przyjętymi w niniejszej pracy, w której zwinność strategiczna stanowi pojęcie znacznie szersze aniżeli pojęcie elastyczności ${ }^{17}$. Inne spojrzenie może jednak wynikać z postrzegania zwinności jedynie w ujęciu operacyjnym (typowym dla zwinności wytwarzania) zorientowanej na dostosowanie procesów i zasobów do zmieniających się potrzeb. Technologie informacyjne umożliwiają modularyzację oraz integrację procesów biznesowych oraz ich konfigurację i rekonfigurację w celu tworzenia nowych procesów. W takim ujęciu rzeczywiście zwinność wytwarzania i elastyczność operacyjna mogą mieć wiele wspólnego. W pracy przyjęto charakterystykę natury elastyczności zaproponowaną przez R. Krupskiego, uznającego, że „elastyczność to zdolność do radzenia sobie z niepewnością, wiążąca się z umiejętnością reagowania na (przewidywalne i nieprzewidywalne) zmiany, przez tworzenie i wybór odwracalnych opcji funkcjonowania i rozwoju, a także kreowania sposobów i środków dokonywania zmian tych opcji z zachowaniem ciągłości działania i optymalnym zaangażowaniem nakładów i czasu" (Krupski, 2008, s. 24). Według autora elastyczność jest głównie właściwością organizmów żywych, jednak może także odnosić się do przedsiębiorstw będących tworami sztucznymi, ale jednak wykazujących pewne cechy systemu naturalnego, jak na przykład dążenie do przetrwania i rozwoju. Elastyczność można więc postrzegać jako atrybut, który zwiększa szanse na istnienie i rozwój przedsiębiorstwa w warunkach ciągłych zmian. Elastyczność stanowi potencjalną cechę systemu, a wykorzystanie jej potencjału wiąże się z określoną aktywnością, która może mieć charakter reakcyjny (w ramach działań podejmowanych w sytuacji pewnego przymusu) lub charakter proaktywny (w warunkach wzmożonej konkurencyjności oraz możliwości antycypowania przyszłych warun-

${ }^{17}$ Poszczególne koncepcje i różnice między nimi zostały wyjaśnione w pracy (Sajdak, 2013b). 
Tabela 3.4. Przegląd wybranych definicji i rodzajów elastyczności

\begin{tabular}{|c|c|c|}
\hline Autor & Definicja elastyczności & Rodzaje i wyróżniki elastyczności \\
\hline $\begin{array}{l}\text { H.I. Ansoff } \\
(1965)\end{array}$ & $\begin{array}{l}\text { elastyczność jest właściwością organiza- } \\
\text { cji ukierunkowaną na radzenie sobie ze } \\
\text { zmianami w otoczeniu (głównie przez } \\
\text { zwiększenie płynności zasobów) }\end{array}$ & $\begin{array}{l}\text { - elastyczność zewnętrzna - związana } \\
\text { ze zdolnością wpływania na otoczenie } \\
\text { organizacji (ofensywna i defensywna) } \\
\text { - elastyczność wewnętrzna - zdolność } \\
\text { do szybkiej adaptacji, aby spełnić wy- } \\
\text { mogi otoczenia }\end{array}$ \\
\hline Eppink (1978) & $\begin{array}{l}\text { elastyczność jako cecha organizacji czyni } \\
\text { ją mniej wrażliwą na nieprzewidywalne } \\
\text { zmiany zewnętrzne lub ustawia ją w lep- } \\
\text { szej pozycji, aby mogła z sukcesem na te } \\
\text { zmiany odpowiadać }\end{array}$ & $\begin{array}{l}\text { - elastyczność operacyjna (dotycząca } \\
\text { bieżącej działalności przedsiębiorstwa) } \\
\text { - elastyczność konkurencyjna - koniecz- } \\
\text { na, aby zareagować na zmiany w oto- } \\
\text { czeniu rynkowym } \\
\text { - elastyczność strategiczna - konieczna } \\
\text { do odpowiedzi na zmian pochodzące } \\
\text { z markootoczenia }\end{array}$ \\
\hline $\begin{array}{l}\text { M.G. Krijnen } \\
(1979)\end{array}$ & $\begin{array}{l}\text { elastyczność to zdolność do zmian, któ- } \\
\text { ra pozwala zachować organizacji ży- } \\
\text { wotność, zmiany odbywają się poprzez } \\
\text { adaptację do zmian w otoczeniu (nieda- } \\
\text { jących się przewidzieć) i wykorzystanie } \\
\text { szans w rozwoju organizacji }\end{array}$ & $\begin{array}{l}\text { - elastyczność operacyjna (w produkcji } \\
\text { jako konsekwencja przejściowych fluk- } \\
\text { tuacji na rynku) } \\
\text { - elastyczność organizacyjna - dotyczy } \\
\text { zmian struktur organizacyjnych, sys- } \\
\text { temów informacyjnych i komunikacji } \\
\text { - elastyczność strukturalna - dotyczy } \\
\text { struktury celów ekonomiczno-spo- } \\
\text { łecznych, kombinacji produkt-rynek }\end{array}$ \\
\hline $\begin{array}{l}\text { K.E. Weick } \\
(1982)\end{array}$ & $\begin{array}{l}\text { elastyczność jest związana z odpowied- } \\
\text { nim zakresem działań bieżących w or- } \\
\text { ganizacji z powodu względnie trwałych } \\
\text { zmian w otoczeniu }\end{array}$ & $\begin{array}{l}\text { - elastyczność jest przeciwieństwem } \\
\text { stabilności, jednak zarówno skrajna } \\
\text { elastyczność, jak i skrajna stabilność } \\
\text { wpływają niszcząco na organizację }\end{array}$ \\
\hline $\begin{array}{l}\text { J.B. Quinn } \\
(1985)\end{array}$ & $\begin{array}{l}\text { elastyczność oznacza utrzymywanie } \\
\text { pewnych opcji przez szeroką specyfikę } \\
\text { celów i przyzwolenie na konkurowanie } \\
\text { między sobą }\end{array}$ & $\begin{array}{l}\text { - elastyczność sprowadza się do utrzy- } \\
\text { mania rezerw określonych zasobów } \\
\text { w celu ich użycia, gdy pojawi się taka } \\
\text { potrzeba }\end{array}$ \\
\hline $\begin{array}{l}\text { M. Slack } \\
(1987)\end{array}$ & $\begin{array}{l}\text { elastyczność całościowa jest opisywa- } \\
\text { na przez zakres możliwych stanów, czas } \\
\text { potrzebny, aby przenieść się z jednego } \\
\text { stanu do drugiego, koszt potrzebny do } \\
\text { zmiany stanu }\end{array}$ & $\begin{array}{l}\text { - elastyczność zakresu (statyczny aspekt } \\
\text { elastyczności) } \\
\text { - elastyczność reakcji (dynamiczny } \\
\text { aspekt elastyczności) }\end{array}$ \\
\hline $\begin{array}{l}\text { M.E. Merchant } \\
(1983) \\
\text { B. Carlsson } \\
(1989)\end{array}$ & $\begin{array}{l}\text { elastyczność jest kategorią, która ściśle } \\
\text { się wiąże z kryterium czasu }\end{array}$ & $\begin{array}{l}\text { - elastyczność natychmiastowa } \\
\text { - elastyczność krótkookresowa } \\
\text { - elastyczność średniookresowa } \\
\text { - elastyczność długookresowa }\end{array}$ \\
\hline $\begin{array}{l}\text { K.A. Pervaiz, } \\
\text { G. Hardeker } \\
\text { i M. Carpenter } \\
\text { (1996) }\end{array}$ & $\begin{array}{l}\text { elastyczność jako uwarunkowanie prze- } \\
\text { wagi konkurencyjnej wiąże się z potrze- } \\
\text { bą integrowania określonych zasobów, tj. } \\
\text { technologii, struktury, procesów, ludzi, } \\
\text { środków finansowych }\end{array}$ & $\begin{array}{l}\text { - elastyczność input (na wejściu) } \\
\text { - elastyczność output (na wyjściu) - wy- } \\
\text { nikowa }\end{array}$ \\
\hline
\end{tabular}


cd. tab. 3.4

\begin{tabular}{|c|c|c|}
\hline Autor & Definicja elastyczności & Rodzaje i wyróżniki elastyczności \\
\hline $\begin{array}{l}\text { A. Sushil } \\
(2001)\end{array}$ & $\begin{array}{l}\text { elastyczność organizacji oznacza zdol- } \\
\text { ność kreowania opcji działania na } \\
\text { różnych poziomach tej organizacji, roz- } \\
\text { wijanie sposobów i środków do zmiany } \\
\text { tych opcji oraz zapewnienie poszczegól- } \\
\text { nym podmiotom swobody wyboru co do } \\
\text { ich wprowadzania }\end{array}$ & $\begin{array}{l}\text { - kluczowe składowe elastyczności to: } \\
\text { opcje działania, zmiany, swoboda wy- } \\
\text { boru }\end{array}$ \\
\hline $\begin{array}{l}\text { A. Stabryła } \\
(2005)\end{array}$ & $\begin{array}{l}\text { elastyczność to możliwość dokonania } \\
\text { przekształceń struktury lub właściwości } \\
\text { systemu, w którym zachodzi utrzymanie } \\
\text { lub osiągnięcie jego równowagi stacjo- } \\
\text { narnej lub dynamicznej }\end{array}$ & $\begin{array}{l}\text { - akcentuje się założenie o utrzymaniu } \\
\text { równowagi; elastyczność traktuje się } \\
\text { jako przeciwstawienie sztywności, jest } \\
\text { ona szczególną postacią sprawności } \\
\text { systemu oraz miarą jego samodziel- } \\
\text { ności }\end{array}$ \\
\hline $\begin{array}{l}\text { R. Krupski } \\
(2005)\end{array}$ & $\begin{array}{l}\text { elastyczność jest kategorią, która obej- } \\
\text { muje dwa wymiary czasoprzestrzeni: } \\
\text { szybkość reakcji (lub kreacji) i stopień } \\
\text { dopasowania w każdym z elementów } \\
\text { organizacji oddzielnie i we wszystkich } \\
\text { naraz }\end{array}$ & $\begin{array}{l}\text { - elastyczność organizacji jest uwarun- } \\
\text { kowana czasem procesów informacyj- } \\
\text { no-decyzyjnych dla działania, czasem } \\
\text { procesów gromadzenia i uruchamiania } \\
\text { zasobów do działania }\end{array}$ \\
\hline $\begin{array}{l}\text { R.C. Pathak } \\
(2005)\end{array}$ & $\begin{array}{l}\text { elastyczność to wielowymiarowa kon- } \\
\text { cepcja utrzymania równowagi między } \\
\text { skrajnościami, związana z dokonywa- } \\
\text { niem zmian (innowacji) zapewniających } \\
\text { stabilność, utrzymanie przewagi konku- } \\
\text { rencyjnej oraz zachowujących zdolność } \\
\text { do dalszego rozwoju }\end{array}$ & $\begin{array}{l}\text { - elastyczność organizacji wymaga } \\
\text { sprawności, wszechstronności oraz } \\
\text { dobrej kondycji }\end{array}$ \\
\hline $\begin{array}{l}\text { S. Trzcieliński } \\
(2008)\end{array}$ & $\begin{array}{l}\text { zdolność do rozszerzania repertuaru } \\
\text { działań niezależnie od tego, czy te dzia- } \\
\text { łania są reakcją na zmiany zachodzące } \\
\text { w otoczeniu, czy są spowodowane inny- } \\
\text { mi okolicznościami }\end{array}$ & $\begin{array}{l}\text { - elastyczność zasobów } \\
\text { - elastyczność struktur organizacyjnych }\end{array}$ \\
\hline $\begin{array}{l}\text { G. Osbert- } \\
\text { Pociecha } \\
(2011)\end{array}$ & $\begin{array}{l}\text { zdolność do dokonywania zmian pod } \\
\text { wpływem impulsów wewnętrznych lub } \\
\text { zewnętrznych w taki sposób, aby - nie } \\
\text { naruszając granic spójności organizacji } \\
\text { gwarantujących osiągnięcie jej efektu sy- } \\
\text { nergicznego - stworzyć warunki do kon- } \\
\text { kurowania na rynku i urzeczywistnienia } \\
\text { wybranych celów efektywnościowych }\end{array}$ & $\begin{array}{l}\text { - elastyczność jako stan pośredni między } \\
\text { sztywnością (brakiem zmiany) a cha- } \\
\text { osem (który odzwierciedla niedają- } \\
\text { cą się opanować zmienność) można } \\
\text { uznać za naturalną granicę dla procesu } \\
\text { zmieniania organizacji }\end{array}$ \\
\hline
\end{tabular}

Źródło: Na podstawie: (Osbert-Pociecha, 2011, s. 136-137; Krupski, 2008, s. 17; Trzcieliński, 2011, s. 99). 
ków) (Krupski, 2008, s. 25). Złożoną naturę elastyczności potwierdza analiza definicji tego pojęcia, wielość wyróżnionych typów i rodzajów elastyczności świadczy o bogactwie znaczeniowym analizowanego konstruktu.

Warto zauważyć, że termin elastyczności jest konstruktem wielowymiarowym, co powoduje znaczne trudności w jego definiowaniu i interpretowaniu przez autorów reprezentujących zarówno nauki o zarządzaniu, jak i nauki pokrewne. B. Nogalski oraz P. Niewiadomski (2017) wskazują nawet na powstanie zamieszania metodologicznego, które może prowadzić do sprzecznych opinii dotyczących istoty elastyczności oraz metod jej identyfikacji, opisu, pomiaru oraz doskonalenia. Mimo że pojęcie elastyczności jest powszechnie znane, teoria i praktyka zarządzania wskazują, że daleko jeszcze do przyjęcia jednej, powszechnie akceptowanej definicji elastyczności.

W sposób szczególny elastyczność odnosi się do zasobów organizacji, tj. zasobów materialnych (majątkowych, finansowych) i niematerialnych (informacyjnych, relacyjnych). To właśnie zasoby stanowią podstawowe narzędzie do kształtowania elastyczności organizacji jako całości (Nogalski i Niewiadomski, 2017). Jednocześnie R. Krupski (2005, s. 22-23) uznaje elastyczność za reakcję na impulsy z otoczenia lub $\mathrm{z}$ wnętrza przedsiębiorstwa $\mathrm{w}$ konfrontacji $\mathrm{z}$ potencjałem zasobowym organizacji (z uwzględnieniem możliwości dostępu do zasobów obcych). Pogląd ten podziela także G. Osbert-Pociecha (2011, s. 146-147), odnosząc elastyczność do transformacji poszczególnych rodzajów zasobów, tj. materialnych (maszyn i urządzeń, surowców, półproduktów), kapitałowych (pieniężnych), informacyjnych oraz ludzkich (w sensie świadczenia przez nich pracy). Autorka, odwołując się do podejścia zasobowego, wskazuje, że (Osbert-Pociecha, 2011, s. 146):

- fundamentem elastyczności przedsiębiorstwa jest elastyczność na poziomie zasobów finansowych, rzeczowych i niematerialnych;

- istotną kwestią związaną z zapewnieniem wysokiej efektywności i skuteczności zarządzania jest odkrycie relacji między elastycznością zasobów, umiejętnościami i procedurami a przewagą konkurencyjną w procesie budowania strategii przedsiębiorstw;

- $\mathrm{w}$ procesie formułowania strategii przedsiębiorstwa istotne jest uwzględnienie substytucji, jaka zachodzi pomiędzy efektywnością procedur a elastycznością zasobów; im bardziej sztywne procedury wynikające z doświadczenia i zastosowania ukrytej wiedzy, tym większa efektywność działania, ale jednocześnie nadmierne usztywnienie i ograniczenie jego elastyczności.

S. Trzcieliński (2011, s. 95-96), odnosząc się do zwinności i podzielając jednocześnie pogląd prezentowany w literaturze przedmiotu (Goldman i in., 1995, s. 330; Krupski, 2005, s. 26-27), że elastyczność można uznać za zdolność przedsiębiorstwa powiązaną z jego zasobami, proponuje rozpatrywać ją w ujęciu „elastyczności zasobowej”. Zakres dostępu do potencjalnych okazji pozostaje w relacji ze specjalizacją przedsiębiorstwa. Im większa jest różnorodność dostępnych zasobów, tym szerszy może być zakres specjalizacji, i odwrotnie, specjalizacja jest tym 
węższa, im bardziej jednorodne zasoby są dostępne dla przedsiębiorstwa. Jak już wskazano w podrozdziale 3.3, zasoby mogą być dostępne przez rozwój zasobów własnych bądź przez nabycie zasobów obcych, co wymaga stworzenia zewnętrznych struktur sieciowych. Zasoby obce mogą $\mathrm{w}$ różnym stopniu, podobnie jak zasoby własne, stwarzać możliwość rozszerzenia repertuaru zadań. Jest to uzależnione od charakteru zewnętrznych struktur sieciowych, które przedsiębiorstwo formułuje lub w których uczestniczy. W sieciach statycznych, których przykładem mogą być związki kooperacyjne, alianse strategiczne i konsorcja, repertuar realizowanych zadań jest mniejszy niż w sieciach dynamicznych, których przykładem mogą być wirtualne organizacje realizujące na bieżąco zlecane im zadania. Zasoby własne mogą być mniej lub bardziej wielocelowe, to znaczy wykorzystywane do wykonywania węższego lub szerszego repertuaru zadań. Umiejętność rozwoju zasobów własnych jest uzależniona od wielkości podejmowanych działań inwestycyjnych, dostępności czasu oraz swoistych cech zasobów w zakresie możliwości ich rozwoju i doskonalenia. Cechę dostępnych zasobów przedsiębiorstwa polegającą na rozszerzeniu zakresu ich wykorzystania, a więc zwiększeniu repertuaru realizowanych z ich użyciem zadań, S. Trzcieliński (2011, s. 95-96) określa właśnie elastycznością zasobową przedsiębiorstwa. Zwinność strategiczna wiąże się z umiejętnością rekonfigurowania dostępnych zasobów oraz zdolnością inicjowania i modyfikowania niezbędnych przedsięwzięć oraz bieżącym sterowaniem ich realizacją. U podstaw tej umiejętności leży elastyczność zasobów, która w dużej mierze przesądza o możliwości wykorzystania pojawiających się szans szybciej aniżeli konkurenci. Y. Doz i M. Kosonen (2008a) również wskazują na kluczowy wpływ elastyczności we współtworzeniu zwinności strategicznej. Uznają mobilność zasobów (resource fludity) jako zdolność do rekonfigurowania systemów biznesowych oraz szybkiego przemieszczania zasobów, opartą na procesach alokacji zasobów, podejściu do zarządzania ludźmi oraz mechanizmach współpracy ukierunkowanych na szybsze i prostsze działanie modeli biznesu. Wskazują na pięć akceleratorów w obszarze mobilności (płynności) zasobów (Doz i Kosonen, 2010):

- punkt oddzielenia (decoupling) - uzyskanie elastyczności organizowanej według domen wartości opartych na segmentacji klientów,

- modularyzacja (modularising) - tworzenie i rekonfigurowanie systemów biznesowych,

- dysocjacja (dissociating) - oddzielenie wykorzystania zasobów od własności zasobów oraz negocjowanie dostępu do zasobów i alokacji,

- przełączanie (switching) - wykorzystywanie różnych modeli biznesowych,

- przeszczepienie (grafting) - nabywanie nowych rozwiązań modeli biznesu w celu własnej transformacji.

Wyodrębnione rodzaje zasobów przedsiębiorstwa mają swoją specyfikę w zakresie elastyczności (identyfikacja zasobu, sposób pomiaru jego elastyczności oraz wpływu na całkowitą elastyczność organizacji). Charakterystykę wybranych zasobów w odniesieniu do ich elastyczności funkcjonalnej przedstawiono w tabeli 3.5. 
Tabela 3.5. Charakterystyka elastyczności wybranych zasobów przedsiębiorstwa

\begin{tabular}{|c|c|}
\hline $\begin{array}{c}\text { Rodzaj } \\
\text { zasobów }\end{array}$ & Charakterystyka elastyczności funkcjonalnej zasobów \\
\hline $\begin{array}{l}\text { Zasoby ludz- } \\
\text { kie }\end{array}$ & $\begin{array}{l}\text { - pracownicy wykazują się gotowością do wykonywania różnych zadań, co wymaga } \\
\text { dysponowania przez nich wieloma umiejętnościami } \\
\text { - rozwój pracowników } \\
\text { - pracownicy szybko i chętnie adaptują się do nowej pracy } \\
\text { - duży potencjał zasobowy pracowników } \\
\text { - wszechstronne lub wieloprofilowe kwalifikacje } \\
\text { - odpowiednia polityka szkoleniowa } \\
\text { - silne utożsamianie się pracowników z celami organizacji }\end{array}$ \\
\hline $\begin{array}{l}\text { Zasoby } \\
\text { rzeczowe } \\
\text { (system pro- } \\
\text { dukcyjny) }\end{array}$ & $\begin{array}{l}\text { - elastyczność asortymentu produkcji - czyli możliwość szybkiego i ekonomicznego } \\
\text { przejścia do produkcji nowych wyrobów } \\
\text { - elastyczność produkcji, czyli ogół typów części, które można produkować w ra- } \\
\text { mach elastycznego systemu } \\
\text { - elastyczność wielkości produkcji, czyli zdolność do efektywnych zmian wielko- } \\
\text { ści produkcji } \\
\text { - elastyczność maszyn, podatność maszyn wchodzących w skład systemu na przepro- } \\
\text { wadzenie niezbędnych zmian w czasie produkcji różnych typów części, dla której } \\
\text { system ten był pierwotnie zaprojektowany } \\
\text { - elastyczność rozwoju systemu, czyli zdolność systemu do łatwej i modularnej roz- } \\
\text { budowy systemu w miarę pojawiających się dodatkowych potrzeb } \\
\text { - elastyczność wielkości personelu, co oznacza możliwość wykonywania procesu } \\
\text { produkcyjnego ze zmienną liczbą biorących w nim udział operatorów } \\
\text { - elastyczność procesu technologicznego, czyli zdolność procesu technologicznego } \\
\text { do szybkiego dostosowania się do zachodzących w nim zmian } \\
\text { - elastyczność marszrut technologicznych, która jest traktowana jako umiejętność } \\
\text { dostosowania się procesu technologicznego do zdarzeń o charakterze losowym, } \\
\text { zakłócających jego przebieg } \\
\text { - elastyczność ograniczeń kolejnościowych, rozumiana jako zdolność do zmiany ko- } \\
\text { lejności wykonywania określonych operacji dla każdego rodzaju części } \\
\text { - elastyczność kwalifikacji, tzn. wielospecjalizacyjność zatrudnionego personelu } \\
\text { - elastyczność wykorzystania czasu pracy } \\
\text { - elastyczność liczby zatrudnionych }\end{array}$ \\
\hline $\begin{array}{l}\text { Zasol } \\
\text { nizac }\end{array}$ & $\begin{array}{l}\text { - przyjmowanie modułowej formy budowy przedsiębiorstwa - moduł definiowany } \\
\text { jest jako pewna całość mogąca samodzielnie ustalać i osiągać cele, a także mogąca } \\
\text { z innymi modułami tworzyć nowe formy zorganizowanego działania } \\
\text { - kształtowanie organicznych relacji wewnątrz przedsiębiorstwa - w takiej struktu- } \\
\text { rze słabo jest zdefiniowany podział pracy, istnieje luźna, wielokierunkowa komu- } \\
\text { nikacja, podział ról ma charakter okresowy i zmienny, a kompetencje cenione są } \\
\text { wyżej niż formalna pozycja w organizacji; popularne dla struktur projektowych } \\
\text { - perfekcja we wdrażaniu zmian organizacyjnych } \\
\text { - otwartość na zmiany promowana jest przez kadrę kierowniczą }\end{array}$ \\
\hline $\begin{array}{l}\text { Zasoby mar- } \\
\text { ketingowe }\end{array}$ & $\begin{array}{l}\text { - dywersyfikacja produktowa } \\
\text { - korzystanie z równoległych kanałów dystrybucji } \\
\text { - elastyczne zarządzanie marką } \\
\text { - innowacyjne narzędzia w kształtowaniu wizerunku }\end{array}$ \\
\hline
\end{tabular}


cd. tab. 3.5

\begin{tabular}{|c|c|}
\hline $\begin{array}{c}\text { Rodzaj } \\
\text { zasobów }\end{array}$ & Charakterystyka elastyczności funkcjonalnej zasobów \\
\hline $\begin{array}{l}\text { Zasoby in- } \\
\text { formacyjne }\end{array}$ & $\begin{array}{l}\text { - szybkość odpowiedzi zasobu na sygnał z otoczenia, umożliwiająca utrzymanie pro- } \\
\text { cesów biznesowych zależnych od zgromadzonych informacji } \\
\text { - innowacyjność zasobu - ekspansja zasobu na nowe obszary, związana z poziomem } \\
\text { przetworzenia informacji, w zasobie elastycznym poziom metaanaliz jest wysoki, } \\
\text { a ich liczba duża, wzrost dotyczy poszerzenia kontekstu i obszaru oddziaływania } \\
\text { - równowaga poziomu wiedzy układu, związana z dezaktualizacją informacji we- } \\
\text { wnętrznej i zastępowaniem jej nowymi informacjami ze źródeł wewnętrznych, } \\
\text { zasób jest elastyczny, jeśli zmiana ilości informacji dopływających powoduje nie- } \\
\text { wielkie zmiany ilościowe w zbiorze informacji zgromadzonych w zasobie } \\
\text { - elastyczność kosztowa produktywności zasobu informacyjnego, dotyczy zmiany } \\
\text { generowanej wartości dodanej w stosunku do zmiany kosztów; im wyższa zmiana } \\
\text { wartości dodanej, generowanej przez zasób przy mniejszej zmianie kosztów, tym } \\
\text { bardziej elastyczny zasób } \\
\text { - elastyczność innowacyjności zasobu, mierzona jako czas wytworzenia określonej } \\
\text { liczby metaanaliz (np. raportów na życzenie); zasób elastyczny to taki, w którym } \\
\text { zmiana czasu wykonywania metaanalizy na krótszy stanowi o wzroście innowa- } \\
\text { cyjności mierzonej wzrostem liczby wykonywanych metaanaliz }\end{array}$ \\
\hline $\begin{array}{l}\text { Zasoby fi- } \\
\text { nansowe }\end{array}$ & $\begin{array}{l}\text { - elastyczność finansowa jest efektem odpowiedniej strategii finansowej; strategia fi- } \\
\text { nansowa to kombinacja strategicznych decyzji w zakresie finansowania przedsię- } \\
\text { biorstwa i jego działalności inwestycyjnej oraz polityki dywidend } \\
\text { - do określenia zdolności przedsiębiorstwa do pozyskania kapitału na korzystnych } \\
\text { warunkach można wykorzystać niektóre wskaźniki stosowane w analizie finanso- } \\
\text { wej, wśród nich: wskaźnik ogólnego zadłużenia oraz wskaźnik zadłużenia kapitału } \\
\text { własnego, miary płynności finansowej } \\
\text { - elastyczność finansowa przedsiębiorstwa zależy także od tzw. pojemności zadłu- } \\
\text { żeniowej przedsiębiorstwa, czyli ilości kapitału obcego; wyróżniamy dwa rodzaje } \\
\text { pojemności zadłużeniowej: trwała pojemność zadłużeniowa (taki poziom trwałe- } \\
\text { go zadłużenia, który pozwala na utrzymanie określonej oceny ratingowej lub jest } \\
\text { zbieżny z docelową strukturą kapitału) oraz maksymalna pojemność zadłużenio- } \\
\text { wa (czyli maksymalny poziom długu, który przedsiębiorstwo może pozyskać i ob- } \\
\text { służyć w określonym czasie) }\end{array}$ \\
\hline
\end{tabular}

Źródło: Na podstawie: (Krupski, 2008, s. 65-73, 87-160).

W odniesieniu z kolei do podejścia procesowego w literaturze podkreśla się, że to właśnie elastyczność procesów ma decydujące znaczenie w funkcjonowaniu przedsiębiorstwa i ostatecznie w skuteczności i efektywności jego działania. Z punktu widzenia dążenia do poprawy elastyczności podejście procesowe odgrywa kluczową rolę, poprzez poszukiwanie wzrostu efektywności współczesnych przedsiębiorstw w zapewnieniu im konkurencyjności poprzez elastyczność procesów (Osbert-Pociecha, 2011, s. 181). W definicjach elastyczności procesowej podkreśla się, że jest to zdolność dokonywania zmiany procesów produkcji (w szczególności w zakresie czasu, jakości i kosztów) i doskonalenia produktów, a jej głównymi składowymi są: zmiany operacji wykonania określonych komponentów, zmiany dróg przebiegu 
strumienia rzeczowego oraz zmiany polegające na wszczęciu nowego procesu. Taka interpretacja elastyczności była szczególnie bliska zwinności wytwarzania (Gunasekaran, 1999b; Zhang i Sharifi, 1999, 2000; Yusuf i in., 1999; Meredith i Francis, 2000). Z kolei P. Grajewski (2007, s.80-81) definiuje elastyczność procesów jako atrybut, który określa zdolność przedsiębiorstwa do: całkowitej zmiany, doskonalenia, przestawienia kolejności wykonywania czynności przez jego transformację użytych zasobów oraz szybkiej reakcji na zmieniające się potrzeby klientów. Według S. Kasiewicza (Kasiewicz, Ormińska, Rogowski i Urban, 2009, s. 62) podejście procesowe pozwala na precyzyjniejszy pomiar elastyczności. Przedmiotem pomiaru mogą być procesy na poziomie przedsiębiorstwa i procesy na poziomie funkcjonalnym (np. proces dystrybucji sprzedaży).

W literaturze przedmiotu wiele miejsca poświęca się weryfikacji dostępnego spektrum koncepcji, metod i narzędzi zarządzania z punktu widzenia możliwości wspomagania przez nie dążenia przedsiębiorstwa do większej elastyczności. Jak zauważa M. Porter (1996, s. 62), w wyniku ich stosowania efektywność operacyjna ulega wyraźnej poprawie. W ostatnich latach w stosunkowo szybkim tempie powstały kolejne koncepcje i metody zarządzania, które uzupełniają dotychczasowe spektrum nowoczesnych instrumentów zarządzania.

Nowoczesne koncepcje i metody zarządzania potencjalnie stanowią instrumenty służące kreowaniu i osiąganiu elastyczności (większość z dostępnych koncepcji służy osiąganiu elastyczności w określonych obszarach, a pośrednio całego przedsiębiorstwa). Zadaniem wyłaniających się koncepcji jest rozwiązanie dotąd niepodjętego problemu poprzez tworzenie warunków jego rozwiązania i nadanie mu odpowiedniej rangi w strukturze procesu zarządzania (Osbert-Pociecha, 2011, s. 179-181). Należą do nich: utrzymanie relacji ze swoimi klientami (CRM - customer relationship management), sprawne pozyskanie i przepływ zasobów rzeczowych (JiT - just in time), problem standardów jakościowych realizacji określonych działań (TQM - total quality management), sprawne pozyskiwanie, dystrybuowanie i wykorzystywanie zasobów informacji/wiedzy (zarządzanie wiedzą), problem rozwoju zasobów ludzkich poprzez kulturę sprzyjającą uczeniu się (LC - learning culture), problem nadania większej odpowiedzialności i decyzyjności pracownikom na szczeblu wykonawczym - upodmiotowienie szczebla wykonawczego (EMP - empowerment), problem respektowania zasad koegzystencji ze środowiskiem naturalnym (zarządzanie ekologiczne), problem współpracy w ramach łańcucha dostaw (partnerstwo w łańcuch dostaw, SCP - supply chain partnering), problem przekazania do otoczenia produkcji wyrobów, procesów oraz funkcji usługowych i pomocniczych w stosunku do procesu głównego, na którym przedsiębiorstwo się koncentruje, wykorzystując swoje kluczowe kompetencje (outsourcing). Kolejną grupę koncepcji i metod zarządzania, stanowią te, których celem jest pełniejsze zintegrowanie elementów składowych realizowanych w przedsiębiorstwie procesów, rozumianych jako zestaw wyodrębnionych działań i czynności zmierzających do osiągnięcia wynikających z koncepcji biznesowego działania zadań i celów przedsiębiorstwa (zarządzanie procesami). W tym zakresie ważne znaczenie 
ma koncepcja komputerowo zintegrowanych systemów zarządzania (ICT - integrated computer-based technology), a w niej metody wykorzystujące technologie teleinformatyczne, takie jak: CAD, CAM, CAPP, CAP, FMS, CIM oraz MRP i ERP. Ważną grupę stanowią także koncepcje i metody zarządzania współczesnymi organizacjami zorientowane na przeprowadzenie zmian w sposób ewolucyjny (lean management) lub rewolucyjny (BPR - business process reengineering).

Na szczególną uwagę zasługuje filozofia szczupłego zarządzania (lean management), która jako metoda zarządzania kreuje kulturę pracy powodującą, że wszyscy uczestnicy organizacji są zainteresowani ustawiczną obniżką kosztów, podnoszeniem poziomu jakości i skracaniem czasu reakcji na potrzeby klientów, by spełnić ich oczekiwania w warunkach zmiennego otoczenia. W koncepcji tej kładzie się nacisk na eliminację wszelkiego rodzaju marnotrawstwa. Lean jako organizacja przedsiębiorstwa szczupłego jest stosowana głównie w zakresie wytwarzania, ale także w zakresie projektowania wyrobu, jego technologii, łańcucha dostaw, relacji z klientami i sprzedaży. Wszystkie te działania wymagają zharmonizowania, tworząc szczupłe przedsiębiorstwo (Trzecieliński, 2011, s. 27-30).

W literaturze przedmiotu jednogłośnie uznano, że w celu osiągnięciu pożądanego poziomu zwinności organizacje wykorzystują przekaźniki zwinności (Dahmardeh i Banihashemi, 2010; Sherehiy i in., 2007). Przekaźniki są utożsamiane właśnie ze wspomnianymi wcześniej nowoczesnymi koncepcjami i metodami zarządzania, które poprzez swój walor w kreowaniu i osiąganiu elastyczności stanowią cenny nośnik zwinności. Badania potwierdzają związek pomiędzy zwinnością strategiczną i wykorzystaniem technologii informacyjnych IT (Sambamurthy i in., 2003, Wade i Hulland, 2004; White i in., 2005; Lu i Ramamurthy, 2011; Tallon i Pinsonneault, 2001; Overby i in., 2006; Nazir i Pinsonneault, 2012; Shin i in., 2015). Strategiczna wartość systemów informacyjnych jest kluczowa dla zwinności (Sambamurthy i in., 2003), jednocześnie wspiera wrażliwość strategiczną przedsiębiorstwa oraz responsywność (Zahher i Zahher, 1997; Overby i in., 2006). W gospodarce, w której cyfryzacja zdominowała większość gałęzi przemysłu, nastąpiła istotna zmiana w procesie wytwarzania wartości. Wiele najbardziej udanych modeli biznesu XXI wieku (Uber, Airbnb, Tesla, Nest, General Electric) opiera się na zdolności wnikania w życie ludzi za pomocą oprogramowania generującego dane na temat zwyczajów konsumentów i stosowanych przez nich wzorców użytkowania produktów oraz usług. Te cyfrowe relacje zapewniają większą intymność, co umożliwia przedsiębiorstwom personalizację ofert i lepsze dostosowanie działań w sferze obsługi klienta.

Elastyczność jest często wykorzystywana przez badaczy jako jedna z miar teoretycznego konstruktu zwinności strategicznej. Wśród grona badaczy wykorzystujących elastyczność jako miarę zwinności strategicznej znaleźli się: Y. Doz i M. Kosonen (2008); O.E. Ofoegbu i P.A. Akanbi (2012); H. Shin i współautorzy (2015); S.P.L. Fourne i współautorzy (2014); N.T. Khoshnood i S. Nematizadeh (2017); R.E. Morgan i K. Page (2008); A. Arbussa i współautorzy (2016); N.B. Mavengere (2013); B. Sherehiy i współautorzy (2007). 
Skuteczność elastyczności może być analizowana w kontekście zmiany bazy zasobowej względem potrzeb otoczenia, co jest wyrazem zamierzonej adaptacji operującej na bazie zasobowej i świadczy o umiejętności efektywnego zarządzania zasobami (Nogalski i Niewiadomski, 2017, s. 196). Doskonalenie efektywności operacyjnej jest konieczne do funkcjonowania przedsiębiorstwa i zapewniania mu przetrwania, nie stanowi natomiast wymogu bycia zdolnym do skutecznego i efektywnego realizowania celów przedsiębiorstwa w turbulentnym otoczeniu. Poprzez zdolność do podejmowania zmian i sprostania wymaganiom rynku elastyczność przedsiębiorstwa wpływa na wyniki jego działalności. W literaturze istnieje ogólnie akceptowany pogląd, że przedsiębiorstwa potrafiące się adaptować do otoczenia uzyskują lepsze wyniki niż te, które nie wykształciły takich zdolności (Das i Elango, 1995). G. Osbert-Pociecha $(2011$, s. 9) zauważa istniejącą zależność: im większa zdolność do dokonywania zmian w przedsiębiorstwie, tym większa elastyczność i tym samym większa gwarancja zachowania konkurencyjności i spełnienia warunku efektywności. U podstaw relacji wpływu elastyczności na wyniki można upatrywać cech elastycznych przedsiębiorstw, takich jak: zdolność nadążania nad zmianami otoczenia i rozwijania się szybciej niż konkurenci; sprawne systemy poznawania opinii klientów i szybkiego reagowania na ich oczekiwania; krótkie procesy decyzyjne oraz kultura organizacyjna sprzyjająca zmianom (Krupski, 2006).

Na podstawie powyższych spostrzeżeń przyjęto kolejną hipotezę badawczą modelu zwinności strategicznej:

H3: Elastyczność (wspóltworzona przez elastycznosś operacyjną i elastyczność finansowa) ma pozytywny wplyw na wyniki rynkowe przedsiębiorstw.

H3a: Elastyczność operacyjna ma pozytywny wplyw na wyniki rynkowe przedsiębiorstw.

H3b: Elastyczność finansowa ma pozytywny wpływ na wyniki rynkowe przedsiębiorstw.

\subsection{Koncepcja przywództwa strategicznego w budowaniu zwinności}

Współczesne organizacje funkcjonują w szybko zmieniającym się świecie, co pogłębia złożoność i niepewność istnienia na wszystkich szczeblach organizacji. Tempo zmian zachodzących jednocześnie w wielu obszarach i konieczność dostosowywania się do nich jest dużym wyzwaniem dla ludzi funkcjonujących w przedsiębiorstwie. Zanim zdążą się oni w pełni dostosować do jednej zmiany, stają przed kolejną, która niesie za sobą nową niepewność i zwiększa złożoność otoczenia. Kluczową rolę od- 
grywa imperatyw uczenia się, będący aktywnością niezależnych ludzi, który może być rozumiany w kategoriach samoorganizujących się, komunikatywnych interakcji powodujących zmiany w postrzeganiu tożsamości ludzi i organizacji. Wynika to $\mathrm{z}$ faktu, że ludzie nie mogą się uczyć w izolacji od swojej organizacji i vice versa (Stacey, 2003). Rolą przywództwa jest aktywne wspieranie tych procesów, ponieważ przywódcy lepiej niż inni mogą dostrzegać i rozumieć implikacje indywidualnych działań oraz respektować rezultaty uczenia się i wspierać powstawanie nowych możliwości (Rokita i Dziubińska, 2016, s. 95).

Wyzwaniem dla przywódców jest działanie w gwałtownie zmieniających się warunkach, co wymaga oceny dotychczasowych paradygmatów przywództwa. Jednym z podstawowych kierunków badawczych $\mathrm{w}$ ramach podejścia zasobowego $\mathrm{w}$ zarządzaniu strategicznym jest przywództwo strategiczne (Polowczyk, 2011, s. 3-7), integrujące cechy wynikające z paradygmatu przywództwa wizjonerskiego (charyzmatycznego) oraz koncepcji przywództwa organicznego (Avery, 2009, s. 39-57). Od wielu lat przywództwo strategiczne jest tematem gorących dyskusji w kręgach teoretyków i praktyków zarządzania, jednak należy podkreślić, że poglądy na ten temat były i są bardzo zróżnicowane. Przyczyną tak odmiennych opinii jest prawdopodobnie fakt, że istota przywództwa jest nadal jednym $z$ najmniej rozpoznanych zagadnień w zarządzaniu strategicznym.

G. Avery (2009) przedstawia cztery duże zbiory idei, które określił jako: przywództwo klasyczne, transakcyjne, wizjonerskie oraz organiczne (tabela 3.6). Najbardziej podstawowym wymiarem, w którego ramach można umieścić paradygmaty, jest czas, co umożliwiło autorowi ich zróżnicowanie ze względu na okres, w jakim pojawiły się w literaturze dotyczącej przywództwa. Cechą różnicującą wyróżnione paradygmaty jest także przywództwo, mieści się ono w przedziale od dominacji (w przypadku przywódców klasycznych) aż do całkowitego odejścia od indywidualnego czy formalnego przywództwa w paradygmacie organicznym (jak również w przywództwie strategicznym). W miarę ewoluowania od przywództwa klasycznego do organicznego rośnie również dobrowolne zaangażowanie pracowników jako członków grupy, w przeciwieństwie do wymuszonej uległości w paradygmacie klasycznym. Ostatnim kryterium różnicującym analizowane paradygmaty jest stosunek zespołu do wizji przywódcy. W tabeli 3.6 podejścia zostały uporządkowane według rosnącej zależności od wizji (Avery, 2009, s. 38-39).

W przywództwie wizjonerskim przywódca odwołuje się do emocji, inspiruje członków grupy do większych osiągnięć. Charyzma przywódcy, wspólna wizja oraz indywidualne podejście do grupy stanowią źródła ich oddania i zaangażowania. Natomiast podstawą przywództwa organicznego jest komunikacja, przywództwo wyłania się z relacji pomiędzy członkami organizacji, którzy wspólnie interpretują otoczenie i zmieniające się warunki. Członkowie grupy tworzą wizję, wartości i procesy oraz się nimi dzielą. W paradygmacie przywództwa organicznego najważniejsza jest grupa jako całość. Przywództwo strategiczne, łącząc cechy obu tych koncepcji, wyłania się jako forma idealna dla przedsiębiorstw, w których potrzeba 
Tabela 3.6. Paradygmaty przywództwa

\begin{tabular}{|c|c|c|c|c|}
\hline $\begin{array}{l}\text { Paradygmaty } \\
\text { przywództwa }\end{array}$ & Klasyczny & Transakcyjny & Wizjonerski & Organiczny \\
\hline $\begin{array}{l}\text { Najważniejszy } \\
\text { okres }\end{array}$ & $\begin{array}{l}\text { od starożytno- } \\
\text { ści do lat } 70 . \mathrm{XX} \\
\text { wieku }\end{array}$ & $\begin{array}{l}\text { od lat } 70 \text {. do po- } \\
\text { lowy lat } 80 . \mathrm{XX} \\
\text { wieku }\end{array}$ & \begin{tabular}{|l|} 
od połowy lat 80. \\
XX wieku do 2000 \\
roku
\end{tabular} & po 2000 roku \\
\hline Przywództwo & $\begin{array}{l}\text { dominacja przy- } \\
\text { wódcy przez sza- } \\
\text { cunek i władzę } \\
\text { służącą wydawa- } \\
\text { niu poleceń i kon- } \\
\text { trolowaniu }\end{array}$ & $\begin{array}{l}\text { wpływ wywiera- } \\
\text { ny na członków } \\
\text { grupy w kontak- } \\
\text { tach osobistych } \\
\text { oraz uwzględnie- } \\
\text { nie ich opinii i od- } \\
\text { czuć; tworzenie } \\
\text { odpowiedniego } \\
\text { środowiska dla za- } \\
\text { rządzających }\end{array}$ & $\begin{array}{l}\text { emocje - przy- } \\
\text { wódca inspiruje } \\
\text { członków grupy }\end{array}$ & $\begin{array}{l}\text { wspólne interpre- } \\
\text { towanie otoczenia } \\
\text { w grupie; przy- } \\
\text { wódcy mogą się } \\
\text { wyłaniać spośród } \\
\text { grupy, zamiast być } \\
\text { formalnie wyzna- } \\
\text { czonymi }\end{array}$ \\
\hline $\begin{array}{l}\text { Źródło za- } \\
\text { angażowa- } \\
\text { nia członków } \\
\text { grupy }\end{array}$ & $\begin{array}{l}\text { strach przed przy- } \\
\text { wódcą lub sza- } \\
\text { cunek dla niego; } \\
\text { dążenie do zdo- } \\
\text { bycia nagrody lub } \\
\text { uniknięcia kary }\end{array}$ & $\begin{array}{l}\text { wynegocjowanie } \\
\text { nagrody, umowy } \\
\text { i oczekiwania }\end{array}$ & \begin{tabular}{|l|} 
wspólna wi- \\
zja; charyzma \\
przywódcy; \\
zindywidualizo- \\
wane podejście do \\
członków grupy \\
\end{tabular} & $\begin{array}{l}\text { popieranie war- } \\
\text { tości i procesów } \\
\text { wspólnych dla da- } \\
\text { nej grupy; chęć sa- } \\
\text { mookreślenia się }\end{array}$ \\
\hline Wizja & $\begin{array}{l}\text { wizja przywódcy } \\
\text { nie jest konieczna, } \\
\text { aby zapewnić so- } \\
\text { bie posłuszeństwo } \\
\text { członków grupy }\end{array}$ & $\begin{array}{l}\text { wizja nie jest ko- } \\
\text { nieczna i może nie } \\
\text { być nigdy wyarty- } \\
\text { kułowana }\end{array}$ & \begin{tabular}{|l|} 
wizja jest najważ- \\
niejsza; członko- \\
wie grupy mogą \\
wnosić wkład \\
w wizję przywódcy
\end{tabular} & $\begin{array}{l}\text { wizja wyłania się } \\
\text { w grupie; wizja jest } \\
\text { ważnym elemen- } \\
\text { tem kultury orga- } \\
\text { nizacji }\end{array}$ \\
\hline
\end{tabular}

Źródło: (Avery, 2009, s. 38).

dostosowania się do permanentnych zmian wymaga dużego zaangażowania pracowników i dobrej komunikacji, co zapewni szybkość i skuteczność realizacji powierzonych zadań (Sajdak, 2013a).

D. Hambrick i A. Pettigrew (2001, s. 36-44) za podstawową różnicę pomiędzy tradycyjnym przywództwem a przywództwem strategicznym uznają szczebel w hierarchii organizacji, którego przywództwo dotyczy. Sama teoria przywództwa odnosi się do przywódców znajdujących się na wszystkich szczeblach zarządzania, natomiast przywództwo strategiczne odnosi się do przywódców znajdujących się na najwyższym szczeblu w hierarchii. Nieco odmienna jest również perspektywa analizy obu zagadnień - tradycyjne przywództwo koncentruje się na relacjach między przywódcą i jego zwolennikami w kontekście ich roli w organizacji, natomiast przywództwo strategiczne skupia się na działaniach kadry kierowniczej i jej aktywności strategicznej poprzez umiejętność tworzenia wartości i utrzymania wysokiej efektywności w długim okresie. Inną perspektywę zauważa I. Ansoff (1985, s. 167), który przekonuje, że przywództwo strategiczne powinno obejmować zasięgiem całe 
przedsiębiorstwo, a nie być domeną jedynie naczelnego szczebla zarządzania. Taki rodzaj przywództwa może sprawować nie tylko naczelne kierownictwo, ale również pracownicy niższych szczebli, którzy często mają dużo większą wiedzę oraz doświadczenie i tym samym mogą się stać podstawowym ośrodkiem strategicznym przywództwa w przedsiębiorstwie. Przywództwo strategiczne kładzie nacisk na przewodzenie całą organizacją, biorąc pod uwagę jej ewolucję, zmieniające się priorytety i zdolności oraz dynamiczne relacje z otoczeniem (Boal, Hooijberg 2000, s. 516).

W. Bennis i B. Nanus (1997) zwracają uwagę, że „pojęcie przywództwa pozostaje nieuchwytne i enigmatyczne, mimo wielu lat wysiłków zmierzających do uchwycenia intelektualnie i emocjonalnie zadowalającej interpretacji przywództwa. Wynika to prawdopodobnie z faktu, że ludzie dyskutujący na temat przywództwa mają najczęściej inne wyobrażenie na jego temat, co utrudnia porozumienie" (Avery, 2009, s. 21). W literaturze można znaleźć więcej opinii potwierdzających to stwierdzenie, choćby B. Kożuch (2009, s. 163), która twierdzi, że „motywowanie i przewodzenie wciąż należą do najmniej odkrytych obszarów ludzkich poszukiwań. Stąd też nie powstała dotychczas jednoznaczna definicja przywództwa, nie istnieje też jedna uniwersalna koncepcja przewodzenia w organizacji”.

Dylemat dotyczący przywództwa wizjonerskiego i operacyjnego jest wciąż obecny w literaturze naukowej (Radomska, 2010). Prawdziwym wyzwaniem jest umiejętność artykułowania i niejako zaszczepiania wśród pracowników długoterminowej wizji działania przy jednoczesnym efektywnym zarządzaniu operacyjnym, które charakteryzuje się koniecznością dbania o detale w codziennym funkcjonowaniu przedsiębiorstwa. Przywództwo strategiczne to umiejętność połączenia wizjonerstwa z zarządzaniem operacyjnym, czyli szerzenia idei, ale jednocześnie umiejętność osadzenia tych idei w działaniach przedsiębiorstwa $\mathrm{z}$ uwzględnieniem jego ograniczeń. Jest to integracja myśli filozoficznej (skupienie na ogólnej wizji, intuicji, przekonaniach i wartościach) z realiami (ograniczeniami zasobowymi - materialnymi i niematerialnymi) danego przedsiębiorstwa. Jak przekonuje W. Dyduch i M. Bratnicki (2017), przywództwo strategiczne nie może się opierać na samym wizjonerstwie skierowanym na przyszłość, musi być mieszanką przywództwa menedżerskiego i wizjonerstwa, opartą na umiejętności takiego wpływania na zachowania pracowników, aby dobrowolnie podejmowali decyzje ukierunkowane na wzmacnianie i rozwój organizacji przy jednoczesnej trosce o krótkoterminową kondycję finansową.

M. Freedman (2004) proponuje połączyć konieczność wizjonerskiego postrzegania przyszłości przedsiębiorstwa z jego operacyjną skutecznością, promując myślenie strategiczne, które charakteryzuje się umiejętnościami w zakresie:

- koncepcyjnego postrzegania oraz wnikliwej i systematycznej analizy kwestii abstrakcyjnych,

- perspektywy holistycznej,

- kreatywności w dziedzinie generowania nowych pomysłów rozwojowych i wykraczania poza istniejące konstrukcje myślowe, 
- ekspresji w implementacji pomysłów z poziomu abstrakcji do postaci werbalnych i ogólnie zrozumiałych koncepcji,

- tolerancji istniejącej niepewności co do dostępności informacji oraz zmian, jakie zachodzą w otoczeniu,

- chęci rozważenia opcji rozwojowych, które poświęcają krótkookresowe zyski na rzecz osiągania długookresowej przewagi.

G. Rowe i M. Nejad (2009), wprowadzając pojęcie przywództwa strategicznego, definiują je jako synergiczną kombinację przywództwa wizjonerskiego i menedżerskiego (operacyjnego) ze zwróceniem szczególnej uwagi na zachowania etyczne i decyzje oparte na wartościach. Przywództwo strategiczne wymaga nadzoru operacyjnego dotyczącego codziennych czynności, a jednocześnie strategicznej - długoterminowej odpowiedzialności. Polega na formułowaniu i implementacji strategii dla nieprzewidzianych zdarzeń oraz konsekwentnym realizowaniu długookresowych celów dla zapewnienia przetrwania i rozwoju. Uwzględnia się w nim zarówno kontrolę strategiczną, jak i finansową z naciskiem na wykonalność planów strategicznych. Przywództwo strategiczne zakłada wymianę zarówno cichej, jak i ukrytej wiedzy na poziomie indywidualnym oraz całej organizacji. Zarządzanie zasobami ludzkim powinno być oparte na praktykach umożliwiających rozwój wysoko wykwalifikowanych, zmotywowanych, obdarzonych zaufaniem ludzi pracujących w zespole (Rowe i Nejad, 2009). Podsumowując te rozważania, można uznać, że przywództwo strategiczne obejmuje dwie umiejętności: interakcji z ludźmi i ich pomysłami oraz wizjonerskiego ukierunkowania całej organizacji. W ramach tego podejścia W. Dyduch i M. Bratnicki (2017) wskazują na cztery procesy je współtworzące. Pierwszy proces obejmuje umiejętne łączenie poprzez budowanie relacji organizacji z otoczeniem, czyli zewnętrznymi interesariuszami. Drugi proces polega na formułowaniu wizji w sposób inspirujący do działania, uwzględniający wartości ludzi w organizacji i ich zdolności. Trzecim procesem jest promowanie i rozwijanie idei pojawiających się w przedsiębiorstwie. Ostatni, czwarty proces dotyczy wizualnego przedstawienia podejmowanych działań.

J. Highsmith (2005, s. 46), wskazując na zasady wiodące dla agile project management, odwołuje się do modelu zarządzania opartego na przywództwie i współpracy, w którym przywództwo zastępuje wydawanie poleceń i rozkazów, a współpraca zastępuje kontrolę. Według tego modelu odpowiedzialność zawiera określenie kierunku działania, zapewnienie wsparcia, ułatwienie procesu decyzyjnego oraz przyspieszenie komunikacji pomiędzy pracownikami a zespołami. Ten rodzaj przywództwa zachęca do podejmowania wyzwań wynikających ze zmian oraz inspiruje do poszukiwania nowych rozwiązań. Strategiczni przywódcy mają zdolność do kreowania wizji i motywowania ludzi do pracy nad niestandardowymi rozwiązaniami. Nie podejmują decyzji bezpośrednio, raczej zapewniają warunki otoczenia umożliwiające grupowe podejmowanie decyzji. Ich zadaniem jest przede wszystkim wspieranie, motywowanie i mentoring zespołu oraz rozwiązywanie ewentualnych problemów i konfliktów (zarówno tych personalnych, jak i grupowych). 
J. Highsmith (2005, s. 74-89) podkreśla, że liderzy nie stają się liderami dzięki temu, co robią, stają się nimi dzięki temu, kim są. Oznacza to, że cechy przywódcze, które są wymagane dla osiągnięcia sukcesu w warunkach zwinności przedsiębiorstw działających w zmiennym i niestabilnym otoczeniu, nie muszą być wyuczone, ale mogą wynikać z indywidualnych predyspozycji zarządzających.

G. Rowe i M. Nejad (2009) wskazują na cechy liderów wizjonerów oraz cechy liderów menedżerów, podkreślając ich zróżnicowaną rolę w przedsiębiorstwie. Bez tych pierwszych nie byłoby rozwoju przedsiębiorstwa, natomiast bez tych drugich przedsiębiorstwo nie wygenerowałoby zysku. Zatem idealny jest strategiczny lider łączący w sobie cechy obu typów przywódcy (tabela 3.7).

Przywództwo strategiczne polega na umiejętności radzenia sobie w sytuacjach trudnych do przewidzenia i wobec ważnych zmian w otoczeniu. Ten rodzaj przywództwa oznacza ciągłe dostosowywanie, reorientację i usprawnienia organizacji szczególnie niezbędnych dla zwinności strategicznej (Rowe i Nejad, 2009). Współcześni przywódcy strategiczni są odpowiedzialni za formułowanie celów i strategii organizacji, rozwój jej struktury, procesów i kompetencji. Ponadto kształtują pożądany kierunek zmian strategicznych oraz kulturę organizacji, która sprzyja kreatywności i wzajemnemu zaufaniu oraz wyzwala chęć partycypacji w kluczowych kwestiach dotyczących przyszłości przedsiębiorstwa. Takie działania mają na celu budowanie kompetencji w zakresie zarządzania w niepewnym i turbulentnym otoczeniu (Bass, 2007, s. 36). Przywództwo strategiczne jest opisywane przez proaktywność, tworzenie chaosu, elastyczność w działaniu i popełnianie błędów (Hosmer, 1982), rozwija umiejętność radzenia sobie ze zmianami w organizacji oraz dostosowywania się do zmian w otoczeniu i kształtowania odpowiednich zdolności dynamicznych (Dyduch i Bratnicki 2017).

Do pożądanych cech przywódcy strategicznego można zaliczyć (Freedman, 2004, s. 2):

- modelowanie, stymulowanie, tworzenie sprzyjającego klimatu oraz wspieranie wszelkich przejawów myślenia strategicznego w przedsiębiorstwie;

- umiejętność kompleksowej integracji procesu zarządzania strategicznego - nie tylko formułowania, ale przede wszystkim wdrażania, monitorowania, rewizji i uaktualniania strategii;

- odwagę podejmowania trudnych wyborów strategicznych;

- umiejętność komunikacji, a więc częstego i szczerego informowania o bieżących trudnościach pojawiających się podczas wdrażania strategii.

M.A. Hitt i współautorzy (2009) przekonują, że esencją dla strategicznego przywództwa jest umiejętność przewidywania, wizjonerstwa, utrzymania odpowiedniego poziomu elastyczności, pozytywnego wzmacniania innych do zaangażowania w budowanie zmiany strategicznej. Do zadań i ról przywódców strategicznych należy ustalanie strategicznego kierunku organizacji w celu wywołania zaangażowania, podejmowanie wyborów strategicznych, zarządzanie portfelem zasobów, zarządzanie kulturą organizacyjną wspierającą strategię przedsiębiorstwa, wzmacnianie 


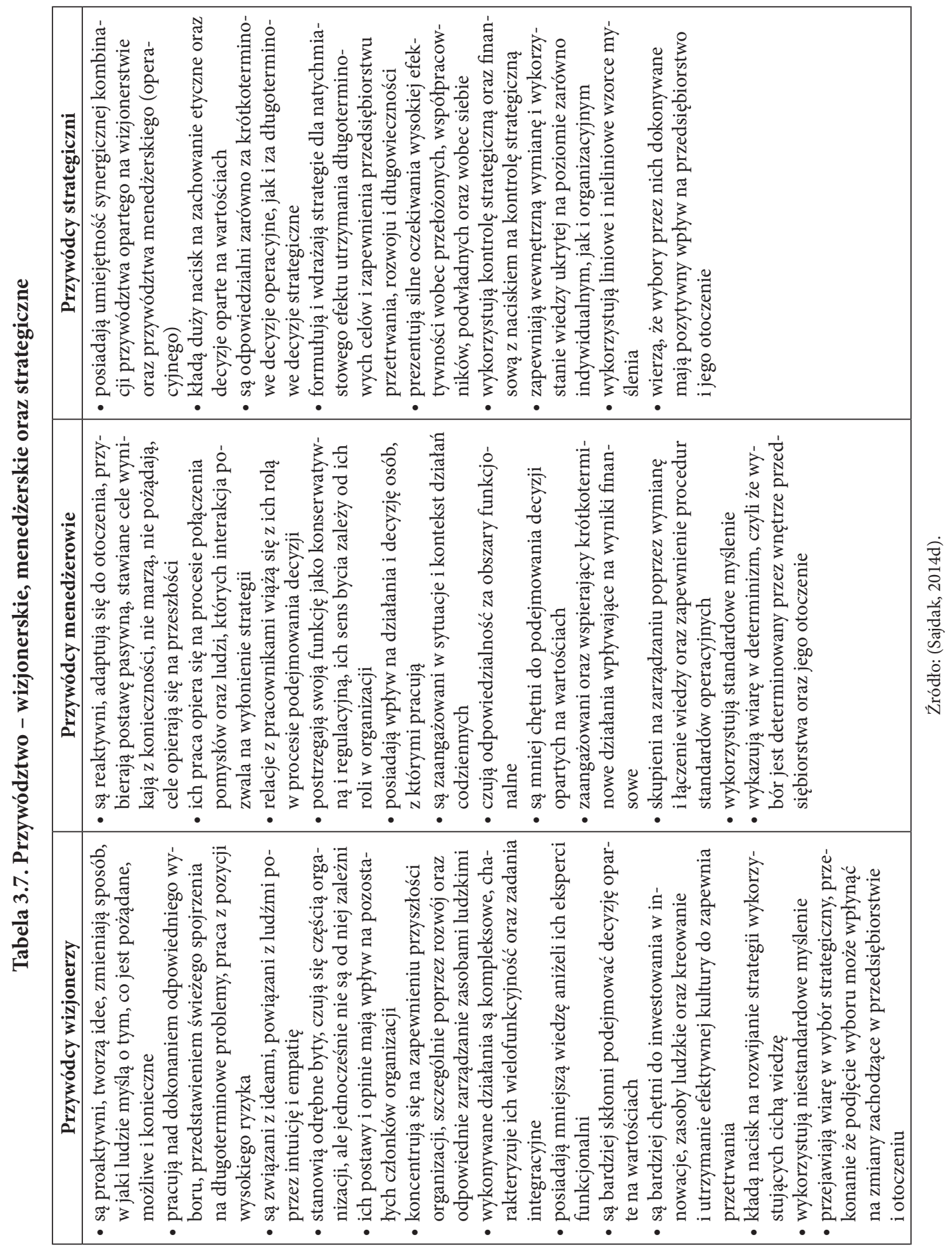


zachowań etycznych, zbudowanie zrównoważonych systemów kontroli, ustalenie struktury organizacyjnej, wspieranie procesu wdrażania strategii oraz zarządzanie efektywnością funkcjonowania organizacji (Amos, 2006),

$\mathrm{Na}$ uwagę zasługują interesujące wyniki badań naukowców, którzy przeanalizowali obszar organizacyjny, menedżerski i indywidualny w kontekście zwinności przedsiębiorstw. W poszczególnych perspektywach zwrócili uwagę na obszary, które uznano za efektywne dla zwinności w kontekście strategicznym (Attafar, Ghandehari i Momeni, 2012):

- organizacyjny (struktura, strategia, technologia, kultura organizacyjna i procesy),

- menedżerski (myślenie strategiczne, podział władzy, sposób zarządzania, skłonność do umocowania szczebla wykonawczego),

- indywidualny (poziom profesjonalizmu, zaangażowanie, motywacja).

A. Gostick oraz C. Elton (2009) uważają, że efektywność przywództwa strategicznego sprowadza się do stosowania prostych zasad:

- zwiększenie zaangażowania pracowników nie tylko poprzez ich udział w ustalaniu celów, lecz także umożliwienie im wpływania na wybór kierunku strategicznego, w którym będzie podążać przedsiębiorstwo,

- stosowanie otwartego stylu komunikacji o charakterze doradczym, który pozwoli na wykorzystanie indywidualnego potencjału pracowników,

- budowanie atmosfery zaufania oraz docenienie zaangażowania i odpowiedzialności,

- wspieranie przekonania o kreatywności pracowników oraz możliwości osiągnięcia sukcesu dzięki współdziałaniu i partycypacji.

M. Crocitto i M. Youssef (2003) zwracają uwagę na rolę przywództwa w warunkach zwinności, które powinno się skupiać na wspieraniu pracowników w formułowaniu bezpośrednich relacji z dostawcami i klientami. Autorzy wprowadzają termin „zwinne zarządzanie”, które odnosi się do przywództwa charakteryzującego się zdolnością do redefiniowania wizji przedsiębiorstwa. Umiejętność ta jest wspierana poprzez organizacyjną zdolność do przewidywania zmian, ich akceptację oraz szybkie adaptowanie się do nowego otoczenia, a nawet wywoływanie zmian warunków rynkowych w celu czerpania z nich korzyści.

Przewaga zasobów ludzkich nad technologiami w tworzeniu zwinności, ale również adaptacyjności przedsiębiorstw została już dawno zauważona (Sherehiy i in., 2007). Wśród autorów panuje zgoda, że zwinność przedsiębiorstwa jest uwarunkowana rozwojem wiedzy i umiejętności jego pracowników, dotyczy to zarówno zwinności wytwarzania (Dove, 1993; Forsythe, 1997; Plonka, 1997), jak i strategicznej (Doz i Kosonen, 2008b; Ofoegbu i Akanbi, 2012; Arbussa i in., 2016).

Y. Doz i M. Kosonen (2008a, 2008b, 2010), dostrzegając zasadniczy wkład obszaru zasobów ludzkich w zwinność przedsiębiorstw, wskazują na jedność przywództwa (leadership unity) jako podstawowy wymiar współtworzący konstrukt zwinności strategicznej. Działaniami stanowiącymi akceleratory w obszarze jedności przywództwa, czyli umiejętności naczelnego kierownictwa szybkiego podej- 
mowania kluczowych decyzji ze wsparciem niższych szczebli, są (Doz i Kosonen, 2010, s. 376-378):

- prowadzenie dialogu (dialoguing) - wspólne dzielenie się założeniami, zrozumienie kontekstu, rozwijanie wspólnej podstawy do dalszej eksploracji problemu;

- odkrywanie (revealing) - transparentność i jasność indywidualnych motywów sprzyjające wzajemnemu szacunkowi i zaufaniu;

- integracje (integrating) - budowanie współzależności, określenie wspólnych warunków sukcesu;

- współdzielenie (aligning) - dzielenie wspólnego zainteresowania, nadawanie głębszego znaczenia wspólnym celom;

- troszczenie się (caring) - zapewnienie empatii oraz współczucia.

Przywództwo strategiczne jest często wykorzystywane przez badaczy jako atrybut zwinności strategicznej, choć nie zawsze dokładnie w ten sposób jest określane. W kontekście postaw i zachowań pracowników atrybut ten jest bliski przedsiębiorczej kulturze organizacyjnej, co może stanowić trudność w pomiarze elementów obu konstruktów. Niemniej elementy, które według naukowców są istotne z punktu widzenia zwinności strategicznej, bezpośrednio nawiązują do atrybutu przywództwa. Wśród grona badaczy uznających elementy przywództwa strategicznego za miarę zwinności strategicznej znaleźli się: Y. Doz i M. Kosonen (2008a); O.E. Ofoegbu i P.A. Akanbi (2012); A. Oyedijo (2012); H. Shin i współautorzy (2015); R.E. Morgan i K. Page (2008); A. Arbussa i współautorzy (2016).

Uznając menedżerów i ich zachowania za jeden z kluczowych elementów budujących zwinność przedsiębiorstw, D.C. Hambrick i P.A. Mason (1984) udowodnili, że wyniki przedsiębiorstwa w większym stopniu są odzwierciedleniem wartości i doświadczeń poznawczych menedżerów zarządzających, niż odbiciem korporacyjnych organów kontrolnych czy wynikiem wpływu otoczenia. W teorii wyższych eszelonów zakłada się, że doświadczenia, wartości oraz osobowość menedżerów w dużym stopniu wpływają na ich interpretacje pojawiających się zdarzeń a w istocie determinują podejmowane przez nich decyzje (Hambrick, 2007, s. 334). Dokonywane przez menedżerów wybory strategiczne bezpośrednio wpływają na wyniki przedsiębiorstwa. W literaturze można znaleźć badania empiryczne potwierdzające wpływ wartości współokreślających przywództwo strategiczne na efektywność organizacyjną. Badania ujawniły, że przywódcy przywiązujący większą wagę do wartości ekonomicznych są postrzegani przez pracowników jako przywódcy autokratyczni, w przeciwieństwie do przywódców przywiązujących wyższą wagę do wartości interesariuszy, którzy zostali uznani za przywódców wizjonerskich (Carter i Greer, 2013). W literaturze wskazuje się na pozytywny wpływ przywództwa wizjonerskiego na wyniki przedsiębiorstwa, w odróżnieniu do przywództwa autokratycznego, gdzie taki wpływ nie został odnotowany (de Luque, Washburn, Waldman i House, 2008). Przywództwo strategiczne uzyskało miano głównej determinanty wyjaśniającej przewagę konkurencyjną przedsiębiorstw (Ussahawanitchakit, 2012). Dorobek literatury w tym zakresie wskazuje także, że przedsiębiorstwa charakteryzujące się 
wyższym poziomem przywództwa strategicznego są bardziej konkurencyjne oraz uzyskują wyższe wyniki działalności w turbulentnym otoczeniu. Wykorzystują przywództwo strategiczne do przetrwania w dynamicznym otoczeniu, jednocześnie podtrzymując swój potencjał strategiczny do zapewniania długotrwałego rozwoju (Hinterhube i Friedrich, 2002). Przywództwo strategiczne wykazuje silną dodatnią zależność z tworzeniem wartości opartym na innowacjach produktowych, rynkowych i administracyjnych (Elkonov, Judge i Wright, 2005).

Powyższe rozważania upoważniają do przyjęcia kolejnej hipotezy badawczej modelu zwinności strategicznej:

H4: Przywództwo strategiczne ma pozytywny wplyw na wyniki przedsiębiorstw.

\subsection{Rezultaty przedsiębiorstw jako zmienna zależna w modelu zwinności strategicznej}

W zdecydowanej większości przedsiębiorstw wykorzystuje się informacje o efektach ich działalności, których pomiar jest bardziej lub mniej usystematyzowany. Przedsiębiorcy mają świadomość, że konkurowanie w otoczeniu podlegającym ciągłym zmianom wymusza monitorowanie i pomiar dokonań ich działalności (Taticchi, Tonelli i Cagnazzo, 2010, s. 4). Przetrwanie w tak dynamicznym otoczeniu stawia przed przedsiębiorstwami wyzwanie sprostania wymaganiom i zapewnienia satysfakcji wszystkim interesariuszom, a jednocześnie zapewnienia przedsiębiorstwu sprawności strategicznej stanowiącej przesłankę ciągłości egzystencji (Urbanowska-Sojkin, 2013b, s. 410-418).

W literaturze z zakresu zarządzania strategicznego można znaleźć wiele metafor, którymi posługują się naukowcy do określenia pozytywnie ocenianych osiągnięć działalności przedsiębiorstw, między innymi stosuje się pojęcie „sukcesu przedsiębiorstwa” (Urbanowska-Sojkin, 2013a), czy „sukcesu organizacji” (Gruszczyńska-Malec i Hładoń, 2011). Pomimo licznego zestawu czynników sukcesu proponowanych przez różnych autorów trudno dokonać ich oceny i wyłonić te, które stanowią o wykorzystaniu mierników o dużym zakresie recepcji, syntetycznie identyfikujących dokonania przedsiębiorstwa. Najbardziej znaną klasyfikacją jest podział na wyniki rynkowe (postrzegane jako perspektywa klienta) oraz na wyniki finansowe (Urbanowska-Sojkin, 2013a; Waśniewski, 2016; Shin i in., 2015). W tym kontekście miary wyniku rezultatów przedsiębiorstwa odnoszą się do wartości rynkowej przedsiębiorstwa, wartości klienta, jego lojalności, zadowolenia, reputacji przedsiębiorstwa, trwałości współpracy z interesariuszami (zarówno klientami, jak i innymi interesariuszami poza klientami), udziału rynkowego (Doligalski, 2013; Wang i Lo, 2003; Szablewski i Tuzimek, 2005, s. 119; Gruszczyńska-Malec i Hładoń, 2011; 
Waśniewski, 2016) oraz wielkości sprzedaży, zysku, rentowności, zwrotu z inwestycji i produktywności (Fynes i Voss, 2002; Hamrol 2010).

Powszechne przekonanie, że miarą powodzenia przedsiębiorstwa jest osiągana przez niego rentowność finansowa, doczekało się słusznej krytyki i refleksji wskazującej na ograniczone odzwierciedlenie dzięki temu wskaźnikowi całokształtu oczekiwań wszystkich zainteresowanych skutkami działalności przedsiębiorstwa (Urbanowska-Sojkin, 2013b, s. 410-411). Poza akcjonariuszami, dla których maksymalizacja wskaźników rentowności stanowi priorytet oczekiwań, istnieje jeszcze szeroka grupa innych interesariuszy zainteresowana ekonomicznymi efektami działalności przedsiębiorstwa. Zależność sprawności strategicznej od wartości tworzonej dla interesariuszy w sposób szczególny wskazuje na wartość dla klientów, która powinna spełniać ich obecne i przyszłe oczekiwania. Z przeprowadzonych przez P. Waśniewskiego (2016) badań wynika, że obecnie największe znaczenie dla przedsiębiorstw mają kluczowe czynniki sukcesu w perspektywie klienta (satysfakcja klienta, atrybuty cenowe oraz pozacenowe produktów spełniające wymagania klientów, rozwój efektywnych relacji z klientami). Akceptowana przez klientów wartość determinuje ich lojalność, reputację przedsiębiorstwa, wpływa na wzrost przychodów oraz określa udział w rynku i możliwości rozwojowe. Naturalną konsekwencją tworzenia wartości dla klienta jest jej wpływ na wyniki rynkowe oraz finansowe (Urbanowska-Sojkin, 2013a, s. 392-393).

Wyniki rynkowe przedsiębiorstwa odzwierciedlają jego zdolność do konkurowania, a w efekcie świadczą o jego przewadze konkurencyjnej. Jak zauważa M.J. Stankiewicz (2000), przewaga konkurencyjna to efekt wykorzystania odpowiedniej konfiguracji składników potencjału konkurencyjności umożliwiających przedsiębiorstwu generowanie skutecznych instrumentów konkurowania, czyli narzędzi i sposobów pozyskania klientów. M. Mitręga (2010) twierdzi, że przewaga konkurencyjna to wyróżnienie polegające na dostarczeniu przez przedsiębiorstwo większej propozycji wartości dla klienta niż konkurenci. Z kolei W. Czakon (2005, s. 5) utożsamia przewagę konkurencyjną z trwałym osiąganiem ponadprzeciętnej rentowności przez przedsiębiorstwo. Niezależnie od definiowania wyniku rynkowego w kontekście przewagi konkurencyjnej istnieje w literaturze przekonanie, że sprawność rynkowa (wyniki rynkowe) determinuje sprawność finansową (wyniki finansowe) przedsiębiorstwa (Urbanowska-Sojkin, 2013b, s. 435). Wynik finansowy odzwierciedla rynkowe rezultaty działania przedsiębiorstw będące skutkiem decyzji podejmowanych przez kierownictwo przedsiębiorstwa. Od kierownictwa wymaga się bowiem umiejętności oceny sfer działalności ekonomiczno-finansowej, technicznej i marketingowej, a więc badania wyposażenia jednostki w kapitały, wyposażenia technicznego, zatrudnienia, odbiorców, polityki cenowej itd. (Sajnóg, 2016). Wskaźniki finansowe, takie jak ROA i ROE, pokazują atrakcyjność przedsiębiorstwa dla inwestorów, jak również sprawność w generowaniu zysku z posiadanego majątku i zainwestowanego kapitału własnego, a tym samym są implikowane przez wyniki rynkowe „generowane” przez przedsiębiorstwo. 
W związku z powyższymi wnioskami sformułowano ostatnią hipotezę modelu zwinności strategicznej, która brzmi następująco:

H5: Wyniki rynkowe maja pozytywny wplyw na ich wyniki finansowe przedsiębiorstw.

\subsection{Model zwinności strategicznej}

Poczynione do tej pory analizy i rozważania teoretyczne pozwoliły na sformułowanie w poszczególnych częściach pracy istotnych ustaleń i rozstrzygnięć, dotyczących uwarunkowań występowania i rozwoju zwinności przedsiębiorstw (rozdział 1), podstaw teoretycznych zwinności stanowiących podbudowę dla zdefiniowania pojęcia zwinności strategicznej (rozdział 2), pojęcia zwinności strategicznej (rozdział 3), konceptualizacji atrybutów zwinności strategicznej i ich wpływu na wyniki rynkowe przedsiębiorstw (rozdział 3).

Efektem poczynionych dotąd rozważań jest stworzenie koncepcyjnego modelu zwinności strategicznej przedsiębiorstwa, którego kluczowymi elementami są jego atrybuty: wrażliwość strategiczna, przedsiębiorczość strategiczna, elastyczność oraz przywództwo strategiczne. Gruntowna analiza teoretyczna stanowiła silną podbudowę dla przyjęcia istnienia określonych związków wyrażonych $\mathrm{w}$ formie hipotez i stanowi podstawę modelu koncepcyjnego pracy.

Podjęte rozważania w rozdziale 1.4. dotyczące prezentacji badań nad zwinnością przedsiębiorstw wskazują na lukę badawczą i niewielkie zainteresowanie badaczy wpływem zwinności strategicznej na przewagę konkurencyjną i wyniki przedsiębiorstw, pomimo że zgodnie z deklarowanymi motywami zwinności to właśnie zdolność do utrzymania przewagi konkurencyjnej oraz poprawa wyników przedsiębiorstw stanowią główne akceleratory podejmowanych działań. Wśród naukowców prowadzących badania w tym zakresie, którym udało się potwierdzić empirycznie pozytywny związek pomiędzy zwinnością strategiczną a wynikami przedsiębiorstw, znaleźli się: K. Fartash i S. Davoudi (2012); O.E. Ofoegbu i P.A. Akanbi (2012); H. Shin i współautorzy (2015). Tak niewielki dorobek badań empirycznych w zakresie wpływu zwinności strategicznej na wyniki przedsiębiorstw nie wypełnia luki poznawczej, którą warto uzupełnić.

W rezultacie przeprowadzonej analizy i rozważań teoretycznych przyjęto, że na wyniki rynkowe przedsiębiorstwa wpływa dziewięć konstruktów teoretycznych współtworzących cztery atrybuty zwinności strategicznej:

- wrażliwość strategiczna (współtworzona przez umiejętność oceny szans oraz skłonność do ryzyka),

- przedsiębiorczość strategiczna (współtworzona przez umiejętność rozwoju zasobów własnych, zdolność współpracy, zdolność innowacyjną oraz kulturę przedsiębiorczą), 
- elastyczność (współtworzona przez elastyczność operacyjną i elastyczność finansową),

- przywództwo strategiczne.

Na podstawie analizy literatury założono, że wszystkie wyłonione atrybuty zwinności strategicznej i współtworzące je konstrukty teoretyczne odrębnie, ale pozytywnie wypływają na wyniki rynkowe, a te z kolei na wyniki finansowe. Graficzna postać modelu została przedstawiona na rysunku 3.4.

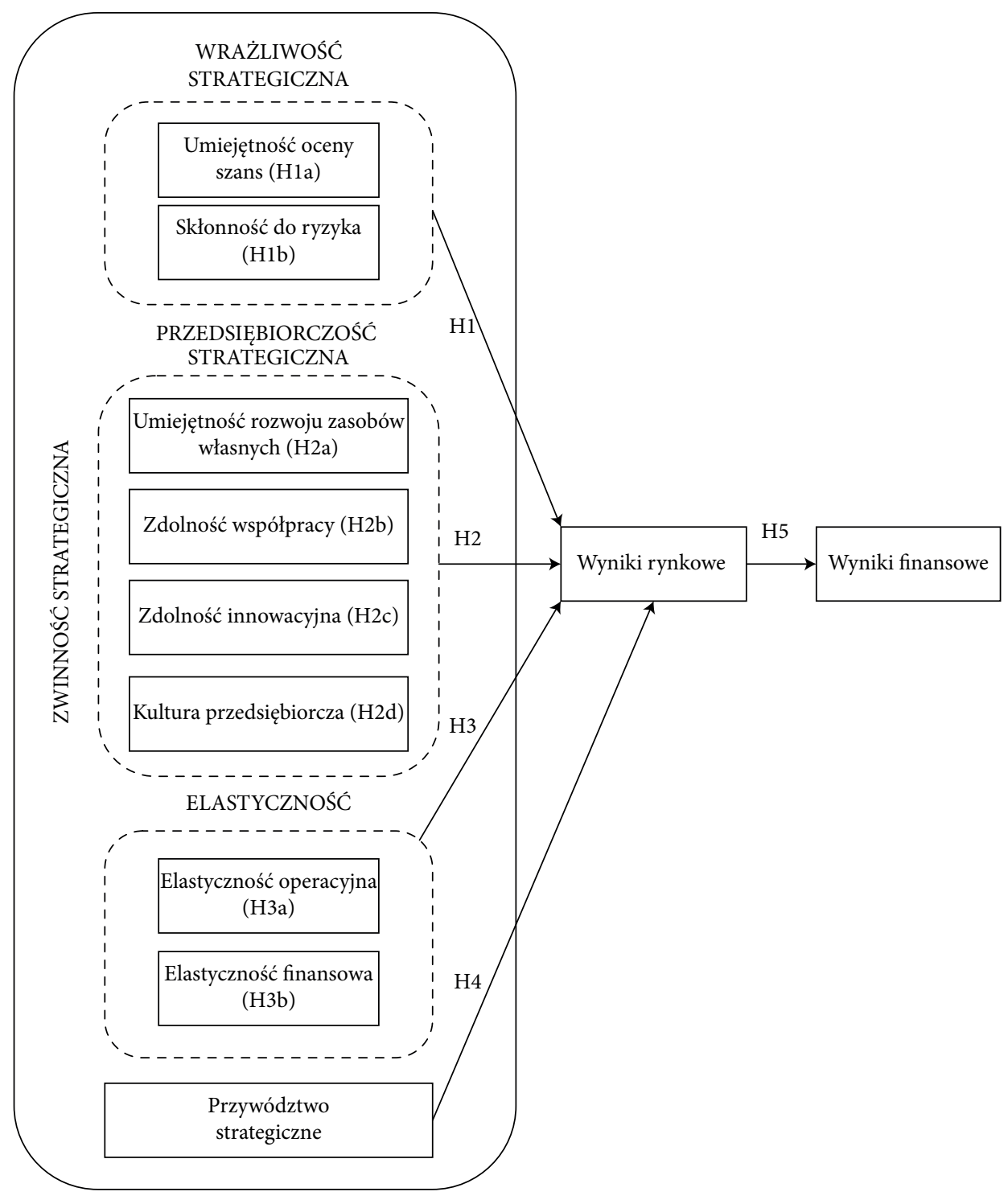

Rysunek 3.4. Model i hipotezy badawcze 
Ze względu na odmienne definiowanie w literaturze $\mathrm{z}$ dziedziny zarządzania pojęcia "model” wymaga ono ustosunkowania się autorki do problemu modelu i modelowania przyjętego w pracy. S. Nowak (2012, s. 264) uznaje, że model stanowi opis teoretyczny pewnego zjawiska, ukazujący siły napędowe procesu. Według autora budowa modelu to po prostu pewien określony sposób uprawiania teorii, czyli systemu logicznie powiązanych twierdzeń ogólnych o wspólistnieniu lub następstwie zjawisk. Model w niniejszej pracy jest rozumiany zgodnie z jego interpretacją zaproponowaną przez S. Nowaka (2012, s. 444): „modelem pewnego zjawiska ze względu na pewną rozważaną własność czy zbiór własności tego zjawiska jest jego opis w terminach, pewnych elementów składowych i związków między nimi lub układu sprzężeń i zależności między własnościami tego przedmiotu, spełniający wymóg adekwatnego wyjaśnienia badanej własności czy zespołu”. W pracy przyjęto podejście zgodne z kanonem krytycznego realizmu (critical realizm), w którym rzeczywistość jest realna, ale postrzeganie jej charakteryzuje się wysokim stopniem „plastyczności”, co powoduje różnice w postrzeganiu rzeczywistości przez różne osoby. Ze względu na omylność teorii i metod rzeczywistość nie jest poznawana perfekcyjnie, jest raczej prawdą probabilistyczną aniżeli absolutną (Bisman, 2010). W tej perspektywie rolę modelowania upatruje się przede wszystkim w wyjaśnieniu i zrozumieniu, predykcja natomiast ma rolę drugorzędną. W ujęciu szerokim realizm krytyczny ma na celu przywrócenie silnej formy ontologii realistycznej. Nacisk kładzie się na odkrycie struktur i mechanizmów bezpośrednio nieobserwowalnych, mniejsze znaczenie ma odkrycie uniwersalnych praw (Mingers, 2006).

Przedstawiony model koncepcyjny stanowi odzwierciedlenie pewnego fragmentu rzeczywistości z pominięciem mniej istotnych elementów tej rzeczywistości. Celem modelu jest odzwierciedlenie charakterystyki zwinności strategicznej przedsiębiorstwa oraz rozpoznanie i wyjaśnienie mechanizmów struktury zmiennych, które nie są bezpośrednio obserwowalne. W procesie budowy modelu zwinności strategicznej dążono zarówno do uproszczonego zrekonstruowania badanej rzeczywistości, jak i identyfikacji zależności między istotnymi elementami, budując hipotezy dotyczące istoty tych zależności. W takim modelowaniu sugeruje się wykorzystanie rozumowania abdukcyjnego. Abdukcja to proces rozumowania, w którym dąży się do (najlepszego) wyjaśnienia analizowanych zjawisk (Urbański, 2009, s. 43). Postępowanie abdukcyjne doprowadza badacza do wniosków dotyczących możliwego stanu rzeczy, nie gwarantuje prawdziwości osądu. Abdukcja jest raczej rozumowaniem niż wnioskowaniem i polega na generowaniu hipotez, selekcji oraz ich testowaniu, jest jednym z kluczowych typów aktywności poznawczej (Urbański, 2009, s. 21). Hipotetyczne założenia określone na podstawie poszukiwań teoretycznych wyraża się za pośrednictwem modelu, testuje dostępnymi metodami i ponownie wnioskuje oraz poprawia pierwotne przypuszczenia (Światowiec-Szczepańska, 2012, s. 197).

Proces modelowania polegał na odzwierciedleniu zjawiska zwinności strategicznej, którego elementy składowe zostały wyłonione w efekcie gruntownych badań literaturowych. Wskazane w modelu cztery atrybuty zwinności strategicznej jako 
struktury nieobserwowalne wymagały operacjonalizacji i ustalenia kluczowych elementów je opisujących. Kolejny aspekt modelowania polegał na określeniu znaczenia relacji między elementami systemu, czego bezpośrednim efektem są przyjęte hipotezy badawcze, wskazujących na ogólny charakter właściwości poszczególnych związków. 


\section{Rozdział 4}

\section{ZWINNOŚĆ STRATEGICZNA W UJĘCIU EMPIRYCZNYM}

W literaturze przedmiotu dopiero w ciągu ostatnich kilku lat pojawiły się pierwsze publikacje dotyczące prowadzenia badań empirycznych z zakresu zwinności strategicznej przedsiębiorstw oraz jej wpływu na budowanie przewagi konkurencyjnej i wyniki przedsiębiorstwa. Zaprezentowany w literaturze dorobek można uznać za fragmentaryczny, brakuje w nim jedności w konceptualizacji i operacjonalizacji pojęcia zwinności strategicznej ( $\mathrm{z}$ uwzględnieniem jej cech i uwarunkowań występowania). Jest to zaledwie zbiór rozmaitych dociekań naukowców, co świadczy o początkowym stadium prowadzonych badań i słabym rozpoznaniu tego zjawiska. Można odnieść wrażenie, że temat zwinności w literaturze polskiej stanowi coraz chętniej podejmowany obszar dyskusji naukowej, jednak brak badań w tym zakresie rodzi wiele wątpliwości i potrzebę wypełnienia luki badawczej. Przeprowadzone przez autorkę niniejszej monografii badania empiryczne obejmują zbiór celów ukierunkowanych na rozpoznanie zwinności strategicznej, a w szczególności pomiar atrybutów ją konstytuujących. Zgodnie z celem badań empirycznych, którym jest sprawdzenie tez dotyczących relacji pomiędzy zmiennymi w modelu teoretycznym (Carton i Hofer, 2006, s.106), zaproponowana w pracy koncepcja zwinności strategicznej, rozwinięta w rozdziale 3 wraz z przyjętym modelem, wyznaczyła cele i zakres badań empirycznych. W procesie badawczym wyróżniono dwa etapy, w ramach pierwszego $z$ nich przeprowadzono badania opisowe (omówione w rozdziale 4 ), natomiast drugi etap badań stanowiły badania przyczynowe (zaprezentowane $\mathrm{w}$ rozdziale 5).

Badania opisowe koncentrowały się na opracowaniu metody pomiaru zwinności strategicznej oraz ustaleniu poziomu i znaczenia poszczególnych zmiennych składających się na atrybuty oraz współtworzące je konstrukty zwinności strategicznej. Interesujący obszar badawczy stanowily opinie respondentów dotyczące intensywności występowania poszczególnych cech w badanych przedsiębiorstwach w zakresie ich zdolności do adaptacji do zmieniających się warunków otoczenia. W tej części analizy procesu badawczego skupiono głównie uwagę na analizie struktury odpowiedzi, testowanie postawionych hipotez przedstawiono w kolejnym rozdziale (rozdział 5), w którym zaprezentowano badania przyczynowe. 
Celem badań przyczynowych jest wyjaśnienie analizowanych zjawisk poprzez określenie zależności między zidentyfikowanymi zmiennymi. Postępowanie badawcze wiąże się z budową modelu pomiarowego, którego celem jest weryfikacja ważności miar modelu dla zmiennych nieobserwowalnych, a następnie sprawdzenie dopasowania modelu strukturalnego (przez konstrukcję modelu zmiennych ukrytych) odpowiadającego modelowi koncepcyjnemu zwinności strategicznej. Procedurę badawczą oraz wyniki modelowania strukturalnego przedstawiono w rozdziale 5 .

\subsection{Metodyka badań}

Jak zauważa W. Dyduch (2016, s. 306), zjawisk w zarządzaniu, a tym samym zwinności strategicznej, nie można zmierzyć ani w procesie obserwacji bezpośredniej, ani nawet w procesie obserwacji pośredniej, poprzez pomiar cech zjawiska. Zatem właściwą metodą, którą przyjęto jednocześnie w opracowaniu, jest stworzenie konstruktu teoretycznego, a następnie jego operacjonalizacja. Konstrukt teoretyczny może mieć wiele wymiarów rozumianych jako zgrupowania podobnych atrybutów, które są odmienne od innych zgrupowań. W prezentowanych badaniach występuje jedenaście konstruktów teoretycznych: umiejętność oceny szans, skłonność do ryzyka, umiejętność rozwoju zasobów własnych, zdolność współpracy, zdolność innowacyjna, kultura przedsiębiorcza, elastyczność operacyjna, elastyczność finansowa, przywództwo strategiczne, wyniki rynkowe oraz wyniki finansowe. $Z$ natury tych zjawisk wynika, że wymagają obserwacji bezpośrednich, czyli należy konkretne cechy zjawisk i zachowań obserwować $\mathrm{w}$ sposób prosty i bezpośredni. Natomiast obserwacje pośrednie polagają na badaniu atrybutów powiązanych z tym szczególnym zjawiskiem, które w istotny sposób stanowi zainteresowanie badacza (Babbie, 2008, s. 449-475). Dzięki precyzyjnemu zdefiniowaniu i przedstawieniu wymiarów konstruktu badacz jest w stanie lepiej zrozumieć złożoność i wielowymiarowość analizowanego zjawiska.

Ze względu na charakter przedmiotu badań zdecydowano się na badania z wykorzystaniem metod ilościowych, które są w głównej mierze nastawione na eksplorację i wyjaśnienie zjawisk słabo rozpoznanych oraz relacji między nimi (Dyduch, 2016, s. 307). Metoda ilościowa pozwala na przeprowadzenie statystycznego opisu i umożliwia wyjaśnienie procesów występujących w większych populacjach na podstawie prezentowanych prób statystycznych, przy zachowaniu reprezentatywności badanej próby (Apanowicz, 2002, s. 71). Z uwagi na przyjęte założenia badawcze i przedmiot badań zdecydowano się na wykorzystanie metody sondażu diagnostycznego z wykorzystaniem popularnego narzędzia, jakim jest kwestionariusz ankiety. Metoda sondażu diagnostycznego to przedsięwzięcie naukowe polegające na statystycznym gromadzeniu faktów i informacji o zjawiskach strukturalnych i funkcjonalnych oraz dynamice ich rozwoju. Zebrany materiał empiryczny dotyczący określonego zjawi- 
ska pozwala ustalić jego zasięg, zakres, poziom i intensywność, co z kolei umożliwia ocenę przyczyn i skutków. Metoda sondażu diagnostycznego umożliwia statystyczny opis i sprzyja wyjaśnieniu pewnych zjawisk masowych, jak również ważniejszych procesów występujących $\mathrm{w}$ wielkich zbiorach na podstawie reprezentatywnych prób statystycznych. Najczęściej stosowaną techniką badawczą w metodzie sondażu diagnostycznego jest wywiad i ankietowanie (Apanowicz, 2002, s. 70-71). Kwestionariusz ankiety to narzędzie szeroko stosowane w badaniach ilościowych ze względu na prosty i bezpośredni sposób gromadzenia materiału empirycznego, a także powszechną możliwość późniejszej jego obróbki w ogólnie dostępnych pakietach statystycznych (Dyduch, 2016, s. 313). Treść kwestionariusza ankiety powstała w wyniku pogłębionych studiów literaturowych, których celem było opracowanie odpowiedniego narzędzia pomiarowego. Przygotowany kwestionariusz składał się z dwóch części: części zasadniczej oraz dodatkowej, którą stanowiła metryczka.

Kwestionariusz ankiety był opatrzony również listem przewodnim, w którym wskazano autorkę prowadzonego projektu badawczego, przedmiot i cel badań oraz planowaną wartość naukową i aplikacyjną z zebranych wyników. Zapewniono respondentów o poufności badania oraz poinformowano, że zebrane informacje zostaną wykorzystane jedynie w celach naukowo-badawczych, a wyniki będą przetwarzane jedynie w postaci zagregowanej. Przed rozpoczęciem badania właściwego przeprowadzono pilotaż, w którym wzięło udział 20 respondentów - członków najwyższego szczebla kierownictwa średnich i dużych przedsiębiorstw działających na terenie Polski. Badanie pilotażowe ujawniło trudności w zrozumieniu niektórych pytań, wynikające z wieloznaczności używanego języka. Dyskusje z respondentami dotyczące zasadności poszczególnych pytań oraz różnych możliwości ich interpretacji doprowadziły do modyfikacji mających wpływ na ostateczną treść kwestionariusza ankiety. Uwagi dotyczące uproszczenia języka ankiety oraz sugestie dotyczące skrócenia kwestionariusza zostały uwzględnione.

Bezpośrednim zebraniem wyników zająl się zewnętrzny podmiot w postaci agencji badawczo-eksperckiej dysponującej dużym doświadczeniem $\mathrm{w}$ realizowanych projektach zarówno dla ośrodków naukowych, jak i biznesowych. W celu zebrania danych empirycznych wybrano metodę CATI (computer assisted telephone interview), czyli wspomagany komputerowo wywiad telefoniczny. Wszystkie wywiady $\mathrm{z}$ respondentami były nagrywane, co zwiększa wiarygodność badania.

Zastosowana technika zbierania danych ma jednak swoje ograniczenia. W badaniach realizowanych $\mathrm{z}$ wykorzystaniem techniki CATI wywiad $\mathrm{z}$ respondentem jest prowadzony przez telefon, a ankieter odczytuje pytania i notuje uzyskiwane odpowiedzi, korzystając ze specjalnego skryptu komputerowego. Ma to swoje zalety, ponieważ respondent nie widzi pytań, ale w razie potrzeby może prosić przeszkolonego ankietera prowadzącego badanie o ich doprecyzowanie lub wyjaśnienie. Ogranicza to dowolność zadawania pytań i podwyższa poziom standaryzacji, sprzyja również lepszemu zrozumieniu przez respondenta stawianych przed nim wymagań i udzielaniu przez niego bardziej precyzyjnych odpowiedzi. Zastosowana technika 
eliminuje również problem braków odpowiedzi, ponieważ ankieter może czuwać nad całkowitym wypełnieniem kwestionariusza ankiety. Z kolei do słabych stron można zaliczyć małą liczbę pytań zawartych w kwestionariuszu oraz ograniczenia związane z poziomem ich trudności. Zbyt duży poziom złożoności pytań i ich niejasna interpretacja może spowodować wskazanie niewłaściwej oceny lub rezygnację z badania. Respondent może odczuwać presję czasową prowadzonego badania, co zwiększa poziom ryzyka związany z „bezrefleksyjnym” wypełnieniem kwestionariusza ankietowego. Aby uniknąć ryzyka związanego z przekazywaniem przez respondentów niewłaściwych ocen, w przeprowadzonym badaniu przeszkolony ankieter upewniał się przy każdym zadawanym pytaniu, że jego istota i sens zadania stojący przed respondentem jest dla niego zrozumiały. Dodatkowym działaniem służącym eliminacji ryzyka było usunięcie na drugim etapie postępowania badawczego tych kwestionariuszy, których wskaźnik odchylenia standardowego wyniósł zero i świadczył o niezaangażowanych respondentach. Odpowiedzi uzyskane przy wykorzystaniu kwestionariusza ankietowego są także obciążone ryzykiem subiektywizmu dokonywanych przez respondentów ocen, które mogą odzwierciedlać w większym stopniu opinie samych respondentów, aniżeli opisywaną rzeczywistość. W celu ograniczenia tego rodzaju ryzyka ankietę skierowano do kierowników najwyższego szczebla, co pozwala przypuszczać, że dzięki ich kompleksowej wiedzy wyrażone przez nich opinie w największym stopniu odpowiadają sytuacji przedsiębiorstwa. Precyzyjne odniesienie się respondentów do zadanych pytań było możliwe dzięki zastosowaniu formuły pytań zamkniętych z ograniczoną liczbą odpowiedzi umożliwiających porównywalność uzyskanych danych. Wszelkie podjęte działania w celu ograniczenia ryzyka związanego z błędem pomiaru sprawiły, że nie stanowi on problemu w niniejszych badaniach.

Zwinność strategiczna przedsiębiorstwa jako przedmiot badań stanowi spore wyzwanie dla badacza, gdyż dotyczy tematów strategicznych, związanych ze zdolnością przedsiębiorstw do radzenia sobie z permanentnie zmieniającymi się warunkami otocznia, wymagającymi od nich wrażliwości strategicznej, przedsiębiorczości strategicznej, elastyczności oraz przywództwa strategicznego. Wiedzę dotyczącą poszczególnych zakresów analizy mają przede wszystkim osoby podejmujące decyzje strategiczne, czyli kierownictwo najwyższego szczebla. To właśnie do tych osób był skierowany kwestionariusz ankiety.

\subsection{Opis doboru próby badawczej}

Badanie dotyczy podmiotów gospodarczych funkcjonujących obecnie na rynku, zatrudniających 50 lub więcej pracowników. Na tej podstawie można określić populację, z której nastąpi dobór próby, jako zbiór jednostek wpisanych do krajowe- 
go rejestru urzędowego podmiotów gospodarki narodowej REGON prowadzących działalność w kraju w czasie realizacji badania, z wykluczeniem jednak podmiotów zatrudniających mniej niż 50 pracowników.

Ze względu na przedmiot badania skoncentrowano się na wybranych kategoriach podmiotów, z badanej populacji zostały zatem wyłączone:

- Sekcja O - administracja publiczna i obrona narodowa; obowiązkowe zabezpieczenia społeczne,

- Sekcja P - edukacja,

- Sekcja Q - opieka zdrowotna i pomoc społeczna,

- Sekcja T - gospodarstwa domowe zatrudniające pracowników; gospodarstwa domowe produkujące wyroby i świadczące usługi na własne potrzeby,

- Sekcja U - organizacje i zespoły eksterytorialne,

- podmioty, dla których szczególna forma prawna to: 48 - fundacje, 50 - kościół katolicki, 51 - inne kościoły i związki wyznaniowe, 55 - stowarzyszenia, 60 -organizacje społeczne oddzielnie niewymienione, 70 - partie polityczne, 72 - związki zawodowe, 73 - organizacje pracodawców, 76 - samorząd gospodarczy i zawodowy, 85 - wspólnoty mieszkaniowe, 90 - związki grup producentów rolnych.

Wyłączenie wymienionych wyżej sekcji z zakresu badania nastąpiło ze względu na to, że jego wyniki mają być powiązane z biznesowym modelem zarządzania. Działalność wskazanych typów podmiotów nie ma charakteru rynkowego, stąd objęcie ich zakresem badania należy uznać za niecelowe. Spis podmiotów użyty do losowania pochodził z bazy REGON będącej w posiadaniu Głównego Urzędu Statystycznego (GUS), zweryfikowanej przy użyciu innych dostępnych w GUS informacji.

Dzięki zastosowaniu rejestru REGON jako operatu uniknięto błędu wytypowania niewłaściwego wykazu populacji generalnej, wynikającego z różnicy między rzeczywistą populacją generalną a listą badanych jednostek używaną na etapie losowania próby badawczej. Nie wszystkie podmioty gospodarcze posiadają telefon lub znajdują się w wykazie telefonicznym, co powoduje wspomniane różnice pomiędzy rzeczywistą listą podmiotów w populacji generalnej a operatem użytym do wylosowania próby badawczej. W takiej sytuacji nie jest zapewniony wymóg wyczerpującego charakteru operatu.

W badaniach reprezentatywnych wyniki można $\mathrm{z}$ dużym prawdopodobieństwem - równym przedziałowi ufności - uogólniać na całą populację generalną. Aby zapewnić możliwie wysoką reprezentatywność, $\mathrm{w}$ celu doboru próby użyta została metoda warstwowo-losowa proporcjonalna. Metoda warstwowo-losowa opiera się na dzieleniu zbiorowości statystycznej na podzbiory wyróżnione na podstawie istotnych dla badania cech, co skutkuje podziałem operatu na ilościowo i jakościowo różniące się części. Umożliwia to dotarcie do wszystkich istotnych grup respondentów (metoda doboru prostego tego nie gwarantuje), gdyż każda warstwa jest reprezentowana - wymusza to konstrukcja próby. W ramach każdej z części losowane są jednostki badania (są nimi poszczególne przedsiębiorstwa spełniające określone kryteria dla poszczególnych warstw - ze względu na sekcję i liczbę zatrudnionych). Losowa- 
nie jednostek badania w ramach poszczególnych podgrup ma charakter losowania prostego, co oznacza, że każda jednostka w ramach danej warstwy ma takie samo prawdopodobieństwo znalezienia się w próbie. Dzieje się tak dlatego, że dokonuje się losowania bezpośredniego niezależnych prób w obrębie każdej warstwy w sposób rozłączny od pozostałych warstw. Liczebność głównej próby badawczej ustalono na 430 jednostek podzielonych według warstw wyodrębnionych na podstawie istotnych zmiennych różnicujących próbę badawczą.

Badaniem empirycznym zostały objęte przedsiębiorstwa zatrudniające powyżej 49 pracowników oraz posiadające siedzibę na terenie Polski, zdefiniowane według PKD. W zbiorze tym przeważają przedsiębiorstwa średnie, czyli zatrudniające

\section{Tabela 4.1. Charakterystyka populacji badanych przedsiębiorstw według liczby zatrudnionych oraz sekcji PKD}

\begin{tabular}{|c|c|c|c|c|c|}
\hline \multirow{3}{*}{$\begin{array}{c}\text { Sekcja } \\
\text { PKD }\end{array}$} & \multirow{3}{*}{ Nazwa sekcji PKD } & \multicolumn{4}{|c|}{ Liczba pracowników } \\
\hline & & \multicolumn{2}{|c|}{$\begin{array}{c}\text { powyżej } 49 \text { osób } \\
\text { (ogółem) }\end{array}$} & \multirow{2}{*}{\begin{tabular}{|c|}
$\begin{array}{c}50-249 \\
\text { osób }\end{array}$ \\
liczba \\
\end{tabular}} & \multirow{2}{*}{\begin{tabular}{|c|}
250 \\
i więcej \\
liczba \\
\end{tabular}} \\
\hline & & liczba & $\%$ & & \\
\hline A & Rolnictwo, leśnictwo, łowiectwo i rybactwo & 613 & 2,0 & 589 & 24 \\
\hline B & Górnictwo i wydobywanie & 158 & 0,5 & 122 & 36 \\
\hline $\mathrm{C}$ & Przetwórstwo przemysłowe & 7465 & 23,8 & 6087 & 1378 \\
\hline $\mathrm{D}$ & $\begin{array}{l}\text { Wytwarzanie i zaopatrywanie w energię elektrycz- } \\
\text { ną, gaz, parę wodną, gorącą wodę i powietrze do } \\
\text { układów klimatycznych }\end{array}$ & 254 & 0,8 & 188 & 66 \\
\hline $\mathrm{E}$ & $\begin{array}{l}\text { Dostawa wody, gospodarowanie ściekami i odpa- } \\
\text { dami oraz działalność związana z rekultywacją }\end{array}$ & 659 & 2,0 & 587 & 72 \\
\hline $\mathrm{F}$ & Budownictwo & 1800 & 6,1 & 1646 & 154 \\
\hline G & $\begin{array}{l}\text { Handel hurtowy i detaliczny, naprawa pojazdów } \\
\text { samochodowych, włączając motocykle }\end{array}$ & 3251 & 10,2 & 2901 & 350 \\
\hline $\mathrm{H}$ & Transport i gospodarka magazynowa & 909 & 2,8 & 713 & 196 \\
\hline I & $\begin{array}{l}\text { Działalność związana z zakwaterowaniem i usługa- } \\
\text { mi gastronomicznymi }\end{array}$ & 317 & 1,0 & 277 & 40 \\
\hline $\mathrm{J}$ & Informacja i komunikacja & 455 & 1,4 & 366 & 89 \\
\hline $\mathrm{K}$ & Działalność finansowa i ubezpieczeniowa & 547 & 1,6 & 443 & 104 \\
\hline $\mathrm{L}$ & $\begin{array}{l}\text { Działalność związana z obsługą rynku nierucho- } \\
\text { mości }\end{array}$ & 755 & 2,3 & 676 & 79 \\
\hline M & Działalność profesjonalna naukowa i techniczna & 863 & 2,7 & 715 & 148 \\
\hline $\mathrm{N}$ & $\begin{array}{l}\text { Działalność w zakresie usług administrowania } \\
\text { i działalność wspierająca }\end{array}$ & 1016 & 3,2 & 784 & 232 \\
\hline $\mathrm{R}$ & $\begin{array}{l}\text { Działalność związana z kulturą, rozrywką i rekre- } \\
\text { acją }\end{array}$ & 639 & 1,9 & 603 & 31 \\
\hline$S$ & Pozostała działalność usługowa & 931 & 2,8 & 793 & 138 \\
\hline
\end{tabular}

Źródło: Na podstawie danych GUS-u i agencji realizującej badania. 
50-249 pracowników, stanowią one 87\% badanej populacji (29 243 podmiotów). Natomiast przedsiębiorstwa duże, czyli zatrudniające 250-999 pracowników lub więcej, stanowią 13,2\% badanej populacji (4443 podmioty). Tabela 4.1 prezentuje liczebność ogółu przedsiębiorstw zarejestrowanych w poszczególnych sekcjach klasyfikacji PKD ze względu na liczbę zatrudnionych - dane te były podstawą do wyznaczenia struktury próby.

Próba do badania została dobrana w sposób proporcjonalny, co oznacza, że struktura próby w ogólnym zarysie stanowi „odbicie” populacji generalnej ${ }^{18}$. Dokładne liczebności próby w poszczególnych warstwach przedstawia tabela 4.2.

$\mathrm{W}$ populacji stanowiącej podstawę badania dominowały podmioty reprezentujące sektor przetwórstwa przemysłowego (32,5\%), budownictwo (8\%), handel hurtowy i detaliczny $(11,8 \%)$ oraz działalność profesjonalną, naukową i techniczną (14,6\%).

Tabela 4.2. Struktura próby badawczej

\begin{tabular}{|c|l|c|c|}
\hline \multirow{2}{*}{$\begin{array}{c}\text { Sekcja } \\
\text { PKD }\end{array}$} & \multicolumn{1}{|c|}{ Nazwa sekcji PKD } & \multicolumn{2}{|c|}{$\begin{array}{c}\text { Powyżej 49 osób } \\
\text { (ogółem) }\end{array}$} \\
\cline { 2 - 4 } & & \multicolumn{1}{|c|}{ liczba } & \% \\
\hline A & Rolnictwo, leśnictwo, łowiectwo i rybactwo & 11 & 2,6 \\
\hline B & Górnictwo i wydobywanie & 138 & 0,5 \\
\hline C & Przetwórstwo przemysłowe & 11 & 2,6 \\
\hline D & $\begin{array}{l}\text { Wytwarzanie i zaopatrywanie w energię elektryczną, gaz, parę wod- } \\
\text { ną, gorącą wodę i powietrze do układów klimatycznych }\end{array}$ & 13 & 3,1 \\
\hline E & $\begin{array}{l}\text { Dostawa wody gospodarowanie ściekami i odpadami oraz działal- } \\
\text { ność związana z rekultywacją }\end{array}$ & 36 & 8,5 \\
\hline F & Budownictwo & 50 & 11,8 \\
\hline G & $\begin{array}{l}\text { Handel hurtowy i detaliczny, naprawa pojazdów samochodowych, } \\
\text { włączając motocykle }\end{array}$ & 18 & 4,2 \\
\hline H & Transport i gospodarka magazynowa & 5 & 1,2 \\
\hline I & $\begin{array}{l}\text { Działalność związana z zakwaterowaniem i usługami gastrono- } \\
\text { micznymi }\end{array}$ & 12 & 2,8 \\
\hline J & Informacja i komunikacja & 6 & 1,4 \\
\hline K & Działalność finansowa i ubezpieczeniowa & 12 & 2,8 \\
\hline L & Działalność związana z obsługą rynku nieruchomości & 62 & 14,6 \\
\hline M & Działalność profesjonalna naukowa i techniczna & 9 & 2,1 \\
\hline N & $\begin{array}{l}\text { Działalność w zakresie usług administrowania i działalność wspie- } \\
\text { rająca }\end{array}$ & 30 & 7,1 \\
\hline R & Działalność związana z kulturą, rozrywką i rekreacją & & \\
\hline S & Pozostała działalność usługowa & & \\
\hline
\end{tabular}

${ }^{18} \mathrm{~W}$ przypadku przedmiotowego badania, $\mathrm{z}$ uwagi na trudności $\mathrm{w}$ dotarciu do respondentów (wyższy szczebel kierownictwa przedsiębiorstw), nie we wszystkich przypadkach udało się zachować proporcjonalny udział podmiotów reprezentujących poszczególne sekcje PKD 2007. 


\subsection{Charakterystyka próby badawczej}

Badanie zostało przeprowadzone w okresie od maja do czerwca 2017 roku. Eliminując kilka błędnie wypełnionych kwestionariuszy, ostatecznie do dalszej analizy zakwalifikowano 424 poprawnie wypełnionych ankiet. Próba badawcza, z której zebrano materiał empiryczny, to w znacznej części $(72,2 \%)$ średnie przedsiębiorstwa zatrudniające 50-249 pracowników. Znacznie mniejszą grupę, bo jedynie 27,8\%, stanowili reprezentanci dużych przedsiębiorstw, zatrudniających powyżej 250 pracowników. Zasięg prowadzonej działalności badanych przedsiębiorstw obejmo-

Tabela 4.3. Charakterystyka próby badawczej

\begin{tabular}{|c|c|}
\hline Kryterium & $\begin{array}{l}\text { Udział w próbie } \\
(\%)\end{array}$ \\
\hline \multicolumn{2}{|l|}{ Zatrudnienie } \\
\hline od 50-249 pracowników & 72,2 \\
\hline 250 i więcej pracowników & 27,8 \\
\hline \multicolumn{2}{|l|}{ Zasięg działalności } \\
\hline Lokalny & 17,2 \\
\hline Regionalny & 12 \\
\hline Krajowy & 25,9 \\
\hline Międzynarodowy & 36,3 \\
\hline Globalny & 8,5 \\
\hline \multicolumn{2}{|l|}{ Forma własności } \\
\hline Przedsiębiorstwo państwowe & 18,9 \\
\hline Przedsiębiorstwo prywatne - własność podmiotów zagranicznych & 13,4 \\
\hline Przedsiębiorstwo prywatne - własność podmiotów krajowych & 42,5 \\
\hline Przedsiębiorstwo prywatne - własność podmiotów krajowych i zagranicznych & 7,5 \\
\hline $\begin{array}{l}\text { Przedsiębiorstwo prywatne-większość udziałów w rękach jednej rodziny biz- } \\
\text { nesowej }\end{array}$ & 17,7 \\
\hline \multicolumn{2}{|l|}{ Wiek przedsiębiorstwa } \\
\hline Do 2 lat & 2,8 \\
\hline Powyżej 2 lat & 5,7 \\
\hline Powyżej 5 do 10 lat & 10,6 \\
\hline Powyżej 10 do 25 lat & 42,0 \\
\hline Powyżej 25 lat & 38,9 \\
\hline \multicolumn{2}{|l|}{ Faza rozwoju sektora } \\
\hline Narodzin & 3,5 \\
\hline Wzrostu & 32,8 \\
\hline Dojrzałości & 58,7 \\
\hline Schyłku & 5,0 \\
\hline
\end{tabular}


wał najczęściej rynek międzynarodowy (36,3\%), a rzadziej krajowy (25,9\%). Pod względem formy własności w analizowanej zbiorowości dominującą część stanowiły przedsiębiorstwa prywatne będące własnością podmiotów krajowych (42\%). Podobne udziały w badanej próbie odnotowano dla przedsiębiorstw państwowych $(18,9 \%)$ oraz przedsiębiorstw prywatnych, w których większość udziałów znajduje się w rękach jednej rodziny biznesowej (17,7\%). Przedsiębiorstwa prywatne, stanowiące własność podmiotów zagranicznych, stanowiły jedynie $13,4 \%$ badanej populacji. W prezentowanej zbiorowości dominowały przedsiębiorstwa $\mathrm{z}$ długoletnim doświadczeniem prowadzenia działalności, aż 42,0\% stanowiły przedsiębiorstwa działające na rynku 10-25 lat, natomiast druga najliczniejsza grupa to przedsiębiorstwa długoletnie, funkcjonujące na rynku powyżej 25 lat, stanowiące 38,9\% badanej populacji. Co 10. przedsiębiorstwo działało 5-10 lat na rynku. Pod względem kryterium fazy rozwoju sektora dominującą część stanowily przedsiębiorstwa będące w fazie jego dojrzałości (58,7\%), natomiast drugim co do wielkości zbiorem były przedsiębiorstwa będące $\mathrm{w}$ fazie wzrostu sektora (32,8\%). Przedsiębiorstwa będące w fazie narodzin $(3,5 \%)$ lub schyłku $(5,0 \%)$ nie stanowiły znacznego odsetka badanej próby (tabela 4.3).

\subsection{Pomiar zwinności strategicznej}

Celem niniejszego podrozdziału jest przedstawienie miar poszczególnych zmiennych modelu zwinności strategicznej, do których zaliczono: umiejętność oceny szans, skłonność do ryzyka, umiejętność rozwoju zasobów własnych, zdolność współpracy, zdolność innowacyjną, kulturę przedsiębiorczą, elastyczność operacyjną, elastyczność finansową oraz przywództwo strategiczne. W celu operacjonalizacji poszczególnych zmiennych dokonano gruntownej analizy literatury (przedstawionej w rozdziale 3), na podstawie której przygotowano bardziej szczegółowy zakres zmiennych w postaci wskaźników oraz odpowiadających im stwierdzeń wskazanych w narzędziu pomiarowym (kwestionariuszu ankiety). Deficyt badań empirycznych nad zwinnością strategiczną przedsiębiorstw powoduje, że narzędzia pomiarowe nie są wystarczająco rozwinięte, a tym bardziej przetestowane. Jednak większość stwierdzeń w ankiecie opisująca daną cechę została zaadaptowana z prac innych badaczy prowadzących badania w kontekście zwinności. Czytelność oraz możliwość interpretacji poszczególnych stwierdzeń zweryfikowano podczas badania pilotażowego, którego wyniki umożliwiły udoskonalenie narzędzia pomiarowego. 


\subsubsection{Wrażliwość strategiczna przedsiębiorstw}

Wrażliwość na otoczenie wymaga od przedsiębiorstwa odnalezienia się w narastającej złożoności zmian, ich nieprzewidywalności oraz związanej z nimi niepewności. $\mathrm{Z}$ jednej strony takie otoczenie przedsiębiorstwa mogą postrzegać jako niesprzyjające, niegodne zaufania, wręcz wrogie, $z$ drugiej jednak strony dynamizm otoczenia może kreować okazje, które jedynie dla wrażliwych strategicznie przedsiębiorstw będą możliwe do eksploracji i eksploatacji. Jak wskazuje D. Latusek-Jurczak (2017), organizacje mogą odnosić sukces mimo otoczenia charakteryzującego się nieufnością, jeśli w praktyce mobilizują zasoby oraz stosują strategie i taktyki pozwalające na przezwyciężenie kultury nieufności narzucanej przez otoczenie, tworząc przedsiębiorstwa oparte na otwartej komunikacji, chętnie podejmujące współpracę z partnerami zewnętrznymi z kraju i z zagranicy. Konkurencja między przedsiębiorstwami przebiega obecnie $\mathrm{w}$ warunkach permanentnego braku równowagi, którą tworzą nieustannie migrujące czynniki sukcesu rynkowego. Taka sytuacja sprawia, że ukształtowana pozycja konkurencyjna nie jest w żadnym momencie trwała, przeciwnie, jej źródła podlegają ciągłej nieustannej erozji. Zatem kluczowym źródłem sukcesu staje się umiejętność dostrzeżenia i wykorzystania pojawiających się szans, zanim zrobią to konkurenci (Sajdak, 2014a).

Przez I.M. Kirznera (1973) umiejętność ta została określona jako swoista wrażliwość lub czujność na szanse pojawiające się w otoczeniu. To właśnie owa wrażliwość jest wyróżnikiem osoby przedsiębiorczej i umożliwia odkrywanie nowych możliwości rynkowych niewidocznych dla innych. I.M. Kirzner (1973) użył terminu „wrażliwość" do wyjaśnienia przedsiębiorczych zdolności w procesie identyfikacji okazji. Zjawisko to utożsamił ze zdolnością przedsiębiorcy do wprowadzania autonomicznych zmian w wyniku rozpoznania okazji. Warunkiem koniecznym czujności jest kreatywność determinująca identyfikację związków przyczynowo-skutkowych pomiędzy elementami z pozoru niepowiązanymi (Kirzner, 2009, s. 151). S. Kaish i B. Gilad (1991) określili wrażliwość jako unikatową gotowość do rozpoznania okazji, kiedy wystąpią, związaną z czynnikami poznawczymi (inteligencją i również kreatywnością). Zdolności te pozwalają jedynie określonym jednostkom identyfikować nowe rozwiązania rynkowe i potrzeby odbiorców - w formie nowych produktów lub usług (Sus, 2014). Według J. Tang, K.M. Kacmar i L. Busenitz (2012) czujność obejmuje dwa odrębne elementy: skanowanie i poszukiwanie informacji oraz łączenie rozbieżnych informacji, i jeden wspólny: dokonywanie oceny potencjalnych możliwości biznesowych. Pierwszy z nich umożliwia przedsiębiorcom budowanie szerokiego wachlarza istotnych informacji o domenie, przyjmujących postać wiedzy jawnej i ukrytej. Poprzez łączenie rozbieżnych informacji, kreatywne myślenie i tworzenie szerszej perspektywy w dotychczas stosowanej logice postępowania, możliwe jest uzyskanie nowych informacji, dających nowe możliwości. W pracy I.M. Kirznera (1973) przedstawiono wnioski dotyczące zależności pomiędzy wrażliwością a poziomem wiedzy, a raczej pełnieniem kontroli nad informacjami. Zwraca on uwagę, 
że asymetria informacji pomiędzy poszczególnymi uczestnikami rynku jest podstawą do zauważenia okazji, a tym samym może stanowić źródło przewagi konkurencyjnej. Wynika z tego, że mniej istotne jest posiadanie informacji, a ważniejsze są czujność i umiejętność w ich odnajdywaniu szybciej niż zrobią to konkurenci.

Wrażliwość w kontekście zwinności strategicznej oznacza zdolność do szybkiego dostrzegania okazji rynkowych, jak również zagrożeń wynikających z otoczenia oraz umiejętność ich oceny i kategoryzowania sytuacji jako sprzyjających bądź niesprzyjających przedsiębiorstwu. W przeprowadzonym badaniu respondenci zostali poproszeni o ustosunkowanie się do sposobów poszukiwania okazji w otoczeniu, za pomocą pięciopunktowej skali od 1 do 5, gdzie 1 oznaczało $z$ decydowanie nie, a 5 zdecydowanie tak. Zdecydowano się na wykorzystanie pięciopunktowej skali porządkowej opartej na skali Likerta, ponieważ uzyskane w ten sposób dane empiryczne można analizować w naukach o zarządzaniu z wykorzystaniem bardziej zaawansowanych technik statystycznych, na przykład modelowania strukturalnego (Mitręga, 2010; Światowiec-Szczepaństka, 2012; Urbanowska-Sojkin, 2013b; Kawa 2017; Zakrzewska-Bielawska, 2018). W tabeli 4.4 przedstawiono średnie oceny umiejętności identyfikacji szans w otoczeniu. Wynika z niej, że dla respondentów najwyższe znaczenie ma umiejętność identyfikacji szans samodzielnie w ramach przedsiębiorstwa, z wykorzystaniem ogólnie dostępnych źródeł informacji oraz określanie szans na podstawie informacji od klientów. Czynniki te uzyskały oceny znacznie powyżej przeciętnej, odpowiednio 4,01 oraz 4,05 . Nie bez znaczenia według respondentów jest również wspieranie oddolnych inicjatyw wychodzących od pracowników, które mogą następnie stanowić przedmiot dyskusji na wyższych szczeblach kierowniczych. Wartość tego wskaźnika została oceniona na poziomie 3,77, co świadczy o dużym zaufaniu szczebla kierowniczego dla inicjatyw i pomysłów zgłaszanych na niższych szczeblach, jak również o zaangażowaniu pracowników niższych szczebli we współtworzenie działań strategicznych.

Tabela 4.4. Średnia ocena umiejętności identyfikacji szans w otoczeniu

\begin{tabular}{|l|c|}
\hline \multicolumn{1}{|c|}{ Umiejętność identyfikacji szans } & $\begin{array}{c}\text { Średnia } \\
\text { ocena }\end{array}$ \\
\hline Zlecamy poszukiwanie szans zewnętrznym firmom specjalizujących się w tym zakresie & 2,45 \\
\hline $\begin{array}{l}\text { Analizujemy otoczenie i identyfikujemy szanse samodzielnie w przedsiębiorstwie, ko- } \\
\text { rzystając z ogólnie dostępnych publicznie źródeł informacji }\end{array}$ & 4,01 \\
\hline $\begin{array}{l}\text { Sami określamy szanse na podstawie informacji zwrotnej od klientów oraz analizy da- } \\
\text { nych }\end{array}$ & 4,05 \\
\hline Wspieramy oddolne inicjatywy zgłaszania okazji przez pracowników & 3,77 \\
\hline
\end{tabular}

Poleganie na własnych kompetencjach i możliwościach identyfikowania szans, którą zadeklarowało aż 84\% badanych, może wynikać między innymi z dobrej znajomości rynków, na których funkcjonują te przedsiębiorstwa. Aż 80\% tych przedsię- 
biorstw prowadzi działalność gospodarczą powyżej 10 lat, prawie $60 \%$ funkcjonuje w sektorach dojrzałych, co może oznaczać bardzo dobrą znajomość uwarunkowań rynkowych oraz wypracowanie sprawdzonych już technik i metod identyfikowania szans rynkowych. Odpowiedzi respondentów wskazują także na wysoką świadomość płynącą z użyteczności social mediów oraz narzędzia big data w budowaniu repozytoriów danych stanowiących podstawę decyzji strategicznych.

Według wyników przeprowadzonych badań $23 \%$ respondentów deklaruje big data jako rozwiązanie wdrożone, natomiast co czwarty pytany planuje wdrożyć to rozwiązanie w najbliższej przyszłości. Jednak niepokojący jest fakt, że co drugi badany uznał, że w jego przedsiębiorstwie nie planuje się wdrożenia tego rozwiązania. Może to wynikać $\mathrm{z}$ braku wiedzy, a tym samym świadomości zalet, jakie niesie jego wdrożenie (ilość danych, szybkość dostarczenia danych, różnorodność danych) lub też kosztów związanych z profesjonalną jego implementacją w przedsiębiorstwie lub zakupieniem rozwiązania i usługi poza przedsiębiorstwem. Big data to popularne określenie opisujące gwałtowny wzrost i dostępność danych zarówno posiadających ustaloną strukturę, jak i nieustrukturyzowanych. Przy czym to nie rozmiar danych jest najważniejszy. Dokładniejsze analizy z wykorzystaniem big data mogą prowadzić do pewniejszych decyzji i zmian w strategii biznesu (Mayer-Schönberger i Cukier, 2014, s. 28-43). O ile sam termin „big data” jest relatywnie nowy, co mogło spowodować brak zrozumienia terminu wśród respondentów, o tyle zbieranie i przechowywanie dużych ilości informacji do celów analitycznych było praktykowane od bardzo dawna. Organizacje zbierają dane z różnorodnych źródeł: transakcje biznesowe, media społecznościowe, dane z sensorów, dane wymieniane między urządzeniami. W przeszłości przechowywanie tych danych stanowiło problem, ale obecnie nowe technologie (takie jak np. Hadoop) znacznie to ułatwiły (Kumari, 2016). Dane powstają i są dostarczane niezwykle szybko i muszą być obsługiwane w odpowiednim reżimie czasowym. Znaczniki RFID, czujniki i inteligentne mierniki wymagają obsługi olbrzymich ilości danych w czasie zbliżonym do rzeczywistego. Dane przychodzą w różnych formatach - od ustrukturyzowanych, numerycznych danych w tradycyjnych bazach danych do niestrukturalnych dokumentów tekstowych, e-maili, materiałów video, audio, danych znaczników magazynowych lub transakcji finansowych (Verma, Agrawal, Patel i Patel, 2016). Przedsiębiorstwa wyposażone $\mathrm{w}$ informacje pochodzące $\mathrm{z}$ analizy dużych zbiorów danych mogą poprzez wykorzystanie szans podnieść jakość produktów, zwiększyć wydajność produkcji oraz ograniczyć straty - co ma kluczowe znaczenie dla osiągnięcia sukcesu na obecnym bardzo konkurencyjnym rynku. Coraz więcej producentów pracuje w trybie kultury analitycznej, przez co mogą szybciej rozwiązywać problemy i podejmować trafne decyzje biznesowe.

Aż $85 \%$ badanych przedsiębiorstw identyfikuje szanse na podstawie informacji zwrotnej od klientów, co w dzisiejszej rzeczywistości gospodarczej, przy wykorzystaniu tak wielu narzędzi dostępnych poprzez social media, jest tanim, wiarygodnym oraz szybkim źródłem pozyskania danych. Stwarza to duże możliwości analityczne, 
ponieważ dzięki informacjom publikowanym przez samych użytkowników możliwe staje się bardzo precyzyjne stworzenie profilu klienta i kierowanie do niego odpowiedniego przekazu komunikacyjnego (Halpern, 2012).

Udział procentowy posiadanych umiejętności respondentów w identyfikacji szans przedstawiono w tabeli 4.5. Niespełna $6 \%$ badanych przedsiębiorstw deklaruje współpracę z zewnętrznymi przedsiębiorstwami w ramach identyfikacji szans, a jedynie co piąte przedsiębiorstwo czasami taką współpracę podejmuje. Niewielkie zainteresowanie przedsiębiorstw wykorzystaniem usług profesjonalnych partnerów może wynikać $z$ braku zaufania lub ograniczonych środków przeznaczonych na ten cel.

Tabela 4.5. Ocena umiejętności identyfikacji szans w otoczeniu

\begin{tabular}{|l|c|c|c|c|c|}
\hline \multirow{2}{*}{ Umiejętność identyfikacji szans } & \multicolumn{5}{|c|}{ Procent wskazań } \\
\cline { 2 - 6 } & $\begin{array}{c}\text { zdecy- } \\
\text { dowa- } \\
\text { nie nie }\end{array}$ & $\begin{array}{c}\text { raczej } \\
\text { nie }\end{array}$ & $\begin{array}{c}\text { ani tak, } \\
\text { ani nie }\end{array}$ & $\begin{array}{c}\text { raczej } \\
\text { tak }\end{array}$ & $\begin{array}{c}\text { zdecy- } \\
\text { dowa- } \\
\text { nie tak }\end{array}$ \\
\hline $\begin{array}{l}\text { Zlecamy poszukiwanie szans zewnętrznym } \\
\text { firmom specjalizujących się w tym zakresie }\end{array}$ & 27,1 & 35,1 & 9,0 & 22,9 & 5,9 \\
\hline $\begin{array}{l}\text { Analizujemy otoczenie i identyfikujemy szan- } \\
\text { se samodzielnie w przedsiębiorstwie }\end{array}$ & 2,1 & 8,5 & 5,7 & 53,3 & 30,4 \\
\hline $\begin{array}{l}\text { Sami określamy szanse na podstawie informa- } \\
\text { cji zwrotnej od klientów oraz analizy danych }\end{array}$ & 1,9 & 7,8 & 5,7 & 52,4 & 32,3 \\
\hline $\begin{array}{l}\text { Wspieramy oddolne inicjatywy zgłaszania } \\
\text { okazji przez pracowników }\end{array}$ & 5,2 & 13,0 & 6,1 & 51,4 & 24,3 \\
\hline
\end{tabular}

Jak zauważa A. Sus (2014), uzyskując z pozoru rozłączne informacje, przedsiębiorca wykorzystujący systemy wczesnego ostrzegania dysponuje pełnym oprzyrządowaniem nie tylko do identyfikacji i łączenia informacji, ale również do ich oceny i wyboru najlepszej z wachlarza możliwości. Kolejne etapy procesu umożliwiają identyfikację nowych informacji, przefiltrowanie ich według określonych kryteriów oraz odrzucenie tych, z którymi nie wiążą się okazje. Zatem na kolejnym etapie przeprowadzonego badania respondenci byli poproszeni o określenie częstotliwości analizy i oceny okazji pojawiających się w otoczeniu przedsiębiorstwa. Do oceny wykorzystano pięciopunktową skalę od 1 do 5, gdzie 1 oznaczało prawie nigdy, a 5 systematycznie.

Uśredniając oceny poszczególnych umiejętności oceny szans, wszystkie wskazane w kwestionariuszu działania mają dla respondentów przynajmniej przeciętne znaczenie (tabela 4.6). Uzyskane średnie niewiele się od siebie różnią. Najwyżej oceniona przez menedżerów została częstotliwość oceny okazji ze względu na jej zgodność $\mathrm{z}$ celami przedsiębiorstwa (wizja, misja, wartości) oraz ewentualną strategią jednostki nadrzędnej. 
Tabela 4.6. Średnia ocena umiejętności oceny szans

\begin{tabular}{|l|c|}
\hline \multicolumn{1}{|c|}{ Umiejętność oceny szans } & Średnia ocena \\
\hline Sprawdzamy, czy pojawiająca się okazja znajduje się w zasięgu przedsiębiorstwa & 3,67 \\
\hline Oceniamy, czy okazja jest zgodna z celami przedsiębiorstwa & 3,81 \\
\hline $\begin{array}{l}\text { Oceniamy wartość pojawiających się szans niezależnie od strategii firmy oraz } \\
\text { szacujemy ewentualne ryzyko z nimi związane }\end{array}$ & 3,52 \\
\hline
\end{tabular}

Znaczna większość respondentów (66\%) stwierdziła, że często, a nawet systematycznie sprawdzają, czy pojawiająca się okazja znajduje się w zasięgu przedsiębiorstwa ze względu na posiadane zasoby lub możliwości nabycia ich spoza przedsiębiorstwa. Prawie 70\% menedżerów uznało, że często lub systematycznie ocenia, czy okazja jest zgodna z celami przedsiębiorstwa, a w szczególności z misją, wizją i obowiązującymi wartościami. Mniejszy, ale nadal znaczny odsetek respondentów (63\%) przyznał, że często lub systematycznie ocenia wartość pojawiających się szans o wysokim potencjale, niezależnie od strategii przedsiębiorstwa, szacując ewentualne ryzyko z nimi związane (tabela 4.7).

Tabela 4.7. Ocena umiejętności oceny szans

\begin{tabular}{|l|c|c|c|c|c|}
\hline \multirow{2}{*}{ Umiejętność oceny szans } & \multicolumn{5}{|c|}{ Procent wskazań } \\
\cline { 2 - 6 } & $\begin{array}{c}\text { prawie } \\
\text { nigdy }\end{array}$ & $\begin{array}{c}\text { od czasu } \\
\text { do czasu }\end{array}$ & $\begin{array}{c}\text { trudno } \\
\text { powie- } \\
\text { dzieć }\end{array}$ & często & $\begin{array}{c}\text { systema- } \\
\text { tycznie }\end{array}$ \\
\hline $\begin{array}{l}\text { Sprawdzamy, czy pojawiająca się okazja } \\
\text { znajduje się w zasięgu przedsiębiorstwa }\end{array}$ & 3,1 & 20,0 & 10,8 & 39,2 & 26,9 \\
\hline $\begin{array}{l}\text { Oceniamy, czy okazja jest zgodna z celami } \\
\text { przedsiębiorstwa }\end{array}$ & 3,1 & 15,6 & 11,6 & 36,8 & 33,0 \\
\hline $\begin{array}{l}\text { Oceniamy wartość pojawiających się szans } \\
\text { niezależnie od strategii firmy oraz szacuje- } \\
\text { my ewentualne ryzyko z nimi związane }\end{array}$ & 6,4 & 21,0 & 9,7 & 40,6 & 22,4 \\
\hline
\end{tabular}

Wcześniejsze wnioski potwierdza również analiza częstotliwości podejmowania dyskusji i analizy pojawiających się szans. Chcąc uzyskać bardziej precyzyjne informacje, zapytano respondentów, jak często pojawiające się szanse stanowią temat dyskusji i analizy, czy powinny być wykorzystane (rysunek 4.1). Zgodnie z wcześniejszymi deklaracjami aż 32\% respondentów odpowiedziało, że w ich przedsiębiorstwach taka dyskusja ma miejsce raz na miesiąc lub nawet częściej, natomiast $23 \%$ badanych wskazało, że jedynie co trzy miesiące podejmowane są rozmowy strategiczne. Prawie co piąty badany zadeklarował, że temat możliwości wykorzystania szans pojawia się w jego przedsiębiorstwie co pół roku.

Interesującym aspektem $w$ ramach prowadzonego badania była ocena efektywności podejmowanych działań w ramach atrybutu wrażliwości, polegająca na częstotli- 


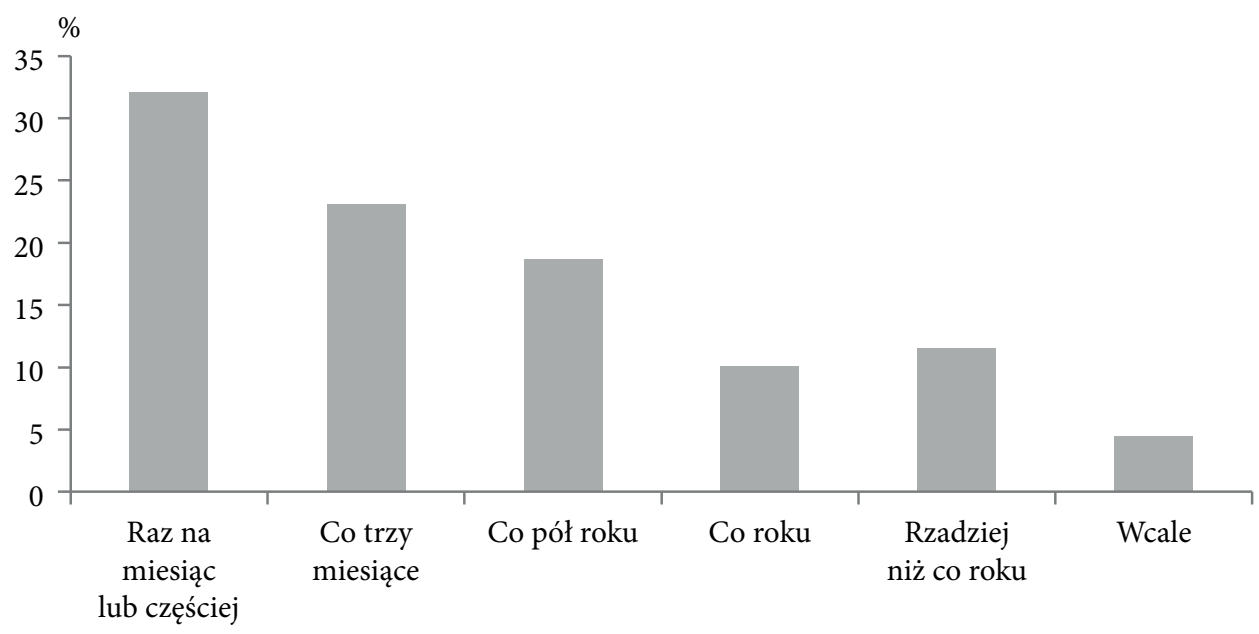

Rysunek 4.1. Częstotliwość analizy i dyskusji nad wykorzystaniem pojawiających się szans

wości wykorzystania pojawiających się szans. W tym celu zapytano respondentów, jak często ich przedsiębiorstwo w ciągu ostatnich trzech lat wykorzystało pojawiające się szanse. Uzyskane wyniki pokrywają się z wcześniejszymi ustaleniami dotyczącymi dużej świadomości i aktywności przedsiębiorstw w tym zakresie. Prawie $30 \%$ badanych uznało, że w ciągu ostatnich trzech lat wykorzystywało szansę częściej niż co pół roku, a 40\% respondentów - co roku (rysunek 4.2).

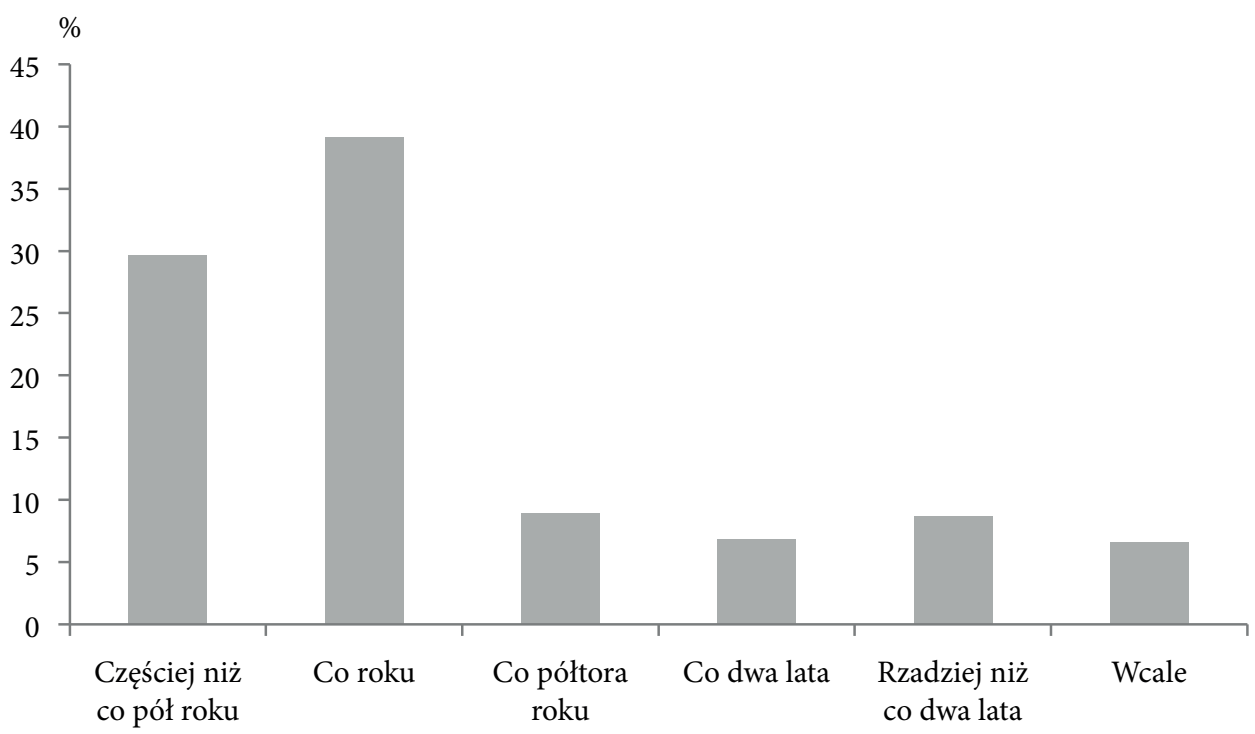

Rysunek 4.2. Częstotliwość wykorzystania pojawiających się szans 
Częstotliwość wykorzystania pojawiających się szans wiąże się bezpośrednio z postawą decydentów dotyczącą podejmowania ryzyka i postrzeganiem go jako naturalnego elementu gry rynkowej. Podejmowanie ryzyka odnosi się do skłonności menedżerów do pracy nad nowymi, ryzykownymi projektami i odzwierciedla preferencje śmiałych decyzji służących osiągnięciu organizacyjnych celów (Gasse, 1982). Skłonność do podejmowania ryzyka oznacza tolerancję błędów, niepewności, niepowodzeń i niejednoznaczności (Chiva i in., 2007). Prowadzone do tej pory badania jednoznacznie wskazują, że zarządzający w przedsiębiorstwach o wysokim poziomie zwinności chętnie podejmują ryzyko (Dai i in., 2013; Mahmoud Hamad i Yozgat, 2017).

Uśredniając odpowiedzi w obszarze skłonności do ryzyka (tabela 4.8), uzyskano informację, że wśród badanych przedsiębiorstw najwyższą ocenę otrzymało stwierdzenie dotyczące przekonania, że ryzyko stanowi naturalny element gry rynkowej i zamiast się go obawiać należy nauczyć się je ograniczać $(3,83)$. Aż $75 \%$ respondentów potwierdziło obecność tego przekonania w swoim przedsiębiorstwie. Pozostałe dwie zmienne uzyskały podobne oceny średniej, bliskie 3,5, co świadczy, że wskazane zmienne określające skłonność do ryzyka mają dla badanych przedsiębiorstw znaczenie powyżej przeciętnej. Konsekwencją skłonności do ryzyka jest uczenie się dobrych praktyk opartych na sukcesach, ale także wyciąganie wniosków z popełnionych błędach, co z kolei może prowadzić do wykreowania nowych szans (Vargas, 2013).

Tabela 4.8. Średnia ocena skłonności do ryzyka

\begin{tabular}{|l|c|}
\hline \multicolumn{1}{|c|}{ Skłonność do ryzyka } & Średnia ocena \\
\hline $\begin{array}{l}\text { Panuje u nas przekonanie, że ryzyko stanowi naturalny element gry rynkowej } \\
\text { i zamiast się go obawiać, należy nauczyć się je ograniczać }\end{array}$ & 3,83 \\
\hline $\begin{array}{l}\text { Ryzyko w otoczeniu gospodarczym traktowane jest przez nas jako szansa na po- } \\
\text { jawienie się ciekawych okazji, które moglibyśmy wykorzystać }\end{array}$ & 3,51 \\
\hline $\begin{array}{l}\text { Zarządzających charakteryzuje energia i przedsiębiorczość, chętnie też podej- } \\
\text { mują ryzyko }\end{array}$ & 3,53 \\
\hline
\end{tabular}

Wśród badanych przedsiębiorstw 64,2\% uznało, że ryzyko w otoczeniu gospodarczym jest przez nie traktowane jako szansa na pojawienie się ciekawych okazji, które można wykorzystać (tabela 4.9). Ten wniosek jest zbieżny z tezą proponowaną w literaturze przedmiotu, wskazującą, że chęć podjęcia ryzyka przyczynia się bezpośrednio do dążenia przedsiębiorstw do rozwijania i wdrażania nowych pomysłów w ramach zamierzeń strategicznych (Jambulingam i in., 2005). Wśród przedsiębiorstw deklarujących otwartą postawę w stosunku do ryzyka, $37,5 \%$ to przedsiębiorstwa w fazie wzrostu sektora, a $47,2 \%$ respondentów stanowili reprezentanci przedsiębiorstw sektorów dojrzałych. Wynik ten jest o tyle zaskakujący, że intuicyjnie można by się spodziewać dominującego odsetka odpowiedzi w sektorach wzrostowych, gdzie duża dynamika sprzedaży przy malejącej liczbie uczestników sektora pozwala na osiągnięcie dużych zysków i skłania inwestorów do wykorzysty- 
wania pojawiających się szans pomimo szacowanego ryzyka. Wśród przedsiębiorstw postrzegających ryzyko jako możliwość pojawienia się szansy 78\% to przedsiębiorstwa działające na rynku 10 lat i więcej.

Istota zwinności tkwi w radzeniu sobie z nieprzewidzianymi zmianami, stąd konieczność podejmowania ryzyka. Niemniej podejmowanie decyzji w warunkach niepewności i presji czasu stanowi trudne wyzwanie dla decydentów. Wyniki badań wskazują, że 64,4\% respondentów deklaruje, że osoby zarządzające w ich przedsiębiorstwach charakteryzuje energia i przedsiębiorczość, chętnie też podejmują ryzyko. Wyniki potwierdzają wnioski prezentowane we wcześniejszych badaniach w tym zakresie, wskazujące na akceptację podejmowania decyzji działań ryzykownych przez przedsiębiorstwa (Urbanowska-Sojkin, 2013b, s. 338).

Tabela 4.9. Ocena skłonności do ryzyka

\begin{tabular}{|c|c|c|c|c|c|}
\hline \multirow{2}{*}{ Skłonność do ryzyka } & \multicolumn{5}{|c|}{ Procent wskazá } \\
\cline { 2 - 6 } & $\begin{array}{c}\text { zdecy- } \\
\text { dowa- } \\
\text { nie nie }\end{array}$ & $\begin{array}{c}\text { raczej } \\
\text { nie }\end{array}$ & $\begin{array}{c}\text { ani tak, } \\
\text { ani nie }\end{array}$ & $\begin{array}{c}\text { raczej } \\
\text { tak }\end{array}$ & $\begin{array}{c}\text { zdecy- } \\
\text { dowa- } \\
\text { nie tak }\end{array}$ \\
\hline $\begin{array}{l}\text { Panuje u nas przekonanie, że ryzyko stanowi } \\
\text { naturalny element gry rynkowej i zamiast się } \\
\text { go obawiać, należy nauczyć się je ograniczać }\end{array}$ & 2,6 & 14,4 & 7,8 & 47,9 & 27,4 \\
\hline $\begin{array}{l}\text { Ryzyko w otoczeniu gospodarczym traktowane } \\
\text { jest przez nas jako szansa na pojawienie się cie- } \\
\text { kawych okazji, które moglibyśmy wykorzystać }\end{array}$ & 4,2 & 21,9 & 9,7 & 47,2 & 17,0 \\
\hline $\begin{array}{l}\text { Zarządzających charakteryzuje energia i przed- } \\
\text { siębiorczość, chętnie też podejmują ryzyko }\end{array}$ & 4,0 & 20,8 & 10,8 & 46,9 & 17,5 \\
\hline
\end{tabular}

\subsubsection{Przedsiębiorczość strategiczna przedsiębiorstw}

Według I.M. Kirznera $(1973,1979)$ przedsiębiorczość strategiczna ma niezwykle istotny wkład w zdolność przedsiębiorstw do adaptacji poprzez identyfikację i wykorzystanie szans w otoczeniu. Wrażliwość przedsiębiorcy pozwala na odkrywanie nowych okazji, także już istniejących, a dotąd niedostrzeżonych. Zwinność strategiczna wymaga jednocześnie wrażliwości umożliwiającej identyfikację okazji oraz umiejętności ich oceny ze względu na zasoby niezbędne do ich wykorzystania. Jak zauważają H.H. Stevenson i J.C. Jarillo (1990), przedsiębiorczość to także poszukiwanie szans będących poza zasobami obecnie kontrolowanymi. Organizacje, które sprzyjają powstawaniu nieformalnych wewnętrznych i zewnętrznych układów sieciowych i umożliwiają stopniową alokację i udostępnianie zasobów, będą wykazywały wyższy stopień zachowań przedsiębiorczych (Stevenson i Jarillo, 1990). Z założeń teorii zasobowej wynika, że nie istnieją przedsiębiorstwa, które posiadałyby wszyst- 
kie potrzebne zasoby i były niezależne od otoczenia. Dlatego tak doceniane są korzyści, jakie przedsiębiorstwo czerpie ze współpracy sieciowej (Stańczyk-Hugiet i Sus, 2012, s. 88; Grandori, 2002). Przedsiębiorstwa tworzą sieci międzyorganizacyjne lub starają się być jej uczestnikami, aby mieć dostęp do zasobów, których same nie posiadają (Romanowska, 2002, s. 165; Czakon, 2005; Dyer i Singh, 1998). Jak twierdzi E. Stańczyk-Hugiet (2016, s. 290), agresywność działań przedsiębiorstw adresowanych do istniejących i potencjalnych partnerów relacji w kategorii eksploatacji bądź też eksploracji relacji międzyorganizacyjnych wynika z przyjętej ścieżki rozwoju na podstawie wewnętrznych vesrus zewnętrznych źródeł zasobów. W prowadzonych badaniach przeanalizowano zdolność przedsiębiorstw do pozyskania zasobów niezbędnych do wykorzystania pojawiających się szans (tabela 4.10). Zastosowano pięciopunktową skalę od 1 do 5 , gdzie 1 oznaczało $z$ decydowanie nie, a 5 zdecydowanie tak. Aż 77\% badanych przedsiębiorstw przyznało, że zna źródła swoich zasobów, co $\mathrm{w}$ razie potrzeby umożliwia im elastyczne dostosowanie ilości i wielkości zasobów do pojawiających się potrzeb. Podobnie duży odsetek badanych respondentów (78\%) uznało, że potrafi ocenić, w jaki sposób pozyskać potrzebne zasoby - czy w ramach własnego przedsiębiorstwa (poprzez rozwój zasobów własnych), czy poprzez relacje międzyorganizacyjne. Tak duża świadomość respondentów w zakresie posiadanych zasobów oraz ich źródeł świadczy o wysokim poziomie wiedzy wewnątrzorganizacyjnej oraz wiedzy dotyczącej korzyści wynikających z budowania relacji partnerskich.

Tabela 4.10. Ocena zdolności do pozyskania zasobów

\begin{tabular}{|c|c|c|c|c|c|}
\hline \multirow{2}{*}{ Zdolność do pozyskania zasobów } & \multicolumn{5}{|c|}{ Procent wskazań } \\
\cline { 2 - 7 } & $\begin{array}{c}\text { zdecy- } \\
\text { dowa- } \\
\text { nie nie }\end{array}$ & $\begin{array}{c}\text { raczej } \\
\text { nie }\end{array}$ & $\begin{array}{c}\text { ani tak, } \\
\text { ani nie }\end{array}$ & $\begin{array}{c}\text { raczej } \\
\text { tak }\end{array}$ & $\begin{array}{c}\text { zdecy- } \\
\text { dowa- } \\
\text { nie tak }\end{array}$ \\
\hline Znamy źródła pozyskania naszych zasobów & 3,8 & 7,5 & 11,3 & 54,2 & 23,1 \\
\hline $\begin{array}{l}\text { Potrafimy ocenić, czy niezbędne zasoby do wy- } \\
\text { korzystania szans jesteśmy w stanie zorganizo- } \\
\text { wać w ramach przedsiębiorstwa, czy musimy } \\
\text { pozyskać je z zewnątrz }\end{array}$ & 3,1 & 8,3 & 10,6 & 55,0 & 23,1 \\
\hline
\end{tabular}

Niezbędne zasoby mogą być uzyskane dzięki umiejętności rozwoju zasobów własnych, czyli poprzez inwestycje w kluczowe obszary, których efektem jest pozyskanie zasobów niezbędnych do wykorzystania szans. Najistotniejszymi umiejętnościami wskazanymi przez respondentów okazały się inwestycje poczynione w rozwój zasobów ludzkich, w postaci szkoleń wewnętrznych i zewnętrznych, oraz umiejętność dostosowania strategii marketingowych do zmieniających się potrzeb odbiorców (zdolność do szybkiego dostosowania w ramach strategii instrumentalnych). Wskazane umiejętności uzyskały kolejno oceny średnie na poziomie 3,83 oraz 3,85 (tabela 4.11). 
Tabela 4.11. Średnia ocena umiejętności rozwoju zasobów własnych

\begin{tabular}{|l|c|}
\hline \multicolumn{1}{|c|}{ Umiejętność rozwoju zasobów własnych } & Średnia ocena \\
\hline Inwestujemy w nową technologię, aparaturę, oprogramowania & 3,78 \\
\hline $\begin{array}{l}\text { Inwestujemy w szkolenia wewnętrzne, zewnętrzne oraz inne formy doszkalania } \\
\text { pracowników }\end{array}$ & 3,83 \\
\hline Dostosowujemy strategię marketingową do naszych potrzeb & 3,85 \\
\hline Systematycznie staramy się o pozyskanie nowych środków finansowych & 3,47 \\
\hline
\end{tabular}

Wyniki badań w obszarze umiejętności rozwoju zasobów własnych napawają optymizmem. Aż $76 \%$ respondentów potwierdziło, że ich przedsiębiorstwa „raczej” lub „zdecydowanie” inwestują w rozwój zasobów rzeczowych, natomiast aż 77\% deklaruje podejmowanie inwestycji w doszkalanie pracowników w celu nabycia przez nich umiejętności dających możliwość wykorzystania szansy (tabela 4.12). Znaczny odsetek badanych, bo aż 76\%, posiada umiejętność dostosowania strategii marketingowej w razie potrzeby, co oznacza, że przedsiębiorstwa te charakteryzują się wysokim poziomem dynamicznych zdolności marketingowych (DMC) stanowiących zbiór wyuczonych, powtarzalnych aktywności, które wdrożone w organizacji są nakierowane na systematyczną ocenę i rekonfigurację zasobów marketingowych tak, aby zasoby te były lepiej dopasowane do aktualnej wiedzy o rynku (Mitręga, 2016). Jedynie co piąte badane przedsiębiorstwo przyznaje, że systematycznie stara się o pozyskanie środków finansowych na rozwój działalności. Może to wynikać $\mathrm{z}$ trudności formalnoprawnych, braku wiedzy niezbędnej do złożenia wymaganych wniosków lub obawy przed kosztami uzyskania dofinansowań i subwencji, jak również niechęci ponoszenia kosztów zobowiązań kredytowych.

Tabela 4.12. Ocena umiejętności rozwoju zasobów własnych

\begin{tabular}{|l|c|c|c|c|c|}
\hline \multirow{2}{*}{ Umiejętność rozwoju zasobów własnych } & \multicolumn{5}{|c|}{ Procent wskazań } \\
\cline { 2 - 6 } & $\begin{array}{c}\text { zdecy- } \\
\text { dowa- } \\
\text { nie nie }\end{array}$ & $\begin{array}{c}\text { raczej } \\
\text { nie }\end{array}$ & $\begin{array}{c}\text { ani tak, } \\
\text { ani nie }\end{array}$ & $\begin{array}{c}\text { raczej } \\
\text { tak }\end{array}$ & $\begin{array}{c}\text { zdecy- } \\
\text { dowa- } \\
\text { nie tak }\end{array}$ \\
\hline $\begin{array}{l}\text { Inwestujemy w nową technologię, aparaturę, } \\
\text { oprogramowania }\end{array}$ & 3,8 & 14,6 & 5,7 & 51,9 & 24,1 \\
\hline $\begin{array}{l}\text { Inwestujemy w szkolenia wewnętrzne, zewnętrz- } \\
\text { ne oraz inne formy doszkalania pracowników }\end{array}$ & 5,2 & 13,2 & 4,7 & 46,7 & 30,2 \\
\hline $\begin{array}{l}\text { Dostosowujemy strategię marketingową do na- } \\
\text { szych potrzeb }\end{array}$ & 3,8 & 11,6 & 8,5 & 48,6 & 27,6 \\
\hline $\begin{array}{l}\text { Systematycznie staramy się o pozyskanie no- } \\
\text { wych środków finansowych }\end{array}$ & 7,5 & 20,0 & 10,8 & 41,3 & 20,3 \\
\hline
\end{tabular}

Alternatywą dla umiejętności rozwoju zasobów własnych jest umiejętność podjęcia współpracy w celu pozyskania niezbędnych zasobów umożliwiających wy- 
korzystanie szansy. Korzyści wynikające ze współpracy są szeroko w literaturze egzemplifikowane (Eisenhardt i Schoonhoven, 1996, s. 136-150; Kogut, 1988, s. 319-332, Kozłowski i Matejun, 2012, s. 36-37). Jak zauważa E. Stańczyk-Hugiet (2013, s. 75-76), współpraca może wzmacniać możliwości generowania wartości, dając możliwość wykorzystania szans, nabycia wiedzy oraz innych zasobów niebędących w posiadaniu przedsiębiorstwa. Istotnym aspektem jest zdolność podmiotów do kształtowania relacji współpracy. Samoorganizacja przedsiębiorstw, stanowiąca warunek konieczny zwinności strategicznej, pozostaje w relacji z mechanizmami, dzięki którym jest możliwe zrozumienie problemów i wyzwań, a w konsekwencji identyfikowanie i kształtowanie relacji z właściwymi partnerami. Współczesne warunki gospodarcze wymusiły zmianę oczekiwań dotyczących współpracy, aspekt jakościowy, jakim jest motyw współpracy, uległ przeformułowaniu. Strategiczne umocnienie konkurencyjności i pozycji na rynku stanowi obecnie główny motyw współpracy (Romanowska, 2007, s. 12).

W obliczu powyższych rozważań poproszono respondentów o ustosunkowanie się do problemu zdolności podejmowania współpracy w celu wykorzystania szans (tabela 4.13). Wykorzystując miary opracowane na podstawie wcześniejszych badań (Maskell, 2001; Zhang i Sharifi, 2001), wyróżniono pięć umiejętności kształtujących obszar współpracy. Do oceny wykorzystano pięciopunktową skalę Likerta, gdzie 1 oznaczało $z$ decydowanie nie, natomiast 5 zdecydowanie tak. Na podstawie wyników ocen średnich można zauważyć, że umiejętności, które zostały przez respondentów najwyżej ocenione, są rozwijanie zdolności współpracy z partnerami zewnętrznymi $(4,18)$ oraz identyfikacja kluczowych partnerów dla przedsiębiorstwa $(4,11)$. Pozostałe umiejętności także uzyskały wysokie oceny średnie, znacznie powyżej przeciętnej, co świadczy o zainteresowaniu przedsiębiorstw obszarem współpracy oraz wagą jego wypływu na działania strategiczne.

Tabela 4.13. Średnia ocena zdolności współpracy

\begin{tabular}{|l|c|}
\hline \multicolumn{1}{|c|}{ Zdolność współpracy } & Średnia ocena \\
\hline Wiemy, jak pozyskać zasoby z zewnątrz przedsiębiorstwa & 3,89 \\
\hline W pozyskaniu zasobów pomagają nam posiadane sieci & 3,79 \\
\hline $\begin{array}{l}\text { Rozróżniamy, kiedy powinniśmy zakupić zasoby z zewnątrz, a kiedy jedynie po- } \\
\text { zyskać do nich dostęp }\end{array}$ & 3,92 \\
\hline Rozwijamy zdolność współpracy z partnerami zewnętrznymi & 4,18 \\
\hline Identyfikujemy kluczowych partnerów & 4,11 \\
\hline
\end{tabular}

Statystyki rozkładu odpowiedzi respondentów wskazują, że zdolności tworzące umiejętność współpracy są w badanych przedsiębiorstwach dość dobrze rozwinięte (tabela 4.14). Co piąte przedsiębiorstwo zdecydowanie wie, jak pozyskać zasoby z zewnątrz, a aż $58 \%$ badanych raczej posiada taką wiedzę. Prawie co czwarte przedsiębiorstwo dysponuje bazą sieci potencjalnych partnerów biznesowych, dzięki cze- 
mu pozyskanie zasobów jest dla nich prostsze. Aż $80 \%$ badanych deklaruje wysoką świadomość dotyczącą umiejętności rozróżnienia, kiedy niezbędne zasoby należy zakupić z zewnątrz, a kiedy jedynie pozyskać do nich dostęp. Znaczny odsetek, bo aż 87\% przedsiębiorstw, raczej lub w pełni deklaruje rozwijanie zdolności współpracy z partnerami, a $85 \%$ identyfikuje kluczowych partnerów dla swojego przedsiębiorstwa. Badanie nie identyfikuje rodzaju relacji współpracy preferowanej przez przedsiębiorstwa, dotyczy jedynie umiejętności i chęci jej podjęcia. Niemniej ciekawe wydają się wnioski z wcześniejszych badań wskazujące, że to właśnie relacje z konkurentami stanowią najważniejszy rodzaj relacji - ze względu na mobilizowanie i aktywizowanie przedsiębiorstw do działania (Stańczyk-Hugiet, 2013, s. 178).

Tabela 4.14. Ocena zdolności współpracy

\begin{tabular}{|l|c|c|c|c|c|}
\hline \multirow{2}{*}{ Zdolność współpracy } & \multicolumn{5}{|c|}{ Procent wskazań } \\
\cline { 2 - 6 } & $\begin{array}{c}\text { zdecy- } \\
\text { dowa- } \\
\text { nie nie }\end{array}$ & $\begin{array}{c}\text { raczej } \\
\text { nie }\end{array}$ & $\begin{array}{c}\text { ani tak, } \\
\text { ani nie }\end{array}$ & $\begin{array}{c}\text { raczej } \\
\text { tak }\end{array}$ & $\begin{array}{c}\text { zdecy- } \\
\text { dowa- } \\
\text { nie tak }\end{array}$ \\
\hline $\begin{array}{l}\text { Wiemy, jak pozyskać zasoby z zewnątrz } \\
\text { przedsiębiorstwa }\end{array}$ & 2,1 & 7,8 & 10,6 & 58,0 & 21,5 \\
\hline $\begin{array}{l}\text { W pozyskaniu zasobów pomagają nam posia- } \\
\text { dane sieci kontaktów }\end{array}$ & 3,8 & 12,0 & 9,2 & 51,9 & 23,1 \\
\hline $\begin{array}{l}\text { Rozróżniamy, kiedy powinniśmy zakupić za- } \\
\text { soby z zewnątrz, a kiedy jedynie pozyskać do } \\
\text { nich dostęp }\end{array}$ & 2,6 & 9,2 & 8,3 & 53,5 & 26,4 \\
\hline $\begin{array}{l}\text { Rozwijamy zdolność współpracy z partnerami } \\
\text { zewnętrznymi }\end{array}$ & 1,7 & 5,0 & 6,4 & 47,9 & 39,2 \\
\hline Identyfikujemy kluczowych partnerów & 1,7 & 6,8 & 7,1 & 47,4 & 37,0 \\
\hline
\end{tabular}

Kolejną ważną miarą przedsiębiorczości strategicznej, której poświęcono uwagę w badaniu, jest zdolność innowacyjna. Innowacyjność jest wykorzystywana jako miara w operacjonalizacji przedsiębiorczości (Li i in., 2009; Jambulingam i in., 2005), również w kontekście zwinności strategicznej (Shin i in., 2015; Oyedijo, 2012), szczególnie ze względu na jej wpływ na tworzenie przewagi konkurencyjnej. Efektywność innowacji jest związana z odmienną zdolnością przedsiębiorstwa do stałego mobilizowania swoich zasobów i zdolności dopasowania do zmieniających się okazji (Lichtenthaler i Muethel, 2012).

Wykorzystane w badaniu miary zostały zaadaptowane z wcześniejszych badań identyfikujących zdolność innowacyjną przedsiębiorstw (Hurley i Hult, 1998; Scott i Bruce, 1994; Jambulingam i in., 2005). Wśród miar zdolności innowacyjnej przyjmuje się między innymi otwartość przedsiębiorstw do poszukiwania innowacyjnych technologii, procesów, technik oraz pomysłów na nowe produkty (Hurley i Hult, 1998; Li i in., 2009). Aż 73\% respondentów zadeklarowało proaktywne działanie w tym 
zakresie, taki sam odsetek badanych przyznał, że w ich przedsiębiorstwach są promowani i wspierani pracownicy, którzy poszukują nowych, kreatywnych rozwiązań. Obie wskazane zdolności uzyskały tę samą ocenę średnią - 3,75 (tabela 4.15). Pozostałe miary uzyskały niższe średnie oceny, jednak przekraczające znacznie poziom przeciętny, co świadczy o dość istotnym ich znaczeniu dla badanych podmiotów.

Tabela 4.15. Średnia ocena zdolności innowacyjnej

\begin{tabular}{|l|c|}
\hline \multicolumn{1}{|c|}{ Zdolność innowacyjna } & Średnia ocena \\
\hline $\begin{array}{l}\text { Poszukujemy innowacyjnych technologii, procesów, technik i (lub) pomysłów } \\
\text { na nowe produkty }\end{array}$ & 3,75 \\
\hline $\begin{array}{l}\text { Promowani i wspierani są pracownicy, którzy poszukują nowych, kreatywnych } \\
\text { rozwiązań }\end{array}$ & 3,75 \\
\hline Nasza firma znana jest jako lider innowacji wśród firm w naszym regionie & 3,28 \\
\hline $\begin{array}{l}\text { Nasza firma intensywnie poszukuje środków (i je zapewnia) potrzebnych do re- } \\
\text { alizacji nowych pomysłów }\end{array}$ & 3,52 \\
\hline Nasza firma nieustannie eksperymentuje z nowymi koncepcjami i pomysłami & 3,35 \\
\hline
\end{tabular}

Pomimo że $64 \%$ badanych przyznało, że ich przedsiębiorstwo intensywnie poszukuje środków potrzebnych do realizacji nowych pomysłów, to aż $34 \%$ respondentów nie zgodziło się ze stwierdzeniem, że ich przedsiębiorstwo znane jest jako lider innowacji wśród przedsiębiorstw w regionie. Zdolność innowacyjna również była mierzona poprzez zdolność przedsiębiorstwa do nieustannego eksperymentowania z nowymi koncepcjami i pomysłami, którą potwierdziło 58\% badanych (tabela 4.16).

Tabela 4.16. Ocena zdolności innowacyjnej

\begin{tabular}{|l|c|c|c|c|c|}
\hline \multirow{2}{*}{ Zdolność innowacyjna } & \multicolumn{5}{|c|}{ Procent wskazań } \\
\cline { 2 - 6 } & $\begin{array}{c}\text { zdecy- } \\
\text { dowa- } \\
\text { nie nie }\end{array}$ & $\begin{array}{c}\text { raczej } \\
\text { nie }\end{array}$ & $\begin{array}{c}\text { ani tak, } \\
\text { ani nie }\end{array}$ & $\begin{array}{c}\text { raczej } \\
\text { tak }\end{array}$ & $\begin{array}{c}\text { zdecy- } \\
\text { dowa- } \\
\text { nie tak }\end{array}$ \\
\hline $\begin{array}{l}\text { Poszukujemy innowacyjnych technologii, proce- } \\
\text { sów, technik i (lub) pomysłów na nowe produkty }\end{array}$ & 5,2 & 14,4 & 7,5 & 45,8 & 27,1 \\
\hline $\begin{array}{l}\text { Promowani i wspierani są pracownicy, którzy } \\
\text { poszukują nowych, kreatywnych rozwiązań }\end{array}$ & 5,4 & 13,2 & 8,7 & 46,0 & 26,7 \\
\hline $\begin{array}{l}\text { Nasza firma znana jest jako lider innowacji } \\
\text { wśród firm w naszym regionie }\end{array}$ & 9.0 & 25,2 & 11,6 & 37,7 & 16,5 \\
\hline $\begin{array}{l}\text { Nasza firma intensywnie poszukuje środków } \\
\text { (i je zapewnia) potrzebnych do realizacji no- } \\
\text { wych pomysłów }\end{array}$ & 5,7 & 19,1 & 11,3 & 45,0 & 18,9 \\
\hline $\begin{array}{l}\text { Nasza firma nieustannie eksperymentuje z no- } \\
\text { wymi koncepcjami i pomysłami }\end{array}$ & 7,5 & 25,5 & 9,0 & 40,3 & 17,7 \\
\hline
\end{tabular}


Zdolność innowacyjna przedsiębiorstwa nie ma możliwości rozwoju bez wsparcia kultury przedsiębiorczej, stanowiącej istotny aspekt przedsiębiorczości strategicznej. Kultura przedsiębiorcza ma na celu jednoczesne poszukiwanie szans i określanie ich korzyści dla przedsiębiorstwa. Jak zauważają R.D. Ireland, M.A. Hitt, D.G. Sirmon (2003), skuteczna kultura przedsiębiorcza to taka, w ramach której oczekuje się nowych pomysłów i kreatywności, zachęcania do podejmowania ryzyka, tolerowania niepowodzenia, promowania uczenia się, innowacji produktowych, procesowych i administracyjnych. Podejmowanie ciągłych zmian jest postrzegane jako potencjalne źródło nowych możliwości. W ramach przeprowadzonego badania w kontekście kultury przedsiębiorczej zaadaptowano miary dostępne w literaturze i wykorzystane we wcześniejszych badaniach (Scott i Bruce, 1994; Li i in., 2009). Wyróżniono pięć czynników współtworzących kulturę przedsiębiorczą oraz poproszono respondentów o ocenę wskazanych postaw i wartości w stosunku do ich przedsiębiorstw w skali $1-5$, gdzie 1 oznaczało $z$ decydowanie nie, natomiast 5 zdecydowanie tak. Prawie $80 \%$ respondentów ocenia swoje przedsiębiorstwa jako elastyczne i umiejące się dostosować do pojawiających się zmian (tabela 4.17). Odpowiedzi respondentów wskazują także, że znaczna większość badanych, bo aż 74\%, potwierdza rozwijanie i podtrzymywanie tych wartości i zachowań w swoich przedsiębiorstwach, które wspierają innowacyjność oraz kreatywność, tworząc kulturę, w której innowacyjność może rozkwitać. Wyniki wskazują na promowanie kultury, w której pracownik może część czasu i zasobów (w pracy) poświęcić na rozwijanie własnych pomysłów, które, jeśli okażą się atrakcyjne, mogą być wdrożone przez przedsiębiorstwo. Taką formę zaangażowania i wykorzystania kreatywności pracowników deklaruje aż 65\% badanych.

Tabela 4.17. Ocena kultury przedsiębiorczej

\begin{tabular}{|l|c|c|c|c|c|}
\hline \multirow{2}{*}{ Kultura przedsiębiorcza } & \multicolumn{5}{|c|}{ Procent wskazań } \\
\cline { 2 - 6 } & $\begin{array}{c}\text { zdecy- } \\
\text { dowa- } \\
\text { nie nie }\end{array}$ & $\begin{array}{c}\text { raczej } \\
\text { nie }\end{array}$ & $\begin{array}{c}\text { ani tak, } \\
\text { ani nie }\end{array}$ & $\begin{array}{c}\text { raczej } \\
\text { tak }\end{array}$ & $\begin{array}{c}\text { zdecy- } \\
\text { dowa- } \\
\text { nie tak }\end{array}$ \\
\hline $\begin{array}{l}\text { Tworzymy kulturę, w której innowacyjność może } \\
\text { rozkwitać }\end{array}$ & 5,0 & 15,1 & 6,8 & 51,4 & 21,7 \\
\hline $\begin{array}{l}\text { Promujemy kulturę, w której pracownik może } \\
\text { część czasu i zasobów (w pracy) poświęcić na } \\
\text { rozwijanie własnych pomysłów }\end{array}$ & 6,6 & 21,0 & 7,3 & 47,6 & 17,5 \\
\hline $\begin{array}{l}\text { Naszą firmę można opisać jako elastyczną } \\
\text { i umiejącą się dostosować do pojawiających } \\
\text { się zmian }\end{array}$ & 2,8 & 11,3 & 6,6 & 57,1 & 22,2 \\
\hline $\begin{array}{l}\text { Rozwijamy i podtrzymujemy te wartości i za- } \\
\text { chowania, które promują innowacyjność oraz } \\
\text { kreatywność }\end{array}$ & 1,9 & 15,3 & 8,7 & 53,5 & 20,5 \\
\hline $\begin{array}{l}\text { W naszej firmie stawiamy na projekty innowa- } \\
\text { cyjne o podwyższonym ryzyku }\end{array}$ & 12,3 & 34,2 & 11,1 & 34,0 & 8,5 \\
\hline
\end{tabular}


Pomimo że niespełna 65\% respondentów uznało, że ryzyko w otoczeniu gospodarczym jest przez nich traktowane jako szansa na pojawienie się ciekawych okazji, a zarządzających w przedsiębiorstwach charakteryzuje energia, przedsiębiorczość i chętnie podejmują ryzyko, to jedynie $8,5 \%$ ankietowanych przyznało, że ich przedsiębiorstwa stawiają na projekty innowacyjne o podwyższonym ryzyku. Wynik ten może oznaczać, że pomimo otwartej postawy wobec ryzyka projekty obarczone wysokim ryzykiem nie są dla badanych przedsiębiorstw priorytetowe.

\subsubsection{Elastyczność przedsiębiorstw}

Zwinność strategiczna przedsiębiorstwa jako zdolność do podejmowania zmian strategicznych i radzenia sobie $z$ dynamiką otoczenia wymaga elastyczności operacyjnej, przejawiającej się w elastyczności zasobów oraz procesów oraz elastyczności finansowej. I to te dwa aspekty elastyczności stanowiły podstawę przygotowania narzędzi pomiarowych w ankiecie. Celem elastyczności działania w warunkach zwinności jest między innymi szybsza reakcja na zróżnicowane wzorce popytu, efektywniejsze zorientowanie na klienta i rynek, lepsze zrozumienie potrzeb klienta i bliższe relacje z klientem, elastyczność produkcji w różnych partiach produkcyjnych, elastyczność produkcji produktów unikatowych, elastyczność produkcji szerokiego zakresu produktów, zdolność do szybkiego reagowania na nowe szanse rynkowe. Elastyczność operacyjna umożliwia przedsiębiorstwu szybką rekonfigurację zasobów oraz obecnych procesów i kreowanie nowych procesów umożliwiających wykorzystanie dynamicznie zmieniających się warunków rynkowych.

W przeprowadzonym badaniu zapytano respondentów o charakterystykę otoczenia, w którym funkcjonują reprezentowane przez nich przedsiębiorstwa, i aż 76\% respondentów zwróciło uwagę na obecność wysokiej dynamiki otoczenia. Co drugi respondent stwierdzil, że jego przedsiębiorstwo funkcjonuje w średnio turbulentnym otoczeniu, natomiast $27,6 \%$ uznało, że zmienność otoczenia ich przedsiębiorstwa jest wysoka. Następnie poproszono respondentów o ocenę ogólnego poziomu umiejętności dostosowawczych ich przedsiębiorstwa. Wyniki badań wskazały, ze znaczna część badanych przedsiębiorstw (85\%) ocenia średnio lub wysoko poziom swoich umiejętności dostawczych (rysunek 4.3). Dalsze pogłębione badania w zakresie poszczególnych obszarów elastyczności potwierdziły złożone na tym etapie deklaracje.

Wśród przedsiębiorstw deklarujących wysoki poziom umiejętności dostosowawczych aż 73,9\% to przedsiębiorstwa średnie, zatrudniające 50-249 pracowników. Jedynie $9,4 \%$ to firmy bardzo młode, prowadzące działalność nie dłużej niż pięć lat, natomiast większość to przedsiębiorstwa dojrzałe prowadzące działalność 10-25 lat $(43,5 \%)$ oraz przedsiębiorstwa funkcjonujące na rynku powyżej 25 lat (34,8\%). Wyniki wskazują, że nabycie umiejętności dostosowawczych to długi proces, wymagający wypracowania skutecznych praktyk zintegrowanych z kluczowymi obszarami przedsiębiorstwa, umożliwiających szybkie, efektywne podejmowanie zmian. Wśród 


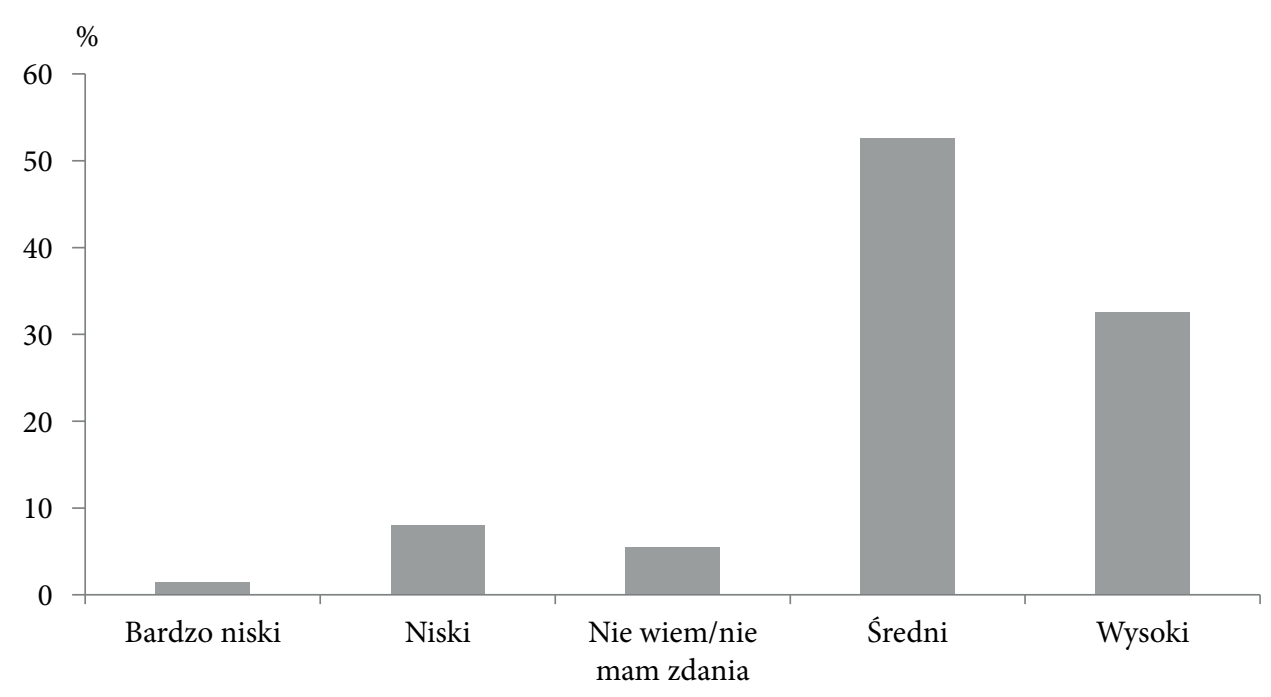

Rysunek 4.3. Ogólny poziom umiejętności dostosowawczych

przedsiębiorstw o wysokim poziomie umiejętności dostosowawczych aż 51,4\% to przedsiębiorstwa, których sektor jest w fazie dojrzałości, natomiast $41 \%$ respondentów reprezentowało sektory $\mathrm{w}$ fazie wzrostowej. Ze względu na zróżnicowanie umiejętności dostosowawczych, umiejętności strategiczne (identyfikacja i wykorzystanie okazji) oraz umiejętności operacyjne (elastyczność działań) otrzymane wyniki można zinterpretować w następujący sposób. Przedsiębiorstwa prowadzące działalność w sektorach dojrzałych, czyli charakteryzujących się bardzo trudnym dostępem do sektora, w którym większość zysków jest przejmowana przez jego liderów, a malejąca dynamika sprzedaży jest rekompensowana spadkiem kosztów inwestowania w nowe technologie, dysponując nadwyżką kapitału, mogą zainwestować ją w działania dostosowawcze do warunków otoczenia. Budowa nowej hali produkcyjnej czy wdrożenie nowego zintegrowanego informatycznego systemu zarządzania, rozbudowa działu handlowego, szkolenia pracowników to tylko niektóre przykłady kapitałochłonnych działań dostosowawczych. Inaczej przedstawia się sytuacja dla przedsiębiorstw funkcjonujących w sektorach wzrostowych, gdzie duża dynamika sprzedaży przy malejącej dynamice uczestników sektora pozwala na osiąganie dużych zysków, ale jednocześnie skłania inwestorów do dalszych inwestycji, czego konsekwencją jest pojawienie się dobrych produktów, silnej dynamiki sprzedaży i ochrony sektora. Znaczne możliwości wzrostu i rozwijające się technologie zachęcają do identyfikowania, odkrywania bądź też tworzenia szans i podejmowania strategicznych wyzwań w celu dostosowania się do zmieniających się warunków rynkowych.

W ramach przeprowadzonego badania przeanalizowano stopień implementacji wybranych przekaźników zwinności, czyli koncepcji, metod i narzędzi zarządza- 
nia, które mogą wspomagać przedsiębiorstwa w osiąganiu większej elastyczności działania (rysunek 4.4). Wśród wybranych przekaźników zwinności największą popularnością cieszy się kultura sprzyjająca uczeniu się, której wdrożenie zadeklarowało co drugie przedsiębiorstwo, co czwarte natomiast wykorzystuje outsourcing oraz koncepcję just in time. Wykorzystanie partnerstwa w łańcuchu dostaw (współpracy między dostawcami i nabywcami w ramach dopełniających się kompetencji w celu zwiększania zdolności konkurowania) zadeklarowało $36 \%$ respondentów. $\mathrm{Na}$ podobnym poziomie (30\%) odnotowano wdrożenie kompleksowego zarządzania jakością (m.in. lean, upraszczanie procesów) oraz systematycznego doskonalenia (kaizen), nieco mniej przedsiębiorstw korzysta z korzyści, jakie przynosi rozwiązanie six sigma (22\%). Design thinking jako kreatywny proces projektowania wykorzystuje $22 \%$ spośród badanych przedsiębiorstw.

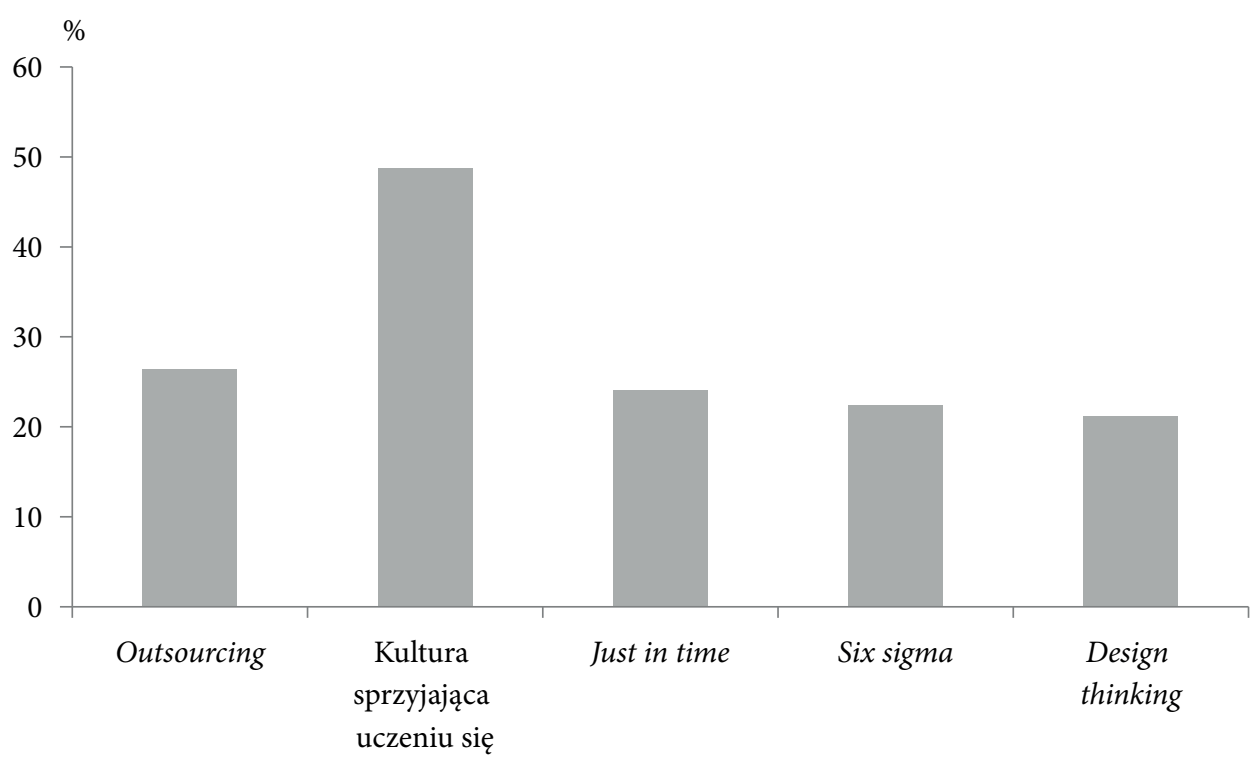

Rysunek 4.4. Wykorzystanie przekaźników zwinności

Przyjmując założenie zgodne z podejściem zasobowym, że przedsiębiorstwo jest rozpatrywane jako zbiór szeroko rozumianych zasobów, który podlega transformacji, elastyczność można odnieść do poszczególnych jego rodzajów (Osbert-Pociecha, 2011, s. 146). R. Krupski (2005, s. 24) uważa, że elastyczność rozumiana jako reakcja na impulsy $\mathrm{z}$ otoczenia lub $\mathrm{z}$ wnętrza przedsiębiorstwa jest podejmowana $\mathrm{w}$ konfrontacji z potencjałem zasobowym organizacji. Zwinność strategiczna wiąże się z umiejętnością rekonfigurowania dostępnych zasobów oraz zdolnością inicjowania i modyfikowania niezbędnych przedsięwzięć oraz bieżącym sterowaniem ich realizacją. U podstaw tej umiejętności leży elastyczność zasobów, która w du- 
żej mierze przesądza o możliwości wykorzystania pojawiających się szans szybciej aniżeli konkurenci. Y. Doz i M. Kosonen (2008a) również wskazują na kluczowy wpływ elastyczności we współtworzeniu zwinności strategicznej. Uznają mobilność zasobów (resource fludity) za zdolność do rekonfigurowania systemów biznesowych oraz szybkiego przemieszczania zasobów opartą na procesach alokacji zasobów, podejściu do zarządzania ludźmi oraz na wykorzystaniu mechanizmów współpracy ukierunkowanych na szybsze i prostsze działanie modeli biznesu.

W przeprowadzonym badaniu respondenci zostali poproszeni o ustosunkowanie się do stwierdzeń określających poziom elastyczności zasobów reprezentowanych przez ich przedsiębiorstwa, stosując pięciopunktową skalę, gdzie 1 oznaczało zdecydowanie nie, a 5 zdecydowanie tak. Analiza przeprowadzonych badań pozwala stwierdzić, że w badanych średnich i dużych przedsiębiorstwach występuje ponadprzeciętna elastyczność zasobów w ramach badanych obszarów (ludzki, rzeczowy, organizacyjny, marketingowy, informacyjny oraz finansowy). W tabeli 4.18 przedstawiono średnie oceny elastyczności poszczególnych rodza-

Tabela 4.18. Średnia ocena elastyczności zasobów

\begin{tabular}{|c|c|}
\hline Elastyczność zasobów & $\begin{array}{c}\text { Średnia } \\
\text { ocena }\end{array}$ \\
\hline \multicolumn{2}{|l|}{ Zasoby ludzkie } \\
\hline $\begin{array}{l}\text { Istnieje możliwość zmiany liczby zatrudnionych w zależności od wielkości produkcji, } \\
\text { płac, wydajności, sytuacji na rynku }\end{array}$ & 3,57 \\
\hline Istnieje możliwość doszkalania pracownika w celu osiągnięcia wielozadaniowości & 3,88 \\
\hline \multicolumn{2}{|l|}{ Zasoby rzeczowe } \\
\hline $\begin{array}{l}\text { Występuje elastyczność asortymentu produkcji, czyli możliwość szybkiego i ekono- } \\
\text { micznego przejścia do produkcji nowych wyrobów }\end{array}$ & 3,38 \\
\hline $\begin{array}{l}\text { Występuje elastyczność wielkości produkcji, czyli zdolność do efektywnych zmian wiel- } \\
\text { kości produkcji }\end{array}$ & 3,50 \\
\hline \multicolumn{2}{|l|}{ Zasoby organizacyjne } \\
\hline Występuje spłaszczona struktura organizacyjna sprzyjająca szybszej decyzyjności & 3,65 \\
\hline Relacje z partnerami są oparte na długoterminowych umowach & 3,91 \\
\hline \multicolumn{2}{|l|}{ Zasoby marketingowe } \\
\hline Istnieje u nas możliwość szybkiej zmiany strategii promocji & 3,47 \\
\hline Wykorzystujemy zróżnicowane kanały dystrybucji & 3,47 \\
\hline \multicolumn{2}{|l|}{ Zasoby informacyjne } \\
\hline $\begin{array}{l}\text { Informacja o zmianach rynkowych jest szybko wykorzystywana do wprowadzania } \\
\text { zmian w działalności firmy }\end{array}$ & 3,52 \\
\hline $\begin{array}{l}\text { Informację o rynku uzyskujemy z baz danych, które są integralną częścią naszego syste- } \\
\text { mu informacyjnego }\end{array}$ & 3,26 \\
\hline \multicolumn{2}{|l|}{ Zasoby finansowe } \\
\hline Korzystamy z celowych źródeł finansowania & 3,39 \\
\hline Wykorzystujemy dźwignię finansową & 2,86 \\
\hline
\end{tabular}


jów zasobów, a w tabeli 4.19 wskazano procentowy udział odpowiedzi poszczególnych ocen tych zasobów.

Wszystkie badane obszary uzyskały oceny znacznie powyżej średniej (z wyjątkiem jednej ze zmiennych składających się na elastyczność finansową), co świadczy o ponadprzeciętnym poziomie elastyczności zasobów badanych przedsiębiorstw. Najwyższą ocenę średnią uzyskała elastyczność zasobów organizacyjnych, na któ-

Tabela 4.19. Ocena elastyczności zasobów

\begin{tabular}{|c|c|c|c|c|c|c|}
\hline \multirow[b]{2}{*}{$\begin{array}{l}\text { Rodzaje } \\
\text { zasobów }\end{array}$} & \multirow[b]{2}{*}{ Czynniki } & \multicolumn{5}{|c|}{ Procent wskazań } \\
\hline & & $\begin{array}{l}\text { zdecy- } \\
\text { dowa- } \\
\text { nie nie }\end{array}$ & $\begin{array}{c}\text { raczej } \\
\text { nie }\end{array}$ & $\begin{array}{l}\text { ani tak, } \\
\text { ani nie }\end{array}$ & $\begin{array}{c}\text { raczej } \\
\text { tak }\end{array}$ & $\begin{array}{l}\text { zdecy- } \\
\text { dowa- } \\
\text { nie tak }\end{array}$ \\
\hline \multirow[t]{2}{*}{$\begin{array}{l}\text { Zasoby } \\
\text { ludzkie }\end{array}$} & $\begin{array}{l}\text { istnieje możliwość zmiany liczby za- } \\
\text { trudnionych w zależności od wiel- } \\
\text { kości produkcji, płac, wydajności, } \\
\text { sytuacji na rynku }\end{array}$ & 7,5 & 17,5 & 7,1 & 46,0 & 21,9 \\
\hline & $\begin{array}{l}\text { istnieje możliwość doszkalania pra- } \\
\text { cownika w celu osiągnięcia wieloza- } \\
\text { daniowości }\end{array}$ & 4,5 & 11,6 & 4,2 & 50,9 & 28,8 \\
\hline \multirow[t]{2}{*}{$\begin{array}{l}\text { Zasoby } \\
\text { rzeczowe }\end{array}$} & $\begin{array}{l}\text { występuje elastyczność asortymen- } \\
\text { tu produkcji, czyli możliwość szyb- } \\
\text { kiego i ekonomicznego przejścia do } \\
\text { produkcji nowych wyrobów }\end{array}$ & 10,8 & 18,4 & 10,6 & 41,7 & 18,4 \\
\hline & $\begin{array}{l}\text { występuje elastyczność wielkości pro- } \\
\text { dukcji, czyli zdolność do efektywnych } \\
\text { zmian wielkości produkcji }\end{array}$ & 5,4 & 20,8 & 10,8 & 44,3 & 18,6 \\
\hline \multirow[t]{2}{*}{$\begin{array}{l}\text { Zasoby } \\
\text { organiza- } \\
\text { cyjne }\end{array}$} & $\begin{array}{l}\text { występuje spłaszczona struktura or- } \\
\text { ganizacyjna sprzyjająca szybszej de- } \\
\text { cyzyjności }\end{array}$ & 4,7 & 16,0 & 9,2 & 49,3 & 20,8 \\
\hline & $\begin{array}{l}\text { relacje z partnerami są oparte na dłu- } \\
\text { goterminowych umowach }\end{array}$ & 4,0 & 10,6 & 6,1 & 48,8 & 30,4 \\
\hline \multirow{2}{*}{$\begin{array}{l}\text { Zasoby } \\
\text { marketin- } \\
\text { gowe }\end{array}$} & $\begin{array}{l}\text { istnieje u nas możliwość szybkiej } \\
\text { zmiany strategii promocji }\end{array}$ & 5,2 & 22,4 & 9,4 & 46,5 & 16,5 \\
\hline & $\begin{array}{l}\text { wykorzystujemy zróżnicowane kana- } \\
\text { ły dystrybucji }\end{array}$ & 7,5 & 20,8 & 9,0 & 42,9 & 19,8 \\
\hline \multirow[t]{2}{*}{$\begin{array}{l}\text { Zasoby } \\
\text { informa- } \\
\text { cyjne }\end{array}$} & $\begin{array}{l}\text { informacja o zmianach rynkowych } \\
\text { jest szybko wykorzystywana do wpro- } \\
\text { wadzania zmian w działalności firmy } \\
\end{array}$ & 5,4 & 21,0 & 8,5 & 46,7 & 18,4 \\
\hline & $\begin{array}{l}\text { informację o rynku uzyskujemy z baz } \\
\text { danych, które są integralną częścią } \\
\text { naszego systemu informacyjnego }\end{array}$ & 10,1 & 25,2 & 9,4 & 38,9 & 16,3 \\
\hline \multirow[t]{2}{*}{$\begin{array}{l}\text { Zasoby fi- } \\
\text { nansowe }\end{array}$} & $\begin{array}{l}\text { korzystamy z celowych źródeł finan- } \\
\text { sowania }\end{array}$ & 12,5 & 16,3 & 9,9 & 42,0 & 19,3 \\
\hline & wykorzystujemy dźwignię finansową & 17,5 & 29,2 & 13,4 & 29,5 & 10,4 \\
\hline
\end{tabular}


rą składała się spłaszczona struktura organizacyjna $(3,65)$, sprzyjająca szybszej decyzyjności, obecna w 70\% przedsiębiorstw oraz relacje z partnerami oparte na długoterminowych umowach $(3,91)$, które deklaruje aż $80 \%$ badanych. Otrzymane wyniki są zgodne z prezentowanymi w literaturze. $Z$ badań $G$. Osbert-Pociechy, M. Moroza oraz J. Lichtarskiego (2008) podejmujących tematykę elastyczności cząstkowych przedsiębiorstwa wynika, że jedną z trzech kluczowych elastyczności cząstkowych w przedsiębiorstwie mających wpływ na elastyczność całkowitą jest elastyczność struktur organizacyjnych, pozostałe dwie to elastyczność zbytu i procesów podstawowych. Ocenę średnią znacznie ponadprzeciętną uzyskał także wskaźnik odnoszący się do zasobów ludzkich, wskazujący na możliwość doszkalania pracowników w celu osiągnięcia zdolności do wielozadaniowości $(3,88)$. Aż 80\% respondentów zadeklarowało możliwość rozwoju pracowników poprzez szkolenia. Wysokie oceny średnie w obszarze zarówno zasobów ludzkich, jak i zasobów organizacyjnych mają poparcie w literaturze. Z badań S. Flaszewskiej oraz A. Zakrzewskiej-Bielawskiej (2013) wynika, że elastyczność struktur organizacyjnych jest tym większa, im bardziej przedsiębiorstwo jest oparte na wiedzy (zwłaszcza w obszarze eksploracji).

Zdolność przedsiębiorstwa do bycia elastycznym i możliwość reagowania na zmiany jest warunkowana zdolnością pozyskania środków finansowych na pokrycie potrzeb związanych z dokonywaniem zmian. Elastyczność finansowa to zdolność do pozyskiwania finansowania lub jego restrukturyzacji przy odpowiednio niskich kosztach transakcyjnych (Osbert-Pociecha i Pociecha, 2006, s. 112). Jak definiują G. Osbert-Pociecha i współautorzy (2008), przedsiębiorstwa elastyczne pod względem finansowym to takie, które są zdolne do unikania problemów finansowych w obliczu nagłych zmian na rynku oraz do relatywnie taniego i szybkiego pozyskania środków za zapewnienie realizacji przedsięwzięć, w sytuacji kiedy pojawiają się nowe możliwości (okazje) osiągania zysków. Elastyczność finansowa według tych autorów może być zatem zwiększana poprzez:

- kształtowanie struktury kapitałowej,

- sterowanie zadłużeniem, czyli kształtowanie jego poziomu oraz dywersyfikacji źródeł pozyskania środków finansowych,

- wykorzystanie innych instrumentów zapewniających elastyczność w tym obszarze.

Najniższe oceny średnie w ramach rodzajów zasobów uzyskał obszar określający właśnie elastyczność finansową. W ramach tego obszaru korzystanie z dźwigni finansowej uzyskało najniższą ocenę średnią $(2,86)$, a jedynie $10 \%$ badanych zadeklarowało zdecydowane jej wykorzystanie. Może to wynikać z trudności w spełnieniu dwóch podstawowych warunków uzyskania dodatniego efektu dźwigni finansowej wyrażającego się wzrostem stopy zwrotu z kapitału własnego przedsiębiorstwa dzięki wykorzystywaniu obcych źródeł kapitału. Po pierwsze, dodatni efekt może wystąpić wówczas, gdy rentowność całego kapitału (własnego i obcego) przedsiębiorstwa będzie wyższa od stopy oprocentowania długu (kapitału obcego). W przeciwnym 
razie zysk operacyjny wypracowany przez kapitał obcy będzie niższy od kwoty odsetek, a dodatkowo należne odsetki mogą pochłonąć część zysku operacyjnego wypracowanego przez kapitał własny, obniżając tym samym jego rentowność. Drugim warunkiem zapewniającym wystąpienie dodatniego efektu dźwigni finansowej jest zachowanie właściwej, optymalnej struktury finansowania. Zbyt wysoki udział długu w strukturze finansowania przedsiębiorstwa może bowiem spowodować wzrost ryzyka bankructwa. Niemniej korzystanie z celowych źródeł finansowania, takich jak kredyty, poręczenia, dotacje, potwierdziło $60 \%$ ankietowanych.

W ramach poszczególnych elastyczności cząstkowych, poza elastycznością zasobów zasadniczą i pierwotną, jest elastyczność procesów podstawowych (Osbert-Pociecha i in., 2008). Procesowe podejście pozwala na precyzyjniejszy pomiar elastyczności (Kasiewicz i in., 2009, s. 62), a przedmiotem pomiaru mogą być procesy na poziomie organizacji, jak i procesy na poziomie funkcjonalnym. W ramach przeprowadzonego badania wyróżniono cztery kluczowe procesy organizacyjne, do których zaliczono: proces produkcyjny, proces logistyczny, proces marketingowy oraz proces sprzedażowy. Zwinność strategiczna jako zdolność do radzenia sobie z dynamiką otoczenia jest determinowana elastycznością procesów poprzez zdolność do (Grajewski, 2007, s. 80):

- całkowitych zmian,

- doskonalenia,

- zmiany kolejności wykonywanych czynności dzięki podatności na transformację użytych zasobów,

- szybkiej reakcji na zmiany oczekiwań klientów.

Analiza średnich ocen elastyczności czterech wskazanych procesów, z których wszystkie uzyskały oceny powyżej 3,0, pozwala wnioskować o ponadprzeciętnym poziomie elastyczności procesów średnich i dużych przedsiębiorstw. Wyniki badań wskazały, że najwyżej została oceniona przez menedżerów elastyczność procesów sprzedażowych $(3,80)$ oraz elastyczność procesów logistycznych $(3,72)$ (tabela 4.20).

Tabela 4.20. Średnia ocena elastyczności procesów

\begin{tabular}{|l|c|}
\hline \multicolumn{1}{|c|}{ Elastyczność procesów } & $\begin{array}{c}\text { Średnia } \\
\text { ocena }\end{array}$ \\
\hline $\begin{array}{l}\text { Występuje u nas elastyczny proces produkcyjny (możliwości przezbrojenia, zmiany wy- } \\
\text { twarzanych wyrobów) }\end{array}$ & 3,46 \\
\hline $\begin{array}{l}\text { Występuje u nas elastyczny proces logistyczny (łańcuch dostaw, realizacja i kontrola) - } \\
\text { zaopatrzenie }\end{array}$ & 3,72 \\
\hline $\begin{array}{l}\text { Występuje u nas elastyczny proces marketingowy (umowy marketingowe, kanały ko- } \\
\text { munikacyjne, narzędzia promocyjne) }\end{array}$ & 3,68 \\
\hline $\begin{array}{l}\text { Występuje u nas elastyczny proces sprzedażowy (badanie potrzeb klienta, przygotowa- } \\
\text { nie oferty, prezentacja oferty i finalizacja transakcji, obsługa) }\end{array}$ & 3,80 \\
\hline
\end{tabular}


Aż 75\% badanych wskazuje na występującą elastyczność procesu sprzedażowego w zakresie badania potrzeb klienta, przygotowania oferty i jej prezentacji oraz finalizacji transakcji i obsługi. Ponad 70\% badanych wskazało także na obecność elastycznego procesu logistycznego w ramach łańcucha dostaw, realizacji i kontroli. Porównywalnie wysoko oceniona została elastyczność procesu marketingowego (ze średnią 3,68), której realizację w reprezentowanych przedsiębiorstwach potwierdziło $70 \%$ respondentów (tabela 4.21). Elastyczność tego obszaru umożliwia przetwarzanie sygnałów rynkowych i adaptację do zmieniających się oczekiwań klientów poprzez kształtowanie wykorzystania instrumentów marketingowo-sprzedażowych.

Tabela 4.21. Ocena elastyczności procesów

\begin{tabular}{|l|c|c|c|c|c|}
\hline \multirow{2}{*}{ Elastyczność procesów } & \multicolumn{5}{|c|}{ Procent wskazań } \\
\cline { 2 - 6 } & $\begin{array}{c}\text { zdecy- } \\
\text { dowa- } \\
\text { nie nie }\end{array}$ & $\begin{array}{c}\text { raczej } \\
\text { nie }\end{array}$ & $\begin{array}{c}\text { ani tak, } \\
\text { ani nie }\end{array}$ & $\begin{array}{c}\text { raczej } \\
\text { tak }\end{array}$ & $\begin{array}{c}\text { zdecy- } \\
\text { dowa- } \\
\text { nie tak }\end{array}$ \\
\hline $\begin{array}{l}\text { Występuje u nas elastyczny proces produkcyjny } \\
\text { (możliwości przezbrojenia, zmiany wytwarza- } \\
\text { nych wyrobów) }\end{array}$ & 4,5 & 21,0 & 15,3 & 42,2 & 17,0 \\
\hline $\begin{array}{l}\text { Występuje u nas elastyczny proces logistycz- } \\
\text { ny (łańcuch dostaw, realizacja i kontrola) - za- } \\
\text { opatrzenie }\end{array}$ & 2,8 & 15,3 & 9,4 & 51,4 & 21,0 \\
\hline $\begin{array}{l}\text { Występuje u nas elastyczny proces marketingo- } \\
\text { wy (umowy marketingowe, kanały komunika- } \\
\text { cyjne, narzędzia promocyjne) }\end{array}$ & 3,3 & 17,0 & 10,1 & 47,9 & 21,7 \\
\hline $\begin{array}{l}\text { Występuje u nas elastyczny proces sprzedażowy } \\
\text { (badanie potrzeb klienta, przygotowanie ofer- } \\
\text { ty, prezentacja oferty i finalizacja transakcji, } \\
\text { obsługa) }\end{array}$ & 3,8 & 11,8 & 9,4 & 50,7 & 24,3 \\
\hline
\end{tabular}

Elastyczność stanowi odpowiedź na rosnącą złożoność i niepewność w funkcjonowaniu organizacji. Niezależnie od jej przejawów, stanowi zestaw cech cząstkowych, właściwości, które składają się na atrybut przedsiębiorstwa. Podsumowując wyniki badań w tym obszarze, można uznać, że w badanych przedsiębiorstwach elastyczność operacyjna i finansowa stanowią istotną i pożądaną cechę, konieczną dla ich funkcjonowania we współczesnych warunkach gospodarczych.

\subsubsection{Przywództwo strategiczne przedsiębiorstw}

Zwinność strategiczna wymaga przywództwa ukierunkowanego na cele przedsiębiorstwa spójne z jego wizją, przy jednoczesnym zapewnieniu szybkiej ich operacjonalizacji oraz osadzeniu w rzeczywistości i ograniczeniach danego przedsiębiorstwa. 
Rozwój przywództwa przez lata był podyktowany zmieniającymi się warunkami funkcjonowania przedsiębiorstw, wzmożoną zmiennością otoczenia oraz eksploracją nowych sposobów zarządzania ludźmi. F. Laloux (2015), łącząc psychologię z zarządzaniem, dokonał klasyfikacji starszych i nowszych technik zarządzania w zależności od ich wpływu na ludzi i kulturę organizacyjną i odkrył, że im lepiej są dostosowane techniki zarządzania do uwarunkowań funkcjonowania przedsiębiorstw, tym wyższy jest stopień kultury organizacyjnej (wyrażony kolorem z teorii Kena Wilbera). Autor twierdzi, że im wyższy stopień kultury organizacyjnej, tym większa zdolność innowacyjna przedsiębiorstwa, większe spełnienie zawodowe jego pracowników oraz trwalsze i lepsze wyniki prowadzonej działalności (Laloux, 2015, s. 7). Praca F. Laloux (2015) stanowiła inspirację dla prowadzonych badań w zakresie przywództwa, potwierdzając zasadność wskazanych cech oraz praktyk i technik wspierających przywództwo strategiczne, a dostępnych w literaturze z zakresu zwinności.

Efektywność przywództwa strategicznego jest uwarunkowana stosowaniem prostych zasad, na które wskazują A. Gostick oraz C. Elton (2009, s. 39). Według autorów podstawą jest zwiększanie zaangażowania pracowników nie tylko poprzez ich udział w ustalaniu celów, lecz także umożliwienie im wpływu na kształt strategii i strategicznego kierunku rozwoju. Konieczne jest także stosowanie otwartego stylu komunikacji o charakterze doradczym, który pozwoli na wykorzystanie indywidualnego potencjału pracowników. Budowanie atmosfery zaufania oraz docenienie zaangażowania i odpowiedzialności motywuje pracowników do większego wysiłku. Przywództwo strategiczne wspiera przekonanie o kreatywności pracowników oraz możliwości osiągnięcia sukcesu dzięki współdziałaniu i partycypacji. Jest to możliwe przy wsparciu organicznej struktury organizacyjnej, szczególnie zalecanej dla przedsiębiorstw funkcjonujących w niestabilnym i trudnym do prognozowania otoczeniu (Burns i Stalker, 1961). Ze względu na szybko zmieniające się uwarunkowania zewnętrzne funkcjonowania przedsiębiorstw pozyskiwanie wiedzy o otoczeniu powinno się odbywać także na niższych szczeblach w hierarchii. Zarówno wiedza, jak i podejmowanie decyzji powinny być dystrybuowane na niższe szczeble. Badania przeprowadzone przez J. Hage oraz R. Dewar (1973) wskazały, że decentralizacja władzy przy niskiej formalizacji oraz wysokiej kompleksowości kompetencyjnej pracowników wpływa na wzrost stopnia innowacyjności przedsiębiorstwa. Konkluzją z przeprowadzonego przez naukowców badania była teza, że struktura organiczna jest bardziej innowacyjna, elastyczna i zdolna do adaptowania się do zmian w warunkach zmiennego i niestabilnego otoczenia (Hage i Dewar, 1973). Wśród cech charakterystycznych dla struktury organicznej wymienia się także: niewielką liczbę szczebli hierarchicznych, otwartą i nieformalną komunikację, brak barier pomiędzy działami funkcyjnymi i jednostkami oraz wielofunkcyjność i płynność pełnionych ról (Sherehity i in., 2007).

Pierwszy etap postępowania badawczego $\mathrm{w}$ ramach przywództwa strategicznego dotyczył oceny natężenia występowania wybranych wymiarów tworzących 
przywództwo. Na podstawie literatury z zakresu zwinności przedsiębiorstw wyróżniono sześć obszarów stanowiących wymiary konstruktu teoretycznego, jakim jest przywództwo strategiczne, są nimi: samodzielność pracowników, poziom formalizacji, empowerment, wielofunkcyjność i zaangażowanie pracowników, podstawa przywództwa (przywództwo charyzmatyczne oraz organiczne) oraz rola przywództwa w przedsiębiorstwie (Vokurka i Fliender, 1998; Meredith i Francis, 2000; Sherehity i in., 2007; Vazquez-Bustelo i in., 2007). Pomiar był dokonywany na pięciostopniowej skali Likerta, gdzie 1 oznaczało zdecydowanie nie, natomiast 5 zdecydowanie tak.

Tabela 4.22. Średnia ocena zdolności przywództwa strategicznego według wybranych cech

\begin{tabular}{|c|c|}
\hline Przywództwo strategiczne & $\begin{array}{c}\text { Średnia } \\
\text { ocena }\end{array}$ \\
\hline \multicolumn{2}{|l|}{ Samodzielność pracowników } \\
\hline $\begin{array}{l}\text { Struktura firmy pozwala pracownikom na dużą samodzielność (płaska struktura orga- } \\
\text { nizacyjna) }\end{array}$ & 3,35 \\
\hline Funkcjonujemy w ramach samoorganizujących się zespołów & 2,91 \\
\hline \multicolumn{2}{|l|}{ Poziom formalizacji } \\
\hline Mamy niską formalizację & 3,23 \\
\hline Kładziemy nacisk na szybkość w podejmowaniu decyzji & 3,72 \\
\hline \multicolumn{2}{|l|}{ Umocowanie szczebla wykonawczego } \\
\hline Pomysły i wiedza pracowników jest często wykorzystywana & 3,77 \\
\hline Cenimy uczących się pracowników & 3,86 \\
\hline \multicolumn{2}{|l|}{ Wielofunkcyjność i zaangażowanie pracowników } \\
\hline $\begin{array}{l}\text { W zarządzaniu ludźmi stawiamy na rozwój wysoko wykwalifikowanych, obdarzonych } \\
\text { zaufaniem ludzi pracujących w zespole }\end{array}$ & 3,96 \\
\hline $\begin{array}{l}\text { Zarządzanie jest oparte na współpracy, wielofunkcyjnych i zaangażowanych pracowni- } \\
\text { ków }\end{array}$ & 3,92 \\
\hline \multicolumn{2}{|l|}{ Podstawa przywództwa } \\
\hline $\begin{array}{l}\text { Przywódca w naszej firmie odwołuje się do emocji, inspiruje członków grupy do więk- } \\
\text { szych osiągnięć }\end{array}$ & 3,43 \\
\hline $\begin{array}{l}\text { Charyzma przywódcy, wspólna wizja oraz indywidualne podejście do grupy stanowią } \\
\text { źródło oddania i zaangażowania pracowników }\end{array}$ & 3,56 \\
\hline Podstawą przywództwa jest komunikacja z pracownikami & 3,76 \\
\hline $\begin{array}{l}\text { W ramach realizowanych projektów przywódcy mogą się wyłaniać spośród grupy za- } \\
\text { miast być formalnie wyznaczeni }\end{array}$ & 3,33 \\
\hline \multicolumn{2}{|l|}{ Rola przywództwa } \\
\hline $\begin{array}{l}\text { Przywództwo w naszej firmie zakłada tworzenie i wdrażanie strategii dla nieprzewi- } \\
\text { dzianych zdarzeń dla zapewnienia przetrwania i rozwoju }\end{array}$ & 3,59 \\
\hline $\begin{array}{l}\text { Istotą przywództwa jest wprowadzanie zmian (zapewnienie firmie adaptacji do otocze- } \\
\text { nia) }\end{array}$ & 3,71 \\
\hline
\end{tabular}


Uzyskane wyniki pozwalają na wskazanie praktyk w ramach przywództwa strategicznego najczęściej wykorzystywanych według opinii respondentów. Oceny średnie prawie wszystkich wskazanych wymiarów (z wyjątkiem jednego - samodzielność pracowników w kontekście samoorganizujących się zespołów - 2,91) uzyskały oceny powyżej wartości przeciętnej (tabela 4.22), co świadczy o dużym zainteresowaniu przedsiębiorstw wskazanymi obszarami wspierającymi rozwój umiejętności przywództwa strategicznego. Najwyższe oceny średnie uzyskały zarówno umocowanie szczebla wykonawczego (empowerment), jak i wielofunkcyjność i zaangażowanie pracowników. Respondenci zadeklarowali, że pomysły i wiedza pracowników są często wykorzystywane i jednocześnie doceniane przez przełożonych. Bardzo wysoko zostało ocenione przez respondentów promowanie wykwalifikowanych pracowników oraz zarządzanie oparte na współpracy, oba działania wspierają wielofunkcyjność i zaangażowanie pracowników.

Prawie 60\% respondentów przyznaje, że struktura ich przedsiębiorstwa pozwala na dużą samodzielność, jednak znacznie mniej badanych (42\%) deklaruje funkcjonowanie w ramach samoorganizujących się zespołów, które same stawiają sobie cele i same się kontrolują (tabela 4.23). Ponad połowa badanych przedsiębiorstw funkcjonuje w ramach procedur i zasad, które dają im możliwość elastycznych działań i decyzji (niska formalizacja). Dla znacznej części respondentów (74\%) istotna jest szybkość w podejmowaniu decyzji. Bardzo wysoki odsetek przedsiębiorstw (77\%) ceni uczących się pracowników i deklaruje, że pomysły i wiedza pracowników jest często wykorzystywana. Wyniki w zakresie wielofunkcyjności i zaangażowania pracowników można uznać za bardzo obiecujące. Aż $80 \%$ badanych deklaruje, że w ich przedsiębiorstwach, w obszarze zarządzania ludźmi, nacisk jest kładziony na rozwój wysoko wykwalifikowanych, obdarzonych zaufaniem ludzi pracujących w zespole. Ceniona jest współpraca, zaangażowanie i wielofunkcyjność. Niespełna $65 \%$ badanych deklaruje obecność przywództwa charyzmatycznego, gdzie charyzma przywódcy, wspólna wizja oraz indywidualne podejście do grupy stanowią źródło oddania i zaangażowania pracowników. Emocje, które towarzyszą pracownikom, mobilizują ich i inspirują do większych osiągnięć. Przywództwo organiczne oparte na komunikacji z pracownikami deklaruje $74 \%$ badanych, przy czym $58 \%$ przyznaje, że przywódcy mogą się wyłaniać spośród grupy, zamiast być formalnie wyznaczeni. W przeprowadzonym badaniu analizowana była także rola przywództwa w przedsiębiorstwie. Aż $72 \%$ respondentów wskazało, że w ich przedsiębiorstwie istotą przywództwa jest wprowadzanie zmian i koncentruje się ono na tworzeniu i wdrażaniu strategii w celu zapewniania przetrwania i rozwoju. Tak liczny odsetek potwierdzających adaptacyjną i proaktywną rolę przywództwa może wynikać $\mathrm{z}$ faktu, że w dzisiejszym niepewnym otoczeniu antycypowanie zmian, przygotowywanie się na nie oraz skuteczne przeprowadzanie ich w przedsiębiorstwach stanowi podstawę efektywnego zarządzania.

Podsumowując uzyskane wyniki badań, należy podkreślić silny potencjał rozwojowy w ramach analizowanych wymiarów przywództwa strategicznego w pol- 
Tabela 4.23. Ocena zdolności w ramach przywództwa strategicznego

\begin{tabular}{|c|c|c|c|c|c|c|}
\hline \multirow[b]{2}{*}{ Wymiary } & \multirow[b]{2}{*}{ Czynniki } & \multicolumn{5}{|c|}{ Procent wskazań } \\
\hline & & $\begin{array}{l}\text { zdecy- } \\
\text { dowa- } \\
\text { nie nie }\end{array}$ & $\begin{array}{l}\text { raczej } \\
\text { nie }\end{array}$ & $\begin{array}{l}\text { ani tak, } \\
\text { ani nie }\end{array}$ & $\begin{array}{c}\text { raczej } \\
\text { tak }\end{array}$ & $\begin{array}{l}\text { zdecy- } \\
\text { dowa- } \\
\text { nie tak }\end{array}$ \\
\hline \multirow{2}{*}{$\begin{array}{l}\text { Samodziel- } \\
\text { ność pracow- } \\
\text { ników }\end{array}$} & $\begin{array}{l}\text { struktura firmy pozwala pracow- } \\
\text { nikom na dużą samodzielność }\end{array}$ & 7,8 & 25 & 7,8 & 43,6 & 15,8 \\
\hline & $\begin{array}{l}\text { funkcjonujemy w ramach samo- } \\
\text { organizujących się zespołów }\end{array}$ & 12,0 & 39,2 & 6,6 & 30,2 & 12,0 \\
\hline \multirow{2}{*}{$\begin{array}{l}\text { Poziom for- } \\
\text { malizacji }\end{array}$} & mamy niską formalizację & 8,5 & 29,2 & 6,8 & 42,0 & 13,4 \\
\hline & $\begin{array}{l}\text { kładziemy nacisk na szybkość } \\
\text { w podejmowaniu decyzji }\end{array}$ & 4,5 & 15,1 & 6,1 & 52,6 & 21,7 \\
\hline \multirow{2}{*}{$\begin{array}{l}\text { Umocowanie } \\
\text { szczebla wy- } \\
\text { konawczego }\end{array}$} & $\begin{array}{l}\text { pomysły i wiedza pracowników } \\
\text { jest często wykorzystywana }\end{array}$ & 3,1 & 13,7 & 5,9 & 47,2 & 30,0 \\
\hline & $\begin{array}{l}\text { cenimy uczących się pracowni- } \\
\text { ków }\end{array}$ & 3,8 & 13,2 & 5,9 & 47,2 & 30,0 \\
\hline \multirow[t]{2}{*}{$\begin{array}{l}\text { Wielofunk- } \\
\text { cyjność i za- } \\
\text { angażowanie } \\
\text { pracowników }\end{array}$} & $\begin{array}{l}\text { w zarządzaniu ludźmi stawiamy } \\
\text { na rozwój wysoko wykwalifiko- } \\
\text { wanych, obdarzonych zaufaniem } \\
\text { ludzi pracujących w zespole }\end{array}$ & 3,5 & 9,2 & 7,3 & 47,9 & 32,1 \\
\hline & $\begin{array}{l}\text { zarządzanie jest oparte na współ- } \\
\text { pracy, wielofunkcyjnych i zaanga- } \\
\text { żowanych pracowników }\end{array}$ & 2,6 & 11,3 & 5,7 & 52,8 & 27,6 \\
\hline \multirow[t]{2}{*}{$\begin{array}{l}\text { Przywództwo } \\
\text { wizjonerskie }\end{array}$} & $\begin{array}{l}\text { przywódca w naszej firmie od- } \\
\text { wołuje się do emocji, inspiruje } \\
\text { członków grupy do większych } \\
\text { osiągnięć }\end{array}$ & 5,9 & 23,3 & 7,5 & 48,1 & 15,1 \\
\hline & $\begin{array}{l}\text { charyzma przywódcy, wspólna } \\
\text { wizja oraz indywidualne podej- } \\
\text { ście do grupy stanowią źródło } \\
\text { oddania i zaangażowania pra- } \\
\text { cowników }\end{array}$ & 5,4 & 16,7 & 12,0 & 48,3 & 17,5 \\
\hline \multirow[t]{2}{*}{$\begin{array}{l}\text { Przywództwo } \\
\text { organiczne }\end{array}$} & $\begin{array}{l}\text { podstawą przywództwa jest ko- } \\
\text { munikacja z pracownikami }\end{array}$ & 3,8 & 14,6 & 7,3 & 50,7 & 23,6 \\
\hline & $\begin{array}{l}\text { w ramach realizowanych projek- } \\
\text { tów przywódcy mogą się wyła- } \\
\text { niać spośród grupy zamiast być } \\
\text { formalnie wyznaczeni }\end{array}$ & 7,5 & 22,9 & 11,6 & 45,0 & 13,0 \\
\hline \multirow[t]{2}{*}{$\begin{array}{l}\text { Rola przy- } \\
\text { wództwa } \\
\text { w przedsię- } \\
\text { biorstwie }\end{array}$} & $\begin{array}{l}\text { przywództwo w naszej firmie } \\
\text { zakłada tworzenie i wdrażanie } \\
\text { strategii dla nieprzewidzianych } \\
\text { zdarzeń dla zapewnienia prze- } \\
\text { trwania i rozwoju }\end{array}$ & 3,3 & 16,3 & 15,1 & 48,6 & 16,7 \\
\hline & $\begin{array}{l}\text { istotą przywództwa jest wprowa- } \\
\text { dzanie zmian (zapewnienie firmie } \\
\text { adaptacji do otoczenia) }\end{array}$ & 3,5 & 12,5 & 11,8 & 53,5 & 18,6 \\
\hline
\end{tabular}


skich przedsiębiorstwach. Wszystkie wskazane w badaniu wymiary przywództwa strategicznego uzyskały ponadprzeciętne rezultaty oraz odnotowano wysoki stopień ich wykorzystania w badanych podmiotach. Duża świadomość współczesnych przedsiębiorców w zakresie zarządzania zasobami ludzkimi jest efektem szybkiego rozwoju ekonomicznego w ostatnich latach, który miał znaczący wpływ na zmianę rynku pracy z rynku pracodawcy na rynek pracownika oraz duży nacisk na dostosowanie ról i obowiązków zarządzania zasobami ludzkimi do intensywnie zmieniających się warunków otoczenia. 


\section{Rozdział 5}

\section{MODELOWANIE STRUKTURALNE ZWINNOŚCI STRATEGICZNEJ}

W poprzednim rozdziale przedstawiono wyniki badań opisowych, które przyczyniły się do opracowania metody pomiaru zwinności strategicznej wraz ze wskazaniem poziomu i znaczenia poszczególnych wskaźników składających się na badany konstrukt. W niniejszym rozdziale zostaną przedstawione wyniki badań, których głównym celem jest wskazanie związków przyczynowo-skutkowych pomiędzy badanymi zmiennymi. $\mathrm{W}$ przedstawionym modelu zmiennymi przyczynowymi są elementy zwinności strategicznej, a zmienną wynikową stanowią wyniki przedsiębiorstw. Na podstawie przeprowadzonych studiów literaturowych założono, że poszczególne konstrukty współtworzące zwinność strategiczną, takie jak: umiejętność oceny szans, skłonność do ryzyka, umiejętność rozwoju zasobów własnych, zdolność współpracy, zdolność innowacyjna, kultura przedsiębiorcza, elastyczność operacyjna, elastyczność finansowa, przywództwo strategiczne, mają pozytywny wpływ na wyniki rynkowe przedsiębiorstw. Natomiast wyniki rynkowe przedsiębiorstw mają pozytywny wpływ na wyniki finansowe. Zależności te zostały sformułowane w postaci szczegółowych hipotez badawczych ujętych w modelu zwinności strategicznej.

Przyjęta w pracy perspektywa krytycznego realizmu zakłada, że nie wszystkie zjawiska mają charakter fizyczny i obserwowalny, co nie umniejsza ich istoty, obiektywizmu występowania i potrzeby badań w celu lepszego ich rozpoznania. Odkrywana rzeczywistość, do której odnoszą się teorie naukowe w krytycznym realizmie oparte na pojęciach nieobserwowalnych, to przede wszystkim struktury i mechanizmy, na podstawie których można wysuwać normatywne wnioski (Światowiec-Szczepańska, 2012, s. 235). Problem zmiennych nieobserwowalnych ${ }^{19}$ (unobserves variables) jest charakterystyczny dla nauk społecznych, w tym nauk o zarządzaniu. Modelowanie związków pomiędzy zmiennymi obserwowalnymi i ukrytymi może być przeprowadzone z wykorzystaniem różnych podejść analitycznych. Wśród nich coraz częściej wykorzystywanym wśród badaczy reprezentujących nauki społeczne (psychologia, pedagogika, socjologia, ekonomia) jest modelowanie równań strukturalnych (structural equation modelling - SEM). Naukowcy coraz chętniej podej-

\footnotetext{
${ }^{19} \mathrm{~W}$ pracy przyjęto, że dla określenia zmiennych nieobserwowalnych używa się zamiennie nazwy zmienne latentne lub zmienne ukryte.
} 
mują problem przyczynowości w badaniach, budują modele teoretyczne aspirujące do wyjaśnienia interesujących ich zjawisk i empirycznie je weryfikują. Wynika to między innymi z faktu, że w ciągu ostatnich dwóch dekad opracowano wiele zaawansowanych programów informatycznych do modelowania strukturalnego, które pozwalają na wielowymiarową i wielozmienną precyzyjną analizę danych empirycznych odnoszących się do określonych aspektów rzeczywistości (Januszewski, 2011, s. 213). Modele równań strukturalnych są zasadniczo podobne do modeli regresji wielowymiarowej, choć bardziej elastyczne w przypadku opisu interakcji między zmiennymi, zwłaszcza jakościowymi, dla których nie są spełnione klasyczne założenia regresji (Sagan, 2003b). W odróżnieniu do modelowania strukturalnego metoda regresji umożliwia jedynie ocenę poszczególnych części modelu, które wykonuje się w kolejnych niezależnych analizach, co utrudnia badaczowi odniesienie się do całości testowanej teorii (modelu koncepcyjnego) (Kawa, 2017, s. 158).

Opracowanie niniejszego rozdziału zostało podporządkowane realizacji celu o charakterze metodycznym oraz celów postawionych na płaszczyźnie empirycznej. Celem metodycznym jest konstrukcja modeli pomiarowych i strukturalnych zwinności strategicznej. Cele empiryczne dotyczą: identyfikacji czynników zwinności strategicznej z zastosowaniem modelowania strukturalnego oraz wskazania zależności występujących między czynnikami modelu zwinności strategicznej. Etapem przygotowującym do realizacji powyższych celów jest wyjaśnienie istoty i procedury modelowania strukturalnego oraz operacjonalizacja zmiennych nieobserwowalnych.

\subsection{Istota i procedura modelowania strukturalnego}

Zastosowanie modelowania strukturalnego w badaniach naukowych zyskało na znaczeniu w ostatnich latach. Pomimo że nie jest to metodyka powszechnie stosowana w naukach o zarządzaniu, zwłaszcza w Polsce, to w polskiej literaturze znajduje się kilka opracowań, w których z sukcesem została wykorzystana (Mitręga, 2010; Światowiec-Szczepańska, 2012; Urbanowska-Sojkin, 2013b; Kawa, 2017; Zakrzewska-Bielawska, 2018). Modelowanie równań strukturalnych umożliwia wykorzystanie zarówno zmiennych obserwowalnych, mierzonych podczas badania, jak i zmiennych nieobserwowalnych, które nie są bezpośrednio mierzone w badaniu, jednak są wyprowadzone na podstawie krytycznej analizy literatury. Poza niepodważalną zaletą modelowania strukturalnego polegającą na bezpośrednim i efektywniejszym niż dotąd skonfrontowaniu teorii z empirią A. Januszewski (2011, s. 216) wskazuje na inne praktyczne korzyści stosowania programów do modelowania: integrowanie wiedzy w obszarach danych empirycznych oraz dokładniejsze niż dotąd badanie 
zależności między konstruktami teoretycznymi a ich empirycznymi argumentami. Dzięki zaawansowanym procedurom i technikom statystycznym możliwe jest szacowanie zależności i ich prezentacja za pomocą modeli graficznych. Umożliwia to interfejs graficzny, który ułatwia badaczowi przeprowadzenie obliczeń opartych na rozwiązywaniu układów równań.

Powszechnym narzędziem wykorzystywanym w ramach modelowania strukturalnego jest diagram ścieżkowy, przedstawiający w graficzny sposób związki przyczynowo-skutkowe pomiędzy poszczególnymi zmiennymi. W prezentacji diagramu zmienne jawne umieszcza się umownie $w$ ramkach, natomiast zmienne ukryte w elipsach, a zmienne resztkowe w niewielkich rozmiarów kołach. Zależności pomiędzy zmiennymi są prezentowane za pomocą strzałek, których grot wskazuje zmienną będącą skutkiem. Analogicznie przy zmiennych resztkowych strzałka

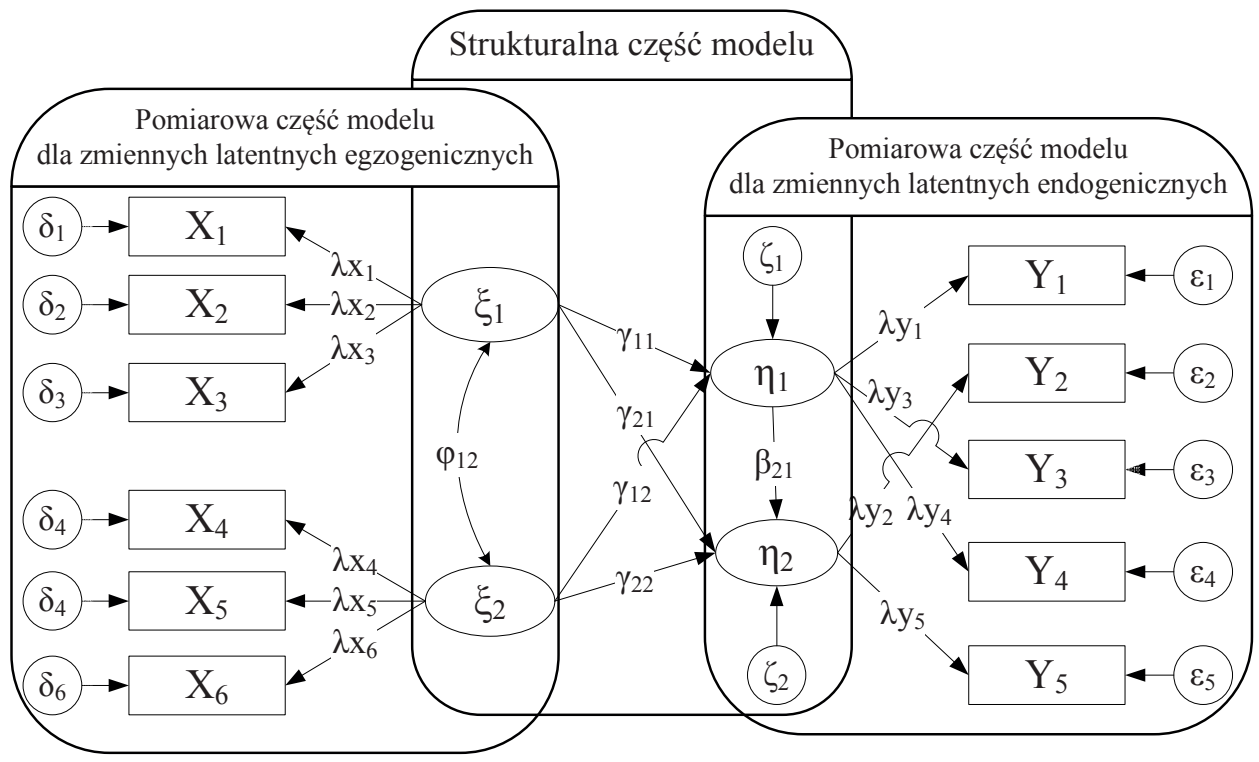

$\mathrm{i}$ - zmienne latentne egzogeniczne (czynniki),

ๆi - zmienne latentne endogeniczne (czynniki),

¡i - błędy (zakłócenia) związane z określonymi zmiennymi latentnymi endogenicznymi,

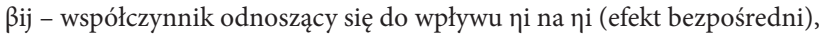

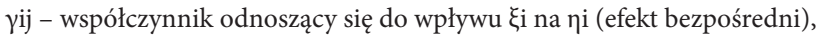

$\varphi \mathrm{ij}$ - kowariancje (korelacje) między latentnymi egzogenicznymi zmiennymi $\xi_{\mathrm{i}}$,

$\mathrm{Xi}$ - wskaźniki obserwacyjne dla $\xi$,

Yi - wskaźniki obserwacyjne dla $\eta i$,

عi - błąd związany z pomiarem określonego wskaźnika Yi,

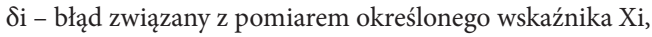

$\lambda$ yi - współczynnik odnoszący się do wpływu ๆi na Yi,

$\lambda$ xi - współczynnik odnoszący się do wpływu $\xi$ i na Xi.

\section{Rysunek 5.1. Ogólny model przyczynowy ze zmiennymi nieobserwowalnymi}

Źródło: (Januszewski, 2011, s. 218-221). 
wskazuje na zmienną obserwowalną obciążoną błędem (Sroka, 2009, s. 195-196; Sagan, 2003b). Podstawowy model przyczynowy składa się z trzech zasadniczych części (Januszewski, 2011, s. 218) - rysunek 5.1:

- część pomiarowa modelu dla latentnych zmiennych egzogenicznych,

- część pomiarowa modelu dla latentnych zmiennych endogenicznych,

- część strukturalna modelu łącząca pomiarowe części modelu.

Rosnące zainteresowanie naukowców wykorzystaniem modelowania strukturalnego wymusiło rozwój zaawansowanych narzędzi statystycznych umożliwiających analizę złożonych danych empirycznych. Najbardziej popularnymi pakietami statystycznymi, dającymi możliwość przeprowadzenia analizy modelowania strukturalnego są: LISREL, AMOS, CALIS, EQS, HLM, SEPATH, MPLUS, SIMPLIS (Januszewski 2011, s. 216; Światowiec-Szczepańska 2012, s. 242-243). Na potrzeby niniejszej pracy został wybrany pakiet AMOS (analysis of moment structures) autorstwa J. Arbuckle’a (2007) ze względu na jego uznanie wśród badaczy oraz możliwość współpracy z IBM SPSS Statistics, który wykorzystano do analiz statystycznych.

Całkowity model na potrzeby modelowania strukturalnego składa się z dwóch podstawowych części: modelu pomiarowego oraz modelu równań strukturalnych. Zadaniem modelu pomiarowego jest określenie, w jaki sposób czynniki ukryte (zmienne nieobserwowalne), jako konstrukty teoretyczne, są wyjaśniane poprzez zmienne obserwowalne, przy jednoczesnym oszacowaniu pomiarowych własności zmiennych obserwowalnych (rzetelność danych). Model ten jest wyprowadzony bezpośrednio z teorii badanej dziedziny nauki i poparty konfirmacyjną analizą czynnikową. Natomiast celem modelu równań strukturalnych jest określenie przyczynowej relacji pomiędzy zmiennymi ukrytymi i wielkości niewyjaśnionej wariancji (Sagan, 2003a, s. 87). Wskazuje on na bezpośrednie i pośrednie związki przyczynowo-skutkowe pomiędzy wcześniej wyznaczonymi modelami pomiarowymi zmiennych ukrytych. Takie dwufazowe podejście sekwencyjne opracowane przez J.C. Andersona i D.W. Gerbinga (1992) zostało wykorzystane w niniejszej pracy.

Procedura modelowania strukturalnego opracowana w literaturze wskazuje na kolejne etapy tworzenia modelu (Górniak i Perek-Biała, 2010; Sagan, 2003b; Hair, Black, Babi i Anderson, 2010; Karasiewicz i Makarowski, 2012), których adaptacja jest widoczna w opracowaniach naukowców wykorzystujących tę metodykę badawczą (Światowiec-Szczepańska, 2012; Urbanowska-Sojkin, 2013b; Kawa, 2017) i zostanie również zaadaptowana w niniejszej pracy. Pierwszy etap obejmuje zdefiniowanie poszczególnych konstruktów na podstawie studiów literaturowych, ze wskazaniem zależności przyczynowo-skutkowych pomiędzy zmiennymi modelu. Wyprowadzenie poszczególnych konstruktów ze źródeł teoretycznych sprawia, że tworzony na kolejnym etapie model pomiarowy jest osadzony w teorii, co zwiększa jego urzeczywistnienie. W dalszej kolejności dokonuje się specyfikacji modelu pomiarowego. W pierwszej fazie tego etapu projektuje się narzędzie pomiarowe, wykorzystując eksploracyjną analizę czynnikową (exploratory factor analysis - EFA), następnie model poddaje się ocenie, w której łączy się wybrane zmienne obserwo- 
walne z konstruktami je mierzącymi. Korzystając z konfirmacyjnej analizy czynnikowej (confirmation factor analysis - CFA), konstruuje się model pomiarowy, który identyfikuje typ i liczbę wskaźników obserwowalnych dla zmiennej ukrytej oraz szacuje rzetelność każdego konstruktu przyjętego do analizy. Na podstawie wybranych kryteriów ocenia się dopasowanie modelu do danych empirycznych. Jeśli model nie spełnia warunków dopasowania, to instrumenty pomiarowe są modyfikowane lub zmieniane. Jeśli jednak model przejdzie pozytywnie testy dopasowania, to rozpoczyna się specyfikację modelu równań strukturalnych, który określa przyczynowe relacje między czynnikami ukrytymi i wielkościami niewyjaśnionej wariancji. W ramach tego etapu porównywane są macierze kowariancji miar teoretycznych i empirycznych, a wynik ich porównania stanowi podstawę oceny dopasowania modelu. Jeśli model nie spełnia warunków dopasowania, ulega modyfikacji i ponownie poddaje się go testowaniu. Ostatnim etapem procedury modelowania strukturalnego jest przygotowanie wniosków z badań.

Do oceny rzetelności modelu wykorzystuje się wskaźniki dopasowania modelu (dobroci modelu), które służą do porównania teoretycznego modelu pomiarowego z rzeczywistym, opartym na danych pochodzących z badań empirycznych. Najczęściej spotykanym wskaźnikiem dopasowania modelu do danych jest wartość statystyki $\chi^{2}$ (chi-kwadrat). Jest ona poddawana testowi, który dotyczy hipotezy zerowej, uznającej, że reszty standaryzowane macierzy empirycznej i teoretycznej wynoszą zero, co świadczy o fakcie, że ograniczenia nałożone przez badacza wynikające z przyjętego modelu teoretycznego są trafne (Sagan, 2003b). Stosowanie tego testu ma jednak swoje ograniczenia wynikające z problemów przy bardzo małych próbach lub bardzo dużych, oraz konsekwencji naruszenia założenia normalności rozkładu wielozmiennego. Wrażliwość testu $\chi^{2}$ na wielkość próby spowodowała opracowanie licznych alternatywnych testów dobroci dopasowania modelu do danych empirycznych. Różnorodne miary dopasowania akcentują alternatywne aspekty oceny jakości modelu, takie jak: efekt wielkości próby, prostotę lub oszczędność modelu, porównanie do modelu zerowego oraz prawdopodobieństwo potwierdzenia modelu w niezależnych próbach danych. Różnorodność miar dopasowania pozwala na ocenę jakości modelu z różnych perspektyw (Konarski, 2009, s. 344).

Mierniki dopasowania modelu można podzielić na trzy podstawowe grupy (Sagan, 2003b):

- Absolutne wskaźniki dopasowania (zwane też bezwzględnymi) - udzielają informacji, jak poprawnie model pomiarowy odzwierciedla obserwowalną macierz kowariancji S.

- Porównawcze wskaźniki dopasowania - określają stopień, w jakim dany model jest lepszy niż tzw. model zerowy (lub podstawowy), w których zakłada się brak zmiennych ukrytych i występowanie relacji jedynie między zmiennymi obserwowalnymi. W tym celu najczęściej stosowaną miarą jest zmiana wartości $\chi^{2}$, przy danej zmianie liczby stopni swobody. Miernik ten umożliwia dobranie modelu najlepiej dopasowanego do danych empirycznych. W ramach tej grupy 
występują także przyrostowe wskaźniki dopasowania, które odnoszą się do rozbieżności badanego modelu, badając zakres, w jakim badany model odpowiada modelowi podstawowemu.

\section{Tabela 5.1. Wskaźniki dopasowania modelu}

\begin{tabular}{|c|c|}
\hline Wskaźnik & Interpretacja \\
\hline \multicolumn{2}{|c|}{ Absolutne wskaźniki dopasowania } \\
\hline $\begin{array}{l}\text { Chi-kwadrat - miara umożliwiająca testowanie } \\
\mathrm{H}_{\mathrm{o}} \text { o braku rozbieżności między obserwowaną } \\
\text { macierzą kowariancji a implikowaną przez model }\end{array}$ & $\begin{array}{l}\text { Dobre dopasowanie jeśli } p>0,05 \text {, reszty standa- } \\
\text { ryzowane obu macierzy wynoszą } 0 \text {, oznacza to, } \\
\text { że ograniczenia nałożone przez badacza w mo- } \\
\text { delu są trafne }\end{array}$ \\
\hline$\chi^{2} / s s-$ normalizowane $\chi^{2}$ & $\begin{array}{l}\text { Dobre dopasowanie, jeśli wartość }<5 \text {, ale jeśli } \\
\text { wartość }<1-\text { kwestionuje prawdziwość modelu }\end{array}$ \\
\hline $\begin{array}{l}\text { RMSEA - pierwiastek średniokwadratowego błę- } \\
\text { du przybliżenia, stanowi miarę rozbieżności nie- } \\
\text { dopasowania modelu do danych }\end{array}$ & $\begin{array}{l}\text { Wartości mniejsze niż } 0,05 \text { wskazują na dobre } \\
\text { dopasowanie modelu. } \\
\text { Wartości mniejsze niż 0,01 wskazują na znako- } \\
\text { mite dopasowanie modelu }\end{array}$ \\
\hline GFI - miara dobroci dopasowania modelu & $\begin{array}{l}\text { Wartości > 0,9 świadczą o dobrym dopasowaniu } \\
\text { modelu, model idealny przyjmuje wartość } G F I=1\end{array}$ \\
\hline $\begin{array}{l}\text { AGFI - rozwinięcie wartości GFI dostosowane } \\
\text { do liczby stopni swobody modelu względem licz- } \\
\text { by zmiennych }\end{array}$ & $\begin{array}{l}\text { Wartości > 0,9 wskazują na dobre dopasowa- } \\
\text { nie modelu, model idealny przyjmuje wartość } \\
A G F I=1\end{array}$ \\
\hline $\begin{array}{l}\text { RMR - pierwiastek z sumy kwadratów różnic } \\
\text { między próbkowymi oraz teoretycznymi warto- } \\
\text { ściami wariancji i kowariancji }\end{array}$ & $\begin{array}{l}\text { Im mniejsza jego wartość, tym model jest le- } \\
\text { piej dopasowany, najlepiej, gdy jego wartość }=0 \text {. } \\
\text { Miernik ten nie uwzględnia złożoności modelu }\end{array}$ \\
\hline \multicolumn{2}{|c|}{ Porównawcze i przyrostowe mierniki dopasowania } \\
\hline $\begin{array}{l}\text { Zmiana wartości } \chi^{2} \text { przy danej zmianie liczby } \\
\text { swobody określonych modeli }\end{array}$ & Zmiana ta powinna być istotna statystycznie \\
\hline IFI - indeks inkrementalny & $\begin{array}{l}\text { Wartości > 0,9 świadczą o dobrze dopasowanym } \\
\text { modelu, wartości bliskie } 1 \text { świadczą o bardzo do- } \\
\text { brym dopasowaniu modelu }\end{array}$ \\
\hline TLI - indeks Tuckera’a-Lewisa & $\begin{array}{l}\text { Wartości }>0,9 \text { świadczą o dobrze dopasowanym } \\
\text { modelu, wartości bliskie } 1 \text { świadczą o bardzo do- } \\
\text { brym dopasowaniu modelu }\end{array}$ \\
\hline CFI - porównawczy indeks dopasowania & $\begin{array}{l}\text { Wartości }>0,9 \text { świadczą o dobrze dopasowanym } \\
\text { modelu, wartości bliskie } 1 \text { świadczą o bardzo do- } \\
\text { brym dopasowaniu modelu }\end{array}$ \\
\hline \multicolumn{2}{|c|}{ Oszczędne mierniki dopasowania } \\
\hline $\begin{array}{l}\text { PNFI - oszczędny unormowany indeks dopa- } \\
\text { sowania }\end{array}$ & $\begin{array}{l}\text { Przyjmuje wartości }\langle 0,1\rangle \text {, } \mathrm{z} \text { większymi wartościa- } \\
\text { mi wskazującymi na lepsze dopasowanie modelu }\end{array}$ \\
\hline $\begin{array}{l}\text { AIC - wskaźnik faworyzujący model, którego } \\
\text { szanse walidacji (dobrego dopasowania) w ko- } \\
\text { lejnych próbach danych są największe }\end{array}$ & $\begin{array}{l}\text { Niższa wartość miernika świadczy o lepszym } \\
\text { dopasowaniu modelu }\end{array}$ \\
\hline
\end{tabular}

Źródło: Na podstawie: (Sagan, 2003b; Konarski, 2009; Januszewski, 2011; Karasiewicz i Makarowski, 2012). 
- Oszczędne wskaźniki dopasowania - wskazują stopnie swobody wymagane dla osiągnięcia odpowiedniego dopasowania modelu do danych, czyli uwzględniają efekt kompensacji pomiędzy dobrocią dopasowania a złożonością modelu.

Wybrane mierniki dopasowania modelu wraz z ich interpretacją przedstawiono w tabeli 5.1 oraz wykorzystano do analizy modeli przygotowanych na potrzeby niniejszej pracy.

Istotnym kryterium oceny modelu pomiarowego jest test trafności zbieżnej (convergent validity) i różnicowej (discriminant validity) zmiennych nieobserwowalnych. Test trafności zbieżnej dotyczy spójności wskaźników mierzących poszczególne konstrukty latentne. W tym celu przeprowadza się analizę i wyznacza wartość ładunków czynnikowych. Poziom ich standaryzowanych wartości powinien przekraczać wartość 0,5 przy zachowaniu istotności statystycznej. Uzupełniającym miernikiem wskazującym, w jakim stopniu zmienne obserwowalne wyjaśniają zmienną nieobserwowalną, jest wskaźnik AVE (average variance extracted), którego wartość powinna być równa lub wyższa niż 0,5 . Wskaźnik ten powinien być obliczany dla każdego z konstruktów oddzielnie. Dodatkowe kryterium spójności stanowi współczynnik CR (construct reliability), który dla wysokiej rzetelności zmiennych latentnych powinien przyjmować wartości powyżej 0,7 (wartość pomiędzy 0,6 a 0,7 jest dopuszczalna pod warunkiem uzyskania właściwego poziomu pozostałych wskaźników ważności konstruktów latentnych w modelu) (Światowiec-Szczepańska, 2012, s. 252).

Z kolei test trafności różnicowej informuje badacza, czy rzeczywiście wyznaczone przez niego konstrukty latentne w modelu są różne (unikatowe) i nie mierzą tego samego, co inne zmienne latentne. Testu trafności różnicowej dokonano przy użyciu miernika AVE. W tym celu porównuje się wartości AVE wskazanych dwóch konstruktów z kwadratem ich korelacji. Wyższe wartości wskaźnika AVE oznaczają pozytywny wynik testu i świadczą o zróżnicowaniu badanych konstruktów (Kawa, 2017, s. 164; Zakrzewska-Bielawska, 2018, s. 136). Dodatkowo przeanalizowano wartość maksymalnej dzielonej wariancji (maximum shared variance - MSV) której wartość powinna być niższa niż AVE dla wyodrębnionych konstruktów (Hair i in., 2010).

\subsection{Operacjonalizacja zmiennych nieobserwowalnych}

Model zwinności strategicznej przedstawiony w rozdziale trzecim składa się z jedenastu konstruktów teoretycznych, które zostały wyprowadzone z obszernych studiów literaturowych i rozważań teoretycznych. Biorąc pod uwagę ich źródła 
oddziaływania, można stwierdzić, że dziewięć z prezentowanych konstruktów ma charakter egzogeniczny, a dwa mają charakter endogeniczny. Do zmiennych nieobserwowalnych egzogenicznych można zaliczy: umiejętność oceny szans, skłonność do ryzyka, umiejętność rozwoju zasobów własnych, zdolność współpracy, zdolność innowacyjną, kulturę przedsiębiorczą, elastyczność operacyjną, elastyczność finansową, przywództwo strategiczne. Natomiast zmienne endogeniczne nieobserwowalne tworzą wyniki rynkowe oraz wyniki finansowe przedsiębiorstw. Dla każdej zmiennej latentnej zostały opracowane zmienne wskaźniki obserwowalne, które zawarto $\mathrm{w}$ kwestionariuszu ankiety w postaci stwierdzeń. Wszystkie wskaźniki zmiennych ukrytych zostały wyprowadzone z wcześniejszych rozważań teoretycznych i stanowią w części adaptację miar innych autorów. Poza analizą literatury do konstrukcji narzędzia pomiarowego posłużyły także wnioski z przeprowadzonego badania pilotażowego.

W celu operacjonalizacji terminów teoretycznych (zmiennych) podjęto szereg działań, dążąc do nadania im sensu empirycznego. Etapy procedury operacjonalizacji odnoszą się do (Hornowska, 2000, s. 394-400):

- rekonstrukcji czynnika ${ }^{20}$ teoretycznego - polegającej na ogólnym, teoretycznym zdefiniowaniu danego pojęcia odnoszącego się do rzeczywistości,

- konceptualizacji wielkości²1, której efektem jest rekonstrukcja modelu pojęciowego wraz z jego wymiarami,

- doboru zmiennych ${ }^{22}$ operacjonalizujących wielkość, polegającego na wyselekcjonowaniu wskaźników (zmiennych obserwowalnych), które umożliwią trafną identyfikację i testowanie zrekonstruowanego modelu pojęciowego.

Pierwszy etap w ramach procedury operacjonalizacji został przedstawiony w rozdziale trzecim, natomiast dwa pozostałe punkty są przedmiotem niniejszego rozdziału. Powiązanie terminów teoretycznych (odnoszących się do nieobserwowalnych właściwości zagadnień) z obserwacjami (oznaczającymi obserwowalne właściwości i relacje) jest podstawowym sposobem wyjaśnienia ich znaczenia (Januszewski, 2011, s. 238).

Przed rozpoczęciem analizy zmiennych usunięto $\mathrm{z}$ bazy odpowiedzi tzw. niezaangażowanych respondentów, których odchylenie standardowe udzielanych odpowiedzi wynosiło zero, zidentyfikowano 14 takich przypadków. Opracowanie wskaźników zmiennych nieobserwowalnych odbyło się z wykorzystaniem eksplora-

20 „Czynnik” to pojęcie teoretyczne o charakterze ontologicznym, które odnosi się do opisywanej przez badawcza rzeczywistości (Hornowska, 2000, s. 392-394).

21 „Wielkość” jest terminem teoretycznym o charakterze epistemologicznym, który pozwala opisać sposób postrzegania rzeczywistości, jest więc obrazem „czynnika” ustalanym przez badacza na drodze teoretycznej rekonstrukcji i wynika z przyjętej teorii (Hornowska, 2000, s. 392-394).

22 „Zmienna” jest pojęciem epistemologicznym odnoszącym się do sposobu opisywania przez badacza świata rzeczywistego. Umożliwia przejście z poziomu pojęciowego (teoretycznego) na poziom empiryczny. Pod pojęciem „zmienna” rozumie się przyjęty przez badacza sposób przejawiania się wielkości na poziomie obserwacji (Hornowska 2000, s. 392-394). 
cyjnej analizy czynnikowej, która obejmuje grupę metod matematyczno-statystycznych pozwalających na sprowadzenie pierwotnego (wyjściowego) zbioru zmiennych, które charakteryzują obiekty poddane obserwacji, do znacznie mniejszej liczby hipotetycznych zmiennych. Nowe wyodrębnione zmienne zawierają podstawową informację o oryginalnych zmiennych. Zadaniem analizy czynnikowej jest zatem wyodrębnienie czynników interpretowanych jako mających znaczenie dla pomiaru, opisu i wyjaśnienia zmienności (Czyż, 1971, s. 17). Wyniki prezentowane w pracy zostały uzyskane przy wykorzystaniu metody największej wiarygodności do wyodrębnienia składowych, która umożliwiła za pomocą istniejącego testu dobroci dopasowania określić właściwą liczbę czynników dla przyjętego modelu (Frątczak, 2009). W konsekwencji wykorzystanie tej metody umożliwiło wyłonienie najistotniejszych składowych spośród zestawu zmiennych pierwotnych wyprowadzonych $\mathrm{z}$ literatury i opisujących analizowany konstrukt teoretyczny.

Jak zauważa E. Urbanowska-Sojkin (2013b, s. 149), w naukach społecznych często można zaobserwować problem luki pomiędzy językiem teorii i empirii - wynikający $\mathrm{z}$ trudności zaobserwowania koncepcji używanych na poziomie teoretycznym w rzeczywistości społecznej. Uzupełnienie tej luki może nastąpić poprzez zastosowanie matematycznych modeli pomiaru, w których związek pomiędzy teoretyczną koncepcją i jej wskaźnikami będzie jasno określony poprzez zmienne (wskaźniki) bezpośrednio obserwowalne i zmienne pośrednio obserwowalne tzw. ukryte (zmienne teoretyczne). M. Nawojczyk (2010, s. 189) przekonuje, że analiza zmiennych ukrytych opiera się na założeniu, że zależności, które występują między wskaźnikami, wynikają ze związku wskaźnika obserwowalnego ze zmienną nieobserwowalną.

Przed rozpoczęciem eksploracyjnej analizy czynnikowej należy sprawdzić podstawowe założenie oceniające zasadność jej zastosowania, a mianowicie skorelowanie zmiennych - im wyższe korelacje między zmiennymi pierwotnymi, tym bardziej uzasadnione jest wykorzystanie analizy. W celu zbadania korelacji pomiędzy zmiennymi wykorzystuje się test sferyczności Bartletta (Walesiak i Gantar, 2009). Wstępnym kryterium przydatności danych pochodzących z próby badawczej do analizy czynnikowej jest także wskaźnik KMO - czyli miara adekwatności doboru próby Kaisera-Meyera-Olkina. Wskaźnik ten przyjmuje wartości od $\langle 0,1\rangle$ - im wyższa jego wartość, tym silniejsze są podstawy do zastosowania metody analizy czynnikowej (Field, 2000, s. 446), wartość graniczna wynosi 0,5 (Stanisz, 2007, s. 218). $\mathrm{W}$ przeprowadzonym badaniu wartość wskaźnika opisywanego współczynnika była bardzo wysoka i przyjmowała wartość powyżej 0,9 . Dalsza procedura polegała na sprawdzeniu wartości statystycznej $\chi^{2}$, liczby stopni swobody oraz istotności statystycznej zbioru zmiennych poddanych analizie. Wartości wszystkich wskaźników uznano za satysfakcjonujące.

Następnie dokonano metody rotacji wyodrębnionych składowych. W tym celu posłużono się rotacją promax. Jest to rotacja skośna czynników, która pozwala na wyodrębnienie skorelowanych rozwiązań czynnikowych. Rotację czynników sugeruje się w często występującym przypadku, kiedy zmienna ma wysokie ładunki na 
kilku czynnikach, co utrudnia jednoznaczną interpretację. Celem tego zabiegu jest redukcja dwuznaczności interpretacji. Dzięki obrotowi można łatwiej utożsamić każdy czynnik ze zmiennymi, z którymi jest mocno skorelowany (Czopek, 2013). Dzięki rotacji możliwa jest minimalizacja liczby zmiennych $\mathrm{z}$ wysokimi ładunkami czynnikowymi lub minimalizacja liczby czynników niezbędnych do objaśnienia poszczególnych zmiennych (Malarska, 2005, s. 228). Następnie określa się miarę adekwatności doboru każdej indywidualnej zmiennej, czyli tzw. wskaźniki MSA (measures of sampling adequacy), których minimalne wartości, upoważniające badacza do wykorzystania zmiennej $\mathrm{w}$ dalszej procedurze analizy czynnikowej, powinny przekroczyć wartość 0,5 (Walesiak, 1996; Field, 2000, s. 446).

$\mathrm{Na}$ kolejnym etapie procedury mającej na celu zwiększenie dopasowania modelu usunięto zmienne, których zasoby zmienności wspólnej po wyodrębnieniu były mniejsze od wartości 0,300. Wyeliminowano również zmienne, w których zidentyfikowano ładunki krzyżowe poniżej wartości 0,300 . W wyniku tego postępowania eliminacji uległa zmienna „umiejętność rozwoju zasobów własnych”, co w konsekwencji uniemożliwiło sprawdzenie hipotezy H2a. Modyfikacja ta jednak nie zmieniła zasadniczo założeń teoretycznych zawartych w modelu.

W ramach przeprowadzonej procedury eksploracyjnej analizy czynnikowej dokonano również zmian w ramach zmiennej „przywództwo strategiczne”, której pierwotnie przypisane zmienne obserwowalne dotyczące umocowania szczebla wykonawczego oraz zaangażowania i wielofunkcyjności pracowników zostały wyodrębnione w ramach zmiennej „kultura przedsiębiorcza”. Z merytorycznego punktu widzenia i bliskości obu konstruktów zmiana ta wydaje się zasadna.

$\mathrm{W}$ rezultacie otrzymano układ zmiennych, których dopasowanie statystyczne czynników potwierdzono wskaźnikiem rzetelności Alfa-Cronbacha, którego wyniki informują, do jakiego stopnia wyznaczony zbiór zmiennych opisuje jeden, ukryty w nim konstrukt. Współczynnik ten przyjmuje wartości od 0 do 1 , minimalna jego wartość potwierdzająca rzetelność zbudowanego konstruktu wynosi 0,6.

Stwierdzenia dotyczące badanych zmiennych wykorzystane w kwestionariuszu opracowano na podstawie studiów literaturowych (rozdz. 3), adaptując częściowo miary uwzględnione przez innych autorów.

W przypadku wymiaru wrażliwości strategicznej przeprowadzona eksploracyjna analiza czynnikowa doprowadziła do redukcji części wskaźników w ramach dwóch zmiennych: „umiejętności oceny szans” oraz „skłonności do ryzyka”.

W ramach konstruktu „umiejętność oceny szans” wyłoniono trzy wskaźniki, które zostały opracowane na podstawie badań następujących autorów: Z. Zhang i H. Sharifi (2000); B. Maskell (2001); K. Fartash i S. Davoudi (2012). Treść stwierdzeń zawartych w kwestionariuszu ankiety, odpowiadające stwierdzeniom kody oraz wyniki oceny rzetelności miar ( $\alpha$-Cronbacha) przedstawiono w tabeli 5.2.

Z kolei przy drugiej zmiennej „skłonność do ryzyka” liczbę wskaźników ograniczono do dwóch z trzech pierwotnie wyznaczonych, zaadaptowanych $\mathrm{z}$ badań T. Jambulingama i współautorów (2005). Treść stwierdzeń zawartych w kwestiona- 
Tabela 5.2. Wskaźniki umiejętności oceny szans

\begin{tabular}{|c|l|}
\hline Symbol & \multicolumn{1}{c|}{ Umiejętność oceny szans (UOS) - stwierdzenie } \\
\hline UOS1 & $\begin{array}{l}\text { Sprawdzamy, czy pojawiająca się okazja znajduje się w zasięgu przedsiębiorstwa (ze } \\
\text { względu na zasoby, które posiadamy lub czy możemy je kupić) }\end{array}$ \\
\hline UOS2 & $\begin{array}{l}\text { Oceniamy, czy okazja jest zgodna z celami przedsiębiorstwa (wizja, misja wartości) oraz } \\
\text { strategią jednostki nadrzędnej }\end{array}$ \\
\hline UOS3 & $\begin{array}{l}\text { Oceniamy wartość pojawiających się szans niezależnie od strategii firmy oraz szacuje- } \\
\text { my ewentualne ryzyko z nimi związane }\end{array}$ \\
\hline \multicolumn{2}{|c|}{ a-Cronbacha $=0,710$} \\
\hline
\end{tabular}

Skala ocen: pięciopunktowa skala Likerta, gdzie 1 oznacza zdecydowanie nie zgadzam się, a 5 zdecydowanie zgadzam się.

Tabela 5.3. Wskaźniki skłonności do ryzyka

\begin{tabular}{|c|l|}
\hline Symbol & \multicolumn{1}{|c|}{ Skłonność do ryzyka (SR) - stwierdzenie } \\
\hline SR1 & $\begin{array}{l}\text { Panuje u nas przekonanie, że ryzyko stanowi naturalny element gry rynkowej i zamiast } \\
\text { się go obawiać, należy nauczyć się je ograniczać }\end{array}$ \\
\hline SR2 & $\begin{array}{l}\text { Ryzyko w otoczeniu gospodarczym traktowane jest przez nas jako szansa na pojawienie } \\
\text { się ciekawych okazji, które moglibyśmy wykorzystać }\end{array}$ \\
\hline \multicolumn{2}{|c|}{ a-Cronbacha $=0,642$} \\
\hline
\end{tabular}

Skala ocen: pięciopunktowa skala Likerta, gdzie 1 oznacza zdecydowanie nie zgadzam się, a 5 zdecydowanie zgadzam się.

riuszu ankiety, odpowiadające im kody oraz wyniki oceny rzetelności miar przedstawiono w tabeli 5.3.

Kolejny analizowany wymiar teoretyczny stanowiła przedsiębiorczość strategiczna w ramach której, za pomocą eksploracyjnej analizy czynnikowej, wyodrębniono trzy zmienne nieobserwowalne: „kulturę przedsiębiorczą, , zdolność innowacyjną” oraz „zdolność współpracy”.

W ramach „kultury przedsiębiorczej” wybrano dziewięć wskaźników, które najlepiej korespondują ze zmienną latentną. Miary zostały opracowane na podstawie badań takich autorów, jak: S.G. Scott i R.A. Bruce (1994); Y.H. Li z zespołem (2008); R. Vokurka i G. Fliender (1998); S. Meredith i D. Francis (2000); D. Vazquez-Bustelo z zespołem (2007). Treść stwierdzeń zawartych w kwestionariuszu ankiety, odpowiadające im kody oraz wyniki oceny rzetelności miar przedstawiono w tabeli 5.4.

Kolejną zmienną stanowi „zdolność innowacyjna”, która została opisana za pomocą pięciu wskaźników zaadaptowanych z badań prowadzonych przez następujących autorów: Hurley i Hult (1998); Y.H. Li z zespołem (2008); T. Jambulingam z zespołem (2005); S.G. Scott i R.A. Bruce (1994). Treść stwierdzeń zawartych w kwestionariuszu ankiety, odpowiadające im kody oraz wyniki oceny rzetelności miar przedstawiono $\mathrm{w}$ tabeli 5.5 . 
Tabela 5.4. Wskaźniki kultury przedsiębiorczej

\begin{tabular}{|c|l|}
\hline Symbol & \multicolumn{1}{|c|}{ Kultura przedsiębiorcza (KP) - stwierdzenie } \\
\hline KP1 & $\begin{array}{l}\text { Inwestujemy w szkolenia wewnętrzne, zewnętrzne oraz inne formy doszkalania pracow- } \\
\text { ników }\end{array}$ \\
\hline KP2 & $\begin{array}{l}\text { Tworzymy kulturę, w której innowacyjność może rozkwitać - pracownicy mogą liczyć } \\
\text { na pomoc w rozwijaniu nowych pomysłów }\end{array}$ \\
\hline KP3 & $\begin{array}{l}\text { Promujemy kulturę, w której pracownik może część czasu i zasobów (w pracy) poświę- } \\
\text { cić na rozwijanie własnych pomysłów, które następnie, jeśli okażą się atrakcyjne, mogą } \\
\text { być wdrożone przez firmę }\end{array}$ \\
\hline KP4 & $\begin{array}{l}\text { Rozwijamy i podtrzymujemy te wartości i zachowania, które promują innowacyjność } \\
\text { oraz kreatywność }\end{array}$ \\
\hline KP5 & $\begin{array}{l}\text { Struktura firmy pozwala pracownikom na dużą samodzielność (płaska struktura orga- } \\
\text { nizacyjna) }\end{array}$ \\
\hline KP6 & Pomysły i wiedza pracowników są często wykorzystywane \\
\hline KP7 & Cenimy uczących się pracowników \\
\hline KP8 & $\begin{array}{l}\text { W zarządzaniu ludźmi stawiamy na rozwój wysoko wykwalifikowanych, obdarzonych } \\
\text { zaufaniem ludzi pracujących w zespole }\end{array}$ \\
\hline KP9 & $\begin{array}{l}\text { Zarządzanie oparte jest na współpracy, wielofunkcyjnych i zaangażowanych pracowni- } \\
\text { ków }\end{array}$ \\
\hline a-Cronbacha 0,903 \\
\hline
\end{tabular}

Skala ocen: pięciopunktowa skala Likerta, gdzie 1 oznacza zdecydowanie nie zgadzam się, a 5 zdecydowanie zgadzam się.

Tabela 5.5. Wskaźniki zdolności innowacyjnej

\begin{tabular}{|c|l|}
\hline Symbol & \multicolumn{1}{|c|}{ Zdolność innowacyjna (ZI) - stwierdzenie } \\
\hline ZI1 & $\begin{array}{l}\text { Poszukujemy innowacyjnych technologii, procesów, technik i (lub) pomysłów na nowe } \\
\text { produkty }\end{array}$ \\
\hline ZI2 & Nasza firma znana jest jako lider innowacji wśród firm w naszym regionie \\
\hline ZI3 & $\begin{array}{l}\text { Nasza firma intensywnie poszukuje środków, potrzebnych do realizacji nowych pomy- } \\
\text { słów i je zapewnia }\end{array}$ \\
\hline ZI4 & Nasza firma nieustannie eksperymentuje z nowymi koncepcjami i pomysłami \\
\hline \multicolumn{2}{|c|}{ a-Cronbacha $=0,798$} \\
\hline
\end{tabular}

Skala ocen: pięciopunktowa skala Likerta, gdzie 1 oznacza zdecydowanie nie zgadzam się, a 5 zdecydowanie zgadzam się.

Zgodnie z przyjętym modelem kolejny konstrukt stanowi „zdolność współpracy”, który został opisany za pomocą pięciu wskaźników rozwiniętych na podstawie badań takich autorów, jak: Z. Zhang i H. Sharifi (2000), B. Maskell (2001). Treść stwierdzeń zawartych w kwestionariuszu ankiety, odpowiadające im kody oraz wyniki oceny rzetelności miar przedstawiono w tabeli 5.6.

W ramach wymiaru elastyczności wyłoniono dwa konstrukty teoretyczne: „elastyczność operacyjną” oraz „elastyczność finansową”, miary obu konstruktów zosta- 
Tabela 5.6. Wskaźniki zdolności współpracy

\begin{tabular}{|c|l|}
\hline Symbol & \multicolumn{1}{|c|}{ Zdolność współpracy $(\mathrm{ZW})$ - stwierdzenie } \\
\hline ZW1 & Wiemy, jak pozyskać zasoby z zewnątrz przedsiębiorstwa \\
\hline ZW2 & $\begin{array}{l}\text { W pozyskaniu zasobów pomagają nam posiadane sieci kontaktów i baz potencjalnych } \\
\text { partnerów biznesowych }\end{array}$ \\
\hline ZW3 & $\begin{array}{l}\text { Rozróżniamy, kiedy powinniśmy zakupić zasoby z zewnątrz, a kiedy jedynie pozyskać } \\
\text { do nich dostęp }\end{array}$ \\
\hline ZW4 & Rozwijamy zdolność współpracy z partnerami zewnętrznymi \\
\hline ZW5 & Identyfikujemy kluczowych partnerów dla naszego przedsiębiorstwa \\
\hline a-Cronbacha $=0,809$
\end{tabular}

Skala ocen: pięciopunktowa skala Likerta, gdzie 1 oznacza zdecydowanie nie zgadzam się, a 5 zdecydowanie zgadzam się.

ły rozwinięte na podstawie badań następujących autorów: S. Kasiewicz z zespołem (2009); R. Krupski (2008); G. Osbert-Pociecha (2011). Treść stwierdzeń zawartych w kwestionariuszu ankiety, odpowiadające im kody oraz wyniki oceny rzetelności miar przedstawiono w tabelach 5.7 i 5.8 .

\section{Tabela 5.7. Elastyczność operacyjna}

\begin{tabular}{|c|l|}
\hline Symbol & \multicolumn{1}{|c|}{ Elastyczność operacyjna (EO) - stwierdzenie } \\
\hline EO1 & $\begin{array}{l}\text { Występuje u nas elastyczny proces produkcyjny (możliwości przezbrojenia, zmiany wy- } \\
\text { twarzanych wyrobów) }\end{array}$ \\
\hline EO2 & $\begin{array}{l}\text { Występuje u nas elastyczny proces logistyczny (łańcuch dostaw, realizacja i kontrola) - } \\
\text { zaopatrzenie }\end{array}$ \\
\hline EO3 & $\begin{array}{l}\text { Występuje u nas elastyczny proces marketingowy (umowy marketingowe, kanały komu- } \\
\text { nikacyjne, narzędzia promocyjne) }\end{array}$ \\
\hline EO4 & $\begin{array}{l}\text { Występuje u nas elastyczny proces sprzedażowy (badanie potrzeb klienta, przygotowanie } \\
\text { oferty, prezentacja oferty i finalizacja transakcji, obsługa) }\end{array}$ \\
\hline EO5 & $\begin{array}{l}\text { Występuje elastyczność asortymentu produkcji, czyli możliwość szybkiego i ekonomicz- } \\
\text { nego przejścia do produkcji nowych wyrobów }\end{array}$ \\
\hline EO6 & $\begin{array}{l}\text { Występuje elastyczność wielkości produkcji, czyli zdolność do efektywnych zmian wiel- } \\
\text { kości produkcji }\end{array}$ \\
\hline EO7 & $\begin{array}{l}\text { Informacja o zmianach rynkowych jest szybko wykorzystywana do wprowadzania } \\
\text { zmian w działalności firmy }\end{array}$ \\
\hline a-Cronbacha = 0,814 \\
\hline
\end{tabular}

Skala ocen: pięciopunktowa skala Likerta, gdzie 1 oznacza zdecydowanie nie zgadzam się, a 5 zdecydowanie zgadzam się.

Następny rozpatrywany konstrukt modelu stanowi „przywództwo strategiczne”, którego miary zostały opracowane na podstawie badań takich autorów, jak: G. Avery 
Tabela 5.8. Elastyczność finansowa

\begin{tabular}{|c|l|}
\hline Symbol & \multicolumn{1}{|c|}{ Elastyczność finansowa (EF) - stwierdzenie } \\
\hline EF1 & Korzystamy z celowych źródeł finansowania (kredyty, poręczenia, dotacje) \\
\hline EF2 & Wykorzystujemy dźwignię finansową \\
\hline \multicolumn{2}{|c|}{-Cronbacha $=0,674$} \\
\hline
\end{tabular}

Skala ocen: pięciopunktowa skala Likerta, gdzie 1 oznacza zdecydowanie nie zgadzam się, a 5 zdecydowanie zgadzam się.

(2009); M. Crocitto i M. Youssef (2003); P. Ussahawanitchakit (2012). Treść stwierdzeń zawartych w kwestionariuszu ankiety, odpowiadające im kody oraz wyniki oceny rzetelności miar przedstawiono w tabeli 5.9.

Tabela 5.9. Wskaźniki przywództwa strategicznego

\begin{tabular}{|c|l|}
\hline Symbol & \multicolumn{1}{|c|}{ Przywództwo strategiczne (PS) - stwierdzenie } \\
\hline PS1 & $\begin{array}{l}\text { W ramach realizowanych projektów przywódcy mogą się wyłaniać z grupy, zamiast być } \\
\text { formalnie wyznaczeni }\end{array}$ \\
\hline PS2 & $\begin{array}{l}\text { Przywództwo w naszej firmie zakłada tworzenie i wdrażanie strategii dla nieprzewidzia- } \\
\text { nych zdarzeń dla zapewnienia przetrwania i rozwoju }\end{array}$ \\
\hline PS3 & Istotą przywództwa jest wprowadzanie zmian (zapewnienie firmie adaptacji do otoczenia) \\
\hline \multicolumn{2}{|c|}{ a-Cronbacha $=0,794$} \\
\hline
\end{tabular}

Skala ocen: pięciopunktowa skala Likerta, gdzie 1 oznacza zdecydowanie nie zgadzam się, a 5 zdecydowanie zgadzam się.

W zaproponowanym modelu zwinności strategicznej dziewięć zaproponowanych konstruktów egzogenicznych ma wpływ na dwa konstrukty o charakterze endogenicznym. Te ostatnie to „wyniki rynkowe” oraz „wyniki finansowe”. W przypadku „wyników rynkowych” wybrano cztery spośród ośmiu wskaźników, które najlepiej korespondują ze zmienną latentną. Natomiast „wyniki finansowe” zostały opisane na podstawie czterech z sześciu pierwotnie wyznaczonych zmiennych obserwowalnych. Respondentów poproszono o ocenę wybranych wyników rynkowych i finansowych ich przedsiębiorstw, osiągniętych w ostatnich trzech latach, w porównaniu do ich głównych konkurentów. Wskaźniki wykorzystane w ramach obu konstruktów zostały zaadaptowane z prac następujących autorów: E. Urbanowska-Sojkin (2013b, s. 435); G. Gruszczyńska-Malec i W. Hładoń (2011); R. Kozielski (2011); A. Zakrzewska-Bielawska (2018, s. 132). Wspomniani autorzy opowiadają się za użyciem percepcyjnych wskaźników do mierzenia wyników przedsiębiorstw. Pomimo potencjalnych słabości przy wykorzystaniu skal uwzględniających miary percepcyjne respondentów często wykorzystuje się je w literaturze (Gabryś i Bratnicki, 2015). Treść stwierdzeń zawartych w kwestionariuszu ankiety, odpowiadające im kody oraz wyniki oceny rzetelności miar przedstawiono w tabelach 5.10. i 5.11. 
Tabela 5.10. Wskaźniki wyników rynkowych

\begin{tabular}{|c|l|}
\hline Symbol & \multicolumn{1}{|c|}{ Wyniki rynkowe (WR) - stwierdzenie } \\
\hline WR1 & Zadowolenie klienta (satysfakcja) \\
\hline WR2 & Reputacja przedsiębiorstwa \\
\hline WR3 & Trwałość współpracy z interesariuszami innymi niż klientami \\
\hline WR4 & Trwałość współpracy z klientami (dynamika zmiany liczby klientów) \\
\hline \multicolumn{2}{|c|}{$a$-Cronbacha $=0,861$} \\
\hline
\end{tabular}

Skala ocen: pięciopunktowa skala Likerta, gdzie 1 oznacza zdecydowanie nie zgadzam się, a 5 zdecydowanie zgadzam się.

Tabela 5.11. Wskaźniki wyników finansowych

\begin{tabular}{|c|l|}
\hline Symbol & \multicolumn{1}{|c|}{ Wyniki finansowe (WF) - stwierdzenie } \\
\hline WF1 & ROS (rentowność sprzedaży) \\
\hline WF2 & ROE (rentowność kapitału własnego) \\
\hline WF3 & ROA (rentowność aktywów) \\
\hline WF4 & Zysk netto \\
\hline \multicolumn{2}{|c|}{ a-Cronbacha $=0,879$} \\
\hline
\end{tabular}

Skala ocen: pięciopunktowa skala Likerta, gdzie 1 oznacza zdecydowanie nie zgadzam się, a 5 zdecydowanie zgadzam się.

Wszystkie zaproponowane zmienne przeszły pozytywnie test wewnętrznej rzetelności, co świadczy o dobrym dopasowaniu skal. Dość niski wskaźnik współczynnika alfa-Cronbacha dla zmiennej „skłonność do ryzyka” oraz „ elastyczność finansowa” jest spowodowana małą liczbą wskaźników (jedynie dwa w ramach każdej zmiennej). Przygotowane zmienne wraz ze wskaźnikami je mierzącymi zostaną poddane testowaniu na kolejnym etapie modelowania strukturalnego, którym jest konstrukcja modelu pomiarowego.

\subsection{Budowa modeli pomiarowych zwinności strategicznej}

Etapem poprzedzającym budowę modelu strukturalnego jest konstrukcja modelu pomiarowego, jego testowanie i ocena. Wyznaczone w modelu pomiarowym informacje o ładunkach czynnikowych będą następnie wykorzystane w modelu strukturalnym uwzględniającym relacje między jego konstruktami latentnymi.

Testowania modelu pomiarowego oraz wyznaczenia wskaźników informujących o dobroci jego dopasowania dokonano, wykorzystując konfirmacyjną analizę czynnikową, która ustala liczbę czynników i powiązań między konstruktami 
(zmiennymi latentnymi) i opisującymi je wskaźnikami wynikającymi z teorii, testując w ten sposób jakość modelu pomiarowego (Zakrzewska-Bielawska, 2018, s. 137). W procesie oceny modelu pomiarowego dopuszczalne są modyfikacje, których celem jest zwiększenie dopasowania modelu do danych uzyskanych podczas wykonywania badań empirycznych, jednak nie powinny one zmieniać jego założeń teoretycznych.

W pierwotnym modelu pomiarowym uwzględniono 44 wskaźniki obserwowalne, a wszystkie ładunki czynnikowe przyjętych zmiennych obserwowalnych były istotne statystycznie i przyjmowały wartości powyżej 0,5 . Model poddano ocenie i testowaniu, korzystając z programu AMOS.

Pomimo akceptowalnych wskaźników dopasowania pierwotnego modelu pomiarowego zdecydowano się na wyłączenie pozycji z najniższą wartością ładunków czynnikowych, niższych od 0,6. Zidentyfikowano sześć takich przypadków. Wśród nich znalazły się wskaźniki: SR3. KP5, EO1, EO5, EO6, EO7. Pozycje te zostały usunięte $\mathrm{z}$ narzędzi pomiarowych. Jedynie wskaźnik SR1 z wartością ładunku czynnikowego 0,51 nie został usunięty ze względu na fakt, że stanowi on jedną z dwóch miar konstruktu „skłonność do ryzyka”. Wskaźniki dopasowania osiągnięte w zmodyfikowanym modelu pomiarowym są satysfakcjonujące, natomiast wyłączone z modelu pozycje nie zmieniają jego zasadniczych założeń teoretycznych.

Przeprowadzono analizę porównawczą mierników dopasowania (absolutnych, porównawczych i przyrostowych oraz oszczędnych) dla modelu pierwotnego oraz zmodyfikowanego, której wyniki przedstawia tabela 5.12.

Można zauważyć poprawę w zakresie statystki $\chi^{2}$, której wartość zmniejszyła się w modelu zmodyfikowanym do 1072,526 przy 618 stopniach swobody. Zmiana świadczy o dobrym dopasowaniu macierzy kowariancji teoretycznej i empirycznej. Ograniczenia nałożone przy konstrukcji modelu teoretycznego zostały więc pozytywnie zweryfikowane. Pozostałe absolutne miary modelu również uzyskały satysfakcjonujący poziom. Znormalizowane $\chi^{2}$ uzyskało wartość 1,73 i jest znacznie niższe od maksymalnej wartości 5 . Wartość wskaźnika RAMSEA pozostała na tym samym poziomie 0,04 , co świadczy o dobrym dopasowaniu modelu. Miary GFI $(0,88)$ oraz jej dostosowana wersja do liczby stopni swobody AGFI $(0,85)$ uległy podwyższeniu i wynoszą niewiele poniżej granicy dobrze dopasowanego modelu, która wynosi 0,9 . Obniżeniu natomiast uległ pierwiastek z sumy kwadratów różnic między próbkowymi oraz teoretycznymi wartościami wariancji i kowariancji w postaci wskaźnika RMR, przyjmując wartość 0,4 . Im mniejsza wartość tego wskaźnika, tym model jest lepiej dopasowany.

W ramach porównawczych i przyrostowych miar dopasowania model spełnia stawiane kryteria. Znacznej poprawie uległa wartość statystyki $\chi^{2}-$ w modelu zmodyfikowanym obniżyła się o 382,56, natomiast liczba stopni swobody zmniejszyła się o 194. Zmiana ta była istotna statystycznie. Wzrostowi uległy natomiast mierniki przyrostowe, a ich wartości w modelu zmodyfikowanym świadczą o bardzo dobrym dopasowaniu modelu do danych. Zarówno wskaźnik inkrementalny (IFI), 
Tuckera-Lewisa (TLI), jak i porównawczy indeks dopasowania (CFI) osiągnęły wartości znacznie powyżej wartości granicznej 0,9 .

Oszczędne miary dopasowania także uległy poprawie, co świadczy o tym, że zmodyfikowany model spełnia przyjęte założenia teoretyczne. Miara PNFI wzrosła z 0,75 do 0,76 , natomiast wartość wskaźnika AIC zgodnie z zaleceniami metodycznymi obniżyła się do 1318,526. W świetle zaprezentowanych powyżej miar zmodyfikowany model pomiarowy może być zaakceptowany jako ostateczny model pomiarowy. Zanim jednak podjęto decyzję o jego przyjęciu, zgodnie z wcześniejszymi zaleceniami dokonano oceny trafności zbieżnej i różnicowej modelu.

Tabela 5.12. Miary dopasowania modeli pomiarowych

\begin{tabular}{|c|c|c|}
\hline Miary & Pierwotny model pomiarowy & $\begin{array}{c}\text { Zmodyfikowany model } \\
\text { pomiarowy* }\end{array}$ \\
\hline \multicolumn{2}{|c|}{ Absolutne wskaźniki dopasowania } \\
\hline$\chi^{2}$ & 1455,087 & 1072,526 \\
\hline Ss & 812 & 618 \\
\hline P & 0,04 & 0,10 \\
\hline$\chi^{2} /$ ss & 1,79 & 1,73 \\
\hline RMSEA & 0,04 & 0,04 \\
\hline GFI & 0,86 & 0,88 \\
\hline AGFI & 0,83 & 0,85 \\
\hline RMR & 0,05 & 0,04 \\
\hline Zmiana $\chi^{2}$ Porównawcze i przyrostowe mierniki dopasowania \\
\hline Zmiana $s s$ & - & 382,561 \\
\hline P & - & 194 \\
\hline IFI & - & 0,000 \\
\hline TLI & 0,92 & 0,94 \\
\hline CFI & 0,91 & 0,93 \\
\hline \multicolumn{2}{|c|}{0,92} & 0,94 \\
\hline PNFI & 0,75 & 0,76 \\
\hline AIC & 1723,09 & 1318,526 \\
\hline
\end{tabular}

${ }^{*}$ Model pomiarowy bez wskaźników SR3. KP5, EO1, EO5, EO6, EO7.

W ocenie trafności zbieżnej zmiennych nieobserwowalnych pierwszym etapem jest analiza niestandardowych ładunków czynnikowych. Wszystkie oszacowane w konfirmacyjnej analizie czynnikowej wskaźniki okazały się istotne statystycznie i powiązane z mierzonymi przez nie konstruktami. Wyliczenia dotyczące ładunków niestandaryzowanych, błędy standardowe oraz ilorazy krytyczne wszystkich zmiennych obserwowalnych zaprezentowano w tabeli 5.13. 
Tabela 5.13. Estymacja niestandaryzowanych ładunków czynnikowych (konfirmacyjna analiza czynnikowa)

\begin{tabular}{|c|c|c|c|c|}
\hline Konstrukt & Wskaźnik & $\begin{array}{l}\text { Niestandaryzo- } \\
\text { wany ladunek } \\
\text { czynnikowy }\end{array}$ & $\begin{array}{c}\text { Błąd } \\
\text { standardowy }\end{array}$ & Iloraz krytyczny \\
\hline \multirow[t]{3}{*}{ UOS } & UOS1 & 1,00 & - & - \\
\hline & UOS2 & 1,01 & 0,09 & 10,87 \\
\hline & UOS3 & 0,91 & 0,09 & 9,77 \\
\hline \multirow[t]{2}{*}{ SR } & SR1 & 0,52 & 0,09 & 5,74 \\
\hline & SR2 & 1,00 & - & - \\
\hline \multirow[t]{5}{*}{ ZW } & ZW1 & 1,00 & - & - \\
\hline & ZW2 & 1,18 & 0,11 & 10,48 \\
\hline & ZW3 & 1,22 & 0,10 & 11,42 \\
\hline & ZW4 & 1,14 & 0,09 & 11,86 \\
\hline & ZW5 & 1,06 & 0,09 & 10,80 \\
\hline \multirow[t]{4}{*}{ ZI } & ZI1 & 0,08 & 0,05 & 13,70 \\
\hline & ZI2 & 0,84 & 0,06 & 13,04 \\
\hline & ZI3 & 0,76 & 0,05 & 12,93 \\
\hline & ZI4 & 1,00 & - & - \\
\hline \multirow[t]{8}{*}{$\mathrm{KP}$} & KP1 & 1,08 & 0,08 & 12,50 \\
\hline & KP2 & 1,30 & 0,08 & 15,33 \\
\hline & KP3 & 1,32 & 0,09 & 14,48 \\
\hline & KP4 & 1,10 & 0,07 & 14,46 \\
\hline & KP6 & 1,12 & 0,07 & 14,52 \\
\hline & KP7 & 1,21 & 0,08 & 14,56 \\
\hline & KP8 & 0,99 & 0,06 & 14,93 \\
\hline & KP9 & 1,00 & - & - \\
\hline \multirow[t]{3}{*}{$\mathrm{EO}$} & $\mathrm{EO} 2$ & 1,00 & - & - \\
\hline & EO3 & 1,26 & 0,12 & 10,19 \\
\hline & EO4 & 1,18 & 0,11 & 10,10 \\
\hline \multirow[t]{2}{*}{$\mathrm{EF}$} & EF1 & 0,88 & 0,14 & 6,25 \\
\hline & EF2 & 1,00 & - & - \\
\hline \multirow[t]{3}{*}{ PS } & PS1 & 0,96 & 0,07 & 12,88 \\
\hline & PS2 & 1,06 & 0,06 & 15,93 \\
\hline & PS3 & 1,00 & - & - \\
\hline \multirow[t]{4}{*}{ WR } & WR1 & 0,92 & 0,06 & 15,23 \\
\hline & WR2 & 1,08 & 0,06 & 16,97 \\
\hline & WR3 & 1,02 & 0,06 & 15,57 \\
\hline & WR4 & 1,00 & - & - \\
\hline \multirow[t]{4}{*}{ WF } & WF1 & 1,19 & 0,08 & 14,09 \\
\hline & WF2 & 1,32 & 0,08 & 15,64 \\
\hline & WF3 & 1,24 & 0,08 & 15,57 \\
\hline & WF4 & 1,00 & - & - \\
\hline
\end{tabular}


Na kolejnym etapie oceny trafności zbieżnej sprawdzono, czy standaryzowana wartość ładunków czynnikowych jest na odpowiednim poziomie przekraczającym 0,5 . Ponadto wyznaczono wartość miernika AVE oraz CR, dzięki którym uzyskano informacje dotyczące spójności wskaźników mierzących poszczególne konstrukty. Wszystkie zmienne ukryte przeszły pozytywnie test trafności zbieżnej, ich wartości AVE są wyższe od granicznego poziomu 50\%, natomiast miernik CR przekroczył wyznaczony próg 0,7 dla badanych konstruktów, świadcząc o rzetelności zmiennych ukrytych. Wyniki obliczeń standaryzowanych ładunków czynnikowych, wartości miernika AVE oraz CR zaprezentowano w tabeli 5.14. Uzyskane wyniki wskazują na spełnienie przez zmienne latentne modelu testu trafności zbieżnej.

Tabela 5.14. Standaryzowane ładunki czynnikowe i mierniki oceny zbieżności zmiennych przyjętego modelu pomiarowego

\begin{tabular}{|c|c|c|c|c|}
\hline Konstrukt & Wskaźnik & $\begin{array}{c}\text { Standaryzowany } \\
\text { ladunek } \\
\text { czynnikowy }\end{array}$ & CR & $\operatorname{AVE}(w \%)$ \\
\hline \multirow[t]{3}{*}{ UOS } & UOS1 & 0,69 & \multirow[t]{3}{*}{0,71} & \multirow[t]{3}{*}{0,51} \\
\hline & UOS2 & 0,71 & & \\
\hline & UOS3 & 0,60 & & \\
\hline \multirow[t]{2}{*}{ SR } & SR1 & 0,51 & \multirow[t]{2}{*}{0,72} & \multirow[t]{2}{*}{0,55} \\
\hline & SR2 & 0,91 & & \\
\hline \multirow[t]{5}{*}{ ZW } & ZW1 & 0,63 & \multirow[t]{5}{*}{0,81} & \multirow[t]{5}{*}{0,52} \\
\hline & ZW2 & 0,64 & & \\
\hline & ZW3 & 0,71 & & \\
\hline & ZW4 & 0,75 & & \\
\hline & ZW5 & 0,66 & & \\
\hline \multirow[t]{4}{*}{ ZI } & ZI1 & 0,69 & \multirow[t]{4}{*}{0,80} & \multirow[t]{4}{*}{0,51} \\
\hline & ZI2 & 0,66 & & \\
\hline & $\mathrm{ZI} 3$ & 0,66 & & \\
\hline & ZI4 & 0,79 & & \\
\hline \multirow[t]{8}{*}{$\mathrm{KP}$} & KP1 & 0,65 & \multirow[t]{8}{*}{0,91} & \multirow[t]{8}{*}{0,55} \\
\hline & KP2 & 0,81 & & \\
\hline & KP3 & 0,76 & & \\
\hline & KP4 & 0,76 & & \\
\hline & KP6 & 0,76 & & \\
\hline & KP7 & 0,77 & & \\
\hline & KP8 & 0,67 & & \\
\hline & KP9 & 0,69 & & \\
\hline \multirow[t]{3}{*}{ EO } & $\mathrm{EO} 2$ & 0,61 & \multirow[t]{3}{*}{0,73} & \multirow[t]{3}{*}{0,53} \\
\hline & EO3 & 0,73 & & \\
\hline & $\mathrm{EO} 4$ & 0,72 & & \\
\hline
\end{tabular}


cd. tab. 5.14

\begin{tabular}{|c|c|c|c|c|}
\hline \multirow{2}{*}{ EF } & EF1 & 0,66 & \multirow{2}{*}{0,71} & 0,51 \\
\cline { 2 - 3 } & EF2 & 0,76 & & \\
\hline \multirow{3}{*}{ PS } & PS1 & 0,65 & 0,80 & 0,59 \\
\cline { 2 - 3 } & PS2 & 0,81 & \\
\cline { 2 - 3 } & PS3 & 0,79 & 0,61 \\
\cline { 2 - 3 } WR & WR1 & 0,75 & \multirow{2}{*}{0,86} & \\
\cline { 2 - 3 } & WR2 & 0,82 & 0,66 \\
\cline { 2 - 3 } & WR3 & 0,76 & \\
\cline { 2 - 3 } & WR4 & 0,77 & \multirow{2}{*}{0,88} & \\
\cline { 2 - 3 } & WF1 & 0,77 & \\
\cline { 2 - 3 } & WF2 & 0,88 & \\
\cline { 2 - 3 } & WF3 & 0,88 & & \\
\hline
\end{tabular}

Następnie oceniono trafność różnicową wyodrębnionych konstruktów w celu sprawdzenia, w jakim stopniu zmienne latentne są różne. Do wykonania tego zadania porównano pierwiastki kwadratowe AVE z odpowiednimi czynnikami korelacji, a ich znacznie wyższe wartości świadczą o pozytywnym teście trafności różnicowej wskazujących na odmienność konstruktów przyjętego modelu. Przeanalizowano również wynik maksymalnej dzielonej wariancji MSV, której wartości powinny być niższe niż AVE. Wyniki zaprezentowane w tabeli 5.15 świadczą o trafności różnicowej zmiennych latentnych w modelu.

Tabela 5.15. Trafność różnicowa dla poszczególnych konstruktów modelu pomiarowego

\begin{tabular}{|c|c|c|c|c|c|c|c|c|c|c|c|c|}
\hline 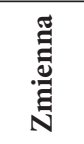 & $\sum_{i}^{\infty}$ & 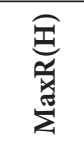 & $\frac{1}{3}$ & ○્પ & 3 & $\frac{\mathfrak{c}}{3}$ & $\overrightarrow{\mathbf{N}}$ & $\tilde{a}$ & oి & 壵 & జ్ & 童 \\
\hline WF & 0,396 & 0,905 & 0,810 & & & & & & & & & \\
\hline EO & 0,300 & 0,742 & 0,320 & 0,692 & & & & & & & & \\
\hline ZW & 0,388 & 0,818 & 0,366 & 0,500 & 0,682 & & & & & & & \\
\hline WR & 0,396 & 0,865 & 0,629 & 0,352 & 0,380 & 0,780 & & & & & & \\
\hline ZI & 0,489 & 0,811 & 0,404 & 0,532 & 0,509 & 0,393 & 0,708 & & & & & \\
\hline PS & 0,520 & 0,819 & 0,338 & 0,513 & 0,570 & 0,405 & 0,625 & 0,760 & & & & \\
\hline UOS & 0,364 & 0,721 & 0,322 & 0,393 & 0,513 & 0,418 & 0,461 & 0,524 & 0,675 & & & \\
\hline $\mathrm{EF}$ & 0,114 & 0,686 & 0,143 & 0,288 & 0,313 & 0,102 & 0,290 & 0,241 & 0,158 & 0,716 & & \\
\hline SR & 0,181 & 0,853 & 0,237 & 0,327 & 0,253 & 0,262 & 0,378 & 0,279 & 0,425 & 0,337 & 0,745 & \\
\hline $\mathrm{KP}$ & 0,520 & 0,911 & 0,323 & 0,548 & 0,623 & 0,434 & 0,699 & 0,721 & 0,603 & 0,152 & 0,312 & 0,741 \\
\hline
\end{tabular}


Uzyskane w ramach analiz wskaźniki dopasowania modelu pomiarowego oraz pomyślne testy trafności zbieżnej i różnicowej potwierdziły zasadność jego przyjęcia jako ostatecznego modelu pomiarowego, który dalej posłuży do procesu modelowania strukturalnego. Graficzną postać modelu zaprezentowano na rysunku 5.2.

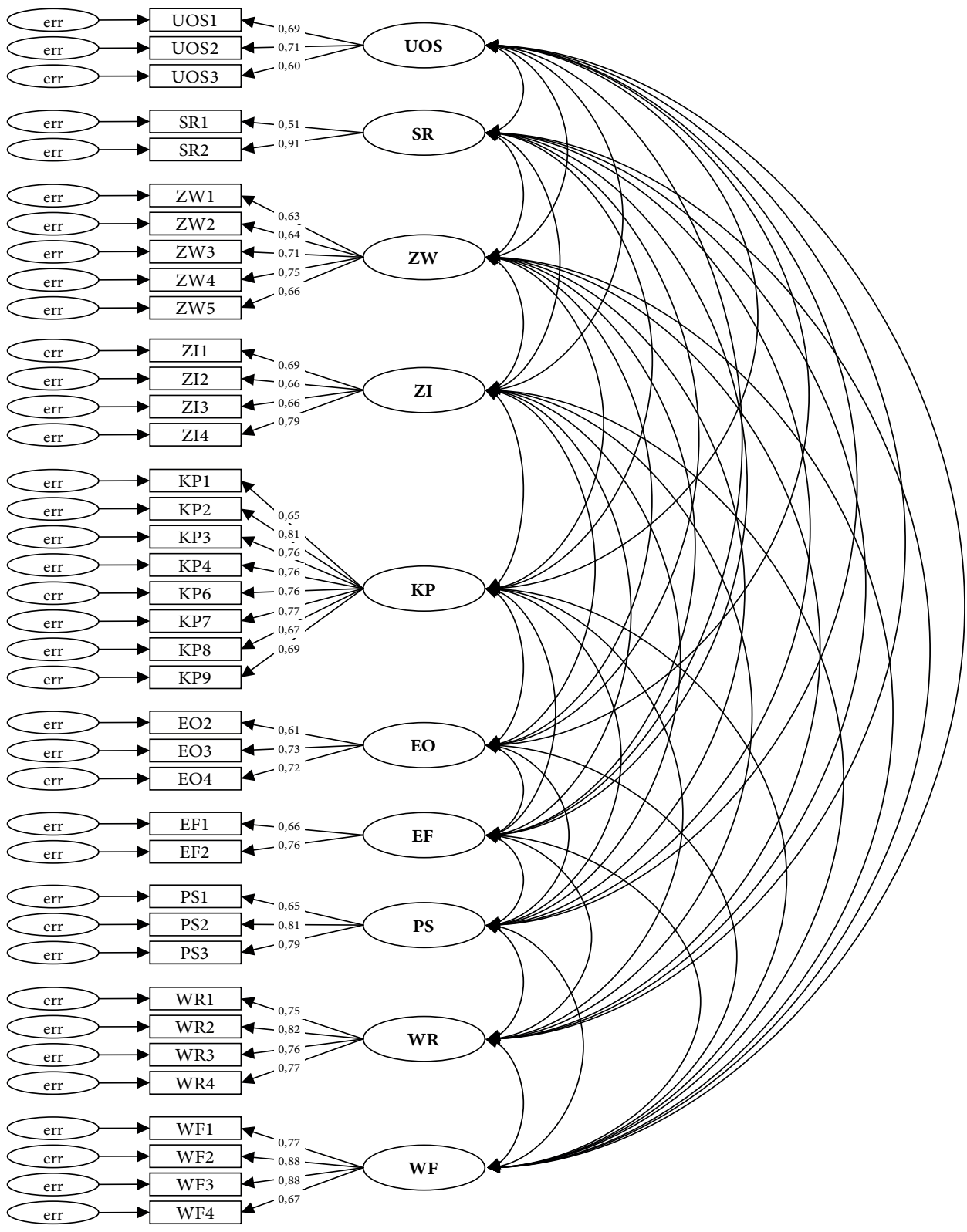

Rysunek 5.2. Model pomiarowy zwinności strategicznej 


\subsection{Model strukturalny zwinności strategicznej}

Drugi etap modelowania polega na przygotowaniu modelu strukturalnego przedstawiającego relacje przyczynowe między konstruktami latentymi, oparte na koncepcyjnym modelu zwinności strategicznej. Analiza i ocena modelu strukturalnego umożliwi estymację założonych związków oraz wstępną ocenę postawionych hipotez. Przyjęte podejście sekwencyjne pozwoli na wykorzystanie informacji o ładunkach czynnikowych zebranych w poprzednim podrozdziale podczas konfirmacyjnej analizy czynnikowej. Model strukturalny zwinności strategicznej, prezentujący relacje pomiędzy konstruktami, siłę związków, wartości standaryzowanych ładunków czynnikowych i związane z nimi błędy, przedstawiono na rysunku 5.3.

Opracowany model strukturalny uzyskał zadowalające miary dopasowania do danych pochodzących z badań empirycznych. Wartość statystyki $\chi^{2}$ jest nieco wyższa niż w zmodyfikowanym modelu konfirmacyjnym i wynosi 1091, 322 przy 626 stopniach swobody. Wynik ten świadczy o dobrym dopasowaniu macierzy kowariancji teoretycznej do macierzy kowariancji empirycznej. Znormalizowane $\chi^{2}$ osiągnęło wartość 1,74 , czyli znacznie poniżej granicznej wartości 5. Wskaźnik

Tabela 5.16. Miary dopasowania modelu strukturalnego

\begin{tabular}{|l|c|}
\hline \multicolumn{1}{|c|}{ Miary } & Model strukturalny \\
\hline$\chi^{2}$ & 1091,322 \\
\hline$s s$ & 626 \\
\hline$p$ & 0,12 \\
\hline$\chi^{2} / s s$ & 1,74 \\
\hline RMSEA & 0,04 \\
\hline GFI & 0,88 \\
\hline AGFI & 0,85 \\
\hline RMR & 0,05 \\
\hline Porównawcze i przyrostowe mierniki dopasowania \\
\hline Zmiana $\chi^{2}$ & - \\
\hline Zmiana $s s$ & - \\
\hline$p$ & - \\
\hline IFI & 0,94 \\
\hline TLI & 0,93 \\
\hline CFI & 0,93 \\
\hline \multicolumn{2}{|c|}{ Oszczędne mierniki dopasowania } \\
\hline PNFI & 0,77 \\
\hline AIC & 1321,322 \\
\hline
\end{tabular}




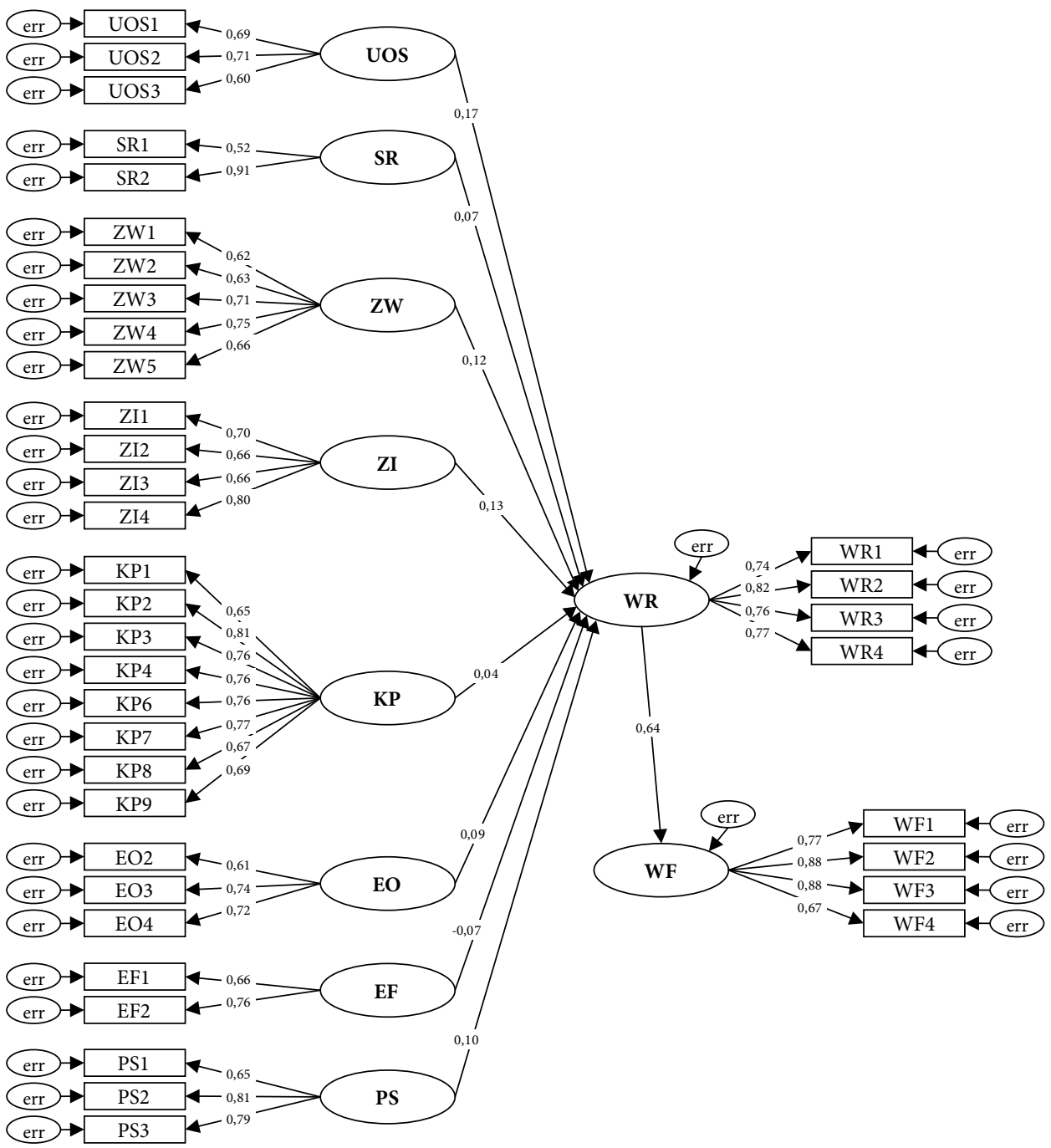

Rysunek 5.3. Model strukturalny zwinności strategicznej

RAMSEA uzyskał satysfakcjonujący wynik na poziomie 0,04 , co świadczy o dobrym dopasowaniu modelu do danych empirycznych. Pozostałe absolutne wskaźniki dopasowania (GFI, AGFI) osiągnęły prawie graniczny poziom 0,9 i wynoszą odpowiednio 0,88 oraz 0,85 . Wartość wskaźnika RMR wyniosła 0,05 i jest na zadowalającym poziomie. Przyrostowe mierniki dopasowania (IFI, TLI, CFI) przekroczyły graniczną wartość 0,9 .

Zadowalające wyniki dopasowania modelu strukturalnego do danych empirycznych upoważniają do oceny przyjętych hipotez badawczych. W tym celu wykorzystano wyniki estymacji parametrów standaryzowanych informujących o sile 
związków pomiędzy poszczególnymi konstruktami latentymi oraz o ich poziomie statystycznym. Ze względu na wyłączenie z modelu konstruktu „umiejętność rozwoju zasobów własnych", który na poziomie eksploracyjnej analizy czynnikowej został usunięty z dalszej procedury badawczej, hipoteza H2a nie była estymowana. W tabeli 5.17 zaprezentowano parametry dla ścieżek wyznaczonych w modelu zwinności strategicznej.

Tabela 5.17. Wyniki estymacji parametrów standaryzowanych modelu strukturalnego

\begin{tabular}{|l|c|}
\hline \multicolumn{1}{|c|}{ Ścieżka (hipoteza) } & $\begin{array}{c}\text { Parametr standaryzowany modelu } \\
\text { strukturalnego }\end{array}$ \\
\hline Umiejętność oceny szans $\rightarrow$ wyniki rynkowe (H1a) & $0,17^{*}$ \\
\hline Skłonność do ryzyka $\rightarrow$ wyniki rynkowe (H1b) & 0,7 \\
\hline Zdolność współpracy $\rightarrow$ wyniki rynkowe (H2b) & $0,12^{*}$ \\
\hline Zdolność innowacyjna $\rightarrow$ wyniki rynkowe (H2c) & $0,13^{*}$ \\
\hline Kultura przedsiębiorcza $\rightarrow$ wyniki rynkowe (H2d) & 0,04 \\
\hline Elastyczność operacyjna $\rightarrow$ wyniki rynkowe (H3a) & $0,09^{*}$ \\
\hline Elastyczność finansowa $\rightarrow$ wyniki rynkowe (H3b) & $-0,07$ \\
\hline Przywództwo strategiczne $\rightarrow$ wyniki rynkowe (H4) & $0,10^{*}$ \\
\hline Wyniki rynkowe $\rightarrow$ wyniki finansowe (H5) & $0,64^{* *}$ \\
\hline
\end{tabular}

* Istotna statystycznie dla $p<0,05$.

** Istotna statystycznie dla $p<0,01$.

W ramach dziewięciu założonych zależności sześć okazało się istotnych statystycznie. Uzyskane wyniki, zgodnie z postawioną hipotezą H1a, wskazują na pozytywny istotny statystycznie wpływ umiejętności oceny szans na wyniki rynkowe przedsiębiorstw. W przypadku skłonności do ryzyka siła analogicznego związku jest niższa, jednak nieistotna statystycznie (H1b). Pozytywny i istotny statystycznie wpływ oddziaływania odnotowano pomiędzy zdolnością współpracy a wynikami rynkowymi (H2b). Analogiczny związek istotny statystycznie o podobnej sile zweryfikowano w przypadku zdolności innowacyjnej i jej wpływu na wyniki rynkowe (H2c). Wbrew oczekiwaniom nie potwierdzono hipotezy H2d. Mimo że kultura przedsiębiorcza pozytywnie wpływa na wyniki rynkowe (choć siła związku jest niska), to wpływ ten nie jest istotny statystycznie. W przypadku elastyczności operacyjnej zgodnie z założeniami odnotowano pozytywny $\mathrm{i}$ istotny statystycznie wpływ zmiennej na wyniki rynkowe przedsiębiorstw (H3a). Natomiast wpływ elastyczności finansowej na wyniki rynkowe okazał się odwrotny do wstępnie zakładanego, związek ten nie jest istotny statystycznie (H3b). Pozytywny związek istotny statystycznie ujawniono między przywództwem strategicznym a wynikami rynkowymi, co potwierdza hipotezę H4. Najsilniejszą siłę związku istotnego statystycznie odnotowano pomiędzy wynikami rynkowymi a wynikami finansowymi, co potwierdza hipotezę H5. 


\subsection{Ocena testowanych hipotez i wnioski badawcze}

Przeprowadzone postępowanie badawcze umożliwiło odniesienie się do przyjętych w rozdziale trzecim hipotez badawczych. W świetle prowadzonych rozważań teoretycznych postawiono hipotezę główną, którą rozwinięto w pięciu hipotezach

\section{Tabela 5.18. Ocena postawionych hipotez badawczych}

\begin{tabular}{|c|c|c|}
\hline Hipotezy & $\begin{array}{l}\text { Rezultat } \\
\text { testowania } \\
\text { hipotezy }\end{array}$ & Uwagi \\
\hline $\begin{array}{l}\text { H1: Wrażliwość strategiczna (współtworzona przez umie- } \\
\text { jętność oceny szans oraz skłonność do ryzyka) ma pozy- } \\
\text { tywny wpływ na wyniki rynkowe przedsiębiorstw }\end{array}$ & $\begin{array}{l}\text { częściowo } \\
\text { potwierdzona }\end{array}$ & $\begin{array}{l}\text { H1a potwierdzona, ale } \\
\text { H1b odrzucona }\end{array}$ \\
\hline $\begin{array}{l}\text { H1a: Umiejętność oceny szans ma pozytywny wpływ na } \\
\text { wyniki rynkowe przedsiębiorstw }\end{array}$ & potwierdzona & $\begin{array}{l}\text { pozytywny wpływ } \\
\text { istotny statystycznie }\end{array}$ \\
\hline $\begin{array}{l}\text { H1b: Skłonność do ryzyka ma pozytywny wpływ na wy- } \\
\text { niki rynkowe przedsiębiorstw }\end{array}$ & odrzucona & $\begin{array}{l}\text { pozytywny wpływ nie- } \\
\text { istotny statystycznie }\end{array}$ \\
\hline $\begin{array}{l}\text { H2: Przedsiębiorczość strategiczna (współtworzona przez: } \\
\text { umiejętność rozwoju zasobów własnych, zdolność współ- } \\
\text { pracy, zdolność innowacyjną, kulturę przedsiębiorczą) ma } \\
\text { pozytywny wpływ na wyniki rynkowe przedsiębiorstw }\end{array}$ & $\begin{array}{l}\text { częściowo } \\
\text { potwierdzona }\end{array}$ & $\begin{array}{l}\text { H2a nieestymowana } \\
\text { w modelu struktural- } \\
\text { nym } \\
\text { H2b potwierdzona } \\
\text { H2c potwierdzona } \\
\text { H2d odrzucona }\end{array}$ \\
\hline $\begin{array}{l}\text { H2a: Umiejętność rozwoju zasobów własnych ma pozy- } \\
\text { tywny wpływ na wyniki rynkowe przedsiębiorstw }\end{array}$ & odrzucona & $\begin{array}{l}\text { nieestymowana w mo- } \\
\text { delu strukturalnym }\end{array}$ \\
\hline $\begin{array}{l}\text { H2b: Zdolność współpracy ma pozytywny wpływ na wy- } \\
\text { niki rynkowe przedsiębiorstw }\end{array}$ & potwierdzona & $\begin{array}{l}\text { pozytywny wpływ } \\
\text { istotny statystycznie }\end{array}$ \\
\hline $\begin{array}{l}\text { H2c: Zdolność innowacyjna ma pozytywny wpływ na wy- } \\
\text { niki rynkowe przedsiębiorstw }\end{array}$ & potwierdzona & $\begin{array}{l}\text { pozytywny wpływ } \\
\text { istotny statystycznie }\end{array}$ \\
\hline $\begin{array}{l}\text { H2d: Kultura przedsiębiorcza ma pozytywny wpływ na } \\
\text { wyniki rynkowe przedsiębiorstw }\end{array}$ & odrzucona & $\begin{array}{l}\text { pozytywny wpływ nie- } \\
\text { istotny statystycznie }\end{array}$ \\
\hline $\begin{array}{l}\text { H3: Elastyczność (współtworzona przez elastyczność ope- } \\
\text { racyjną i elastyczność finansową) ma pozytywny wpływ na } \\
\text { wyniki rynkowe przedsiębiorstw }\end{array}$ & $\begin{array}{l}\text { częściowo } \\
\text { potwierdzona }\end{array}$ & $\begin{array}{l}\text { H3a potwierdzona, ale } \\
\text { H3b odrzucona }\end{array}$ \\
\hline $\begin{array}{l}\text { H3a: Elastyczność operacyjna ma pozytywny wpływ na } \\
\text { wyniki rynkowe przedsiębiorstw }\end{array}$ & potwierdzona & $\begin{array}{l}\text { pozytywny wpływ } \\
\text { istotny statystycznie }\end{array}$ \\
\hline $\begin{array}{l}\text { H3b: Elastyczność finansowa ma pozytywny wpływ na } \\
\text { wyniki rynkowe przedsiębiorstw }\end{array}$ & odrzucona & $\begin{array}{l}\text { ujemny wpływ nieistot- } \\
\text { ny statystycznie }\end{array}$ \\
\hline $\begin{array}{l}\text { H4: Przywództwo strategiczne ma pozytywny wpływ na } \\
\text { wyniki przedsiębiorstw }\end{array}$ & potwierdzona & $\begin{array}{l}\text { pozytywny wpływ } \\
\text { istotny statystycznie }\end{array}$ \\
\hline $\begin{array}{l}\text { H5: Wyniki rynkowe mają pozytywny wpływ na ich wy- } \\
\text { niki finansowe przedsiębiorstw }\end{array}$ & potwierdzona & $\begin{array}{l}\text { pozytywny wpływ } \\
\text { istotny statystycznie }\end{array}$ \\
\hline
\end{tabular}


cząstkowych ujętych w modelu badawczym zwinności strategicznej. Wyniki przeprowadzonych analiz statystycznych oraz efekty testowania hipotez pozwoliły na potwierdzenie części z hipotez cząstkowych i odniesienie się do hipotezy głównej. W tabeli 5.18 przedstawiono podsumowanie wyników testowania empirycznego hipotez badawczych. W dalszej części opracowania zostaną omówione wyniki badań, poparte parametrami estymacji przyjętego modelu strukturalnego.

\section{Wrażliwość strategiczna a wyniki rynkowe}

W wyniku estymacji modelu strukturalnego udało się częściowo potwierdzić hipotezę pierwszą dotyczącą pozytywnego wpływu wrażliwości strategicznej (współtworzonej przez umiejętność oceny szans oraz skłonność do ryzyka) na wyniki rynkowe przedsiębiorstw. Ocena hipotezy możliwa była dzięki sprawdzeniu dwóch hipotez szczegółowych, H1a dotyczącej wpływu umiejętności oceny szans na wyniki rynkowe oraz H1b postulującej analogiczny wpływ skłonności do ryzyka. Wyniki badań potwierdziły pozytywny, istotnie statystyczny wpływ umiejętności oceny szans na wyniki rynkowe, co umożliwiło przyjęcie hipotezy H1a $(0,17 ; p<0,05)$. W przekonaniu kierownictwa najwyższego szczebla umiejętność oceny szans, będąca następstwem ich identyfikacji, wpływa pozytywnie na wyniki rynkowe średnich i dużych polskich przedsiębiorstw. Oznacza to, że umiejętność podjęcia szans o dużym potencjale, umożliwiających tworzenie wartości dla klienta, ma pozytywny wpływ na jego satysfakcję, trwałość współpracy, reputację oraz współpracę z innymi interesariuszami przedsiębiorstwa. Poprzez wyniki rynkowe wpływa także pośrednio („ścieżka” przez wyniki rynkowe) na sprawność finansową. Wynik ten pozostaje w zgodzie z prezentowanym w literaturze poglądem postulującym podejście oparte na okazjach (Krupski, 2003), eksponujące wpływ przyjęcia filtru oraz przestrzeni okazji (Krupski, 2010) do rozwijania zdolności wrażliwości na okazje, antycypowania potrzeb klientów, a w efekcie budowania przewagi konkurencyjnej (Fartash i Davoudi, 2012). W ramach wymiaru wrażliwości poddano także weryfikacji empirycznej skłonność do ryzyka i jej wpływ na wyniki rynkowe przedsiębiorstw. Pomimo zakładanego pozytywnego wpływu związek ten nie jest istotny statystycznie $(0,7 ; p>0,1)$. Nie udało się zatem potwierdzić hipotezy H1b. Wyniki badań opisowych zaprezentowane w rozdziale czwartym wskazały, że trzy czwarte badanych przedsiębiorstw przyznaje, że ryzyko stanowi dla nich naturalny element gry rynkowej, a zadaniem osób zarządzających jest nauczyć się je ograniczać. Podejmowanie decyzji ryzykownych jest zatem nieodłącznym atrybutem działań strategicznych jednak wyniki badań nie potwierdzają wpływu skłonności do ryzyka na rezultaty działań w perspektywie rynkowej. 


\section{Przedsiębiorczość strategiczna a wyniki rynkowe}

W zaproponowanym w pracy modelu zwinności strategicznej częściowo potwierdzono hipotezę drugą dotyczącą pozytywnego wpływu przedsiębiorczości strategicznej (współtworzonej przez umiejętność rozwoju zasobów własnych, zdolność współpracy, zdolność innowacyjną, kulturę przedsiębiorczą) na wyniki rynkowe przedsiębiorstw. Hipoteza H2a, według której umiejętność rozwoju zasobów własnych ma pozytywny wpływ na wyniki rynkowe, nie była poddana estymacji ze względu na wyeliminowanie zmiennej już na etapie eksploracyjnej analizy czynnikowej. Zmienna „umiejętność rozwoju zasobów własnych” nie przeszła pozytywnie procedury wyodrębnienia składowych w ramach eksploracyjnej analizy czynnikowej, tym samym wyeliminowano ją z modelu i nie estymowano jej relacji ze zmienną „wyniki rynkowe”. Nie można zatem przyjąć hipotezy H2a, według której umiejętność rozwoju zasobów własnych ma pozytywny wpływ na wyniki rynkowe przedsiębiorstw.

W wyniku estymacji modelu udało się natomiast potwierdzić hipotezę H2b dotyczącą pozytywnego wpływu zdolności współpracy przedsiębiorstw na wyniki rynkowe $(0,12 ; p<0,05)$. Oznacza to, że wiedza zarządzających dotycząca rodzajów potrzebnych zasobów dla wykorzystania szans, źródeł ich pozyskania, jak również umiejętność identyfikowania kluczowych partnerów i zdolność rozwoju współpracy z nimi mają pozytywny wpływ na tworzenie sukcesu rynkowego i pośrednio na wyniki finansowe polskich średnich i dużych przedsiębiorstw. Dzięki współpracy następuje kreacja wiedzy oraz dostęp do potrzebnych zasobów materialnych i niematerialnych. Jednym z efektów podjętej współpracy może być impuls do realizacji określonych przedsięwzięć strategicznych poprzez elastyczne dostosowywanie się do zmieniających się warunków w drodze kształtowania form i zakresu współpracy międzyorganizacyjnej. Uzyskane wyniki podtrzymują prezentowany w literaturze postulat dotyczący oczekiwań wobec współpracy, wskazujący na jej ukierunkowanie na strategiczne umocnienie konkurencyjności i pozycji przedsiębiorstw na rynku (Romanowska, 2007, s. 2). Uzyskane wyniki potwierdzają też wnioski wynikające $\mathrm{z}$ badań przeprowadzonych przez Ch. Yanga oraz H. Liu (2012), którzy udowodnili pozytywny wpływ struktury sieciowej na kształtowanie konkurencyjności w obszarze wyników przedsiębiorstw, tym samym wskazując na pośredniczącą rolę struktury sieciowej we wpływie zwinności na wyniki działalności.

Badania potwierdziły także pozytywny wpływ zdolności innowacyjnej na wyniki rynkowe przedsiębiorstw, dając podstawę do przyjęcia hipotezy $\mathrm{H} 2 \mathrm{c}(0,13 ; p<0,05)$. W odczuciu kierownictwa najwyższego szczebla zdolność do poszukiwania innowacyjnych technologii, procesów oraz pomysłów na nowe produkty oraz zapewnienie środków potrzebnych do ich realizacji przyczynia się do poprawy wyników rynkowych i konkurencyjności przedsiębiorstwa. Nie bez znaczenia jest także nieustanne eksperymentowanie z nowymi koncepcjami i pomysłami, które zapewniają zdobycie nowej wiedzy i testowanie proponowanych rozwiązań. Otrzymany wynik pozostaje w zgodzie z poglądem, że najskuteczniejszym sposobem przekształcenia 
innowacji w trwałą przewagę konkurencyjną jest budowanie zdolności przedsiębiorstw do ciągłej transformacji wiedzy i idei w nowe produkty, procesy i systemy dla ich korzyści (Lawson i Samson, 2001). Wpływ ten potwierdzono także w badaniach empirycznych, w których wykazano pozytywną relację pomiędzy zwinnością strategiczną (współtworzoną przez wymiar oparty na innowacyjności) a lojalnością wobec klientów (Shin i in., 2015).

Najmniej spodziewane wyniki dotyczą braku wpływu kultury przedsiębiorczej na wyniki rynkowe przedsiębiorstw. Pomimo że w literaturze przedmiotu wskazuje się na aktywną rolę kultury przedsiębiorczej w sukcesie rynkowym przedsiębiorstwa (Ireland i in., 2003), to przeprowadzone badania tego nie potwierdziły. Kultura przedsiębiorcza oparta na innowacyjności, kreatywności, doszkalaniu i zaangażowaniu pracowników oraz umocowaniu szczebla wykonawczego nie ma pozytywnego wpływu na wyniki rynkowe średnich i dużych polskich przedsiębiorstw. Badany związek jest nieistotny statystycznie, a korelacja bardzo słaba $(0,04 ; p>0,1)$, w związku z tym należy odrzucić hipotezę $\mathrm{H} 2 \mathrm{~d}$.

\section{Elastyczność a wyniki rynkowe}

Z kolei wymiar elastyczności i jego wypływ na wyniki rynkowe przedsiębiorstw został zbadany poprzez weryfikację wpływu dwóch zmiennych ją współtworzących elastyczności operacyjnej oraz finansowej. Z przeprowadzonych badań wynika, że elastyczność operacyjna ma pozytywny wpływ na wyniki rynkowe $(0,09 ; p<0,05)$, co umożliwiło potwierdzenie hipotezy H3a. Wynik ten świadczy o pozytywnym wpływie elastyczności procesu logistycznego, marketingowego oraz sprzedażowego na wyniki rynkowe i pośrednio na wyniki finansowe przedsiębiorstw. Podejmowanie szybkich i efektywnych zmian w ramach kluczowych procesów tworzących wartość dla klienta zapewnia wzrost poziomu jego zadowolenia, lojalności oraz poprawia reputację przedsiębiorstwa. Doskonałość operacyjna wspiera zaufanie i wiarygodność, co przejawia się także w pozytywnym wpływie na trwałość współpracy $\mathrm{z}$ innymi interesariuszami niż klienci. Uzyskany wynik pozostaje $\mathrm{w}$ zgodzie z poglądem, że podejście procesowe, polegające na poszukiwaniu wzrostu efektywności przedsiębiorstw, odgrywa kluczową rolę w zapewnieniu im konkurencyjności poprzez elastyczność procesów (Osbert-Pociecha, 2011, s. 181). Ponadto elastyczność procesów określa zdolność przedsiębiorstwa do: całkowitej zmiany, doskonalenia, przestawienia kolejności wykonywania czynności przez jego transformację użytych zasobów, szybkiej reakcji na zmieniające się potrzeby klientów, tym samym przyczyniając się do poprawy jego wyników rynkowych.

W zaproponowanym w pracy modelu zwinności strategicznej nie udało się potwierdzić hipotezy H3b, według której elastyczność finansowa wpływa pozytywnie na wyniki rynkowe przedsiębiorstw. Kierunek wpływu okazał się odwrotny niż zakładany i nieistotny statystycznie $(-0,07 ; p>0,1)$. Częściowo potwierdziły to wyniki 
badań opisowych przedstawione w rozdziale czwartym, gdzie wskazano, że zaledwie co piąte $\mathrm{z}$ badanych przedsiębiorstw korzysta $\mathrm{z}$ celowych źródeł finansowania, takich jak kredyty, poręczenia, dotacje, a jedynie co dziesiąte wykorzystuje dźwignię finansową. W opinii respondentów elastyczność finansowa uzyskała najniższą średnią ocenę wśród badanych rodzajów zasobów.

\section{Przywództwo strategiczne a wyniki rynkowe}

W wyniku estymacji modelu strukturalnego udało się potwierdzić hipotezę H4 dotyczącą pozytywnego wpływu przywództwa strategicznego na wyniki rynkowe średnich i dużych polskich przedsiębiorstw $(0,10 ; p<0,05)$. Można zatem uznać, że im bardziej przywództwo w przedsiębiorstwie jest ukierunkowane na wprowadzanie zmian zapewniających adaptację do otoczenia, tworzenie i wdrażanie strategii dla nieprzewidzianych zdarzeń, tym wyższa jego sprawność rynkowa. Przywództwo strategiczne zakłada także samodzielność pracowników w zakresie realizowanych projektów, w ramach których przywódcy mogą się wyłaniać spośród grupy zamiast być formalnie wyznaczeni. Świadczy to o dużym zaufaniu najwyższego szczebla do kwalifikacji swoich podwładnych, z drugiej strony o zaangażowaniu i chęci współuczestniczenia $\mathrm{w}$ realizowaniu wizji i celów przez pracowników.

Badania potwierdziły tezę prezentowaną $\mathrm{w}$ literaturze, że przedsiębiorstwa charakteryzujące się wyższym poziomem przywództwa strategicznego są bardziej konkurencyjne oraz uzyskują wyższe wyniki działalności w turbulentnym otoczeniu (Ussahawanitchakit, 2012). Wcześniejsze badania potwierdziły, że przywództwo strategiczne wykazuje silną dodatnią zależność z tworzeniem wartości opartym na innowacjach produktowych, rynkowych i administracyjnych (Elkonov i in., 2005). Ustanawiając wprowadzanie zmian jako istotę przywództwa, przedsiębiorstwa dążą do przetrwania $\mathrm{w}$ dynamicznym otoczeniu poprzez proaktywną orientację strategiczną (Hinterhube i Friedrich, 2002).

\section{Wyniki rynkowe a wyniki finansowe}

Najsilniejszy z zakładanych związków w opracowanym modelu zwinności strategicznej okazał się związek pomiędzy wynikami rynkowymi a wynikami finansowymi. Wynik estymacji modelu strukturalnego pozwolił na potwierdzenie hipotezy H5 o pozytywnym wpływie wyników rynkowych na wyniki finansowe średnich i dużych polskich przedsiębiorstw $(0,64 ; p<0,01)$. Zaakceptowanie przez klientów przygotowanej dla nich atrakcyjnej i konkurencyjnej wartości determinuje bezpośrednio poziom ich zadowolenia, trwałość współpracy z interesariuszami przedsiębiorstwa oraz jego reputację. Z kolei wysoko oceniane osiągnięcia przedsiębiorstw w perspek- 
tywie rynkowej pozytywnie oddziałują na wyniki finansowe. Uzyskany wynik jest zgodny z prezentowanym w literaturze przekonaniem, że sprawność rynkowa determinuje sprawność finansową przedsiębiorstwa (Urbanowska-Sojkin, 2013b, s. 435).

\section{Podsumowanie wyników badań}

Głównym celem pracy było opracowanie modelu zwinności strategicznej ukierunkowanego na poprawę wyników przedsiębiorstw. Realizacja głównego celu pracy wymagała osiągnięcia wielu celów szczegółowych. Przede wszystkim przeprowadzono systematyzujące studia literaturowe w zakresie zwinności, które umożliwiły identyfikację zwinności strategicznej, a następnie jej konceptualizację poprzez atrybuty ją współtworzące. Dzięki analizie i krytycznej ocenie podstaw teoretycznych, na których gruncie rozwija się współczesna wiedza naukowa na temat zwinności przedsiębiorstw, wskazano na podstawy teoretyczne zwinności strategicznej. Zebrano najważniejsze koncepcje i podejścia teoretyczne, które uzasadniają i wyjaśniają pojęcie zwinności. Przesłanki wynikające z rozważań teoretycznych dały podstawę do wskazania wpływu poszczególnych podejść teoretycznych na wybór atrybutów współtworzących zwinność strategiczną. Sformułowano autorską definicję zwinności strategicznej przygotowaną na potrzeby monografii oraz dokonano identyfikacji i konceptualizacji elementów współtworzących zwinność strategiczną. W ramach czterech atrybutów zwinności strategicznej (wrażliwości strategicznej, przedsiębiorczości strategicznej, elastyczności oraz przywództwa strategicznego) wyróżniono dziewięć konstruktów teoretycznych współtworzących poszczególne atrybuty i wskazano na ich pozytywny wpływ na wyniki rynkowe przedsiębiorstw, a tych $\mathrm{z}$ kolei na wyniki finansowe. Wskazane konstrukty składają się na model zwinności strategicznej. Zastosowanie szczegółowej procedury modelowania strukturalnego umożliwiło dokonanie operacjonalizacji zmiennych nieobserwowalnych poprzez prezentację narzędzi pomiarowych wykorzystanych następnie w modelowaniu. Skonstruowano i przetestowano model pomiarowy oraz dokonano jego oceny. Następnie zaprezentowano model strukturalny, w którego ramach, na postawie rezultatów empirycznych procesu modelowania, sformułowano wnioski dotyczące postawionych hipotez.

W wyniku estymacji modelu strukturalnego udało się częściowo potwierdzić hipotezę pierwszą dotyczącą pozytywnego wpływu wrażliwości strategicznej (współtworzonej przez umiejętność oceny szans oraz skłonność do ryzyka) na wyniki rynkowe przedsiębiorstw. Ocena hipotezy była możliwa dzięki sprawdzeniu dwóch hipotez szczegółowych, Wyniki badań potwierdziły pozytywny, istotny statystycznie wpływ jedynie pierwszej hipotezy szczegółowej, dotyczącej umiejętności oceny szans na wyniki rynkowe. Oznacza to, że proces dokonywania oceny szans przez zarządzających, polegający na sprawdzeniu, czy szansa jest zgodna z celami przedsiębiorstwa, określeniu jej wartości oraz oceny, czy znajduje się w zasięgu przed- 
siębiorstwa ze względu na posiadane zasoby lub możliwości ich nabycia, wpływa pozytywnie na sprawność rynkową i pośrednio na sprawność finansową średnich i dużych polskich przedsiębiorstw. Ze względu na statystycznie nieistotny zakładany wpływ skłonności do ryzyka na wyniki rynkowe odrzuceniu uległa hipoteza H1b.

Hipoteza druga, dotyczącą pozytywnego wpływu przedsiębiorczości strategicznej (współtworzonej przez: umiejętność rozwoju zasobów własnych, zdolność współpracy, zdolność innowacyjną, kulturę przedsiębiorczą) na wyniki rynkowe przedsiębiorstw, została częściowo potwierdzona. Szczegółowa hipoteza H2a, według której umiejętność rozwoju zasobów własnych ma pozytywny wpływ na wyniki rynkowe, nie była poddana estymacji ze względu na wyeliminowanie zmiennej już na etapie eksploracyjnej analizy czynnikowej. W wyniku estymacji modelu udało się natomiast potwierdzić hipotezę H2b dotyczącą pozytywnego wpływu zdolności współpracy przedsiębiorstw na wyniki rynkowe. Oznacza to, że wiedza zarządzających dotycząca sposobów budowania i rozwijania relacji opartych na potrzebnych zasobach dla wykorzystania szans ma pozytywny wpływ na tworzenie sukcesu rynkowego i pośrednio na wyniki finansowe polskich przedsiębiorstw. Badania potwierdziły także pozytywny wpływ zdolności innowacyjnej na wyniki rynkowe przedsiębiorstw, dając podstawę do przyjęcia hipotezy H2c. Zdolność do poszukiwania innowacyjnych technologii, procesów oraz pomysłów na nowe produkty oraz zapewnienie środków potrzebnych do ich realizacji przyczynia się do poprawy wyników rynkowych i konkurencyjności polskich przedsiębiorstw. Ze względu na nieistotny statystycznie związek pomiędzy kulturą przedsiębiorczą a wynikami rynkowymi odrzucono hipotezę $\mathrm{H} 2 \mathrm{~d}$.

W przeprowadzonym postępowaniu badawczym udało się częściowo potwierdzić hipotezę trzecią, dotyczącą pozytywnego wpływu elastyczności (współtworzonej przez elastyczność operacyjną i elastyczność finansową) na wyniki rynkowe przedsiębiorstw. Z przeprowadzonych badań wynika, że elastyczność operacyjna ma pozytywny wpływ na wyniki rynkowe, co umożliwiło potwierdzenie hipotezy H3a. Podejmowanie szybkich i efektywnych zmian w ramach kluczowych procesów tworzących wartość dla klienta zapewnia wzrost poziomu jego zadowolenia, lojalności oraz reputacji przedsiębiorstwa. Ze względu na statystycznie nieistotny zakładany wpływ elastyczności finansowej na wyniki rynkowe odrzuceniu uległa hipoteza $\mathrm{H} 3 \mathrm{~b}$.

Hipoteza H4, zakładająca pozytywny wpływ przywództwa strategicznego na wyniki rynkowe średnich i dużych polskich przedsiębiorstw, została potwierdzona. Oznacza to, że im bardziej przywództwo odnosi się do strategicznego przewodzenia całym przedsiębiorstwem, biorąc pod uwagę jego ewolucję, zmieniające się cele i zdolności oraz dynamiczne relacje z otoczeniem, tym sprawniej przedsiębiorstwo radzi sobie z wyzwaniami rynkowymi. Silne przywództwo strategiczne pozwala zintegrować zasoby i umiejętności konieczne do tego, aby sprawnie wykorzystać potencjał innowacyjności i umiejętność przedsiębiorczego działania dla szybkiego podejmowania zmian strategicznych. 
Ostatnia z weryfikowanych hipotez dotyczyła pozytywnego wpływu wyników rynkowych na wyniki finansowe przedsiębiorstw. Pozytywny kierunek związku oraz jego statystyczna istotność pozwoliły na potwierdzenie hipotezy H5. Modelowanie strukturalne umożliwiło porównanie ustaleń teoretycznych z wynikami badań empirycznych i testowanie postawionych hipotez. Dzięki postępowaniu badawczemu możliwe było przyjęcie części ze sformułowanych hipotez cząstkowych dotyczących wpływu zwinności strategicznej na wyniki średnich i dużych polskich przedsiębiorstw. 


\section{ZAKOŃCZENIE}

Złożoność otoczenia, jego nieprzewidywalność i trudności w projektowaniu przyszłości sprawiają, że uwarunkowania przedsiębiorstw w momencie formułowania strategii mogą się znacznie różnić od rzeczywistości w momencie jej implementacji. Postuluje się zatem podejście oparte na okazjach oraz doskonalenie sprawności operacyjnej (Zakrzewska-Bielwawska, 2018, s. 7), które jest determinowane zdolnością szybkiego i efektywnego podejmowania zmian. Definiując strategię jako dynamiczny proces podejmowania wyborów w warunkach niepewności (Zakrzewska-Bielawska, 2018, s. 7-8), należy stwierdzić, że zwinność jako zdolność do podejmowania zmian strategicznych i radzenia sobie $\mathrm{z}$ dynamiką otoczenia, jest konieczna do utrzymania potencjału rozwojowego w długiej perspektywie czasowej.

W rozprawie, oprócz rozważań teoretycznych oraz wniosków z analizy literatury na temat zwinności i jej rozwoju, zaprezentowano rezultaty badań empirycznych, które wykorzystano do wyjaśnienia mechanizmu kształtowania sukcesu rynkowego polskich przedsiębiorstw poprzez atrybuty zwinności strategicznej. Na podstawie krytycznej analizy literatury zidentyfikowano i przeprowadzono konceptualizację czterech wymiarów zwinności strategicznej: wrażliwości strategicznej, przedsiębiorczości strategicznej, elastyczności oraz przywództwa strategicznego. Wyłonione w ramach każdego wymiaru konstrukty teoretyczne ujęto w modelu zwinności strategicznej. Ponadto zdefiniowano dwa konstrukty związane z wynikami przedsiębiorstw w perspektywie rynkowej oraz finansowej. Wyniki badań opisowych dostarczyły informacji na temat poziomu i znaczenia poszczególnych wskaźników składających się na wyodrębnione konstrukty. Natomiast wyniki badań przyczynowych umożliwiły odniesienie się do postawionych w pracy hipotez badawczych przetestowanych na reprezentatywnej próbie średnich i dużych polskich przedsiębiorstw. Otrzymane wyniki posłużyły osiągnięciu celu głównego pracy, który polegał na opracowaniu modelu zwinności strategicznej ukierunkowanego na poprawę wyników przedsiębiorstw. Przeprowadzone badania przyczynowe służyły potwierdzeniu przyjętej hipotezy głównej o pozytywnym wpływie zwinności strategicznej na wyniki przedsiębiorstw. Wyniki postępowania badawczego pozwoliły na przyjęcie części ze sformułowanych hipotez cząstkowych, dotyczących pozytywnego wpływu wrażliwości strategicznej, przedsiębiorczości strategicznej, elastyczności oraz przywództwa strategicznego na wyniki rynkowe przedsiębiorstw. Ponadto rezultaty przeprowadzonych badań potwierdzają eksponowany w publikacjach silny 
związek pomiędzy wynikami rynkowymi a wynikami finansowymi (Urbanowska-Sojkin, 2013b, s. 435). Wyniki rynkowe przedsiębiorstw (zadowolenie klienta, reputacja przedsiębiorstwa, trwałość współpracy z klientami oraz innymi interesariuszami) wzmacniają sprawność przedsiębiorstwa w perspektywie finansowej, ułatwiającej większe wysiłki w budowaniu i utrzymaniu przewagi konkurencyjnej. Wykorzystanie modelowania strukturalnego umożliwiło porównanie założeń teoretycznych z wynikami badań empirycznych i sprawdzenie hipotetycznych relacji. Istotną zaletą modelowania jest możliwość jednoczesnego dopasowania opracowanego modelu do danych i odniesienia się do całości założeń teoretycznych. Należy zaznaczyć, że każdy model, nawet z najlepszymi miernikami dopasowania, stanowi tylko jedno z potencjalnych wyjaśnień badanego fragmentu rzeczywistości. Przyjęte w pracy podejście abdukcyjne umożliwia wskazanie jedynie najbardziej prawdopodobnych hipotez w wybranym fragmencie rzeczywistości (Urbański, 2009, s. 43). Oznacza to, że model nie odzwierciedla w całości rzeczywistości gospodarczej i nie daje gwarancji pełnego potwierdzenia teorii.

Podjęte w pracy rozważania nie wyczerpują problemów dotyczących istoty zwinności strategicznej i jej wpływu na wyniki przedsiębiorstw. Można jednak wskazać wkład niniejszej pracy w rozwój teorii nauk o zarządzaniu na trzech płaszczyznach: teoriopoznawczej, metodologicznej oraz empirycznej.

Na płaszczyźnie teoriopoznawczej:

- Usystematyzowano dotychczasowy dorobek w zakresie zwinności przedsiębiorstw, wskazując na rolę zwinności jako zdolności przedsiębiorstw do przystosowania się do otoczenia. Wskazano na jej historyczne uwarunkowania oraz źródła pochodzenia. Dokonano przeglądu badań w zakresie zwinności, który umożliwił zaprezentowanie jej rozwoju i wyłonienie trzech rodzajów: zwinności wytwarzania, organizacyjnej oraz strategicznej.

- Opracowano podstawy teoretyczne zwinności strategicznej przedsiębiorstw. Zebrano najważniejsze podejścia teoretyczne stanowiące o istocie, podstawach i zasadności zwinności. Opisano wybrane podejścia i koncepcje teoretyczne ze wskazaniem ich wpływu na wyjaśnienie i uzasadnienie istoty zwinności oraz wkładu w budowanie kluczowych atrybutów współtworzących zwinność strategiczną.

- Zdefiniowano pojęcie zwinności strategicznej przedsiębiorstwa na trzech płaszczyznach poznawczych: funkcjonalnej, ewolucyjnej, behawioralnej. Dokonano konceptualizacji pojęcia zwinności strategicznej, wskazując jego położenie na styku przedstawionych perspektyw. Zaprezentowano konstrukty teoretyczne współtworzące zwinność strategiczną, do których zaliczono: wrażliwość strategiczną, przedsiębiorczość strategiczną, elastyczność i przywództwo strategiczne oraz dokonano ich konceptualizacji.

- Opracowano model zwinności strategicznej oraz ustalono mechanizm wpływu zwinności strategicznej na wyniki przedsiębiorstw poprzez określenie związków przyczynowo-skutkowych stanowiących podstawę modelu, w którym zakłada się 
współistnienie konstruktów i ich łączny wpływ w postaci zmiennej „zwinność strategiczna" na wyniki rynkowe przedsiębiorstw.

Na płaszczyźnie metodologicznej:

- Opracowano metodę pomiaru zwinności strategicznej oraz określono poziom i znaczenie poszczególnych wskaźników składających się na konstrukty teoretyczne współtworzące zwinność strategiczną.

- Zastosowano ilościowe podejście empiryczne z wykorzystaniem modelowania równań strukturalnych, rozwinięto procedurę testowania modelu oraz dokonano pomiaru zmiennych nieobserwowalnych. Zgodnie z założeniem wynikającym z przyjętego w pracy stanowiska krytycznego realizmu o satysfakcjonującym charakterze rzeczywistości, w której pojęcia teoretyczne wykorzystane w modelowaniu mają charakter abstrakcyjny i odwołują się do płaszczyzny pozaempirycznej, odzwierciedlając ukryte struktury oraz mechanizmy, znaleziono właściwe reguły korespondencji zmiennych nieobserwowalnych ze zmiennymi możliwymi do bezpośredniego pomiaru.

- Skonstruowano modele pomiarowe i model strukturalny zwinności strategicznej, gdzie za nieodłączny element modelowania uznano testowanie ustaleń osiągniętych na poziomie teoretycznym. W tym celu dokonano niezbędnej redukcji elementów modelu, wnikając $w$ istotę i rolę poszczególnych zmiennych w sposób umożliwiający ich pomiar, dążąc do testowania empirycznego modelu koncepcyjnego.

Na płaszczyźnie empirycznej:

- Ustalano zależności występujące między elementami modelu strukturalnego zwinności strategicznej. Przeprowadzone badania empiryczne potwierdziły częściowy pozytywny wpływ atrybutów zwinności strategicznej na wyniki rynkowe i pośredni na wyniki finansowe polskich przedsiębiorstw. W ramach wymiaru wrażliwości strategicznej potwierdzono pozytywny wpływ umiejętności oceny szans na wyniki rynkowe odzwierciedlające przewagę przedsiębiorstwa w zakresie oferowania atrakcyjnej i konkurencyjnej wartości dla klientów. Potwierdzono także częściowy wpływ przedsiębiorczości strategicznej na wyniki rynkowe. $\mathrm{W}$ ramach tego wymiaru ujawniono pozytywny wpływ zdolności współpracy oraz zdolności innowacyjnej na sukces przedsiębiorstwa w perspektywie rynkowej i pośrednio finansowej. W ramach wymiaru elastyczności potwierdzono pozytywny wpływ elastyczności operacyjnej na tworzoną przez przedsiębiorstwo wartość dla klientów mierzoną ich zadowoleniem, trwałością współpracy i reputacją przedsiębiorstwa. Wykazano pozytywny wpływ przywództwa strategicznego na skutki wyników rynkowych przedsiębiorstw poprzez wprowadzanie zmian i działań adaptacyjnych.

Przeprowadzone $\mathrm{w}$ pracy studia literaturowe oraz badania empiryczne na reprezentatywnej grupie przedsiębiorstw pozwalają na sformułowanie implikacji dla praktyki gospodarczej. Podstawową kwestią jest budowanie świadomości menedżerów w zakresie zdolności adaptacyjnych przedsiębiorstw ukierunkowanych na 
atrybuty zwinności strategicznej. Menedżerowie średnich i dużych przedsiębiorstw zdają sobie sprawę z tego, jak ważna jest adaptacja oraz proaktywna orientacja strategiczna, niemniej nie wykorzystują w pełni potencjału szybkiego i efektywnego podejmowania zmian strategicznych. Wyniki badań skłaniają do sformułowania następujących zaleceń w zakresie praktyki gospodarczej:

- Rozwijanie umiejętności oceny szans poprzez świadomość dotyczącą potencjału przedsiębiorstwa dotyczącego wykorzystania szansy w zakresie posiadanych zasobów lub możliwości ich zakupu poza przedsiębiorstwem. Określenie kryterium oceny szans poprzez pryzmat realizowanych celów i strategii oraz szacowanie ewentualnego ryzyka związanego z podejmowaniem nowych kierunków działań strategicznych.

- Rozwijanie zdolności innowacyjnej przedsiębiorstw poprzez efektywną implementację nowych pomysłów, procesów oraz produktów. Złożoność otoczenia oraz permanentnie zmieniające się oczekiwania klientów sprawiły, że obecnie przedsiębiorstwa bardziej konkurują zdolnościami do rozwoju nowych produktów niż nowymi produktami. Potrzeba dążenia do zwiększania efektywności innowacji poprzez odmienną zdolność przedsiębiorstw do stałego mobilizowania swoich zasobów i zdolności dopasowania do zmieniających się okazji.

- Rozwijanie zdolności współpracy z partnerami zewnętrznymi, która wymaga wyboru właściwych partnerów zorientowanych długoterminowo na osiąganie wspólnych celów i korzyści oraz dążących do elastycznego rozwiązywania bieżących problemów. Potrzeba identyfikowania kluczowych partnerów do współpracy oraz zapewnienia wiarygodności i zaufania w ramach budowanych relacji. Konieczne jest też podjęcie działań zmierzających do redukcji ryzyka relacji (dążenie do kontraktowania) jako czynnika obniżającego wyniki współpracy.

- Wspieranie elastyczności operacyjnej poprzez elastyczny proces logistyczny, marketingowy oraz sprzedażowy. Zapewnienie operacyjnej doskonałości sprowadza się do biegłości przedsiębiorstwa w radzeniu sobie ze zmianami, czyli szczególnej łatwości i szybkości reagowania na nie oraz dokonywania odpowiednich przekształceń. Informacja o zmianach rynkowych powinna być jak najszybciej odzwierciedlona w działalności przedsiębiorstwa oraz przygotowywanej wartości dla klienta.

- Rozwijanie przywództwa strategicznego opartego na zaufaniu do pracowników, w którym charyzma przywódcy, wspólna wizja oraz indywidualne podejście do grupy stanowi źródło ich oddania i zaangażowania. Dążenie do wykorzystania pomysłów i wiedzy pracowników przez umocowanie ich w ramach realizowanych projektów. Budowanie świadomości utożsamiania przywództwa strategicznego z tworzeniem i wdrażaniem strategii dla nieprzewidzianych zdarzeń oraz wprowadzania zmian niezbędnych do zapewnienia adaptacji do otoczenia.

Omówione rezultaty badań oraz sformułowane na ich podstawie zalecenia dla praktyki gospodarczej powinny wesprzeć najwyższy szczebel kadry kierowniczej 
w rozwijaniu zdolności adaptacyjnych i skutecznym podejmowaniu zmian strategicznych. Kluczowe jest jednak budowanie otwartej i przedsiębiorczej kultury organizacyjnej na wszystkich szczeblach zarządzania, której implementacja poprzez wymiary zwinności strategicznej może się przyczynić do budowania przewagi konkurencyjnej.

Zrealizowane w pracy postępowanie badawcze poświęcone problematyce zwinności strategicznej w polskich przedsiębiorstwach jest obarczone ograniczeniami zarówno natury metodycznej, jak i merytorycznej, które mogą stanowić przedmiot dalszych poszukiwań i badań w przyszłości. Ograniczenia wynikają z przyjętego $\mathrm{w}$ pracy postępowania badawczego związanego $\mathrm{z}$ wykorzystaniem modelowania strukturalnego, którego metodyka jest adekwatna do przyjętego w pracy stanowiska krytycznego realizmu. Zwolennicy tego podejścia wskazują na liczne zalety stosowania modelowania strukturalnego, podkreślając przede wszystkim możliwości bezpośredniej konfrontacji teorii z empirią, testowania złożonych hipotez między zmiennymi nieobserwowalnymi oraz możliwością jednoczesnej oceny dopasowania całego modelu do danych empirycznych. W perspektywie krytycznego realizmu rolę modelowania upatruje się przede wszystkim w wyjaśnieniu i zrozumieniu istoty analizowanych zagadnień poprzez weryfikowanie ustaleń teoretycznych, mniejszy nacisk kładzie się na samą predykcję i odkrywanie uniwersalnych prawd. Jednak ograniczeniem natury metodycznej jest sama istota modelu, która stanowi odzwierciedlenie uproszczonego fragmentu rzeczywistości z pominięciem mniej istotnych elementów tej rzeczywistości (Sadowski, 1964, s. 11) poprzez zredukowanie stanu faktycznego do istotnych elementów podstawowych. Najważniejszym problemem i jednocześnie ograniczeniem modelowania $\mathrm{z}$ wykorzystaniem zmiennych nieobserwowalnych jest ich nieostry i rozmyty charakter utrudniający ich operacjonalizację. W opracowaniu modelu zwinności strategicznej wskazano na atrybuty zwinności i współtworzące je konstrukty, które poparte analizą literatury przedmiotu uznano za najbardziej istotne. Relacje pomiędzy wskazanymi elementami zostały przedstawione w postaci hipotezy głównej oraz hipotez cząstkowych, celem zrozumienia i wyjaśnienia struktury zwinności strategicznej oraz jej wpływu na wyniki przedsiębiorstw. Przyjęte do analizy zmienne mają charakter nieobserwowalny, zatem pomiar ich nie jest jednoznaczny. Fakt ten stanowi zasadniczy problem opracowania modeli na potrzeby nauk o zarządzaniu, gdzie niejednoznaczny i rozmyty charakter abstrakcyjnych pojęć utrudnia modelowanie obiektów „miękkich”, dla których nie można użyć klasycznych metod modelowania formalnego, charakterystycznych dla nauk ścisłych (Światowiec-Szczepańska, 2012, s. 273). Przyjęte w modelu zmienne nieobserwowalne są opisane w literaturze przedmiotu, jednak zaleca się prowadzenie dalszych prac badawczych w celu rozwoju i doskonalenia pomiaru zmiennych odzwierciedlających zwinność strategiczną.

Znacznym ograniczeniem charakterystycznym dla badań w obszarze zarządzania strategicznego pozostaje ich statyczność zarówno w zakresie prowadzonych badań, jak i konstruktów modelu badawczego. Opracowany model opiera się na wynikach 
badań sondażu diagnostycznego z wykorzystaniem metody ankiety, w których trudno jest zidentyfikować procesy rozwoju określonych zjawisk. W rzeczywistości gospodarczej procesy adaptacji przedsiębiorstw poprzez podejmowanie zmian strategicznych mają charakter dynamiczny, czego nie można zaobserwować w badaniu odzwierciedlającym jedynie bieżący stan rzeczy.

W świetle przeprowadzonych rozważań należy stwierdzić, że zwinność strategiczna jest pojęciem stosunkowo nowym zarówno w sferze poznawczej, jak i metodycznej, wymagającym dalszych badań przyczyniających się nie tylko do głębszego rozpoznania zdolności adaptacyjnych przedsiębiorstw, ale także doskonalenia metod badań. Proces poznawczy ma charakter ciągły, realizacja każdego kolejnego projektu badawczego stanowi etap w dążeniu naukowców do odkrywania rzeczywistych struktur i mechanizmów interesujących ich zjawisk. Przyjęte w krytycznym realizmie założenie o omylności teorii, obserwacji i metod skłania w kontekście tej pracy do podejmowania kolejnych wysiłków badawczych zorientowanych na doskonalenie sposobów testowania i pomiaru zmiennych nieobserwowalnych. Pomimo że badania nad zdolnościami przedsiębiorstw ułatwiającymi im radzenie sobie ze złożonością i dynamiką otoczenia cieszą się coraz większą popularnością, nie jest to całkowicie rozpoznany obszar zainteresowań w naukach o zarządzaniu. Można uznać, że problematyka ta znajduje się we wczesnej, wyłaniającej się fazie rozwoju, zatem wymaga zachowania ciągłości badawczej w pogłębianiu zarówno wiedzy teoretycznej, jak i praktycznej w zakresie zwinności strategicznej oraz mechanizmów odpowiadających za jej kształtowanie.

Zrealizowane w pracy badania pozwalają wytyczyć kierunki dalszych eksploracji naukowych w zakresie zwinności strategicznej przedsiębiorstw. Należą do nich:

- Rozwinięcie badań dotyczących wpływu antecedencji zwinności strategicznej na kształtowanie i rozwój zdolności adaptacyjnych przedsiębiorstw.

- Określenie ważności poszczególnych wymiarów zwinności strategicznej, do których zaliczono: wrażliwość strategiczną, przedsiębiorczość strategiczną, elastyczność oraz przywództwo strategiczne. W pracy nie dokonano analizy umożliwiającej określenie ewentualnej hierarchii wymiarów zwinności strategicznej dla jej skuteczności. Ciekawe wnioski mogłaby przynieść analiza tego problemu w kontekście etapów faz rozwoju przedsiębiorstw.

- Określenie wpływu zwinności strategicznej na inne wymiary postrzegania efektywności przedsiębiorstw ( $\mathrm{w}$ pracy ocenę efektywności zawężono do wyników rynkowych oraz finansowych), dalsze badania mogłyby rozszerzyć tę problematykę o skuteczność osiągania celów i dokonywania wyborów strategicznych.

- Rozwinięcie praktyk i narzędzi umożliwiających rozwój zdolności adaptacyjnych w zakresie wymiarów zwinności strategicznej, których implementacja przyczyniłaby się do rozwoju zdolności zwinności strategicznej.

- Podjęcie badań jakościowych z perspektywy longitudinalnej pozwoliłoby na lepsze rozpoznanie związków przyczynowo-skutkowych wpływu poszczególnych wymiarów zwinności na wyniki przedsiębiorstw i umożliwiłoby okre- 
ślenie ewentualnego opóźnionego efektu zwinności strategicznej na wyniki finansowe.

Zaproponowane kierunki dalszych badań nie stanowią propozycji zamkniętej, autorka wyraża nadzieję, że niezwykle aktualne i interesujące poznawczo pojęcie zwinności strategicznej będzie stanowiło dla teoretyków i praktyków zarządzania inspirację do dalszych poszukiwań naukowych i jeszcze lepszego rozpoznania jego potencjału. 


\section{BIBLIOGRAFIA}

Adeleye, E. O. i Yusuf, Y. Y. (2006). Towards agile manufacturing models of competition and performance outcomes. International Journal Agile Systems and Management, 1(1), 93-110.

Agarwal, R. i Helfat, C. E. (2009). Strategic renewal of organizations. Organization Science, 20(2), 281-293.

Aguilar, F. J. (1967). Scanning the business environment. New York: McMillan.

Ali, A., Krapfel, R. i Labahn, D. (1995). Product innovativeness and entry strategy: Impact on cycle time and break-even time. The Journal of Product Innovation Management, 12(1), 54-70.

Almahamid, S., Awwad, A. i McAdams, A. C. (2010). Effects of organizational agility and knowledge sharing on competitive advantage: an empirical study in Jordan. International Journal of Management, 27(3), 387-404.

Alon, I., Madanoglu, M. i Shoham, A. (2016). Strategic agility explantations for managing franchising espansion during economic cycles. Competitiveness Review, 27(2), 113-131.

Amit, R. i Schoemaker, P. J. H. (1993). Strategic assets and organizational rents. Strategic Management Journal, 14, 33-46.

Amit, R. i Zott, C. (2001). Value creation in e-business. Strategic Management Journal, 22 (Special Issue), 493-520.

Amos, T. (2006). Strategic leadership: key driver of strategy implementation. W: L. Louw i Venter, P. (Eds.), Strategic management: Winning in the southern African workplace. Cape Town: Oxford Univeristy Press.

Amram, M. i Kulatilaka, N. (1999). Real options: Managing strategic investment in an uncertain world. Boston: Harvard Business School Press.

Anderson, J. C. i Gerbing, D. W. (1992). Assumptions and comparative strengths of the two-step approach: Comment on fornell and yi. Sciological Methods and Research, 20, 321-333.

Andrews, K. R. (1971). The concept of corporate strategy. Homewood: Dow Jones Irwin, Homewood, IL.

Ansoff, H. I. (1965). Corporate strategy. New York: McGraw-Hill.

Ansoff, H. I. (1985). Zarzadzanie strategiczne. Warszawa: PWE.

Antoncic, B. (2003). Risk taking in intrapreneurship: translating the individual level risk aversion into the organizational risk taking. Journal of Enterprising Culture, 11(1), 1-23.

Antoncic, B. (2006). Impacts of diversification and corporate entrepreneurship strategy making on growth and profitability: A normative model. Journal of Enterprising Culture, 14(1), 49-63.

Antoncic, B. i Hisrich, R. D. (2004). Corporate entrepreneurship contingencies and organizational wealth creation. The Journal of Management Development, 23(6), 518-550. 
Aoki, M. (1986). Horizontal vs. vertical information structure of the firm. The American Economic Review, 76(5), 971-983.

Aoki, M. (1990). Toward and economic model of the Japanese firm. Journal of Economic Literature, 28, 1-27.

Apanowicz, J. (2002). Metodologia ogólna. Gdynia: Wydawnictwo Bernardinum.

Appelbaum, S. H., Calla, R., Desautels, D. i Hasan, L. (2017). The challenges of organizational agility (part 1). Industrial and Commercial Training, 49(1), 6-14.

Arbuckle, J. I. (2007). Amos 16.0 User's guide. Spring House, PA: Amos Development Corporation.

Arbussa, A., Bikfalvi, A. i Marques, P. (2016). Strategic agility - driven business model renewal: the case of an SME. Management Decision, 55(2), 271-293.

Argyris, C. i Schön, D. A. (1978). Organizational learning: A theory of action perspective. Reading. MA: Addison-Wesley Publishing Company.

Argyris, C. (1999). On organizational learning. Oxford, England: Blackwell.

Ashrafi, N., Xu, P., Sathasivam, M., Kuilboer, J. P., Koelher, W., Heimann, D. i Waage F. (2005). A framework for implementing business agility through knowledge management systems. Proceedings - Seventh IEEE International Conference on E-Commerce Technology Workshops, CEC 2005 Workshops,116-121.

Attafar, A., Ghandehari, M. i Momeni, G. (2012). Study of required organizational base for implementation of agility strategy in organizations. Interdisciplinary Journal of Contemporary Research in Business, 3(11).

Augier, M. i Teece, D. J. (2008). Strategy as evolution with design: Dynamic capabilities and the design and evolution of the business enterprise. Organization Studies, 29, 1187-1208.

Avery, G. (2009). Przywództwo w organizacji. Paradygmaty i studia przypadków. Warszawa: Polskie Wydawnictwo Ekonomiczne.

Avlonitis, G. J., Kouremenos, A. i Tzokas, N. (1994). Assessing the innovativeness of organizations and its antecedents: Project innovstrat. European Journal of Marketing, 28(11), 5-28.

Babbi, E. (2008). Podstawy badań społecznych. Warszawa: Wydawnictwo Naukowe PWN.

Babuji, H. i Crossan, M. M. (2004). From questions to answers: Reviewing organizational learning research. Management Learning, 35(4), 397-441.

Bahrami, M. A., Kiani, M. M., Montazeralfaraj, R., Zadeh, H. F. i Zadeh, M. M. (2016). The mediating role of organizational learning in the relationship of organizational intelligence and organizational agility. Osong Public Health Res Perspect, 7(3), 190-196.

Baker, J. (1996). Agility and flexibility: What's the difference? Cranfield School of Management Working Papers Series, SWP 5/96, 1-7.

Banaszyk, P. (2013). Zmiana kluczowych problemów strategicznych. W: S. Trzcieliński (red.), Wybrane problemy zarządzania. Teraźniejszość i przyszłość, 23-37. Poznań: Wydawnictwo Politechniki Poznańskiej.

Barney, J. B. (1991). Firm resources and sustained competitive advantage. Journal of Management, 105-106.

Barney J. B. (2001). Is the resources and sustained competitive advantage. Journal of Management, 17(1), 99-120.

Barringer, B. R. i Harrison, J. S. (2000). Walking a tightrope: Creating value through interorganizational relationships. Journal of Management, 26(3), 367-403.

Bass, B. (2007). Executive and strategic leadership. International Journal of Business, 1. 
Bateson, G. (1972). Steps to an ecology of mind. New York: Ballantine.

Battistella, C. (2014). The organization of corporate foresight: a multiple case study in the telecommunication industry. Technological Forecasting and Social Change, 87, 60-79.

Becker, M. C. (2002). The concept of routines twenty years after Nelson and Winter (1982). A review of the literature. Denmark: DRUID Working Paper, 03-06.

Becker, P. (2002). Corporate foresight in Europe: a first overview Foresight Brief 082. The European Foresight Monitoring Network.

Bennis, W. i Nanus B. (1997). Leaders, strategies for taking charge. New York: Harper Business.

Bernardes, E. S. i Hanna, M. D. (2009). A theoretical review of flexibility, agility and responsiveness in the operations management literature. International Journal of Operations \& Production Management, 29(1), 30-53.

Besanko, D., Dranove, D. i Shanley, M. (1996). The economics of strategy. New York: John Wiley \& Sons, Inc.

Bessant, J., Francis, D, Meredith S. i Kaplinsky K. (2001). Developing manufacturing agility in SME's. International Journal of Technology Management, 22(1), 28-54.

Bharadwaj, A. S. (2000). A resource-based perspective on information technology capabilities and firm performance: an empirical investigation. MIS Quarterly, 24(1), 169-196.

Bisman, J. (2010). Postpositivism and accounitng research: A (persnoal) primer on critical realism. Australasian accounting. Business and Finance Journal, 4(4), 3-25.

Blaug, M. (1995). Metodologia ekonomii. Warszawa: Wydawnictwo Naukowe PWN.

Blind, K., Cuhls, K. i Grupp, H. (1999). Current foresight activities in central Europe. Technology Forecasting and Social Change 60(1), 15-35.

Blyler, M. I. i Coff, R. (2003). Dynamic capabilities, social capital, and rent appropriation: ties that split pies. Strategic Management Journal, 24, 677-686.

Boal, K. B. i Hooijberg, R. (2000). Strategic leadership research: moving on. Leadrship Quarterly, 11(4), 515-549.

Bogner, W. C. i Barr, P. S. (2000). Making sense in hypercompetitive environments: A cognitive explanation for the persistence of high velocity competition. Organization Science, 11(2), 123-261.

Borkowska, B. (2004). Ewolucyjne koncepcje przedsiębiorstwa. Ekonomista, 4.

Bourgeois, L. J. i Eisenhardt, K. M. (1998). Strategic decision processes in high velocity environment as: Four cases in the microcomputer industry. Management Science, 34(7), 805-920.

Boyd, B. K. i Fulk, J. (1996). Executive scanning and perceived uncertainty: a multidimensional model. Journal of Management, 22(1), 1-22.

Bradley MacKey, R. i Costanzo, L. A. (2009). Introduction. W: R. Bradlay MacKay i L. A. Costanzo (Eds.), Handbook of research on strategic foresight. Cheltenham: Edward Elagar.

Brannen, M. Y. i Doz, Y. L. (2012). Corporate languages and strategic agility: trapped in your jargon or lost in translation?. California Management Review, 54(3), 77-97.

Bratnicki, M. (2000). Kompetencje przedsiębiorstwa. Od określenia kompetencji do zbudowania strategii. Warszawa: Agencja Wydawnicza Placet.

Bratnicki, M. (2002). Przedsiębiorczość i przedsiębiorcy współczesnych organizacji. Katowice: Wydawnictwo Akademii Ekonomicznej w Katowicach. 
Braunscheidel, M. J. i Suresh, N. C. (2009). The organizational antecedents of a firm's supply chain . agility for risk mitigation and response. Journal of Operational Management, 27(2), 119-140.

Breu, K., Hmingway, C. J., Strathern, M. i Bridger, D. (2001). Workforce agility: The new employee strategy for the knowledge economy. Journal of Information Technology, 17(1), 231.

Brown, S. L. i Eisenhardt, K. M. (1998). Competing on the edge. Strategy as a structural chaos. Boston: Harvard Business School Press.

Brown, S. L. i Eisenhardt, K. M. (2000). Patching: Restitching business portfolios in dynamic markets. The McKinsey Quarterly, 77(3), 137-146.

Bruller, N. N., Carmeli, A. i Drori, I. (2014). How do different types of mergers and acquisitions facilitate strategic agility? California Management Review, 56(3), 39-57.

Burgeois, L. J. (1980). Strategy and environment: a conceptual integration. Academy of Management Review, 5(1), 25-39.

Burgeois, L. J. (1985). Strategic goals perceived uncertainty, and economic performance in volatile environments. Academy of Management Journal, 28(3), 548-573.

Burnes, B. (2009). Managing change. A strategic approach to organizational dynamics. 5th ed. Harlow, Essex: Pearson.

Burns, T. i Stalker, G. M. (1961). The management of innovation. London: Travistock Publishing.

Burt, R. S. (1992). Structural holes: The social structure of competition. Cambridge: Harvard University Press.

Capon, N., Farley, J. U., Hulbert, J. i Lehmann, D. R. (1992). Profiles and product innovators among large US manufactures. Management Science, 38,157-169.

Capra, F. (2002). The hidden connections. New York: Anchor Books.

Carter, S. M. i Greer, Ch. R. (2013). Strategic leadership: values, styles, and organizational performance. Journal of Leadership and Organizational Studies, 20(4), 375-393.

Carton, R. B. i Hofer, C. W. (2006). Measuring organizational performance: Metrics for entrepreneurship and strategic management. Cheltenham - Northampton: Edward Elgar.

Cao, Q. i Dowlatshahi, S. (2005). The impact of alignment between virtual enterprise and information technology on business performance in an agile manufacturing environment. Journal of Operations Management, 23(5), 531-550.

Cavusgil, E., Seggie, S. H. i Berk Talay, M. (2007). Dynamic capabilities view: Foundations and research agenda. Journal of Marketing Theory and Practice 15(2), 159-166.

Cegarra-Navarro, J. G., Soto-Acosta, P. i Wensley, A. K. P. (2016). Structured knowledge process and firm performance: The role of organizational agility. Journal of Business Research. http://dx.doi.org/10.1016/j.jbusres.2015.10.014

Certo, S. T, Covin, J. G., Daily, C. M. i Dalton, D. R. (2001). Wealth and the effects of founder management among IPO-stage new ventures. Strategic Management Journal, 22, 641-658.

Chakravarthy, B. S. (1982). Adaptation: A promising metaphor for strategic management. Academy of Management Review, 7(1), 35-44.

Charbonnier-Voirin, A. (2011). The development and partial testing of the psychometric properties of a measurement scale of organizational agility. Management, 14(2),119-156.

Charles, A., Lauras, M. i Van Wassenhove, L. (2010). A model to define and assess the agility of supply chains: building on humanitarian experience. International Journal of Phyical, Distribution and Logistics Management, 40(8/9), 711-741. 
Chen, W. H. i Chiang, A. H. (2011). Network agility as a trigger for enhancing firm performance: a case study of a high-tech firm implementing the mixed channel strategy. Industrial Marketing Management, 40(4), 643-651.

Chiang, C. Y, Kocabasoglu-Hillmer, C. i Suresh, N. (2012). An empirical investigation of the impact of strategic sourcing and flexibility on firm's supply chain agility. International Journal Operations Production Management, 32(1), 49-78.

Child, J. (1972). Organizational structure, environment, and performance: The role of strategic choice. Sociology, 6, 1-22.

Chiva, R., Alegre, J. i Lapiedra, R. (2007). Measuring organizational learning capability among the workforce. International Journal of Manpower, 28(3/4), 224-242.

Cho, H., Jung, M. i Kim, M. (1996). Enabling technologies of agile manufacturing and its related activities in Korea. Computers and Industrial Engineering, 30(3), 323-334.

Cohen, W. M. i Levinthal, D. A. (1990). Absorptive capacity: A new perspective on learning and innovation. Administrative Science Quarterly,35,128-152.

Cohendet, P. i Lleren,a P. (1998, 9-11 June). Theory of the firm in an evolutionary perspective: a critical development. W: Competence, governance and entrepreneurship. Copenhagen.

Cooper, A. C. (1973). Technical entrepreneurship: What do we know? Research and Development Management, 3, 59-64.

Cooper, J. R. (1998). A multidimensional approach to the adoption of innovation. Management Science, 36(8), 493-502.

Coronado, A. E., Sarhadi, M. i Millar, C. (2002). Defining a framework for information systems requirements for agile manufacturing. International Journal of Production Economics, 75, 57-68.

Covin, J. G. i Slevin, D. P. (1989). Strategic management of small firms in hostile and bengin environments. Strategic Management Journal, 10, 75-87.

Covin, J. G. i Slevin, D. P. (2002). The entrepreneurial imperatives of strategic leadership. W: M. A. Hitt, R. D. Ireland, S. M. Camp i D. L. Secton (Eds.), Strategic entrepreneurship: Creating a new mindset (s. 309-327). Oxford: Blackell Publishers.

Crocitto, M. i Youssef, M. (2003). The human side of organizational agility. Industrial Management \& Data Systems, 103(6).

Cyert, R. M. i March, J. G. (1963). A behavioral theory of the firm. New York: Englewood Cliffs.

Cyert, R. M. i March, J. G. (1992). A behavioral theory of the firm. Cambridge: Blackwell Business.

Cyfert, S. i Krzakiewicz K. (2017). Procesy kształtowania dynamicznych zdolności w polskich przedsiębiostwach. W: K. Krzakiewicz i S. Cyfert (red.), Strategiczny wymiar dynamicznych zdolności polskich przedsiębiorstw (s. 329-342). Poznań: Wydawnictwo Uniwersytetu Ekonomicznego w Poznaniu.

Czakon, W. (2005). Ku systemowej teorii przewagi konkurencyjnej przedsiębiorstwa. Przegląd Organizacji, 5, 5-8.

Czakon, W. (2008). Kompetencje dynamiczne w badaniach zarządzania strategicznego. W: R. Krupski (red.), Zarządzanie strategiczne - podstawowe problemy (s. 133-144). Wa1brzych: Prace Naukowe Wałbrzyskiej Wyższej Szkoły Zarządzania i Przedsiębiorczości.

Czakon, W. (2012). Sieci w zarządzaniu strategicznym. Warszawa: Oficyna a Wolters Kluwer Business. 
Czopek, A. (2013). Analiza porównawcza efektywności metod redukcji zmiennych - analiza składowych głównych i analiza czynnikowa. Zastosowanie metod matematycznych w ekonomii i zarządzaniu. Studia Ekonomiczne, Uniwersytet Ekonomiczny w Katowicach, 132(7-23).

Czyż, T. (1971). Zastosowanie metody analizy czynnikowej do badania ekonomicznej struktury regionalnej Polski. Wrocław: Wydawnictwo Polskiej Akademii Nauk.

Daft, R. L., Sormunen, J. i Parks, D. (1988). Chief executive scanning, environmental characteristics, and company performance an empirical study. Strategic Management Journal, 9, 123-139.

Dahmardeh, N. i Banihashemi, S. A. (2010). Organizational agility and agile manufacturing. European Journal of Economics, Finance and Administrative Sciences, 27.

Dai, G., De Meuse, K. P. i Tang, K. Y. (2013). The role of learning agility in executive career success: The results of two field studies. Journal of Managerial Issues, 25(2),108-131.

Daily, C. M., McDougall, P. P, Covin, J. G. i Dalton, D. R. (2002). Governance and strategic leadership in entrepreneurial firms. Journal of Management, 28, 387-412.

Danneels, E. i Kleinschmidt, E. J. (2001). Product innovativeness form the firm's perspective: its dimensions and their relation with product selection and performance. The Journal of Product Innovation Management, 18, 357-373.

Das, T. K. i Elango, B. (1995). Managing strategic flexibility: Key to effective performance. Journal of General Management, 20(3).

Day, G. S. (2000). Managing market relationships. Journal of Academy Marketing Science, 28(1), 24-30.

Day, G. S. i Shoemaker, P. J. H. (2005). Peripheral vision. Boston: Harvard Business School Press.

Dess, G. G. i Beard, D. W. (1984). Dimensions of organizational task environments. Administrative Science Quarterly, 29(1), 52-73.

De Luque, M. S., Washburn, N. T., Waldman, D. A. i House, R. J. (2008). Unrequited profit: How stakeholders and economic values relate to subordinates' perceptions of leadership and firm performance. Administrative Science Quarterly, 53, 626-654.

De Vor, R. i Mills, J. (1995). Agile manufacturing. American society of mechanical engineers, Manufacturing Engineering Division, 2(2), 997.

De Wit, B. i Meyer, R. (2007). Synteza strategii. Warszawa: PWE.

Dixit, A. K. i Pindyck, R. S. (1994). Investement under uncertainty. Princeton: Princeton University Press.

Doligalski, T. (2013). Zarządzanie wartością klienta. Próba charakterystyki. Marketing i Rynek, 6 .

Donaldson, L. (2001). The contingency theory of organization. London: Sage Publication.

Dove, R. (2001). Response ability: The language structure and culture of the agile enterprise. New York: Wiley.

Dove, R. (1993). Lean and agile: synergy, contrast, and emerging structure. W: Proceedings of the Defense Manufacturing Conference '93, San Francisco.

Dove, R. (1996). Agile and otherwise. Production Magazine, 07-11.

Dove, R. (2001). Response ability: The language, structure and culture of the agile enterprise. New York: Wiley. 
Doz, Y. L. i Kosonen, M. (2007). Strategic renewal: Building strategic agility. International Strategic Management Society Conference, San Diego.

Doz, Y. L. i Kosonen, M. (2008a). Fast strategy. How strategic agility will help you stay ahead of the game. London: Wharton School Publishing.

Doz, Y. L. i Kosonen, M. (2008b). The dynamics of strategic agility: Nokia's rollercoaster experience. California Management Review, 50(3).

Doz, Y. L. i Kosonen, M. (2010). Embedding strategic agility. A leadership agenda for accelerating business model renewal. Long Range Planning , 43, 370-382.

Drnevich, P. L. i Kriauciunas, A. P. (2011). Clarifying the conditions and limits of the contributions of ordinary and dynamic capabilities to relative firm performance. Strategic Management Journal, 32(11), 254-279.

Drucker, P. F. (1992). Innowacja i przedsiębiorczość. Warszawa: Praktyka i zasady.

Drucker, P. F. (1995). Zarządzanie w czasach burzliwych. Warszawa: Nowoczesność.

Duncan, R. B. (1972). Characteristics of organizational environments and perceived environmental uncertainty. Administrative Science Quarterly, 17, 313-327.

Dwyer, F. R. i Welsh, M. A. (1985). Environmental relationships of the internal political economy of marketing channels. Journal of Marketing Research, 22(4), 397-414.

Dyduch, W. (2008). Pomiar przedsiębiorczości organizacyjnej, Prace Naukowe Akademii Ekonomicznej im. Karola Adamieckiego w Katowicach. Katowice.

Dyduch, W. (2016). Ilościowe badanie i operacjonalizacja zjawisk w naukach o zarządzaniu. W: W. Czakon (red.), Podstawy metodologii badań naukowych o zarządzaniu (s. 306-331). Warszawa: Wydawnictwo Nieoczywiste.

Dyduch, W. i Bratnicka K. (2014). Strategiczna przedsiębiorczość: koncepcja i pomiar. Prace Naukowe Wałbrzyskiej Wyższej Szkoły Zarządzania i Przedsiębiorczości, 27(2), 167-192.

Dyduch, W. i Bratnicki, M. (2016). Charakterystyki organizacji inteligentnej. Studia i Prace, Kolegium Zarządzania i Finansów, Zeszyty Naukowe, 149. Szkoła Główna Handlowa w Warszawie.

Dyduch, W. i Bratnicki, M. (2017). Przywództwo strategiczne a tworenie wartości w orgnizacjach. Organizacja i Kierowanie, 2, 121-135.

Dyer, J. H. i Singh, H. (1998). The relational view: cooperative strategy and sources of interorganizational competitive advantage. Academy Management Review, 23, 660-679.

Dyer, L. i Shafer, R. A. (1998). From human resource strategy to organizational effectiveness: Lessons from research on organizational agility. CAHRS Working Paper, NY: Cornell University, School of Industrial and Labor Relations, Center for Advanced Human Resource Studies.

Easton, G. (1998). Case research as a methodology for industrial network: a realist approach. W: P. Naude i P. W. Turnbull (Eds.), Network dynamics in marketing (s. 73-78). Oxford: Pragamon Press.

Eisenhardt, K. M. (1989). Making fast strategic decision in high-velocity environments. Academy of Management Journal, 32(3), 543-576.

Eisenhardt, K. M. i Martin, J. A. (2000). Dynamic capabilities: What are they? Strategic Management Journal, 21(10-11), 1105-1121.

Eisenhardt, K. M. i Schoonhoven, C. B. (1996). Resource - based view of strategic alliance formation: Strategic an social effects in entrepreneurial firms. Organizational Science, 7. Eisenhardt, K. M. i Sull, D. N. (2001). Strategy as simple rules. Harvard Business Review, 79(1). 
Elenkov, D. S. (1997). Strategic uncertainty and environmental scanning: the case for institutional influences on scanning behavior. Strategic Management Journal, 18(4), 287-302.

Elkonov, D. S., Judge, W. i Wright, P. (2005). Strategic leadership and exectutive innovation influence: an international mutli-cluter comparative study. Strategic Management Journal, 26(7), 665-682.

Eppink, D. J. (1978). Planning for strategic flexibility. Long Range Planning, 11(4), 9-15.

Evaristo, R. i Zaheer, S. (2014). Making the most of your firm's capabilities. Business Horizons, 57, 329-335.

Fahey, L. i Narayanan, V. K. (1989). Linking changes in revealed causal maps and environmental change: an empirical study. Journal of Management Studies, 26(4), 361-378.

Fahey, L. i Randall, R. (1998). Learning form the future. New York: John Willey and Sons,

Fartash, K. i Davoudi, S. (2012). The important role of strategic agility in firms capability and performance. International Journal of Engineering and Management Research, 2(3).

Felipe, C. M., Roldan, J. L. i Leal-Rodriguez, A. L. (2016). An explanatory and predictive model for organizational agility, Journal of Business Research. http://dx.doi.org/10.1016/j. jbusres.2016.04.014

Field, A. (2000). Discovering Statistics using SPSS for Windows. London - Thousand Oaks -New Delhi: Sage publications.

Finkelstein, S. i Hambrick, D. C. (1996). Strategic leadership: Top executives and their effects on organizations. West's Strategic Management Series. Minneapolis/St. Paul.

Fiol, C. i Lyles, M. (1985). Organizational Learning. Academy of Management Review, 10(4), 803-813.

Fiol, M. (2001). Revisiting an identity-based view of sustainable competitive advantage. Journal of Management, 6, 691-699.

Fisher, M. L. (1997). What is the right supply chain for your product? A simple framework can help you figure out the answer. Harvard Business Review, 75(2).

Flaszewska, S. i Zakrzewska-Bielawska, A. (2013). Elastyczność struktury organizacyjnej przedsiębiorstw opartych na wiedzy. Zeszyty Naukowe Wyższej Szkoły Bankowej w Poznaniu, 49(4).

Flynn B. B. i Flynn E. J. (2004). An exploratory study of the nature of cumulative capabilities. Journal of Operations Management, 22(5), 439-457.

Forsythe, C. (1997). Human factors in agile manufacturing: a brief overview with emphasis on communications and information infrastructure. Human Factors and Ergonomics in Manufacturing 7(1), 3-10.

Foster, J. i Metcalfe, J. S. (2012). Economic emergence: An evolutionary economic perspective. Journal of Economic Behaviour \& Organization, 82.

Fourne, S. P. L., Jansen, J. J. P. i Mom, T. J. M. (2014). Strategic agility in MNEs: Managing tensions to capture opportunities across emerging and established markets. California Management Review, 56(3), 13-38.

Frątczak, E. (2009). Wielowymiarowa analiza statystyczna. Teoria - przykłady zastosowań z systemem SAS. Warszawa: Szkoła Główna Handlowa.

Freedman, M. (2004, Fabruary). Strategic leadership - how does your team measure up? Strategic Direction. 
Fynes, B. i Voss, C. (2002). The moderating effect of buyer-supplier relationship on quality practices and performance. International Journal of Operation \& Production Management, 22.

Gabryś, B. (2016). Organizacja inteligentna w perspektywie podejścia mieszanego: granice interpretacji, W: C. Suszyński i G. Leśniak-Łebkowska (red.), Organizacja inteligentna. Perspektywa zasobów ludzkich (s. 445-453). Warszawa: Oficyna Wydawnicza Szkoła Główna Handlowa w Warszawie.

Gabryś, B. i Bratnicki, M. (2015). Luz organizacyjny jako potencjał odnowy organizacyjnej. Management Forum, 3(1), 31-36.

Galbraith, J. R. (2010). The multi-dimensional and reconfigurable organization. Organizational Dynamics, 39(2).

Ganguly, A., Nilchiani, R. i Farr, J. V. (2009). Evaluating agility in corporate enterprises. International Journal of Production Economics, 118, 410-423.

Gasse, Y. (1982). Elaboration on the psychology of the entrepreneur. W: Encyklopedia of Enterprenurship (s. 209-223).

Gerwin, D. (1993). Manufacturing flexibility: a strategic perspective. Management Science, 39(4), 395-410.

Gibson, C. B. i Birkinshaw, J. (2004). The antecedents, consequences, and mediating role of organizational ambiedexterity. Academy of Management Journal, 47(2), 209-226.

Ginsberg, A. (1985). Measuring changes in entrepreneurial orientation following industry deregulation: The development of a diagnostic instrument. Proceedings of the International Council of Small Business (s. 50-57).

Gnyawali, D. R. i Madhavan, R. (2001). Cooperative networks and competitive dynamics: a structural embeddedness perspective. Academy of Management Review, 26(3), 431-445.

Gold, A. H, Malhotra, A. i Segars, A. H. (2001). Knowledge management: An organizational capabilities perspective. Journal of Management Information Systems 18(1).

Goldman, S. L, Nagel, R. N. i Preis, K. (1995). Agile competitors and virtual organizations. Strategies for enriching the customer. New York: Van Nostrand Reinhold.

Goldman, S. L i Preis, K., Nagel, R. N i Dove, R. (1991). Principal investigators, the 15 industry executives. W: 21st century manufacturing enterprise strategy: An industry-led view, 2. Bethlegem: Iacocca Institute at Lehigh University.

Goriwondo, W. M., Mhlanga, S. i Mutsambwa, T. (2013). Agility for sustainability in Zimbabwe: A case study for manufacturing companies in Bulawayo. China-USA Business Review, 12(1), 38-51.

Gorynia, M., Jankowska, B. i Owczarzak, R. (2007). Zarządzanie strategiczne jako próba syntezy teorii przedsiębiorstwa. W: M. Gorynia, Studia nad transformacja i internacjonalizacja gospodarki polskiej. Warszawa: Difin.

Gostick, A. i Elton, C. (2009). Zasada marchewki. Doceniaj i motywuj. Warszawa: MT Biznes. Górniak, J. i Perek-Biała, J. (2010). Wprowadzenie do modelowania równań strukturalnych a AMOS - em, Materiały szkoleniowe do Letnich Warsztatów Analitycznych organizowanych przez AGH i SPSS Polska, Kraków.

Grajewski, P. (2007). Organizacja procesowa. Warszawa: PWE.

Grandori, A. (2012). Interfirm networks: Organization and industrial competitiveness. Routledge. 
Grant, R. M. (1991). The resource-based theory of competitive advantage: Implications for strategy formulation. California Management Review, 33(3), 114-135.

Grant, R. M. (2003). Strategic planning in a turbulent environment: evidence from the oil majors. Strategic Management Journal, 24(49), 491-517.

Gruszczyńska-Malec, G. i Hładoń, W. (2011). Sukces organizacji - przegląd mierników i sposobów wykorzystania. Prace i Materiały Wydziału Zarzadzania Uniwersytetu Gdańskiego.

Gruszecki, T. (2002). Współczesne teorie przedsiębiorstwa. Warszawa: Wydawnictwo Naukowe PWN.

Gunasekaran, A. (1998). Agile manufacturing: enablers and an implementation framework. International Journal of Production Research, 36(5).

Gunasekaran, A. (1999a). Agile manufacturing: A framework for research and development. International Journal of Production Economics, 62(1-2), 87-106.

Gunasekaran, A. (1999b). Design and implementation of agile manufacturing systems. International Journal of Production Economics, 62(1-2), 1-6.

Gunasekaran, A. i Yusuf, Y. (2002). Agile manufacturing: a taxonomy of strategic and technological imperatives. International Journal of Production Research, 40(6), 1357-1385.

Haeckel, S. H. (1999). Adaptive enterprise: creating and leading sense and respond organization. Boston: Harvard Business School Press.

Hage, J. i Dewar, R. (1973). Elite values versus organizational structure in predicting innovation. Administrative Science Quarterly, 18, 279-290.

Hagedoorn, J. (1993). Understanding the rationale of strategic technology partnering - interorganizational modes of cooperation and sectoral differences. Strategic Management Journal, 14.

Hallgren, M. i Olhager, J. (2009). Lean and agile manufacturing external and internal drivers and performance outcomes. International Journal of Operations \& Production Management, 29(10), 976-999.

Halpern, N. (2012). Use of the social media by airports. Journal of Airline and Airport Management, 2(2).

Hair Jr., J. F., Black, W. C., Babin, B. J. i Anderson, R. E. (2010). Multivariate data analysis. A ggobal perspective. 7th ed. Pearson Education. New Jersey: Upper Saddle River.

Hambrick, D. C. (1982). Environmental scanning and organizational strategy. Strategic Management Journal, 2, 159-174.

Hambrick, D. C. (2007). Upper echelons theory: An update. Academy Management Review, $32,334-343$.

Hambrick, D. C. i Mason, P. A. (1984). Upper echelons: The organization as a reflection of its top managers. Academy Management Review, 9, 195-206.

Hambrick, D. i Pettigrew, A. (2001). Upper echelons: Donald Hambrick on executives and strategy. Academy of Management Review, 15(3).

Hamel, G. (1991). Competition for competences and inter-partner learning within International strategic alliance (Special Issue). Strategic Management Journal, 12, 83-103.

Hamel, G. i Prahalad, C. K. (1990. May-June). The core competences of the corporation. Harvard Business Review.

Hamrol, M. (2010). Analiza finansowa. Ujęcie sytuacyjne. Poznań: Uniwersytet Ekonomiczny w Poznaniu. 
Harrison, J. S., Hitt, M., Hoskisson, R. E. i Irealand, D. (1991). Synergies and post-acquisition performance: Differences versus similarities in resources allocations. Journal of Management, 17(1), 193-190.

Hatch, M. J. (1997). Organization theory: Modern, symbolic and postmodern perspectives. Oxford: University Press.

Henard, D. H. i Szymanski, D. M. (2001). Why some new products are more successful than others. Journal of Marketing Research, 38(3), 362-375.

Highsmith, J. (2005). APM: Agile project management. Jak tworzyć innowacyjne produkty. Warszawa: Wydawnictwo Mikom.

Himmelman, A. T. (1996). On the theory and practice of transformational collaboration: from social service to social justice. W: C. Huxham (Ed.), Creating collaborative advantage. London: Sage.

Hinterhuber, H. H. i Friedrich, S. A. (2002). The technology dimension of strategic leadership: The leadership chalange for production economists. International Journal of Production Economics, 77, 191-203.

Hitt, M. A. i Ireland, R. D., 2000, The intersection of entrepreneurship and strategic management research. W: D. L. Sexton i H. Landstrom. Handbook of entrepreneurship. Oxford: Blackwell Publishers.

Hitt, M. A., Ireland, R. D., Camp, S. M. i Sexton, D. L. (2001). Strategic entrepreneurship: Entrepreneurial strategies for wealth creation. Strategic Management Journal, 22 (Special Issue), 479-491.

Hitt, M. A., Ireland, R. D., Camp, S. M. i Sexton, D. L. (2002). Strategic entrepreneurship: Integrating entrepreneurial and strategic management perspectives. W: M. A. Hitt, R. D. Ireland, S. M. Camp i D. L. Sexton, Strategic entrepreneurship: Creating a new mindset, (s. 1-16). Oxford: Blackwell Publishers.

Hitt, M. A., Ireland, R. D. i Hoskisson, R. E. (2009). Strategic management. Concept \& cases. Competitiveness and globalization. 8th ed., South-Western Cengage Learninig, USA.

Hitt, M. A., Ireland, R. D., Sirmon G. i Trahms, Ch. A. (2011). Strategic entreprenurship: Creating value for individuals, organizations and society. Academy of Management, 57-75.

Hockuba, Z. (1995). Droga do spontanicznego porzadku. Transformacja ekonomiczna w świetle problemu regulacji. Warszawa: Wydawnictwo Naukowe PWN.

Hoek, R. I, Harrison, A. i Christopher, M. (2001). Measuring agile capabilities in the supply chain. International Journal of Operations \& Production Management, 21(1/2), 126-147.

Hofer, C. i Schendel, D. (1978). Strategy formulation: Analytical concepts. St. Paul, MN:West.

Holweg, M. (2005). The three dimensions of responsiveness. International Journal of Operations \& Production Management, 25(7/8), 603-622.

Hornowska, E. (2000). Opercjonalizacja terminów teoretycznych: czynnik, wielkość, zmienna. W: J. Brzeziński i E. Hornowska (red.), Podstwowe metody badawcze - teoria i praktyka testowania. W: J. Strelau (red.), Psychologia. Podręcznik akademicki, t.1. Gdańsk: Gdańskie Wydawnictwo Psychologiczne.

Hormozi, A. M. (2001). Agile manufacturing: the next logical step. Benchmarking. An International Journal, 8(2), 132-143.

Hosmer, L. T. (1982). The importance of strategic leadership. Journal of Business Strategy, $3(2), 47-57$. 
Hrebiniak, I. i Joyce, W. (1985). Organisational adaptaion: strategic choice and environmental determinizm. Administrative Science Quarterly, 30(3).

Hurley, R. F i Hult, G. T. M. (1998). Innovation, market orientation, and organizational learning: Am integration and empirical examination. Journal of Marketing, 62, 42-54.

Hurt, H. T., Joseph, K. i Cook, C. D. (1977). Scales for the measurement of innovativeness. Human Communication Research, 4(1), 58-65.

Iacocca Institute (1991). 21 st Century Manufacturing Enterprise Strategy: An Industrial led View (Volume 1). Bethelham: Lehigh University.

Inman, R. A., Sale, R. S. Green, Jr. K. W. i Whitten, D. (2011). Agile manufacturing relation to JIT, operational performance and firm performance. Journal Operations Management, 29(4), 343-355.

Ireland, R. D., Hitt, M. A. i Sirmon, D. G. (2003). A model of strategic entrepreneurship: The construct and its dimensions. Journal of Management, 29(6), 963-989.

Irealand, R. D., Hitt, M. A. i Vaidyanath, D. (2002). Alliances management as a source of competitive advantage. Journal of Managerial Issues, 28, 413-446.

Ireland, R. D., Kuratko, D. F. i Covin, J. G. (2003). Antecedents, elements, and consequences of corporate entrepreneurship strategy. W: D. H. Nago (Ed.), Proceedings of the sixty-third annual meeting of the Academy of Management, CD. ISSN 1543-8643.

Ismail, H. S., Snowden, S. P., Poolton, J., Ried, I. R. i Arokiam, I. (2006). Agile manufacturing framework and practice. International Journal of Agile Systems and Management, $1(1), 11-28$.

Jacobs, M., Droge, C., Vickery, S. K. i Calantone, R. (2011). Product and process modularity's effects on manufacturing agility and firm growth performance. Journal Production Innovation Management, 28(1), 123-137.

Jambulingam, T., Kathuria, R. i Doucette, W. R. (2005). Entrepreneurial orientation as a basis for classification within a service industry: the case of retail pharmacy industry. Journal of Operations Management, 23, 23-42.

Jamrog, J. J., McCann, J., Lee, J. M., Morrison, C. L., Selsky, J. W. i Vickers, M. (2006). Agility and resilience in the face of continuous change: A global study of current trends and future possibilities 2006-2016. New York: American Management Association.

Janasz, W. i Kozioł, K. (2007). Determinanty działalności innowacyjnej przedsiębiorstw. Warszawa: Polskie Wydawnictwo Ekonomiczne.

Januszewski, A. (2011). Modele równań strukturalnych w metodologii badań psychologicznych. Problematyka przyczynowości w modelach strukturalnych i dopuszczalność modeli. W: O. Gorbaniuk, M. Wiechetek, A. Błachnio i A. Przepiórka (red.), Studia z Psychologii w KUL (Tom 17, s. 213-245). Lublin: Wydawnictwo KUL.

Jarillo Mossi, J. C. (1989). Entrepreneurship and growth: The strategic use of external resources. Journal of Business Venturing, 4, 133-147.

Jaworski, B. J. i Kohli, A. K. (1993). Market orientation: antecedents and consequences. Journal of Marketing, 57(3), 53-70.

Jefferson, M. (2012). Shell scenarios: what really happened in the 1970's and what may be learned for current world prospects. Technology Forecasting and Social Change, 79(1), 186-197.

Joroff, M. L., Porter, W. L., Feinberg, B. i Kukla, C. (2003). The agile workplace. Journal of Corporate Real Estate, 5(4), 293-311. 
Kaczmarek, B. (2013). Tworzenie organizacji inteligentnej jako nowej wartości firmy. Zeszyty Naukowe Uniwersytetu Szczecińskiego, 786, Finanse, Rynki Finansowe, Ubezpieczenia, 64/1,157-162.

Kaish, S. i Gilad, B. (1991). Characteristics of opportunities search of entrepreneurs versus executives: sources, interest, and general alertness. Journal Business Venturing, 6.

Kantur, D. (2016). Strategic entrepreneurship: mediating the entrepreneurial orientation performance link. Management Decision, 54(1), 24-43.

Karaś, M. (2008). Teoria ewolucyjna firmy, Prace Naukowe Uniwersytetu Ekonomicznego we Wrocławiu, Kierunki i dylematy rozwoju nauki o przedsiębiorstwie, 34.

Karasiewicz, K., Makarowski, R. (2012). Modelowanie strukturalne z programem AMOS wybrane modele równań strukturalnych na przykładach z psychologii. Warszawa: Zimowe Warsztaty Analityczne. Kasiewicz, S., Ormińska, J., Rogowski, W. i Urban, W. (2009). Metody osiagania elastyczności przedsiębiorstw. Od zarządzania zasobowego do procesowego. Warszawa: Oficyna Wydawnicza SGH.

Kasprzak, T. (2000). Ewolucja przedsiębiorstw ery innowacji. Warszawa: WNE, Uniwersytet Warszawski.

Kassim, N. M. i Zain, M. (2004). Assessing the measurement of organizational agility. The Journal of American Academy of Business, 4(1), 174-177.

Katayama, H. i Bennett, D. (1996). Lean production in a changing competitive world: a Japanese perspective. International Journal of Operations \& Production Management, 16(2), 221-229.

Katayama, H. i Bennett, D. (1999) Agility, adaptability, leanness: a comparison of concepts and a study of practice. International Journal of Production Economics, 60(61), 43-51.

Kauffman, S. A. (1991, August). Antichaos and Adaptation. Scientific American.

Kawa, A. (2017). Orientacja sieciowa przedsiębiorstw branży usług logistycznych. Poznań: Wydawnictwo Wydawnictwo Uniwersytetu Ekonomicznego w Poznaniu.

Khoshnood, N. T. i Nematizadeh, S. (2017). Strategic agility and its impact on the competitive capabilities in Iranian private banks. International Journal of Business and Management, 12(2), 220-229.

Kidd, P. T. (1994). Agile manufacturing: Forging new frontiers. Reading, MA: Addison Weseley. Kirsch, L. J., Sambamurhty, V., Ko, D.G. i Purvis, R. L. (2002). Controlling information systems development projects: The view from the client. Management Science, 48(4), 484-498.

Kirzner, I. M. (1973). Competition and Entrepreneurship. Chicago: Chicago University Press. Kirzner, I. M. (1979). Perception, opportunities and profit. Studies in the theory of entrepreneurship. Chicago: University of Chicago Press.

Kirzner, I. M. (2009). The alert and creative entrepreneur: a clarification. Small Business Economics, 32.

Kisch, H. (1979). Joseph Alois Schumpeter. Journal of Economics Issues, 1.

Kitchell, S. (1997). CEO characteristics and technological innovativeness: A Canadian perspective. Canadian Journal of Administrative Science, 14(2), 111-125.

Knight, F. H. (1964). Risk, uncertainty and profit. New York: By Sentry Press.

Kogut, B. (1988). Joint ventures: Theoretical and empirical perspectives. Strategic Management Journal, 9.

Konarski, R. (2009). Modele równań strukturalnych. Teoria i praktyka. Warszawa: PWN. 
Kotler, P. i Caslione, J. A. (2009). Chaos. Zarządzanie i marketing w erze turbulencji. Warszawa: MT Biznes.

Kozielski R. (2011). Źródła sukcesu firm we współczesnej gospodarce - nowy paradygmat biznesu (ujęcie modelowe i analiza retrospektywna). W: E. Urbanowska-Sojkin (red.), Wybory strategiczne w przedsiębiorstwach. Ujęcie sektorowe. Zeszyty Naukowe, 171.

Kożuch, B. (2009). Nauka o organizacji. Warszawa: Wydawnictwo Fachowe CeDeWu.

Kraus, S, Kauranen, J. i Reschke, C. H. (2011). Identification of domains for a new conceptual model of strategic entrepreneurship using the configuration approach. Management Research Review, 34, 58-74.

Kritchanchai, D. i MacCarthy, B. L. (1999). Responsiveness of the order fulfillment process. International Journal of Operations \& Production Management, 19(8), 812-833.

Krohwinkel-Karlsson, A. (2007). Knowledge and learning in aid organizations: A literature review with suggestions for further studies. Karlstad: Swedish Agency for Development Evaluation.

Krupski, R. (2003). Strategia bez celów. Przegląd Organizacji, 11, 8-11.

Krupski, R. (red.), (2005). Zarzadzanie przedsiębiorstwem $w$ turbulentnym otoczeniu. Warszawa: Polskie Wydawnictwo Ekonomiczne.

Krupski, R. (2006). Elastyczność organizacji - elementy teorii, Refleksje społeczno- gospodarcze, Zeszyty Naukowe WWSZiP, 9(2).

Krupski, R. (red.) (2008). Elastyczność organizacji. Wrocław: Wydawnictwo Uniwersytetu Ekonomicznego we Wrocławiu.

Krupski, R. (2010). Dyskusja o treści strategii. Przegląd Organizacji, 6.

Krupski, R. (2011). Kontekst turbulencji otoczenia w badaniach empirycznych nad strategiami przedsiębiorstw. Przegląd Organizacji, 9, 3-5.

Krupski, R. (2013). Rodzaje okazji w teorii i praktyce zarządzania. Prace Naukowe WSSZIP, 21(1).

Krupski, R. (2014). Zasoby niematerialne jako główny składnik strategii przedsiębiorstwa działającego w turbulentnym, nieprzewidywalnym otoczeniu. Organizacja $i$ Kierowanie, 1A(159).

Kuivalainen, O., Sundqvist, S., Puumalainen, K. i Cadogan, K. W. (2004). The effect of environmental turbulence and leader characteristics on international performance: are knowledge-based firm different? Canadian Journal of Administrative Sciences, 21(1), 35-50.

Kumar, A. i Motwani, J. (1995). A methodology for assessing time - based competitive advantage of manufacturing firms. International Journal of Operations \& Production Management, 15(2), 36-53.

Kumari, S. (2016). Impact of big data and social media on society. Research Paper Engineering, 5(3).

Kuratko, D. F., Morris, M. H. i Covin, J. C. (2011). Corporate entrepreneurship \& innovation, 3rd ed. Mason: Thomas/Southwestern Publishing.

Kyrgidou, L. P. i Hughes, M. (2010). Strategic entrepreneurship: origins, core elements and research directions. European Business Review, 22, 43-63.

Laloux, F. (2015). Pracować inaczej. Warszawa: Studio Emka.

Latusek-Jurczak, D. (2017). Firmy szybkiego wzrostu w środowisku niskiego zaufania - badanie empiryczne. Studia Oeconomica Posnaniensia, 5(9). Poznań: Uniwersytet Ekonomiczny w Poznaniu. 
Lawrence, P. R. i Lorsch, J. W. (1967). Organization and environment: Managing differentiation and integration. Boston: Harvard Business School Press.

Lawson, B. i Samson, P. (2001). Developing innovation capability in organizations: a dynamic capabilities approach. International Journal of Innovation Management, 5(3).

Li, M. i Gao, F. (2003). Why Nonaka highlights tacit knowledge: a critical review. Journal of Knowledge Management, 7(4), 6-14.

Li, X., Chung, C., Goldsby, T. J. i Clyde, W. H. (2008). A unified model of supply chain agility: the work design perspective. International Journal Logistics Management, 19(3), 408-435.

Li, Y., Chen, H., Liu, Y. i Peng, M. W. (2014). Managerial ties, organizational learning, and opportunity capture: a social capital perspective. Asia Pacific Journal of Management, 31(1), 271-291.

Li, Y. H., Huang, J. W. i Tsai, M. T. (2009). Entrepreneurial orientation and firm performance: The role of knowledge creation process. Industrial Marketing, 38, 440-449.

Lichtarski, J. (2005). Strategiczne problemy i kierunki uelastycznienia przedsiębiorstwa. W: J. Rokita i W. Grudzewski (red.), Elastyczność organizacji. Katowice: Wydawnictwo Górnośląskiej Wyższej Szkoły Handlowej.

Lichtarski, J. (red.). (2007). Podstawy nauki o przedsiębiorstwie. Wrocław: Wydawnictwo Akademii Ekonomicznej we Wrocławiu.

Lichtenthaler, U. (2009). Absorptive capacity, environmental turbulence, and the complementarity of organizational learning process. Academy of Management Journal, 52(4), 822-846.

Lichtenhaler, U. i Muethel, M. (2012). The impact of family involvement on dynamic innovation capabilities: evidence form German manufacturing firms. Entrepreneurship. Theory and Practice, 36(6), 1235-1253.

Lin, C. T., Chiu, H. i Chu, P. Y. (2006). Agility index in the supply chain. International Journal of Production Economics, 100(2), 285-299.

Lovelace, K., Shapiro, D. L. i Weingart, L. R. (2001). Maximizing cross-functional new product teams. Innovativeness and constraint adherence: A conflict communications perspective. Academy of Management Journal, 44(4), 779-793.

Lu, Y. i Ramamurthy, K. (2011). Understanding the link between information technology capability and organizational agility: an empirical examination. MIS Quarterly, 35(4), 931-954.

Lumpkin, G. T. i Dess, G. G. (1996). Clarifying the entrepreneurial orientation construct and linking it to performance. Academy of Management Review, 21, 135-171.

Łobejko, S. (2009). Trendy rozwojowe inteligentnych organizacji w globalnej gospodarce. Ekspertyza współfinansowana przez Unię Europejskiego Funduszu Społecznego. EMAR Reserach Marketing. Warszawa.

Lyytinen, K. i Rose, G. M. (2006). Information system development agility as organizational learning. European Journal of Information Systems, 15(2), 183-199.

Mahmoud Hamad, Z. M. i Yozgat, U. (2017). Does organizational agility affect organizational learning capability? Evidence from commercial banking. Management Science Letters, 7, 407-422.

Makadok, R. (2001). Toward a synthesis of the resources - based and dynamic - capability views of rent creation. Strategic Management Journal, 22(5), 387-401.

Malarska, A. (2005). Statystyczna analiza danych wspomgana programem SPSS. Kraków: Wydawnictwo SPSS Polska. 
Malewska, K. i Sajdak, M. (2017). Wpływ dynamicznych zdolności na zwinność strategiczną przedsiębiorstwa. W: K. Krzakiewicz i S. Cyfert (red.), Strategiczny wymiar dynamicznych zdolności polskich przedsiębiorstw. Poznań: Wydawnictwo UEP.

March, J. G. (1991). Exploration and exploitation in organizational learning. Organizational Science, 2(1), 71-87.

Markides, C. (1998, Spring). Strategic innovation in established companies. Sloan Management Review, 31-42.

Martin, B. (1995). Foresight in science and technology. Technical Analysis of Strategic Management, 7, 139-168.

Maskell, B. (2001). The age of agile manufacturing. Supply Chain Management. An International Journal, 6(1), 5-11.

Mason, A. J. (2010). Inside the black box: Investigating agility as a dynamic capability for sustaining competitive advantage within consulting firms. Ph. D. Dissertation, South Carolina: Capella University.

Massaki, K. i Scott, S. K. (1995). The role of strategic alliances in high-technology new product development. Strategic Management Journal, 16(8), 621-636.

Mat, A. i Cherazak, R. C. (2011). The influence of organizational learning capability on success of technological innovation (product) implementation with moderating effect of knowledge complexity. International Journal of Business and Social Science, 2(17), 217-225.

Matson, J. B. i McFarlane, D. C. (1999). Assessing the responsiveness of existing production operations. International Journal of Operations \& Production Management, 19(8), 765-784.

Mayer-Schönberger, V. i Cukier, K. (2014). Big Data. Rewolucja, która zmieni nasze myślenie prace $i \dot{z} y$ cie. Warszwa: MT Biznes.

Mavengere, N. B. (2013). Role of information systems for strategic agility in supply chain setting: telecommunication industry study. The Electronic Journal Information Systems Evaluation, 16(4), 327-340.

McCline, R. L., Bhat, S. i Baj, P. (2000). Opportunity recognition: An exploratory investigation of a component of the entrepreneurial process in the context of the health care industry. Entrepreneurship Theory and Practice, 25(2), 81-94.

McEvily, B. i Marcus, A. (2005). Embedded ties and the acquisition of competitive capabilities. Strategic Management Journal, 26(11), 1033-1055.

McGaughey, R. E. (1999). Internet technology: contribution to agility in the twenty - first century. International Journal of Agile Management Systems, 1(1), 7-13.

McGrath, R. G. i MacMillan, I. (2000). The entrepreneurial mindset. Boston: Harvard Business School Press.

Meade, L. M. i Rogers, K. J. (1997). A method for analyzing agility alternatives for business processes. Proceedings of the Sixth Industrial Engineering Research Conference, Miami Beach (s. 960-965).

Meehan, S. i Dawson, C. (2002). Customer responsiveness: getting it fast and right through impatience and intolerance. Business Strategy Review, 13(4), 26-37.

Mehta, S. N. (2001, May). Cisco fractures its own fairy tale. Fortune, 104.

Meindl, J. R. (1998). Invited reaction. Enabling visionary leadership. Human Resources Development Quarterly, 9(1). 
Meredith, S. i Francis, D. (2000). Journey towards agility: the agile wheel explored. The TQM Magazine, 12(2), 137-143.

Meyer, G. D. i Heppard, K. A. (2000). Entrepreneurial strategies: The dominant logic of entrepreneurship. W: G. D. Meyer i K. A. Heppard (Eds.), Entrepreneurship as strategy: Competing on the entrepreneurial edge (s. 1-22). Thousand Oaks: Sage Publications.

Michael, S., Storey, D. i Thomas, H. (2002). Discovery and coordination in strategic management and entrepreneurship. W: M. A. Hitt, R. D. Ireland, S. M Camp i D. L. Secton (Eds.) Strategic entrepreneurship: Creating a new mindset, Oxford: Blackell Publishers.

Miles, R. E. i Snow, C. C. (1978). Organization strategy, structure and process. New York: McGraw-Hill.

Miller, D. (1983). The correlates of entrepreneurship in three types of firms. Management Science, 29, 770-791.

Miller, D. (1987). Structural and environmental correlates of business strategy. Strategic Management Journal, 8, 55-76.

Miller, D. i Friesen, P. H. (1982). Innovation in conservative and entrepreneurial firms: two models of strategic momentum. Strategic Management Journal, 3.

Miller, D. i Friesen, P. H. (1983). Strategy making and the environment: the third link. Strategic Management Journal, 4, 221-235.

Miller, K. D. i Tsang, E. W. (2010). Testing management theories: critical realist philosophy and research methods. Strategic Journal Management, 32,139-158.

Milliken, F. J. (1978). Three types of perceived uncertainty about the environment: state, effect, and response uncertainty. Academy of Management Review, 12(1), 133-143.

Mingers, J. (2006). A critique of statistical modelling in management science from a critical realist perspective: Its role within mulitmethodoloy. The Journal of the Operational Research Society, 57, 202-219.

Mishra, S., Mahapatra, S. S. i Datta, S. (2014). Agility evaluation in fuzzy context: influence of decision-makers' risk bearing attitude. Benchmarking. An International Journal, 21(6), 1084-1119.

Mitręga, M. (2010). Zdolność sieciowa jako czynnik przewagi konkurencyjnej na rynku przedsiębiorstw. Prace Naukowe Akademii Ekonomicznej w Katowicach. Katowice.

Mitręga, M. (2016). Dynamiczne zdolności marketingowe jako obiekt badań w zarządzaniu. Prace Naukowe Uniwersytetu Ekonomicznego we Wrocławiu, 422.

Monckza, R. M. i Morgan, J. (2000). Competitive supply strategies for the 21st century. Purchasing, 128(1), 48-59.

Mondragon, A. E., Lyons, A. C. i Kehoe, D. F. (2004). Assessing the value of information systems in supporting agility in high-tech manufacturing enterprises. International Journal of Operations \& Production Management, 24(2).

Morgan, G. (2008). Obrazy organizacji. Warszawa: Wydawnictwo Naukowe PWN.

Morgan, R. E. i Page, K. (2008). Managing business transformation to deliver strategic agility. Strategic Change, 17, 155-168.

Morris, M. H. (1998). Entrepreneurial intensity: Sustainable advantages for individuals, organizations, and societies. Westport: Quorum Books.

Morris, M. H. i Paul, G. W. (1987). The relationship between entrepreneurship and marketing in established firms. Journal of Business Venturing, 2(3), 247-259. 
Mróz, B. (2014). Relacje konsument-przedsiębiorstwo: nowe wyzwania dla nauk o zarządzaniu. W: M. Romanowska i J. Cegler (red.), Granice zarządzania. Warszawa: Oficyna Wydawnicza Szkoła Główna Handlowa w Warszawie.

Najda-Janoszka, M. (2016). Dynamic capability - based approach to value appropriation. Warszawa: Jagiellonian University Press.

Naman, J. L. i Slevin, D. P. (1993). Entrepreneurship and the concept of fit: A model and empirical tests. Strategic Management Journal, 14, 137-153.

Narasimhan, R., Swink, M. i Kim, S. W. (2006). Disentangling leanness and agility: an empirical investigation. Journal of Operations Management, 24(5), 440-457.

Nawojczyk, M. (2010). Przewodnik po statystyce dla socjologów. Kraków: Wydawnictwo SPSS Polska.

Nazir, S. i Pinsonneault, A. (2012). IT and firm agility: An electronic integration perspective. Journal of the Association for Information Systems, 13(3), 150-171.

Naylor, J. B., Naim, M. M. i Berry, D. (1999). Leagility: integrating the lean and agile manufacturing paradigms in the total supply chains. International Journal of Production Economics, 62, 107-118.

Nelson, R.R. (1995). Recent evolutionary theorizing about economic change. Journal of Economic Literature, 33(1), 48-90.

Nelson, R. R. i Winter, S. G. (1982). An evolutionary theory of economic change. Cambridge: Belknap Press.

Nijssen, M. i Paauwe, J. (2012). HRM in turbulent times: how to achieve organizational agility? The International Journal of Human Resource Management, 23(16), 3315-3335.

Noga, A. (2009). Teorie przedsiębiorstw. Warszawa: Polskie Wydawnictwo Ekonomiczne.

Nogalski, B. i Niewiadomski, P. (2017). Elastyczność - atrybut przedsiębiorstwa wytwórczego tworzący i wzmacniający jego zdolności dynamiczne. W: K. Krzakiewcz i S. Cyfert (red.), Strategiczny wymiar dynamicznych zdolności polskich przedsiębiorstw. Poznań: Wydawnictwo Uniwersytetu Ekonomicznego w Poznaniu.

Nonaka, I. i Takeuchi, H. (1995). The knowledge - creating company: How Japanese companies create the dynamics of innovation. New York: Oxford University Press.

Nonaka, J. (1991, November - December). The knowledge creating company. Harvard Business Review.

Nowak, S. (2012). Metodologia badań społecznych. Biblioteka Socjologiczna. Warszawa: Wydawnictwo Naukowe PWN.

Ofoegbu, O. E. i Akanbi, P. A. (2012). The influence of strategic agility on the perceived performance of manufacturing firms in Nigeria. International Business \& Economics Research Journal, 11(2).

Oliveira, M. A., Valentina, L. V. i Possamai, O. (2012). Forecasting project performance considering the influence of leadership style on organizational agility. International Journal of Productivity and Performance Management, 61(6), 653-671.

Osbert-Pociecha, G. (2011). Zdolność do zmian jako siła sprawcza elastyczności organizacji. Wrocław: Wydawnictwo Uniwersytetu Ekonomicznego we Wrocławiu.

Osbert-Pociecha, G., Moroz, M. i Lichtarski, M. (2008). Elastyczność przedsiębiorstwa jako konfiguracja elastyczności cząstkowych. Gospodarka Narodowa, 4.

Osbert-Pociecha, G. i Pociecha, W. (2006). Financial flexibility as a prerequisite for firm's flexibility. Management, 10(1). 
Osińska, M., Pietrzak, M. B. i Żurek, M. (2011). Wykorzystanie modeli równań strukturalnych do opisu psychologicznych mechanizmów podejmowania decyzji na rynku kapitałowym. Acta Universitatis Nicolai Copernici, Ekonomia XLII - Nauki Humanistyczno-Społeczne, Toruń, 402.

Ouchi, W. G. (1978). The transmission of control through organizational hierarchy. Academy of Management Journal, 21(2), 173-192.

Ouchi, W. G. (1979). A conceptual framework for the design of organizational control mechanisms. Management Science, 25(9), 833-848.

Overby, E., Bharadwaj, A. i Sambamurthy, V. (2006). Enterprise agility and the enabling role of information technology. European Journal of Information Systems, 15(2), 120-131.

Oyedijo, A., (2012), Strategic agility and competitive performance in the Nigeria telecommunication industry: An empirical Investigation. Business and Management Review, 1(12), 39-50.

Pagell, M. (2004). Understanding the factors that enable and inhibit the integration of operations, purchasing and logistics. Journal of Operations Management, 22(5), 459-487.

Panayides, P. M. (2007). The impact of organizational learning on relationship orientation, logistics, service effectiveness and performance. Industrial Marketing Management, 36, 68-80.

Peng, M. W. (2001). How entrepreneurs create wealth in transition economies. Academy of Management Executive, 15(1), 95-108.

Penrose, E. (1959). The theory of the growth of the firm. New York: Oxford University Press.

Pisano, G. P. (1996). In search of dynamic capabilities. W: Dosi, Nelson, Winter (Eds.), The nature and dynamics of organizational capabilities (s. 129-154).

Plonka, F. S. (1997). Developing a lean and agile work force. Human Factors and Ergonomics in Manufacturing 6(4), 323-349.

Plowman, D. A., Baker, L. T., Beck, T. E., Kolkarni, M., Solansky, S. T. i Travis, D. V. (2007). Radical change accidentally: The emergence and amplification of small change. Academy of Management Journal, 50, 515-543.

Polanyi, M. (1958). Personal knowledge: Towards a post-critical philosophy. Chicago: University of Chicago Press.

Polanyi, M. (1966). The Tacit dimension. London: Routledge, Kegan Paul.

Polowczyk, J. (2011). Przywództwo strategiczne w świetle osiągnięć psychologii. Przegląd Organizacji, 1 .

Porter, M. (1985). Competitive advantage. New York: Free Press.

Porter, M. E. (1996). What is strategy? Harvard Business Review, 11-12.

Potts, J. (2000). The new evolutionary microeconomics. Edward Elgar, Norhampton, Mass.

Prahalad, C. i Hamel, G. (1990, May - June). The core competences of the corporation. $\mathrm{Ha}$ rvard Business Review, 79-91.

Prahalad, C. K. i Ramaswamy, V. (2005). Przyszłość konkurencji. Współtworzenie wyjątkowej wartości wraz z klientami. Warszawa: PWE.

Preston, D. S. i Karahanna E. (2009). Antecedents of IS strategic alignment: A nomological network. Information System Research, 20(2), 159-179.

Prigogine, I. i Stengers, I. (1984). Order out of Chaos. New York: Bantam Books.

Radomska, J. (2010). Przywództwo strategiczne w organizacji. Zarządzanie strategiczne w praktyce i teorii. Prace Naukowe Uniwersytetu Ekonomicznego we Wrocławiu, 116. 
Ranft, A. L. i Lord, M. D. (2002). Acquiring new technologies and capabilities: a grounded model of acquisition implementation. Organizational Science, 13(4), 420-441.

Raport PMI's 2012 Pulse of the Profession In-Depth Report: Organizational agility. Pobrane 7 marca 2013 r. $\mathrm{z}$ www.pmi.org

Rapp, A., Trainor, K. J. i Agnihotri, R. (2010). Performance implications of customer-linking capabilities: examining the complementary role of customer orientation and CRM technology. Journal of Business Responsibility, 63(11), 1229-1236.

Raschke, R. i Smith, D. J. (2007). An empirical analysis of business process agility: Examining the relationship of IT on business process agility and the effects of business process agility on process outcomes. Arizona State University.

Raschke, R. L. (2010). Process - based view of agility: The value contribution of IT and the effects on process outcomes. International Journal of Accounting Information Systems, 11, 297-313.

Reich, B. H. i Benbasat, I. (1996). Measuring the linkage between business and information technology objectives. MIS Quarterly, 20(1), 55-81.

Reichhart, A. i Holweg, M. (2007). Creating the customer - responsive supply chain: a reconciliation of concepts. International Journal of Production Planning \& Control, 27(11), 1144-1172.

Ren, J., Yusuf, Y. Y. i Burns, N. D. (2003). The effects of agile attributes on competitive priorities: a neural network approach. Integrated Manufacturing Systems, 14(6), 489-497.

Reynolds, C. W. (1987). Flocks, herds, and schools. A distributed behavioral model. Computer Graphics, 12(4).

Rigby, C. M., Day, P. i Forrester, J. B. (2000). Agile supply: rethinking systems thinking. International Journal of Agile Management Systems, 2(7), 534 - 548.

Rindova, V. i Kotha, S. (2001). Continuous "morphing", competing through dynamic capabilities, form and function. The Academy of Management Journal, 6.

Ringland, G. (2010). The role of scenarios in strategic foresight. Technological Forecasting and Social Change, 77(9), 1493-1498.

Roberts, N. i Grover, V. (2012). Investigating firm's customer agility and firm performance: The importance of aligning sense and respond capabilities. Journal of Business Research, 65.

Robertson, M. i Jones, C. (1999). Application of lean production and agile manufacturing concepts in the telecommunications environment. International Journal of Agile Management Systems, 1(1), 14-17.

Rohrbeck, R. (2012). Exploring value creation from corporate foresight activities. Futures, 44(5), 440-452.

Rohrbeck, R., Mahdjour, S., Knab, S. i Freese, T. (2009). Benchmarking report: Strategic foresight in multinational companies. Berlin: European Corporate Foresight Group.

Rokita, J. (2003). Organizacja ucząca się. Katowice: Akademia Ekonomiczna.

Rokita, J. i Dziubińska, A. (2016). Systemy złożone w zarządzaniu. Katowice: Wydawnictwo Uniwersytetu Ekonomicznego w Katowicach.

Romanowska, M. (2002). Alianse strategiczne w świetle koncepcji zasobowej. W: M. Romanowska i M. Trocki, (red.), Przedsiębiorstwo partnerskie. Warszawa: Difin.

Romanowska, M. (2007). Trwałe tendencje w zarządzaniu. Organizacja i Kierowanie, 1. 
Rosenzweig, E. D. i Roth, A. V. (2004). Towards a theory of competitive progression: evidence from high-tech manufacturing. Journal of Operations Management, 13(4), 354-368.

Roth, A. (1996). Achieving strategic agility through economies of knowledge. Strategy Leadership, 24(2), 30-37.

Roth, A. V. i Jackson, W. (1995). Strategic determinants of service quality and market performance: evidence from the banking industry. Management Science, 41(11), 1720-1733.

Rowe, G. i Nejad, H. (2009). Strategic leadership: short term stability and long-term viability. Ivey Business Journal, 73(5).

Rudnicki, L. (2000). Zachowanie konsumentów na rynku. Warszawa: PWE.

Rugman, A. M. i Verbeke, A. (2002). Edith Penrose's contribution to the resource-based view of strategic management. Strategic Management Journal, 23,769-780.

Rumelt, R. (1984). Towards a strategic theory of the firm. W: R. Lamb (Ed.), Competitive strategic management. Prentice Hall: Englewood Cliffs.

Sadowski, W. (1964). Teoria podejmowania decyzji. Wstęp do badań operacyjnych. Wydanie 3. Warszawa: Państwowe Wydawnictwo Ekonomiczne.

Sagan, A. (2003a). Model strukturalny między satysfakcją i lojalnością wobec marki. StatSoft Polska, 87-92.

Sagan, A. (2003b). Model pomiarowy satysfakcji i lojalności. Statsoft Polska, 5-85.

Sajdak, M., (2013a). Przywództwo strategiczne w zwinnym przedsiębiorstwie. Zeszyty Naukowe Politechniki Łódzkiej: Organizacja i Zarządzanie, 49, 203-212.

Sajdak, M. (2013b). An agile, lean or flexible enterprises - ate they synonymus or different notions? W: S. Trzcieliński (Ed.), Chosen problems of management. Issues on present and the future. Poznań: Publishing House of Poznań University of Technology.

Sajdak, M., (2013c). Zwinność jako źródło przewagi konkurencyjnej i sukcesu przedsiębiorstwa. Zarządzanie i Finanse, 11(4). Część 1. Gdańsk: Wydawnictwo Wydziału Zarządzania Uniwersytetu Gdańskiego.

Sajdak, M. (2013d). Innowacyjność jako niezbędna cecha zwinnego przedsiębiorstwa. Nauki o Zarządzaniu, 1(14). Wrocław: Wydawnictwo Uniwersytetu Ekonomicznego we Wrocławiu.

Sajdak, M. (2014a). Koncepcja zwinności w kształtowaniu konkurencyjności przedsiębiorstw. Prace Naukowe Uniwersytetu Ekonomicznego we Wrocławiu, 358, 58-70. Wrocław.

Sajdak, M. (2014b). Zwinność przedsiębiorstwa jako koncepcja zarządzania między stabilnością a chaosem. W: M. Romanowska i J. Cygler (red.), Granice zarządzania. Warszawa: Oficyna Wydawnicza Szkoła Główna Handlowa.

Sajdak, M. (2014c). Zwinność w odpowiedzi współczesnych przedsiębiorstw na nowe wyzwania otoczenia. Studia Oeconomica Posnaniensia - poprzedni tytuł: Zeszyty Naukowe Uniwersytetu Ekonomicznego (AE) w Poznaniu, 11,138-152.

Sajdak, M. (2014d). Przywództwo strategiczne jako wyzwanie dla współczesnych przedsiębiorstw. Prace Naukowe Uniwersytetu Ekonomicznego (AE) we Wrocławiu, 366, 460-469.

Sajdak, M. (2015). Specyfika strategii w zwinnym przedsiębiorstwie. Marketing i Rynek, 9. PWE.

Sajdak, M. (2017). A proposal for operationalizing strategic entrepreneurship from the perspective of business strategic agility. W: Ch. Loué i S. B. Slimane (Eds.), Proceedings of the 12th European Conference on Innovation and Entrepreneurship ECIE 2017, 21-22 September 2017, Academic Conferences and Publishing International Ltd, Reading, 563-571. 
Sajnóg, A. (2016). Wpływ pozostałego wyniku całkowitego na wynik operacyjny przedsiębiorstwa. Studia Ekonomiczne. Zeszyty Naukowe, 282. Uniwersytet Ekononomiczny w Katowicach.

Sambamurthy, V., Bharadwaj, A. i Grover, V. (2003). Shaping agility through digital options: reconceptualizing the role of information technology in contemporary firms. MIS Quarterly, 27(2), 237-263.

Sanchez, L. M. i Nagi, R. (2001). A review of agile manufacturing systems. International Journal of Production Research, 39(16), 3561-3600.

Schafer, D. S. (1990). Level of entrepreneurship and scanning source usage in very small businesses. Entrepreneurship Theory and Practice, 15(2), 19-31.

Schmidt, J. B. i Calantone, R. J. (1998). Are really new product development projects harder to shut down. The Journal of Product Innovation Management, 15(2), 111-123.

Schoonhoven, C. B. i Romanelli, E., (2001). Emergent themes and the next wave of entrepreneurship research. W: C. B. Schoonhoven i E. Romanelli (Eds.), The entrepreneurship dynamic: Origins of entrepreneurship and the evolution of industries. Stanford: Stanford University Press.

Schreyögg, G. i Kliesch-Eberl, M. (2007). How dynamic can organizational capabilities be? Towards a dual process model of capability dynamization. Strategic Management Journal, 28, 913-933.

Schumpeter, J. A. (1934). The theory of economics development. Cambridge: Harvard University Press.

Schumpeter J. A. (1942). Capitalism, socialism, and democracy. New York: Harper. (Reprint: Routledge, 2013).

Schumpeter, J. A. (1960). Teoria rozwoju gospodarczego. Warszawa: PWN.

Schumpeter, J. A. (1964). Business cycles. A theoretical, historical and statistical analysis of the capitalist process. New York: McGraw Hill.

Schumpeter, J. A. (1965). Kapitalizm, socjalizm, demokracja. Warszawa: PWN.

Schwarz, P. (1991). The art of the long view: Planning for the future in an uncertain world. New York: Doubleday Currency.

Scott, S. G. i Bruce, R. A. (1994). Determinants of innovative behavior: A path model of individual innovation in the workplace. Academy of Management Journal, 37(3), 580-607.

Senge, P. (1990). The fifth discipline: The art and practice of the learning organization. New York: Doubleday Currency.

Sethi, R., Smith, D. C. i Park, C. W. (2001). Cross-functional product development teams creativity, and the innovativeness of new consumer products. Journal of Marketing Research, 3(1), 73-85.

Shahin, A., Nikjoot, M. i Nilipour, A. (2011). Designing L3Y2T model for analyzing and prioritization of the innovation and agility factors. Interdisciplinary Journal of Contemporary Research in Business, 3(3), 87-100.

Shahrabi, B. (2012). The role of organizational learning and agility in change management in state enterprises: A customer - oriented approach. International Research Journal of Applied an Basic Science, 3(12), 2540-2547.

Shane, S. i Venkataraman, S. (2000). The promise of entrepreneurship as a field of research. Academy of Management Review, 25, 217-236. 
Sharma, P. i Chrisman, J. J. (1999). Toward a reconciliation of the definitional issues in the field of corporate entrepreneurship. Entrepreneurship Theory and Practice, 23(3), 11-27.

Sharp, J. M., Irani, Z. i Desai, S. (1999). Working towards agile manufacturing in the UK industry. International Journal of Production Economic, 62, 155-169.

Sheffi, Y. (2005). The Resilient Enterprise. Boston: MIT Press.

Sherehiy, B., Karwowski, W. i Layer, J. K. (2007). A review of enterprise agility: Concepts, frameworks and attributes. International Journal of Industrial Ergonomics, 37(5), 445-460.

Shin, H., Lee, J., Kim, D. i Rhim, H. (2015). Strategic agility of Korean small and medium enterprises and its influence on operational and firm performance. International Journal of Production Economics, 168, 181-196.

Shukla, M. (2013). To study the relationship between knowledge utilization and learning capability in a team. Proceedings of the 10th International Conference on Intellectual Capital, Knowledge Management and Organizational Learning: ICICKM 2013, 394-400. Academic Conference Limited.

Słownik jezzyka polskiego. (2017). PWN. Pobrane z http://sjp.pwn.pl

Smith, D. C. (1992, September). From lean to nimble: is agile production the next paradigm? Ward's Auto World.

Smith, K. G. i Cao Q. (2007). An entrepreneurial perspective on the firm environment relationship. Strategic Entrepreneurship Journal, 1(3-4), 329-344.

Smith, K. G. i Di Gregorio (2002). Bisociation, discovery, and the role of entrepreneurial action. W: M. A. Hitt, R. D. Ireland, S. M. Camp i D. L. Sexton (Eds.), Strategic entrepreneurship: Creating a new mindset (s. 29-150). Oxford: Blackwell Publishers.

Sobel, M. E. (1982). Asymptotic confidence intervals for indirect effects in structural equation model. W: Leinhardt editor, Sociological methodology (290-312). Washington, D.C.: American Sociological Association.

Sousa, F. J. (2010). Metatheories in research: Positivism, postmodernism, and critical realism, Advances in Business Marketing and Purchasing, 16, 455-503.

Sroka, W. (2009). Wykorzystanie modelu równań strukturalnych do oceny wplywu kapitału ludzkiego na sukces ekonomiczny przodujących gospodarstw karapckich. Roczniki Nauk Rolniczych, Seria G.T., 96, 4.

Stacey, R. D. (2003). Learning as the Activity of Interdependent People. The Learning Organisation, 10(6), 325-334.

Stanisz, A. (2007). Przystępny kurs statystyki z zastosowaniem Statistica PL na przykładach $z$ medycyny. Tom 3. Analizy wielowymiarowe. Kraków: StatSoft.

Stankiewicz, M. J. (2000). Istota i sposoby oceny konkurencyjności przedsiębiorstwa. Gospodarka Narodowa, 7-8, 95-109.

Stańczyk-Hugiet, E. (2005). Organizacja ucząca się. W: R. Krupski (red.), Zarządzanie przedsiębiorstwem $w$ turbulentnym otoczeniu. Warszawa: PWE.

Stańczyk-Hugiet, E. (2013). Dynamika strategiczna w ujęciu ewolucyjnym. Wrocław: Wydawnictwo Uniwersytetu Ekonomicznego we Wrocławiu.

Stańczyk-Hugiet, E. (2015). Rutyna relacyjna w świetle podejścia ewolucyjnego i relacyjnego. Marketing i Rynek, 9.

Stańczyk-Hugiet, E. (2016). Eksplorować czy eksploatować relacje międzyorganizacyjne?. Prace Naukowe Uniwersytetu Ekonomicznego we Wrocławiu, 420, 286-299. 
Stańczyk-Hugiet, E. (2017). Zdolności dynamiczne - w poszukiwaniu Świętego Graala? W: K. Krzakiewicz i S. Cyfert (red.), Strategiczny wymiar dynamicznych zdolności polskich przedsiębiorstw. Poznań: Wydawnictwo Uniwersytetu Ekonomicznego w Poznaniu.

Stańczyk-Hugiet, E. i Sus A. (2012). Konsekwencje przynależności do sieci. W: J. Niemczyk, E. Stańczyk-Hugiet i B. Jasiński (red.), Sieci międzyorganizacyjne. Współczesne wyzwanie dla teorii i praktyki zarządzania (s. 86-96). Warszawa: C.H. Beck.

Stevenson, H. H. (1983). A perspective on entrepreneurship. Harvard Business School Working Paper, 9, 384-131.

Stevenson, H. H. i Jarillo, J. C. (1990). A paradigm of entrepreneurship: entrepreneurial management. Strategic Management Journal, 11, 17-27.

Storey, J., Emberson, C. i Reade, D. (2005). The barriers to customer responsive supply chain management. International Journal of Operations \& Production Management, 25(3), 242-260.

Stuart, T. E., Hoang, H. i Hybels, R. C. (1999). Interorganizational endorsement and the performance of entrepreneurial ventures. Administrative Science Quarterly, 44(2), 315-349.

Sudoł, S. (2007). Nauki o zarządzaniu. Węzłowe problemy i kontrowersje. Toruń: TNOiK.

Sulimowska-Formowicz, M. (2002). Nurt zasobowy teorii firmy. Gospodarka Narodowa, 5-6.

Sull, D. (2009). How to thrive in turbulent markets. Harvard Business Review, 87(2), 78-88

Sus, A. (2014). Wybrane determinant procesu wykorzystania okazji w zarządzaniu strategicznym. Marketing i Rynek, 5.

Suszyński, C. (2014). Współtworzenie wartości jako proces przesuwający granice organizacji i zarządzania. W: M. Romanowska i J. Cegler (red.), Granice zarządzania. Warszawa: Oficyna Wydawnicza Szkoła Główna Handlowa w Warszawie.

Swafford, P. M., Ghosh, S. i Murthy, N. N. (2006a). A framework for assessing value chain agility. International Journal of Operations \& Production Management, 26(2), 118-140.

Swafford, P. M., Ghosh, S. i Murthy, N. N. (2006b). The antecedents of supply chain agility of a firm: scale development and model testing. Journal of Operations Management, 24(2), 170-188.

Swamidass, P. M. i Newell, W. T. (1987). Manufacturing strategy, environmental uncertainty and performance: a path analytic model. Management Science, 33(4), 509-524.

Szablewski, A. i Tuziemek, R. (2005). Wycena i zarządzanie wartością firmy. Warszawa: Poltex.

Światowiec-Szczepańska, J. (2012). Ryzyko partnerstwa strategicznego przedsiębiorstw. Ujęcie modelowe. Poznań: Wydawnictwo Uniwersytetu Ekonomicznego w Poznaniu.

Tallon, P. P. i Pinsonneault, A. (2011). Competing perspectives on the link between strategic information technology alignment and organizational agility: insights from a mediation model. MIS Quarterly, 35(2), 463-486.

Tang, J., Kacmar, K. M. i Busenitz, L. (2012). Entrepreneurial alertness in the pursuit of new opportunities. Journal of Business Venturing, 27.

Taticchi, P., Tonelli, F. i Cagnazzo, L. (2010). Performance measurement and management: A literature review and a research agenda. Measuring Business Excellence, 14(1), 4-18.

Teece, D. J. (1998). Capturing value from knowledge assets: the new economy, markets for know-how, and intangible assets. California Management Review, 40(3), 55-79.

Teece, D. J. (2007). Explicating dynamic capabilities: the nature and microfoundations of (sustainable) enterprise performance. Strategic Management Journal, 28(13), 1319-1350. 
Teece, D. J (2012). Dynamic Capabilities: Routines versus Entreprenurial Action. Journal of Management Studies, 49(8), 1395-1401.

Teece, D. J. i Augier, M. (2009). Dynamic capabilities and the role of managers in business strategy and economic performance. Organization Science, 20(2), 410-421.

Teece, D. J., Pisano, G. i Shuen, A. (1997). Dynamic capabilities and strategic management. Strategic Management Journal, 18(7), 509-533.

Thannhuber, M. J. (2005). The intelligent enterprise: theoretichal concepts and practical implications. Physica-Verlag. New York: A Springer Company.

Timmons, J. A. (1999) New Venture creation. Entrepreneurship for the 21st Century ( $5^{\text {th }} \mathrm{ed}$.). Singapore: Irwin/McGraw-Hill.

Trigeorgis, L. (1996). Real options, managerial flexibility and strategy in resources allocation. Cambridg: MIT Press.

Tsoukas, H. (1989). The validity of idiographic research explanations. Academy of Management Review, 14(4), 551-561.

Trzcieliński, S. (2011). Przedsiębiorstwo zwinne. Poznań: Wydawnictwo Politechniki Poznańskiej.

Tsourveloudis, N. C. i Valavanis, K. P. (2002). On the measurement of enterprises agility. Journal of Intelligent and Robotic Systems, 33(3), 329-342.

Urbanowska-Sojkin, E. (red.). (2011). Podstawy wyborów strategicznych $w$ przedsiębiorstwach. Warszawa: PWE.

Urbanowska-Sojkin, E. (2013a). Zasobowy kontekst sukcesu przedsiębiorstwa. Zarządzanie i Finanse, 4(1), 389-402.

Urbanowska-Sojkin, E. (red.). (2013b). Ryzyko $w$ wyborach strategicznych $w$ przedsiębiorstwach. Warszawa: PWE.

Urbański, M. (2009). Rozumowania abdukcyjne. Modele i procedury. Poznań: Wydawnictwo Naukowe UAM.

Ussahawanitchakit, P. (2012). Effects of organizational learning and strategic leadership on competitive advantage of electronics businesses in Thailand via competitive environment as a moderator. Journal of International Business and Economics, 12(1).

Utterback, J. M. (1994). Mastering the dynamics of innovation. Boston: Harvard Business School Press.

Uzzi, B. (1997). Social structure and competition in interfirm networks: the paradox of embeddedness. Administrative Science Quarterly, 42(1), 35-67.

Vagnoni, E. i Khoddami, S. (2016). Designing competitive activity model through the strategic agility approach in a turbulent environment. Foresight, 18(6), 625-648.

Van Wijk, R., Jansen, J. P. i Lyles, M. A. (2008). Inter and intra organizational knowledge transfer: a meta-analytic review and assessment of its antecedents and consequences. Journal of Management Studies, 45(4), 815-838.

Vargas, M. I. R. (2013). Underlying dimensions and organizational values in organizational learning. Strategy for capacity building in developing countries. Journal of Technology Management and Innovation, 8(3), 57-69.

Vazquez-Bustelo, D., Avella, L. i Fernandez, E. (2007). Agility drivers, enablers and outcomes. Empirical test of an integrated agile manufacturing model. International Journal of Operations \& Production Management, 27(12), 1303-1332. 
Vecchiato, R. (2015). Creating value through foresight: First mover advantages and strategic agility. Technological Forecasting and Social Change, 101, 25-36.

Vecchio, R. P. (2006). Organizational behavior: Core concepts. Cincinnati: Thomson/Southwest Learning.

Verma, J. P., Agrawal, S., Patel, B. i Patel, A. (2016). Big data analytics: challenges and applications for text, audio, video, and social media data. International Journal on Soft Computing, Artificial Intelligence and Applications, 5(1).

Vernadat, F. B. (1999). Research agenda for agile manufacturing. International Journal of Agile Management Systems, 1(1), 37-40.

Vickery, S. K., Droge, C., Setia, P. i Sambamurthy, V. (2010). Supply chain information technologies and organizational initiatives: complementary versus independent effects on agility and firm performance. International Journal of Production Research, 48(23), 7025-7042.

Vinodh, S., Sundararaj, G., Devadasan, S. R., Kuttalingam, D. i Rajanayagam, D. (2010). Amalgamation of mass customization and agile manufacturing concept: the theory and implementation study in an electronics switches manufacturing company. International Journal of Production Research, 48(7).

Vokurka, R. i Fliender, G. (1998). The journey toward agility. Industrial Management \& Data Systems, 98(4), 165-171.

Wade, M. i Hulland, J. (2004). The resource - based view and information systems research: review extension and suggestions for future research. MIS Quarterly, 28(1), 107-142.

Walesiak, M. (1996). Metody analizy danych marketingowych. Warszawa: Wydawnictwo Naukowe PWN.

Walesiak, M. i Gantar, E. (2009). Statystyczna analiza danych z wykorzystaniem programu $R$. Warszawa: PWN.

Walsh, J. P. i Ungson, G. R. (1991). Organizational memory. Academy Management Review, $16,57-91$.

Wałecka-Jankowska, K. (2012). Przywództwo a innowacyjność polskich przedsiębiorstw - wyniki badań empirycznych. W: G. Bełz i S. Cyfert (red.), Strategie i mechanizmy odnowy przedsiębiorstw. Prace Naukowe Uniwersytetu Ekonomicznego we Wrocławiu, 276. Wrocław: Wydawnictwo Uniwersytetu Ekonomicznego we Wrocławiu.

Wang, C. L. i Ahmed, P. K. (2004). The development and validation of the organizational innovativeness construct using confirmatory factor analysis. European Journal of Innovation Management, 7(4), 303-313

Wang, C. L. i Ahmed, P. K. (2007). Dynamic capabilities: A review and research agenda. International Journal of Management Reviews, 9(1), 31-51.

Wang, Y. i Lo, H. (2003). Customer-focused performance and the dynamic model of competence building and leveraging: A resource-based view. Journal of Management Development, 22(6), 483-526.

Ward, P. T., Duray, R., Leong, G. K. i Sum, C. (1995). Business environment, operations strategy and performance: an empirical study of Singapore manufactures. Journal of Operations Management, 13(4), 99-115.

Waśniewski, P. (2016). Kluczowe czynniki sukcesu jako podstawa pomiaru dokonań. Finanse, Rynki Finansowe, Ubezpieczenia, 2(80), cz 1.

Weber, Y. i Tarba, S. Y. (2014). Strategic agility: A state of the art. California Management Review, 56(3). 
Wei, Z., Zhao, J. i Zhang, C. (2014). Organizational ambidexterity, market orientation, and firm performance. Journal of Engineering and Technology Management, 31(4), 832-847. Wells, J. R. (2014). Inteligencja strategiczna. Jak stworzyć mądra firmę. Poznań: Rebis.

Wernerfelt, B. (1984). A rosource-based view of the firm. Strategic Management Journal, 5, 171-180.

Wheelwright, S. C. i Clark, K. B. (1992, March - April). Creating project plans to focus product development. Harvard Business Review.

White, A., Daniel, E. M. i Mohdzain, M. (2005). The role of emergent information technologies and systems in enabling supply chain agility. International Journal of Information Management, 25(5), 396-410.

Wholley, D. R. i Brittain, J. (1989). Characterizing environmental variation. Academy of Management Journal, 32(4), 867-882.

Whitten, G. D., Green Jr., K. W. i Zelbst, P. J. (2012). Triple - A supply chain performance. International Journal Operations Production Management, 32(1), 28-48.

Wiklund, J. i Shepherd, D. (2003). Knowledge based resources, entrepreneurial orientation, and the performance of small and medium sized businesses. Strategic Management Journal, 24(3), 1307-1314.

Wiltbank, R., Dew, N., Read, S. i Sarasvathy, S. D. (2006). What to do next? The case for non-predictive strategy. Strategic Management Journal, 27(10), 981-998.

Winter, S. G. (2003). Understanding dynamic capabilities. Strategic Management Journal, 24, 991-995.

Wirtz, B. W., Mathieu, A. i Schilke, O. (2007). Strategy in high velocity environments. Long Range Planning, 40(3).

Witczak, H. (2016). System innowacji. W: S. Gregorczyk i W. Mierzejewska, Zarzadzanie przedsiębiorstwem inteligentnym. Wybrane zagadnienia. Warszawa: Oficyna Wydawnicza SGH.

Witkowski, J. (2003). Zarządzanie łańcuchem dostaw. Warszawa: PWE.

Witt, U. (2008). Evolutionary economics and psychology. W: A. Lewis (Ed.), The Cambridge handbook of psychology an economic behavior. Cambridge: Cambridge University Press.

Womack, J. P., Jones, D. T. i Roos, D. (1990). The machine that changed the world. New York: Rawson Associates.

Womack, J. P. i Jones D. T. (2001). Odchudzanie firm. Warszawa: Centrum Informatyzacji Menedżera.

Worley, Ch. G., Williams, T. i Lawler III, E. E. (2014). The agility factor. Building adaptable organizations for superior performance. USA: Jossey-Bass.

Wójcik-Karpacz, A. (2012). Zdolności dynamiczne jako przedmiot eksploracji naukowej zarządzania strategicznego, Prace Naukowe WWSZiP, 22(2).

Yang, Ch. i Liu, H. M. (2012). Boosting firm performance via enterprise agility and network structure. Management Decision, 50(6), 1022-1044.

Yauch, Ch. A. (2011). Measuring agility as a performance outcome. Journal of Manufacturing Technology Management, 22(3), 384-404.

Yusuf, Y. Y. i Adeleye, E. O. (2002). A comparative study of lean and agile manufacturing with a related survey of current practices in UK. International Journal of Production Research, 40(17), 4545-4562. 
Yusuf, Y. Y., Sarhadi, M. i Gunasekaran, A. (1999). Agile manufacturing: the drivers, concepts and attributes. International Journal of Production Economics, 62(1-2), 33-43.

Zaheer, A. i Bell, G. G. (2005). Benefiting from network position: firm capabilities, structural holes, and performance. Strategic Management Journal, 26(9), 809-825.

Zaheer, A. i Zaheer, S. (1997). Catching the wave: alertness, responsiveness and market influence in global electronic networks. Management Science, 43(11), 493-509.

Zahra, S. i George, G. (2002). Absorptive capacity: A review, reconceptualization and extension. Academy of Management Review, 27(2), 213-240.

Zahra, S. A. (1991). Predictors and financial outcomes of corporate entrepreneurship: an exploratory study. Journal of Business Venturing, 8(4), 319-340.

Zahra, S. A. (1993). Environment, corporate entrepreneurship, and financial performance: a taxonomic approach. Journal of Business Venturing, 8(4), 259-285.

Zahra, S. A. i Covin, J. G. (1995). Contextual influences on the corporate entrepreneurship - performance relationship: a longitudinal analysis. Journal of Business Venturing, 10(1), 43-58.

Zahra, S. A. i Garvis, D. M. (2000). International corporate entrepreneurship and firm performance: the moderating effects of international environmental hostility. Journal of Business Venturing, 15(5-6), 469-492.

Zahra, S. A., Ireland, R. D., Gutierrez, I. i Hitt, M. A. (2000). Privatization and entrepreneurial transformation: Emerging issues and a future research agenda. Academy of Management Review, 25, 509-524.

Zakrzewska-Bielawska, A. (2016). Paradoks eksploracji i eksploatacji - ambidexterity w zarządzaniu strategicznym. Prace Naukowe Uniwersytetu Ekonomicznego we Wrocławiu, 420.

Zakrzewska-Bielawska, A. (2018). Strategie rozwoju przedsiębiorstw. Nowe spojrzenie. Warszawa: PWE.

Zaltman, G., Duncan, R. i Holbek, J. (1973). Innovations and organizations. New York: John Wiley \& Sons.

Zhang, J.A., Garrett-Jones, S. i Szeto, R. (2013). Innovation capability and market performance: the moderating effect of industry dynamism. International Journal of Innovation Management, 17(2).

Zhang, Z. i Sharifi, H. (1999). A methodology for achieving agility in manufacturing organizations: An Introduction. International Journal of Production Economics , 62(1-2), 7-22.

Zhang, Z. i Sharifi, H. (2000). A methodology for achieving agility in manufacturing organizations. International Journal of Operations \& Production Management, 20(4), 496 - 512.

Zhang, Z. i Sharifi, H. (2001). Agile manufacturing in practice: Application of a methodology. International Journal of Operations \& Production Management, 21(5/6), 772-794.

Zhang, Z. i Sharifi, H. (2007). Towards theory building in agile manufacturing strategy a taxonomical approach. IEEE Transactions on Engineering Management, 54(2), 351-370.

Zirger, B. J. (1997). The influence of development experience and product innovativeness on product outcome. Technology Analysis \& Strategic Management, 9(3), 287-297.

Zollo, M. i Winter, S. G. (2002). Deliberate learning and the evolution of dynamic capabilities. Organization Science, 13(3). 


\section{SPIS RYSUNKÓW}

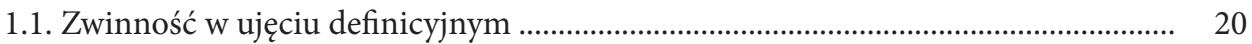

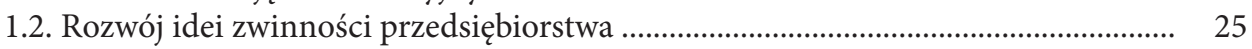

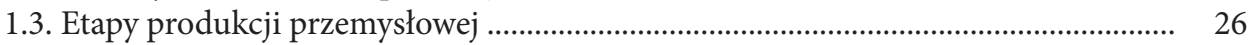

1.4. Przedmiotowy kontekst badawczy w obszarze zwinności przedsiębiorstw ............. 39

2.1. Podział podejść wykorzystywanych w badaniach nad zwinnością przedsię-

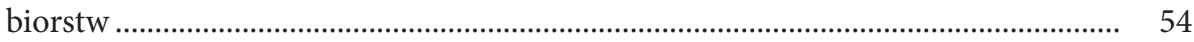

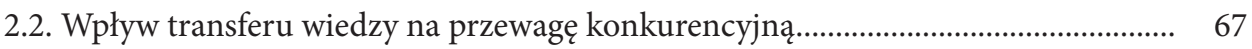

3.1. Delimitacja pojęcia zwinności strategicznej przedsiębiorstw .................................... 85

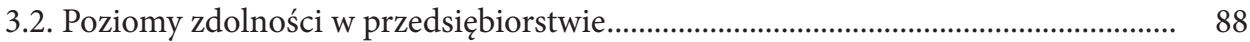

3.3. Opracowanie składowych przedsiębiorczości strategicznej ..................................... 107

3.4. Model i hipotezy badawcze .................................................................................. 131

4.1. Częstotliwość analizy i dyskusji nad wykorzystaniem pojawiających się szans....... 148

4.2. Częstotliwość wykorzystania pojawiających się szans .............................................. 148

4.3. Ogólny poziom umiejętności dostosowawczych ..................................................... 158

4.4. Wykorzystanie przekaźników zwinności .................................................................... 159

5.1. Ogólny model przyczynowy ze zmiennymi nieobserwowalnymi ............................. 172

5.2. Model pomiarowy zwinności strategicznej .............................................................. 190

5.3. Model strukturalny zwinności strategicznej........................................................... 192 


\section{SPIS TABEL}

1.1. Kluczowe definicje zwinności prezentowane w najczęściej cytowanych artykułach

1.2. Porównanie wybranych cech dla odmiennych etapów produkcji przemysłowej..

1.3. Implikacje biznesowe dla poszczególnych faz produkcji przemysłowej

1.4. Porównanie przedsiębiorstw produkcyjnych zorientowanych i niezorientowanych na praktyki zwinne

1.5. Przegląd wybranych definicji zwinności strategicznej

1.6. Wpływ zwinności strategicznej na sprawność konkurowania w branży telekomunikacyjnej w Nigerii

1.7. Wpływ zwinności na wyniki przedsiębiorstwa.

1.8. Wpływ zwinności współpracy z klientem na wyniki przedsiębiorstwa

1.9. Poprawa wyników przedsiębiorstwa poprzez jego zwinność i strukturę sieciową

1.10. Wpływ zwinności strategicznej na postrzegane wyniki w przedsiębiorstwach produkcyjnych w Nigerii

1.11. Wpływ zwinności strategicznej na działania operacyjne i wyniki przedsiębiorstwa.

12. Podsumowanie dorobku w ramach badań dotyczących wpływu zwinności na wyniki przedsiębiorstw

2.1. Podejścia uzasadniające zwinność przedsiębiorstw

2.2. Wymiary innowacyjności organizacji w świetle badań

2.3. Rola zwinności w wybranych podejściach teoretycznych

3.1. Typologia zdolności przedsiębiorstwa.

3.2. Definiowanie i wykorzystanie wymiarów orientacji przedsiębiorczej w warunkach zwinności strategicznej.

3.3. Charakterystyka mechanistycznych i organicznych organizacji.

3.4. Przegląd wybranych definicji i rodzajów elastyczności

3.5. Charakterystyka elastyczności wybranych zasobów przedsiębiorstwa .

3.6. Paradygmaty przywództwa

3.7. Przywództwo - wizjonerskie, menedżerskie oraz strategiczne.

4.1. Charakterystyka populacji badanych przedsiębiorstw według liczby zatrudnionych oraz sekcji PKD

4.2. Struktura próby badawczej.

4.3. Charakterystyka próby badawczej...................................................................... 141

4.4. Średnia ocena umiejętności identyfikacji szans w otoczeniu ................................. 144

4.5. Ocena umiejętności identyfikacji szans w otoczeniu............................................. 146

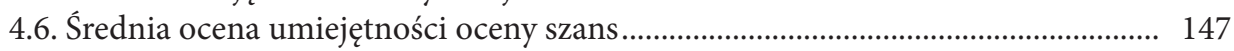

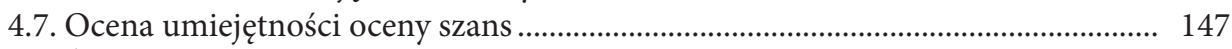

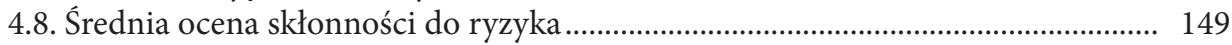

4.9. Ocena skłonności do ryzyka ................................................................................... 150 
4.10. Ocena zdolności do pozyskania zasobów ........................................................... 151

4.11. Średnia ocena umiejętności rozwoju zasobów własnych ...................................... 152

4.12. Ocena umiejętności rozwoju zasobów własnych ................................................. 152

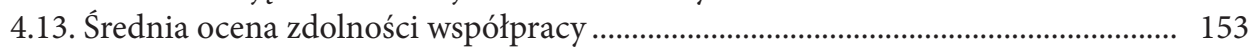

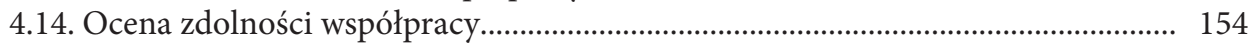

4.15. Średnia ocena zdolności innowacyjnej ................................................................ 155

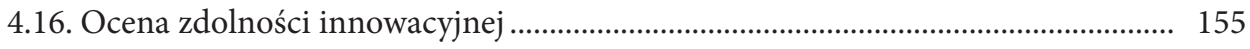

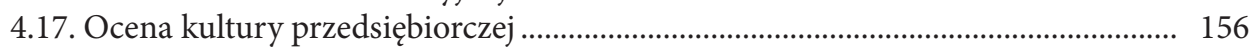

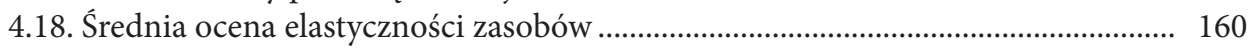

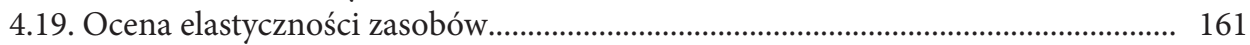

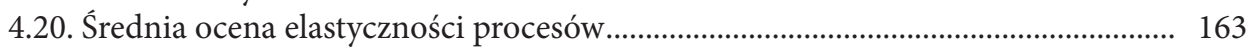

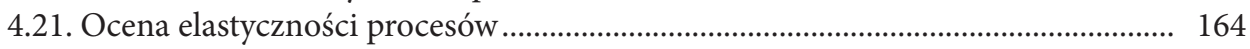

4.22. Średnia ocena zdolności przywództwa strategicznego według wybranych cech.. 166

4.23. Ocena zdolności w ramach przywództwa strategicznego ......................................... 168

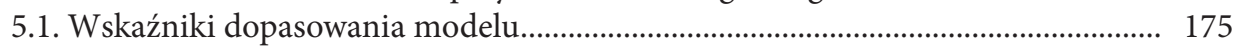

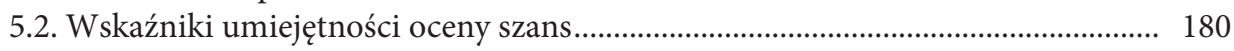

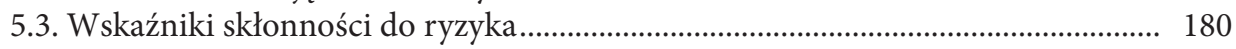

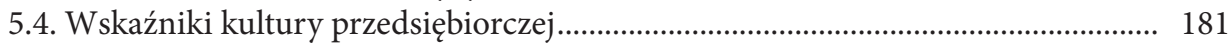

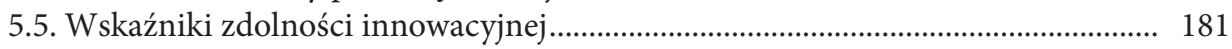

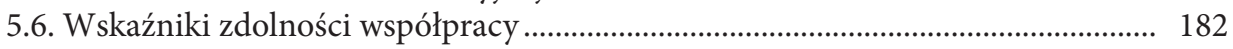

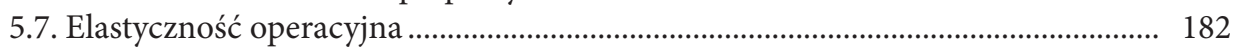

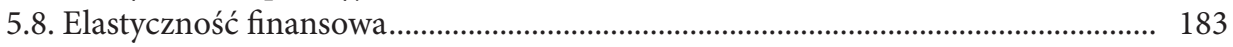

5.9. Wskaźniki przywództwa strategicznego …............................................................. 183

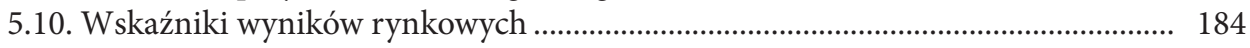

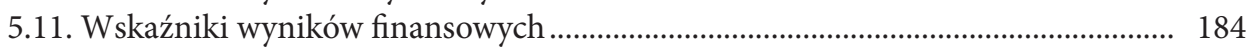

5.12. Miary dopasowania modeli pomiarowych.............................................................. 186

5.13. Estymacja niestandaryzowanych ładunków czynnikowych (konfirmacyjna analiza czynnikowa) ................................................................................................ 187

5.14. Standaryzowane ładunki czynnikowe i mierniki oceny zbieżności zmiennych przyjętego modelu pomiarowego .................................................................... 188

5.15. Trafność różnicowa dla poszczególnych konstruktów modelu pomiarowego...... 189

5.16. Miary dopasowania modelu strukturalnego ....................................................... 191

5.17. Wyniki estymacji parametrów standaryzowanych modelu strukturalnego .......... 193

5.18. Ocena postawionych hipotez badawczych .......................................................... 194 


\section{STRATEGIC AGILITY OF ENTERPRISES}

\section{Summary}

The results of the projects are a cognitively interesting study that deals with the issues of business agility from a strategic perspective. On the basis of an extensive analysis of the literature on the subject, a successful conceptualization and operationalization of a strategic agility construct was accomplished, together with a description and empirical verification of the variables and attributes included in this construct. The empirical part of the study resulted in the creation of a model of strategic agility linked to the effectiveness of the surveyed enterprises. The valuable cognitive results are a synthesis of knowledge in the field of management science, especially in the area of strategic management, an intellectually interesting research project making use of structural modelling, as well as the proposed linking of agility with effectiveness; making the project results a possible starting point for future scientific research as well as being a source of recommendations for company managers. The literature study and empirical research on a representative group of enterprises conducted within the project make it possible to formulate specific implications for business practice. The fundamental issue is to develop awareness among managers with regard to the adaptability of enterprises oriented to the attributes of strategic agility. Although managers of medium-sized and large enterprises are generally aware of the importance of adaptation and proactive strategic orientation, they do not fully exploit the potential of implementing fast and effective strategic changes. The results of the project are a valuable contribution to the state of knowledge and the development of the theory of management, as well as being the first study in Poland which comprehensively presents the theoretical perspective of the strategic agility approach with a view to improve the understanding of the relationship between the influence of the environment on the strategic response of enterprises and their performance.

Keywords: strategic agility, competitive advantage, results. 